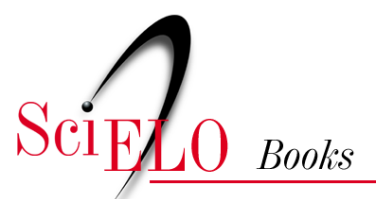

\title{
Doença de Chagas, doença do Brasil ciência, saúde e nação, 1909-1962
}

\author{
Simone Petraglia Kropf
}

\section{SciELO Books / SciELO Livros / SciELO Libros}

KROPF, S. Doença de Chagas, doença do Brasil: ciência, saúde e nação, 1909-1962 [online]. Rio de Janeiro: Editora FIOCRUZ, 2009, 596 p. História e Saúde collection. ISBN 978-85-7541-315-9. https://doi.org/10.7476/9788575413159.

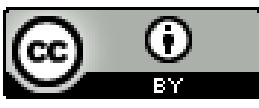

All the contents of this work, except where otherwise noted, is licensed under a Creative Commons Attribution 4.0 International license.

Todo o conteúdo deste trabalho, exceto quando houver ressalva, é publicado sob a licença Creative Commons Atribição 4.0. 


\section{Doença de Chagas, Doença do Brasil}

ciência, saúde e nação, 1909-1962 
FUNDAÇÃO OSWALDO CRUZ

Presidente

Paulo Gadelha

Vice-Presidente de Ensino, Informação e Comunicação

Maria do Carmo Leal

\section{EDITORA FIOCRUZ}

Diretora

Maria do Carmo Leal

Editor Executivo

João Carlos Canossa Pereira Mendes

Editores Científicos

Nísia Trindade Lima e Ricardo Ventura Santos

Conselho Editorial

Ana Lúcia Teles Rabello

Armando de Oliveira Schubach

Carlos E. A. Coimbra Jr.

Gerson Oliveira Penna

Gilberto Hochman

Joseli Lannes Vieira

Lígia Vieira da Silva

Maria Cecília de Souza Minayo

Coleção História e Saúde

Editores Responsáveis: Gilberto Hochman

Flavio C. Edler

Jaime L. Benchimol 


\section{Doença de Chagas, Doença do Brasil}

ciência, saúde e nação, 1909-1962

Simone Petraglia Kropf

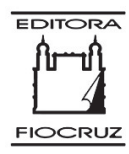


Copyright (C) 2009 da autora

Todos os direitos desta edição reservados à

FUNDAÇÃO OSWALDO CRUZ / EDITORA

Capa e projeto gráfico

Carlota Rios e Guilherme Ashton

Editoração eletrônica

Daniel Pose Vazquez

Revisão

Janaina Silva e Ana Prôa

Normalização de referências

Clarissa Bravo

Catalogação na fonte

Instituto de Comunicação e Informação Científica e Tecnológica em Saúde/Fiocruz

Biblioteca de Saúde Pública

K93d Kropf, Simone Petraglia

Doença de Chagas, doença do Brasil: ciência, saúde e nação,1909 1962. / Simone Petraglia Kropf - Rio de Janeiro: Editora FIOCRUZ, 2009.

600 p., il. (Coleção História e Saúde)

ISBN: 978-85-7541-175-9

1. Doença de Chagas-história. 2. Trypanosoma cruzi-parasitologia. 3. Saúde Pública-história. 4. Brasil. I. Título.

CDD - 616.93630981

2009

EDITORA FIOCRUZ

Av. Brasil, $4036-1^{\circ}$ andar

sala 112 - Manguinhos

21040-361 - Rio de Janeiro - RJ

Tel.: (21) 3882-9039 e 3882-9041

Telefax: (21) 3882-9006

e-mail: editora@fiocruz.br

http://www.fiocruz.br/editora 
Para Gilberto e Ana Clara 



\section{Sumário}

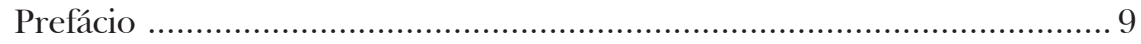

Apresentação ..................................................................... 13

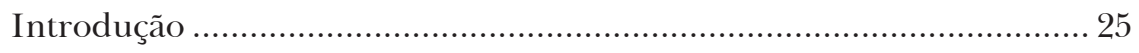

1. Medicina Tropical e Ciência Nacional: Carlos Chagas e a descoberta de uma nova tripanossomíase humana ....................... 51

2. Moléstia Tropical, Endemia dos Sertões: o desenho da doença do Brasil (1910-1913) ....................................................... 129

3. Entre Dúvidas e Glórias: a tripanossomíase americana no foco da ciência e da política (1914-1918) ........................................ 177

4. Calamidade Nacional ou Mal de Lassance? A doença do Brasil em questão (1919-1934)

5. Manguinhos e a Saúde Pública a partir de 1930: novos caminhos para o estudo das endemias rurais ...................................... 285

6. Os Estudos sobre a Doença após Carlos Chagas (1935-1943) .......... 337

7. Identificando o Inimigo e as Armas: as pesquisas do Instituto Oswaldo Cruz em Bambuí, Minas Gerais (1943-1949)

8. Para Além do Laboratório: arregimentando aliados na guerra contra a doença do coração do Brasil (1942-1950) .... 
9. A Doença de Chagas em Tempos de Desenvolvimento

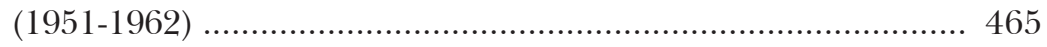

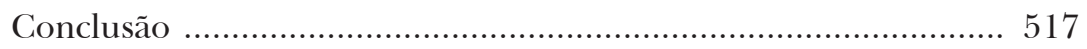

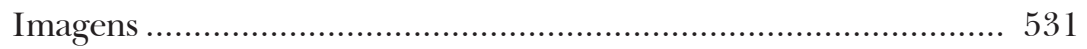

Fontes e Referências ............................................................... 549 


\section{Prefácio}

Em 1909, em Lassance, um pequeno lugarejo de Minas Gerais, Carlos Chagas, médico e pesquisador do Instituto Oswaldo Cruz (IOC), descreveu uma nova doença identificando ao mesmo tempo o protozoário causador (o Trypanossoma cruzi) e o vetor que a transmitia, um inseto popularmente chamado de 'barbeiro', muito comum nos casebres de barro do interior do país. A descoberta da 'doença de Chagas' foi imediatamente comemorada como grande feito da ciência nacional, fato que comprovava o caminho do 'progresso' trilhado pela então jovem República brasileira, empenhada em construir seu lugar entre os 'países civilizados'. Para o IOC, a façanha de Carlos Chagas era uma grande oportunidade de transformar a instituição em um centro de ciência nos moldes do Instituto Pasteur.

Entretanto, alguns anos depois, entre 1915 e 1923, os enunciados de Carlos Chagas sobre a doença foram objeto de muitas dúvidas e questionamentos, inicialmente entre médicos argentinos e posteriormente no próprio campo científico brasileiro. Quando Carlos Chagas faleceu, em 1934, duvidava-se que a doença que leva seu nome fosse um grande problema sanitário no Brasil; muitos eram os que apontavam tratar-se de doença limitada aos 'sertões de Minas'. 
Dois de seus discípulos, Evandro Chagas, seu filho mais velho, e Emmanuel Dias, diretor do Centro de Estudos e Profilaxia da Moléstia de Chagas (CEPMC - posto do IOC na cidade mineira de Bambuí), retomaram as pesquisas sobre a doença nas décadas de 1930 e 1940, e, ao longo da década de 1950 estabeleceu-se um novo acordo científico sobre a tripanossomíase americana e sua profilaxia, concluindo - segundo a perspectiva dos seguidores de Carlos Chagas - um processo iniciado em Minas Gerais no ano de 1909.

A pesquisadora da Casa de Oswaldo Cruz da Fundação Oswaldo Cruz (COC/Fiocruz), Simone Petraglia Kropf, municiada com sofisticadas ferramentas conceituais das ciências humanas e, sobretudo, com seu enorme talento e vocação para a pesquisa histórica, debruçou-se sobre a narrativa tradicionalmente linear sobre a descoberta e as pesquisas sobre a doença de Chagas, desconfiada que, entre 1909, ano da descoberta da doença, e 1962, ano da morte de Emmanuel Dias, o caminho para o 'desvelamento' do mal de Chagas, não foi uma 'linha reta', como registraram muitos de seus memorialistas, mas sim um "percurso acidentado, cheio de entradas e saídas, em que às trilhas estritas da ciência se sobrepuseram personagens, estratégias e significados afetos a outras esferas da vida social".

Para desvendar este 'percurso acidentado', Simone Kropf elaborou algumas questões que nortearam sua investigação: como a doença 'descoberta' por Carlos Chagas foi aceita e estabelecida cientificamente como uma entidade nosológica específica? Como se produziu o reconhecimento social de que a nova patologia era um problema de saúde pública no Brasil? De que forma se pode considerar o 'mal de Chagas' como um produto da história?

Inspirada por estas perguntas e teoricamente fundamentada pelas novas abordagens da sociologia e história das ciências, a autora analisou os fatos relativos à descoberta, controvérsias e reconhecimento científico da doença de Chagas, buscando associar seus aspectos 'externos' - suas circunstâncias sociais e históricas - a seus conteúdos científicos específicos, ou seja, seus aspectos 'internos'.

A partir desta abordagem, Simone argumenta que a doença de Chagas foi estabelecida ou, para usar a expressão do historiador Charles Rosenberg, 'emoldurada' ao mesmo tempo como fato científico e fato social, a partir de um longo e complexo processo de negociação entre diversos atores e instâncias da vida social. Tal perspectiva implica reconhecer que o ‘enquadramento' desta doença como entidade nosológica específica, a 
partir dos critérios científicos pelos quais foi definida, foi articulado ao processo pelo qual "a ela se atribuiu o papel de representar e dar sentido a certa visão da sociedade brasileira, de seus problemas e, sobretudo, do papel da ciência nesta sociedade". Ou seja, os enunciados especificamente médico-científicos sempre estiveram coligados aos significados políticos, sociais e simbólicos que caracterizaram a doença de Chagas como 'doença do Brasil'.

Para analisar o processo de 'enquadramento' da doença de Chagas, Simone buscou dois momentos desta trajetória: o primeiro vai da identificação da nova doença, em 1909, e inclui as pesquisas realizadas por Carlos Chagas e sua equipe, até sua morte em 1934. Neste período, os enunciados sobre a classificação clínica e a importância médico-social da doença estavam associados ao debate sobre o 'atraso' do Brasil, que o movimento sanitarista afirmou ser resultado das péssimas condições de saúde e do abandono da população rural do país. A doença de Chagas, além de outras endemias rurais do "vasto hospital" chamado Brasil, corroía a produtividade do homem do campo e impedia o progresso nacional. Entretanto, também neste período, as primeiras proposições de Chagas, elaboradas entre 1910 e 1913, foram objeto de muitas dúvidas, que questionaram a associação clínica com os distúrbios endócrinos (particularmente a 'papeira'/bócio) e neurológicos. A polêmica que se seguiu culminou com intenso debate na Academia Nacional de Medicina (ANM), entre 1922-1923, no qual as dimensões epidemiológica e social da doença foram colocadas sob suspeita.

Um segundo momento dessa trajetória abrange o período 19341962 quando dois discípulos de Carlos Chagas - Evandro Chagas e Emmanuel Dias - retomaram os estudos sobre a moléstia sob novas condições institucionais, políticas e sociais que permitiriam produzir um novo 'enquadramento' da doença. O novo framing - de acordo com o conceito original de Rosenberg - do mal de Chagas significava redefinilo como doença crônica, cardíaca, socialmente importante por implicar o impedimento produtivo dos trabalhadores rurais brasileiros - a grande maioria de suas vítimas.

Do ponto de vista político-social, os seguidores de Chagas beneficiaram-se com as condições abertas pelo projeto político e econômico de modernização do Brasil nas décadas de 1940 e 1950. Ainda que o projeto privilegiasse a industrialização do país, a questão do desenvolvimento do campo ganhou importância não apenas com a 'Marcha para o Oeste' de 
Vargas, mas também com o 'nacional-desenvolvimentismo' e a interiorização do poder do Estado representado pela construção de Brasília, no governo JK. No plano internacional, o 'otimismo sanitário’ do pós-guerra significou um repensar a respeito do lugar da saúde pública na agenda do desenvolvimento. A saúde, considerada um bem de valor econômico, passou a ser requisito para o desenvolvimento, favorecendo o campo institucional da saúde pública no país.

Este belo livro, que ora sai publicado pela Editora Fiocruz, foi originalmente uma tese de doutorado defendida no Programa de PósGraduação em História da Universidade Federal Fluminense (UFF), em 2006. O trabalho foi selecionado como sua melhor tese naquele ano e, nesta condição, indicado para concorrer ao Prêmio Capes, recebendo a distinção 'menção honrosa'.

Fundamentado em uma ampla diversidade de fontes primárias e dialogando com vasta bibliografia, esta obra é, além de um exemplar livro de História do Brasil, uma contribuição metodológica ímpar para aqueles interessados em estudar a interface entre história, saúde e ciência. Isto porque, dominando com maestria referências teóricas, bibliografia e fontes, e exercitando com estilo a escrita da História, este trabalho é, ao mesmo tempo, um estudo sobre história da medicina, história das doenças e história da saúde pública no Brasil republicano.

Outra qualidade digna de nota é o texto. Apesar do rigor acadêmico, a narrativa da autora nem por isto utiliza-se do recurso que confunde escrita científica com esoterismo semântico. Ao contrário: o texto prima pela clareza da exposição e, quando conceitos e considerações teóricas se fazem necessários, estão perfeitamente integrados na narrativa na qual interagem informações e explicações, sem que se perca de vista a preocupação com a temporalidade que, afinal de contas, é traço fundamental do ofício do historiador.

A publicação de Doença de Chagas, Doença do Brasil é, sem dúvida, uma grande oportunidade de difundir este belo trabalho que, com certeza, é uma referência no campo de estudos da história da ciência e da saúde pública no país.

André Luiz Vieira de Campos Doutor em história pela Universidade do Texas, professor associado do Departamento de História da Universidade Federal Fluminense (UFF) e professor adjunto do Departamento de História da Universidade do Estado do Rio de Janeiro (Uerj). 


\section{Apresentação}

O presente livro é a versão modificada de minha tese de doutorado em história social, realizada, sob a orientação de André Luiz Vieira de Campos, na Universidade Federal Fluminense (UFF), entre 2001 e 2006. Ele trata da história dos conhecimentos e das ações que definiram e tornaram reconhecida a doença de Chagas como objeto médico-científico e problema de saúde pública no Brasil, num processo que envolveu estreitamente ciência, saúde e concepções sobre a nação.

A tripanossomíase americana foi descoberta em 1909 por Carlos Chagas, médico e pesquisador do Instituto Oswaldo Cruz (IOC), também conhecido como Instituto de Manguinhos. Trata-se de uma enfermidade endêmica causada pelo protozoário Trypanosoma cruzie transmitida por um inseto hematófago, da subfamília Triatominae, popularmente conhecido no Brasil como barbeiro (vinchuca, em países de língua hispânica). ${ }^{1}$ Os reservatórios naturais do T. cruzi, ou seja, seus hospedeiros no ambiente silvestre, são mamíferos, como gambás, tatus, morcegos, macacos e roedores. Nestes animais, os barbeiros adquirem o parasito que transmitem aos seres humanos. No ambiente doméstico, cães e gatos são reservatórios do protozoário. Os barbeiros podem ser encontrados em fendas de pedras, ninhos de aves, tocas de mamíferos ou sob cascas secas de troncos de árvores. Originalmente vivendo no ambiente silvestre, estes insetos 
'colonizam' o domicílio humano tanto em função da escassez de alimento em seu ambiente natural (situação provocada, por exemplo, pelo desmatamento) quanto pela tendência em buscar ambientes estáveis e que sejam fontes permanentes de alimento (Diotaiuti, 2007).

Pesquisas em paleoparasitologia indicam que a infecção pelo T. cruzi remonta aos primórdios da presença humana nas Américas. As evidências mais antigas da infecção foram encontradas em múmias no Peru com datação de 9.000 anos e, no Brasil, num corpo mumificado datado de 7.000 anos. A primeira hipótese para a origem e a dispersão da infecção chagásica era a de que ela teria surgido na região andina, quando, com a adoção de hábitos sedentários, a criação de pequenos animais (como roedores) no interior das habitações atraiu triatomíneos silvestres, que passaram a se alimentar do sangue dos humanos e dos animais domésticos. A partir daquela região, correspondente ao atual território boliviano, a infecção teria se dispersado pelo continente, com o comércio e a circulação das populações. Esta hipótese foi revista em meados da década de 1990, quando pesquisas utilizando técnicas de biologia molecular identificaram material genético do parasito em corpos mumificados fora da região dos Andes, cuja datação era anterior à introdução de hábitos sedentários e à domesticação de animais. Assim, acredita-se que a infecção remonta ao contato de caçadores/coletores em seu convívio com mamíferos reservatórios do parasito e com insetos vetores, antes de sua domiciliação (Araújo, Sabroza \& Ferreira da Silva, 2007).

O ciclo de vida do T. cruzi se inicia quando o barbeiro, ao alimentar-se do sangue do hospedeiro vertebrado, elimina, em suas fezes e urina, formas alongadas do parasito. Penetrando no organismo por meio de mucosas ou por ferimentos na pele, elas infectam células do hospedeiro, como as do coração. No interior destas, o parasito ganha forma arredondada, multiplicando-se por divisão binária. Quando as células estão repletas de parasitos, eles novamente mudam de forma e, com a ruptura da célula hospedeira, disseminam-se pela corrente sangüínea, infectando novos tecidos e órgãos. Se o indivíduo ou animal infectado é picado pelo barbeiro, os parasitos em seu sangue podem ser transmitidos ao inseto. No intestino deste, assumem nova forma, multiplicam-se e tornam-se, novamente, formas infectantes, eliminadas com as fezes e a urina do inseto.

$\mathrm{Na}$ fase aguda da infecção chagásica, de curta duração (entre três e oito semanas), os sintomas mais comuns são febre, ingurgitamento dos gânglios linfáticos, aumento do baço e do fígado e inflamação no local de 
entrada do parasito no organismo, mas a maioria dos casos não apresenta sintomas evidentes. Neste período, em que é possível identificar grande número de parasitos no sangue e nos órgãos afetados, a infecção pode ser fatal em crianças de baixa idade ou em indivíduos imunocomprometidos. A grande maioria dos infectados evolui para a fase crônica, dos quais a maior parte permanece assintomática (na chamada fase indeterminada) por anos ou mesmo décadas. Os que vêm a manifestar a doença crônica apresentam alterações cardíacas e/ou digestivas. A cardiomiopatia chagásica crônica é a mais freqüente e pode resultar em morte.

A transmissão se dá, principalmente, por intermédio do vetor, em cujas fezes e urina se encontram as formas infectantes do parasito. A infecção é prevalente, sobretudo, nas áreas rurais, porque o inseto abriga-se nas frestas das paredes de barro e em outros 'esconderijos' das chamadas 'cafuas' (casas de pau-a-pique). ${ }^{2}$ Outras formas de transmissão são a transfusional e a congênita (por meio da placenta). A transmissão por transfusão de sangue assumiu particular relevância com o aumento das migrações em direção aos centros urbanos. O controle rigoroso dos bancos de sangue - intensificado com o surgimento da pandemia de Aids na década de 1980 - tornou-se uma medida fundamental de prevenção. A transmissão pode ocorrer ainda por acidente de laboratório, transplante de órgão e ingestão de bebidas/alimentos acidentalmente contaminados com barbeiros infectados, mas estes são episódios com pouco significado epidemiológico.

O primeiro inquérito sorológico nacional realizado no Brasil, entre 1975 e 1980, apontou que havia risco de transmissão vetorial em 36\% do território nacional, com barbeiros domiciliados em 2.493 municípios, em 18 estados. A prevalência da infecção na população rural do país foi estimada em 4,2\%, com coeficientes mais altos em Minas Gerais $(8,8 \%)$, Rio Grande do Sul $(8,8 \%)$, Goiás $(7,4 \%)$ e Bahia $(5,4 \%)$ (Vinhaes \& Dias, 2000: 8).

Segundo estimativas recentes, a doença de Chagas atinge entre $12 \mathrm{e}$ 15 milhões de pessoas em 18 países endêmicos na América Latina; por volta de 28 milhões encontram-se sob risco de contrair a infecção. No Brasil, João Carlos Pinto Dias assinala que a maioria (cerca de 70\%) dos portadores da infecção vive nas cidades, em função das migrações internas das últimas décadas (Dias, 2007; Dias, Prata \& Correia, 2008).

A primeira campanha de profilaxia no Brasil foi inaugurada em 1950, na cidade de Uberaba, Triângulo Mineiro. Desde então, a principal 
forma de controle da doença tem sido o combate químico aos vetores, mediante o uso de inseticidas piretróides aplicados nas habitações e nos seus anexos. Associada a esta medida, preconiza-se a realização de melhorias nas habitações, de modo a impedir a infestação pelos barbeiros. A partir da década de 1980, quando teve início o Programa Nacional de Controle da Doença de Chagas, a borrifação sistemática de inseticidas e a seleção obrigatória dos doadores de sangue fizeram reduzir substancialmente a transmissão da infecção no país. A Iniciativa do Cone Sul - programa de cooperação entre governos da Argentina, do Brasil, do Chile, do Uruguai, do Paraguai, da Bolívia e do Peru, firmado em 1991 sob a chancela da Organização Pan-Americana da Saúde (Opas) e que cobre uma área onde se situam mais de dois terços dos portadores de doença de Chagas nas Américas - foi decisiva para a implementação e a reprodução de políticas de controle da doença no continente. As diretrizes fundamentais eram interromper a transmissão vetorial por meio da eliminação do Triatoma infestans (principal vetor da doença no Cone Sul), controlar outras espécies vetoras nas regiões endêmicas e interromper a transmissão transfusional por meio da triagem sorológica dos doadores de sangue (Dias \& Schofield, 2007).

Em 2006, o Brasil recebeu, da Organização Mundial da Saúde (OMS), o certificado de eliminação da transmissão da doença de Chagas pelo T. infestans (Organización Mundial de la Salud/Programa Especial de Investigaciones y Enseñanzas sobre Enfermedades Tropicales-TDR, 2007). De todo modo, alertam os especialistas, a doença de Chagas deve ainda ser considerada um importante problema de saúde pública do continente. A vigilância epidemiológica e as ações de controle precisam ser mantidas e reforçadas, de modo a possibilitar a destruição de focos residuais do T. infestans e a evitar os riscos de que outras espécies de barbeiros (como o Triatoma brasiliensis, ocorrente no Nordeste) possam deixar o ambiente silvestre e 'colonizar' as moradias. A questão socioambiental merece especial atenção, já que a presença do vetor junto aos seres humanos está relacionada ao desmatamento e à precariedade das habitações. Além disso, apesar de controlada a transmissão vetorial, a doença segue sendo motivo de preocupação, tendo em vista, sobretudo, a necessidade do diagnóstico e da assistência aos portadores da infecção. ${ }^{3}$

A terapêutica da doença - para a qual não há vacina - se divide entre o tratamento voltado para os sintomas e o tratamento específico, que busca eliminar o parasito. Quanto ao primeiro, os avanços em 
cardiologia, como o implante de marca-passos, o uso de desfibriladores e de drogas antiarrítmicas, foram de grande valia para gerar mais conforto e sobrevida aos portadores da cardiopatia chagásica. Uma perspectiva promissora, que já vem apresentando resultados positivos, é o recurso à terapia com células-tronco, visando à recuperação funcional do coração dos pacientes. Quanto ao tratamento com drogas tripanossomicidas, o benzonidazol e o nifurtimox, desenvolvidos no final da década de 1960 e início da década de 1970, foram amplamente utilizados por pesquisadores e médicos, especialmente no Brasil, no Chile e na Argentina, sendo os melhores resultados obtidos em pacientes na fase aguda, especialmente crianças. Contudo, eles causam vários efeitos colaterais e não são eficazes para os casos crônicos (Coura \& Cançado, 2007). Outro problema apontado pelos especialistas é a falta de interesse, por parte da indústria farmacêutica, em desenvolver novas drogas para uma doença que afeta sobretudo a população de baixa renda em algumas regióes da América Latina (Dias, 2007). Atualmente, a busca por alternativas inclui testes com medicamentos usados para outras enfermidades ou que sejam específicos para moléculas do T. cruzi.

As pesquisas e ações públicas sobre a doença de Chagas vêm mobilizando, desde 1909, gerações de médicos, pesquisadores, profissionais da saúde, governos e organizações internacionais, conformando uma das mais expressivas tradições de ciência no Brasil. Refletir sobre a dimensão histórica e social deste processo, no qual este fato científico foi sendo produzido e validado em estreita relação com vários grupos e esferas da vida social brasileira, é o objetivo central deste livro. São focalizados dois momentos decisivos nesta trajetória. Em primeiro lugar, a fase que abrange as pesquisas de Carlos Chagas, entre 1909 e 1934 (ano de seu falecimento), durante a qual foram formulados os primeiros enunciados sobre a doença e também intensas críticas sobre sua caracterização clínica e importância social. O segundo momento diz respeito ao período compreendido entre 1935 e o início da década de 1960, quando os discípulos de Chagas no IOC deram continuidade às pesquisas sobre o tema e produziram novos conhecimentos e ações para que se alcançasse um consenso básico em torno da doença, tanto como entidade nosológica específica quanto como problema a ser incluído na pauta das políticas estatais de saúde.

O livro é composto de nove capítulos. No primeiro, sob uma perspectiva que considera as descobertas científicas eventos socialmente circunscritos e endossados, serão analisadas as condições teóricas, 
institucionais e sociais que propiciaram a descoberta da nova tripanossomíase humana e os sentidos que lhe foram conferidos como 'grande feito' da ciência nacional. Após um breve panorama dos estudos sobre a 'patologia tropical' no Brasil durante o século XIX, acompanharei a formação médica de Carlos Chagas, entre 1897 e 1903. Tal período foi vivido, no cenário internacional e no Brasil, como divisor de águas no pensamento médico, em função das novas teorias da microbiologia e da medicina tropical, que ganharam significados e implicações particulares no contexto sanitário e político da capital federal. Serão identificados, assim, os parâmetros teóricos e a visão a respeito da ciência que norteariam Chagas em seus primeiros trabalhos e que seriam determinantes tanto para a descoberta quanto para a produção dos conhecimentos sobre a nova doença. Serão abordados, também, os primeiros anos da trajetória profissional de Chagas, dedicados ao estudo e à profilaxia da malária (1903-1908), bem como a descoberta de 1909, apontando-se a centralidade que esta assumiu no processo de construção e consolidação institucional de Manguinhos. Investigando as características cognitivas e sociais do processo da descoberta, apontarei os sentidos e caminhos que este próprio processo impôs ao desenho da enfermidade erigido a partir de então.

No segundo capítulo, será examinada a primeira fase das pesquisas desenvolvidas por Chagas e seus colaboradores, no IOC, entre 1910 e 1913, quando foram produzidas as primeiras formulações sobre a caracterização clínica e a importância médico-social da 'nova entidade mórbida'. Analisando as publicações e conferências de Chagas, acompanharei as estratégias discursivas e retóricas pelas quais tais enunciados foram estabelecidos e apresentados junto à comunidade médica e ao público mais amplo. Defendo o argumento de que foi no contexto particular de produção deste fato científico que Carlos Chagas formulou a noção, que a partir de 1916 ganharia projeção no âmbito do chamado movimento sanitarista, de que as endemias rurais constituíam um dos grandes obstáculos ao progresso do país, a serem enfrentados pelos poderes públicos. A idéia de um 'país doente' nascia ao mesmo tempo que o laboratório delineava os traços clínicos desta enfermidade particular, proclamada como um fator de 'degeneração' física e mental das populações do interior do país. A nova tripanossomíase humana, descrita sob os marcos teóricos da medicina tropical européia, conformava-se, assim, como doença nacional, com sentidos próprios ao contexto da modernização brasileira do início do século XX. 
No terceiro capítulo, tratarei das primeiras críticas feitas aos enunciados sobre a nova doença, apresentadas entre 1915 e 1916 por pesquisadores na Argentina, e que puseram em dúvida aspectos centrais do desenho clínico proposto por Chagas (como a caracterização como afecção endócrina), bem como suas teses sobre a relevância social e epidemiológica da tripanossomíase. Estas críticas conduziram a uma revisão no arranjo geral pelo qual Chagas estabelecia a fisionomia clínica da doença, esboçando-se uma reorientação nos caminhos da investigação, que levaria a uma progressiva proeminência dos elementos cardíacos na definição clínica da enfermidade. No Brasil, os aspectos que vinham sendo questionados na Argentina - como a correlação com o bócio e com as desordens neurológicas - foram reforçados, pela força simbólica que possuíam como signos de dramaticidade da 'doença do Brasil', no debate político mais amplo promovido, entre 1916 e 1920, pelos partidários do movimento pelo saneamento dos sertões.

No quarto capítulo, focalizarei a polêmica que envolveu a doença de Chagas a partir de 1919 e que culminaria em intenso debate na Academia Nacional de Medicina entre 1922 e 1923. Alguns médicos brasileiros, partindo dos questionamentos feitos na Argentina, confrontaram diversos aspectos das pesquisas de Chagas. Negaram a dimensão epidemiológica e social atribuída à doença, apontando a escassez dos casos considerados efetivamente diagnosticados, questionaram a patogenicidade do T. cruzi e atribuíram a descoberta deste parasito a Oswaldo Cruz. Acompanhando de perto a controvérsia, apontarei em que medida os argumentos de natureza científica estiveram intimamente imbricados com fatores políticos, relativos a disputas, tensões e divergências na maneira pela qual se encaminhava o debate em torno da relação entre doença, medicina tropical e identidade nacional no país. Discutindo as interpretações propostas por médicos memorialistas e pela historiografia sobre este episódio, reconhecido como divisor de águas na trajetória da tripanossomíase por ter levado a um processo de 'esquecimento' só revertido após a morte de seu descobridor, defenderei que os sentidos e impactos da polêmica devem ser compreendidos em referência ao próprio processo de construção e estabilização deste fato científico. Analisarei, ainda, os estudos sobre a doença realizados por Chagas até seu falecimento, em 1934, e os desafios e rumos percebidos como necessários para superar as dúvidas que, desde as controvérsias na Argentina e, sobretudo, depois de 1923, pairavam sobre a realidade clínica e social da tripanossomíase americana. 
No quinto capítulo, tratarei das novas condições políticas e sociais que garantiram a continuidade das pesquisas sobre este tema no IOC, num momento em que este redefinia seus vínculos com o campo da saúde pública, no bojo das transformações por que passaram a sociedade e o Estado brasileiro a partir de 1930. Serão indicadas distintas dimensões contextuais que propiciaram a reconfiguração do estudo das endemias rurais no IOC. O projeto político e econômico de modernização do governo de Getúlio Vargas, pelos significados que conferia ao tema do trabalho e da modernização agrícola, ensejou novas perspectivas de legitimação a ações destinadas a melhorar as condições de saúde do homem do campo, ao mesmo tempo que, para empreendê-las, garantiu novas condições operacionais no âmbito do então criado Ministério da Educação e Saúde. Além disso, a Segunda Guerra Mundial, sobretudo pelo surgimento de novos recursos técnicos para o controle das doenças infecciosas, conferiu grande visibilidade às discussões sobre a relação entre saúde e desenvolvimento e propiciou uma nova inserção de Manguinhos no campo da saúde pública. Foi sob tais condições que, no início da década de 1940, criou-se, como posto aplicado do IOC, o Centro de Estudos e Profilaxia da Moléstia de Chagas (CEPMC), em Bambuí, Minas Gerais, que será estudado mais detidamente em seguida.

No sexto capítulo, serão enfocadas as investigações sobre a tripanossomíase americana nos anos que se seguiram ao falecimento de Carlos Chagas, a começar pelos estudos realizados pela Misión de Estúdios de Patología Regional Argentina (Mepra), chefiada por Salvador Mazza, que levaram à identificação de centenas de casos agudos em diversos países do continente americano e no Brasil. Das contribuições da Mepra, destacarei a orientação de pesquisa que incorporava os clínicos das áreas rurais na disseminação e na própria produção dos conhecimentos sobre a doença, tornando-os elementos decisivos para seu fortalecimento como fato científico e social. No Brasil, o Serviço de Estudo das Grandes Endemias (Sege), criado no IOC em 1937 pelo filho mais velho de Chagas, Evandro Chagas, inspirou-se nesta diretriz e deu continuidade aos estudos sobre a tripanossomíase americana, conduzindo à descrição de um importante foco da doença em Bambuí, onde seria instalado o CEPMC em 1943.

O programa de pesquisas do CEPMC, em suas duas grandes frentes - o desenvolvimento de técnicas de profilaxia e o estudo clínico da doença - será objeto do sétimo capítulo. No contexto da Segunda Guerra 
Mundial, em que se imprimiu grande impulso à perspectiva de combate aos vetores por meio de inseticidas (especialmente com o uso do DDT), Emmanuel Dias, diretor do posto, realizou uma série de experimentos até identificar, em 1948, um produto considerado eficaz contra os barbeiros, o gamexane (BHC). No que diz respeito às pesquisas clínicas, serão analisados os recursos e elementos que propiciaram a definição e o reconhecimento da doença como enfermidade crônica essencialmente cardíaca, socialmente importante por prejudicar a capacidade produtiva de suas vítimas. Este processo envolveu a mobilização de novos esquemas interpretativos e recursos técnicos, referidos à experiência clínica em cardiologia (especialidade que se institucionalizava, naquele momento, no Brasil), bem como novos procedimentos persuasivos. O redirecionamento da pesquisa para o domínio da clínica foi decisivo para que os conhecimentos produzidos pelo CEPMC viessem a proporcionar um novo consenso básico em torno da materialidade e da especificidade clínica da doença de Chagas. Tendo em vista a questão das diferenças e das continuidades em relação às pesquisas e enunciados de Chagas, discutirei os sentidos desta contribuição, qualificada pelos próprios cientistas e pela memorialística médica como tendo propiciado as 'provas' necessárias para afastar as dúvidas e estabelecer a 'reconstrução' do interesse pela doença.

No oitavo capítulo, pretendo mostrar que este novo consenso sobre a definição clínica e a importância social da doença de Chagas viabilizou-se mediante uma intensa mobilização por parte dos cientistas vinculados ao CEPMC, em especial seu diretor, no sentido de difundir, para além dos círculos estritos da ciência, os novos conhecimentos sobre o tema, conquistando o interesse de outros atores sociais. Dentre estes, destacaram-se os chamados clínicos do Brasil Central, que fizeram da doença um símbolo de sua própria identidade socioprofissional como conhecedores dos males do interior do país. No contexto do pós-guerra, em que, no mundo e no Brasil, eram comemoradas novas perspectivas para a vitória contra as ‘doenças de massa' e a importância da saúde como fator de desenvolvimento assumia proeminência no planejamento da modernização, esta mobilização conduziu, em 1950, à primeira campanha de profilaxia contra a tripanossomíase americana. Iniciada em Uberaba, Minas Gerais, foi realizada sob a orientação técnica do CEPMC e implementada por um dos mais importantes orgãos do Ministério da Educação e Saúde - o Serviço Nacional de Malária. 
Finalmente, no nono capítulo, será traçado um panorama dos principais caminhos pelos quais, ao longo da década de 1950, o tema da doença se institucionalizou como objeto de novos grupos científicos e das políticas de saúde pública no país. Continuando a acompanhar a movimentação de Emmanuel Dias neste processo, observarei os diversos espaços e estratégias mediante os quais, no Brasil e no exterior, ele e outros pesquisadores vinculados ao CEPMC disseminaram os conhecimentos clínicos sobre a cardiopatia chagásica e buscaram novos aliados para a idéia de que sua profilaxia deveria ser uma prioridade nas políticas sanitárias mediante campanhas de erradicação de seu transmissor. Sob o otimismo internacional de um mundo em reconstrução e sob o intenso debate nacionalista, no Brasil, em torno das perspectivas do desenvolvimento, aprofundavam-se as discussões sobre como romper o chamado 'círculo vicioso da doença e da pobreza' e sobre o lugar da saúde como parte de planos mais amplos de reforma social. Neste contexto, a tradição de pesquisa iniciada por Chagas ganhou novos espaços de reprodução, no campo da ciência (como nas faculdades médicas criadas no interior do país) e da saúde pública (como nos organismos sanitários nacionais e internacionais).

Antes de convidar o leitor a seguir por este percurso, gostaria de registrar meus agradecimentos àqueles que propiciaram ou colaboraram, de alguma maneira, para a realização deste livro. Em primeiro lugar, agradeço a André Luiz Vieira de Campos, pela atenção e confiança com que me orientou durante a elaboração da tese.

Aos professores Silvia Figueirôa, Jaime Benchimol, Angela de Castro Gomes e Magali Engel, que compuseram minha banca de doutorado, sou grata pelas sugestões que me auxiliaram a aprimorar o trabalho.

À Casa de Oswaldo Cruz (COC) agradeço pelas amplas condições proporcionadas para que eu desenvolvesse este estudo, condições preciosas e raras no cenário acadêmico brasileiro. Agradeço o apoio de meus colegas do Departamento de Pesquisa, especialmente Wanda Hamilton, Maria Rachel Fróes da Fonseca, Cristina Fonseca, Flavio Edler, Marcos Chor Maio, Angela Porto e Robert Wegner. Sou grata, especialmente, a Magali Romero Sá, pela parceria em projetos sobre a história da medicina tropical no Brasil; a Nísia Trindade Lima e a Dominichi Miranda de Sá, com quem compartilho o encanto pelos sertões e vários interesses intelectuais; e a Nara Azevedo e Luiz Otávio Ferreira, que me propiciaram o ingresso na pesquisa sobre a história da doença de Chagas e nas questões da história e da sociologia da ciência. 
A outros profissionais da COC, registro igualmente meus agradecimentos: a Sheyla Lacerda e colegas da secretaria do Departamento de Pesquisa; a Jean Maciel e Rose Oliveira, da sala de consulta do Departamento de Arquivo e Documentação; à equipe da biblioteca, particularmente Wanda Weltman; e à equipe do arquivo iconográfico da COC, em especial Roberto Jesus Oscar.

Entre os muitos médicos que entrevistei, agradeço ao dr. João Carlos Pinto Dias, doador do arquivo constituído por seu pai, Emmanuel Dias, no CEPMC em Bambuí, precioso material de pesquisa que utilizei neste trabalho. Foi uma honra ouvi-lo em seu valioso depoimento e em outras conversas sobre Carlos Chagas e seus seguidores. Ao dr. Anis Rassi, que com muita solicitude deu-me algumas aulas de cardiologia da doença de Chagas, agradeço o esclarecimento das muitas dúvidas que enfrentei ao aventurar-me neste fascinante campo do conhecimento médico. E, muito especialmente, ao dr. Joffre Marcondes de Rezende, que com sua gentileza bem-humorada disse que eu havia sido 'inoculada' com a paixão pela história de Carlos Chagas e que, para este mal, não há cura... Ao querido dr. Joffre - que, depois de tantas conversas, tornou-se um grande amigo agradeço pela enorme disponibilidade em responder às minhas muitas perguntas e em acompanhar a realização deste trabalho. Este médico goiano, tão importante na história da doença de Chagas e da medicina brasileira, ajudou-me a compreender os sentidos da tradição que uniu os pesquisadores de Manguinhos aos médicos do Brasil Central, numa bela aproximação entre litoral e interior.

Desde que defendi a tese, em 2006, tenho tido o privilégio de conviver com vários profissionais da Fundação Oswaldo Cruz envolvidos na comemoração do centenário da descoberta da doença de Chagas. A Maria de Nazaré Soeiro e a Joseli Lannes Vieira, pesquisadoras do IOC e do Programa Integrado de Doença de Chagas da Fiocruz, agradeço a oportunidade deste rico diálogo entre a história e a área biomédica. Lisabel Klein, em sua incansável dedicação às múltiplas ações institucionais para a preservação da memória de Carlos Chagas e de outros personagens da história da Fiocruz, tem sido uma companheira constante.

Registro ainda meus agradecimentos aos que, fora do domínio profissional, proporcionaram-me apoios fundamentais no percurso que gerou esta publicação. Minha amiga-irmã Kátia Lerner, que viveu, na mesma época que eu, a experiência de ser 'mãe fazendo tese', compartilhou comigo os sentimentos, medos e alegrias que isso significa. A meu avô 
Francisco Petraglia, a minha avó Renée e a minha tia-avó Nadyr, in memoriam, agradeço por terem me ensinado, desde cedo, o gosto pelo relato dos tempos passados. A minha prima-avó Neusa Feital Wörhle, pioneira da educação no Brasil recentemente falecida em seus 90 e poucos anos, sou grata pelo apoio para que eu seguisse esse caminho do saber que ela própria trilhou numa época em que eram poucas as mulheres que a isso se aventuravam. A meus pais e a meu irmão, obrigada pelo carinho e pelo apoio de sempre.

A Gilberto Hochman, um registro mais do que especial. Com ele dividi os passos deste caminho profissional, minhas questões, minhas dúvidas, meu entusiasmo, e dele recebi preciosos apoios no sentido intelectual, no sentido afetivo e também nos sentidos mais corriqueiros de uma vida compartilhada. Ao meu querido Gil, expresso meu amor e a feliz constatação de que, mesmo sem termos subido ao altar, temos honrado o juramento de que nosso casamento seja para sempre, "na saúde e na doença... de Chagas".

Finalmente, acima de tudo, agradeço à minha filha, Ana Clara, minha tão amada Aninha, sentido maior de minha vida. Graças a ela, eu pude realizar este trabalho com muita alegria, entre cantigas de roda, brinquedos e programas do Discovery Kids.

\section{Notas}

1 As informações sobre a doença aqui apresentadas foram obtidas, fundamentalmente, nos textos que compõem o Portal Doença de Chagas (Programa Integrado de Doença de Chagas da Fiocruz, 2007). Ver também: Brasil (2005); Organización Mundial de la Salud/Programa Especial de Investigaciones y Enseñanzas sobre Enfermedades Tropicales-TDR (2007), World Health Organization (2007); Pan American Health Organization (2007); Dias (2007), Dias, Prata e Correia (2008).

2 Termo usado para designar as habitações rústicas, de pau-a-pique, típicas das áreas rurais, feitas com paredes barreadas, sem revestimento de piso e com cobertura de capim ou de telha.

3 Para uma análise sobre os desafios e as perspectivas do enfrentamento da endemia chagásica num contexto internacional de iniqüidade e globalização, ver Dias (2007). 


\section{Introdução}

Em 1958, enquanto o traço de arquitetos modernistas riscava, no Brasil Central, os contornos do que se esperava ser a nova capital do desenvolvimento, um médico goiano lamentou a triste sorte dos trabalhadores do interior do país, acometidos pela doença de Chagas, descoberta quase cinqüenta anos antes, nos sertões de Minas Gerais.

Vis insetos, párias do campo,

Dizimadores em série do meu povo.

Apetrechos que não desintegram o núcleo

Mas bombardeiam impiedosamente

Aqueles que mais trabalham.

Claudica a enxada que mal se erguia;

As pernas bambas cruzam com os caules tenros

Para que uma safra de cruzes

Preceda a colheita do trabalho.

Quando a lavoura encurta sem miopia

$\mathrm{E}$ o ar que falta não se renova,

As noites sucedem em pleno dia

Nas várias fugas da consciência.

Bate no peito, lenta revolta,

Na luta pelo pão que estanca. 
O 'avexume'1 é agonia eterna

Nascido no sereno desejo de viver.

Oh! Deus do Brasil, do mundo ou de Goiás!

Atentai ao crime perpetrado

E fazei nascer nos semimortos

A esperança de sol e de tratores!

(Carneiro, 1958: 196) ${ }^{2}$

Em abril de 1909, no pequeno povoado de Lassance, em Minas Gerais, Carlos Chagas, médico e pesquisador do Instituto Oswaldo Cruz (IOC) ou Instituto de Manguinhos, identificou uma nova doença humana, causada por um protozoário até então desconhecido (uma nova espécie de tripanossoma, denominada por ele Trypanosoma cruzi, em homenagem a Oswaldo Cruz), e transmitida por um inseto hematófago popularmente conhecido como 'barbeiro', muito comum no interior das casas de pau-apique típicas da população pobre das áreas rurais do Brasil. A tripla descoberta - realizada, nos marcos da medicina tropical, sob a seqüência incomum de se partir do encontro do vetor e do parasito para, em seguida, identificar a infecção humana - foi comemorada como uma das maiores proezas da ciência nacional. Ela tornou-se a principal vitrine do projeto de Oswaldo Cruz para criar, na então capital federal, um centro de excelência em medicina experimental. À elucidação dos elementos clínicos e de outros aspectos da nova tripanossomíase, Chagas e outros pesquisadores de Manguinhos dedicariam suas carreiras profissionais.

Nos versos citados de Omar Carneiro, trata-se de uma enfermidade que ataca o coração dos trabalhadores rurais e, numa evolução lenta, silenciosa e progressiva, esgota a capacidade produtiva de suas vítimas, levando-as à morte, muitas vezes subitamente. Num país que, na década de 1950, estava em plena 'marcha para o interior', as metáforas associadas àquele órgão vital faziam-se particularmente eloqüentes e reforçavam a dimensão simbólica de uma doença cardíaca que sintetizava a nação no diagnóstico de suas mazelas - as "pernas bambas" do homem do campo e no receituário de sua redenção: uma "esperança de tratores" para a "colheita do trabalho".

Em 1918, num outro contexto em que o interior do Brasil projetou-se na cena pública, o escritor Monteiro Lobato (1956: 240-243) também denunciou "o monstruoso quadro patológico que [Carlos Chagas] entrevira na paisagem rude dos sertões à guisa de um círculo inédito de 
Dante" como o emblema de um país que se constituía como "um gigantesco hospital". Também ele clamou pela recuperação dos "braços aleijados" da lavoura brasileira e indicou a ciência e o saneamento como soluções. Contudo, conforme os primeiros estudos de seu descobridor, esta era uma doença caracterizada, fundamentalmente, por distúrbios endócrinos e neurológicos. Apesar de serem apontados aspectos cardíacos, reconheciam-se como seus principais sinais clínicos o aumento anormal da tireóide (bócio ou 'papeira'), paralisias, retardo no desenvolvimento físico e "uma escala de depressões mentais oscilantes entre o simples aparvalhamento e o cretinismo completo" (Lobato, 1956: 240). As vítimas da doença de Chagas eram, nas palavras do criador do Jeca Tatu, "idiotas e papudos" (Lobato, 1956: 239).

Se as citações de Omar Carneiro e de Monteiro Lobato expressam diferenças na definição clínica da enfermidade, elas se aproximam na sua caracterização como problema sanitário de dimensão nacional, por prejudicar a produtividade do trabalho agrícola e, conseqüentemente, $\mathrm{o}$ progresso do país. Entretanto, também neste aspecto, nem sempre houve acordo. Chegou-se a afirmar que se tratava de um mal menor, restrito a um punhado de doentes na região em que fora descoberta. Como se deu o percurso pelo qual a "nova entidade mórbida" (Chagas, 1909d) descrita por Carlos Chagas foi estabelecida e aceita como 'fato científico', uma entidade nosológica definida e individualizada por características clínicas e patogênicas peculiares? Como se produziu o reconhecimento social de que se tratava de uma questão de relevância para a saúde pública? Em que medida se pode considerar esta doença um produto da história? Estas são as perguntas que motivam este livro, sob o argumento geral de que, desde o início daquele percurso, a doença de Chagas foi construída, ao mesmo tempo, como fato científico e fato social.

No plano teórico, tais questões estão referidas à questão central que inspirou as novas abordagens propostas para a sociologia e a história da ciência, a partir da década de 1970, pelo chamado Programa Forte da Sociologia do Conhecimento Científico: é possível analisar a dimensão histórico-social dos fatos científicos não apenas no que diz respeito às 'circunstâncias' que envolveram sua produção (ou aos significados que lhes foram atribuídos), mas também no que se refere aos 'conteúdos' dos conhecimentos que os definiram como tal? Qual a dimensão social dos processos pelos quais o conhecimento científico é produzido, transmitido, se estabiliza e muda ao longo do tempo (Bloor, 1991: 5)? 
Criado em Edimburgo por David Bloor e Barry Barnes, o Programa Forte filiava-se à perspectiva pioneira de Ludwig Fleck (que, em 1935, afirmou que os fatos da ciência não eram meros construtos formais, mas produtos de pensamentos e práticas coletivas) e, mais diretamente, à nova amplitude que esta perspectiva viria a encontrar nas formulações de Thomas Kuhn. O livro A Estrutura das Revoluções Científicas, publicado em 1962, tornou-se um marco na história das ciências ao postular, com base no conceito de paradigma, a natureza convencional do conhecimento científico e a noção de que a ciência é uma atividade indissociavelmente sociocognitiva, produzida por coletividades concretas e historicamente situadas, do ponto de vista tanto de sua organização social quanto dos esquemas interpretativos compartilhados para dar sentido ao mundo e à natureza. Assim, a chamada Escola de Edimburgo pretendia estender para o domínio da ciência a tese proposta por Karl Mannheim, com base na sociologia de Emile Durkheim, de que o conhecimento é um produto histórica e socialmente determinado.

O preceito fundamental desta nova sociologia da ciência - que daria origem a distintas vertentes interpretativas, por muitos englobadas sob a designação de 'estudos sociais da ciência' - foi a idéia de que, como outras formas de elaboração do conhecimento e de representação simbólica, os produtos intelectuais da ciência constituem um sistema de crenças socialmente produzido e sustentado. Fruto dos acordos resultantes de um processo coletivo de negociação, a prática e, sobretudo, os conteúdos da ciência passaram a ser tratados como objetos legítimos para a investigação sociológica. ${ }^{3} \mathrm{O}$ objetivo era superar os limites identificados na sociologia de Robert Merton, que, analisando a ciência em termos das características e das normas peculiares de sua organização institucional, considerava o conhecimento científico como objeto não para os sociólogos, mas para os epistemólogos. O Programa Forte corroborou as críticas feitas por Kuhn à concepção tradicional da filosofia da ciência, segundo a qual este seria um saber epistemologicamente superior, cuja certificação se dava como resultado da aplicação correta de um método racional, ou seja, da lógica interna de seus conteúdos, sendo, portanto, independente de fatores históricos ou sociais. Buscava-se, em suma, transcender as fronteiras que limitavam o acesso dos sociólogos e dos historiadores aos aspectos ditos 'externos' à ciência, reservando seus elementos 'internos' para inquirições no âmbito da lógica e da epistemologia. ${ }^{4}$ 
Estas novas diretrizes teóricas provocaram uma importante reconfiguração no campo dos estudos históricos e sociológicos da ciência, tendo como uma de suas principais implicações o estímulo às investigações empíricas sobre como se produzem concretamente os conhecimentos científicos por grupos sociais específicos, em determinados contextos históricos. Foi a partir desta orientação que surgiram as abordagens do chamado construtivismo social da ciência, como as etnografias de laboratório e os estudos sobre controvérsias científicas, produzidos por Karin Knorr-Cetina, Bruno Latour, Steve Woolgar e Harry Collins. Os trabalhos de Steven Shapin, por sua vez, exemplificam a fecundidade do diálogo estabelecido, no campo da história da ciência, com a perspectiva sociológica do Programa Forte, que veio a reforçar a concepção de que a reconstrução histórica deve ser pautada por conceitos e por teorias capazes de imprimir à narrativa uma dimensão explicativa, que confira aos objetos situados em outras temporalidades uma inteligibilidade para além de sua dimensão contingente. ${ }^{5}$ Para Shapin (1982a), a análise empírica dos casos históricos constitui, por sua vez, uma dimensão fundamental à compreensão sociológica da ciência, pois, se partimos do postulado teórico geral de que ela está relacionada à sociedade na qual é praticada, o desafio é mostrar 'como' e 'por que' esta relação acontece e assume formatos específicos em diferentes temporalidades e espacialidades. ${ }^{6}$

No domínio específico da história da medicina, a discussão sobre a construção social das doenças assumiu grande projeção nas últimas décadas, ainda que nem sempre referida diretamente aos princípios do construtivismo formulados no âmbito dos estudos sociais da ciência. Utilizando perspectivas teóricas diversas, tanto da história social e cultural quanto de outros campos disciplinares, como a antropologia e a sociologia, muitos autores vêm se debruçando sobre os processos pelos quais, num dado contexto histórico-social, indivíduos e grupos atribuem sentidos particulares à experiência da doença e sobre como esta experiência gera conseqüências na organização e na percepção do mundo social (Hochman \& Armus, 2004; Silveira \& Nascimento, 2004). O pressuposto comum a tais trabalhos é a crítica à concepção tradicional de que as doenças são eventos essencialmente biológicos, isentos de injunções culturais ou de atributos sociais, constituindo-se como fatos do mundo da natureza que caberia à medicina 'desvendar' e explicar, desenvolvendo meios eficazes para seu tratamento e sua prevenção. O corolário imediato desta crítica é a afirmação das doenças como objetos historicamente situados. 
Os significados pelos quais elas são reconhecidas, bem como suas implicações na vida dos indivíduos e da sociedade, devem ser compreendidos a partir de múltiplos fatores relacionados ao contexto sociocultural específico no qual ocorrem. Segundo Allan Brandt (1991: 93):

Disease is not a merely biological phenomenon: it is shaped by powerful behavioral, social and political forces. Social values affect both the way we come to see and understand a particular disease and the interventions we undertake". ${ }^{7}$

Ou, como afirma Claudine Herzlich (1995: 151):

(...) illness, health and death are highly 'natural', 'physical' and 'objective' subjects, so that they seem at first to fall outside the realm of social reality; (...) but they are indissolubly linked to social reality in many ways. Illness is first of all a social fact. ${ }^{8}$

Com base neste pressuposto, muitos trabalhos vêm abordando os sentidos sociais atribuídos às doenças em distintos momentos históricos. As epidemias têm sido particularmente privilegiadas, por constituírem situações percebidas como de grande gravidade e impacto na vida social. Assim, são recorrentes as análises que examinam como os significados e estigmas atribuídos às doenças epidêmicas derivam da associação com comportamentos ou práticas socialmente qualificados como 'desviantes' ou das conseqüências que produzem como fatores de desarticulação da ordem econômica, política e cultural (Rosenberg, 1992b; Ranger, 1992).

Uma noção bastante utilizada para caracterizar a doença como construto social tem sido a de que ela se configura como forma de 'representação’ da sociedade. Esta é, por exemplo, a perspectiva seguida no livro organizado por Jacques Le Goff (1991: 8), para quem “a doença pertence não só à história superficial dos progressos científicos e tecnológicos, mas também à história profunda dos saberes e das práticas ligadas às estruturas sociais, às instituições, às representações, às mentalidades”. Segundo Claudine Herzlich (1995: 161), constituindo-se como fenômeno que "requer interpretação", a doença se apresenta como um significante, cujo significado é a relação do indivíduo com a ordem social. É nesse sentido que funciona como metáfora, como acentuou Susan Sontag (1989). ${ }^{9}$ Ou seja, através dela, fala-se de outras coisas: as normas sociais e as maneiras como os indivíduos são vistos em sua relação com estas normas.

Contudo, ao se analisar o aspecto simbólico das enfermidades, muitas vezes sua dimensão como evento biológico é considerada um terreno 
'natural', previamente dado, sobre o qual incidem os significados e as representações sociais. Sob tal perspectiva, se a sociedade está implicada na construção das doenças, isso acontece essencialmente em relação ao entorno de uma realidade orgânica já definida. Com base nas diretrizes teóricas dos estudos sociais da ciência, torna-se possível ampliar estas fronteiras e afirmar que as doenças constituem objetos histórica e socialmente construídos no que diz respeito às maneiras pelas quais indivíduos ou grupos as 'percebem' ou 'respondem' a elas em termos de valores e práticas, mas também no que concerne à sua própria conceituação como entidades biológicas específicas. Em outras palavras, o desafio é analisar como fatores sociais interferem não somente na maneira de se representar, atribuir significados e enfrentar concretamente um fenômeno da natureza, já caracterizado como tal, mas inclusive no processo de definição e aceitação deste fenômeno como realidade orgânica, dotada de características específicas. Trata-se, em suma, da perspectiva de analisar a dimensão social das doenças em seu estatuto de fatos produzidos pela ciência médica. ${ }^{10}$

Acredito que a aproximação entre a história social da medicina e a história social da ciência associada às perspectivas lançadas pelo Programa Forte constitui um caminho promissor para que se possa, mediante o estudo do caso da doença de Chagas, seguir tal perspectiva. ${ }^{11}$ Como eixo para tal aproximação, recorrerei às formulações propostas por Charles Rosenberg. Segundo este historiador da medicina, a noção de que os fenômenos patológicos constituem entidades conceitualmente específicas e ontologicamente reais, tipos-ideais que existem para além da natureza idiossincrática dos distúrbios manifestos em indivíduos particulares, vem assumindo, desde o século XIX (especialmente a partir da institucionalização da bacteriologia), cada vez maior centralidade na maneira pela qual a própria categoria de doença faz sentido e se justifica científica e socialmente. Diz o autor: "In our culture, its existence as specific entity is a fundamental aspect of intellectual and moral legitimacy of disease. If it is not specific, it is not a disease" (Rosenberg, 1992c: 310; grifo do autor). ${ }^{12}$

É exatamente neste processo, pelo qual as categorias do conhecimento médico definem a materialidade e a especificidade das doenças, que se pode dizer que elas são histórica e socialmente constituídas. Como chave conceitual para apreender este movimento, o autor utiliza a noção de framing. ${ }^{13}$ Trata-se da idéia de que uma enfermidade, concebida e 
aceita como entidade nosológica específica, é produto de um 'enquadra mento' a partir de determinados esquemas interpretativos e classificatórios, referidos a contextos histórico-sociais particulares. Ao mesmo tempo que é 'emoldurada', assinala Rosenberg, a doença também gera ações específicas sobre o mundo, constituindo-se ela mesma um frame, um fator estruturante para diversas situações da vida social. Nesse sentido, funciona como força social concreta que orienta o comportamento e a prática dos atores humanos em complexas redes de negociações. Nas duas direções deste movimento, pelos quais a doença é 'emoldurada' como entidade particular e se torna ela própria uma 'moldura' da vida social, existe uma intrincada articulação entre fatores de ordem cognitiva e social. O processo de enquadramento é, como afirma Rosenberg (1992c: 305), resultado de um acordo coletivamente produzido: "In some ways disease does not exist until we have agreed that it does, by perceiving, naming and responding to it". ${ }^{14}$

Ou seja, os esquemas pelos quais a doença é compreendida e explicada, bem como o papel que desempenha como força social, implicam, ao mesmo tempo, maneiras socialmente partilhadas de se conceber as características do evento biológico ao qual ela é referida, bem como certas formas e esforços coletivos de se lidar com este evento. Cabe aos historiadores estabelecer como se articulam, em distintos marcos temporais e espaciais, as dimensões biológica e social desta 'realidade', acentua o autor. ${ }^{15}$

Considerando-se que, a partir de um determinado momento histórico, o saber médico se institucionalizou e se legitimou socialmente como responsável por definir as 'verdadeiras' características biológicas das doenças, uma questão central é acompanhar como este saber atua na construção social das enfermidades. Para Rosenberg, o pensamento e a prática médica constroem socialmente as doenças não apenas porque, ao 'aplicarem' certos esquemas conceituais que as classificam como realidades biológicas (como o paradigma da microbiologia, por exemplo), sancionam determinadas condutas e valores. Isso acontece também no que diz respeito à própria 'formulação' destes frames. Ou seja, se a utilização das teorias e dos modelos médicos é socialmente negociada, também o são os conteúdos que conformam tais esquemas interpretativos, mediante os quais determinadas ocorrências físicas são classificadas como 'sinais' de uma dada entidade nosológica. É no âmbito deste processo que o ato do diagnóstico assume papel fundamental, como instrumento que nomeia e 
garante especificidade às doenças. Ao colocar em ação um conjunto de procedimentos, aparelhos e registros técnico-científicos tidos como objetivos e inquestionáveis, o diagnóstico materializa a crença coletiva e a aprovação social indispensáveis para que tais entidades existam, bem como a autoridade daqueles que produzem os conhecimentos que as desenham. Diz Rosenberg (2002: 240):

Diagnosis is central to the definition and management of the social phenomenon that we call disease. It constitutes an indispensable point of articulation between the general and the particular, between agreed-upon knowledge and its application. (...) Diagnosis labels, defines, and predicts and, in doing so, helps constitute and legitimate the reality that it discerns. ${ }^{16}$

Ao enfatizar a dimensão sociocognitiva dos processos pelos quais o conhecimento médico produz o enquadramento das doenças, a perspectiva teórica de Rosenberg converge com as diretrizes teórico-metodológicas dos estudos sociais da ciência, especialmente da perspectiva construtivista.

De acordo com Ludmilla Jordanova (1995), um dos fatores que dificultou uma utilização mais consciente e sistemática, por parte dos historiadores da medicina, das ferramentas conceituais do construtivismo social foi a tendência, já referida, de considerar como sujeitos à influência de fatores sociais apenas os aspectos 'externos' da medicina (em geral, associados à prática médica) e não o seu 'núcleo interno', ou seja, as idéias e teorias constitutivas do conhecimento médico. Segundo a autora, somente transcendendo-se a distinção entre fatores internos e externos, conteúdos e contextos, aspectos cognitivos e sociais da medicina, será possível tratá-la como atividade social em todas as suas facetas. ${ }^{17}$

Outra fonte de reservas, por parte dos historiadores da medicina, em relação às teses construtivistas é, como ressalta Jordanova (1995), a preocupação quanto às implicações relativistas destas abordagens. A questão que muitas vezes se coloca é: como pensar a 'realidade' dos fenômenos naturais - no caso, a materialidade biológica das doenças -, uma vez que se considere que os conteúdos do conhecimento médico são determinados socialmente? Ou seja, como evitar uma posição relativista ou idealista radical segundo a qual a noção de 'construção' equivaleria a tratar as doenças como invenções arbitrárias das categorias de pensamento?

No caso de Rosenberg (1992c), a preocupação em não incorrer neste tipo de relativismo - que, segundo ele, marcou uma certa vertente 
historiográfica influenciada, sobretudo, pelas formulações de Michel Foucault -, foi um dos motivos que o levou a evitar o termo 'construção social' e optar pela noção de framing para analisar os processos sociais de conceituação e reconhecimento das doenças. ${ }^{18}$ Para o autor, os historiadores da medicina das décadas de 1960 e 1970, politicamente comprometidos com a crítica às até então inquestionáveis legitimidade e autoridade social da profissão médica, foram particularmente eficazes no questionamento da concepção positivista - que tomava as doenças como entidades 'objetivas', 'neutras' e 'naturais' -, ao afirmarem que, ao contrário, tratava-se de objetos socialmente negociados. Contudo, representando, muitas vezes, mais uma posição política do que epistemológica, os argumentos relativistas foram a partir de então, como acentua Rosenberg, utilizados para negar a efetividade do conhecimento médico e a própria existência concreta e material das doenças. O surgimento da Aids na década de 1980 reforçou as críticas às posições positivistas, mas também colocou a necessidade de se rever o argumento relativista.

Aids could hardly be dismissed as an exercise in stigmatizating the deviant; it obviously had a strong biological component. It was not simply a construction, even if it had been constructed (...). Aids has, in fact, helped to create a new consensus in regard to disease, one that finds a place for both biological and social factors and emphasizes their interaction. ${ }^{19}$ (Rosenberg, 1992a: 258, 260)

Em suma, reivindica o autor, não devemos incorrer nem no reducionismo biológico positivista, nem em um "construtivismo social exclusivo" (Rosenberg, 1992c: 307).

Ainda que algumas versões do construtivismo possam sugerir ou afirmar a posição a que Rosenberg se refere, cabe destacar que esta não é uma conseqüência necessária dos princípios do construtivismo social. Como afirma Jordanova (1995: 368; grifos meus):

On the contrary, material world is constantly shaped and interpreted through human actions and consciousness. Social constructionism takes this as one of its main tenets and without the dynamic relationship just described it would have no meaning. It is not a form of idealism. But it does insist that there is a room for a variety of interpretations and meanings, that behind consensus or 'knowledge' lie social processes, and that such processes involve negotiations and conflict, both overt and implicit. It follows that forms of knowledge and the social processes whereby they are 
created are given intellectual priority. I does not follow that materiality and physical embodiment are denied. ${ }^{20}$

Este é um ponto fundamental para se compreender o que significa dizer que uma doença - não apenas como fenômeno social, mas também como entidade biológica - é socialmente construída ou 'emoldurada'. David Bloor esclarece as fronteiras que distinguem a abordagem relativista preconizada pela sociologia do conhecimento científico do relativismo em sua versão radical. Segundo o criador do Programa Forte, o conhecimento deve ser compreendido nos termos de uma interação entre o objeto do conhecimento e o sujeito conhecedor, a partir de determinados princípios de receptividade - poderíamos aqui nos referir aos frames conceituais classificatórios de que fala Rosenberg. Respondendo às críticas de que tal programa incorreria no subjetivismo ou no idealismo por pretender explicar a natureza concentrando-se nos sujeitos sociais do conhecimento e rejeitando a importância dos 'fatos' da natureza, Bloor (1999a: 87) ${ }^{21}$ afirma: “(...) the aim isn't to explain nature, but explain shared beliefs about nature. The enquiry is into the character and causes of knowledge, or what passes as knowledge, and not (in general) into the objects which the knowledge is meant to be about". ${ }^{22}$

Para Bloor (1991), o relativismo deve ser um princípio acionado em oposição ao absolutismo, funcionando como um relativismo metodológico. Apesar de sua natureza compulsória e inquestionável, assim como a moral, a verdade lógica não é absoluta, mas relativa. É importante frisar que o Programa Forte não considera a objetividade ilusória, mas atribui este efeito de realidade aos acordos coletivos que a sustentam. Ao adotar uma abordagem derivada da tradição empirista, o objetivo deste programa é compreender como sujeitos do conhecimento descrevem e respondem ao mundo e como estas descrições e respostas são viabilizadas graças a padrões de compreensão coletivos, com suas convenções e tradições compartilhadas. É somente mediante a separação entre objeto do conhecimento e sujeito cognoscente, ou seja, entre a natureza e as descrições que os atores sociais fazem dela, que se pode indicar como aquelas duas instâncias interagem na produção destas descrições, assinalando o caráter relativo, variável, socialmente negociado do conhecimento.

Portanto, tanto a natureza quanto a sociedade estão implicadas na formação das crenças coletivas, tanto a experiência do mundo das 'coisas' 
quanto a experiência do mundo das pessoas. Os sistemas de crenças, referidos ao mundo da cultura, são o meio pelo qual os indivíduos e os grupos coordenam e dão sentido a suas interações com os objetos da natureza, a partir de recursos cognitivos e sociais específicos, situados histórica e culturalmente. Assim, Bloor (1991, 1999a, 1999b) deixa claro que nunca houve qualquer tendência do Programa Forte de negar a existência da natureza e dos objetos que os cientistas observam ou de negar que tais objetos desempenhem um papel na formulação e na sustentação das crenças sobre eles. Contudo, embora os cientistas estejam sempre reagindo e observando a natureza, eles o fazem coletivamente mediante conceitos compartilhados e institucionalizados. É nessa medida que o conhecimento é socialmente construído. A observação e a formulação de enunciados sobre os objetos da natureza são sempre processos de filtragem, de modo a apropriá-la conforme determinados esquemas conceituais.

It is because complexity must be reduced to relative simplicity that different ways of representing nature are always possible. How we simplify it, how we choose to make approximations and selections, is not dictated by (non-social) nature itself. These processes, which are collective achievements, must ultimately be referred to properties of the knowing subject. This is where the sociologist comes into the picture. (...) The sorts of question that can be asked, and to whose answer the sociologist can contribute, concern the range of interpretations that might have been put on Pasteur's observations, the way his questions were framed, and his techniques for dealing with the uncertainties and unresolved problem in his data. Why did he bring these particular interpretatives resources to bear, and why did he employ them in this precise way? ${ }^{23}$ (Bloor, 1999a: 90-91)

Aplicando estas formulações às noções de Rosenberg sobre como o conhecimento médico-científico enquadra socialmente as doenças, poderíamos dizer que cabe ao historiador ou ao sociólogo analisar os procedimentos pelos quais os fenômenos orgânicos, ao serem descritos de acordo com determinados recursos interpretativos, ganham o estatuto de entidades biológicas (doenças) definidas e explicadas mediante certas características. É porque tais recursos (frames) pelos quais se produz o conhecimento não são 'necessários' do ponto de vista de uma racionalidade interna que estabeleça uma correspondência com a realidade a ser conhecida, mas, ao contrário, constituem-se como sistemas de convenções e crenças socialmente negociados e legitimados, que se 
pode afirmar a natureza social dos produtos deste conhecimento. Não se trata, pois, de negar a existência biológica da doença, mas de afirmar que tal dimensão só se transforma em 'realidade', nomeada e classificada como 'doença específica', mediante procedimentos e recursos particulares postos em ação no ato de conhecer. ${ }^{24}$

Poderíamos lidar com a questão do realismo/relativismo - e evidenciar a proximidade entre as concepções de Rosenberg e os postulados da nova sociologia do conhecimento científico - aprofundando a própria metáfora do frame. Ela nos permite evitar o risco do relativismo radical na medida em que se considere que qualquer moldura pressupõe um conteúdo, um objeto a ser 'emoldurado' (dimensão biológica). Porém, a imagem nega também a postura positivista do realismo, uma vez que se compreenda que este objeto não está 'dado', mas só adquire forma específica - transformando-se na entidade 'doença' - pelos contornos particulares que lhe impõe a moldura. E, é importante ressaltar, os contornos desta moldura não são prévios nem necessários, ou seja, não correspondem ou se 'encaixam' em fronteiras previamente delimitadas pelo objeto, mas são arbitrados, selecionados, negociados pelos sujeitos que realizam o ato de 'enquadramento'. Assim, a possibilidade do 'quadro’ pressupõe conteúdo e moldura, e ele só se completa como realidade distinta, recortada da natureza, pela interação entre estas duas dimensões - ambas variáveis -, estabelecida de maneira contextual por aqueles que a implementam. É nesse sentido que podemos afirmar que o que se vê neste quadro é um produto social. O potencial das formulações construtivistas - expresso, ainda que implicitamente, na abordagem que Rosenberg propõe para a análise histórica das doenças - é bem mais promissor do que o autor reconhece, ao prevenir-se contra os riscos do relativismo. Recorrerei, portanto, à noção de enquadramento como meio de operacionalizar, no estudo específico sobre a doença de Chagas, os postulados e conceitos do construtivismo social da ciência derivados do Programa Forte da Sociologia do Conhecimento Científico.

Além das formulações gerais de Bloor, são pertinentes algumas noções propostas por Bruno Latour a respeito da produção e da validação dos fatos científicos como processos que envolvem não apenas o mundo do laboratório, mas outras esferas e outros atores da vida social. Para este autor, o destino dos enunciados formulados pelos cientistas - se eles vão permanecer como 'artefatos', isto é, objetos instáveis, ou se estabilizar como 'fatos', tidos como inquestionáveis e naturais - é dado, fundamentalmente, 
pelo uso concreto que outras pessoas, cientistas e não cientistas, fazem deles (Latour, 2000: 52). Assim, a certificação do conhecimento científico depende de uma série de procedimentos e de estratégias por parte dos cientistas para convencerem outros indivíduos e grupos a aceitarem - e utilizarem - as afirmações e os objetos por eles produzidos. Para analisar 'a ciência em ação', ou seja, os processos pelos quais se estabilizam os fatos científicos, é preciso, de acordo com Latour (2000), 'seguir os cientistas sociedade afora' e examinar os recursos de que estes lançam mão para 'mobilizar o mundo' e produzir concretamente, em circunstâncias específicas, o consenso necessário ao fechamento das "caixas-pretas" da ciência. ${ }^{25}$

No estudo etnográfico de laboratório que desenvolveu com Steve Woolgar, Latour analisou pormenorizadamente os mecanismos e as estratégias persuasivas pelos quais os enunciados científicos são formulados e negociados nos espaços particulares do mundo da ciência, como a literatura científica e os instrumentos próprios aos laboratórios (Latour \& Woolgar, 1997). Tal dimensão é essencial no itinerário em direção à estabilização dos fatos da ciência. Contudo, o percurso se completa na medida em que o cientista ultrapassa as fronteiras deste mundo, imprimindo a seus enunciados a capacidade de se propagarem "no tempo e no espaço" (Latour, 2000: 177). Para isso, deve recrutar 'aliados' os mais diversos, que vejam algum sentido em utilizar tais enunciados e lhes imprimam a força para que se transformem em fatos. A noção-chave para analisar esse processo é a de "tradução de interesses". ${ }^{26}$ Os cientistas, segundo Latour, devem construir uma associação de interesses em torno de seus enunciados, reunindo atores e elementos heterogêneos em esferas diversificadas da vida social. É ao longo desse processo associativo que o conhecimento científico é construído e endossado como expressão da 'natureza', e é nesse sentido que se pode afirmar que a ciência é uma atividade sociocognitiva. Nos múltiplos recursos e estratégias de persuasão utilizados pelos cientistas, explicita-se o sentido político da atividade científica: esta não é meramente influenciada pela política ou pelas relações de poder, mas é, em si própria, uma forma de se fazer política, de se estabelecer tais relações e, assim, de agir sobre o mundo. ${ }^{27}$

O recurso a estas formulações de Latour pressupõe, contudo, a consciência quanto a alguns limites de sua abordagem, já apontados por comentadores (Bloor, 1999; Collins \& Yearley, 1992; Gieryn, 1982; Pickering, 1992; Shapin, 1988). O principal destes limites reside em que, ao tratar o cientista como um ator que se movimenta intencionalmente em 
busca da maximização de seus interesses, Latour considera que não existe qualquer condição prévia - seja ela de natureza social, institucional, cultural, econômica ou política - à própria ação, no sentido de explicála. O comportamento dos atores é referido unicamente ao momento contingente, circunstancial, da interação que estabelecem a partir de um objetivo comum. Não compartilho desta concepção, na medida em que considero que as ações e a movimentação dos cientistas, inclusive nos sentidos em que Latour as descreve, só podem ser compreendidas a partir das características específicas do contexto institucional e social mais amplo que lhes confere sentido e viabilidade num dado momento histórico. ${ }^{28} \mathrm{~A}$ importância da dimensão institucional, no caso que analiso neste livro, é decisiva e será destacada, considerando-se, como sugere Silvia Figueirôa (1997), o seu sentido sociológico como espaço agregador e normatizador de valores e práticas compartilhados por uma dada coletividade. Este é o espaço que estabelece, como afirma esta autora, as mediações e interfaces entre a produção científica e as demandas e os interesses sociais, materializando o caráter sociocognitivo desta atividade. ${ }^{29}$

Tendo por base tais reflexões teóricas, o argumento geral aqui desenvolvido é o de que a doença de Chagas foi instituída, 'emoldurada', como fato científico e fato social ao mesmo tempo, num processo longo que envolveu negociações e acordos e que articulou diversos atores e instâncias da vida social. Sua configuração como entidade nosológica específica, a partir das pesquisas de Carlos Chagas e seus colaboradores e seguidores, deu-se de modo indissociado do processo pelo qual a ela se atribuiu o papel de representar e dar sentido a uma certa visão da sociedade brasileira, de seus problemas e, sobretudo, do papel da ciência nesta sociedade. Ou seja, os enunciados pelos quais a doença foi definida em seu quadro clínico - e também as críticas e revisões destes enunciados no processo de sua estabilização como fato científico - foram estabelecidos em estreita associação com os significados que a enquadraram como 'doença do Brasil', em vários sentidos, além da dimensão geográfica: a imagem de um 'país doente', cujo progresso se inviabilizava por conta das endemias rurais que prejudicavam a produtividade de seus trabalhadores, e, ao mesmo tempo, o símbolo da ciência que descobria este Brasil desconhecido do interior e sugeria os meios para sua incorporação à marcha do progresso nacional.

'Emoldurada' pelos esquemas conceituais das novas teorias médicas emergentes no cenário internacional, na passagem do século XIX ao 
XX, em especial a medicina tropical, e pelo projeto institucional de ciência que Oswaldo Cruz buscava implementar em Manguinhos (uma ciência que articulasse aplicabilidade social e excelência acadêmica), a doença de Chagas funcionou, por sua vez, como 'moldura' para um dado recorte da sociedade brasileira. Ela materializou a identidade social atribuída à ciência como atividade comprometida publicamente com os destinos da nação não apenas na resposta a demandas sociais concretas, mas pela própria capacidade de descortinar seus problemas e de indicar caminhos para superá-los. Nesse sentido, se o desenho deste objeto expressou as especificidades do processo de institucionalização da ciência no Brasil, ele constituiu um importante elemento conformador deste processo. Em suma, esta foi uma doença construída e legitimada a partir dos múltiplos significados, valores e interesses que associaram, ao longo da primeira metade do século XX, ciência, saúde pública e nação no Brasil. Tanto as diferenças como os elementos de continuidade que marcaram, em termos cognitivos e sociais, os distintos arranjos que ela assumiu ao longo do período estiveram referidos a esta associação, igualmente marcada por transformações e permanências.

Algumas características deste objeto o tornavam particular do ponto de vista dos desafios enfrentados para sua legitimação, em termos de sua definição como entidade clínica e da idéia de que se tratava de um problema de vasta proporção e gravidade no país e no continente. A doença de Chagas foi descrita num momento em que, diferentemente de uma tradição médica que definia as enfermidades sobretudo por suas manifestações clínicas e sintomáticas, a especificidade do agente causal era um elemento decisivo para o reconhecimento e a definição das doenças infecciosas como entidades patológicas particulares. Conseqüentemente, este era o critério fundamental para o seu diagnóstico. Contudo, no decorrer das pesquisas, verificou-se que, na grande maioria dos casos de infecção pelo T. cruzi, a detecção do parasito no organismo humano era bastante difícil. Assim, o desafio que se colocou para os cientistas foi produzir o convencimento não apenas em relação aos elementos clínicos que definiam a doença, mas quanto à própria possibilidade de se garantir a convicção do diagnóstico com base nestes elementos.

Produzida como símbolo da chamada 'medicina de laboratório', consagrada com a teoria dos germes e a medicina tropical, em que o agente microbiano era a instância determinante para a definição e a atestação de uma doença infecciosa (Cunningham, 1992), ${ }^{30}$ a nova 
tripanossomíase foi desenhada clinicamente a partir dos traços imputados à ação do parasito que a causava. Seu reconhecimento como entidade nosológica específica, todavia, dependeria de elementos clínicos que fossem persuasivos o suficiente para suplantar a exigência da demonstração do agente etiológico. Ou seja, uma doença nascida sob a égide do laboratório como árbitro final de sua definição e de seu diagnóstico veria, em função da impossibilidade de se atender a exigências do próprio laboratório, sua legitimidade estabelecida mediante uma associação decisiva com o domínio da clínica. Outro desafio peculiar enfrentado por Chagas foi afirmar a importância médico-social de uma doença endêmica, fundamentalmente crônica, que não tinha, como as doenças epidêmicas, sua existência e sua dramaticidade social materializadas em surtos que atingiam, e muitas vezes levavam à morte, grandes quantidades de indivíduos.

A produção dos enunciados sobre a doença de Chagas constitui um objeto particularmente fértil para refletir sobre as várias dimensões da relação entre ciência e sociedade, em contextos históricos particulares. $\mathrm{O}$ percurso pelo qual esta doença foi configurada como nova enfermidade tropical, endemia rural e 'doença do Brasil' faz deste um caso especialmente revelador de como os cientistas brasileiros se referenciaram a esquemas teóricos produzidos fora do país - no caso, a medicina tropical européia , não apenas no sentido de uma inserção ativa no movimento de produção e de afirmação destes esquemas, ${ }^{31}$ mas, sobretudo, no sentido de conferirlhes significados e sentidos peculiares a partir dos contextos específicos da ciência e da sociedade brasileiras. ${ }^{32}$ Se o critério fundamental que justificou a 'necessidade de treinamento especial em medicina tropical' era, para Patrick Manson (1897), o fato de serem as doenças tropicais as que concretamente interessavam aos médicos e ao império britânico nas colônias, para Chagas o sentido social e político da medicina tropical no país se dava por serem estas as 'doenças da nação' (Chagas, 1935f).

Embora compartilhasse com a matriz européia modelos de compreensão e de manejo das doenças tropicais e padrões de organização institucional da ciência, a medicina tropical no Brasil não esteve relacionada com o projeto imperial e o colonialismo, mas foi um instrumento do projeto de construção da nacional. Trata-se, assim, de um bom caso para pensar o intercâmbio de modelos e de referências entre países distintamente situados, bem como a historicidade das idéias científicas.

Como afirma Löwy (2006: 40), ao analisar os estudos e as ações sobre a febre amarela no Brasil, o estatuto da medicina tropical como 
espaço de trocas onde saberes e práticas referidos à 'ciência universal' ganham sentidos específicos como saberes e práticas locais, inscritos em contextos nacionais singulares, torna-se particularmente perceptível nos países que não estiveram submetidos a um regime colonial.

O objetivo do presente livro é focalizar dois momentos na trajetória de construção e de reconhecimento científico e social da doença de Chagas no Brasil. Em primeiro lugar, as pesquisas realizadas por Carlos Chagas e seus colaboradores, no Instituto Oswaldo Cruz (IOC), desde a identificação da nova doença, em 1909, até o falecimento de seu descobridor, em 1934. Ao longo deste período, em que Chagas alcançou grande proeminência científica e política no Brasil e no exterior (foi diretor do IOC e dos serviços federais de saúde pública), os enunciados sobre a definição clínica e a importância médico-social da nova doença ensejaram um intenso debate sobre as condições do atraso das áreas rurais, a relação entre doença e identidade nacional e o papel social da ciência, culminando com o chamado movimento pelo saneamento dos sertões, entre 1916 e 1920. Ao mesmo tempo, tais enunciados foram objeto de intensas críticas e questionamentos, iniciados na Argentina em 1915/1916 e aprofundados no campo médico brasileiro entre 1919 e 1923.

Um segundo momento desta trajetória diz respeito aos estudos sobre a doença liderados por dois discípulos de Carlos Chagas em Manguinhos, após 1934: Evandro Chagas, seu filho mais velho e diretor do Serviço de Estudo das Grandes Endemias (Sege), e, principalmente, Emmanuel Dias, que chefiou o Centro de Estudos e Profilaxia da Moléstia de Chagas (CEPMC), posto do IOC na pequena cidade de Bambuí, Minas Gerais, desde sua criação, em 1943, até seu falecimento em 1962. Nesta fase, foi produzido um novo acordo sobre a caracterização clínica e social da doença, bem como os meios técnicos para a sua profilaxia. Mediante intensa mobilização política em torno do tema, viabilizou-se seu reconhecimento tanto como realidade médico-científica quanto como questão de saúde pública e objeto das políticas sanitárias do país. O marco cronológico final da presente análise se justifica, assim, não apenas pelo encerramento da atuação de Dias no CEPMC, mas porque, naquele momento, se completava uma fase essencial de estabilização e de institucionalização deste fato científico.

Um aspecto que merece ser destacado neste percurso de análise da trajetória da doença de Chagas é a centralidade assumida pelos indivíduos que lideraram este empreendimento, nos dois momentos focalizados. 
Primeiramente, Carlos Chagas se apresenta com o personagem central de um processo em que objeto e sujeito praticamente se confundem em seus caminhos de construção e de legitimação pública. Se a doença identificada em Lassance se fez um símbolo, seu descobridor também teve sua própria biografia 'emoldurada' como representação de um quadro maior. Se Oswaldo Cruz foi consagrado como o 'saneador do Rio de Janeiro', que venceu todas as resistências em nome da ciência e da saúde da população, seu discípulo entraria neste panteão como mito da ciência nacional, exibindo o signo mais representativo do fazer ciência: uma descoberta.

Os mitos aparecem sempre como um desafio e um estímulo para os historiadores, como já mostrou Nara Britto (1995), na medida em que se busque compreender os sentidos e as circunstâncias de sua produção no âmbito das estreitas relações entre biografia, sociedade e história. Eles constituem um caminho particularmente rico para se refletir sobre os complexos processos pelos quais os indivíduos se constroem, conforme aponta Angela de Castro Gomes (2004), ao longo de uma intricada dinâmica entre sua dimensão social e as singularidades que lhe são irredutíveis, entre o movimento que busca conformar uma identidade e aquele que a dispersa na multiplicidade e na fragmentação. Acompanhar o caminho de individualização da doença de Chagas significa, assim, seguir Carlos Chagas também em seu caminho de construção de identidade. O objetivo deste livro é justamente mostrar em que medida, em ambos os casos, a unidade que constitui o resultado deste processo pressupôs negociações, conflitos, acomodações e, sobretudo, um conjunto de atores sociais que, sob circunstâncias históricas específicas, agiram coletivamente na produção dos vários sentidos desta unidade.

A mesma orientação motiva a análise do caminho trilhado por seu discípulo, Emmanuel Dias. Trata-se, neste caso, de um personagem cuja biografia foi construída e reconhecida não como parte do panteão nacional, mas como trajetória dedicada a continuar e, sobretudo, a glorificar a obra do mestre, garantindo-lhe inclusive o consenso que ele não alcançara ao final de sua vida. Entre mestre e discípulo, um traço fundamental em comum: cientistas que se viam e eram vistos como imbuídos da missão de produzir os conhecimentos que ordenariam o caminho da nação, comprometidos com um projeto institucional de ciência materializado na figura, também mítica e simbólica, do castelo de Manguinhos. 
O protagonismo destes personagens no percurso que tece o presente trabalho se expressa na centralidade, como fontes privilegiadas para a narrativa, dos arquivos e documentos que lhes correspondem: o Fundo Carlos Chagas e o Fundo Centro de Pesquisas René Rachou (Seção Posto Avançado de Pesquisas Emmanuel Dias). Este último, que constitui o arquivo institucional do CEPMC, reúne cerca de 16 mil documentos textuais de distintas naturezas, como correspondências, relatórios, livros de registro de experiências e de exames, recortes de jornais e diversos outros documentos relativos aos aspectos administrativos e técnico-científicos do posto, além de centenas de fotografias em que se registram os variados aspectos das experiências científicas ali realizadas, sobretudo no que se refere à profilaxia. Trata-se de um precioso conjunto documental, não apenas pela extensão e pela diversidade, mas pela sistematicidade com que os documentos foram preservados e organizados pelo próprio Emmanuel Dias, o que constitui em si um elemento para a reflexão sobre os sentidos que ele pretendeu conferir àquele empreendimento científico.

Assim, pode-se, por exemplo, acompanhar a correspondência do cientista, ativa e passiva, sobre os mais variados aspectos da atuação do posto desde sua criação, como as pesquisas realizadas, as estratégias de divulgação de seus resultados, as relações com outros grupos de pesquisa no Brasil e no exterior e, sobretudo, as estratégias de convencimento, junto a distintos grupos sociais, sobre a importância da endemia chagásica e de seu combate. ${ }^{33}$ A compreensão dos sentidos coletivamente atribuídos à tradição de Carlos Chagas beneficiou-se, além destas fontes arquivísticas, dos vários depoimentos orais tomados com médicos que trabalharam com a doença desde a década de 1940.

Outro tipo de fonte privilegiada foram os textos científicos sobre a tripanossomíase americana produzidos, no período em questão, por Carlos Chagas, seus colaboradores e pelos pesquisadores filiados ao CEPMC. A utilização destas fontes expressa o desafio a ser enfrentado pela análise histórica a partir das referências teóricas expostas anteriormente. A perspectiva de franquear os conteúdos do conhecimento científico à reflexão da história requer a disposição de trilhar um caminho por vezes árido, seguindo enunciados e termos que parecem opacos em sua tecnicalidade e 'descolados' de qualquer dimensão atinente ao mundo externo às bancadas dos laboratórios. Entretanto, como salientou Latour (2000: 103), a natureza técnica dos textos científicos expressa não a sua impermeabilidade a fatores sociais, mas justamente o sentido social particular desta literatura: 
a especificidade discursiva de uma determinada maneira de apreensão do mundo, que se encaminha mediante linguagens, signos e operações próprias. Ainda que o leitor se sinta 'isolado' diante destes enunciados, 'levado' por eles num caminho que parece único e inescapável, este efeito persuasivo é parte essencial do que deve ser analisado, ou seja, as estratégias pelas quais as alegações vão sendo "modalizadas", como diz Latour, canalizadas e orientadas de modo a que, ao final, quando elas se transformam em fatos, produza-se a sensação de que só havia um percurso até eles. ${ }^{34} \mathrm{O}$ desafio é vencer as resistências impostas por este 'mundo de papel' dos textos científicos e mostrar que, embora 'protegido' por códigos supostamente impenetráveis, este também é um espaço social, conectado a outras dimensões supostamente mais tangíveis da sociedade, como as instituições, os interesses, a política.

Na tentativa de enfrentar este desafio, convido os leitores a seguir por este itinerário, ao longo do qual a doença de Chagas foi emergindo a partir de traços e zonas de sombra em movimento, formando distintos arranjos na busca por uma composição que se pudesse reconhecer como definitiva. Apesar de, a cada momento em que se julgou haver chegado a tal composição, afirmar-se que o caminho que a gerou foi uma linha reta, direcionada ao seu 'desvelamento', cabe ao historiador mostrar que este desenho resultou de um percurso acidentado, cheio de entradas e saídas, em que às trilhas estritas da ciência se sobrepuseram personagens, estratégias e significados afetos a outras esferas da vida social.

\section{Notas}

1 Termo popular usado para expressar sensações subjetivas de alterações cardíacas.

2 Todas as citações transcritas neste livro tiveram sua grafia atualizada, para fins de melhor fluência na leitura.

3 No livro Knowledge and Social Immagery, um dos marcos fundadores do Programa Forte, publicado em 1976, David Bloor (1991: 7) estabeleceu os quatro princípios metodológicos que deveriam reger o estudo sociológico da ciência. O princípio da causalidade preconiza que o objetivo não é apenas descrever o processo de produção do conhecimento, mas explicá-lo, ou seja, identificar as condições que o determinam. O princípio da imparcialidade significa que tanto os conhecimentos considerados verdadeiros como aqueles abandonados como falsos devem ser explicados, ou seja, há que se buscar meios de se explicar as crenças independentemente da maneira pela qual elas são avaliadas. Conforme o princípio da simetria, para que a sociologia do conhecimento seja capaz de produzir teorias generalizadoras, devese recorrer ao mesmo tipo de causa para explicar crenças verdadeiras e crenças 
falsas. Questiona-se assim frontalmente a concepção tradicional de que causas sociais interferem somente no que diz respeito ao erro, e não ao conhecimento tido como verdadeiro. Finalmente, as análises devem se pautar pelo princípio da reflexividade, segundo o qual os padrões de explanação utilizados pela sociologia do conhecimento devem ser aplicáveis à própria sociologia, para que esta seja coerente com sua pretensão generalizadora.

4 Para um panorama do campo dos estudos sociais da ciência, ver Shapin (1982a, 1982b), Callon e Latour (1991), Woolgar (1991), Pickering (1992), Portocarrero (1994), Pestre (1996) e Kreimer (1999).

5 O próprio trabalho de Bloor, que aplica seu modelo teórico à análise da matemática na Grécia Antiga, expressa a proximidade entre história e sociologia da ciência nesta nova chave interpretativa. Sobre os benefícios e os desafios deste diálogo, ver Jasanoff (2000).

${ }_{6}$ Em suas palavras, "An empirical sociology of knowledge has (...) to go on to show why particular accounts were produced and why particular evaluations were rendered; and it has to do this by displaying the historically contingent connections between knowledge and the concerns of various social groups in their intellectual and social settings" (Shapin, 1982a: 164). ["Uma sociologia do conhecimento empírica (...) deve avançar com vistas a apontar porque certas explicações foram produzidas e determinadas avaliações foram realizadas; e há que fazer isso mostrando as conexões historicamente contingentes entre o conhecimento e as preocupações de distintos grupos sociais em seus contextos intelectuais e sociais" Tradução livre].

7 "A doença não é um fenômeno meramente biológico: ela é moldada por poderosas forças comportamentais, sociais e políticas. Os valores sociais afetam tanto a maneira pelas quais nós vemos e compreendemos uma doença particular quanto as intervenções que realizamos sobre ela" - Tradução livre.

8 “(...) enfermidade, saúde e morte são temas altamente 'naturais', 'físicos' e 'objetivos', tanto que eles parecem a princípio estar fora da esfera da realidade social; (...) entretanto, eles são indissociáveis da realidade social de várias maneiras. A enfermidade é antes de tudo um fato social" - Tradução livre.

9 Devee-se observar que Sontag, amplamente reconhecida por esta proposição, destacou-se pela militância política visando denunciar as conseqüências profundamente negativas que as metáforas e significados associados à Aids e a outras enfermidades geram nas vidas dos doentes, em termos de estigmatização e isolamento. Marcada pela experiência pessoal com o câncer, a autora reivindicava que as doenças deixassem de ser tratadas como metáforas, sendo encaradas como fenômenos orgânicos aos quais se deve responder com esforços terapêuticos precisos e não com condenações morais ou sociais. Tal formulação despertou muita polêmica entre os historiadores. Ver, por exemplo, Brandt (1991: 94).

10 Como sublinha Paula Treichler (1999: 149), “To call Aids 'cultural' may mean simply that - like any great event or crisis - Aids significantly affects social life and symbolic expression. But to call it 'culturally constructed' invokes long-standing debates about human knowledge and the nature of the world". ["Chamar a Aids de 'cultural' pode significar simplesmente que - assim como qualquer outro evento ou crise - a Aids afeta substancialmente a vida social e as expressões simbólicas. 
Contudo, chamá-la de 'culturalmente construída' evoca debates recorrentes sobre o conhecimento humano e a natureza do mundo" - Tradução livre].

11 Seguindo uma concepção que articula os estudos históricos da saúde pública às questões mais gerais da história social, o presente estudo converge também com uma vertente de investigação que focaliza a relação historicamente circunscrita entre a atuação dos cientistas no campo biomédico e a formulação de políticas públicas, práticas e valores para a saúde. Ver Fee (1993) e Porter, D. (1999).

12 "Em nossa cultura, sua existência como entidade específica é um aspecto fundamental da legitimidade moral e intelectual da doença. Se não é específica, não é uma doença" - Tradução livre. Este texto também foi publicado como introdução a uma coletânea (Rosenberg \& Golden, 1992).

13 De difícil tradução para o português, o substantivo frame tem o sentido material de uma estrutura ou armação que dá forma e sustenta algo (a moldura de um quadro, uma porta etc.). No sentido figurado, significa ordem ou sistema geral que origina e estrutura alguma coisa. Como verbo, poderia ser traduzido como 'moldar', 'emoldurar', 'enquadrar'. Ao longo do livro, usarei tais verbos (e os substantivos associados) remetendo-me à noção de Rosenberg (1992c).

14 "Em certos sentidos a doença não existe até que tenhamos concordado quanto a isso, percebendo-a, nomeando-a e respondendo a ela" - Tradução livre.

15 Na coletânea editada com Janet Golden, Rosenberg reuniu uma série de estudos de caso bastante interessantes como exemplos de operacionalização desta perspectiva (Rosenberg \& Golden, 1992).

16 "O diagnóstico é central para a definição e o manejo do fenômeno social ao qual chamamos de doença. Ele constitui um ponto indispensável de articulação entre o geral e o particular, entre o conhecimento consensual e sua aplicação (...). O diagnóstico rotula, define e prediz e, ao fazer isso, ajuda a constituir e a legitimar a realidade que ele distingue" - Tradução livre.

17 Embora conceda especial importância, nesta análise, às abordagens filiadas aos estudos sociais da ciência pós-1970, Jordanova (1995) refere-se a outras correntes intelectuais que partilham de uma perspectiva construtivista, como certas abordagens da antropologia cultural e da filosofia da ciência e alguns autores filiados ao marxismo.

18 Rosenberg (1992c: 307) manifesta sua crítica à perspectiva construtivista dirigindo-se aos que, recorrendo a Foucault, reduzem os sujeitos do conhecimento médico a meros agentes legitimadores de uma ordem social opressiva, no curso da chamada 'medicalização' da sociedade.

19 "A Aids dificilmente poderia ser reduzida a um exercício de estigmatização do desviante; ela obviamente tem um forte componente biológico. Não foi simplesmente uma construção, ainda que tivesse sido construída (...). A Aids, de fato, ajudou a criar um novo consenso em relação à doença, que encontra lugar para fatores tanto biológicos quanto sociais e que enfatiza a sua interação" - Tradução livre.

20 "Ao contrário, o mundo material é constantemente moldado e interpretado mediante as ações e a consciência humana. O construcionismo social toma isso como um de seus principais preceitos e não faria sentido algum sem esta relação dinâmica. Não é uma forma de idealismo. Mas de fato insiste que há espaço para uma variedade 
de interpretações e sentidos, que por trás do consenso ou do 'conhecimento' jazem processos sociais e que tais processos envolvem negociação e conflito, tanto abertos como implícitos. Deduz-se disso que é conferida prioridade intelectual às formas do conhecimento e aos processos sociais pelos quais elas são criadas. Isso não equivale a negar a materialidade e a corporeidade físicas" - Tradução livre.

${ }^{21}$ Em intenso e rico debate, na revista Studies in History and Philosophy of Science, Bloor (1999a, 1999b) defende os princípios do Programa Forte diante da proposta de 'simetria generalizada' de Latour (1999), segundo a qual as categorias sociológicas usadas para explicar a ciência deveriam ser postas em suspeição tanto quanto as categorias utilizadas pelos cientistas que constituem objeto de análise.

22 “(...) o objetivo não é explicar a natureza, mas as crenças compartilhadas sobre a natureza. As perguntas incidem sobre as características e as causas do conhecimento, ou aquilo que se considera conhecimento, e não (em geral) sobre os objetos aos quais supõe-se que o conhecimento se refere" - Tradução livre.

23 "É porque a complexidade deve ser reduzida a uma relativa simplicidade que diferentes modos de representar a natureza são sempre possíveis. A maneira pela qual nós a simplificamos, como escolhemos fazer aproximações e seleções, não é ditada pela natureza (não-social) em si. Estes processos, que são empreendimentos coletivos, devem ser referidos em última instância às propriedades do sujeito cognoscente. Aqui é onde o sociólogo entra em ação. (...) Os tipos de questão que podem ser feitas, e para as quais o sociólogo pode contribuir, dizem respeito ao âmbito das interpretações que poderiam ter sido feitas sobre as observações de Pasteur, o modo pelo qual suas questões foram estruturadas, e suas técnicas para lidar com as incertezas e os problemas não-resolvidos em seus dados. Por que ele acionou estes recursos interpretativos particulares, e por que ele os empregou deste modo específico?” - Tradução livre.

24 Vários autores filiados às vertentes contemporâneas da história social da ciência manifestam explicitamente que, ao assinalarem a dimensão social/cultural dos produtos da ciência, não estão incorrendo nesta posição relativista radical, muitas vezes atribuída à expressão 'construção social'. Vejamos, por exemplo, a formulação de Nancy Stepan (2001: 14), ao apresentar seu livro sobre as representações visuais da natureza tropical: "I am not one of those who think that the natural world does not exist, or that there is nothing 'outside the text'. On the contrary, I think that the real world of nature is physically very present to most of us and speaks to some of our deepest symbolic and emotional needs; and that some representations we make of nature are better - more accurate, more subtle, more expressive - than others. I would argue, however, that history shows us that there is no single map or picture of the natural world that increasing knowledge progressively fills in, but rather many different maps and representations, articulated and shaped by numerous factors of politics, culture and aesthetics, by beliefs about reality, codes of seeing and representational conventions." ["Eu não sou daqueles que pensam que o mundo natural não existe, ou que não existe nada 'fora dos textos'. Ao contrário, penso que o mundo real da natureza é fisicamente muito presente para a maioria de nós e fala a algumas das nossas mais profundas necessidades simbólicas e emocionais; e que algumas das representações que fazemos da natureza são melhores - mais acuradas, mais sutis, mais expressivas - do que outras. Eu argumento, 
todavia, que a história nos mostra que não há um único mapa ou quadro do mundo natural que o conhecimento crescente progressivamente preencha, mas ao invés disso muitos diferentes mapas e representações, articuladas e moldadas por numerosos fatores da política, da cultura e da estética, por crenças sobre a realidade, códigos de observação e convenções representacionais" - Tradução livre].

${ }_{25}$ Latour (2000) utiliza a expressão "caixas-pretas" para designar os conhecimentos consensualmente aceitos como naturais, não problemáticos, sobre os quais não paira qualquer dúvida.

26 Segundo Latour (2000: 194), a palavra exata seria "translação", na medida em que indica um deslocamento ao mesmo tempo semântico e espacial.

27 Em sua análise histórica sobre a chamada 'revolução' da microbiologia, Latour (1984) mostra que, mediante o apoio conquistado junto a diversos grupos e interesses sociais, as idéias científicas de Louis Pasteur tiveram um impacto transformador não apenas na ciência médica, mas também sobre a própria sociedade francesa. Este aspecto da contribuição de Latour é salientado por Steven Shapin (1988) em resenha do livro Ciência em Ação.

${ }_{28}$ Para uma análise crítica das formulações de Latour e Woolgar, em A Vida de Laboratório, quanto ao caráter circunstancial da ação e dos cálculos dos cientistas, num contraponto com os conceitos de capital e campo científico de Pierre Bourdieu e com a perspectiva mertoniana sobre a organização institucional da ciência, ver Kropf e Ferreira (1998).

29 Para um panorama das abordagens historiográficas que focalizam a dimensão institucional da ciência, ver Dantes (2001).

30 Cunningham (1992: 224) enfatiza que o laboratório não foi um mero espaço para novas técnicas e instrumentos de pesquisa dos fenômenos naturais, mas constituiu um conjunto de práticas a definir e governar modos de pensar e de ver o mundo e, particularmente, as doenças.

31 Ao final da década de 1980, historiadores das ciências na América Latina propuseram uma crítica incisiva sobre a visão preconizada por George Basalla a respeito da difusão da ciência moderna européia, apontando sua ótica eurocêntrica e linear, que tomava os países não europeus essencialmente como receptores e repetidores passivos das idéias e práticas científicas vindas dos 'centros'. A renovação historiográfica que nasceu desta crítica - que teve manifestações importantes no Brasil - vem, desde então, sublinhando a necessidade de análises que privilegiem a dinâmica complexa das relações entre atividades e instituições científicas em contextos culturais e nacionais específicos. Ver Saldaña (2000).

32 Sobre como determinadas enfermidades assumiram centralidade em agendas nacionais, a evidenciar estreitas relações entre, por um lado, a institucionalização e a afirmação social da ciência/medicina, e, por outro lado, os debates/projetos políticos de construção da nação, ver o estudo de Marcos Cueto $(1987,1996)$ a respeito da enfermidade de Carrión no Peru e o de Diana Obregón (2002) a respeito da lepra na Colômbia. O caso da doença de Carrión ou verruga peruana assume paralelo interessante com o da doença de Chagas, ambas configuradas como 'doenças nacionais', emblemas dos problemas peculiares aos países em que foram descritas, bem como da expertise médica local em identificar e enfrentar tais problemas. 
O estudo de Alan Marcus (1988) sobre a ancilostomose como enfermidade 'típica' do sul dos Estados Unidos e o de Frank Snowden (2006) sobre a malária como 'doença nacional' na Itália são outros interessantes exemplos desta perspectiva.

33 Este é um arquivo particularmente interessante para a reflexão proposta por Angela de Castro Gomes (2004) a respeito dos significados dos arquivos pessoais para a 'escrita de si'.

34 Modalidades são sentenças que modificam ou qualificam outras. Segundo Latour (2000: 45; grifos do autor), "uma sentença pode ser tornada mais fato ou mais ficção, dependendo da maneira como está inserida em outras. Por si mesma, uma sentença não é nem fato nem fição; torna-se um ou outro mais tarde graças a outras sentenças". 


\section{Medicina Tropical e Ciência \\ Nacional: Carlos Chagas e a \\ descoberta de uma nova tripanossomíase humana}

Sr. Dr. Carlos Chagas, V. Ex. entra nesta casa como ninguém nela penetrou ainda. A Academia, considerando singular e ímpar a posição que $V$. Ex. conquistou na medicina brasileira, decidiu e decidiu bem que a admissão de $V$. Ex. entre os seus titulares tivesse a notoriedade e o relevo de uma exceção. (...) A Academia que tenho a honra de presidir não quis ficar indiferente quando sentiu a medicina nacional dignificada e enaltecida por um descobrimento de que o mais sábio dos sábios que lidam com cousas da ciência se ufanaria de ser o notável autor e por isso, ao mesmo tempo em que creditou a V. Ex. a homenagem de uma sessão extraordinária, prevaleceu-se do ensejo para inaugurar a sua instalação elétrica inspirado pela delicada atenção de que não fosse a $V$. Ex. faltar a apoteose dessa luz triunfante que, inseparável do progresso, é a predileta da inteligência.

Miguel Pereira $^{1}$

Aos 22 de abril de 1909, Oswaldo Cruz anunciou na Academia Nacional de Medicina (ANM) que um pesquisador de Manguinhos havia descoberto, no interior de Minas Gerais, uma nova doença humana, além de identificar o protozoário que a causava e o inseto que a transmitia 
(ANM, 1909). Cerca de um ano e meio depois, o jovem Carlos Chagas tornou-se membro titular desta academia, a mais prestigiosa associação médico-científica brasileira na época e cujas origens remontam aos primórdios da institucionalização da ciência médica no Brasil (ANM, 1910b). ${ }^{2}$

A solenidade, realizada com pompa e circunstância e conduzida por Miguel Pereira, foi uma celebração do "inédito e extraordinário" (Jornal do Commercio, 1910b: 3) - como ressaltou o então presidente da academia - não apenas por tratar-se de uma descoberta científica considerada 'ímpar', mas pelos significados que lhe foram atribuídos como 'grande feito' da ciência nacional, festejado sob circunstâncias também marcadas pela singularidade. Abrindo uma exceção às suas normas, pela primeira vez a ANM recebia um novo titular sem que houvesse vaga disponível. Além disso, a luz elétrica vinha sintetizar, com sua força material e simbólica, o sentido primordial do 'novo' que se pretendia entronizar, naquela noite, num espaço também particularmente evocativo dos 'tempos modernos' que se inauguravam. No salão nobre do Silogeu Brasileiro, no coração da cidade recém-reformada e que reunia as mais importantes academias científicas e literárias, a grande homenageada era a própria ciência nacional, glorificada como instrumento da 'civilização' do país, e que exibia, entre suas principais conquistas, a obra de Oswaldo Cruz, o 'Pasteur brasileiro'.

A escola de Manguinhos, consagrada pelo saneamento da capital, era então enaltecida por uma contribuição 'espetacular' ao estudo da patologia tropical. Como salientou Chagas em seu discurso de posse, antes de apresentar os primeiros estudos sobre a nova doença: "Tais resultados representam, meus senhores, os pequenos frutos de uma orientação científica coletiva (...) e, mais que tudo, expressam o método ensinado na prática da medicina experimental pelo Dr. Oswaldo Cruz" (Jornal do Commercio, 1910b: 3).

Como ressalta Augustine Brannigan (1984), a descoberta científica é considerada, na imaginação dos cientistas e dos leigos, a própria essência da atividade científica, sobretudo a partir do século XVII, quando a esta se passou a atribuir a responsabilidade de desvendar os mistérios e os enigmas de uma natureza vista como realidade regida por leis e/ou estruturas não acessíveis ao senso comum. O próprio termo 'descoberta' explicita a prévia existência de fenômenos latentes, à espera do desvelamento por parte do olhar treinado da razão. 
Ao focalizar a descoberta de Chagas, assumo a perspectiva crítica proposta pelas vertentes contemporâneas da história e da sociologia da ciência, derivadas, sobretudo, das formulações de Thomas Kuhn (1989). Questionando a tradicional distinção entre os chamados 'contexto da descoberta' e 'contexto da justificação', bem como a visão de que as descobertas ocorrem como inferências racionais a partir dos dados da natureza, Kuhn argumentou que estes são eventos contextualmente referidos tanto a um esquema interpretativo prévio (o 'paradigma') quanto a práticas sociais constitutivas dos espaços concretos de produção e reprodução da ciência (a 'ciência normal'). Como salienta Barry Barnes (1986), a descoberta científica é, para Kuhn, algo que se explica pela cultura e não pela natureza, uma vez que esta não 'fala' por si mesma, mas por conceitos e crenças partilhados por uma dada coletividade. ${ }^{3}$

Visando a desnaturalizar a descoberta científica a partir destes novos marcos conceituais e analíticos, Brannigan (1984) enfatiza que não apenas ela acontece sob certas condições e contextos sociais, mas que o seu próprio estatuto como descoberta é resultado de um processo socialmente circunscrito. Assim, tratar criticamente a descoberta implica compreender como e por que um dado acontecimento ou realização científica foi reconhecido/sancionado como tal.

O objetivo deste capítulo é analisar as condições cognitivas e sociais que levaram à descoberta realizada por Carlos Chagas e os significados que esta assumiu no processo de institucionalização da ciência brasileira, bem como no próprio percurso de construção da nova tripanossomíase humana. ${ }^{4} \mathrm{O}$ episódio constituiu não apenas o marco cronológico do início deste processo, mas um marco fundamental de sentido. Tendo sido viabilizada e emoldurada a partir de determinados recursos cognitivos, sociais e institucionais, a descoberta da doença de Chagas configurou-se, em si mesma, como uma moldura básica mediante a qual seria produzido, a partir de então, o desenho da nova entidade nosológica.

Ocorrida num momento de difusão internacional e institucionalização da chamada 'medicina experimental' (mais particularmente, da medicina tropical), e num período em que se criavam, sob as condições específicas do contexto brasileiro, espaços institucionais referidos a este campo, a descoberta da nova tripanossomíase foi representada, de imediato, como tendo uma dimensão bem mais ampla do que a realização científica de um indivíduo. Ela se constituiu como evento simbolicamente expressivo e legitimador do projeto de ciência materializado 
no projeto institucional de Manguinhos. Mais do que uma contribuição aos novos conhecimentos produzidos internacionalmente sobre a relação entre vetores, parasitos e doenças humanas, tornou-se desde logo o emblema da capacidade e das potencialidades da ciência nacional em ditar os caminhos pelos quais o Brasil alcançaria o progresso e se integraria ao 'concerto das nações civilizadas'.

O presente capítulo está dividido em distintas seções. Primeiramente, traçarei um breve panorama da ciência médica brasileira no século XIX, anteriormente ao tradicional marco da 'revolução pasteuriana'. O objetivo é apontar questões levantadas pela historiografia no que diz respeito ao estudo da patologia brasileira neste período e refletir sobre os significados que tal marco assumiu na conformação da identidade dos que, como Chagas, filiando-se à medicina dita 'de laboratório', proclamaram-se representantes de uma nova fase da medicina e da ciência nacionais.

Em seguida, analisarei o cenário intelectual e social no qual Chagas realizou sua formação médica, visando a identificar as principais referências socioculturais e científicas que norteariam sua trajetória profissional. Também com esta perspectiva, focalizarei os primeiros trabalhos que desenvolveu sobre a malária no Instituto de Manguinhos. Importa destacar tanto as questões teóricas e os recursos interpretativos que Chagas mobilizou no estudo desta doença, como alguns processos vividos pela instituição naquele momento, decisivos para que as perspectivas teóricas e disciplinares da medicina tropical se materializassem num programa de pesquisa que conferisse identidade científica e social à instituição.

Compondo um painel dos vários elementos e dimensões do caminho que levou Chagas ao interior de Minas, tratarei então da descoberta realizada em Lassance, chamando a atenção para os sentidos e impactos que ela imprimiria ao processo então inaugurado de construção da nova 'entidade mórbida'.

\section{Medicina nos Trópicos antes de Pasteur, Manson e Oswaldo Cruz}

Na abertura do VII Congresso Brasileiro de Medicina e Cirurgia, em 1912, Chagas declarou que os grandes problemas sanitários do país eram as endemias rurais, notadamente a malária, a ancilostomose e a 
tripanossomíase por ele descoberta. Cabia aos cientistas estudá-las e pressionar os poderes públicos para que fossem combatidas. Ao apresentar esta missão social que distinguiria a ciência experimental de Manguinhos, dedicou boa parte de sua conferência a traçar um panorama da história da medicina. Reportando-se ao pensamento médico europeu, contrapôs os "dias de empirismo" dos "tempos idos" à "fase luminosa" do momento em que vivia, sublinhando a "renascença da medicina" ao longo do século XIX, que, graças sobretudo ao recurso da anatomia patológica, foi progressivamente abandonando a "hipótese arbitrária" e ingressando na "via segura da experimentação". Esta "evolução animadora”, segundo ele, teria culminado na "obra genial de Pasteur", a esclarecer as causas e garantir a cura e a prevenção dos "maiores flagelos humanos" (Chagas, 1912a: 4-5).

Em relação à "medicina pátria”, exaltou a contribuição, no século XIX, das "grandes inclinações médicas que souberam sistematizar os fatos clínicos, principalmente nos assuntos da patologia tropical” (Chagas, 1912a: 5). Um exemplo louvado foi a "escola clínica" de Torres Homem e Francisco de Castro, eminentes professores da Faculdade de Medicina do Rio de Janeiro (FMRJ): "escola da observação minuciosa, do estudo aprofundado do sintoma em todas as suas modalidades, da interpretação do fato mórbido baseado na análise demorada de todos os elementos de indução" (Chagas, 1912a: 5). Contudo, ponderou, faltou-lhes "prestigiar na clínica o laboratório, ou melhor, prestigiar a clínica com os recursos soberanos da experimentação" (Chagas, 1912a: 7). Mesmo reconhecendo que alguns discípulos daqueles mestres seguiram este caminho no ambiente renovado da FMRJ no último quartel do século XIX, Chagas assinalou:

Verdade é que a medicina experimental no Brasil vem apenas de ontem e representa a ação exclusiva de um moço que a tornou o objetivo único de sua vida científica (...). Venceu muito depressa o experimentador brasileiro; prestigiou, no Velho Mundo, a medicina pátria e conseguiu, entre nós, fazer amado o laboratório e torná-lo, pela verdade de seus resultados, de uso habitual e imprescindível na clínica. Levou a todo o país os benefícios de sua escola, conseguindo, deste modo, iniciar aqui uma fase nova na medicina prática. (Chagas, 1912a: 7)

É a este marco de transformação, encarnado em Oswaldo Cruz, que Chagas associava sua formação e atuação como cientista, no que dizia respeito tanto às referências conceituais sob as quais fora treinado e que 
orientavam sua produção acadêmica quanto às diretrizes de sua prática e inserção na vida pública. Tal filiação, declarada sistematicamente em seus trabalhos e pronunciamentos, constituía bem mais do que um vínculo teórico ou institucional. Era uma importante estratégia de afirmação e legitimação de sua identidade como alguém que, sendo discípulo de uma escola renovadora, apresentava-se como sujeito decisivo na construção e reprodução deste processo de renovação.

A memorialística médica e muitos historiadores consagraram como lugar-comum a noção de que as duas últimas décadas do século XIX, por entronizarem o laboratório como espaço por excelência de produção das verdades científicas, foram uma época de ruptura no pensamento e na prática da medicina ocidental. O principal fator desta inflexão teriam sido as teorias e técnicas propostas por Louis Pasteur e Robert Koch para a compreensão e o combate das doenças infecciosas, vistas então como entidades ontologicamente singulares. A noção de que microorganismos eram as causas específicas dessas doenças, o estabelecimento de regras experimentais rigorosas para verificá-los e as promessas que a soroterapia e as vacinas traziam para confrontar sua ação patogênica foram exaltados como uma verdadeira revolução que, a partir da década de 1880, rapidamente se espraiou da Europa para o resto do mundo, conferindo novo ímpeto aos princípios e métodos da experimentação estabelecidos por Claude Bernard em meados do século XIX. Às inovações da microbiologia se somariam as descobertas a respeito do papel dos insetos na transmissão de várias daquelas doenças, que fariam da medicina tropical uma especialidade. Deixando para trás o mundo dos miasmas e um emaranhado de teorias que associavam as doenças (sobretudo as epidêmicas) a múltiplas causas relativas ao ambiente, o saber médico teria ingressado numa nova era, legitimado pelas respostas 'claras e precisas' do laboratório. ${ }^{5}$

No caso brasileiro, este momento de inflexão foi associado à atuação de Oswaldo Cruz, visto como emblema de uma nova fase da ciência nacional, aberta com a criação dos institutos de pesquisa bacteriológica (Stepan, 1976; Schwartzman, 1979). Ojovem médico, formado pela FMRJ em 1892 e que havia bebido na fonte das novas teorias ao especializar-se no Instituto Pasteur de Paris, projetou-se na cena pública ao comandar, nos primeiros anos do século XX, a luta contra importantes epidemias que afligiam a capital federal e ao imprimir ao instituto que dirigia (e que receberia seu nome) o objetivo de estudar e enfrentar os problemas sanitários do país sob os novos parâmetros da medicina experimental. ${ }^{6}$ 
A narrativa sobre o sentido 'revolucionário' assumido pela teoria dos germes nas duas décadas finais do século XIX vem sendo problematizada pela historiografia recente. Salientam-se as nuances e complexidades de um processo que, ao invés de uma marcha linear e cumulativa em direção ao triunfo do laboratório (qualificado como espaço da 'verdade'), foi permeado de tensões e negociações, e que, apesar das transformações que acarretou, constituiu-se mediante muitos elementos de continuidade com as tradições que pretendeu substituir (Worboys, 2000). ${ }^{7}$

No que concerne à produção historiográfica internacional, tem-se apontado que vários conceitos consagrados pela microbiologia (como os de germe, contágio, infecção, etiologia específica e concepção ontológica da doença) e noções às quais este novo modelo pretendia se opor e substituir (como miasmas e ambiente) tiveram uma história intricada e complexa, assumindo significados variados no âmbito de múltiplas teorias que, sobretudo a partir do século XVI, disputavam com a tradição hipocrático-galênica a definição dos elementos constitutivos das doenças. Ainda que estabelecidos, muitas vezes, mediante pares de oposição, as fronteiras que os demarcavam foram, em geral, pouco nítidas. Pelo fato de corresponder a dissensos tanto no plano conceitual quanto no plano das práticas e dos interesses profissionais, tais conceitos conformaram um campo de debate marcado por disputas e controvérsias. Estas diziam respeito não apenas ao ambiente médico-científico, mas a outras esferas da vida social (Hannaway, 1997; Pelling, 1997; Worboys, 2000)..$^{8}$ Do mesmo modo, argumenta-se que questões como a natureza das causas das enfermidades e o próprio estatuto de 'doença', como entidade ontologicamente específica ou experiência única sob uma perspectiva holística, foram objeto de diversos arranjos teóricos bem antes das respostas que lhes foram dadas ao final do século XIX (Bynum, 1997).

No campo da história da medicina tropical, vários autores vêm confrontando as demarcações consagradas pelas narrativas tradicionais, que afirmam que o estabelecimento de bases 'verdadeiramente' científicas para o estudo das chamadas doenças tropicais se deu a partir da década de 1880, num processo derivado da emergência da microbiologia e cujo marco fundamental teria sido a criação daquela especialidade, nos últimos anos do século XIX, pelo britânico Patrick Manson (grande autoridade no estudo das doenças tropicais e conselheiro médico do Colonial Office), no contexto de expansão do imperialismo europeu, especialmente na África. A preocupação tem sido a de chamar a atenção para a intensa 
produção de conhecimentos médicos sobre os trópicos antes da institucionalização da medicina tropical mansoniana.

David Arnold (1996a, 1996b) enfatiza que a atenção em relação às doenças dos 'climas quentes' remonta aos primeiros anos da conquista e exploração européia de outros continentes, tendo se intensificado no século XVIII, quando a expansão mercantil e colonial impulsionou as viagens ao redor do mundo. ${ }^{9} \mathrm{O}$ desenvolvimento da geografia médica, especialmente na primeira metade do século XIX, fortaleceu a idéia de que as doenças eram causadas por fatores ambientais (como o clima e a topografia) particulares a cada localidade, reforçando a noção de uma nosologia peculiar aos trópicos. ${ }^{10}$ Estes, até então representados como 'paraíso', passaram a ser progressivamente temidos por seus efeitos 'maléficos', expressos, sobretudo, na grande virulência das moléstias que causavam a morte ou a decadência dos brancos europeus. Se, na visão romântica do naturalista alemão Alexander von Humboldt e de seus seguidores, a natureza tropical era o espaço harmonioso e edênico da fertilidade e da abundância, à medida que avançava o processo de estabelecimento dos europeus nestas terras o lado sombrio e pestilencial da 'tropicalidade' era realçado, mediante relatos e representações sobre a lassidão e indolência de seus habitantes e a insalubridade de seus lugares. Em fins do século XVIII e no decorrer do século XIX, os textos médicos foram veículos privilegiados deste olhar negativo sobre os trópicos, como espaço de atraso e 'degeneração', antitético à civilização (Arnold, 1996b; Stepan, 2001). ${ }^{11}$

A reflexão sobre as continuidades e as diferenças entre a antiga medicina dos climas quentes e a medicina tropical erigida por Manson é, conforme Arnold, um caminho frutífero para a compreensão das condições particulares do próprio processo de institucionalização de um campo disciplinar que se legitimou justamente pela ênfase em pretensas especificidades em relação aos modelos cognitivos e às práticas institucionais que o precederam. Tal perspectiva é compartilhada por Michael Worboys $(1996,1997)$ ao analisar o deslocamento da 'medicina nos trópicos' (em que as diferenças entre as doenças dos climas quentes e dos climas temperados não implicavam a demarcação de tipos distintos de doenças) para a 'medicina dos trópicos', estruturada em torno da categoria peculiar de 'doenças tropicais'. ${ }^{12}$

Em suma, o que estes autores acentuam é que, para se compreender o que tornou a medicina tropical mansoniana específica e diferente, é 
preciso examinar os conceitos e as práticas em relação aos quais ela pretendeu se diferenciar e/ou se contrapor. Além disso, há a preocupação de tratar a constituição desta especialidade não como uma marcha 'triunfante' da ciência médica contra as doenças, pontuada por descobertas acerca de patógenos, seus ciclos de vida e vetores, mas como um processo em que a dimensão cognitiva esteve estreitamente imbricada com fatores sociais, políticos e culturais mais amplos, contextualmente circunscritos e especialmente referidos à relação entre medicina e império. ${ }^{13}$

A historiografia da medicina no Brasil, acompanhando a renovação na historiografia das ciências implementada no país nas últimas décadas (Dantes, 2001), vem seguindo orientação semelhante, tendo produzido importantes trabalhos sobre a ciência médica antes da criação dos institutos bacteriológicos (Peard, 1999; Ferreira, 1996; Chalhoub, 1996; Edler, 1992, 1999). ${ }^{14}$ Apontando o caráter anacrônico e teleológico das narrativas que consideram a medicina no século XIX uma 'medicina pré-científica', dominada por sistemas especulativos e pela tradição clínica, em contraposição ao paradigma da experimentação, estes trabalhos convergem na preocupação de analisar as condições particulares de institucionalização da ciência médica brasileira em distintas conjunturas ao longo daquele período. ${ }^{15}$ Buscou-se, assim, evidenciar em que medida certos temas e práticas tidos como específicos à medicina pós-Oswaldo Cruz foram recorrentes e estruturantes da medicina oitocentista, ainda que sob outras condições cognitivas, sociais e institucionais.

Um primeiro ponto a ser destacado na reflexão proposta por estes estudos é a centralidade do debate sobre a peculiaridade da patologia tropical, mais especificamente da patologia brasileira, no processo de constituição e legitimação do pensamento médico no Brasil no século XIX. Num contexto de particular atenção da historiografia latino-americana aos processos de difusão/recepção de idéias científicas entre distintas regiões e países (Saldaña, 2000), tais autores buscam evidenciar como os médicos brasileiros utilizaram os instrumentais teóricos da ciência européia não de modo defasado ou passivo, mas seletiva e criativamente para produzir, em contextos socioinstitucionais específicos, soluções originais para a compreensão e o enfrentamento dos problemas médicos tidos como particulares ao país.

Uma das primeiras contribuições nesse sentido foi o estudo de Julyan Peard $(1996,1999)$ sobre a chamada Escola Tropicalista Baiana, grupo que ficou conhecido especialmente pelas pesquisas de Otto 
Wücherer, que, em 1866, estabeleceu que a opilação ou hipoemia intertropical (mais tarde denominada ancilostomose) era causada por um parasito intestinal. Para a autora, este foi um exemplo de que, antes da hegemonia da teoria dos germes, havia médicos no Brasil que, buscando articular uma medicina específica dos climas quentes, não apenas mantiveram-se atualizados face às novas teorias européias, mas adaptaram-nas à realidade local e forjaram instrumentos conceituais e institucionais alternativos para desafiar o discurso sobre a inviabilidade da civilização nos trópicos.

Flavio Edler (1992, 1999, 2003, 2004), por sua vez, argumenta que havia medicina científica no Brasil oitocentista não apenas pela experiência 'marginal' e 'precursora' dos tropicalistas, mas pelos marcos cognitivos e institucionais do próprio establishment médico. Ele analisa como o paradigma da climatologia médica (hegemônico a partir do início do século XIX e segundo o qual as doenças estavam inextricavelmente associadas às características do meio ambiente em cada localidade) constituiu, em associação com a anatomoclínica, o terreno no qual, mediante critérios de cientificidade partilhados pela medicina da época, forjou-se a crença na existência de uma patologia peculiar aos trópicos e criaramse as condições cognitivas e institucionais para a produção de conhecimentos originais sobre esta patologia. ${ }^{16}$

Segundo Edler (1999), este modelo interpretativo, fundado na noção de que as doenças tinham causas múltiplas e de distintas naturezas, estabeleceu uma epistemologia particularista e empirista, segundo a qual as enfermidades eram pensadas não a partir das categorias classificatórias gerais da patologia, mas com base na especificidade da observação sintomatológica, circunscrita localmente em termos territoriais e climáti$\cos .{ }^{17} \mathrm{Ou}$ seja, quaisquer teorias sobre determinados eventos mórbidos, ainda que apoiadas na universalidade dos princípios da anatomia, química ou fisiologia, deveriam se ancorar no lastro factual de uma experiência clínica concreta e coletivamente sancionada, fonte primordial dos critérios de prova empírica do conhecimento médico. ${ }^{18}$

Focalizando a primeira metade do século XIX, Luiz Otávio Ferreira (1996, 1999) também analisa a importância do tema das particularidades da nosografia nacional para a conformação do campo médico brasileiro. No contexto da organização territorial, econômica e política da nova nação e de crescentes trocas mercantis, o medo de que chegassem ao país as tão temidas epidemias de febre amarela, cólera e peste (que, como reite- 
ravam os médicos brasileiros, até então nos haviam 'poupado') produziu um intenso debate, entre 1830 e 1850, sobre as características das doenças 'locais', em comparação às 'doenças externas'. Este debate, que projetou a medicina nacional na cena pública, revelou os dilemas teóricos e práticos enfrentados na tentativa de lidar com teorias e conceitos, muitas vezes conflitantes, para tratar de temas e interesses particulares à sociedade brasileira. ${ }^{19}$

Um segundo elemento fundamental discutido por esta historiografia diz respeito ao protagonismo reivindicado pela medicina imperial no projeto de construção da nacionalidade e de civilização dos trópicos. Tais trabalhos evidenciam em que medida as características do regime imperial escravista forneceram as condições contextuais específicas para que a ciência médica, com base numa orientação utilitarista/pragmatista (Dias, 1968), buscasse legitimar-se publicamente a partir do compromisso de responder às demandas da sociedade, pelo enfrentamento de questões sanitárias concretas e urgentes, como as epidemias.

Segundo Ferreira (1996, 1999), a invenção de uma agenda sanitária em torno dos principais problemas da patologia brasileira (como as chamadas 'febres intermitentes' ou 'palustres' e a opilação), vocalizada pelos periódicos médicos na Corte, foi a via preferencial para a institucionalização e a legitimação social da prática e do conhecimento médico e para sua inscrição na vida pública, especialmente a partir da década de 1830. Mediante este 'campo de diálogo' entre a medicina e a sociedade, estabelecido no domínio da higiene, compreende-se a maneira pela qual foram produzidos conhecimentos científicos sobre determinadas doenças e como estas foram alçadas à condição de problemas de relevância social. ${ }^{20} \mathrm{Ou}$ seja, os significados sociais atribuídos a certas enfermidades estiveram diretamente referidos às formas pelas quais a ciência médica, no período em questão, estabelecia suas relações com a sociedade e pensava seu papel nos caminhos da modernização do país.

Ao analisar o debate em torno da transmissão e da profilaxia da febre amarela - que se traduziu em intensa discussão sobre as habitações coletivas na cidade do Rio de Janeiro -, Sidney Chalhoub (1996) expõe, por sua vez, em que medida as teorias acionadas para explicar as epidemias, no contexto de uma ordem social fundada na escravidão, sustentaram ideologicamente a atuação dos médicos e higienistas como agentes desta ordem, com profundos impactos na vida social urbana da Corte. 
Finalmente, esta vertente historiográfica, além de confrontar a visão de uma 'idade das trevas' anterior às 'revolucionárias' décadas do final do século XIX, salienta que o questionamento de tais demarcações propicia melhores instrumentos para a compreensão do próprio processo de emergência e de consolidação, no contexto brasileiro, das novas doutrinas associadas ao pasteurianismo. Tem sido enfatizado que este processo, longe de expressar um movimento de substituição de paradigmas contrastantes, implicou "uma paisagem mais matizada", que pressupôs controvérsias, disputas e acomodações, tanto cognitivas quanto políticas, entre distintos atores e modelos interpretativos (Edler, 1999: 1).

Conforme Peard $(1996,1999)$, as formulações da Escola Tropicalista Baiana sobre a etiologia da opilação são exemplos desta articulação entre a tradição climatológica e a teoria dos germes. Apesar de defenderem que a causa da doença era um parasito, Wücherer e outros tropicalistas reiteravam que a sua ação patogênica ocorria somente sob certas condições ambientais (físicas e sociais), daí o fato de serem os escravos e os homens pobres suas principais vítimas. O recurso ao paradigma ambientalista serviu, segundo Peard, como instrumento a garantir a perspectiva de intervenção daqueles médicos sobre os problemas sanitários dos trópicos. Num contexto internacional marcado pelo debate sobre as condições de trabalho nas fábricas européias e, no Brasil, pelas discussões sobre a abolição da escravidão, a articulação entre os dois paradigmas era não apenas uma questão atinente aos conteúdos do conhecimento médico, mas uma questão política (Peard, 1996).

Edler (1999) aprofunda esta perspectiva ao investigar como as pesquisas parasitológicas emergentes no Brasil em meados do século XIX (que pretendiam contrapor-se à climatologia médica e instaurar uma nova concepção sobre a causalidade das doenças, fundada no laboratório) impuseram-se mediante disputas e negociações que envolveram não apenas diferentes conceitos sobre os agentes patológicos, mas distintos sistemas de autoridade reguladores do saber, da prática e das carreiras no campo médico. A constituição da medicina tropical como disciplina, a partir da última década daquele século, ocorreu, segundo o autor, não por uma ruptura com o paradigma climatológico da higiene, mas mediante um quadro cognitivo-institucional moldado por ele. A suposta incomensurabilidade entre os dois paradigmas, tida como fundadora da nova disciplina, "não foi o ponto de partida, mas o resultado de uma construção coletiva feita em torno de um conjunto de práticas e conceitos progressivamente homogeneizados" (Edler, 1999: 6). 
Jaime Benchimol (1999) segue nesta trilha ao salientar que, até mesmo para se compreender o sentido inovador da 'ciência dos micróbios' de Oswaldo Cruz, deve-se retroceder a uma ou duas gerações de médicos que introduziram a problemática da medicina pasteuriana no país. Acompanhando as diferentes teorias propostas por bacteriologistas brasileiros, a partir da década de 1880, sobre a etiologia, os modos de transmissão e a profilaxia da febre amarela, o autor aponta como este tema, central para a saúde pública brasileira desde meados do século XIX, foi o veículo principal para a entrada e a difusão da medicina pasteuriana no país, num processo em que os brasileiros, apesar da assimetria em relação aos centros europeus, não foram meros reprodutores de idéias, mas tiveram papel ativo num campo que ainda enfrentava importantes desafios para sua estabilização. ${ }^{21}$ Este processo, profundamente marcado por controvérsias e negociações conceituais e políticas, extravasou os limites do campo médico brasileiro e teve profundos impactos sobre a discussão do saneamento e da modernização da capital federal, envolvendo seus vários atores com outros interesses e grupos presentes na sociedade. ${ }^{22}$

Tais estudos contribuem para a reflexão que pretendo desenvolver por mostrarem que, em contextos distintos e com instrumentais interpretativos diversos, os médicos brasileiros enfrentaram, ao longo do século XIX, uma questão que se colocaria também para os atores envolvidos na construção científica e social da doença de Chagas: o compromisso da ciência em estudar e em propor soluções para as doenças vistas como peculiares ao Brasil e, nesse sentido, seu protagonismo na formulação de um projeto de modernização nacional. Mesmo que os termos desta associação ('patologia brasileira', 'progresso', 'nação') tenham assumido significados específicos nos diferentes contextos, ela foi um importante fio condutor do processo de institucionalização da ciência médica no país, ao qual a descoberta e os estudos sobre a doença de Chagas estariam referidos e cujos rumos tais estudos iriam ajudar a estabelecer.

Além disso, no diálogo com esta literatura, cabe assinalar que o questionamento às narrativas que incensaram os 'pais fundadores' da microbiologia ou da medicina tropical como mitos de origem da medicina científica não implica desconsiderar os sentidos de descontinuidade que estes marcos expressam e a importância que esta demarcação cumpriu para os que a propagaram e dela se beneficiaram. De fato, aqueles médicos construíram sua imagem e foram socialmente reconhecidos em sua época como sujeitos de um 'novo tempo'. O que importa é qualificar, 
historicamente, os sentidos em que este 'novo' foi estabelecido e compreendido naquele contexto. ${ }^{23}$

Da mesma maneira que se pretende recuperar as percepções, categorias e estratégias de atores tradicionalmente vistos como secundários ou mesmo ausentes, a perspectiva de contextualização segue valendo para aqueles que foram consagrados como os pólos hegemônicos nestas demarcações, até mesmo para melhor compreender este lugar. Ambas as posições constituem construções coletivas historicamente produzidas e sancionadas. Se a "base do pedestal" de Manguinhos (Benchimol, 1999: 9) era a idéia de que Oswaldo Cruz inaugurou a medicina científica no Brasil, o desafio é compreender como esta representação foi construída e qual o seu sentido histórico (Britto, 1995). A descoberta da doença de Chagas é um objeto a ser analisado justamente como algo que se estabeleceu a partir desta representação e que foi um dos principais elementos para erigi-la e consolidá-la.

Os sentidos subjacentes a estas demarcações devem ser levados em conta também por colocar, aos historiadores, a necessidade de qualificar as diferenças que separam períodos distintos no processo de institucionalização da ciência no Brasil.

Nesse sentido, a questão central posta por Stepan (1976) permanece válida: há que se compreender quais as condições que permitiram a Oswaldo Cruz e seus discípulos estabelecer, sob as circunstâncias peculiares da sociedade brasileira do início do século XX, bases cognitivas, materiais, políticas e sociais para garantir a ampliação e a sobrevivência de um instituto criado sob objetivos restritos, de modo a torná-lo, de fato, uma experiência institucional diferente e nova na ciência brasileira. A descoberta da doença de Chagas - elemento-chave na legitimação dos novos significados atribuídos à ciência médica experimental praticada em Manguinhos - foi, como sugeriu Stepan, um importante elemento deste processo de institucionalização.

\section{Carlos Chagas e um 'Bando de Idéias Novas': formação médica, microbiologia e medicina tropical}

Carlos Ribeiro Justiniano Chagas nasceu no dia 9 de julho de 1878, na Fazenda Bom Retiro, a cerca de vinte quilômetros da pequena cidade 
de Oliveira, interior de Minas Gerais. ${ }^{24}$ Seus antepassados, de origem portuguesa, estabeleceram-se na região havia quase um século e meio. Órfão de pai aos quatro anos, passou a infância nesta e em outra fazenda da família, em Juiz de Fora (MG), onde sua mãe administrava o cultivo do café. Embora distante dos centros ilustrados, a convivência com os tios maternos (dois deles advogados e um médico, dono de uma clínica em Oliveira) fez com que o menino manifestasse vontade de avançar nos estudos, com particular interesse pela medicina (Chagas Filho, 1993). ${ }^{25}$

Aos oito anos, já alfabetizado, Carlos Chagas foi matriculado no Colégio São Luís, internato dirigido por jesuítas em Itu, interior de São Paulo. Mas não ficaria ali por muito tempo. Em maio de 1888, ao ter notícias de que os escravos recém-libertados estariam depredando fazendas, fugiu para encontrar-se com sua mãe. A indisciplina foi punida com a expulsão, e o menino transferiu-se para o Ginásio São Francisco, em São João del Rey. ${ }^{26}$ Concluídos os estudos, sua mãe decidiu que ele deveria formar-se em engenharia. Em 1895, ingressou no curso preparatório da Escola de Minas de Ouro Preto, tradicional centro de ensino superior. Contudo, os excessos da vida boêmia custaram-lhe a reprovação nos exames e o retorno a Oliveira. Com a ajuda do tio médico, venceu a resistência da mãe e mudou-se para a capital federal, para estudar medicina (Chagas Filho, 1993).

No Rio de Janeiro, foi morar com outros estudantes mineiros numa pensão no bairro da Tijuca, próxima à residência de um primo, deputado federal por Minas Gerais. ${ }^{27}$ Em abril de 1897, matriculou-se na Faculdade de Medicina, na rua de Santa Luzia, centro da cidade. Conforme Chagas Filho (1993), seu pai impressionou-se vivamente com a agitação política da capital. O governo de Prudente de Morais (1894-1898), primeiro presidente civil da República, buscava pacificar os ânimos conflagrados que vinham sacudindo o novo regime. Em novembro daquele ano, recebendo as tropas federais vindas do sertão da Bahia, a cidade comemorou efusivamente aquela que foi exaltada como uma das grandes vitórias republicanas: a aniquilação das forças de Antonio Conselheiro no arraial de Canudos. O governo de Campos Sales (1898-1902) selaria a estabilização política e econômica iniciada por seu antecessor. Ao longo desse período, no qual Chagas realizou sua formação médica, seriam estabelecidas as bases da tão propalada modernização republicana que, sob as diretrizes liberais da Constituição Federal de 1891, se propunha a intensificar os avanços econômicos em curso desde meados do século 
XIX, especialmente da década de 1870, marco do apogeu do Império e da expansão da cafeicultura no vale do Paraíba (Lessa, 1988).

No curso da chamada segunda Revolução Industrial, beneficiando-se dos melhoramentos propiciados pelos investimentos sobretudo britânicos e vivenciando as transformações derivadas da introdução do trabalho assalariado, a cidade do Rio de Janeiro era o grande centro comercial e financeiro da nação. As novas ferrovias intensificavam o movimento no porto da cidade em torno da exportação do café e outros produtos agrícolas e da entrada de imigrantes, manufaturas e capitais. A instalação de serviços públicos de iluminação, esgoto, limpeza e transportes urbanos criava a infra-estrutura para a expansão das atividades econômicas na cidade (Neves, 2003; Benchimol, 2003).

Além da agitação política, Chagas impressionou-se com a efervescência cultural da cidade. O jovem estudante, que assistira logo ao chegar à criação da Academia Brasileira de Letras, entusiasmava-se com os novos escritores e estilos que se projetavam na cena literária, como Olavo Bilac, Coelho Neto e o romance realista de Artur Azevedo e Manoel Joaquim de Almeida (Chagas Filho, 1993). Disseminada no meio intelectual estava a crença de que se vivia um novo tempo, simbolicamente expresso no novo século que se aproximava, em que o Brasil ingressaria finalmente no rol das 'nações civilizadas'. A ciência e a técnica eram exaltadas, sob os valores do positivismo e de outras teorias cientificistas, como elementos norteadores de um saber objetivo e eficaz sobre a realidade que, contrapondo-se à cultura livresca e bacharelesca, apontaria os caminhos seguros para o bem-estar moral e material da sociedade. Este ambiente era fruto de um processo iniciado no Império, com a chamada geração de 1870, que se engajou na perspectiva da modernização a partir do "bando de idéias novas" que, na célebre frase de Silvio Romero, esvoaçavam de todos os pontos do horizonte (apud Alonso, 2002: 21). Esta foi o que Maria Alice Rezende de Carvalho (1991) chamou de 'fase heróica da intelectualidade brasileira', que assumiu uma vocação pública, expressa na intenção de dar solução às grandes questões morais e políticas que deveriam fundamentar a vida em sociedade a partir do esclarecimento dos atores para uma ação racional no mundo. ${ }^{28}$

Na FMRJ, Chagas encontrou uma instituição que também vivia as conseqüências do espírito reformista da década de 1870, quando teve início um importante movimento em prol da profissionalização da medicina acadêmica no Brasil, que se expressou em intenso debate sobre os 
padrões de formação profissional dos médicos (Edler, 1992). Denunciando a precariedade material e pedagógica das instituições médicas oficiais, a elite médica, sobretudo na Corte, passou a reivindicar maior liberdade e autonomia face à burocracia imperial e uma ampla redefinição do próprio estatuto de cientificidade do saber médico. A incorporação, ao campo da clínica, das novas disciplinas e dos instrumentos e métodos da ciência experimental era reivindicada como caminho indispensável para que a medicina brasileira, mediante um amplo programa de pesquisas orientadas para a patologia nacional, se tornasse depositária da grande confiança vigente sobre a ciência como chave fundamental do progresso. Este movimento teve grande ressonância junto à opinião pública ilustrada e conduziu a uma reforma do ensino médico, que na FMRJ foi implementada, entre 1881 e 1889, pelo Visconde de Sabóia. Em 1872, ele havia percorrido, em viagem científica, diversos países europeus para conhecer suas escolas médicas e recomendar diretrizes para a renovação das faculdades brasileiras. ${ }^{29}$

As duas principais diretrizes da 'reforma Sabóia' foram a liberdade de ensino e a renovação acadêmica. Esta se daria mediante, principalmente, o ensino prático e especializado nos laboratórios, não apenas como suporte à habilitação profissional dos futuros clínicos, mas como fonte de novos conhecimentos médicos, a fim de colocar o Brasil na trilha das grandes descobertas no cenário internacional. Deslocando a tradicional influência do modelo francês erigido em torno da clínica, a reforma inspirava-se no sistema de ensino superior alemão, que defendia que a investigação científica deveria ser parte inseparável da atividade docente (Edler, 1992). Em discurso na solenidade de doutoramento dos estudantes em 1883, Sabóia resumiu o sentido daquele momento, enaltecido como portal de uma nova temporalidade, à qual Chagas viria a se identificar alguns anos depois: "Nunca compreendi estudo médico sem laboratório, em que a objetividade dos fatos, que possam ser percebidos ou caiam debaixo de nossos sentidos, tenha a sua confirmação na análise e verificação experimental bem estabelecida em todas as fases do fenômeno que se queira estudar ou conhecer" (apud Edler, 1996: 293).

O novo regulamento instituído em 1881 reestruturou o currículo da faculdade, criando clínicas especializadas e novas cadeiras. A preocupação em impulsionar estudos de natureza experimental expressou-se tanto na construção de novos laboratórios e no estímulo ao aperfeiçoamento científico dos professores quanto no caráter eliminatório concedido às provas práticas e na obrigatoriedade da presença às aulas de laboratório 
(Edler, 1992). ${ }^{30}$ Ainda que não se tenha concretizado em toda a amplitude prevista pela reforma Sabóia, a renovação da FMRJ foi um momento de particular valorização da importância social da atividade científica. As potencialidades teóricas e técnicas da chamada 'medicina de laboratório' foram exaltadas como poderosas ferramentas para enfrentar as questões sanitárias tidas como estratégicas para o país.

Este clima de otimismo esteve diretamente associado à grande repercussão, no cenário internacional, dos trabalhos de Robert Koch e Louis Pasteur, base do novo paradigma da microbiologia. A partir de 1880, com seus estudos sobre a raiva, Pasteur deixou o campo da veterinária para investigar os agentes microbianos de doenças humanas. ${ }^{31} \mathrm{Em}$ 1882 e 1883, Koch identificou, respectivamente, os bacilos causadores da tuberculose e do cólera. Em 1884, estabeleceu os protocolos experimentais para a demonstração dos vínculos causais entre agentes microbianos e patologias, critérios estes que serviram para definir a própria noção de 'causa' específica das doenças infecciosas (Cunningham, 1992). ${ }^{32}$

Segundo Charles Rosenberg (1992b), a concepção de etiologia específica estabelecida pela microbiologia foi um instrumento poderoso para disseminar a idéia de que as doenças constituem realidades ontológicas particulares, definidas pela ação de um ente particular. Além disso, a vacina anti-rábica - desenvolvida por Pasteur com base na inoculação de microorganismos de virulência atenuada e utilizada pela primeira vez num ser humano em 1885 - foi o primeiro grande resultado da aplicação da microbiologia à medicina. Abrindo grandes perspectivas para a profilaxia e a terapêutica das enfermidades infecciosas, trouxe a consagração definitiva a Pasteur e à microbiologia. Em 1888, foi criado em Paris o instituto que leva seu nome.

Aqueles foram anos importantes para a definição de fronteiras internas ao próprio domínio da teoria dos germes, que balizariam, algum tempo depois, a emergência da medicina tropical como disciplina. Em 1880, o médico militar francês Charles Louis Alphonse Laveran anunciou ter identificado, em suas experiências na Argélia, o hematozoário causador da malária. A idéia de que não apenas bacilos e bactérias, mas os protozoários, organismos mais complexos, causavam doenças humanas era inovadora e enfrentou resistências. ${ }^{33}$ A descoberta de Laveran só seria plenamente aceita ao final da década, quando Eugène Richard, Camilo Golgi e Ettore Marchiafava vincularam o ciclo de vida daquele parasito às manifestações clínicas da doença (Benchimol \& Sá, 2005). ${ }^{34}$ 
Em consonância com esta efervescência mundial em torno da busca dos agentes causais das doenças infecciosas e dos instrumentos para preveni-las e tratá-las, intensificaram-se, no Brasil, os esforços dos 'caçadores de micróbios', que dirigiam suas investidas, sobretudo, para as doenças que compunham a nosologia nacional. Os primeiros pasteurianos brasileiros se engajariam na busca do agente etiológico da febre amarela. Desde 1849/1850, quando se manifestou pela primeira vez na cidade do Rio de Janeiro, a doença tornou-se a grande questão sanitária nacional, em função dos prejuízos causados pelas freqüentes epidemias que afugentavam da cidade os capitais e a força de trabalho estrangeiros. A febre amarela tornou-se o tema fundamental a partir do qual médicos, higienistas e diversos segmentos da sociedade discutiriam as perspectivas da modernização no país (Chalhoub, 1996; Benchimol, 1999, 2001; Löwy, 2006).

Confrontando a visão de que esta, como outras doenças epidêmicas, era causada pelas condições climáticas e topográficas de cidades litorâneas como o Rio de Janeiro, Domingos José Freire, catedrático de química orgânica da FMRJ, anunciou, em 1879, a descoberta de uma alga microscópica que julgava ser o agente causal da febre amarela. Em 1883, desenvolveu em seu laboratório, mediante técnicas pasteurianas, uma vacina contra a doença, que foi aplicada com grande receptividade no país. O invento do bacteriologista brasileiro, que contava com o apoio de abolicionistas e republicanos, conquistou expressiva adesão no meio médico nacional e entre pasteurianos franceses. Consagrado como herói da ciência nacional, Freire foi um ator importante na implantação, na FMRJ, dos princípios da reforma Sabóia, pela visibilidade que conferiu às potencialidades da medicina experimental. Ele não foi o único a reivindicar a descoberta da causa e do meio de combate da febre amarela. A intensa e longa controvérsia que se abriu a este respeito, envolvendo Freire e outros cientistas no Brasil e no exterior, evidenciou tanto o entusiasmo dos ‘caçadores de micróbios' quanto os desacordos e as negociações que permearam a institucionalização da medicina pasteuriana no Brasil nas décadas de 1880 e 1890 (Benchimol, 1999). ${ }^{35}$

Na primeira década republicana, estudos e discussões sobre as doenças infecciosas - especialmente as de natureza epidêmica - se intensificaram, sobretudo em função do agravamento das condições sanitárias da capital federal. Apesar da expansão urbana para os novos bairros, o centro do Rio de Janeiro continuava a viver os efeitos críticos da condensação populacional, explicitando a incompatibilidade entre a 
antiga estrutura material da cidade e as novas relações capitalistas que vinham se estruturando havia algumas décadas. Grandes contingentes de ex-escravos das zonas cafeeiras decadentes e de imigrantes europeus afluíam para as habitações coletivas da 'cidade velha', condenadas por higienistas e políticos como o emblema da insalubridade urbana. Por suas ruas estreitas e sinuosas, trafegavam cada vez mais mercadorias e pessoas sob o ritmo crescente das atividades econômicas, relacionadas tanto às empresas comerciais e financeiras ali localizadas quanto às transações entre a estação ferroviária e o porto, articulando a lavoura cafeeira ao mercado mundial. Sob tais condições, as temidas epidemias, sobretudo de febre amarela, tornavam-se devastadoras. Intensificava-se a discussão entre médicos, engenheiros e autoridades públicas sobre a necessidade de intervenções no espaço urbano da capital, em pauta desde os anos de 1870. A reforma preconizada visava não apenas ao saneamento, por meio do dessecamento dos pântanos, alargamento de ruas e arrasamento de morros, mas a garantir à cidade uma feição arquitetônica e urbanística mais adequada à sua pretensão de 'vitrine' da modernização brasileira (Benchimol, 1990b, 2003; Neves, 2003).

Neste contexto, o governo federal estabeleceu novas estruturas administrativas para lidar com as candentes questões sanitárias. Em 1897, ano em que Chagas ingressou na FMRJ, foi criada a Diretoria Geral de Saúde Pública (DGSP), subordinada ao Ministério da Justiça e Negócios Interiores. ${ }^{36}$ Contudo, embora avançasse a adesão às doutrinas da microbiologia, o campo médico brasileiro permaneceu marcado na década de 1890 por polêmicas e incertezas sobre os 'infinitamente pequenos'. O termo 'micróbio' tinha sido cunhado exatamente para contornar estas dúvidas. Em 1897, a controvérsia em torno do agente etiológico da febre amarela estava na ordem do dia na capital federal, com vários pesquisadores e médicos competindo por tão ansiada descoberta (Benchimol, 1999). ${ }^{37}$

Além das questões no campo da etiologia, havia muitas dúvidas sobre os mecanismos pelos quais estes micróbios agiam e, sobretudo, sobre os meios de sua transmissão. Entre divergentes teorias sobre como as epidemias tinham origem e se disseminavam - e, conseqüentemente, sobre o modo de evitá-las ou combatê-las -, as explicações mais correntes não se fundamentavam mais na idéia de miasmas, mas mantinham a noção de que o meio ambiente era, de alguma maneira, um fator fundamental na propagação das doenças. Acreditava-se que, mediante alguma combinação, os múltiplos e heterogêneos elementos do meio - que envol- 
via fatores climáticos (atmosfera, calor, umidade, chuvas), telúricos (solo, águas estagnadas, morros, matérias em putrefação) e sociais (navios, habitações, cemitérios, matadouros, mercados, esgotos) - forneciam as condições indispensáveis para que os micróbios sobrevivessem fora do organismo humano e se tornassem capazes de infectá-lo (Benchimol, 1999). ${ }^{38}$

Foi em meio a estes debates sobre a natureza e o controle das epidemias que se projetaram, ao longo da década de 1890, a geração de microbiologistas da qual Chagas se tornaria discípulo e as primeiras instituições diretamente identificadas à microbiologia. ${ }^{39} \mathrm{Em} \mathrm{1892, \text {fo- }}$ ram criados o Instituto Bacteriológico Domingos Freire e o Instituto Bacteriológico de São Paulo, este último dirigido, a partir do ano seguinte, por Adolpho Lutz, médico brasileiro que, formado em instituições germânicas, se tornaria uma das principais lideranças da microbiologia e da medicina tropical brasileiras. ${ }^{40}$

Em 1894, Oswaldo Cruz (que se formara na FMRJ dois anos antes), Eduardo Chapot-Prévost, Francisco Fajardo (ambos professores daquela escola) e Lutz diagnosticaram uma epidemia de cólera no vale do Paraíba, um dos eixos da economia cafeeira, e propuseram rigorosas medidas de isolamento. Enfrentaram duras resistências dos médicos locais, que não aceitavam aquele diagnóstico, nem as medidas profiláticas indicadas, acreditando tratar-se de diarréias causadas por fatores locais. Em 1899 (quando Chagas estava no terceiro ano de seu curso médico), uma forte epidemia irrompeu no porto de Santos. O diagnóstico de peste bubônica, firmado por Vital Brazil em nome do Instituto Bacteriológico, suscitou forte oposição entre os comerciantes locais e a imprensa paulista. O órgão federal de defesa sanitária enviou, do Rio de Janeiro, Oswaldo Cruz para examinar a questão. O jovem médico, recém-chegado do Instituto Pasteur de Paris, confirmou os estudos do colega paulista. A dificuldade em obter-se o soro antipestoso (produzido somente no Instituto Pasteur de Paris) levou à criação de um laboratório destinado à sua fabricação, vinculado ao Instituto Bacteriológico de São Paulo, e que, sob a direção de Vital Brazil, se converteria no Instituto Butantan (Benchimol \& Teixeira, 1993).

Ainda em 1899, antecipando-se a um possível alastramento da epidemia, o prefeito da capital federal Cesário Alvim solicitou ao barão de Pedro Afonso (proprietário do Instituto Vacínico Municipal, onde se produzia a vacina antivariólica) a criação, no Rio de Janeiro, de um laboratório análogo ao paulista, para produzir e fornecer o soro 
antipestoso à DGSP. Instalado na fazenda de Manguinhos, o Instituto Soroterápico Federal, sob a direção geral de Pedro Afonso e tendo Oswaldo Cruz como diretor técnico, foi inaugurado em 25 de maio de 1900. Chagas iria se integrar ao Instituto de Manguinhos, como também ficaria conhecido o Soroterápico, ao final de sua formação acadêmica, e a ele estaria ligado durante toda sua trajetória profissional, (Benchimol, 1990a, 2001; Benchimol \& Teixeira, 1993).

Ao mesmo tempo que testemunhou as controvérsias da microbiologia em seu processo de institucionalização (a cadeira de bacteriologia foi criada na FMRJ em 1901), Chagas realizou sua formação num momento marcado pela emergência do que se estabeleceria como um novo modelo para a pesquisa médica, estruturado em torno do papel dos artrópodes (grupo que compreende os insetos, aracnídeos e crustáceos), particularmente os insetos hematófagos, como transmissores de doenças, animais ou humanas.

Uma primeira contribuição decisiva ao conceito de inseto-vetor dizia respeito às descobertas de Patrick Manson, que, depois de desvendar quase todo o ciclo do parasito que causava a filariose, estabeleceu em 1879 que os mosquitos tinham um papel fundamental na transmissão da doença aos seres humanos, servindo de 'hospedeiros intermediários' para o parasito. Este cumpriria parte de sua evolução no organismo do inseto antes de transferir-se para o 'hospedeiro definitivo': o homem. ${ }^{41} \mathrm{Em} 1893$, Theobald Smith e Fred Lucius Kilborne desvendaram a transmissão, por carrapatos, do protozoário que causava a doença do gado chamada 'febre do Texas' e, três anos depois, David Bruce demonstrou que as moscas eram transmissoras de tripanossomas (um tipo de protozoário) causadores do nagana (doença de eqüinos). Ganhavam força, assim, as hipóteses de que a malária e a febre amarela também fossem veiculadas por insetos (Benchimol, 1999; Benchimol \& Sá, 2005, 2006). ${ }^{42}$

Ao longo da década de 1890, a partir destas descobertas, os periódicos brasileiros, e mesmo a imprensa leiga, publicariam cada vez mais artigos sobre a questão. Os insetos eram vistos, geralmente, como agentes mecânicos de transmissão de microorganismos apanhados em águas estagnadas ou em matérias pútridas. Especulava-se, em menor medida, que animais sugadores de sangue, como os mosquitos, poderiam disseminar doenças tanto diretamente, pela picada, quanto por meio da água contaminada pelos insetos infectados que nela morriam, como supunha Manson para a filariose (Benchimol, 1999; Benchimol \& Sá, 2005, 2006). 
Benchimol (1999: 396-397) sintetiza o espírito vigente no campo médico brasileiro em meados da 'tumultuada' década de 1890:

(...) as partes componentes das teorias de matriz pasteuriana sobre malária, febre amarela e outras doenças eram como que 'imantadas' pelo campo de força da medicina tropical, formado por constelação em parte diferente de objetos, métodos e disciplinas científicas. Novos elos vivos passavam a ser incorporados aos constructos elaborados sob a égide da bacteriologia, rearrumando-os. Os liames que prendiam solo, água, ar, alimentos, casas e homens nas teias percorridas pelos supostos micróbios dessas doenças acolhiam com dificuldade os novos actantes. Ligações eram refeitas, novos componentes adicionados, mas os insetos permaneciam estranhos naqueles ninhos. A lógica que presidia a investigação de ponta na medicina tropical inglesa parecia ser incompatível ou incomensurável com a lógica de reprodução das teorias microbianas que caducavam.

O marco decisivo na afirmação da abordagem do inseto-vetor se deu com a elucidação do modo de transmissão daquela que era considerada a doença tropical por excelência: a malária. Seguindo orientação de Manson, Ronald Ross (funcionário do Indian Medical Service) desvendou, em 1898, o ciclo do parasito da malária das aves nos mosquitos do gênero Culex. No ano seguinte, o italiano Giovanni Grassi e seus colaboradores Amico Bigman e Giuseppe Bastinelli demonstraram que a malária humana era transmitida por mosquitos Anopheles. ${ }^{43}$

As descobertas de Ross e Grassi, fazendo multiplicar os estudos sobre o papel dos insetos na transmissão das doenças, foram fundamentais para a institucionalização da medicina tropical como especialidade distinta no campo da pesquisa e do ensino médicos. Tendo como cerne o modelo do parasito-vetor, ela se reportava a um conjunto particular de enfermidades (como a malária, febre amarela, esquistossomose, filariose e tripanossomíase africana) causadas por protozoários ou helmintos (organismos mais complexos do que as bactérias, cuja transmissão, em vários casos, depende de que seu ciclo evolutivo se complete no organismo dos hospedeiros). As condições climáticas e geográficas típicas das regiões tropicais favoreceriam a existência das espécies parasitárias e dos artrópodes que as transmitiam, influenciando também o metabolismo humano de modo a intensificar os efeitos do parasitismo (Worboys, 1997). ${ }^{44}$

Em articulação direta com a expansão imperialista, especialmente dos britânicos, o argumento de que as doenças peculiares aos trópicos 
exigiam conhecimentos específicos para seu diagnóstico, sua profilaxia e seu tratamento, sobretudo como meio de subsidiar a atuação dos médicos europeus nas colônias, foi apresentado, em outubro de 1897, por Manson, em conferência aos estudantes do Saint George's Hospital, em Londres, sobre a "necessidade de uma educação especial em medicina tropical" (Manson, 1897). Em 1898, ano em que Manson publicou a primeira edição do seu Tropical Diseases (Manson, 1903), o secretário de Estado para as colônias, Joseph Chamberlain, endereçou um memorando às escolas médicas britânicas requerendo que estas estabelecessem instrução e treinamento em medicina tropical para os oficiais médicos que fossem atuar nas colônias. A orientação de Manson de que tal formação deveria ser oferecida em escolas especializadas prevaleceu e, em 1899, foram criadas as primeiras escolas de medicina tropical em Liverpool e em Londres, seguidas da fundação de instituições congêneres em outros países (Farley, 1991; Worboys, 1997). ${ }^{45}$ No Brasil, o estudo da febre amarela foi reorientado no Instituto Bacteriológico de São Paulo. Seu diretor, Adolpho Lutz, que já vinha associando a presença de mosquitos às epidemias de febre amarela no estado de São Paulo, começou, em 1898, a investigar a distribuição dos mosquitos no país. ${ }^{46}$

A consagração da teoria sobre o papel dos insetos como vetores de doenças tropicais ocorreria em 1900/1901, em Cuba, quando a equipe chefiada pelo norte-americano Walter Reed comprovou a teoria de Finlay sobre a transmissão da febre amarela pelo mosquito Culex. As experiências demonstraram também que, contrariamente ao que se pensava, os elementos do ambiente (como o ar e a água) e os chamados fomites (vômitos, fezes e urina dos doentes) não tinham qualquer influência na veiculação do germe. Uma habitação só era perigosa se houvesse mosquitos infectados em seu interior, sendo assim totalmente desnecessários os tradicionais processos de desinfecção. As experiências de Reed foram apresentadas ao Congresso Pan-Americano de Havana em 1901, ao mesmo tempo em que William Gorgas iniciava uma campanha contra o mosquito naquela cidade. Por meio do extermínio de suas larvas em águas estagnadas e do isolamento dos doentes com mosquiteiros, a doença foi rapidamente vencida. Em 1904, Gorgas assumiria o combate à febre amarela com vistas a viabilizar a grande obra de construção do canal do Panamá, ícone da expansão das rotas comerciais entre países e continentes (Benchimol, 1999; Benchimol \& Sá, 2005, 2006). 
Este foi um divisor de águas na história da medicina e da saúde pública internacional, que, no Brasil, reorientou não apenas o pensamento médico, mas a política sanitária. A disseminação da idéia de que a cadeia de transmissão de duas temidas doenças tropicais - malária e febre amarela - não incluía qualquer fator ligado ao meio exterior, resumindo-se a uma equação entre micróbios e mosquitos, abriu uma nova perspectiva para a tão controvertida questão sobre como enfrentar as epidemias. $\mathrm{O}$ ataque aos insetos-vetores mediante campanhas verticalmente orientadas a doenças específicas passaria a ser mais um argumento a inspirar, juntamente com as vacinas e soros dos pasteurianos e as 'balas mágicas' da quimioterapia, a confiança de que, no limiar do novo século, a medicina dispunha de armas sem precedentes para vencer os grandes 'flagelos' da humanidade. ${ }^{47}$ Tal período foi decisivo para a disseminação do que Randall Packard e Peter Brown (1997: 184) chamam de "concepção biomédica estrita” da relação entre saúde e desenvolvimento, ou seja, a idéia de que a saúde e a doença constituem fenômenos da vida social que dizem respeito essencialmente ao domínio técnico da medicina, tanto em termos da compreensão quanto das intervenções sobre eles.

No Brasil, logo após a fundação das escolas inglesas de medicina tropical, cogitou-se criar, nas faculdades de medicina do Rio e da Bahia, uma cátedra de 'patologia tropical'. A proposta, apresentada na revista Brazil-Medico por Carlos Seidl em maio de 1900 (Seidl, 1900), foi discutida no IV Congresso Brasileiro de Medicina e Cirurgia, realizado em junho do mesmo ano no Rio de Janeiro, tendo sido derrotada por 21 votos contra três (Congresso Brasileiro de Medicina e Cirurgia, 1901: 74, 86). Os paulistas foram pioneiros na incorporação da abordagem testada em Cuba. Em 1901, o diretor do serviço sanitário do estado, Emílio Ribas, determinou que se incluísse o combate às larvas do mosquito entre as medidas de profilaxia da febre amarela. Com apoio do governador do estado, Rodrigues Alves, entre 1902 e 1903, Ribas e Lutz reproduziram com sucesso em São Paulo as experiências feitas em Cuba (Almeida, 2003).

No Rio de Janeiro, pesquisadores enviados pelo Instituto Pasteur de Paris também realizaram experiências para comprovar a chamada doutrina havanesa, além de estudos sobre as muitas questões ainda em aberto acerca dos mosquitos transmissores. ${ }^{48} \mathrm{Na}$ capital federal, a polêmica em torno dessa teoria se dava, sobretudo, em função de suas implicações sobre as perspectivas de saneamento e intensificou-se justamente quando, em 1902, Rodrigues Alves chegou à presidência da República com a 
prioridade de concretizar o tão ansiado plano de melhoramentos urbanos. Apesar de reconhecerem a transmissão da doença pelo mosquito, muitos médicos, como o então diretor da Saúde Pública Nuno de Andrade, defendiam que o combate ao inseto deveria adicionar-se às medidas profiláticas voltadas para neutralizar o germe no meio exterior (como o dessecamento do solo ou as desinfecções) e não substituí-las. A controvérsia se expressou, principalmente, por ocasião do V Congresso Brasileiro de Medicina e Cirurgia, realizado no Rio de Janeiro em 1903, no qual, após intensos debates - que envolveram questões científicas e políticas -, as diretrizes firmadas em Cuba foram aprovadas, ainda que com algumas restrições (Benchimol, 1999).

A corporação médica dava, assim, seu aval à estratégia de Oswaldo Cruz (adepto da teoria de Finlay), que em março daquele ano assumira a DGSP. Com amplos poderes garantidos pelo governo federal, seu programa saneador era estruturado em campanhas dirigidas a três alvos precisos, mediante estratégias igualmente específicas: a varíola, que se pretendia vencer com a vacina, a peste bubônica e a febre amarela, a serem combatidas por meio do ataque a seus vetores. ${ }^{49}$ A partir de 1903 , ano em que Chagas defendeu sua tese de doutoramento, a capital federal passou a ser o "primeiro laboratório a céu aberto para o teste de uma campanha calcada na teoria culicidiana", sob condições que não eram as de ocupação militar, como em Cuba (Benchimol \& Sá, 2005: 192)..$^{50}$

As relações que Chagas estabeleceu durante seu curso na FMRJ, entre 1897 e 1903, com os dois professores que mais marcaram a sua formação - Miguel Couto e Francisco Fajardo - evidenciam exatamente os caminhos seguidos por ele neste momento de particular intensidade do debate médico-científico. Com o primeiro, Chagas aprendeu a utilizar os métodos e os princípios da medicina experimental para o diagnóstico e o estudo clínico das doenças da nosologia brasileira, como a febre amarela ${ }^{51}$ Por seu intermédio, acompanhou estudos dessa doença, que iria atingi-lo pessoalmente ao levar à morte o tio, alguns meses mais moço e que com ele havia se matriculado na faculdade de medicina. Couto, de quem Chagas se tornou amigo pessoal, foi decisivo em sua formação sobretudo por incutir-lhe a concepção de que a clínica médica deveria ser renovada e subsidiada pelos novos conhecimentos e técnicas propiciados pelas pesquisas científicas.$^{52}$ Foi também por seu intermédio que Chagas ingressou na vida social das elites da capital, vindo a conhecer Íris Lobo, filha do senador por Minas Gerais Fernando Lobo Leite Pereira, com 
quem iria se casar e ter dois filhos, Evandro e Carlos Chagas Filho, nascidos, respectivamente, em 1905 e 1910 (Chagas Filho, 1993).

Francisco Fajardo, por sua vez, conduziu Chagas aos temas da medicina tropical. Pioneiro da microbiologia no Brasil, foi um dos que se lançaram à corrida para desvendar o agente da febre amarela. ${ }^{53}$ Manifestava grande interesse pelas problemáticas particulares à teoria do parasito-vetor, especialmente no que dizia respeito à malária. Neste terreno, estabelecia constante parceria com Lutz, ambos fazendo parte da rede internacional montada pelo Museu Britânico para coletar mosquitos. Desde o início da década de 1890, Fajardo realizava estudos experimentais sobre o ciclo evolutivo do parasito daquela doença, sendo reconhecido pela imprensa carioca como o 'descobridor', no Brasil, do hematozoário de Laveran, com quem mantinha contatos pessoais (Benchimol \& Sá, 2005, 2006).

Fajardo, assim como Lutz, não apenas acompanhava os estudos que ingleses e italianos desenvolviam sobre a etiologia e o modo de transmissão da malária, mas, conforme salientam Benchimol e Sá (2005, 2006), colaborava ativamente neste campo. Os problemas constitutivos da medicina tropical, como os ciclos parasitários e a relação entre parasitos e seus hospedeiros, exigiam protocolos de pesquisa específicos e demorados (como dissecações de insetos e observação da morfologia, localização e pluralidade das formas evolutivas dos parasitos) e requeriam procedimentos ainda pouco padronizados e difundidos no Brasil (como o domínio da microscopia e das técnicas de fixação e coloração).

No pequeno laboratório de Fajardo, na Santa Casa de Misericórdia, Chagas iniciou-se em algumas destas questões e técnicas, atuando como auxiliar na realização de exames hematológicos e na identificação das diferentes espécies do parasito da malária, base para o diagnóstico das várias formas clínicas da doença. Com o tempo, acumulou material para suas próprias experiências. Em fins de 1902, levando uma carta de apresentação deste professor, procurou Oswaldo Cruz no Instituto de Manguinhos a fim de realizar ali as pesquisas para sua tese de doutoramento, prérequisito para a conclusão do curso médico. O tema escolhido foram os aspectos hematológicos da malária (Chagas Filho, 1993). ${ }^{54}$ 


\section{A Tese de Doutoramento: o primado do laboratório (1902-1903)}

Chagas realizou sua tese de doutoramento sobre a malária num momento em que o tema despertava grande interesse no cenário internacional. O estudo do hematozoário de Laveran, especialmente de sua evolução nos hospedeiros vertebrados (o homem e outros animais) e nos invertebrados (mosquitos), estava na ordem do dia desde os trabalhos de Ross e Grassi (1898/1899). O trabalho de Chagas (1903) expressa o impacto que as novas teorias em voga na ciência médica tinham sobre o campo da clínica, tanto em termos de um otimismo quanto às perspectivas para a compreensão e o trato das doenças quanto no que se refere ao enquadramento que a elas se impunha a partir destas teorias. ${ }^{55}$

Qualificando a medicina experimental como "o início de uma era nova de triunfos" (Chagas, 1903: 5), Chagas sublinhou a importância das conquistas de natureza prática advindas dos conhecimentos produzidos no laboratório:

(...) o laboratório representa em nossa terra uma esperança. Dele esperamos esclarecidos os inúmeros problemas de patologia tropical, que por aí prevalecem obscuros, zombando da sagacidade dos observadores e cujas incógnitas estão repletas das ilações as mais benéficas ao nosso bem-estar. (Chagas, 1903: 14)

O campo da hematologia era particularmente promissor nesse sentido. No âmbito dos novos conhecimentos sobre os processos imunológicos pelos quais o organismo humano reage aos agentes infecciosos - cujo marco fundamental foi a teoria da defesa fagocitária proposta, na década de 1880, pelo cientista russo Elie Metchnikoff, do Instituto Pasteur de Paris -, outra referência importante das contribuições que os estudos hematológicos traziam à prática médica dizia respeito aos trabalhos do alemão Paul Ehrlich, que impulsionou as pesquisas imunológicas na direção da quimioterapia (Porter, R., 1999). Seu método de especificação dos leucócitos havia tornado a investigação do sangue, como apontou Chagas (1903: 59-60), "um processo do domínio clínico e dos melhores, daqueles menos cheios de enganos, mais producentes de ensinamentos aproveitáveis". ${ }^{56}$

A variação dos leucócitos no sangue (fórmula hemo-leucocitária), por expressar fases específicas da ação infecciosa e da defesa do organismo, era vista como precioso elemento para o diagnóstico etiológico, o 
prognóstico e a terapêutica das diferentes doenças infecciosas ${ }^{57}$ No campo do diagnóstico, este dado hematológico servia para dirimir dúvidas provocadas pela inespecificidade dos sintomas clínicos, como dor e febre. No caso da malária, poderia ser útil também para atestar a positividade do diagnóstico nos casos em que o parasito não pudesse ser identificado diretamente na circulação sangüínea.

O objetivo de Chagas na tese era justamente demonstrar a importância da fórmula hemo-leucocitária como método de diagnóstico da malária, em suas diversas modalidades clínicas. ${ }^{58}$ As pesquisas para o trabalho foram desenvolvidas durante seu internato no serviço da primeira cadeira de clínica médica da FMRJ, sob a responsabilidade de Nuno de Andrade, e, em Manguinhos, sob a orientação de Oswaldo Cruz. A este, Chagas reservou a maior ênfase em seus agradecimentos, por "toda a educação técnica e científica de que precisamos, todos os ensinamentos necessários à conclusão destes estudos" (Chagas, 1903: 3)..$^{59}$

Lamentando a carência de estudos em hematologia no Brasil, destacou que, além de sua importância prática para o diagnóstico etiológico, tratava-se de uma área de pesquisa fundamental para esclarecer aspectos desconhecidos de muitas entidades nosológicas, especialmente das doenças tropicais que grassavam em nosso país ${ }^{60} \mathrm{O}$ Instituto de Manguinhos começava a investir nesta trilha a partir de trabalhos do próprio Oswaldo Cruz. ${ }^{61}$

No processo de afirmação da medicina experimental, acreditavase, portanto, que cabia ao laboratório não apenas propiciar novos recursos práticos à medicina, mas, sobretudo, conduzir a prática clínica para o "domínio de verdades irrecusáveis". O "veredictum da razão científica" era o aval indispensável para a compreensão e o enfrentamento dos problemas sanitários que "trazem os mais acentuados obstáculos ao progredir material da nossa Pátria” (Chagas, 1903: 14-15). Este era o papel social atribuído à ciência que se institucionalizava em Manguinhos. Sintetizando esta posição, Chagas enunciou a diretriz que nortearia sua trajetória profissional como cientista, bem como a trajetória da instituição à qual ele começava a se vincular:

É uma aspiração que fortalece o nosso espírito, que vivifica a nossa consciência, a de ver ainda o laboratório e a observação clínica, de mãos dadas, numa aliança proveitosa, engrandecer a medicina brasileira, que entrará assim numa via próspera de imensas conquistas. E ficaremos contentes, todos nós que para esta terra 
ambicionamos um alto posto na hierarquia intelectual dos povos cultos, que a desejamos luminosa na ciência universal. (Chagas, 1903: 17; grifos meus)

O ideal desta cooperação expressava-se, contudo, numa relação hierarquizada. Ainda que a clínica conferisse o sentido social de aplicação ao trabalho do laboratório, este assumia primazia como espaço de validação do conhecimento médico, num movimento de diferenciação substantiva em relação à tradição da medicina brasileira oitocentista, estruturada na experiência clínica (Edler, 2003). Assim, cabia ao laboratório definir e demonstrar os traços de especificidade/materialidade de entidades nosológicas como a malária, doença que, segundo Chagas, "encerra uma soma enorme de problemas a pesquisar" (Chagas, 1903: 16).

Um exemplo da necessidade desta orientação era a discussão em torno da idéia, defendida pelo eminente clínico e professor da FMRJ Francisco de Castro, de que não havia malária na cidade do Rio de Janeiro, contrariamente ao que preconizava a tradição climatológica que a esta doença associava as 'febres' há muito observadas na cidade. Apesar de reconhecer que a clínica confirmava "de modo absoluto o pensar do grande sábio", Chagas (1903: 16) asseverou que somente os métodos laboratoriais forneceriam os elementos de convicção para esta tese. ${ }^{62}$ Era isso que os pesquisadores de Manguinhos vinham fazendo ao investigarem a presença do hematozoário de Laveran no sangue dos internos dos hospitais do Rio de Janeiro. ${ }^{63}$

Os estudos sobre o parasito traziam, ainda, novos elementos para a compreensão clínica da doença. Eles permitiam, por exemplo, esclarecer a questão da intermitência febril, que há muito despertava diferentes interpretações, e que, com o trabalho de Golgi, foi considerada uma conseqüência das diferentes fases evolutivas do parasito (Chagas, 1903: 35). A associação entre ciclo parasitário e modalidades clínicas era mais uma evidência de como o laboratório poderia subsidiar a prática médica.

Estas colocações de Chagas a respeito da medicina laboratorial revelam não apenas sua inserção no campo médico-científico da época, mas também os padrões e critérios cognitivos que regiam sua percepção e sua compreensão dos objetos daquele campo. Sob tal perspectiva, as doenças infecciosas constituíam entidades cuja materialidade era validada pela verificação dos agentes causais específicos, por meio de procedimentos laboratoriais, e cujo quadro clínico também se desenhava em função dos traços da ação patogênica destes microorganismos. Como salientou 
Worboys (1996), o caso da malária é emblemático de como a teoria dos germes produziu uma transformação ampla nos conceitos e procedimentos para a definição das doenças, passando-se de uma definição essencialmente sintomática para uma definição etiológica. Seria por meio deste esquema classificatório que Chagas viria descrever, alguns anos depois, a doença parasitária que leva seu nome.

A discussão clínica que Chagas fez da malária é particularmente reveladora deste processo pelo qual a medicina de laboratório, expressa no domínio específico da medicina tropical, propiciava um novo enquadramento daquela entidade mórbida, gerando um deslocamento fundamental de sentido: não mais o impaludismo identificado às 'febres palustres', mas o impaludismo como doença 'parasitária'. Depois de apresentar as correspondências entre os diferentes tipos e estágios do parasito e as distintas manifestações febris da doença, Chagas criticou os critérios vigentes na classificação clínica da malária. Segundo ele, não era razoável, chegando mesmo a ser "ilógico", que as modalidades da febre (terçã e quartã, benigna ou maligna) constituíssem o critério principal para tal classificação, ficando a doença dividida em tantas formas quantos fossem os tipos febris, uma vez que isso significaria identificar a doença por meio apenas de um de seus sintomas: “(...) o que aí fica classificado é o elemento febre e não a espécie mórbida de cujo todo ele faz parte” (Chagas, 1903: 45). A questão era importante não apenas no plano teórico, mas tinha implicações práticas expressivas, já que a deficiência daquelas classificações prejudicava a avaliação, pelo médico, do prognóstico da doença e, conseqüentemente, as decisões quanto às intervenções terapêuticas. A alternativa ao critério sintomatológico era o critério parasitológico: "É necessário [que] seja o tipo morfológico do parasito o elemento principal no critério de classificação das formas clínicas do impaludismo, porque o evoluir da infecção e suas manifestações clínicas estão imediatamente ligadas à variedade parasitária" (Chagas, 1903: 46; grifos meus). Era o parasito, portanto, que determinava a existência daquela entidade nosológica e suas características clínicas peculiares. ${ }^{64}$

Podemos identificar nestas colocações de Chagas não apenas a preocupação em derivar das teorias etiológicas novas perspectivas para a compreensão clínica das doenças infecciosas, mas a complexidade que enfrentavam os médicos dispostos a fazer isso num contexto de reordenação das categorias classificatórias no domínio da patologia. O desafio era estabelecer, num quadro estável e padronizado, as relações 
causais entre a ação patogênica do parasito, em suas variações, e os elementos sintomatológicos manifestados pelos doentes.

Entre os caminhos de investigação que Chagas aponta em sua tese, para responder a tal desafio, percebem-se não apenas os marcos teóricos da medicina tropical, mas o modo pelo qual estas diretrizes se adequavam às perspectivas peculiares do projeto institucional de Manguinhos. Ao posicionar-se diante de uma das muitas questões ainda em aberto sobre o parasito da malária, como a natureza de suas variações morfológicas, Chagas recorreu ao princípio fundamental da medicina tropical mansoniana:

Acreditamos na influência das condições climáticas sobre as propriedades do parasito, quer agindo sobre o organismo do indivíduo infeccionado, provocando nele variações de receptividade que irão influenciar a morfologia do hematozoário, quer agindo sobre este no mundo exterior, no organismo do culicídio, hospedeiro habitual do parasito. (Chagas, 1903: 27)

Chamando a atenção para a diversidade climática no território brasileiro, ele sublinhou a importância de um programa de investigação destinado a "estudar o tipo morfológico do parasito nos diversos pontos do Brasil e levar Anopheles infeccionados de uns para outros pontos" (Chagas, 1903: 27), de modo a examinar as características peculiares das espécies parasitárias e da doença nestas distintas regiões. Esta era a perspectiva então idealizada por Oswaldo Cruz, que pretendia ampliar o escopo institucional de Manguinhos não apenas no tocante às linhas de pesquisa, mas no que dizia respeito ao sentido social de suas atividades. Conhecer os parasitos e insetos do Brasil, na trilha aberta pela medicina tropical, era um caminho promissor para uma instituição que, atenta às tendências da ciência internacional, buscava construir sua legitimidade em associação com os interesses da sociedade brasileira, como a solução das questões sanitárias representadas pelas doenças tropicais.

Apesar de a tese de Chagas estar ancorada nos princípios e procedimentos da pesquisa experimental, trata-se de um trabalho direcionado fundamentalmente para a clínica. Esta foi a opção que Chagas tomou ao concluir seu doutoramento na FMRJ, em maio de 1903, apesar do convite feito por Oswaldo Cruz para que se integrasse à equipe de pesquisadores de Manguinhos. Em março de 1904, foi nomeado médico da DGSP, passando a trabalhar no hospital de isolamento de Jurujuba, Niterói, 
destinado a atender, sobretudo, doentes de peste. Ao mesmo tempo, instalou seu consultório particular no centro do Rio (Chagas Filho, 1993). ${ }^{65}$

Se o jovem médico via a clínica com o olhar de quem comemorava as vantagens práticas trazidas pelas novas teorias médicas, o caminho que o levaria de volta aos laboratórios de Manguinhos (e que orientaria sua trajetória científica no âmbito da medicina tropical) também seria marcado por esta perspectiva. Em sua tese esta interface explicitou-se na questão do diagnóstico da malária. Em seu retorno às atividades de pesquisa, agora como profissional formado, ela se daria pelo tema da profilaxia.

\section{As Campanhas de Profilaxia da Malária: a ida ao campo e a expansão de Manguinhos}

O Instituto Soroterápico Federal foi criado para atender a um objetivo bastante específico: reproduzir conhecimentos e técnicas importadas com vistas a evitar uma epidemia de peste bubônica na capital. ${ }^{66}$ No entanto, Oswaldo Cruz, desde o início, buscou a ampliação das fronteiras de Manguinhos, no que dizia respeito tanto à fabricação de produtos imunobiológicos quanto a seus objetos de pesquisa e linhas de atividade. ${ }^{67}$ Para Jaime Benchimol e Luiz Antonio Teixeira (1993), foi mediante uma estratégia plural de crescimento, em que uma reduzida equipe de pesquisadores se via às voltas com múltiplos temas e atribuições, que Manguinhos cumpriu uma primeira fase de desenvolvimento em direção ao que iria constituir sua área de excelência e o traço principal de sua identidade pública: o estudo e a profilaxia das doenças parasitárias tropicais ${ }^{68}$ Chagas ingressou no instituto, como estudante, neste momento inicial e participou ativamente de sua expansão, assumindo uma posição de protagonismo neste processo a partir da descoberta que faria em 1909. ${ }^{69}$

Os primeiros esforços de Oswaldo Cruz para ampliar o escopo institucional do Soroterápico encontraram muitas resistências. Em 1903, ano em que assumiu a direção da saúde pública federal, ele enviou ao Congresso Nacional um projeto de reforma dos serviços sanitários do qual constava a transformação do instituto num centro de estudos de doenças tropicais que, à semelhança do Instituto Pasteur de Paris, englobaria também a fabricação de soros, vacinas e demais produtos biológicos, além do ensino da bacteriologia. Este item do projeto não foi aprovado, ex- 
pressando a visão de que Manguinhos deveria continuar sendo "um laboratório prático que já servia às necessidades imediatas do público" (Stepan, 1976: 91). Apesar disso, com sobras de verbas da DGSP e pautando-se na associação entre pesquisa, produção e ensino, Cruz conseguiu fazer com que a instituição fosse ampliando progressivamente a pauta de doenças humanas e animais que lhe serviam de objeto nestas distintas vertentes de atuação.

As atividades de ensino consistiam, nestes primeiros anos, na orientação de alunos da FMRJ que, como Chagas, desenvolviam suas teses de doutoramento. Estes alunos, juntamente com os que atuavam nas campanhas da DGSP, eram a principal base de recrutamento para a instituição. As atividades de fabricação de imunobiológicos foram expandidas, principalmente no campo da veterinária. O desenvolvimento, por Alcides Godoy, de uma técnica original de preparo da vacina contra o carbúnculo sintomático ou peste da manqueira, por solicitação de pecuaristas mineiros, foi comemorado como a primeira grande descoberta de Manguinhos. Fabricada a partir de 1906 e patenteada em 1908, a venda da vacina da manqueira garantiria uma renda própria fundamental para a expansão do instituto.

No que diz respeito à pesquisa, os estudos bacteriológicos foram reforçados em 1903 com o ingresso de Henrique da Rocha Lima, que, formado na Alemanha, trouxe para a instituição a expertise numa outra disciplina fundamental para o estudo das doenças infecciosas: a anatomia patológica. Rocha Lima foi peça-chave para o intercâmbio entre Manguinhos e os institutos de pesquisa europeus, no que diz respeito tanto à divulgação dos trabalhos quanto a diretrizes e modelos para a organização da pesquisa.

A medicina tropical, apesar das filiações que mantinha com a teoria dos germes, pretendeu assumir-se como especialidade justamente a partir das problemáticas particulares que trazia, como os mecanismos de transmissão das doenças pelos artrópodes, os ciclos evolutivos dos parasitos e sua interação com os hospedeiros e com o ambiente. O estudo de tais questões exigia conhecimentos específicos, como as regras de classificação das diferentes espécies de protozoários e insetos, os hábitos e a distribuição geográfica dos transmissores e as características do ambiente específico em que viviam. Para isso, eram mobilizadas disciplinas como a entomologia, a parasitologia (especialmente a protozoologia), a história natural, a botânica e a ecologia (Worboys, 1997; Benchimol, 1999; Benchimol 
\& Sá, 2005, 2006). Num momento em que Oswaldo Cruz, como diretor da DGSP, empreendia o combate aos vetores da febre amarela, uma área que mereceu particular investimento em Manguinhos foi a entomologia. Esta foi a via pela qual Chagas se integrou ao empreendimento de construção e consolidação da medicina tropical nesta instituição.

O mundo científico foi marcado, na passagem do século XIX ao $\mathrm{XX}$, por uma ávida busca de transmissores alados para as doenças, especialmente mosquitos. Em fins de 1898, a Royal Society de Londres formou uma comissão de estudos sobre a malária nas colônias e, para dar suporte a esta empreitada, Joseph Chamberlain determinou que fosse realizado um amplo programa de coleta e classificação dos mosquitos em todo o mundo, coordenado pelo Museu Britânico de História Natural. ${ }^{70}$ Lutz, que já vinha estudando o parasito da malária e interessara-se, naquele ano, por seus transmissores, foi convidado a participar do projeto, tornando-se um dos mais prolíficos colaboradores da coleção que, sob a supervisão do zoólogo Frederick Theobald, iria se constituir naquele museu. Lutz era a principal autoridade científica em entomologia médica no Brasil e, em permanente intercâmbio com pesquisadores e instituições estrangeiras, exerceria grande influência sobre outros cientistas que enveredariam por este caminho (Benchimol \& Sá, 2005, 2006).

Em Manguinhos, Oswaldo Cruz realizava trabalhos de coleta e de classificação de insetos do Brasil, tendo, em 1901, identificado um novo anofelino (mosquito do gênero Anopheles) às margens da lagoa Rodrigo de Freitas, batizando-o em homenagem a Lutz. Em 1906, as pesquisas entomológicas no instituto foram reforçadas com a incorporação de Arthur Neiva, egresso do Serviço de Profilaxia da Febre Amarela da capital federal. Neiva se tornaria uma liderança na área, desenvolvendo importantes estudos sobre os transmissores da malária e da tripanossomíase americana. Tendo como referência os trabalhos de Lutz, Cruz e Neiva, Chagas publicou, nesta época, trabalhos sobre mosquitos identificados no Brasil, com a descrição de novas espécies (Chagas, 1907a, 1907b, 1907c).

O desenvolvimento da entomologia médica em Manguinhos e a inserção de Chagas neste processo estiveram diretamente relacionados, por sua vez, a uma importante frente de ampliação das fronteiras geográficas, sociais e cognitivas da instituição, acionada por Oswaldo Cruz especialmente em função da experiência adquirida nas campanhas sanitárias que comandava, como diretor da DGSP, na capital federal. Reproduzindo prática comum entre os médicos e microbiologistas europeus que se des- 
locavam para a África e a Ásia a fim de combater epidemias e estudar as doenças tropicais, os pesquisadores de Manguinhos empreenderam expedições científicas a diversos pontos do território brasileiro. Tais missões serviam tanto para estudar as condições sanitárias das distintas regióes como também para debelar crises epidêmicas que prejudicavam obras de companhias públicas ou privadas associadas à modernização econômica do país (COC, 1991; Lima, 1998). ${ }^{71}$ Se, na capital, a febre amarela e outras doenças recrudesciam desde a última década do século XIX, a realização destas obras, sobretudo quando adentravam matas e regiões inóspitas, era freqüentemente acompanhada de surtos epidêmicos, especialmente de malária. Isso se dava principalmente por ocasião da construção das ferrovias, cujas linhas e ramais se multiplicavam pelo território nacional visando ao escoamento da produção agrícola para exportação (Benchimol \& Silva, 2008). ${ }^{72}$

A primeira destas viagens foi feita pelo próprio Oswaldo Cruz, entre 1905 e 1906, para inspecionar as condições sanitárias dos principais portos marítimos e fluviais brasileiros, visando a propor um plano de melhoramentos. ${ }^{73}$ Em 1906, Antonio Cardoso Fontes foi enviado ao Maranhão para combater a peste bubônica e, em 1907, o instituto criou, por solicitação do governador de Minas Gerais, uma filial na recémfundada capital do estado, para realizar, sob a direção de Ezequiel Dias, estudos sistemáticos sobre as doenças locais, especialmente as que atacavam os rebanhos (Benchimol, 1990a; Klein \& Thielen, 2003; Starling, Germano \& Marques, 2007). Tais viagens reforçavam a imagem pública destes cientistas como atores diretamente envolvidos com a solução de questões sanitárias de interesse nacional.

Estas expedições funcionavam também como ocasiões impulsionadoras da pesquisa em torno das novas questões da medicina tropical. ${ }^{74}$ Nesses canteiros de obras, os pesquisadores realizavam experiências e estudos sobre temas variados da patologia tropical brasileira, relacionados tanto aos aspectos médico-sanitários quanto às questões biológicas concernentes a seus parasitos e vetores. Foi por meio de viagens como estas que Chagas refez seu vínculo com Manguinhos e com o tema da malária, desenvolvendo habilidades e conhecimentos específicos que o levariam à descoberta de uma nova doença tropical.

Em 1905, a Companhia Docas de Santos solicitou a Oswaldo Cruz providências para combater uma epidemia de malária que atacava os trabalhadores que construíam uma central hidrelétrica em Itatinga, 
município de São Paulo, destinada a abastecer o porto de Santos. Em função de seus conhecimentos sobre a doença, Chagas, que era então médico da DGSP, foi requisitado por Cruz para Manguinhos, sendo encarregado de coordenar a campanha de profilaxia, a primeira do país desde que se comprovou o papel dos mosquitos como vetores. ${ }^{75}$ No início de 1907, missão semelhante foi iniciada por ele, em parceria com Arthur Neiva, em Xerém, na Baixada Fluminense, Rio de Janeiro, onde a doença prejudicava os trabalhos de captação de água para a capital federal, realizados pela Inspetoria Geral de Obras Públicas (Gazeta de Notícias, 1907). ${ }^{76}$ Em junho daquele ano, igualmente por solicitação de Cruz, Chagas partiu para o norte de Minas Gerais em nova campanha antipalúdica, junto a trabalhadores da Estrada de Ferro Central do Brasil (Chagas, 1906, 1908a, 1909e). ${ }^{77}$

Desde que o modo de transmissão da malária foi desvendado, iniciou-se o debate sobre os meios para a prevenção e o combate à doença. Havia dois focos principais: os mosquitos vetores e o indivíduo portador do parasito. As ações contra os insetos contemplavam métodos de natureza ofensiva e defensiva. O primeiro era o combate direto aos anofelinos, mediante campanhas, de feição militar, visando a sua eliminação. As "brigadas contra os mosquitos", termo cunhado por Ronald Ross, deveriam atacá-los em seu estágio aquático, tanto por meio de aplicação de substâncias tóxicas visando a eliminar as larvas (como o petróleo ou o Verde Paris, composto arsênico desenvolvido na década de 1920) quanto pela drenagem dos terrenos alagadiços que pudessem servir-lhes de habitat. ${ }^{78}$ As medidas defensivas consistiam na proteção individual e coletiva contra os mosquitos, através de cortinados nas camas e telas nas portas e janelas das casas. As ações dirigidas ao parasito (profilaxia específica ou terapêutica), preconizadas por Robert Koch, se davam mediante a ingestão de quinina, visando tanto a prevenir a infecção quanto a eliminar o hematozoário do sangue. De modo geral, os ingleses e os norte-americanos concentravam seus programas no ataque ao vetor, enquanto os alemães, os italianos e os franceses privilegiavam a ação germicida da quinina (Worboys, 1997). ${ }^{79}$

Nas campanhas que comandou, Chagas procurou colocar tais diretrizes em prática, implementando, sobretudo, a quininização e a proteção dos indivíduos contra os mosquitos (Chagas, 1906, 1908a, 1909f). Desde a experiência em Itatinga, ele formulou o princípio de que o ataque direto ao mosquito não deveria restringir-se às ações antilarvárias, tanto por 
causa das restrições para sua realização em locais em que obras de saneamento eram impraticáveis como porque acreditava que os insetos deveriam ser combatidos principalmente em sua forma adulta, alada, no interior dos domicílios. Era nestes espaços que, na maior parte das vezes, ocorriam a contaminação do mosquito pelo doente parasitado e a infecção do indivíduo são. Ou seja, segundo Chagas (1906: 42), a malária era "uma moléstia essencialmente de contágio domiciliário". Ele observou que, depois de picarem suas vítimas no interior das habitações, os mosquitos adquiriam um peso que os fazia permanecer ali por um longo tempo, digerindo o sangue e maturando os ovos. Desse modo, a destruição dos mosquitos alados deveria ser feita mediante a fumigação de substâncias inseticidas, como o enxofre e o piretro, no interior destes ambientes (Chagas, 1906) ${ }^{80}$ Este método, que décadas mais tarde seria usado em larga escala com os inseticidas sintéticos de ação residual, como o DDT, foi aplicado em Itatinga com "resultados favoráveis", na avaliação de Chagas (1906: 35). ${ }^{81}$

Se, na tese de doutoramento, Chagas havia articulado seus conhecimentos em microbiologia e em medicina tropical ao domínio da clínica médica, as campanhas contra a malária levaram-no a direcionar tais conhecimentos a uma outra frente fundamental de aplicação das 'conquistas do laboratório': as ações de saúde pública. Ele enfatizava a importância do conhecimento das distintas fases do ciclo evolutivo do hematozoário para o planejamento das medidas de combate à doença, tanto das que visavam ao anofelino quanto das que se dirigiam ao doente de malária. Além disso, apontava a necessidade imperiosa de se conhecer os hábitos do vetor, terreno no qual ele próprio começava a aventurar-se na ocasião, estudando os mosquitos existentes nas regiões onde aconteciam as campanhas. Os conhecimentos clínicos e epidemiológicos também constituíam elemento a orientar as medidas profiláticas, já que os doentes eram reservatórios do parasito e, conseqüentemente, fontes de contaminação do mosquito e de propagação da doença (Chagas, 1906).

Num movimento análogo ao que ocorreu na trajetória individual de Chagas, esta 'ida ao campo' implementada por Manguinhos - em seu duplo sentido, pois tais viagens eram dirigidas, sobretudo, para áreas rurais do país, num movimento que se intensificaria na década seguinte - foi um caminho privilegiado para ampliar a base social e cognitiva de seu projeto institucional. Para Sandra Caponi (2002), este foi um fator decisivo para que a instituição se pusesse no caminho do que Anne-Marie 
Moulin (1996) chama de perspectiva global e ambientalista da medicina tropical, estruturada nas complexas interações entre parasitos, insetos e populações, tanto do ponto de vista biológico quanto no que concerne aos aspectos sociais. ${ }^{82}$

Tais campanhas materializavam, emblematicamente, os três pilares que, segundo Stepan (1976: 102), sustentaram a construção e a reprodução de Manguinhos como instituição de pesquisa científica capaz de sobreviver aos objetivos utilitaristas restritos que justificaram sua criação: a) uma relação com o governo e outros órgãos públicos e privados em que estes 'clientes' se beneficiavam concretamente do conhecimento produzido pelos cientistas; b) a capacidade de recrutar e treinar profissionais para a pesquisa; c) o desenvolvimento de uma agenda de investigações que, voltada para os problemas brasileiros, se associava a questões mais amplas da agenda científica internacional, não se restringindo em demasia a preocupações locais.

\section{O Instituto Oswaldo Cruz e a Medicina Tropical}

A campanha contra a malária realizada por Chagas no norte de Minas entre 1907 e 1908 ocorreu num momento de grande importância na trajetória do Instituto de Manguinhos: a conquista de um arcabouço institucional que permitiu a sua transformação num centro de produção de imunobiológicos mas também de pesquisa e de ensino em medicina tropical. Em 1906, último ano do governo de Rodrigues Alves, quando foi proclamado o sucesso de Oswaldo Cruz no combate à febre amarela e à peste bubônica no Rio de Janeiro, ${ }^{83}$ foi enviado ao Congresso Nacional um projeto de lei que transformava o Soroterápico em Instituto de Medicina Experimental de Manguinhos, "legitimando as funções que, na prática, já exercia” (Benchimol \& Teixeira, 1993: 25). Contudo, as resistências foram grandes e sua aprovação só se deu dois anos depois, graças à repercussão da conquista, por Manguinhos, da medalha de ouro no XIV Congresso Internacional de Higiene e Demografia realizado em Berlim, em setembro de 1907. Nessa ocasião, além dos resultados da campanha contra a febre amarela no Rio de Janeiro, a instituição deu grande destaque ao que se considerou a primeira grande descoberta científica de Manguinhos no terreno da medicina tropical: o estudo de Henrique 
Aragão sobre o ciclo evolutivo do parasito da malária aviária, que contribuía para elucidar aspectos fundamentais dos ciclos parasitários nos hospedeiros vertebrados (Fonseca Filho, 1974).

Em seu retorno ao Brasil, Oswaldo Cruz foi recebido como herói da ciência nacional: "O Rio de Janeiro, que se tornara a 'Paris das Américas', agora tinha seu 'Pasteur' para canonizar” (Benchimol \& Teixeira, 1993: 25). Em dezembro de 1907, sancionou-se o decreto que transformava Manguinhos em Instituto de Patologia Experimental. Em março de 1908, o regulamento pelo qual passava a chamar-se Instituto Oswaldo Cruz (IOC) trouxe maior autonomia administrativa e orçamentária, retirando-o da alçada da DGSP para uma vinculação direta ao Ministério da Justiça e Negócios Interiores. A autorização para vender os produtos biológicos fabricados na instituição foi fundamental para proporcionar maior flexibilidade financeira. Esta, por sua vez, impulsionou a ampliação de seu quadro de pessoal. ${ }^{84}$ As atividades de ensino também se expandiram, com a criação, naquele ano, do chamado Curso de Aplicação, que oferecia treinamento em microbiologia e em zoologia médica visando à formação de pesquisadores no campo da medicina experimental. Sob estas novas condições institucionais, Manguinhos caminharia rumo a uma maior especialização de suas áreas de pesquisa. Os investimentos iriam incidir especialmente na protozoologia, que cada vez mais constituía o caminho privilegiado para o reconhecimento científico da instituição (Fonseca Filho, 1974; Stepan, 1976; Benchimol, 1990a; Benchimol \& Texeira, 1993; Benchimol \& Sá, 2005).

Segundo Benchimol e Teixeira (1993), um dos fatores que propiciou esta orientação foi o acúmulo de trabalhos que os pesquisadores haviam produzido em temas centrais a esta área, como a evolução de parasitos em seus hospedeiros, a sistemática e a biologia dos transmissores e a profilaxia da malária. A polivalência das atividades na instituição, que tornava os pesquisadores extremamente versáteis, favoreceu este processo. ${ }^{85}$ Em 1908, além do reforço no estudo de protozoários e insetosvetores propiciado com a contratação de Lutz, a instituição se beneficiou da presença de dois professores do Instituto de Doenças Marítimas e Tropicais de Hamburgo (Institut für Schiffs- und Tropenkrankheiten), que estavam na vanguarda da protozoologia alemã. ${ }^{86}$ Stanislas von Prowazek, discípulo e sucessor de Fritz Schaudinn no Instituto de Hamburgo, e o químico Gustav Giemsa, autor do método de coloração mais utilizado para a observação de hematozoários, foram contratados para 
um estágio de seis meses na instituição. ${ }^{87}$ No ano seguinte, outro conceituado protozoologista alemão, Max Hartmann (do Instituto de Moléstias Infecciosas de Berlim), também viria se integrar, pelo mesmo período de tempo, à equipe de Manguinhos. ${ }^{88}$

A trajetória pela qual o Instituto Soroterápico Federal, criado sob o figurino pasteuriano, ampliou-se de modo a tornar-se um centro de medicina experimental especializado no estudo das doenças tropicais nos remete à questão das relações entre microbiologia e medicina tropical, que tem recebido ênfase na historiografia recente. John Farley (1992) e Michael Worboys (1996, 1997) analisam como a medicina tropical mansoniana constituiu-se não como simples aplicação da teoria dos germes para a compreensão das doenças existentes nos trópicos, e sim mediante um processo de substantiva diferenciação em relação à bacteriologia. O argumento de Manson (1897, 1903), ao defender a criação da disciplina, era o de que sua especificidade derivava da natureza peculiar das doenças ditas tropicais. As doenças bacterianas, objeto da microbiologia, seriam 'cosmopolitas', uma vez que seus patógenos, por não terem vida longa fora do corpo humano, não eram afetados pelo clima ou por condições geográficas. Já as doenças tropicais comporiam uma categoria distinta, relativa às enfermidades parasitárias, cuja transmissão dependia de que o ciclo de seus patógenos (protozoários ou helmintos) se completasse no interior de um vetor. Nesse sentido, eram geograficamente situadas, na medida em que a existência e distribuição de seus vetores-hospedeiros, bem como as condições para os ciclos parasitários, dependiam de fatores climáticos e ambientais peculiares aos trópicos. A complexidade dos elos que ligavam parasitos, hospedeiros e ambiente também era um fator a diferenciar as doenças tropicais das enfermidades bacterianas transmitidas pela água ou pelo ar.

Segundo Farley (1992), a medicina tropical mansoniana, ao afirmar a existência de dois tipos diferentes de doenças, as bacterianas/cosmopolitas e as parasitárias/tropicais, reforçou as fronteiras que, ao longo do século XIX, separavam a parasitologia (associada fortemente à helmintologia) do mundo das doenças infecciosas, impedindo a formulação de uma teoria parasitária geral das doenças. Worboys (1996) afirma que tal visão subestima a maleabilidade das teorias dos germes ao final do século XIX (que compreendiam tanto bactérias quanto vermes e protozoários, vistos como parasitos na medida em que eram organismos que se desenvolviam no interior do corpo humano). Segundo ele, a distinção entre doenças 
bacterianas e doenças parasitárias foi estabelecida e legitimada pela medicina tropical mansoniana. Foi somente com a descoberta do papel dos vetores/hospedeiros intermediários na transmissão da malária, marco fundamental para a especialidade proposta por Manson, que a diferenciação entre parasitologia e bacteriologia se estabeleceu, não apenas por fatores cognitivos relativos à compreensão da natureza das doenças, mas, sobretudo, em função dos interesses políticos e práticos que envolviam a expansão imperial e a prática médico-sanitária nas colônias.

As fronteiras estabelecidas pela nova especialidade da medicina tropical expressavam estratégias de demarcação politicamente orientadas, tanto no âmbito interno da medicina quanto no que dizia respeito ao contexto de expansão imperialista e ao próprio desenvolvimento econômico-social europeu (Worboys, 1997). Segundo Stepan (2001), um dos fatores determinantes para que, ao final do século XIX, se aprofundasse a noção de uma nosologia peculiar nos trópicos, em contraposição aos climas temperados, foi a expressiva queda na mortalidade e na morbidade nos países industrializados europeus, derivada de intervenções sanitárias e também do próprio desenvolvimento econômico-social. Tal processo teria levado a uma reconceituação de muitas doenças infecciosas comuns na Europa e que, a partir de então, passariam a ser vistas como fundamentalmente tropicais e 'estrangeiras'.

O próprio Manson reconheceu que o termo 'doenças tropicais' era "mais conveniente do que acurado", pois poucas doenças poderiam ser consideradas, efetivamente, restritas aos trópicos (Manson, 1903: IX). Na introdução de Tropical Diseases: a manual of the diseases of warm climates, ele declarou: "If by 'tropical diseases' be meant diseases peculiar to, and confined to, the tropics, then half a dozen pages might have sufficed for their description; for, at most, only two or three comparatively unimportant diseases strictly deserve that title" (Manson, 1903: IX). ${ }^{89}$

A malária, por exemplo, considerada um modelo para a noção de 'doença tropical' e definida por Manson (1897) como 'o grande flagelo da humanidade', havia sido endêmica na Europa (Worboys, 1997).

A necessidade da especialidade era dada, acima de tudo, conforme enfatizou em sua aula de 1897, pela perspectiva de prover, aos médicos e às autoridades que atuavam nas colônias tropicais, os conhecimentos necessários para diagnosticar e lidar com as doenças que, concretamente, eles enfrentavam nessas áreas, conhecimentos estes que não eram oferecidos nos cursos médicos até então existentes (Manson, 1897). ${ }^{90}$ Tais interesses 
em imprimir maior eficácia ao empreendimento imperial nas colônias foram a base para que, diferentemente da microbiologia, que se incorporou rapidamente à formação e à prática médicas, a medicina tropical britânica se institucionalizasse não como treinamento complementar, mas como formação pós-graduada, em instituições especializadas, num processo de autonomização no próprio campo médico (Farley, 1992; Worboys, 1996). ${ }^{91}$

Sandra Caponi (2002) também sublinha os elementos de descontinuidade entre a microbiologia e a medicina tropical, reiterando que não existiu uma relação de derivação lógica e necessária entre o programa pasteuriano e os estudos baseados no reconhecimento dos artrópodes como vetores. A emergência da medicina tropical exigiu, segundo a autora, uma reorganização do saber a partir da associação com disciplinas (como a entomologia, a história natural e a protozoologia), métodos e modos de produção do conhecimento bastante diferentes dos que eram praticados pelos ‘caçadores de micróbios', vindo a constituir-se em outro modelo de inteligibilidade das doenças e de seus meios de prevenção.

Contudo, na passagem do século XIX ao XX, o interesse em aprofundar os estudos sobre a patologia tropical nas colônias - onde enfermidades, como a doença do sono africana, desafiavam os protocolos de pesquisa tradicionais da microbiologia - fez com que instituições pasteurianas passassem a incorporar as perspectivas teóricas e metodológicas, bem como as estratégias políticas, da medicina tropical (Caponi, 2002). Este movimento expressou-se, como aponta Anne-Marie Moulin (1996), nas missões científicas enviadas pelo Instituto Pasteur de Paris às colônias francesas no norte da África. ${ }^{92}$ Em 1907/1908, Alphonse Laveran formalizou-o ao criar, naquele instituto, um serviço especial baseado em três seções: protozoologia, microbiologia e entomologia médica. Em 1908, juntamente com o protozoologista Félix Mesnil, ele criou a Société de Pathologie Exotique e o Bulletin de Pathologie Exotique. Desde então, esta foi uma tendência cada vez mais marcante das pesquisas realizadas pelos herdeiros de Pasteur. A complementaridade entre microbiologia e medicina tropical surgiu também em função da relação com a política e com as questões de saúde pública locais que os pasteurianos estabeleceram nos trópicos. O combate aos vetores era visto como mais uma arma a somar-se às vacinas e aos soros na perspectiva 'missionária' da ciência médica européia, justificadora das ações do chamado 'imperialismo construtivo', pelo qual a presença dos europeus nas colônias significaria o aporte dos benefícios da ‘civilização’ (Moulin, 1996). 
A conciliação foi exatamente o que marcou, segundo Caponi (2002), as relações entre microbiologia e medicina tropical no Brasil. A incorporação desses novos modelos de conhecimento médico se deu, segundo a autora, em dois momentos distintos, aos quais estiveram subjacentes diferentes maneiras de se pensar a natureza da patologia nacional. Primeiramente, a criação dos institutos bacteriológicos de São Paulo e de Manguinhos significou um cancelamento da dimensão nacional/particularizada da nosologia brasileira, na medida em que, opondo-se à primazia do clima como elemento de causalidade das doenças, a microbiologia demonstrava que muitas das enfermidades tidas como peculiares aos climas quentes e ao Brasil eram parte integrante de um quadro internacional de doenças, como o cólera, a peste e outras doenças bacterianas. Num momento seguinte, a partir do reconhecimento da teoria do insetovetor, já não se tratava mais de afirmar que no Brasil ocorriam as mesmas doenças que na Europa, mas justamente de chamar a atenção para o fato de que as doenças aqui assumiam certas peculiaridades, relacionadas, sobretudo, a seus transmissores. Segundo Caponi, a trajetória de Oswaldo Cruz expressou justamente estes dois momentos no deslocamento de seus principais interesses de estudo. Enquanto na última década do século XIX seus trabalhos focalizavam questões como o papel da água na transmissão de doenças infecciosas, especialmente o cólera - 'doença cosmopolita' por excelência, emblema do programa pasteuriano -, nos primeiros anos do século XX suas pesquisas passaram a incidir sobre os vetores de doenças tropicais, como a malária e a febre amarela.

A hipótese de Caponi (2002) é a de que tal processo, apesar das fases distintas, teria conduzido não a uma diferenciação entre as tradições da microbiologia e da medicina tropical mansoniana, mas a que elas se imbricassem, de modo a dar resposta aos problemas constituídos pelas enfermidades tropicais. ${ }^{93}$

A trajetória de Manguinhos foi emblemática desta associação. Assim como os trabalhos de Lutz, os estudos de Carlos Chagas, sublinha a autora,

(...) se sitúan en esse mismo espacio de intersección donde se entrecruzan dos tipos de saber y dos programas de investigación que no siempre pudieran convivir pacificamente. Los estúdios microbiológicos de laboratório (muchos de los cuales ocurríam dentro de los hospitales o en espacios anexos a los mismos) y los estudios entomológicos de campo, basados en el modelo classificatório de los naturalistas. (Caponi, 2002: 123) ${ }^{94}$ 
Esta é uma chave interpretativa interessante para pensar as circunstâncias históricas específicas pelas quais as novas teorias médicas produzidas na Europa, na passagem do século XIX para o XX, foram apropriadas pelos pesquisadores brasileiros no contexto particular de institucionalização da ciência nacional. A associação entre microbiologia e medicina tropical derivou-se do próprio caminho de legitimação social da medicina experimental no Brasil (referido, por sua vez, ao padrão geral de institucionalização da ciência brasileira), ou seja, um caminho em que os diferentes tópicos do conhecimento científico convergiam na perspectiva de serem vistos como relacionados a questões tidas como socialmente relevantes no âmbito do projeto nacional de modernização.

A possibilidade de articular conhecimento biológico, conhecimento médico e ações sanitárias em torno dos temas concretos da patologia brasileira conferia justificativa social e possibilidade de integração aos estudos sobre os múltiplos aspectos da relação entre microorganismos, insetos e doenças. Assim, poderíamos dizer que a inspiração, por parte do Instituto de Manguinhos, no modelo do Instituto Pasteur, assumiu, em 1908, um sentido bem mais amplo do que o da associação entre pesquisa, ensino e produção, tradicionalmente apontada pelos historiadores: tratava-se de um movimento de adequação da microbiologia aos rumos da medicina tropical. E, neste caso, também numa analogia ao que ocorreu com o Instituto Pasteur, a 'ida ao campo', motivada pela associação entre ciência, política e demandas sociais e econômicas, garantiu o caminho dos nossos pasteurianos na trilha da medicina tropical. Esta vinculação entre laboratório e campo, como forma de articular a ciência de Manguinhos à sociedade brasileira, conformou os balizamentos cognitivos e sociais que enquadrariam o objeto ao qual Chagas dedicaria sua vida a construir.

\section{Descoberta no Interior de Minas: um vetor, um parasito e uma nova doença tropical (1908-1909)}

Em junho de 1907, Chagas foi designado para combater uma epidemia de malária que grassava no norte de Minas Gerais, entre Corinto e Pirapora, paralisando as obras de prolongamento da Estrada de Ferro 
Central do Brasil, principal eixo de escoamento da produção agrícola para exportação. ${ }^{95}$ No povoado de São Gonçalo das Tabocas (situado às margen do rio das Velhas e que, com a inauguração da estação ferroviária, em 1908, passou a denominar-se Lassance, em homenagem ao engenheiro Ernesto Antônio Lassance Cunha), ele improvisou um laboratório num vagão de trem, que também usava como dormitório. Enquanto coordenava as atividades de profilaxia, costumava observar e examinar espécies da fauna brasileira, graças a seu crescente interesse pela entomologia e pela protozoologia. Em 1908, ao examinar o sangue de um sagüi (Callithrix penicillata), identificou um protozoário do gênero Trypanosoma, que batizou de Trypanosoma minasense. A nova espécie era um parasito habitual, não patogênico, do macaco (Chagas, 1908b).

$\mathrm{Na}$ época, o estudo dos tripanossomas estava na ordem do dia, sobretudo porque se demonstrara que, além de doenças animais, eles também eram patogênicos para o homem (Sá, 2005). A partir de 1901, a enfermidade conhecida como 'doença do sono' ou 'letargia dos pretos' espraiouse na África Central e Oriental em intensa epidemia, fazendo com que os países europeus que tinham colônias na região enviassem comissões para estudar o assunto e propor medidas de controle. Segundo Worboys (1997), este foi um importante caso para testar os preceitos da nova especialidade da medicina tropical. Corroborando o modelo do parasito-vetor, David Bruce demonstrou, em 1903, tratar-se de uma doença causada por tripanossoma e transmitida pela mosca tse-tsé (Lyons, 1992; Worboys, 1997). ${ }^{96}$ Além dos aspectos médico-sanitários, a tripanossomíase africana despertou grande interesse em função das questões específicas e complexas que trazia às teorias sobre os ciclos evolutivos dos protozoários. Lutz, que havia estudado tripanossomas em laboratórios europeus, começou a pesquisá-los no Brasil em 1907, ao ser comissionado pelo governo do Pará para investigar uma enfermidade de cavalos na ilha de Marajó, conhecida como 'mal de cadeiras', causada por um tripanossoma e transmitida por uma mosca (Benchimol \& Sá, 2005).

$\mathrm{O}$ assunto era particularmente importante para os protozoologistas alemães seguidores de Schaudinn, entre os quais Prowazek, que, presente em Manguinhos desde julho de 1908, acompanhou de perto as descobertas feitas por Chagas neste terreno. O estudo dos tripanossomas foi o caminho específico, segundo Magali Romero Sá (2005), pelo qual a protozoologia alemã exerceu um papel decisivo na organização e na consolidação da medicina tropical no Instituto Oswaldo Cruz. Prowazek, 
que era chefe do laboratório de protozoários do Instituto de Doenças Marítimas e Tropicais de Hamburgo, tinha experiência no estudo destes microorganismos a partir das pesquisas que realizara com Schaudinn (que, em 1904, havia publicado importante trabalho sobre tripanossomas de pássaros) e das investigações que ele próprio desenvolvera em 1905. Ao chegar em Manguinhos, trouxe, para experiências, alguns animais infectados por um tripanossoma patogênico para cavalos. Naquela ocasião, comunicou aos colegas que acabara de ser anunciada na Alemanha a descoberta de uma nova espécie de tripanossoma num macaco brasileiro exibido num circo. Assim, tudo indica que Chagas já conhecia estudos de tripanossomas ao realizar as pesquisas que o levariam, em Lassance, ao encontro não apenas do minasense, mas de um outro tripanossoma, identificado logo depois e que viria a compor a descoberta que o consagraria como cientista (Sá, 2005).

O início da seqüência que conduziria a este segundo tripanossoma revela outro aspecto do olhar qualificado de Chagas: além da busca por parasitos, o interesse por artrópodes que pudessem servir-lhes de vetores. Numa viagem a Pirapora, Chagas e Belisário Penna (médico da DGSP que o acompanhou na missão) pernoitaram, junto com os engenheiros da ferrovia, num rancho às margens do riacho Buriti Pequeno (Imagem 3). Foi ali que Belisário Penna capturou alguns exemplares de um inseto sugador de sangue muito comum na região, sobre o qual lhes havia falado o chefe da comissão de engenheiros, Cornélio Homem Cantarino Mota. ${ }^{97}$ Era conhecido vulgarmente como 'barbeiro', pelo hábito de picar o rosto de suas vítimas enquanto dormiam..$^{98}$ Proliferava "nas habitações pobres, nas choupanas de paredes não rebocadas e cobertas de capim”, atacando o homem à noite, "depois de apagadas as luzes, [e] ocultando-se, durante o dia, nas frestas das paredes, nas coberturas das casas, em todos os esconderijos, enfim, onde possa encontrar guarida" (Chagas, 1909d: 159). Aquele tipo de inseto nunca tinha chamado a atenção dos cientistas como possível vetor de infecções, pois a maioria das espécies da família dos Reduviidae se alimenta da seiva de plantas (Sá, 2005) (Imagem 5). ${ }^{99}$

Sabendo da "importância de insetos sugadores de sangue em patologia humana e veterinária, como transmissores de espécies mórbidas parasitárias" aos homens e aos animais, Chagas examinou alguns barbeiros e encontrou, em seu intestino, formas flageladas de um protozoário, com certas características que o fizeram pensar que poderia tratar-se de 
"um parasito natural do inseto ou (...) uma fase evolutiva de um tripanossoma de vertebrado" (Chagas, 1910b: 423). Quanto a esta segunda hipótese, a primeira suspeita foi a de que poderia ser o próprio Trypanosoma minasense, sendo o barbeiro, portanto, o vetor que o transmitiria aos sagüis (Chagas, 1911c: 221).

Por não dispor em Lassance de condições experimentais para elucidar a questão (uma vez que os macacos da região estavam contaminados pelo minasense), Chagas enviou a Manguinhos alguns daqueles insetos. Oswaldo Cruz os fez picarem sagüis criados em laboratórios (e, portanto, livres de qualquer infecção). Cerca de um mês depois, encontrou formas de tripanossoma no sangue de um dos animais, que havia adoecido. Voltando ao instituto, Chagas constatou que o protozoário não era o minasense, mas uma nova espécie de tripanossoma, à qual batizou de Trypanosoma cruzi, em homenagem ao mestre (Imagem 6). ${ }^{100}$ A nota anunciando esta descoberta foi redigida em Manguinhos em 17 de dezembro de 1908 e publicada nos Archiv für Schiffs- und Tropen-Hygiene, revista do Instituto de Doenças Marítimas e Tropicais de Hamburgo (Chagas, 1909a). ${ }^{101}$

Sob a orientação de Prowazek, Chagas iniciou estudos sistemáticos sobre o ciclo evolutivo do novo parasito, que, em cumprimento a dois postulados de Koch, mostrou-se capaz de infectar experimentalmente cães, cobaias e coelhos e de ser cultivado em agar-sangue. ${ }^{102}$ Os barbeiros foram identificados como sendo da espécie Conorhinus megistus (posteriormente classificada como Panstrongylus megistus) e passaram a ser minuciosamente estudados por Neiva, que se tornaria especialista no assunto (Neiva, 1910). ${ }^{103}$ Em busca de outros hospedeiros vertebrados do T. cruzi e suspeitando que o homem pudesse ser um deles (hipótese reforçada por seus conhecimentos sobre a malária, também transmitida por um inseto hematófago domiciliário e causada por um hematozoário), Chagas retornou a Lassance. "Dada a preferência do conorhinus pelo sangue humano, suspeitamos, de acordo com a teoria da evolução filogenética dos hemoflagelados, pudesse ser parasito do homem o tripanossoma encontrado no aparelho digestivo daquele hematófago. Orientamos dest'arte nossas pesquisas (...)" (Chagas, 1909c: 161). ${ }^{104}$

Com base nestas hipóteses, empreendeu exames sistemáticos de sangue nos moradores de casas onde houvesse barbeiros, além de procurar "a existência de elementos mórbidos característicos de tripanossomíases" (Chagas, 1909d: 162). Ao examinar animais domésticos, verificou a 
presença do T. cruzi no sangue de um gato. Depois de várias tentativas sem sucesso, no dia 14 de abril de 1909, encontrou finalmente o parasito no sangue de uma criança febril. ${ }^{105}$ Em 'nota prévia' escrita em Lassance no dia seguinte e enviada ao Brazil-Medico, uma das principais e mais difundidas revistas médicas do país na época, anunciou sua descoberta:

Num doente febricitante, profundamente anemiado e com edemas, com plêiades ganglionares engurgitadas, encontramos tripanossomas, cuja morfologia é idêntica à do Trypanosoma cruzi. $\mathrm{Na}$ ausência de qualquer outra etiologia para os sintomas mórbidos observados e ainda de acordo com a experimentação anterior em animais, julgamos tratar-se de uma tripanossomíase humana, moléstia ocasionada pelo Trypanosoma cruzi, cujo transmissor é o Conorhinus sanguissuga (?). ${ }^{106}$ (Chagas, 1909c: 161)

Berenice, uma menina de dois anos, era o primeiro caso do que seria considerado, a partir de então, uma nova doença humana. ${ }^{107} \mathrm{O}$ fato seria imediatamente divulgado também junto à comunidade científica internacional, mediante publicações nos Archiv für Schiffs- und TropenHygiene e no Bulletin de la Société de Pathologie Exotique (Chagas, 1909b, 1909g).

Em 22 de abril, ao mesmo tempo que o Brazil-Medico trazia em suas páginas a descoberta feita em Lassance, ela foi comunicada em sessão da ANM por Oswaldo Cruz, que leu trabalho escrito por Chagas, apresentando uma síntese do processo da descoberta, informações sobre os hábitos do inseto transmissor ("vorazmente hematófago, atacando como um verdadeiro flagelo os moradores, impedindo e perturbando o sono"), dados clínicos sumários sobre a nova entidade mórbida ("que o vulgo denomina 'opilação' e que nada tem que ver clinicamente com a anquilostomíase”) e características do novo tripanossoma, que "apresenta pontos inteiramente novos em seu ciclo evolutivo” (Chagas, 1909f: 190).

O episódio foi noticiado na imprensa. Em alguns casos, a exaltação de "um dos mais belos ornamentos do Instituto Oswaldo Cruz" vinha acompanhada de algumas imprecisões na tentativa de traduzir, para os leigos, o significado da descoberta face às teorias científicas do momento. Na Gazeta de Notícias, afirmando que os estudos de Chagas vinham "revolucionar a ciência médica no que diz respeito aos tripanossomas", o redator salientava que "as idéias de Mansen [sic], Schaudinn e outros patologistas eminentes ruíram por terra” (Gazeta de Notícias, 1909: 1). Depois dos trabalhos anunciando a descoberta, Chagas publicou, em 
agosto de 1909, no primeiro volume das Memórias do Instituto Oswaldo Cruz, um extenso estudo sobre o novo parasito e seu ciclo evolutivo (Chagas, 1909d).

A descoberta e os estudos em Lassance tiveram um impacto imediato na carreira do jovem pesquisador do IOC, que alcançou grande proeminência no mundo científico, com efeitos diretos em sua inserção no instituto. Em março de 1910, Oswaldo Cruz abriu concurso para preencher a vaga de 'chefe de serviço', aberta com a ida de Rocha Lima para a Alemanha. A seleção adotou como critério primordial o mérito científico, auferido pelas publicações dos candidatos, e, em segundo lugar, o tempo de serviço. Este foi um evento decisivo para a instituição. Segundo Benchimol e Teixeira (1993), o novo ocupante do cargo era visto como o mais provável candidato à sucessão de Oswaldo Cruz. Chagas obteve a primeira colocação. A partir de então, ele de fato iria conquistar cada vez mais poder nas estruturas internas de Manguinhos. ${ }^{108}$

Em 26 de outubro de 1910, após publicar os primeiros resultados de seus estudos clínicos sobre a doença, Chagas foi admitido como membro titular da ANM, onde proferiu uma conferência detalhando tais estudos (Chagas, 1910b). Nos anos seguintes, seguiria apresentando suas pesquisas nas principais associações e eventos do campo médico brasileiro, em geral com grande repercussão na imprensa. Em julho de 1911, realizou conferência na Sociedade de Medicina e Cirurgia de Minas Gerais (Chagas, 1911a), em Belo Horizonte, e, em agosto, retornou à ANM para outra apresentação (Chagas, 1911b). Em 1912, além de conferência na Sociedade de Medicina e Cirurgia de São Paulo (Chagas, 1912b), a classe médica mineira tornou a ouvi-lo, por ocasião do VII Congresso Brasileiro de Medicina e Cirurgia, realizado na capital do estado (Chagas, 1912a). Nestas comunicações, publicadas em periódicos médicos, Chagas apresentou os principais enunciados sobre o quadro clínico e os aspectos sociais da nova entidade mórbida.

Em meados de 1911, um evento marcou a divulgação da descoberta e da nova doença no cenário científico internacional. No pavilhão brasileiro da Exposição Internacional de Higiene e Demografia (realizada em Dresden, Alemanha, e que documentava os trabalhos do Instituto Butantan, a campanha contra a febre amarela de Oswaldo Cruz na capital federal e as pesquisas e coleções científicas do IOC), a doença de Chagas teve grande destaque, evidenciando a centralidade que o tema assumia em Manguinhos. Vasto material sobre o assunto foi exibido (Imagem 12), 
incluindo imagens cinematográficas feitas em Lassance. O próprio Oswaldo Cruz registrou seu entusiasmo quanto à repercussão do trabalho de seu discípulo: "Com efeito, à Exposição tem ido uma verdadeira romaria de sábios de toda a Alemanha. (...) ficaram todos encantados pelos estudos de Chagas. Quando no cinematógrafo viram as fitas dos doentes de Chagas, não se puderam conter e irromperam em aplausos e vivas" (Cruz apud Benchimol \& Teixeira, 1993: 45-46).

Em junho de 1912, Chagas foi agraciado com uma importante distinção no campo científico internacional: o Prêmio Schaudinn, concedido de quatro em quatro anos pelo Instituto de Doenças Marítimas e Tropicais de Hamburgo ao melhor trabalho em protozoologia. ${ }^{109}$ A comissão formada para a concessão do prêmio, da qual fazia parte Oswaldo Cruz, era composta pelos mais importantes nomes da microbiologia e da medicina tropical, como Koch (falecido durante o processo do julgamento), Manson, Ross, Laveran, Metchnikoff, Roux, Golgi e Grassi (Chagas Filho, 1993: 98). ${ }^{110} \mathrm{Na}$ época, Oswaldo Cruz obteve, junto ao governo federal, verbas especiais para equipar um pequeno hospital em Lassance, a fim de sediar os estudos clínicos sobre a nova doença, e para dar início, em Manguinhos, à construção de um hospital destinado às pesquisas e ao acompanhamento dos casos identificados no norte de Minas Gerais e em outras regiões do país (Benchimol, 1990a; Benchimol \& Teixeira, 1993).

Sob a liderança de Chagas e com a colaboração de vários pesquisadores associados à Comissão de Profilaxia e Assistência Médica da Moléstia de Chagas, criada no IOC, a nova tripanossomíase passou a ser estudada em seus vários aspectos, como as características biológicas do vetor, do parasito e de seu ciclo evolutivo, o quadro clínico e a patogenia (evolução) da infecção, suas características epidemiológicas, os mecanismos de transmissão e as técnicas de diagnóstico. ${ }^{11}$

\section{Os Sentidos da Descoberta}

A historiografia sobre a descoberta da doença de Chagas ressalta sua inscrição no contexto de afirmação e de institucionalização da medicina tropical européia (Benchimol \& Teixeira, 1993; Kean, 1997; Perleth, 1997; Coutinho, 1999, 2003; Stepan, 1976, 2001; Delaporte, 2003; Sá, 2005). Stepan (2001: 182) ressalta: 
(...) the discovery of a human disease hitherto unsuspected by physicians, right at the moment when other parasitic and vectorborn diseases like malaria and African sleeping sickness were defining the new discipline of tropical medicine, was originally seen in Brazil as a major medical event. ${ }^{12}$

Worboys (1997) comenta que a particularidade de Chagas ter identificado o patógeno e o transmissor antes da descrição clínica da doença foi mais uma evidência do poder do modelo do parasito-vetor sobre o qual estava estruturada a medicina tropical mansoniana. Delaporte (2003) sublinha que a escola alemã de protozoologia foi determinante para as proposições de Chagas quanto ao ciclo evolutivo do T. cruzi. Sá (2005) argumenta que o estreito intercâmbio entre Manguinhos e a protozoologia alemã constituiu uma via de mão dupla: ao mesmo tempo em que tal vertente da medicina tropical propiciou os referenciais teóricos de Chagas, os conhecimentos que o cientista brasileiro produziu, especialmente sobre o novo parasito, vieram elucidar aspectos centrais e ainda controversos daquele emergente campo do saber (sobretudo quanto ao estudo das doenças causadas por tripanossomas), contribuindo para o processo de legitimação da própria especialidade.

Este aspecto pode ser identificado nos estudos de 1909 sobre as características biológicas do T. cruzi e "o modo de evolver todo particular deste protozoário" tanto no organismo dos hospedeiros vertebrados (entre os quais o homem) quanto no do inseto transmissor (Chagas, 1909c: 161). O novo parasito foi o primeiro tema de pesquisa ao qual Chagas se dedicou sistematicamente, antes mesmo de se lançar ao estudo clínico da nova entidade mórbida. Para isso, contou com a colaboração de Max Hartmann, presente em Manguinhos desde maio de 1909. No trabalho publicado no primeiro volume das Memórias do Instituto Oswaldo Cruz, explicita-se sua filiação a vários enunciados e teorias propostos pela escola de Schaudinn, Prowazek e Hartmann (Chagas, 1909d).

Segundo Chagas, o estudo do novo parasito trazia contribuições importantes aos debates sobre a classificação dos protozoários. Ao encontrar, no tecido pulmonar de animais infectados experimentalmente no laboratório, formas que julgou resultantes de divisão múltipla (esquizogonia) do parasito, ele estabeleceu uma diferença substantiva em relação aos tripanossomas até então conhecidos, cuja multiplicação se dava por divisão binária. Assim, considerou que deveria ser criado um novo gênero (Schizotrypanum) para classificar aquela espécie, que passou a 
denominar Schizotrypanum cruzi. Esta noção de reprodução esquizogônica, abandonada em 1913, teria importantes conseqüências para o diagnóstico da doença. Chagas afirmava também que, além da esquizogonia, outras características do parasito vinham confirmar a teoria de Schaudinn sobre o parentesco estreito entre os tripanossomas e os hemosporídios (protozoários que se reproduzem no interior das hemácias, entre os quais o parasito da malária), até então tidos como autônomos e bem delimitados. A descoberta viria, assim, dar suporte à proposta de Hartmann para que os hemosporídios e os tripanossomas fossem reunidos sob a nova ordem dos Binucleatta (Chagas, 1909d). ${ }^{113}$

Contudo, como salienta Sá (2005), o aspecto mais importante deste trabalho para o debate da medicina tropical foi sua contribuição para o entendimento do papel dos insetos hematófagos na transmissão de tripanossomas de vertebrados. Embora se acumulassem evidências nesta direção, o tema era controverso e ainda não se aceitava que estes insetos funcionassem como hospedeiros intermediários para os tripanossomas, que neles cumpriam parte de seu ciclo evolutivo. Acreditava-se que as moscas tsé-tsé eram meros transmissores mecânicos do parasito causador da tripanossomíase africana. Justamente em 1909, o alemão Friedrich Kleine publicou um trabalho contestando esta hipótese. Reportando-se à controvérsia, Chagas afirmou que suas investigações sobre a evolução do S. cruzi no organismo do barbeiro vinham produzindo resultados de interesse "para as questões de doutrina relativas ao mecanismo da transmissão dos hemoflagelados pelos invertebrados" e, apesar dos pontos ainda não esclarecidos, elucidavam "muitos fenômenos até aqui obscuros, do papel dos hospedeiros intermediários nas tripanossomíases" (Chagas, 1909d: 181).

Seu trabalho endossava a tese de Kleine, compartilhada por Schaudinn, Prowazek e outros cientistas, de que a transmissão dos tripanossomas não se dava de modo mecânico, mas dependia de uma relação biológica fundamental entre o parasito e o vetor, conforme o modelo preconizado por Manson. ${ }^{114}$ Assim, concluía Chagas (1909d: 213):

Fica, destarte, excluído o papel mecânico exclusivo do hemíptero, e mesmo que esse possa atuar como simples veiculador na transmissão imediata do parasito, o que nunca verificamos, a função principal será de hospedeiro intermediário, no qual o flagelado passa por ciclo evolutivo, que se completa no prazo mínimo de 10 dias. 
A contribuição de Chagas foi divulgada na comunidade científica alemã pelo próprio Prowazek, logo após seu regresso para aquele país. O cientista brasileiro ingressou ativamente na busca de soluções para os 'quebra-cabeças' da medicina tropical, mediante uma interlocução com os pesquisadores alemães que, como aponta Sá (2005), forneceram-lhe a base científica e a legitimidade para construir sua própria atuação naquele campo. ${ }^{115}$

Conforme Stepan (1976: 117), apesar da descoberta de Chagas ser uma contribuição científica original, os brasileiros começaram a investigar segundo linhas já estabelecidas: "era muito menos provável que, se a microbiologia estivesse em sua infância em 1900, a comunidade científica brasileira possuísse os recursos intelectuais e profissionais para contribuir frutiferamente no desenvolvimento do campo". Na mesma direção, Simon Schwartzman (1979: 136) sublinha que a ciência brasileira "de qualidade" feita no início do século XX era "ciência de tipo 'normal', de consolidação, em função de cânones de trabalho já bem estabelecidos, e não uma ciência 'de ponta', de abertura de novas fronteiras de conhecimento".

A literatura recente vem questionando tal concepção, mostrando que a ciência médica européia baseada nas novas doutrinas do final do século XIX (tanto a microbiologia como, sobretudo, a medicina tropical) não estava, nos primeiros anos do século XX, tão estabilizada (Arnold, 1996a). Além disso, tem-se enfatizado que, embora recorrendo a conceitos e teorias elaborados nos centros científicos no exterior, alguns cientistas brasileiros tiveram papel importante não apenas na recepção, mas também no que diz respeito à produção e à validação desses conhecimentos. Os trabalhos de Chagas, como os de Lutz, exemplificam esta participação ativa da ciência brasileira - ainda que de segmentos restritos - na construção e no reconhecimento daquele campo médico-científico (Benchimol \& Sá, 2005, 2006; Sá, 2005).

Outro aspecto salientado pelos historiadores é a importância da descoberta da doença de Chagas como fonte de legitimação, visibilidade e recursos, materiais e simbólicos, para o projeto institucional de Oswaldo Cruz (Stepan, 1976, 2001; Schwartzman, 1979; Benchimol \& Teixeira, 1993). Benchimol e Teixeira (1993: 49) enfatizam que o principal efeito da descoberta em Lassance foi a consolidação da protozoologia - "território cognitivo e institucional no qual se insere a descoberta" - como área de concentração das pesquisas do IOC, bem como o impulso ao 
reconhecimento de Manguinhos na comunidade científica internacional como centro de investigação sobre doenças tropicais.

Uma das várias evidências do empenho de Oswaldo Cruz em realçar a obra de Chagas, dentro e fora do país, como emblema da 'excelência' de Manguinhos e da própria ciência nacional foi a ênfase com que a ela se referiu em conferência pronunciada na Biblioteca Nacional em 1915, na qual enumerou as principais conquistas brasileiras no campo da protozoologia. O diretor do IOC acentuou o que se tornaria um dos elementos mais evocados pelos que, como ele, glorificariam o 'grande feito' de Chagas: tratava-se de um feito único na história da medicina, em que o mesmo pesquisador identificara o vetor, o agente e a doença humana por este causada.

Dentre as doenças de protozoários de que tratamos, a que entre todas apresenta maior importância, no ponto de vista em que nos colocamos - moléstias cujo estudo foi feito no Brasil - é indubitavelmente a Tripanossomíase americana, muito merecidamente denominada 'moléstia de Carlos Chagas', como justa homenagem prestada a seu descobridor. (...) Nunca, até agora, nos domínios das pesquisas etiológicas, se tinha feito descoberta tão completa e tão brilhante em tão curto prazo, e, o que é mais, por um só experimentador. A descoberta da moléstia de Chagas, tal como foi feita, é a demonstração prática e brilhante do axioma do imortal Francisco de Castro, que pontificava: só é ciência por fora aquilo que é lógica por dentro. (Cruz, 1915: 353-354)

Por sua vez, sob a retórica de quem se colocava como discípulo, Chagas também imputava à descoberta o sentido maior de representar a 'escola de Oswaldo Cruz'. Suas primeiras palavras na ANM, quando foi recebido como membro titular, reiteraram:

Pertencem (...) ao Instituto de Manguinhos os resultados que tão generosamente quisestes premiar, sendo bem diminuta a parte que neles me cabe, o simples contingente do esforço pessoal. Tive, nesse assunto, a felicidade de ser o executor dos conselhos científicos de um mestre a quem todos vós muito prezais e daí, só daí, qualquer merecimento prático que acaso tenhais querido encontrar nesses trabalhos. (Jornal do Commercio, 1910b: 3)

A descoberta e o estudo da tripanossomíase americana foram decisivos para a conformação de um modelo institucional que permitia ao IOC auferir legitimidade de sua face aplicada, de vinculação às demandas 
sociais, e ao mesmo tempo afirmar-se como centro de pesquisa científica pautado nos valores e nos princípios da excelência acadêmica. Este processo nos remete à concepção proposta por Robert Merton (1984) de que a ciência conquista legitimidade e condições para se diferenciar como atividade social específica a partir da interdependência que estabelece com diferentes esferas da vida social. Assim, como sugere Stepan (1976), a base social que Manguinhos conquistou em sua conexão com os interesses da saúde pública, intermediada pelo Estado, foi justamente o que propiciou meios para que a instituição construísse gradativamente sua legitimidade como espaço de ciência que, para além de corresponder aos interesses pragmáticos dos setores sociais que o sustentavam, estava afinado com o movimento de ampliação das fronteiras do conhecimento.

Um dos aspectos fundamentais em que a descoberta e os trabalhos de Chagas contribuíram para este processo foi terem propiciado elementos que engendraram um novo sentido para a noção de apropriabilidade social da ciência de Manguinhos. ${ }^{116}$ Os conhecimentos produzidos no IOC passaram a ser vistos como referidos aos interesses e às demandas da sociedade brasileira não apenas pelas respostas imediatas aos problemas que se encontravam na ordem do dia (como a fabricação de soros e vacinas ou campanhas de profilaxia), mas também pela possibilidade de identificar os próprios problemas desta sociedade. Ou seja: os pesquisadores não só atendiam a demandas, mas também as criavam, apresentando-se como os que forneceriam as soluções para elas. Trata-se de uma concepção de pesquisa aplicada que advém não da materialização direta do conhecimento científico em produtos e ações, mas da estreita vinculação entre ciência e projeto nacional, do qual os próprios cientistas - adotando o perfil de uma intelligentsia reformadora - se colocavam como porta-vozes, e em referência ao qual os temas por eles abordados se revestiam de utilidade social. O lugar assumido pelas endemias rurais - e particularmente pela doença de Chagas - no processo de articulação entre a ciência de Manguinhos e a sociedade brasileira, durante a década de 1910, esteve diretamente relacionado a esta forma de se conceber o papel social da instituição e da atividade científica em geral.

Assumindo centralidade no projeto institucional do IOC e no próprio processo de institucionalização da ciência naquele período, a descoberta de Carlos Chagas passou a ser tratada, pelos contemporâneos e pela memorialística médica, até o presente, como mito glorificador da ciência brasileira. ${ }^{17}$ Ao analisar as reconstruções históricas da descoberta com o 
objetivo de questionar tal mitologia, François Delaporte (1995, 2003) argumenta que aquilo que muitos consideraram "o mais belo exemplo do poder da lógica a serviço da ciência”, como disse Oswaldo Cruz (1915: 354), foi, na realidade, fruto do desvio inesperado de uma hipótese inicial equivocada (segundo a qual o flagelado encontrado no barbeiro era um estágio do T. minasense e não um tripanossoma desconhecido) e que estava relacionada ao campo exclusivo da protozoologia, sem nenhuma referência a temas afetos a patologias humanas. ${ }^{118}$

Ao analisar os relatos do episódio feitos pelo próprio Chagas, Delaporte aponta que, a partir de um dado momento, o cientista alterou a ordem e o sentido dos eventos, afirmando que, antes mesmo de encontrar o barbeiro, suspeitava da existência de uma doença desconhecida na região e que, assim que dissecou o inseto, pensou tratar-se de um parasito patogênico do homem. ${ }^{119} \mathrm{Ou}$ seja: a descoberta teria coroado uma busca orientada por suspeitas prévias. Delaporte (1995: 40) afirma que esta narrativa, corroborada por seus seguidores e presente até hoje em relatos históricos da descoberta, constitui uma "reconstituição historicamente falsa". Ela teria sido motivada pela preocupação de Chagas em enfrentar os críticos que, a partir de finais da década de 1910, questionaram, entre outros aspectos de seus estudos, seu mérito científico como responsável por todos os passos da descoberta. O cientista teria recorrido a "uma história transfigurada" (Delaporte, 1995: 41) para transformar em encadeamento orientado um processo cujo grand final era, na realidade, o resultado de um percurso inicialmente referido ao estudo de um tripanossoma de macacos, que somente depois, de modo imprevisto, encontraria relação com a patologia humana. Delaporte (1995: 42) sintetiza assim seu argumento sobre a descoberta da tripanossomíase americana: "Eis a história de uma pesquisa que encontra seu projeto no desvio de sua primeira linha de investigação, é balizada por acidentes de percurso e marcada pelos jogos, incofessáveis, do acaso e do erro".

De fato, ao encontrar o flagelado no barbeiro, a hipótese que pareceu a Chagas mais provável foi a de tratar-se de um estágio do T. minasense, como ele próprio registrou em seus trabalhos iniciais. ${ }^{120}$ Uma outra evidência disso pode ser encontrada no relatório oficial do IOC, publicado no ano da descoberta (IOC, 1909), em que, ao lado de outras imagens representativas das principais contribuições da instituição, vê-se um desenho reunindo, como num dístico, as figuras do conorhinus (barbeiro), das formas flageladas do tripanossoma e de um 
sagüi, sob as quais lê-se "tripanossoma do sagüi”. ${ }^{121}$ Também é possível concodar com Delaporte quando este afirma que as reconstruções posteriores de Chagas, ao reforçar o aspecto de coesão entre os vários fios da meada em seu raciocínio, foram realizadas com o objetivo de legitimar-se e fortalecer-se diante dos críticos. ${ }^{122}$

Uma primeira ressalva faz-se, contudo, necessária. Delaporte (1995: 40) credita aos historiadores a responsabilidade por corroborar a reconstrução feita por Chagas, transformando esta "epopéia brasileira" num mito. No entanto, os relatos históricos aos quais o autor se refere são eminentemente textos da memorialística médica, alguns dos quais escritos pelos que conviveram com o próprio Chagas (como Eurico Villela, seu colaborador em Manguinhos, e Émille Marchoux, do Instituto Pasteur de Paris). De fato, médicos e cientistas vêm produzindo, desde então, narrativas sacralizadoras da memória de Chagas e um dos elementos mais acionados é justamente a idéia de que, mesmo antes de encontrar o barbeiro, o jovem cientista 'suspeitava' de uma nova patologia. Como os historiadores vêm mostrando, este processo de glorificação e mitificação da figura de Chagas está referido ao próprio lugar e significado que a descoberta e os estudos da nova doença assumiram na institucionalização e na legitimação da medicina e da ciência nacionais (Stepan, 1976; Schwartzman, 1979; Benchimol \& Teixeira, 1993; Britto, 1995). Tratar desta dimensão nacional não significa produzir "história nacionalista", como sugere o autor (Delaporte, 2005: 327), mas, ao contrário, cumprir o próprio objetivo da perspectiva histórica, que é inserir a doença de Chagas no contexto social que lhe conferiu sentido.

Além disso, ao afirmar que a descoberta foi o resultado imprevisto do "erro" e do "falso", e que Chagas introduziu uma "mentira" para ocultá-los, Delaporte (1995: 49, 48, 50) desconsidera que tanto os 'desvios' quanto as tentativas de apagá-los são dimensões constitutivas do próprio processo de produção e validação do conhecimento científico. Os historiadores e sociólogos da ciência têm apontado sistematicamente que tais processos não devem ser pensados em termos das idiossincrasias individuais de um cientista que quer 'esconder a verdade' em benefício próprio ou de seu grupo, mas como uma característica da própria ciência: percursos acidentados, marcados por hipóteses que mais tarde são abandonadas, aspectos imprevistos, conflitos de interesses e outros fatores que, ao final do processo, são deliberadamente apagados pelos cientistas como se tudo tivesse transcorrido 'naturalmente' em direção à verdade. 
Bruno Latour (2000) foi um dos muitos que apontaram os meandros deste processo, que já constitui lugar-comum nos estudos sociais da ciência. Na visão dos historiadores, estes procedimentos, assim como a produção de mitos, são elementos corriqueiros e constitutivos da ciência (e de qualquer outra atividade social): a preocupação em se autolegitimar. O que nos cabe não é denunciar estratégias mitificadoras tanto de Chagas quanto de seus seguidores (a denúncia, neste caso, equivale à afirmação do mito ao avesso), mas compreendê-las. Para isso, devemos situá-las em suas circunstâncias históricas e sociais específicas. ${ }^{123}$

O presente livro pretende somar-se aos esforços nesse sentido. Lançando mão da perspectiva de Charles Rosenberg (1992a, 1992b, 1992c), um aspecto importante a ser salientado é que, se a descoberta contribuiu para emoldurar o projeto de Manguinhos (tanto em termos de suas áreas de conhecimento quanto em seu projeto político-institucional), ela foi emoldurada pelos significados associados a este projeto. Tal moldura, por sua vez, teria conseqüências decisivas sobre o processo de construção científica e social do objeto identificado em Lassance.

Uma questão importante é a própria idéia da descoberta de 'uma nova doença'. Embora Chagas declarasse que encontrara uma "nova entidade mórbida”, "uma nova tripanossomíase humana”, em abril de 1909 ele estava diante de uma entidade nosológica 'a ser construída'. Cabia-lhe estabelecer seus traços de especificidade, no que dizia respeito tanto a um quadro sintomatológico considerado típico quanto à relação causal entre este quadro e a ação do parasito ao qual ele era atribuído. Sob a perspectiva histórica e sociológica que desnaturaliza as descobertas (Brannigan, 1984), não havia ainda uma doença propriamente dita, mas uma hipótese sobre sua existência e, sobretudo, um caminho - cognitivo e social - para defini-la.

Uma das considerações que se tornariam mais recorrentes na memorialística médica sobre a importância da descoberta como feito único da ciência nacional foi o caráter incomum da seqüência sob a qual ela ocorreu, partindo-se da identificação do vetor e do agente causal para, em seguida, determinar a patologia a eles associada. O próprio Chagas sublinhou este aspecto em 1910. ${ }^{124}$ Considerando-se os desafios e caminhos postos para Chagas a partir do encontro do parasito no sangue de Berenice, este é um elemento que torna particular o processo de construção da 'nova entidade mórbida'. Não foi a mera ordem dos eventos que foi incomum, mas o próprio fato de que, diferentemente do que ocorreu 
para as outras doenças infecciosas de maior evidência no debate médico da época, não se tinha qualquer conhecimento clínico ou descrição prévia, mesmo que sob outros modelos e critérios definidores, de uma enfermidade atribuída àquele patógeno. Não havia experiência clínica que servisse de referência, ainda que para ser reenquadrada sob novos parâmetros (como aconteceu com a malária, por exemplo). Ou seja, ao encontro do vetor e do parasito, seguiu-se não a associação a uma doença, mas a busca de processos patológicos passíveis de constituir uma doença referida àqueles dois elementos interligados. ${ }^{125}$

Chagas (1909c: 161) afirmou que, quando regressou a Lassance depois da identificação do T. cruzi, assinalou a presença de "um quadro mórbido uniforme, apreciável em quase todas as crianças da zona onde abunda o invertebrado". ${ }^{126}$ Como vimos, em alguns relatos, chegou a dizer que já havia desconfiado de uma nova patologia antes mesmo de encontrar o barbeiro. Contudo, o que ele tinha de concreto, em 14 de abril de 1909, era uma criança com sintomas inespecíficos e com um tripanossoma no sangue, que lhe havia sido transmitido por um dos muitos barbeiros que proliferavam na cafua em que morava. Todavia, o mais importante é que ele dispunha de um esquema interpretativo, erigido em torno dos conceitos da medicina tropical e firmado sobre a base institucional de Manguinhos. Este esquema, tendo-o levado até àqueles elementos, conformaria o caminho pelo qual Chagas e seus colaboradores se dedicariam a demonstrar que tal estado patológico era específico, causado por aquele patógeno, e acontecia em Berenice e em outros indivíduos portadores do T. cruzi.

Como as investigações clínicas ainda não haviam sido iniciadas, é interessante observar uma estratégia discursiva utilizada por Chagas neste momento inicial de construção/individualização da doença. No trabalho lido por Oswaldo Cruz na ANM, ele comenta que a população da região 'confundia' a nova entidade mórbida com a opilação, mas que, na realidade, tratava-se de enfermidades distintas. Ou seja, a própria inespecificidade dos sintomas, alguns dos quais de fato poderiam ser atribuídos à ancilostomíase (como anemia e decadência orgânica), era usada para advertir que, naquele fundo confuso de sintomas e sinais, a ciência estava desvendando algo novo e diferente (Chagas, 1909f: 190).

O parasito, sob a inteligibilidade que lhe era conferida pela protozoologia, foi, portanto, mais do que um ponto de partida cronológico para a construção daquela nova doença tropical. Sob os marcos 
cognitivos da chamada medicina de laboratório, em que o agente microbiano constituía a dimensão determinante para a caracterização e a comprovação de dada doença infecciosa (Cunningham, 1992), o T. cruzi constituiu sua instância fundamental de enquadramento. Não apenas porque foi o elemento que norteou Chagas na suposição de que estava diante de uma nova entidade mórbida, mas porque sua presença no organismo dos indivíduos seria o critério fundamental tanto para determinar as manifestações e sinais clínicos considerados específicos desta entidade como para a validação de seu diagnóstico. A aceitação de que se estava diante de uma nova doença foi proporcionada pela própria força do modelo da microbiologia e da medicina tropical. A teoria do insetovetor e seus exemplos (doenças causadas por protozoários e transmitidas por insetos hematófagos) fizeram com que o terceiro elo da descoberta (a doença) estivesse 'garantido' antes mesmo de ser apresentado e validado como uma entidade distinta. Na busca por destacar um quadro clínico peculiar de um emaranhado de sinais inespecíficos (ou que poderiam ser atribuídos a outras causas), o guia primordial de Chagas era a presença do T. cruzi. Ele era a garantia de que, daquele fundo, seria possível recortar, progressivamente, os contornos e significados científicos e sociais de uma figura particular, individualizada.

\section{Notas}

1 Discurso de Miguel Pereira na Academia Nacional de Medicina, na sessão de 26 de outubro de 1910, em que Chagas foi recebido como membro titular desta associação (Jornal do Commercio, 1910b: 3).

2 A Sociedade de Medicina do Rio de Janeiro, criada em 1829, transformou-se em Academia Imperial de Medicina em 1835 e, com a proclamação da República, passou a chamar-se Academia Nacional de Medicina (ANM).

3 Para os filósofos da ciência do início do século XX, somente o contexto da justificação (a maneira pela qual os cientistas demonstram a validade de suas teorias diante de outros cientistas) constituiria objeto de análise, por ser regido pelos princípios universais da racionalidade e da lógica, subjacentes à aplicação do método científico. Já o contexto da descoberta (os processos mentais e concretos pelos quais o pensamento é formulado) deveria ser objeto para a psicologia ou para os que se interessam pelos fatores ditos 'externos' aos conteúdos lógicos da ciência, como historiadores ou sociólogos. Segundo Kuhn (1989), tal distinção não existe na prática real da ciência, uma vez que tanto a descoberta quanto a validação da ciência estão sujeitas a fatores sociais, constituindo processos não distintos, mas associados. A adesão a uma nova teoria depende da maneira pela qual ela foi produzida e dos significados que lhe foram atribuídos no ato de sua formulação. O questionamento 
desta demarcação foi decisivo para as perspectivas de um estudo sócio-histórico da ciência para além de fronteiras entre os seus aspectos internos e externos. Para um debate sobre a obra de Kuhn vis-à-vis distintas posições do campo da filosofia da ciência, ver Lakatos e Musgrave (1979).

4 Ainda que balizada pela perspectiva de desnaturalização deste evento denominado 'descoberta', seguirei adotando o termo na medida em que constitui não apenas uma categoria usada pelos sujeitos históricos que acompanhamos, mas uma noção estruturante do entendimento acerca da atividade científica.

5 Sobre as transformações na medicina ao longo do século XIX, ver, entre outros, Cunningham (1992), Rosen (1994) e Porter, R. (1999).

6 Para uma análise histórica da construção da imagem de Oswaldo Cruz como 'saneador do Rio de Janeiro' e 'introdutor da medicina experimental' no Brasil, ver Britto (1995).

7 Analisando o caso da tuberculose, doença emblemática das transformações impostas pelo modelo da etiologia microbiana, Worboys (2000, capítulo 6) apresenta várias dimensões pelas quais a institucionalização da bacteriologia configurou-se como um processo complexo, envolvendo descontinuidades e continuidades, tanto em termos conceituais quanto em termos das ações médico-sanitárias. Apesar de ter sido reconfigurada como entidade clínica pela identificação do patógeno por Koch, em 1882, a tuberculose foi um exemplo da acomodação entre a teoria dos germes e o modelo ambientalista da higiene, o qual permaneceu influenciando, sobretudo, as medidas para o seu tratamento no âmbito dos sanatórios.

8 A oposição entre contagionistas e anticontagionistas, por exemplo, tinha implicações no debate político entre os partidários de um Estado liberal e os que defendiam um Estado intervencionista, na medida em que às diferentes posições se associavam distintas maneiras de pensar temas como responsabilidade individual e social e as atribuições do poder público, particularmente no que diz respeito à adoção de medidas de quarentena e isolamento. Ver Ackerknecht (1948).

9 Sobre o papel da medicina como instrumento do colonialismo, em termos militares, de exploração econômica e de justificação ideológica, ver Arnold (1997).

10 O termo 'doenças tropicais' foi introduzido pela primeira vez pelo inglês Benjamin Moseley em seu Treatise on Tropical Diseases and on the Climate of the West Indias, em 1787 (Stepan, 2001: 17).

11 Arnold (1996a) argumenta que uma das principais características desta medicina tropical na longa duração foi o sentido de 'alteridade' que os trópicos - entendidos não em sua dimensão meramente física/geográfica, mas como espaço conceitual, a associar elementos culturais, políticos e estéticos - expressavam face ao olhar europeu. Sob tal perspectiva, coloca-se a questão da interação da medicina européia com culturas e ambientes distintos. A contrapartida seria o impacto dos saberes e práticas locais sobre a própria medicina das metrópoles. Nesse sentido, sublinha o autor, o tema conduz à reflexão sobre as relações entre os chamados 'centros' produtores de conhecimento e as regiões 'periféricas', sob uma perspectiva que contesta a visão tradicional de simples transferência e imposição de idéias e técnicas por parte dos 'centros'. Para uma rica análise sobre as representações visuais da natureza tropical em distintos contextos históricos (inclusive sobre as imagens dos portadores da doença de Chagas), ver Stepan (2001). 
12 Worboys (1997: 514) identifica três fases na história da medicina tropical. Primeiramente, o período anterior ao estabelecimento da especialidade, em que, ao invés de lidarem com a noção de 'doenças tropicais' como categoria distinta, os médicos se viam diante de 'doenças nos trópicos', definidas localmente em referência ao modelo da geografia médica e a uma compreensão multicausal das doenças. O segundo período diz respeito às últimas décadas do século XIX e ao início do século XX, quando, em referência às teorias dos germes, a elucidação da etiologia e do modo de transmissão das doenças tropicais levou à institucionalização da disciplina criada por Manson. Como terceira fase, Worboys indica a implementação de medidas e campanhas destinadas a combater tais enfermidades, que, no âmbito do chamado 'imperialismo construtivo', firmou o modelo das campanhas verticais, tecnicamente orientadas por estratégias específicas, como o controle ou a erradicação dos vetores.

13 Preconizando tal orientação, Farley (1991) cita como exemplo das narrativas tradicionais o clássico trabalho de Harold Scott (1939) e menciona os trabalhos de Roy McLeod e Milton Lewis (1988) e de Arnold (1988) como marcos importantes do surgimento de uma perspectiva historiográfica mais analítica e crítica.

14 Desde a década de 1980, historiadores da ciência vêm questionando a visão de que, até a criação das universidades, os institutos de ciências biomédicas estabelecidos na virada do século - especialmente o Instituto Oswaldo Cruz (IOC) - haviam sido os primeiros centros de pesquisa relevantes para a história das ciências no Brasil. Problematizando esta demarcação, que situa no começo do século XX o início da ciência institucionalizada no Brasil, e buscando trazer à luz a diversidade e a riqueza das atividades científicas anteriores a este marco temporal (em especial, ao longo do século XIX), realizaram-se estudos aprofundados sobre várias e distintas instituições científicas, como museus, escolas profissionais, jardins botânicos, institutos de pesquisa, comissões e associações científicas. Para um panorama das principais questões e diretrizes apresentadas por esta nova historiografia das ciências no Brasil, ver Figueirôa (1998) e Dantes (2001).

15 Para uma revisão crítica de tais narrativas, ver Edler (1996).

16 A anatomoclínica associava os sintomas clínicos aos dados da anatomia patológica (estudo das lesões em órgãos e tecidos, mediante necropsias). Edler (1999, 2003) mostra como a Academia Imperial de Medicina constituiu não apenas o lócus oficial de representação profissional da comunidade médica, mas o espaço que estabelecia os conceitos e os protocolos para a produção e a validação de conhecimentos sobre a nosologia brasileira, bem como os meios de se aplicar tais conhecimentos à política imperial de saúde pública.

17 Para José Francisco Xavier Sigaud - cuja obra Du Climat e des Maladies du Brésil ou Statistique Médicale de cet Empire, de 1844, representou os esforços da elite médica brasileira em produzir dados sistemáticos sobre a patologia nacional -, a singularidade desta patologia residia na força do 'elemento intermitente' (miasma), fruto das condições de umidade típicas do clima tropical. Sua presença constante nas manifestações mórbidas nos trópicos, conferindo uma feição particular à sintomatologia, desafiava os manuais europeus de patologia e tornava a experiência clínica concreta a principal instância de explicação destas manifestações (Edler, 2003: 50).

18 A medicina brasileira do século XIX foi fortemente influenciada pela medicina clínica francesa que, ao final do século XVIII, introduzira uma ruptura fundamental na 
medicina hospitalar, fazendo com que esta deixasse de ser orientada pelas classificações dos naturalistas e se estruturasse na observação sistemática, ao leito dos doentes, dos fenômenos patológicos concretos, mediante a articulação entre semiologia clínica e anatomia patológica. Ver Ferreira et al. (2001).

19 As discussões sobre a etiologia da opilação (considerada, desde o período colonial, uma das principais causas de morte entre os escravos e cujo principal sintoma era a debilidade física e a geofagia), sobretudo a partir dos trabalhos de José Martins da Cruz Jobim, na década de 1830, são um exemplo destes dilemas. Depois de vê-la como 'anemia intestinal' causada pelas condições de vida dos pobres (como a deficiência na alimentação), Jobim considerou o clima o fator determinante da 'degeneração' do sangue tida como característica daquela doença, rebatizada então de 'hipoemia intertropical' (Ferreira, 1999).

20 Ferreira considera os periódicos médicos uma das primeiras instituições científicas do país, fundamentais para a formação e ampliação da audiência da medicina e, conseqüentemente, para sua legitimação como prática social. Ao servir como intermediário entre a comunidade médica e a sociedade, eles expressam a interdependência entre a ciência e outras esferas da vida social (Ferreira, 1999).

${ }^{21}$ O estudo de Ilana Löwy (2006) também enfatiza a centralidade dos estudos e debates sobre a febre amarela como canal para a incorporação dos saberes e das práticas da microbiologia no Brasil, não como transferência unilateral, mas como um processo complexo de circulação e trocas entre a ciência mundial e os contextos nacionais particulares.

22 A articulação entre microbiologia e higiene constituiu uma importante estratégia política utilizada por Pasteur (Latour, 1984). Esta associação, aponta Benchimol (2003), também marcou a incorporação das doutrinas pasteurianas no Brasil, expressando-se na atuação de Oswaldo Cruz à frente do saneamento da capital federal, no início do século XX.

23 Dominichi Miranda de Sá, acompanhando o processo de especialização da atividade intelectual brasileira nos últimos anos do século XIX e no início do século XX, analisa a emergência da categoria social de 'cientista' e o processo pelo qual estes 'homens de ciência' se viram e se apresentaram publicamente como inovadores, não apenas por introduzirem a perspectiva da experimentação e da observação/ intervenção na realidade, mas porque, ao fazê-lo, afirmaram sua desconexão com um estilo de produção cultural fundado no saber livresco, enciclopédico e retórico, típico dos 'literatos' e 'bacharéis'. A autora, filiando-se à renovação historiográfica que questionou o papel precursor desta primeira geração de cientistas ao recuperar tradições e espaços de ciência em muito anteriores a ela, sublinha a importância de se aquilatar os vários sentidos deste 'novo', que efetivamente foi vivido como tal: "não inauguraram a atividade científica, mas representaram efetivamente uma variação nos modos de produzir idéias no país. A grande novidade de sua agenda foi a defesa da especialização intelectual como o mais seguro caminho para a prosperidade do trabalho científico brasileiro e sua equiparação internacional” (Sá, 2006: 15).

24 Por ocasião do centenário de nascimento de seu pai, Carlos Chagas Filho (1993: 37) obteve uma certidão da paróquia de Oliveira da qual constava a informação de que Chagas nascera em 1878, e não em 1879, como ele próprio declarou durante toda a sua vida. 
25 Sobre a trajetória biográfica de Carlos Chagas, ver também Kropf e Hochman (2007) e COC/Biblioteca Virtual Carlos Chagas.

26 O padre João Batista do Sacramento, fundador do colégio e amante de botânica, história natural e zoologia, foi uma influência marcante na formação de Chagas, despertando-lhe o gosto pelos conhecimentos da natureza (Chagas Filho, 1993).

27 Augusto das Chagas era sogro de Epitácio Pessoa, que começava a se destacar na política (Chagas Filho, 1993).

28 Ao analisar a atuação dos engenheiros, Carvalho $(1991,1994)$ sublinha que os intelectuais de formação científica, ao evocarem a realidade brasileira a partir da crença no primado da razão como expressão da vontade construtiva do mundo e da história, assumiam a posição de intelligentsia no sentido proposto por Karl Mannheim (1974), pois concebiam as motivações de sua intervenção não em função de interesses de classe, sua própria ou de outros segmentos sociais, mas tendo em vista a afirmação de seu papel como condutores da nação. Ver também Hershmann, Kropf e Nunes (1996).

29 Esta reforma teve origem em decreto aprovado, em 1879, por Leôncio de Carvalho, ministro do Império, com base em proposta elaborada por alguns professores da FMRJ, entre os quais Sabóia. Foram instituídas a freqüência livre às aulas, a realização de cursos não oficiais nos recintos destas escolas, a supressão das sabatinas, a liberdade de prestar juramento nos atos acadêmicos conforme a religião de cada um e a diplomação de mulheres. Ver Edler (1992) e Ferreira et al. (2001).

30 Sobre as principais medidas preconizadas e implementadas pela reforma Sabóia, bem como outras reformas na FMRJ, ver também Escola Anatômica, Cirúrgica e Médica do Rio de Janeiro (2006).

31 Formado em química, Pasteur desenvolveu, na década de 1850, estudos que apontaram o papel de microorganismos nos processos de fermentação de várias substâncias. Ao realizar, na década de 1870, uma série de experiências sobre doenças animais, passou a defender a tese de que grande parte das enfermidades contagiosas e dos processos infecciosos era causada pela ação de germes específicos. Ver Geison (2002).

32 Os famosos 'postulados de Koch' são: o patógeno deve ser identificado em todos os casos da doença; deve ser isolado do hospedeiro e crescer em meios de cultura; deve reproduzir a doença original quando inoculado em um hospedeiro suscetível; e deve ser identificado no hospedeiro experimentalmente infectado (Cunningham, 1992; Porter, R., 1999).

33 Os principais entraves à aceitação desta idéia eram a complexidade dos ciclos de vida dos protozoários, a ausência de um sistema de classificação preciso dos microorganismos e a dificuldade de se obter meios artificiais para o seu cultivo. A hipótese mais aceita na época foi a de que o agente da malária era uma alga microscópica, com afinidades com o bacilo do antraz (Benchimol \& Sá, 2005).

34 Richard demonstrou que a quinina (produto extraído da árvore da quina) era capaz de eliminar o parasito.

35 O agente causal da doença, um vírus filtrável, só seria desvendado em 1927. Dez anos depois, a Fundação Rockefeller passou a fabricar, no IOC, uma vacina contra a doença, em uso até os dias de hoje (Benchimol, 1999, 2001). 
36 De acordo com o modelo federativo estabelecido pela Constituição Federal de 1891, os serviços relativos à saúde pública eram atribuições dos governos estaduais. Cabiam à DGSP, basicamente, a direção dos serviços sanitários do Distrito Federal, dos portos marítimos e dos fluviais, a fiscalização do exercício da medicina e da farmácia, os estudos sobre as doenças infectocontagiosas, a organização de estatísticas demográfico-sanitárias e o auxílio aos estados, mediante solicitação dos respectivos governos e em casos previstos constitucionalmente (Hochman, 1998).

37 No início daquele ano, o bacteriologista italiano Giuseppe Sanarelli anunciou ter finalmente identificado o bacilo que causava a febre amarela. $\mathrm{O}$ assunto tornou-se manchete dos principais jornais na capital brasileira, e vários cientistas correram para apresentar os resultados de suas pesquisas. Em julho, a descoberta do bacilo icteróide de Sanarelli foi reconhecida na ANM (Benchimol, 1999).

38 Um exemplo desta associação entre o modelo climatológico da higiene e a nova perspectiva pasteuriana foi a 'teoria do solo', do higienista bávaro Max von Pettenkoffer, muito aceita entre os higienistas brasileiros, segundo a qual os germes do cólera e de outras doenças epidêmicas só eram 'ativados' mediante certas condições climáticas e telúricas. Amadurecidos no solo, eles seriam transmitidos pelo ar, inalados pelo homem. Koch, por sua vez, defendia a chamada 'teoria hídrica', formulada por John Snow, para quem a água era o principal veículo do cólera (Benchimol, 1999).

39 Num contexto de expansão do imperialismo europeu, esta década foi marcada pela disseminação internacional das doutrinas e das instituições da microbiologia, com as viagens de Koch pelo mundo e com a criação de filiais do Instituto Pasteur nos vários continentes (Worboys, 1997; Moulin, 1996).

40 Criado como uma das repartições do Serviço Sanitário do Estado de São Paulo, o Instituto Bacteriológico destinava-se à preparação de vacinas, ao exame de substâncias com fins higiênicos e terapêuticos e a pesquisas sobre epidemias e epizootias que irrompiam no estado. Sobre Adolpho Lutz, ver Benchimol e Sá $(2005,2006)$ e Biblioteca Virtual em Saúde Adolpho Lutz.

${ }^{41}$ Como explicam Benchimol e Sá (2005: 115), Manson verificou que os vasos de um cão podiam conter milhões de embriões. Se atingissem ali a forma adulta, alcançariam peso agregado superior ao do hospedeiro. Morrendo este, morreriam também os parasitos, antes de dar à luz uma segunda geração, e a espécie se extinguiria. Tal situação seria evitada se os embriões abandonassem o hospedeiro e se desenvolvessem fora de seu organismo. A presença dos parasitos no sistema circulatório e o fato de que não possuíam meios para abandoná-lo levaram Manson a pensar na intervenção de um animal sugador de sangue, como os mosquitos. Assim, as larvas seriam distribuídas entre vários mosquitos, desenvolvendo-se no interior destes e sendo liberadas na água após a morte dos insetos.

42 Em 1880/1881, o cubano Carlos Juan Finlay formulou a hipótese de que a febre amarela era causada por um germe que sofria transformações fora do corpo do homem antes de infectar o indivíduo. Afirmou que isso acontecia no organismo do mosquito Culex e que este era o veículo que transmitia o germe da pessoa doente àquela saudável. $\mathrm{O}$ papel do mosquito como vetor da doença só seria reconhecido, contudo, a partir de 1900 (Benchimol, 1999).

43 As pesquisas de Ross derivaram da hipótese formulada por Manson em 1894 de 
que, como na filariose, um mosquito ou outro sugador de sangue extrairia o parasito da malária do sangue humano e, ao morrer, o transferiria à água; ao ingeri-la, os indivíduos se infectariam. Ao verificar a presença do hematozoário nas glândulas salivares do inseto, Ross demonstrou que o inseto não apenas 'pegava' o parasito do sangue do indivíduo infectado, mas levava-o de volta ao organismo humano, infectando o indivíduo são. Se Manson havia criado o conceito de 'hospedeiro intermediário', Ross estabelecia então o conceito de 'vetor' (Benchimol, 1999; Benchimol \& Sá, 2005, 2006).

44 Para uma exposição do próprio Manson acerca dos fatores a justificar a demarcação desta categoria de 'doenças tropicais', ver a introdução de seu Tropical Diseases: a manual of the diseases of warm climates, cuja primeira edição foi em 1898 (Manson, 1903).

45 Para uma análise das diferenças e rivalidades entre as escolas de Londres e Liverpool (dirigidas, respectivamente, por Manson e Ross), em termos de suas bases sociais e políticas, modelos institucionais, parâmetros de legitimação pública e programas de intervenção no âmbito do projeto imperialista britânico, ver Worboys (1988). Sobre as diferenças entre as escolas de medicina tropical na Inglaterra e nos Estados Unidos, como expressão dos distintos empreendimentos imperiais nestes países, ver Farley (1991).

46 Em meados da década de 1880, ao estudar a lepra, Lutz especulara sobre o papel dos animais sugadores de sangue na transmissão de doenças (Benchimol \& Sá, 2005, 2006).

47 As investigações do alemão Paul Ehrlich sobre os processos de imunidade e seus esforços por elaborar produtos terapêuticos para as doenças infecciosas foram outros aspectos importantes do desenvolvimento da ciência médica na última década do século XIX. Seu objetivo era encontrar substâncias químicas que tivessem afinidades especiais com os organismos patogênicos e por isso funcionassem como 'balas mágicas', direcionadas a alvos específicos. O principal marco de seu trabalho foi o Salvarsan, que em 1910 foi reconhecido como medicamento eficaz para o tratamento da sífilis (Porter, R., 1999).

48 A Alemanha também enviou comissões a lugares onde a febre amarela era freqüente, como o Rio de Janeiro, com o objetivo de testar a nova abordagem profilática, para aplicá-la em suas colônias, evitando gastos com as tradicionais quarentenas impostas aos navios mercantes (Benchimol \& Sá, 2005).

49 Apesar de balizadas por uma concepção que não admitia mais a importância de fatores ambientais como causas de doenças, as ‘brigadas sanitárias' de Cruz atuaram lado a lado aos engenheiros que, encarregados do embelezamento e das obras de melhoramentos da capital, implementavam muitas das medidas preconizadas pela higiene desde o século XIX (Benchimol, 2003).

50 Culicídio designa os mosquitos do gênero Culex, depois reclassificados no gênero Aedes.

51 Miguel de Oliveira Couto (1865-1934) nasceu na cidade do Rio de Janeiro e formou-se pela FMRJ, em 1885, com uma tese sobre a etiologia parasitária de doenças infecciosas. Iniciou estudos sobre a febre amarela em 1896 e, em 1898, tornou-se professor daquela escola, vindo a assumir, em 1901, a cátedra de clínica médica, substituindo Francisco de Castro. Couto se destacaria como um dos mais renomados 
clínicos brasileiros da primeira metade do século XX e teria um papel importante na trajetória dos estudos de Chagas sobre a tripanossomíase americana. Foi presidente da ANM de 1913 a 1934, quando faleceu. Foi também membro da Academia Brasileira de Letras (eleito em 1916) e presidente de honra da Liga Brasileira de Higiene Mental, criada em 1923. Em 1933, elegeu-se deputado à Assembléia Nacional Constituinte pelo Distrito Federal, na legenda do Partido Economista (Magalhães, 1932; Lacaz, 1963; Fonseca, 1965).

52 Couto era um ferrenho defensor do recurso à anatomia patológica para o diagnóstico e o estudo da patogenia das doenças infecciosas, num momento em que a prática de necropsias ainda enfrentava muitas resistências por parte dos leigos (Chagas Filho, 1993).

53 Francisco de Paula Fajardo Júnior (1864-1906) nasceu em Santa Maria Madalena, Rio de Janeiro. Em sua tese de doutoramento na FMRJ (1888), apresentou um estudo sobre o hipnotismo, matéria desacreditada e fortemente combatida nos meios acadêmicos. Faleceu prematuramente, aos 42 anos, em conseqüência da contaminação acidental por soro antipestoso (Lacaz, 1977).

54 Ao final de 1902, em função de divergências com o barão de Pedro Afonso, Oswaldo Cruz assumiu a direção integral do instituto.

55 A tese, concluída em março de 1903, foi defendida e aprovada 'com distinção' em maio.

56 Na década de 1880, Metchnikoff formulou sua teoria celular da imunidade, ao observar células do sangue atacando e parecendo 'ingerir' microorganismos (daí a denominação de fagócitos). Tal formulação, conectada diretamente com a escola francesa da microbiologia, constituiu, como indica Porter, R. (1999), o primeiro modelo para o entendimento da resposta imunológica.

57 A fórmula hemo-leucocitária foi estabelecida, em 1897, por pesquisadores do Instituto Pasteur na Argélia (Chagas, 1903).

58 Chagas observou "cento e tantos" casos de malária no hospital da Santa Casa de Misericórdia e apresentou os dados leucocitários e a morfologia parasitária encontrados em 46 casos. Sintetizando sua conclusão, afirmou: “(...) o conhecimento da fórmula hemo-leucocitária leva ao diagnóstico do impaludismo com a mesma segurança quase que o exame positivo do sangue em relação ao hematozoário" (Chagas, 1903: 48, 90).

59 Chagas também se refere à "intervenção amiga" de Francisco Fajardo (Chagas, 1903: 3).

60 Disse Chagas: "Da febre amarela, flagelo da nossa terra, peia do nosso progresso, foi feita a hematologia pelo ilustrado professor Miguel Couto (...). E só; nada mais a respeito de hematologia patológica entre nós” (Chagas, 1903: 13).

61 Oswaldo Cruz publicou um trabalho sobre a curva leucocitária em 1900. O interesse científico em Manguinhos pelos estudos hematológicos expressava-se também nos investimentos feitos para que fossem aperfeiçoados os métodos de coleta e exame do material ao microscópio. Chagas declarou, por exemplo, que as lâminas confeccionadas em seu estudo foram fixadas e coloridas pelo processo de Laveran, “modificado no Instituto de Manguinhos", pelo próprio Oswaldo Cruz (Chagas, 1903: 28). Mencionou também a importância do estudo sobre técnicas de pesquisa 
hematológica desenvolvido por Ezequiel Dias, seu contemporâneo na FMRJ e que igualmente havia recorrido a Manguinhos para desenvolver sua tese de doutoramento. Ezequiel Dias, que se incorporaria ao quadro de pesquisadores em 1908 e colaboraria com Chagas no estudo hematológico da tripanossomíase americana, tornou-se a principal liderança da área de hematologia na instituição. Além de Dias, outros estudantes contemporâneos a Chagas na FMRJ desenvolveram em Manguinhos, em 1903, teses no campo da hematologia. Ver IOC (1909).

${ }^{6} 2$ Este princípio geral de que cabia ao laboratório suplantar a imprecisão da experiência clínica encontra-se formulado, de modo exemplar, na aula em que Manson (1897) defendeu a necessidade de criação da especialidade da medicina tropical. Dando exemplos de diagnósticos e de procedimentos equivocados feitos por médicos europeus nas colônias, que desconheciam as novas técnicas de diagnóstico etiológico para doenças como a malária ou a filariose, Manson declarou: "The microscope would problably have diagnosed this case correctly, but then one must be taught how to use it". (Manson, 1897: 843) ["O microscópio provavelmente teria diagnosticado o caso corretamente, mas para isso alguém deveria ter sido ensinado a usá-lo" - Tradução livre.]

63 Estes estudos vinham sendo realizados no hospital da Santa Casa de Misericórdia e confirmavam que os casos diagnosticados positivamente como malária eram de pessoas residentes nas vizinhanças da cidade ou em outras regiões (Chagas, 1903).

${ }^{64}$ Como ponto de partida para o ensaio de classificação que propõe, Chagas tomou por referência os trabalhos de Golgi, o primeiro a formular "uma classificação toda etiológica", na qual os diferentes tipos febris derivavam diretamente das variações no ciclo evolutivo das espécies parasitárias (Chagas, 1903: 46).

65 Chagas casou-se como Íris Lobo em julho daquele ano.

${ }^{6}$ Em 1900, além de Oswaldo Cruz, trabalhavam em Manguinhos, na preparação do soro e da vacina contra a peste bubônica, Henrique Figueiredo de Vasconcellos, seu contemporâneo na FMRJ, e os estudantes de medicina Antonio Cardoso Fontes e Ezequiel Dias, que seriam incorporados ao instituto depois de formados.

${ }^{67}$ As informações sobre o Instituto de Manguinhos apresentadas nesta seção foram obtidas em Stepan (1976), Benchimol (1990a), Benchimol e Teixeira (1993) e Benchimol (2001).

68 Uma das características principais de Manguinhos em sua primeira fase foi a inexistência de uma divisão de trabalho entre pesquisa, ensino e produção, cabendo aos pesquisadores atividades nestas três áreas de atuação (Benchimol \& Teixeira, 1993).

$\theta$ Para uma descrição minuciosa das atividades de Manguinhos em seus primórdios, ver Fonseca Filho (1974).

70 Antes mesmo do dinamismo assumido pela entomologia médica ao final do século XIX, a face aplicada do estudo dos insetos se mostrara particularmente evidente no campo da entomologia econômica, sobretudo pela questão das pragas agrícolas. Esta vertente da entomologia se desenvolveu, particularmente, nos Estados Unidos, no início do século XX (Benchimol \& Sá, 2006).

71 Além das viagens científicas de Manguinhos, outro exemplo de expedições que associavam projetos de modernização e infra-estrutura, de integração e conhecimento do território nacional e de produção de conhecimentos científicos foram as 
comissões de construção de linhas telegráficas, iniciadas em 1891, das quais a mais célebre foi a Comissão de Linhas Telegráficas Estratégicas do Mato Grosso ao Amazonas, realizada entre 1907 e 1915 sob a liderança de Cândido Mariano Rondon. Sobre a atuação científica da chamada Comissão Rondon, ver Sá, Sá e Lima (2008).

72 A campanha contra a malária realizada na Argélia em 1902 pelos irmãos Sergent, enviados pelo Instituto Pasteur de Paris, foi iniciada numa estação ferroviária, onde a doença grassava com particular intensidade. O "railway phenomenon" também foi identificado em inquéritos realizados na Índia (Moulin, 1996: 170171). Segundo Snowden (2006), um dos primeiros relatos pormenorizados sobre o impacto da malária na Itália, que funcionou como importante alarme quanto à necessidade de uma ampla mobilização para estudar e enfrentar o problema, foi produzido por um membro da Comissão de Estradas de Ferro (Parliamentary Railway Comission), em 1878. Neste ano, 1.455 dos 2.200 trabalhadores em estradas de ferro na Sicília foram atacados pela malária.

73 Em 1910, Cruz comandou missões científicas na Amazônia, uma delas combatendo a malária entre os trabalhadores da Estrada de Ferro Madeira-Mamoré, em Rondônia, e outra em Belém do Pará contra a febre amarela (Benchimol, 1990a).

74 Um dos primeiros exemplos nesse sentido, antes da criação de Manguinhos, foi a descoberta realizada por Lutz de uma nova modalidade de transmissão de malária, por ele chamada de "malária silvestre". A ocorrência de uma epidemia em 1897 (pouco antes de se confirmar a transmissão da doença pelos mosquitos), por ocasião da duplicação da São Paulo Railway Company (que ligava Santos à capital da província e aos principais centros produtores de café) intrigou o cientista. O ambiente de montanhas apresentava condições muito diferentes das tradicionalmente associadas à doença, como planícies costeiras e áreas pantanosas. Lutz, na mesma ocasião em que os italianos confirmavam o papel dos anofelinos na transmissão da doença, suspeitou dos mosquitos que encontrou na região. Com base em seus conhecimentos sobre as relações entre animais e plantas armazenadoras de água, concluiu que aqueles mosquitos se reproduziam na água contida nas bromeliáceas, típicas das florestas tropicais. A nova espécie vetora, inicialmente incluída no gênero Anopheles, foi classificada pelo inglês Theobald como Myzomya lutzii, em homenagem ao cientista brasileiro. O estudo sobre estes "mosquitos das florestas" foi publicado por Lutz em 1903 (Benchimol \& Sá, 2005: 129-145).

75 O manuscrito do relatório da expedição a Itatinga encontra-se no Fundo Carlos Chagas (doravante FCC), grupo: pesquisa; subgrupo: malária; atividade: divulgação de atividades realizadas; função: pesquisador assistente do IOC; séries: relatórios. Este arquivo está sob a guarda da COC/Fiocruz. Sobre o impacto da construção de hidrelétricas no sentido de gerar condições para surtos/epidemias de malária, ver Humphreys (2001).

76 Neiva (1941: 172) considerava a campanha de Xerém um "marco para os estudos referentes à malária", do ponto de vista dos métodos de profilaxia e dos conhecimentos sobre a biologia e os hábitos dos mosquitos transmissores: "todos os elementos encontravam-se naquele vasto campo de observação e de experiências". Na ocasião, ele observou que, em função da própria intensidade da quininização obrigatória praticada na região, algumas "raças" de parasitos haviam se tornado resistentes ao medicamento, justificando o aumento das doses ministradas conforme os padrões internacionais. Além da questão dos hábitos das distintas espécies de 
anofelinos, este foi um dos distintos aspectos que, em revisão publicada em 1941, Neiva (1941: 190) enfatizou ao reiterar sua convicção de que "o problema de combate à malária apresenta sempre um aspecto de ordem local, que deve ser levado em conta" e que, portanto, os textos de medicina tropical produzidos pelos autores estrangeiros deveriam ser sempre adaptados às características de cada região.

$\pi$ Sobre as campanhas antipalúdicas realizadas no país nas primeiras décadas do século XX, ver Cruz (1910) e Neiva (1941). Para uma análise histórica destas campanhas no contexto da difusão da medicina tropical e da modernização republicana, ver Benchimol e Silva (2008).

78 Sobre Ronald Ross e a profilaxia da malária, ver Ross $(1897,1910)$ e Harrison (1978). Oswaldo Cruz, em sua campanha contra a febre amarela no Rio de Janeiro, utilizou o modelo das brigadas sanitárias contra o vetor, ficando por isso conhecido como 'general mata-mosquitos' (Benchimol, 2001). Cruz, que em 1910 chefiou o combate à malária junto aos trabalhadores da Estrada de Ferro Madeira-Mamoré, na Amazônia, foi o único latino-americano a contribuir para o livro The Prevention of Malaria, publicado, naquele ano, por Ross (Cruz, 1910).

79 Margareth Humphreys (2001: 72-74) aponta ainda a segregação, por meio de habitações afastadas, dos indivíduos portadores do parasito, de modo a que não servissem como fonte de infecção para o mosquito e, conseqüentemente, para outros indivíduos (método utilizado para proteger os colonos europeus na África), e, ainda, a abordagem (defendida principalmente pelos malariologistas italianos, cujo expoente foi Angelo Celli) que associava o combate à malária ao combate à pobreza e às más condições de vida (como habitação, nutrição etc.).

so Expurgos domiciliários com piretro e enxofre vinham sendo feitos pelo Serviço de Profilaxia da Febre Amarela na capital federal desde 1903 (Benchimol, 2001). Segundo Chagas Filho (1993), esta contribuição original de seu pai para a compreensão e a profilaxia da malária só seria reconhecida plenamente no I Congresso Internacional de Paludismo, realizado em Roma, em 1925. Sobre a teoria da infecção domiciliária da malária proposta por Chagas como exemplo de como os cientistas de Manguinhos atuavam nestas campanhas sanitárias tanto para responderem a demandas concretas da modernização quanto para testar teorias e produzir novos conhecimentos científicos, ver Benchimol e Silva (2008).

81 Em trabalho de 1908, Chagas reiterou sua crença na eficácia dos expurgos domiciliários, mas afirmou que o método não deveria ser adotado de maneira exclusiva e sim em combinação com as outras medidas, sobretudo a aplicação de quinina (Chagas, 1908a). Ver também Chagas (1935h) e Pinto (1936). Conforme Stepan (2003), ao estudar a malária na Amazônia, em 1912-1913, no âmbito da expedição organizada pela Superintendência de Defesa da Borracha, Carlos Chagas sublinhou a especificidade da doença naquela região (e, conseqüentemente, dos meios a serem adotados para o seu controle), partilhando da percepção crescente entre os malariologistas que realizavam estudos de campo em diversas partes do mundo de que esta era uma enfermidade a ser compreendida em termos de suas variantes locais, a partir da correlação entre múltiplos fatores envolvendo vetores, parasito, hospedeiro e ambiente. Sobre esta expedição, ver Cruz (1913) e Chagas (1935e). Sobre a malária como enfermidade local, ver Neiva (1941).

82 Ao analisar o relatório produzido pela expedição de Arthur Neiva e Belisário Penna 
ao interior do país (Neiva \& Penna, 1916), Nísia Trindade Lima (2003: 190) argumenta que esta perspectiva ambientalista da medicina tropical garantiu, no contexto nacional brasileiro, uma "afinidade eletiva entre conhecimento médico sobre o processo de saúde e doença e imaginação social”. Sob esta perspectiva - que vincula o entendimento das doenças a fatores da natureza e também a elementos da cultura e da história -, as viagens dos cientistas do IOC aos sertões assumiram, num contexto de intensa discussão da nacionalidade, grande importância na produção de interpretações de natureza sociológica sobre o Brasil.

83 O terceiro objetivo de suas campanhas, a varíola, ficou comprometido em função do episódio conhecido como 'revolta da vacina', em 1904 (Benchimol, 2003).

${ }^{84}$ Em 1908, foram formalmente incorporados, como pesquisadores assistentes, Antonio Cardoso Fontes, Alcides Godoy, Arthur Neiva, Carlos Chagas (sua nomeação se deu em 19 de março), Henrique Aragão e Ezequiel Dias. Entre os que seriam contratados com a chamada 'verba da manqueira', estavam Adolpho Lutz, Gaspar Vianna e Astrogildo Machado (Benchimol \& Teixeira, 1993).

85 Segundo Benchimol e Teixeira (1993: 28-29): “(..) a partir de 1908 prevaleceu a orientação de formar especialistas, mas sem esta polivalência não teria sido possível sedimentar os pontos de apoio que viabilizariam as novas condições materiais e institucionais de trabalho, nem as múltiplas raízes disciplinares que nutriram a abundante safra de estudos originais sobre a patologia brasileira nos anos seguintes".

s6 À semelhança da escola de medicina tropical de Liverpool, o Institut für Schiffsund Tropenkrankheiten, fundado em 1901, tinha entre seus objetivos, além do ensino da nova especialidade, estudar doenças que, em função do intenso comércio com os países tropicais, ameaçavam os portos europeus Sá (2005).

87 O alemão Fritz Schaudinn era uma liderança na ciência médica por seus estudos sobre a evolução dos plasmódios no tubo digestivo dos anofelinos e no sangue humano e, principalmente, por ter descoberto, em 1905, juntamente como Hoffmann, o causador da sífilis (Treponema pallidum) (Benchimol \& Sá, 2005).

\&s Sobre o intercâmbio entre estes pesquisadores alemães e os pesquisadores de Manguinhos, ver Sá (2005).

89 'Se o termo'doenças tropicais' for entendido como doenças peculiares e confinadas aos trópicos, então bem meia dúzia de páginas teria sido suficiente para sua descrição, pois, no máximo, apenas duas ou três doenças relativamente sem importância merecem esta designação" - Tradução livre.

9) Num indício expressivo de como a dimensão congnitiva da produção dos novos conhecimentos médicos sobre as doenças infecciosas imbricava-se com a dimensão política dos interesses imperialistas, Manson (1897: 842-843) declarou, em sua aula no Saint George's Hospital: "It is more especially of recent years, partly in consequence of the enormous expansion of our Empire and partly in consequence of the advances in tropical pathology which have signalized the last two decades, that the claims of tropical medicine have become urgent". ["Foi principalmente nos últimos anos, em parte como conseqüência da enorme expansão de nosso Império e em parte como resultado dos avanços em patologia tropical produzidos nas duas últimas décadas, que as reivindicações da medicina tropical tornaram-se prementes" - Tradução livre]. 
${ }_{91}$ As escolas de medicina tropical de Londres e Liverpool estabeleceram aulas em protozoologia, helmintologia, parasitologia e entomologia, deixando a bacteriologia e a higiene fora de seu currículo (Farley, 1992). Sobre o processo que levou à criação destas escolas como instituições especializadas no campo médico, conforme projeto de Manson, apesar de alguns estabelecimentos de ensino médico terem reivindicado que poderiam prover este treinamento em medicina tropical de forma articulada à formação que vinham oferecendo em bacteriologia, ver Farley (1991, capítulo 2).

92 Em 1902, o Instituto Pasteur de Paris incumbiu os irmãos Edmond e Etienne Sergent de investigarem a malária na Argélia e estabelecer ações de profilaxia. Diz Moulin (1996: 170-171): “The Sergent Brothers chose 'anti-paludism' as their touchstone and the emblem of the new Pastorian medicine. Field studies and interventions came side-by-side with the production of sera and vaccines, in the typical combination of basic research and applied science that was becoming the stamp of Pastorian medicine". ["Os irmãos Sergent escolheram o 'anti-paludismo' como a pedra-de-toque e o emblema da nova medicina pasteuriana. Estudos de campo e intervenções vieram lado a lado à produção de soros e vacinas, numa típica combinação de pesquisa básica e ciência aplicada que estava se tornando a marca da medicina pasteuriana" - Tradução livre].

93 Segundo Caponi (2002), enquanto os pesquisadores brasileiros adotaram estes dois modelos como perspectivas complementares, os argentinos privilegiaram o programa de pesquisa pasteuriano e não incorporaram, pelo menos até meados da década de 1910, as questões e os modos de pesquisa da medicina tropical. O interessante contraponto estabelecido por Caponi neste estudo é ilustrativo das grandes potencialidades analíticas que a perspectiva comparada pode trazer à compreensão das particularidades do processo de institucionalização da medicina tropical em distintos contextos locais.

94 “(...) se situam neste mesmo espaço de intersecção onde se entrecruzam dois tipos de saber e dois programas de pesquisa que nem sempre puderam conviver pacificamente. Os estudos microbiológicos de laboratório (muitos dos quais ocorriam dentro dos hospitais ou em espaços anexos aos mesmos) e os estudos entomológicos de campo, fundados no modelo classificatório dos naturalistas" - Tradução livre.

95 Desde sua inauguração em 1855, esta ferrovia era vista como um dos principais meios de integração do território nacional, daí o projeto de estendê-la da capital federal a Belém do Pará. Em 1904, foi inaugurada a estação de Curvelo e, dois anos depois, a estação de Corinto. No verão de 1906/1907, contudo, a malária paralisou as obras na ponte do rio Bicudo, impedindo a construção do ramal para Pirapora. A estação de Lassance foi inaugurada em fevereiro de 1908 e, em 1910, a estação de Pirapora. O projeto de prolongar a ferrovia até o Pará não se concretizou (ANPF, 2005).

96 Maryinez Lyons (1992) argumenta que as epidemias de tripanossomíase africana estiveram diretamente associadas às mudanças sociais e ambientais impostas pelo colonialismo. É nesse sentido que a autora afirma tratar-se de uma 'doença colonial'.

97 Em discurso na ANM em 1921, Belisário Penna relatou com orgulho o momento imortalizado como o ponto de partida da 'grande descoberta': "Tínhamos notícia do 'barbeiro', mas não o havíamos ainda visto. Quis a minha boa estrela que eu pernoitasse em casa de um sertanejo, onde pude colher em flagrante de sucção de 
sangue em crianças da casa, grande número de exemplares do inseto (...). Foram esses os primeiros examinados por Carlos Chagas, e era de ver-se o seu alvoroço ao descobrir no sangue retirado dos seus intestinos um parasito flagelado". Fundo Belisário Penna (doravante FBP), Série Trajetória Profissional (19210915), p. 1011. Este arquivo está sob a guarda da COC/Fiocruz. Cantarino Mota também se orgulhava de haver sido personagem decisivo naquele acontecimento. Ver "Um engenheiro da história da 'moléstia de Chagas". Singra, 7(10), 1954. Fundo Cornélio Homem Cantarino Mota. Este arquivo encontra-se sob a guarda da COC/Fiocruz. Em 1919, o próprio Chagas referiu-se à participação de Mota e Penna na descoberta do barbeiro: "Quando, no desempenho da incumbência que me veio de Oswaldo Cruz, realizava os trabalhos de profilaxia antipalúdica na E. de Ferro Central do Brasil, tive conhecimento pelas referências inteligentes de um engenheiro ilustre, o Dr. Cantarino Mota, da existência de um inseto hematófago nas residências humanas daquela região. Obtive pelo esforço do meu grande amigo Belisário Penna diversos exemplares do inseto (...)" (Jornal do Commercio, 1919: 6-7).

98 Chagas menciona também como origem para esta denominação o fato de que, naquelas regiões, ainda era comum os barbeiros aplicarem sangrias e sanguessugas com objetivos terapêuticos (Chagas, 1910b: 423). Para uma interessante discussão das razões pelas quais os vetores da doença de Chagas são chamados de barbeiros, ver Rezende e Rassi (2008).

99 Em 1842, descrevendo sua viagem pelo mundo, Charles Darwin relatou ter sido picado por um inseto daquela família (que depois se confirmaria ser um barbeiro, conhecido na América hispânica como vinchuca, termo de origem quéchua). Especula-se que ele tenha morrido em conseqüência da doença de Chagas.

100 Os detalhes desta seqüência seriam objeto de controvérsia anos depois, quando alguns médicos afirmariam que Cruz, por ter sido o autor da infecção experimental em Manguinhos, deveria ser considerado o verdadeiro autor da descoberta do T. cruzi. Tal questão será tratada no capítulo 4 .

101 Em 20 de março de 1908, Chagas havia sido nomeado pesquisador assistente do Instituto de Manguinhos.

102 Cobaia é uma espécie de roedor sul-americano (em português, é popularmente conhecido como 'porquinho da Índia') muito usado em experiências de laboratório e o termo acabou sendo utilizado para designar quaisquer animais com este fim. Agar-sangue era um meio de cultura tradicionalmente usado desde que Koch estabeleceu seus postulados para a pesquisa bacteriológica. Era preparado com agar (substância extraída de algas), infuso de coração de animal, cloreto de sódio e sangue desfibrilado (Rey, 1999).

103 Arthur Neiva (1880-1943) nasceu em Salvador e formou-se pela FMRJ em 1903, tendo participado, ainda estudante, da campanha contra a febre amarela promovida por Oswaldo Cruz no Rio de Janeiro. Ingressou em Manguinhos em 1906, dedicando-se a pesquisas em entomologia. Depois de estudar diversas espécies vetoras da doença de Chagas, produziu, em sua tese para livre-docência de história natural médica e parasitologia da FMRJ, em 1914, uma ampla revisão do gênero Triatoma (ao qual pertenciam os barbeiros até então estudados), em vários países do continente americano. Sobre Neiva, ver Lent (1943) e Benchimol \& Teixeira (1993).

Sobre o raciocínio que empreendeu naquele momento, declarou: "Leváramos, 
como idéia diretriz, a noção de constituírem os domicílios humanos o habitat predileto, senão exclusivo, do hematófago, assim como fato, amplamente verificado, de ser o sangue humano a alimentação por excelência dele. Seria razoável pensar, daí, numa condição infectuosa intradomiciliária e que o vertebrado hospedeiro do parasito fosse algum animal doméstico ou o próprio homem" (Chagas, 1910b: 423).

Chagas realizou um 'exame a fresco', ou seja, a observação, ao microscópio, de uma gota de sangue entre lâmina e lamínula.

Interrogação do autor, relativa à dúvida acerca da espécie da qual fazia parte o barbeiro.

Para uma descrição mais detalhada do caso de Berenice, ver Chagas (1909d). Tendo se recuperado das manifestações graves da doença aguda que apresentava em 1909, Berenice passou a ser acompanhada, quase sessenta anos depois (a partir de 1961), por pesquisadores mineiros, sendo submetida a diversos exames clínicos e laboratoriais. Ela levava uma vida normal e apresentava manifestações clínicas compatíveis com as de pessoas da sua idade, mesmo sendo verificada a presença do T. cruzi. Naquela ocasião, amostras do parasito retiradas do sangue da paciente foram isoladas e conservadas em laboratório com o nome de 'cepa Berenice', vindo a servir de objeto para várias pesquisas científicas. Em relato aos médicos e cientistas, Berenice contou que, apesar das poucas lembranças do contato com Chagas, havia guardado os presentes que ele lhe dera, como uma medalha e uma boneca. Contou ainda que ele propôs levá-la para ser educada no Rio de Janeiro, mas que seus pais se opuseram à idéia. Berenice faleceu em 1981, aos 73 anos, de insuficiência cardíaca (Salgado, 1980).

Este concurso, no qual se inscreveram os então pesquisadores assistentes Carlos Chagas, Ezequiel Dias, Alcides Godoy, Cardoso Fontes, Arthur Neiva e Henrique Aragão, foi intensamente disputado e gerou polêmicas sobre os critérios e procedimentos utilizados. Além da avaliação de Oswaldo Cruz e de Figueiredo de Vasconcellos, cada competidor dava notas aos trabalhos dos outros. No item trabalhos publicados, a maior pontuação era destinada àqueles que fossem julgados como "de alto valor científico, que apresentem descobertas importantes ou métodos novos de grande valor prático" (apud Benchimol \& Teixeira, 1993: 41). O único a receber a nota máxima de todos os votantes foi o trabalho de Chagas publicado em agosto de 1909 nas Memórias do Instituto Oswaldo Cruz. Oswaldo Cruz também deu nota máxima para os trabalhos que anunciavam a descoberta da tripanossomíase no Brasil e na Alemanha. Segundo Benchimol e Teixeira (1993: 30), o concurso constituiu, por um lado, um emblema da "metamorfose de Manguinhos" em sua nova fase de profissionalização e amadurecimento, iniciada com as transformações implementadas em 1908, e, por outro lado, evidenciou os conflitos e as cisões internas que este processo acarretava. Os documentos relativos ao concurso, com as notas e os comentários a respeito de cada competidor, encontram-se no FCC; grupo: administração da carreira; atividade: participação em concurso; função: pesquisador assistente do Instituto Oswaldo Cruz. Sobre os conflitos internos em Manguinhos à época, ver também Britto (1995). Ver A Noite (1912) e Diário de Notícias (1912).

Chagas receberia diversas homenagens, títulos e condecorações no Brasil e no 
exterior, ao longo de sua vida. Em 1921, foi o primeiro brasileiro a receber o título de doutor honoris causa da Universidade de Harvard. A mesma distinção lhe foi concedida em 1926 pela Universidade de Paris. Foi membro de inúmeras instituições médicas e científicas em diversos países, entre as quais a Academia Brasileira de Ciências, a Associação Médica Argentina, a Associação Médica PanAmericana, a Société de Pathologie Exotique, a Royal Society of Tropical Medicine and Hygiene, a Société Royale des Sciences Medicales et Naturelles de Bruxelas e as academias de medicina de Paris, Madri, Roma e Nova York. Por duas vezes foi indicado ao Prêmio Nobel, para os anos de 1913 e 1921. Ver IOC (1959), Kropf e Hochman (2007).

111 Sobre os estudos de Chagas no IOC, ver, entre outros, Benchimol e Teixeira (1993), Chagas Filho (1993), Coura (1997), Perleth (1997), Morel (1999), Dias (1999), Coutinho (1999, 2003), Kropf, Azevedo e Ferreira (2003), Delaporte (2003).

112 “(...) a descoberta de uma doença humana até então desconhecida dos médicos, justamente no momento em que outras doenças parasitárias transmitidas por vetores, como a malária e a doença do sono africana, estavam definindo a nova disciplina da medicina tropical, foi considerada inicialmente no Brasil como um grande feito da medicina" - Tradução livre.

113 Para a análise e crítica destes enunciados de Chagas, ver Delaporte (2003: 52-59).

114 O trabalho de Kleine foi confirmado por Bruce e colaboradores somente em 1911 e o ciclo do parasito causador da tripanossomíase africana foi desvendado por completo em 1913. Só então a mosca tsé-tsé tornou-se consensualmente reconhecida como hospedeiro intermediário do T. gambiense (Sá, 2005).

115 Chagas publicou vários trabalhos em parceria com Prowazek e Hartmann. Ver Prata e Sant'Anna (1981).

116 Sobre a idéia de 'apropriabilidade social' da ciência, ver Thomas e Kreimer (2002).

117 Entre os muitos médicos e cientistas que escreveram sobre Carlos Chagas, ver Villela (1934), Chagas (1935), Fraga et al. (1935), Marchoux (1936), Magalhães (1944), Almeida (1938), Bacellar (1938), Paraense (1964), Rezende (1959a), Vasconcellos (1959), Fonseca (1964), Lacaz (1963), Carneiro (1963), Brener (1989), Chagas Filho (1993), Morel (1999) e Dias (2008).

118 A via que ligaria o tripanossoma desconhecido a uma patologia humana - 'fechando' assim a associação com a medicina tropical - somente seria aberta, segundo Delaporte (1995), com a infecção experimental realizada por Cruz em Manguinhos, a partir da qual foi identificado o T. cruzi.

119 Em trabalho produzido como retrospecto da descoberta, escreveu Chagas: "Mais de um ano permanecemos naquela zona, sem que houvéssemos sabido da existência ali, nas choupanas dos regionais, de um inseto hematófago, denominado vulgarmente barbeiro, chupão ou chupança. (...) E desde então foi-nos penosa a absoluta impossibilidade de classificar, no quadro nosológico conhecido, muitos dos casos mórbidos que se ofereciam a nosso estudo. Nem valiam, para elucidação do diagnóstico, os recursos experimentais do laboratório, e nem decidiam os elementos da semiótica mais segura e meditada. Alguma cousa de novo, nos domínios da patologia, aí perdurava desconhecida, e se impunha a nossa curiosidade" (Chagas, 1922a: 68; grifos meus). 
Na seguinte descrição, fica clara a ênfase na hipótese do minasense: “(...) examinamos exemplares de barbeiros e encontramos, no intestino posterior, um flagelado com morfologia de critídias. Restava saber se era parasito exclusivo do inseto ou estádio evolutivo de um flagelado de vertebrado. Em sagüis (Callithrix penicillata) da mesma região, havíamos encontrado um tripanossoma parasitando quase todos os exemplares; e por isso suspeitamos que o barbeiro fosse o hospedador intermediário, sendo as formas flageladas do intestino estádios evolutivos deste hemoflagelado, o Trypanosoma minasense CHAGAS. Por esta razão, mandamos exemplares do hematófago ao nosso diretor e mestre Dr. Oswaldo Cruz, que os alimentou em um Callithrix, obtendo a infecção deste por um hemoflagelado, de morfologia muito diversa da do Trypanosoma minasense, que foi denominado por nós Trypanosoma cruzi" (Chagas, 1911c: 221).

${ }^{121}$ Este relatório inclui, na bibliografia, os trabalhos em que Chagas já havia afirmado que não se tratava do minasense, mas a existência do desenho pode ser vista como um indício de que, em algum momento anterior, o protozoário detectado por Chagas no barbeiro foi, de fato, considerado como o tripanossoma do macaco (IOC, 1909).

122 Benchimol e Teixeira (1993) atribuem tais reconstruções, sobretudo o relato de 1922, especificamente ao contexto da polêmica iniciada em 1919 e intensificada em 1922/1923, onde foram questionadas a autoria da descoberta do T. cruzi (que alguns atribuíram a Oswaldo Cruz) e a importância da doença.

123 Para uma análise da relação entre mito e memória, na trajetória de Oswaldo Cruz, ver Britto (1995).

124 "Como vedes, meus senhores, o estudo desta moléstia apresenta de curioso o fato de termos partido aqui do conhecimento prévio do germe, de o haver estudado minuciosamente em sua biologia, para, mais tarde chegar, baseado, de alguma forma, nessa mesma biologia, à noção, praticamente a mais importante, de ser ele fator etiológico de uma espécie mórbida humana. No esclarecimento etiológico das outras espécies mórbidas nada de similar encontramos; em todas elas, depois de profundamente estudada a moléstia, em sua sintomatologia, em suas condições epidemiológicas, temse chegado à verificação do agente mórbido" (Chagas, 1910b: 423).

${ }^{125}$ Stepan (2001: 188) chama a atenção para este aspecto: "the links between parasites and disease were loose, nor tight; it was as though there were signs looking for parasites, and parasites chasing signs". ["os elos entre os parasitos e a doença eram frouxos, não estreitos; era se como existissem sinais procurando parasitos, e parasitos buscando sinais" - Tradução livre].

126 Deste quadro, mais freqüente nas crianças, relatou ter destacado os seguintes elementos mais salientes: "grande anemia, decadência orgânica acentuada, edema subpalpebral e freqüentemente edemas generalizados, engurgitamento ganglionar considerável, havendo volumosos gânglios nas plêiades periféricas (axila, regiões inguinal e crural, pescoço etc.). Em algumas crianças, é notável a atrofia do desenvolvimento. É uma condição mórbida permanente, com incidentes agudos, que se expressam em reação febril e em outros elementos mórbidos. As noções clínicas que temos da moléstia são ainda muito incompletas, estando apenas iniciadas, nesse sentido, nossas observações" (Chagas, 1909c: 161). 



\section{Moléstia Tropical, Endemia dos Sertões: o desenho da doença do Brasil (1910-1913)}

Vi tudo isso, vi, talvez, mais do que isto, mas nem tudo sei exprimir na forte impressão que me causaram os fatos observados. E, quando vendo ainda passar diante de minha retina mental a figura da miséria humana que a moléstia identificou corporizada e semimorta na imensidade de sua desdita, só consigo voltar a mim mesmo considerando o trabalho científico que visa à redenção daquele povo, e, num natural desvelo patriótico, descanso aos acenos da esperança de uma profilaxia inadiável, em trabalho fecundo e salvador. (Fraga, 1911: 477)

O médico Clementino Fraga, ao descrever o que testemunhara em Lassance, referiu-se a uma doença que representava algo mais do que uma nova entidade mórbida: era o emblema dos males que 'degeneravam' a nação e, ao mesmo tempo, da ciência que poderia redimi-la. O objetivo deste capítulo é analisar a fase inicial de produção de conhecimentos sobre a doença identificada em 1909. Para isso será necessário focalizar os trabalhos publicados por Carlos Chagas entre 1910 e 1913, quando foi estabelecido um primeiro desenho clínico da nova tripanossomíase, e acompanhar o processo de elaboração destes enunciados, bem como as estratégias e os recursos acionados para imprimir-lhes 
poder de persuasão, de modo a que fossem aceitos como expressão de uma dada realidade.

A doença de Chagas foi representada como entidade médico-científica e, ao mesmo tempo, como questão social, num movimento que evoca o duplo significado que Roger Chartier (1996) identifica na noção de 'representação'. Esta possui, primeiramente, uma dimensão 'reflexiva'. Representar significa o ato pelo qual algo 'é visto', se exibe e apresenta a si mesmo publicamente, como numa encenação teatral. Neste caso, o referente e a sua imagem dizem respeito à mesma entidade. Assim, a doença é uma representação na medida em que ela própria se mostra publicamente, é representada como objeto, mediante certos traços, imagens e características.

Porém, 'representação' diz respeito a algo que ‘dá a ver' um objeto ou uma pessoa ausente. Representar é, nesta situação, conhecer ou apresentar as coisas de maneira mediada, como no caso dos emblemas, das fábulas e das alegorias. No sentido jurídico ou político, o representante é aquele que ocupa o lugar de alguém, substituindo-o. Nesta dimensão 'transitiva', representar implica, como assinala Chartier (1996), uma distinção entre o significado (o representado) e o significante (aquele que o representa). Este é o sentido em que a doença funciona como metáfora, significante que representa a sociedade (Sontag, 1989). A partir da analogia entre desequilíbrio orgânico e desesquilíbrio social, ela constitui um veículo, um significante pelo qual se apresentam certos aspectos da vida social, embora representante e representado sejam 'coisas' distintas (Herzlich, 1995). Cabe ao historiador, neste caso, investigar quais as categorias e os procedimentos discursivos que, em cada situação, permitem que o objeto-representante seja considerado e reconhecido como representação/imagem emblemática do objeto-representado.

As duas dimensões da noção de representação estão articuladas entre si, e este é o aspecto que a torna enriquecedora para os historiadores, no sentido de pensarem as relações complexas que os indivíduos e os grupos mantêm com o mundo social. ${ }^{1}$ Trata-se de perceber, por um lado, as operações de recorte e de classificação que produzem redes de significação, pelas quais um objeto é socialmente configurado como significante para a percepção e a representação de uma dada realidade (no caso, a doença como metáfora ou representação da sociedade). Por outro, há que se considerar as práticas e os significados que levam ao reconhecimento de um objeto a partir de uma determinada identidade e maneira 
própria de ser no mundo (a doença representada em si mesma). Num diálogo com Charles Rosenberg (1992c), cabe refletir sobre os mecanismos pelos quais a doença constitui uma metáfora/significante para a vida social e também um fenômeno representado em si mesmo por meio de certos conteúdos. Em suma, emoldurada (framed) por processos cognitivos e sociais específicos, a doença constitui, ela própria, uma moldura (frame) para a sociedade.

Ao mesmo tempo que produziu a figura de uma entidade nosológica que, em função da ação parasitária sobre distintos sistemas orgânicos, comprometia o desenvolvimento físico e mental das populações no interior do país, Chagas formulou e difundiu a noção de que tal doença descortinava os 'males do Brasil', as endemias rurais. Como tal, deveria servir de bandeira para que o Estado, orientado pelos cientistas, promovesse o saneamento dos sertões, visando ao progresso nacional.

Argumento que as bandeiras da campanha pelo saneamento rural do Brasil, levantadas por Miguel Pereira, Belisário Penna, Monteiro Lobato e pelo próprio Chagas, entre 1916 e 1920, tiveram sua origem e seu sentido diretamente referidos ao processo particular de definição e legitimação da doença de Chagas, construída, ao mesmo tempo, como fato médico-científico e fato social, a representar uma certa visão da sociedade brasileira, de seus problemas e suas possíveis soluções. A doença de Chagas foi o tema primordial a propiciar, a partir de 1910, a associação entre ciência, endemias rurais e projeto nacional, associação esta que, como aponta a historiografia (Labra, 1985; Castro-Santos, 1985, 1987; Lima \& Britto, 1996; Lima \& Hochman, 1996, 2004; Hochman, 1998; Lima, 1999), assumiria grande visibilidade no debate nacionalista no contexto da Primeira Guerra Mundial.

A 'nova moléstia tropical' descoberta no sertão mineiro, assumindo significados particulares como 'endemia dos sertões', foi caracterizada, em seu processo de definição enquanto entidade nosológica específica, como 'doença do Brasil', a expressar a identidade nacional em vários sentidos. Era o símbolo de um 'país doente' e 'atrasado', devastado por endemias que incapacitavam as populações rurais, e, também, o emblema da ciência que revelava este Brasil do interior e indicava os rumos para que ele se tornasse efetivamente parte da nação.

Este caminho - que articulou ciência, saúde pública e processo de modernização na Primeira República - foi a via pela qual os esquemas interpretativos da medicina tropical européia, a partir das condições do 
contexto nacional, foram utilizados pelos cientistas brasileiros não apenas para produzir conhecimentos originais neste campo, mas para conferir-lhes sentido em associação aos significados peculiares do ambiente físico e social ao qual estavam referidos tais conhecimentos.

Num momento em que a ciência era valorizada pela perspectiva de prover os meios materiais para o 'progresso' (em especial numa instituição publicamente legitimada por sua face 'aplicada'), a construção desse objeto científico foi uma via de afirmação para um projeto de avanço na fronteira do conhecimento e que, para a própria consecução deste objetivo, pressupunha igualmente uma dimensão de utilidade social. Foi assim que, no início da formulação dos enunciados definidores da nova entidade nosológica, e antes mesmo de um mapeamento sistemático de sua dimensão epidemiológica, a doença de Chagas foi proclamada como problema de saúde pública e exemplo dos obstáculos ao progresso do país.

\section{O Primeiro Quadro Clínico: a tireoidite parasitária e o 'selo' da doença}

No trabalho que publicou nas Memórias do Instituto Oswaldo Cruz, em 1909, Chagas forneceu um quadro sumário dos principais sintomas da nova tripanossomíase, aos quais já havia feito menção nos artigos em que anunciou a descoberta. Apresentando a descrição de três casos (entre os quais o de Berenice), observou, contudo, que "a história clínica da nova espécie mórbida humana é ainda muito deficiente, porquanto não nos foi dado acompanhar longamente doentes, estudando neles, com a seqüência desejável, a sintomatologia completa" (Chagas, 1909d: 162). O estudo clínico minucioso da esquizotripanose foi iniciado cerca de dez meses depois do encontro do parasito no sangue de Berenice, ou seja, por volta de fevereiro de 1910 (Imagem 8). ${ }^{2}$ Em julho, Chagas (1910a: 263, 264) publicou um arranjo classificatório preliminar que dividia a doença em três modalidades clínicas: 'infecção aguda', 'estado mórbido crônico' e 'determinações nervosas'.

Na primeira modalidade, observou "elementos mórbidos às vezes de grande intensidade", cujo tempo de evolução, em geral, não passava de um mês. Em alguns casos, sobretudo em crianças menores de seis meses, a infecção levava à morte. Com mais de um ano de vida, muitas 
"conseguem vencer o período agudo, entrando na fase crônica da moléstia”. Registrou que, na fase aguda, o diagnóstico parasitológico não apresentava maiores dificuldades, pela abundância do parasito na circulação sangüínea, facilmente verificável pelo "exame de gota de sangue entre lâmina e lamínula (exame a fresco)". Os principais sintomas a orientar o diagnóstico clínico da infecção aguda seriam, além da febre, "degeneração mucosa do tecido celular subcutâneo" ou mixedema, ${ }^{3}$ gânglios numerosos na região cervical e volumosos nas axilas e na região inguinal, esplenomegalia (aumento do baço), hepatomegalia (aumento do fígado), alterações do sistema nervoso (fenômenos de meningismo), alterações do sistema circulatório ${ }^{4}$ e afecções oculares (conjuntivite ou queratite) (Chagas, 1910a: 263).

Para a segunda modalidade clínica, "um estado mórbido crônico, de longa duração", que compreenderia a maioria dos doentes, Chagas enunciou o que acreditava constituir um traço fundamental e "quase constante" da nova entidade: as perturbações funcionais da tireóide, expressas pela hipertrofia desta glândula (bócio), "sendo extremamente raros os doentes que não apresentam esse sinal” (Chagas, 1910a: 264). Uma evidência da importância que Chagas vinha conferindo a este aspecto era o fato de que, antes mesmo desta nota prévia, sua primeira publicação sobre aspectos clínicos da doença, de maio de 1910, havia sido dedicada à hipótese da etiologia parasitária do bócio endêmico (Chagas, 1910c). ${ }^{5}$

O bócio, popularmente conhecido como 'papo', tinha grande prevalência em Minas Gerais e, desde o século XVIII, despertava a atenção de naturalistas, viajantes e médicos, que o atribuíam, entre outros fatores, à má qualidade da água consumida pela população. Pela desfiguração física que provocava (sobretudo quando atingia grandes volumes) e pela associação com o cretinismo, era tido como um dos principais motivos do 'atraso' dos camponeses mineiros: "a estranha 'grossura no pescoço’ (...) era o aspecto negativo de uma terra premiada por bons ares e clima temperado" (Marques \& Mitre, 2004: 183). No final do século XIX, o bócio alcançou grande visibilidade pública, por ocasião dos debates sobre a construção da nova capital mineira. Sua presença em Curral del Rei (futura Belo Horizonte) foi um dos argumentos para criticar a escolha deste local, conhecido como 'arraial dos papudos', para sede de uma capital projetada conforme os modernos padrões da engenharia e da higiene. Além da carência de iodo na água, especulava-se sobre outras causas, em geral vinculadas à pobreza e às mulheres: má alimentação e 
insuficientes condições de abrigo, hábitos anti-higiênicos, conseqüência do parto ou mal hereditário (Marques \& Mitre, 2004).

A doença atraía a atenção da comunidade médica também pelo fato de que, com base na teoria microbiana, vários autores defendiam que patologias endócrinas poderiam ser de natureza infecciosa (Delaporte, 2003). Oswaldo Cruz foi um dos que se interessou pelo tema, realizando viagem de estudos a Minas Gerais em 1901, o que provavelmente foi um fator a mais a motivar a atenção conferida por Chagas ao assunto. ${ }^{6}$ Segundo ele, em Minas Gerais e em outras regiões onde houvesse a infecção pelo Trypanosoma cruzi, o bócio endêmico não era a mesma entidade nosológica que existia na Europa, possuindo outra etiologia: tratava-se de uma decorrência da ação patogênica daquele parasito sobre a tireóide. Sua conviçãao sustentava-se em vários elementos: a observação de crianças em aleitamento exclusivo e que tinham bócio incipiente (o que afastaria a hipótese da composição química da água); a detecção do parasito no sangue de crianças com hipertrofia da glândula; e a constatação da intensa ocorrência do 'papo' numa região onde proliferavam os barbeiros nas cafuas, ambiente propício à transmissão da doença. A partir de então, seria freqüente nos trabalhos de Chagas a afirmação de que "nas crianças que residem em choupanas barreadas, habitat prediletos do conorhinus, a hipertrofia da tireóide é observada como fenômeno constante, simultaneamente com outros sintomas da moléstia” (Chagas, 1910c: 163).

A associação entre a distribuição geográfica de vetores e a prevalência de doenças era recorrente no âmbito da medicina tropical. No caso da nova tripanossomíase, por se tratar de uma entidade ainda não definida, o raciocínio pautava-se pela observação de sintomas que, em áreas onde houvesse vetores, ocorriam com uma freqüência peculiar, não observada em regiões livres desses insetos. A correlação entre bócio e cafuas infestadas por barbeiros ganhou, assim, centralidade como critério para a suspeita diagnóstica da nova enfermidade.

Considerando-se os efeitos que o comprometimento da tireóide provocava no desenvolvimento orgânico dos indivíduos, estava colocado um dos principais caminhos pelos quais, a partir de então, Chagas passaria a propagar a importância médico-social da doença. Apesar do estágio inicial das pesquisas, ele já declarava tratar-se de

(...) uma das infecções tropicais mais maléficas, quer como causa imediata de grande letalidade, especialmente das crianças, nas zonas contaminadas, quer como a determinante de condição mórbida 
crônica que inutiliza o indivíduo para a atividade vital, quer finalmente como um fator importante de degeneração humana. (Chagas, 1910c: 163)

Na descrição clínica que publicou depois desta nota sobre o bócio, Chagas identificou, além da disfunção tireoidiana, outros elementos que comporiam a fase crônica da infecção, como certos distúrbios cardíacos, constituídos basicamente pela perturbação do ritmo. Comentando a importância deste aspecto, afirmou que "esse ponto de semiologia cardíaca, que desde o início das atuais pesquisas muito impressionou nossa atenção, merece estudo demorado, que procura esclarecer-lhe o mecanismo" (Chagas, 1910a: 264). ${ }^{7}$

Na modalidade crônica, diferentemente da fase aguda, Chagas observou que os parasitos tornavam-se muito escassos na circulação sangüínea, o que impedia o diagnóstico etiológico por observação direta. O procedimento que utilizava, nestes casos, era a inoculação do sangue suspeito em animais sensíveis. Com a morte das cobaias, a identificação de formas esquizogônicas em seu pulmão (consideradas por Chagas estágios evolutivos do T. cruzi) determinaria a positividade do diagnóstico (Chagas, 1910a).

Neste primeiro esboço clínico da doença, Chagas estabeleceu ainda uma outra modalidade que chamou de "determinações nervosas". Elas abrangeriam perturbações motoras (como diplegia), da linguagem (como afasia ou disartria) $)^{8}$ e da inteligência, como idiotia (retardo mental grave) e demência. Estes aspectos, presentes especialmente em crianças, eram importantes "quer como fator de inutilização do indivíduo, quer pelos elementos que poderão trazer aos estudos de fisiopatologia do sistema nervoso" (Chagas, 1910a: 264-265).

Quanto à extensão geográfica da enfermidade, apesar de serem "ainda muito incompletas" as noções naquele momento, Chagas salientou que a presença do barbeiro vinha sendo atestada em "quase todo o norte de Minas, em vastas regiões do Oeste do mesmo Estado e ainda nos Estados de Mato-Grosso e Goiás", o que lhe permitia conjecturar: "se a distribuição da moléstia estiver em relação com a do Conorhinus transmissor, nesse caso vastíssima será a extensão do país onde grassará a esquizotripanose" (Chagas, 1910a: 265). Tais dados advinham, sobretudo, das pesquisas realizadas por Arthur Neiva, que, em 1910, descreveu as características biológicas da espécie identificada em Lassance, o 
Conorhinus megistus (posteriormente denominado Panstrongylus megistus). ${ }^{9}$

Já neste trabalho inicial, Chagas valeu-se de um elemento decisivo para a classificação clínica que começava a empreender: os dados anatomopatológicos, que revelavam, mediante necropsias, a localização do parasito e as lesões a ele atribuídas em vários órgãos e sistemas orgânicos. Gaspar Vianna, pesquisador de Manguinhos, desvendou um aspecto crucial da evolução do T. cruzi, determinante para a compreensão da patogenia da doença: depois de um curto período na circulação sangüínea, o parasito se abriga no interior dos tecidos, onde, multiplicando-se por divisão binária, provoca um processo inflamatório que leva à destruição das células. ${ }^{10}$ Nesta nota de 1910, Chagas anunciou que Vianna, ao examinar as vísceras do primeiro caso autopsiado, localizara parasitos em grande número nas células cardíacas, com lesão das "células nobres" do miocárdio, num processo inflamatório tão intenso que, em alguns pontos, observava-se a ruptura da membrana celular. A identificação de focos parasitários no encéfalo e na medula espinhal fundamentava, por sua vez, a ocorrência dos sintomas neurológicos. No caso da tireóide, ainda que não se tivesse detectado diretamente o parasito, a "esclerose considerável" identificada por Vianna foi apontada por Chagas como um indício da ação do T. cruzi sobre a glândula (Chagas, 1910a: 264-265). ${ }^{11}$

Além de dar fundamento ao esquema classificatório que ia sendo montado por Chagas (correlacionando o sinal/sintoma clínico a lesões atribuídas à ação do parasito), estes dados funcionavam como poderoso argumento a dar concretude a um elemento que nem sempre se fazia visível (embora fosse visto como indispensável à certeza diagnóstica): o parasito. Se, em vida, muitas vezes não era fácil surpreendê-lo, o exame post-mortem era tido como capaz de revelá-lo em sua localização direta nos tecidos ou em seus 'rastros', isto é, as reações inflamatórias a ele atribuídas. Este caminho, esboçado nesta primeira descrição clínica, seria reforçado em trabalhos posteriores (Chagas, 1911c). ${ }^{12}$

Tal sistema cognitivo estava diretamente referido aos protocolos de pesquisa e modelos para a classificação das doenças impostos pela teoria dos germes ao final do século XIX. No processo de progressiva consolidação da medicina experimental, os cientistas enfrentavam ainda grandes dificuldades em estabelecer a relação causal entre o microorganismo patogênico e a doença. Para tanto, dois fatores eram considerados 
fundamentais: demonstrar o agente causal no organismo do indivíduo (um dos postulados de Koch) e estabelecer as relações entre este fator etiológico, os processos patogênicos a ele atribuídos (revelados pelos dados anatomopatológicos) e os sinais clínicos da doença (Worboys, 1996, 2000). Num ambiente médico fortemente marcado pela tradição clínica, Chagas enfrentou o desafio de, pautando-se na autoridade do laboratório, caracterizar uma doença da qual não havia nenhuma descrição clínica prévia, e, neste processo, reforçar esta autoridade.

Em sua primeira conferência na Academia Nacional de Medicina (ANM), em outubro de 1910, Chagas apresentou uma sistematização mais detalhada e completa do quadro clínico da doença. Revendo alguns elementos da formulação anterior, conferiu um arranjo mais estável à trama conceitual pela qual a nova tripanossomíase ganhava forma. Esta ficou dividida não mais em três, mas em duas modalidades clínicas: 'infecção aguda' e 'infecção crônica', entre as quais não havia "diferenças essenciais, senão na maior ou menor intensidade dos elementos mórbidos e no tempo de permanência deles" (Chagas, 1910b: 426).

Quanto aos casos agudos, Chagas sublinhou que eram "relativamente raros nas zonas contaminadas", não porque não ocorressem, mas justamente por causa da "intensidade das condições epidemiológicas" (a abundância do vetor nas habitações e a freqüência das picadas) (Chagas, 1910b: 427). A contaminação se dava nos primeiros dias de vida e os que sobreviviam à morte rapidamente saíam da fase aguda (dez a trinta dias), evoluindo para o estado crônico. A dificuldade de acesso da população aos serviços médicos dificultava ainda mais a detecção dos casos agudos, assinalava Chagas. ${ }^{13}$ Esta modalidade da infecção dividia-se em duas formas: casos com graves distúrbios cerebrais (como meningoencefalite, derivada da ação do parasito no sistema nervoso central), constituídos geralmente por crianças menores de um ano, que quase nunca sobreviviam; e casos com prognóstico mais benigno, cujos sintomas regridiam com a evolução para a fase crônica.

Do conjunto sintomatológico da fase aguda, Chagas destacou alguns sinais que, sendo "absolutamente constantes", poderiam servir de base ao diagnóstico clínico. Eram sintomas do comprometimento tireoidiano: aumento de volume da tireóide e intumescência no rosto (mixedema). Valendo-se do apoio do professor e amigo, acentuou a importância do mixedema: "A intensidade deste fenômeno, presente em crianças desde os primeiros dias da infecção, faz dele, segundo a valiosa 
opinião do Professor Miguel Couto, um processo mórbido exclusivo da esquizotripanose" (Chagas, 1910b: 427).

Um aspecto salientado na caracterização da fase aguda foi a noção de que a infecção atingia, sobretudo, crianças (pela sua exposição aos barbeiros desde o nascimento) e que, nos casos com manifestações cerebrais graves, o indivíduo que escapasse à morte ficaria totalmente inutilizado. Numa formulação de forte conteúdo dramático, dizia Chagas: “A morte atua aqui como elemento benéfico: comuta a fatalidade de existências monstruosas na perda inicial da vida" (Chagas, 1910b: 428).

Para a fase crônica, Chagas propôs sua subdivisão em cinco formas clínicas: 1) forma pseudomixedematosa; 2) forma mixedematosa; 3) forma nervosa; 4) forma cardíaca; 5) incidentes agudos e subagudos. ${ }^{14} \mathrm{~A}$ primeira destas formas seria a de maior relevo, compreendendo a maioria dos portadores da infecção pelo T. cruzi. Eram crianças ou jovens de até cerca de 15 anos que sofriam os efeitos, ainda leves, do hipotireoidismo, decorrente do que, segundo ele, constituía a ação parasitária sobre a tireóide. O ‘papo', nestes casos, ainda não tinha o grande volume que, depois de uma evolução progressiva, viria a ter nos adultos. ${ }^{15}$ Contudo, ainda que incipiente, a disfunção tireoidiana comprometia o desenvolvimento orgânico geral do indivíduo, refletindo-se "em todos os sistemas e aparelhos, perturbando neles o regular mecanismo fisiológico” (Chagas, 1910b: 433).

A forma mixedematosa compreenderia os casos, menos comuns, em que o comprometimento da tireóide assumia maior gravidade e intensidade. ${ }^{16}$ Ao invés da hipertrofia da glândula, observava-se sua atrofia, ou seja, a total destruição da função. A doença revelava-se extremamente debilitante. Como exemplo, Chagas citou o caso de uma mulher que, tendo contraído a infecção ao se mudar para uma casa infestada de barbeiros, sentiu "o decair de modo sensível na atividade física e intelectual, chegando, finalmente, ao estado de absoluta inatividade, de apatia profunda, indiferente ao mundo exterior" (Chagas, 1910b: 434). ${ }^{17}$

As considerações sobre a constância do comprometimento tireoidiano reforçavam o argumento sobre a etiologia do 'bócio de Minas', totalmente distinta do 'bócio europeu' fosse ele de origem hídrica ou infecciosa (Chagas, 1910c: 163). Tal concepção foi apresentada nesta conferência na ANM com base em três ordens de evidências. Em primeiro lugar, os sinais clínicos do hipotireoidismo, tanto na fase aguda quanto na fase crônica. Somando-se a estes, as evidências anatomopatológicas, 
que revelavam a lesão da tireóide, expressando a "predileção especial" do parasito pelas glândulas de secreção interna. ${ }^{18} \mathrm{E}$, em terceiro, os dados epidemiológicos: "até agora, de observações pessoais e de informações colhidas, ns regiões de Minas, onde existe o bócio existe também o inseto transmissor da esquizotripanose". Um exemplo citado por Chagas era a cidade de Belo Horizonte, construída no antigo 'arraial dos papudos' "eliminadas ali as residências humanas compatíveis com a existência do barbeiro, de lá desapareceu o bócio” (Chagas, 1910b: 445).

A terceira das cinco formas clínicas crônicas seria a "forma nervosa” (Chagas, 1910b: 434), cujos sintomas (distúrbios motores, da fala e da inteligência) Chagas já mencionara no trabalho anterior (Chagas, 1910a). Juntamente com o bócio, suas características assumiam grande relevo como expressão dos efeitos 'degenerativos' da doença. Assim como nos casos graves da fase aguda, também neste aspecto se tornaria freqüente, a partir de então, a alusão a "criaturas condenadas à existência de monstros" (Chagas, 1911c: 257). Do mesmo modo que para as outras formas clínicas, o raciocínio demarcatório baseou-se na observação da freqüência de certos sinais na população focalizada, em comparação a outras populações não expostas à transmissão da doença. Como esta foi descoberta numa área rural, com características próprias a este ambiente (materializadas, sobretudo, na cafua), o contraponto era a população dos centros urbanos. Assim, dizia Chagas (1910b: 434): “Um fator etiológico intenso deveria ali existir para justificar o alto coeficiente de paralisias, de afasias e outros fenômenos nervosos, nunca observado, em proporção aproximada, nos grandes centros de população condensada, em qualquer das clínicas infantis que conhecemos na capital do país". Também aqui os dados anatomopatológicos que evidenciariam a "ação intensa do schizotrypanum sobre o sistema nervoso" (1910b: 434) conferiam sustentação aos sinais clínicos. ${ }^{19}$

A quarta modalidade clínica da fase crônica era a forma cardíaca. Assim como nas outras formas, sua especificidade era dada pela observação da incidência incomum de certos sintomas e na correlação destes com os dados fornecidos pelas necropsias. Ressaltava Chagas (1910b: 443):

Entre as expressões clínicas mais interessantes da esquizotripanose figuram, sem dúvida pela sua alta importância no ponto de vista médico e fisiopatológico, as perturbações do ritmo cardíaco, ocasionadas pela localização e pelas lesões do Schizotrypanum no miocárdio. Tal fenômeno de semiótica, de grande freqüência na 
zona de nossos estudos, freqüência impressionante e seguramente nunca observada fora daquela condição epidemiológica, havia despertado nossa atenção no início dos estudos clínicos, sem que, entretanto, fosse possível, naquela época, suspeitar de seu mecanismo patogênico. A autópsia, porém, de um caso agudo da moléstia, primeira que realizamos, veio desde logo esclarecer o assunto (...). ${ }^{20}$

Nesta ocasião, Chagas apresentou enunciados que, desenvolvidos em trabalhos posteriores, seriam retomados pelos pesquisadores que, na década de 1940, caracterizariam definitivamente a cardiopatia chagásica crônica. Primeiramente, assinalou os principais distúrbios de ritmo que constituiriam sinais peculiares da forma cardíaca crônica: as extra-sístoles (distúrbio da excitabilidade do coração) e, em menor grau, as perturbações na condução do estímulo, como o bloqueio cardíaco completo. ${ }^{21}$ Diferentemente das outras formas, que atingiam crianças ou indivíduos bem jovens, observou "o fato curioso da presença exclusiva destes fenômenos do ritmo nos doentes de certa idade, depois dos 16 anos". Quanto ao prognóstico, afirmou que "não raro tais doentes apresentam crises agudas de assistolia, vindo alguns a falecer delas" (Chagas, 1910b: 444).

Em suma, neste primeiro desenho clínico da doença proposto em 1910, destacavam-se os seguintes traços de enquadramento: 1) tratava-se de uma doença essencialmente crônica, de evolução progressiva; 2) era contraída nas primeiras idades, por praticamente todos aqueles que residiam em habitações infestadas por barbeiros; 3) por atingir os indivíduos em plena fase de formação física e mental, produzia impactos permanentes sobre sua vitalidade e seu desenvolvimento orgânico; 4) tinha, como principais manifestações clínicas, distúrbios endócrinos (principalmente tireoidianos), neurológicos e cardíacos, provocados pela ação do parasito sobre estes respectivos sistemas orgânicos.

Chagas dava importância a estes três eixos do quadro clínico, mas com nítida ênfase ao primeiro. A nova tripanossomíase foi apresentada como uma afecção endócrina por excelência. Segundo François Delaporte (2003), a endocrinologia constituiu, juntamente com a protozoologia e a microbiologia, uma disciplina fundamental a propiciar a emergência do sistema médico pelo qual Chagas definiu a doença por ele descoberta. Ela forneceu "a grade de leitura" para o quadro sintomatológico da doença. O estudo das doenças endócrinas foi um dos campos em que a medicina sofreu o impacto da microbiologia. A teoria, defendida por vários médicos ao final do século XIX, de que as desordens tireoidianas 
(entre as quais o bócio) poderiam ser causadas por agentes infecciosos ou toxinas por eles produzidas foi um importante fator a orientar Chagas em sua tese sobre a etiologia parasitária do bócio endêmico. Segundo Delaporte (2003: 52), "esse conjunto de relações permite estabelecer a significação, o alcance e os limites do empreendimento do médico brasileiro".

Além desses aspectos concernentes aos referenciais teóricos de Chagas, a importância social e política que o bócio assumia no contexto mineiro, visto como fator de ‘atraso’ e de ‘degeneração’, certamente também contribuiu para a primazia conferida por Chagas a este e a outros elementos endócrinos que compunham o desenho clínico da doença. ${ }^{22} \mathrm{Um}$ dos principais indícios desta primazia foi a denominação "tireoidite parasitária”, proposta em 1910 pelo então presidente da ANM, Miguel Pereira, e utilizada por Chagas a partir de então de forma recorrente em seus trabalhos. Nesta mesma época, a hipertrofia da tireóide foi referida por Miguel Couto como o "selo da doença” (apud Chagas, 1910b: 445). Este sinal físico, que, nos casos mais graves, tinha grande visibilidade e efeito dramático, passou a constituir o traço de maior destaque no 'recorte' daquele objeto médico que emergia. Reconhecido, como aponta Stepan (2001: 196), como "elemento visual definidor da doença de Chagas", o bócio tornou-se o principal sinal para o diagnóstico clínico dos processos mórbidos atribuídos ao T. cruzi.

\section{O Encontro da Academia com o Sertão: o espetáculo da doença}

A descoberta e os primeiros estudos sobre a doença de Chagas foram apresentados aos médicos brasileiros como uma glória da ciência nacional, à qual toda a comunidade médica deveria manifestar seu reconhecimento e sua adesão. Tal estratégia foi posta em ação pelo próprio Oswaldo Cruz, que viu no feito de seu jovem discípulo uma oportunidade ímpar para seu projeto de transformar Manguinhos num renomado centro científico, publicamente reconhecido pelo compromisso com os interesses da sociedade, não apenas por combater os problemas sanitários, mas por identificá-los. Além de anunciar pessoalmente a descoberta de Chagas na ANM (Chagas, 1909f), Cruz sugeriu que esta associação enviou a Lassance, em 1910, uma comissão formada por alguns de seus 
membros mais ilustres para observar e avaliar os estudos sobre a nova doença. Além do presidente Miguel Pereira, ela era composta por Miguel Couto, Antonio Austregésilo Rodrigues Lima, Juliano Moreira e Antonio Fernandes Figueira. ${ }^{23}$ Foi durante esta viagem que Miguel Couto propôs, com o apoio dos presentes, que a nova doença fosse chamada de 'moléstia de Chagas' (Chagas Filho, 1993: 87). ${ }^{24}$ No discurso que precedeu sua conferência ao tomar posse como membro titular da ANM, assim como em várias outras ocasiões, Chagas deu destaque à importância desta comissão:

Realizando o Instituto de Manguinhos o estudo clínico da moléstia nas zonas infectadas, julgou o seu Diretor de imprescindível necessidade a colaboração dos nossos mestres, a orientação deles na continuidade daqueles trabalhos. Solicitados pelo Dr. Oswaldo Cruz alguns dos nossos mais eminentes cientistas afrontaram os sacrifícios de uma longa e fatigante viagem, submetendo-se às contingências de uma ausência quase absoluta de comodidades pessoais, e lá foram a Lassance, levar-nos os ensinamentos de sua vasta erudição. O que deles lucramos, a interpretação dos fatos clínicos, os ensinamentos de técnica propedêutica, a corrigenda das falsas observações, enfim a orientação necessária para prosseguirmos, com proveito, em nossas pesquisas, constituíam, meus senhores, a melhor garantia para a verdade das nossas conclusões definitivas. (Jornal do Commercio, 1910b: 3)

Como num "teatro da prova" (Latour, 1984: 95), ${ }^{25}$ os luminares da medicina nacional foram levados a assistir, no interior de Minas, às experiências pelas quais a ciência de Manguinhos realizava a composição de uma nova doença tropical, objeto do qual aqueles médicos não mais diriam ter ouvido falar, mas testemunhado, tornando-se aliados e partícipes de sua construção e legitimação. Eles não só aceitaram os enunciados de Chagas como se tornariam atores decisivos para o percurso que estes seguiriam, conferindo-lhes credibilidade e contribuindo ativamente para que, daquele conjunto inicial de formulações, algumas fossem fortalecidas e corroboradas, como traços mais salientes de um desenho, conformando uma dada percepção do conjunto. ${ }^{26}$

Além dos elementos tireoidianos, avalizados e estimulados por Miguel Pereira e Miguel Couto, havia os aspectos neurológicos que certamente chamaram a atenção especialmente de Juliano Moreira e Austregésilo, destacados nomes da psiquiatria brasileira. ${ }^{27}$ Desde o final do século XIX, as pesquisas sobre as glândulas de secreção interna (como 
a tireóide) atraíam o interesse dos que estudavam as doenças mentais, já que problemas endócrinos eram vistos como possíveis fatores de desordens neurológicas, como a idiotia e a epilepsia. Este interesse foi o que determinou, segundo Delaporte (2003), a grande influência que os médicos da ANM tiveram sobre Chagas e seu modo de ver a doença.

"O destino das coisas que dizemos está nas mãos de quem as usar depois”, assinalou Latour (2000: 52). Conquistando o interesse dos principais representantes da medicina brasileira, os enunciados de Chagas começavam a circular entre outras - e importantes - mãos. ${ }^{28}$ Neste processo, suas formulações sobre a tireoidite parasitária eram produzidas e progressivamente fortalecidas também nos significados pelos quais representavam um fato social, tanto no sentido reflexivo quanto no sentido transitivo, conforme os termos de Chartier (1996). Num momento em que a nação comemorava a estabilização política e econômica do regime republicano e o saneamento urbano de sua capital litorânea - vitrine do progresso e da Belle Époque tropical (Neves, 2003) -, Chagas afirmou que a ciência, a medicina e a sociedade brasileiras entravam em contato não apenas com uma doença que 'em si' tinha graves implicações sociais, mas com uma moléstia capaz de 'dar a ver' realidades e problemas estruturais do país, em sua face rural e 'atrasada'.

A viagem da comissão da ANM a Lassance havia sido o primeiro movimento a promover este encontro. As palavras de Austregésilo, relatando suas impressões, são emblemáticas de como a doença descoberta 'no sertão' deixava antever o que seria considerada a doença 'do sertão', num movimento em que este termo deixava de expressar um espaço meramente geográfico para, revestindo-se dos conteúdos que lhe foram atribuídos poucos anos antes por Euclides da Cunha, tornar-se o significante da própria nacionalidade. ${ }^{29}$ Os traços com os quais Chagas compunha a figura clínica da doença - especialmente o 'papo' e as perturbações neurológicas - condensavam a correspondência entre o organismo humano 'degenerado', 'decadente', sem vitalidade e um ambiente físico e social caracterizado pelo abandono, pela miséria e pela improdutividade. Disse Austregésilo:

O sertão mineiro que atravessamos é de aspecto desolador, com as suas casinhas raras e a vegetação encarquilhada, retorcida, de folhagem pobre. Em Lassance encontramos o Dr. Chagas, que nos conduziu ao seu bem montado laboratório e depois ao hospital, onde vimos mais de trinta doentes da nova tripanossomíase. (...) É 
tristíssimo observar aqueles entes de aspecto miserável, indolentes, entre os quais abundam os inválidos e os idiotas. Se os organismos são assim degenerados, mais miseráveis ainda são as cousas que os cercam - habitações, terras etc. Bastará dizer-lhe que não achamos uma só fruta do país! Nenhuma idade escapa à moléstia. Até os lactantes já apresentam o papo. (Jornal do Commercio, 1910a: 4)

A posse na ANM, realizada logo após o retorno de Lassance da referida comissão, foi um novo e ampliado ‘palco' para o encontro pretendido por Chagas. Diante da elite médica do país e de representantes do presidente da República e do ministro do Interior, ele enunciou publicamente, pela primeira vez e com grande ênfase retórica, a noção de que se tratava de uma enfermidade que, por levar à 'degeneração' física e mental, comprometia a produtividade das populações afetadas e, conseqüentemente, o progresso do país. Apresentando seus estudos clínicos, alertou:

(...) a ação patogênica dessa moléstia é a das mais intensas que se conhece em patologia humana. Constitui ela o terrível flagelo de vasta zona do país, aí inutilizando numerosa população para a atividade vital, criando gerações sucessivas de homens inferiores, de indivíduos inúteis, fatalmente votados à condição mórbida crônica, a tal coeficiente de inferioridade que os torna elementos inaproveitáveis na evolução progressista da Pátria. É bem dolorosa a impressão trazida pelos fatos mórbidos observados naquelas zonas; dolorosa para o médico, que nos recursos atuais da ciência não encontra ainda meio eficaz de combate ao terrível inimigo; dolorosa para o estadista que demoradamente raciocinar sobre o obstáculo fatalmente oposto por aquela condição mórbida a quaisquer tentativas de progresso coletivo (...). Nem existe aqui a atenuante de limitação geográfica do mal; ao contrário, embora desse ponto não possamos ainda falar com amplitude, sendo aí necessárias mais demoradas observações, viagens pelo interior do país, visando estabelecer precisamente a distribuição do conorhinus, do que temos observado já avaliamos da grande extensão do mal. (Chagas, 1910b: 446)

Suas palavras foram, na ocasião, amplificadas por uma estratégia de grande efeito persuasivo. A luz elétrica, inaugurada nos salões da Academia naquela noite solene como símbolo do progresso, fez projetar imagens cinematográficas produzidas em Lassance, mostrando doentes, a maioria crianças com sérios distúrbios mentais e físicos, e barbeiros movimentando-se nas paredes de uma casa. O cinematógrafo, ao mesmo tempo que simbolizava as 'luzes' do progresso, era um poderoso instrumento, na vanguarda da própria fotografia, para conferir concretude aos 'fatos' para os 
quais os cientistas pretendiam chamar a atenção. Chagas materializava, diante das elites da capital recém-renovada, imagens perturbadoras de brasileiros que se afiguravam como a antítese da 'civilização' ${ }^{30}$ Se a Academia havia ido ao encontro de uma enfermidade desconhecida numa remota vila do interior de Minas, a sessão no Silogeu Brasileiro trazia a 'doença do sertão' para o centro da medicina e do país. Além das imagens em movimento, Chagas valeu-se do aparato específico do laboratório para convencer aquela importante audiência: trouxe peças anatomopatológicas e preparações em 16 microscópios, franqueados a quem quisesse observar o 'perigoso' parasito (ANM, 1910b).

O 'espetáculo' repercutiu na imprensa, ampliando ainda mais os canais de circulação e de visibilidade dos enunciados de Chagas. O médico Ismael da Rocha comentou:

O Brasil registra: no homem mais uma glória; no fato mais uma desgraça, a que os poderes públicos precisam acudir sem detença. (...) Todos os que assistiram, e era legião o auditório, à sessão da Academia Nacional de Medicina, no seu salão do Silogeu Brasileiro, não puderam reprimir a maior expressão de tristeza, reconhecendo (...) que há, em uma vasta zona central do Brasil, um grande flagelo, inclemente como o paludismo de certas regióes amazônicas, cruel como a febre amarela ora felizmente banida desta cidade. Aquela procissão de desgraçados, que só o cinematógrafo podia nos deixar apreciar na sua vida atual; aquele bando de infelizes, que vivem sofrendo ou nascem morrendo, são as vítimas de uma endemia, cuja causa animada Carlos Chagas desvendou, e que todo o mundo científico confirmou e aplaudiu. E a projeção luminosa cinematográfica apresentada à Academia demonstrou a evidência, a lúgubre peregrinação noturna dos insetos veiculadores do mal. Todos viram, descendo ou subindo traiçoeiramente pelas paredes de uma casa de campo, inúmeros insetos, que a fotografia pelo magnésio surpreendera no momento em que saíam ou eram tocados dos seus esconderijos! E a sensação foi simplesmente de horror. (Ismael da Rocha, 1910: 6) ) $^{31}$

Nas passagens citadas de Austregésilo, do próprio Chagas e de Ismael da Rocha, o ambiente físico-social associado à doença parece ser geograficamente delimitado à região de sua descoberta, o 'sertão mineiro'. Contudo, já se encaminhava um movimento de ampliação de tais fronteiras por meio de operações discursivas que aprofundavam a associação entre doença e sertão no seu sentido mais amplo, como 'moldura' para a nação. 
A cafua era um elemento central no mosaico de significados que faziam daquela doença tropical uma doença particularizada nos marcos de um determinado ambiente físico e social, ligado ao rural, ao interior, e expressivo, assim, de um certo recorte da identidade nacional.

Sob a perspectiva do próprio modelo da medicina tropical, em que fatores naturais associam-se às condições de vida da população em complexas interações, a casa de pau-a-pique - espaço em que se dão as condições propícias para o encontro do homem e do barbeiro infectado - traduzia e materializava, em termos locais, esta concepção ampla de ambiente. ${ }^{32}$ Este era o emblema do processo pelo qual os 'trópicos' adquiriam, no caso em questão, um sentido geográfico, cultural e social circunscrito e peculiar. Na conferência na ANM, Chagas explicitou a associação entre doença, habitação, interior e pobreza ao afirmar que "lá pelo interior do país, nas zonas da moléstia, a população pobre habita choupanas nas mais precárias condições, tendo as paredes cheias de numerosas fendas, que constituem ninhos colossais de conorhinus" (Chagas, 1910b: 424).

Expressando-se como 'doença do interior', 'doença do sertão', a doença de Chagas reconstruía, a partir do ambiente peculiar que a enquadrava, o conceito de 'doença tropical' como 'doença nacional', 'doença do Brasil'. Se, como aponta David Arnold (1996a, 1996b), o encontro dos europeus com os trópicos (espaço não apenas físico, mas conceitual, cultural e político) significou a experiência da 'alteridade', o encontro com a doença tropical descoberta em Minas Gerais também revelava um 'outro' que, descrito pela ciência, tornava-se uma dimensão do país afirmada, a partir de então, como central, nos sentidos físico, político e simbólico.

As implicações políticas das formulações de Chagas foram imediatas, expressando-se na reivindicação de medidas enérgicas por parte dos poderes públicos.

Poder-se-á, na higiene pública, encontrar meios eficazes de atenuação do mal? Acreditamos que sim, se tal problema, seguramente problema de Estado e de humanidade, se tornar preocupação de um estadista cientificamente bem orientado. (...) o homem de Estado que fizer da campanha contra esse mal um programa de administração e aí obtiver êxito feliz, terá conquistado dos meus patrícios, das gerações futuras de Minas, o maior penhor de reconhecimento. (Chagas, 1910b: 447) 
Chagas mencionou, nesta ocasião, que recebera do cientista alemão Paul Ehrlich um medicamento usado no tratamento da tripanossomíase africana para ser testado em casos de infecção pelo T. cruzi. ${ }^{33}$ Quanto à profilaxia, ela deveria basear-se fundamentalmente, segundo Chagas, na melhoria das habitações rurais. Como afirmou Neiva (1910: 211): “(...) deve-se estabelecer como condição primordial para se impedir o desenvolvimento dos barbeiros o reboco das casas de taipa e das frestas e fendas, das paredes das habitações infestadas". ${ }^{34}$

A afirmação de que, por ser uma doença 'evitável', deveria ser objeto das ações do Estado, foi uma via decisiva pela qual os enunciados de Chagas começaram a circular no espaço da política. Na Câmara Federal, um "representante dos sertões mineiros" (Vidal, 1910: 1) cobrou providências. No Correio da Manhã, Gil Vidal (pseudônimo de Leão Veloso Filho, primeiro redator-chefe do jornal) endossou a iniciativa e criticou os que apontavam limites constitucionais à intervenção da União nas questões de saúde dos estados.

E todos os nossos aplausos merece a atitude do solícito deputado mineiro Camillo Prates, ocupando a tribuna da Câmara para expor a gravidade do mal como uma das maiores calamidades que até hoje têm afligido grande parte do povo brasileiro, e concluindo pela indicação para que a comissão de Saúde Pública da Câmara dos Deputados sugira aos poderes públicos os meios de a debelar. Objetaram-se, na discussão, as dificuldades que encontraria a comissão de Saúde Pública no regime constitucional com relação à higiene. Sendo a higiene terrestre da competência dos Estados, e só a marítima da União, pareceu a alguns deputados que se fizeram ouvir em apartes impossível qualquer providência federal. Não se nos afigura procedente a objeção, uma vez que se trata não do interesse propriamente de um ou outro Estado, mas do interesse de muitos Estados. São necessidades não de Minas ou de Goiás somente que impóem essas providências, mas do Brasil inteiro. (...) O que aconselhamos e pedimos é que os poderes públicos nacionais não se conservem em inércia criminosa diante dessa calamidade, nem recuem diante da perspectiva de grandes despesas. (...) O Brasil não é só o Rio de Janeiro. Não esqueçam os nossos legisladores e governantes de que vivem aqui, mais ou menos comodamente, um milhão de brasileiros, ao passo que mourejam nos sertôes cerca de dezoito milhões. (Vidal, 1910: 1; grifos meus) $)^{35}$

No contexto específico do debate sobre a moléstia de Chagas, surgiam, assim, as bandeiras e os argumentos que conformariam, anos depois, o 
movimento pelo saneamento dos sertões e suas implicações na reforma da saúde pública brasileira, que, em 1920, ampliou a intervenção do Estado neste campo, especialmente no interior do país (Hochman, 1998).

Ao colocar o tema da 'doença do sertão' na ordem do dia e na cena pública, Chagas imprimia visibilidade e legitimidade também ao projeto de ciência que Oswaldo Cruz vinha implementando em Manguinhos: uma ciência que, distinguindo-se pela excelência científica na medicina experimental, afirmava-se como responsável por identificar os problemas nacionais e apontar as ações para superá-los. Chagas assumia, assim, em sua identidade como cientista, um perfil de intelligentsia, atualizando, num contexto marcado pela confiança nos novos recursos para o estudo e o combate das doenças infecciosas, o compromisso público que os intelectuais brasileiros de formação técnico-científica haviam assumido, desde a geração de 1870, com os destinos da nação (Alonso, 2002). ${ }^{36}$

Sob a forte ressonância da conferência de 1910 na ANM, os estudos de Chagas no norte de Minas prosseguiram. Em 1911, ele publicou, em alentado trabalho, nova sistematização geral de suas pesquisas. Um aspecto que ganhou maior ênfase foi a dificuldade no diagnóstico parasitológico da fase crônica. As inoculações em cobaias, com vistas a identificar o parasito nos órgãos e nos tecidos depois da morte do animal, nem sempre davam resultados conforme o esperado, "havendo numerosos casos positivos nos quais as mais demoradas pesquisas só conseguiram mostrar a presença de uma ou outra forma parasitária” (Chagas, 1911c: 236). ${ }^{37}$

Quanto às formas clínicas, Chagas manteve a classificação anterior. Para a fase aguda, sublinhou que em todos os casos era possível identificar um conjunto de sintomas "absolutamente constantes e inconfundíveis com os de outros processos patológicos", relacionados, principalmente, ao comprometimento tireoidiano. O mixedema no rosto, expresso na "facies empapuçada (...), que já à distância faz suspeitar a moléstia”, foi realçado como "sinal dos mais característicos" (Chagas, 1911c: 240).

Sobre a infecção crônica, reiterou as cinco formas sob as quais a havia classificado. Apesar de manter a ênfase nos elementos tireoidianos, destacou a importância da forma cardíaca, observando que, em muitos casos, as irregularidades do ritmo cardíaco eram "o fenômeno mais facilmente apreciável, que primeiro fere a atenção do observador, salientando-se como elemento capital nos dados fornecidos pela semiótica física" (Chagas, 1911c: 250). Chamando a atenção para a elevada percentagem 
de arritmias em indivíduos jovens, reiterou o valor destes sinais como traço de especificidade da doença.

A concepção de que o bócio era uma manifestação clínica da tripanossomíase foi reforçada. Os argumentos que lhe serviam de base eram, segundo Chagas, "de tal ordem decisivos", que ele declarou-se autorizado "a considerar esse ponto como um dos mais bem fundamentados" (Chagas, 1911c: 266). Fortalecendo a supremacia dos sinais tireoidianos expressos no 'papo' como elemento primordial no enquadramento da doença, concluiu: "pensamos ser muito acertada a denominação de tireoidite parasitária, proposta pelo ilustre professor Miguel Pereira para a nova entidade mórbida" (Chagas, 1911c: 273; grifo do autor).

A coloração política que a doença vinha assumindo ganhou tons ainda mais fortes. Mais uma vez, as associações médicas serviram de espaço para a apresentação pública de um objeto cujos traços uniam, cada vez mais, ciência, política e nação. Em 30 de julho de 1911, Chagas fez uma conferência na Associação Médico-Cirúrgica de Minas Gerais, onde foi recebido como membro honorário, na presença do presidente do Estado e de outras autoridades políticas. Suas reivindicações junto aos poderes públicos tornavam-se cada vez mais incisivas. Desta vez, a dimensão social do tema apareceu não ao final da exposição técnico-científica, mas como ponto de partida e sentido maior da apresentação, que, segundo explicitou, era movida por um "objetivo de ordem prática” (Chagas, 1911a: 337): abordar "o mais alto problema de estado que se impõe à atenção dos governantes de nossa terra" (Chagas, 1911a: 356). ${ }^{38}$

Esta foi mais uma viagem reveladora das estratégias com que Chagas fazia circular seus enunciados: levando-os a Minas, ele buscava arregimentar aliados que avalizassem suas pesquisas e que, principalmente, corroborassem a denúncia, junto aos poderes centrais da nação, de um mal profundamente identificado àquele estado. Minas Gerais era não apenas o local da descoberta e a terra natal do descobridor. A área de prevalência da endemia, pelos dados até então produzidos sobre a distribuição dos barbeiros, confundia-se com seu próprio território, simbolicamente evocativo do 'interior' e da 'vocação agrícola' da nação. Num momento em que a estagnação econômica do estado vinha sendo motivo de crescente preocupação para a elite mineira (Dulci, 1992, 1999; Borges, 1997), Chagas encontrou um bom terreno para reivindicar o apoio de seus patrícios. ${ }^{39}$ 
Sobre a verdade dos resultados a que chegamos poderiam assim os ilustres colegas emitir opinião valiosa, analisando-os na amplitude de uma crítica que vimos solicitar; mais ainda, conhecendo de perto os malefícios da nova moléstia e vendo neles uma das maiores calamidades sociais desta grande terra, poderiam, com o prestígio de seu saber, altamente influenciar a iniciativa de uma campanha necessária ao terrível flagelo. (Chagas, 1911a: 337). ${ }^{40}$

A exortação feita em Minas seria, poucos dias depois, amplificada numa segunda conferência na ANM, diante do presidente da República, Hermes da Fonseca, dos ministros da Justiça e Negócios Interiores, da Fazenda, da Viação e da Agricultura. Amparando-se na "palavra autorizada dos maiores mestres da nossa medicina" (Chagas, 1911b: 341), que haviam certificado seus estudos em Lassance, seu objetivo era evidenciar aos poderes públicos da nação, aos mestres de medicina pátria, à classe médica da capital da República e aos alunos estudiosos da nossa Faculdade, a existência nos sertões mineiros e em grande parte do interior do país, de uma condição endêmica que constitui, naquelas zonas, obstáculo definitivo ao progresso material de um grande povo, ao aperfeiçoamento de uma raça, ao aumento natural e progressivo de uma população, ao trabalho produtivo, à energia criadora, à felicidade, enfim, da vida humana ali fatalmente destinada ao aniquilamento trazido pela ação intensa e permanente de um grande mal. (...) se a tanto me animo é porque não temo a argüição de incorrer em exagero, senão em deficiência, quando desse modo eu aprecio, em toda sua amplitude, as conseqüências dessa moléstia (...). A eminência de um auditório assim constituído (...) só me traz a confiança de que desta conferência vão resultar as mais benéficas conseqüências na iniciativa de uma obra sanitária salvadora. É que eu espero, na demonstração prática dos fatos, tornar irrecusável a minha convicção de que esse assunto constitui problema de Estado cuja solução é imposta pelos deveres de civilização e de humanidade, senão pelo interesse mesmo do progresso econômico de grandes zonas do país. (Chagas, 1911b: 340-341)

Ao apresentar os avanços das pesquisas diante daquela importante audiência, Chagas imprimiu ênfase a alguns pontos, de modo a fortalecer o alerta que pretendia disseminar. Com base nos estudos de Neiva, citou, por exemplo, as peculiaridades dos triatomíneos no sentido de sua grande capacidade de propagação da doença: a presença constante nas habitações rurais - "é raríssimo, se possível, encontrar naquelas zonas uma choupana única livre da infestação pelo barbeiro" -, a vida longa, a 
resistência a prolongados jejuns e a possibilidade de que fossem transportados em bagagens. Tudo isso permitia "ter a idéia da importância de um único inseto como demorado fator epidemiológico" (Chagas, 191 lb: 341). ${ }^{41}$ O barbeiro apresentava-se, assim, como 'inimigo poderoso', que poderia 'colonizar' outras regiões do país, acompanhando o avanço econômico e o deslocamento das populações provenientes de áreas endêmicas.

Quanto aos enunciados sobre o quadro clínico, Chagas aprofundou o caminho que vinha trilhando: a proeminência do que denominou então "síndromes glandulares" (Chagas, 1911b: 353). ${ }^{42}$ Em seus traços primordiais e constantes de especificidade, a doença assumia, assim, a identidade de uma afecção endócrina. Os aspectos cardíacos e os neurológicos, ainda que importantes, eram considerados variáveis e secundários.

Associando os elementos do enquadramento médico-científico àqueles que conformavam a doença como objeto social, Chagas produziu, nesta segunda conferência na Academia, uma síntese particularmente significativa do esquema interpretativo e classificatório a partir do qual emergia um determinado 'retrato' da doença:

No ponto de vista prático, para salientar os malefícios da moléstia, lembraremos, na forma cardíaca, essa condição quase universal de insuficiência circulatória nas zonas fortemente contaminadas; lembraremos, na forma nervosa, o grande número de monstros, reduzidos à condição miserável de paralíticos, de idiotas e de dementes; lembraremos, nas grandes síndromes glandulares, o total desequilíbrio da vida orgânica, inutilizand o o homem para o trabalho produtivo e furtando-lhe o gozo de viver; (...) lembraremos, em todas as formas clínicas da moléstia, principalmente na forma aguda meningo-encefálica, a poli-letalidade familiar, obstando o aumento natural e progressivo da população em vastas regiões do país; (...) minando lentamente o organismo humano e nele produzindo uma queda progressiva da vitalidade, tornando o indivíduo incapaz para o trabalho e perpetuando-se, talvez, por transmissão hereditária, em gerações sucessivas de homens inferiores, a tireoidite parasitária cria, em vastas regiões de Minas Gerais e de outros Estados do Brasil, uma população de degenerados, certamente inaproveitáveis na evolução progressiva do país. (Chagas, 1911b: 373; grifos meus $)^{43}$

Ao justificar a importância das medidas profiláticas, Chagas utilizou um argumento que se tornaria corrente na caracterização desta e de outras enfermidades do interior do país como obstáculos ao progresso: 
o prejuízo não apenas à produtividade das zonas sertanejas já ocupadas, mas ao próprio povoamento do território nacional. No caso dos novos núcleos populacionais abertos com a expansão das ferrovias, a construção de casas 'primitivas', propícias à infestação pelos barbeiros, fazia com que, rapidamente, eles se transformassem em focos da doença. Lassance era o grande exemplo, e Chagas narrou o processo, por ele acompanhado, de progressiva infestação daquele povoado onde foi construída uma estação ferroviária (Chagas, 191 1b: 374).

A correlação da doença com problemas específicos da modernização brasileira era o caminho pelo qual a medicina tropical assumia significados particulares no contexto nacional. Chagas recorria explicitamente a esta noção. Dando o exemplo dos europeus, que estudavam e combatiam a doença do sono na África por interesses colonialistas, chamou a atenção para o fato de que, no Brasil, o compromisso da medicina tropical era com os destinos da própria nação:

Entre nós a iniciativa de medidas sanitárias justifica-se, sem dúvida, em considerações bem mais elevadas: é o futuro de um grande povo que se deverá zelar; são deveres de humanidade e de patriotismo que devem atuar no espírito progressista dos homens de estado; é a vida humana, é progresso material, o aperfeiçoamento de uma raça que degenera, o obstáculo ao trabalho produtivo e à grandeza econômica de vastas zonas do país; é, finalmente, o alto problema do povoamento do solo por indivíduos fortes, tudo indicando a urgência de medidas sanitárias capazes de atenuar a ação maléfica do Conorhinus megistus. (Chagas, 1911b: 374-375)

Estava assim formulada, de maneira clara e incisiva, a idéia que seria, a partir de então, cada vez mais veiculada por ele e outros médicos e intelectuais: a decadência orgânica de grande parte da população, produzida por esta e outras doenças parasitárias, era um grande entrave ao progresso social e econômico do Brasil, a ser removido mediante a intervenção do Estado, orientada pelos cientistas. No contexto específico da produção de conhecimentos sobre a nova enfermidade tropical, a ciência médica imprimia novos significados à tradicional associação entre saúde e progresso: se, até então, o projeto civilizatório encontrava no ambiente urbano seu espaço de afirmação, tratava-se então de 'regenerar' o interior do país.

A idéia seguiu fazendo novos e importantes adeptos. As palavras de Carlos Seidl, presidente da ANM, ao receber Chagas nesta segunda con- 
ferência, foram significativas, explicitando o teor nacionalista que se intensificaria na cena pública poucos anos depois:

Que raça degenerada vai ser a dos sertanejos do nosso imenso país, se mão forte e inteligente não puser um paradeiro pronto às devastações que a endemia descoberta pelo Dr. Carlos Chagas produz pelos Estados de Minas, Goiás, S. Paulo, Bahia e Mato Grosso? Que trabalho produtivo se pode esperar de homens, já inválidos nos albores da vida, com a fibra cardíaca atingida e profundamente lesada, com o sistema nervoso embotado? Que progresso será o de um povo de edemaciados, morbidamente pálidos, de gânglios enfartados, de imbecis? Que geração vai sendo essa de crianças, já aguilhoadas pelo ferrete da precoce decadência orgânica? (...) Que belos defensores da pátria ou cultores da terra poderá ter o Brasil nesse povo de anões e retardados? (Correio da Manhã, 1911a: 3)

Seidl manifestou sua disposição em fazer daquela ocasião um meio de dar visibilidade nacional ao assunto, sobretudo em função de seu impacto em questões econômicas concretas para o país, como a força de trabalho, o povoamento e a integração nacional. Além do ministro da Fazenda, "filho de Minas, um dos Estados mais interessados no caso", justificou a presença de outras autoridades do Executivo federal:

Solicitei a vinda, aqui, nesta hora, do Exmo. Sr. ministro da Agricultura, para que S. Ex. lançasse olhar carinhoso sobre estes enfezados, raquíticos e estiolados tipos da planta humana; e ele, oriundo de S. Paulo, outro Estado que não pode ficar indiferente ao clamor patriótico do nosso colega [Chagas], conhecesse as circunstâncias em que se encontram esses campos de cultura, que são as zonas habitadas pelos infectados do Schizotrypanum cruzi. À S. Ex., certamente, não passará despercebida a necessidade que há de virilizar o braço nacional, atrofiado por moléstia evitável, quando tantos dispêndios se fazem para obter o auxílio do estrangeiro o qual virá, fatalmente, a sofrer do mesmo mal, indo trabalhar em zona contaminada. (...) Pedi ao Sr. ministro da Viação que viesse a esta conferência, porquanto fora lícito pensar interessar-lhe o conhecimento íntimo do estado da decadência orgânica destes homens e destas mulheres, habitantes todos eles das zonas pelas quais estendem seus nervos de aço as vias férreas brasileiras, portadoras do progresso e também da moléstia de Chagas (...). (Correio da Manhã, 1911a: 3)

Neste mesmo ano, Clementino Fraga - mais um dos que haviam testemunhado a doença em Lassance - destacava, perante a classe médica 
baiana, este mesmo aspecto, com palavras de grande força retórica: assim como o parasito que 'invadia' e 'conquistava' as fibras centrais do organismo humano, esta era uma enfermidade que exauria a fonte primordial de energia da nação: o trabalho rural.

Imaginai toda uma população rural que a moléstia faz miserável, porque, invalidada para o trabalho, arrasta os seus dias no brusco da desolação, absolutamente incapaz, lívida e espoliada na força de seus braços, reduzida, senão anulada, na energia de sua inteligência. A inaptidão para o esforço físico, a indolência que logo denunciam aqueles desgraçados, é o fato de uma incapacidade mórbida: o músculo parasitado perde o seu tônus, falta-lhe a energia contrátil, como perde a sua qualidade superior, criadora e diretriz, o centro cerebral que o parasito conquistou, espancando a luminosa função que lhe era antes nume e apanágio. (Fraga, 1911: 477)

Também nessa ocasião, Chagas lançou mão de recursos de grande impacto para transformar o auditório da Academia, novamente, num ‘palco' para a apresentação e o convencimento públicos quanto às 'provas' da doença. Desta vez, o sertão doente fez-se presente não apenas por meio de imagens cinematográficas, mas pela dramaticidade concreta dos próprios enfermos, trazidos de Lassance. O evento foi descrito pelos jornais, que traduziram aos leigos os contornos da terrível doença revelada pela ciência de Manguinhos.

Às 8 e 15 da noite, a Academia de Medicina regurgitava. Estudantes e médicos enchiam o vasto salão, entupiam os corredores e até ocupavam as janelas, à disputa de lugar (...). Após a leitura do seu trabalho, o Dr. Chagas passou a mostrar ao auditório vários doentes, presentes à sessão. O presidente da República impressionouse vivamente com o que viu. Em primeiro lugar, apareceu uma criancinha, que aparentava ter 4 a 5 anos, tipo de imbecil, já com um papo visível. Agora, imagine-se a sensação da assistência, quando o Dr. Chagas disse que aquela criança tinha... 19 anos de idade! E outras apareceram, no mesmo gênero! Alguns doentes apresentavam o quadro clássico da imbecilidade ou da idiotia. Havia uma mulher com fenômenos de delírio. Curiosidades clínicas encerravam as formas cardíacas: homens que, em vez de possuírem 75 pulsações cardíacas, tinham, apenas, 20 a 30! Era manifesta a sensação profunda que esses doentes causaram, particularmente no Marechal Hermes e ministros presentes. (Correio da Manhã, 1911a: 3) 
Antecipando a imagem do Jeca Tatu de Monteiro Lobato, a reportagem destacava o espírito patriótico de Chagas, por prover "a regeneração do sertanejo brasileiro, agora reabilitado de sua famosa e malsinada indolência, conseqüência fatal da invasão de vísceras essenciais pelo parasito da multifária entidade mórbida" (Correio da Manhã, 191 la: 3).

No Hospital da Santa Casa de Misericórdia, três dias depois, o 'espetáculo' seria reencenado para os estudantes da faculdade de medicina. Mais uma vez, a imprensa deu destaque ao evento, numa descrição que, em tons hiperbólicos, mostrava em que medida aqueles sertanejos causavam tanta estranheza que se chegava a vê-los como objetos puramente científicos:

Ninguém se pode mexer. Pior que um formigueiro. Os estudantes comprimem-se nas arquibancadas, abarrotadas a mais não poder. Médicos e professores conservam-se de pé no recinto das aulas, acotovelando-se pela absoluta falta de espaço. E a cada minuto que se escoa, é mais gente que chega. Vidros das janelas do pavilhão quebram-se, devido à formidável compressão... E mais gente. Já às portas ninguém pode estar. Nem no corredor. E chega mais gente ainda... (...) Quatorze doentes foram apresentados. Lindos casos clínicos. Alguns, de infantilismo puro; outros, apenas de pequeno crescimento. Tais, com grande bócio, ou papeira; quais, com atrofia da glândula tireóide. Nestes, a forma cardíaca dominava; naqueles, os fenômenos nervosos sobressaíam. Foi uma hora de verdadeiro encanto científico. (...) Terminada a conferência, o Dr. Chagas foi cumprimentado pelos professores presentes e vitoriado delirantemente pelos estudantes. (Correio da Manhã, 1911b: 3) (4 $^{44}$

Em entrevista a outro jornal, Chagas pontificou suas certezas e afirmou, em tom confiante: "Eu trouxe 14 exemplares clínicos da moléstia, porque a mais não me permitiam os recursos, mas, se quiserem cem, duzentos, quantos queiram, é só ter o trabalho de ir buscá-los..." A reportagem concluiu: a moléstia era "a única que se pode chamar de estritamente nacional” (A Imprensa, 1911: 1).

$\mathrm{O}$ 'teatro da prova', que alcançava seu ápice na capital federal, contou, ainda em 1911, com um espaço de grande importância fora do país. Na Exposição Internacional de Higiene e Demografia, realizada em Dresden, Alemanha, além das projeções cinematográficas, das peças anatômicas e de "um cortejo grandioso de documentação científica", foram expostos quatro bustos, encomendados a um escultor francês, representando doentes com os principais sintomas. O 'papo' era o traço mais 
saliente. Reportagem da época destacou: "Eram quatro verdadeiras estátuas do Mal. Ali se via no gesso quatro criaturas sofrerem" (A Noite, 1912: 1). Em 1913, Chagas seria indicado ao Prêmio Nobel de Medicina. ${ }^{45}$

\section{Endemias Rurais, Obstáculo ao Progresso: a tripanossomíase brasileira}

Em 1912, o governo federal destinou fundos especiais para construir, em Lassance e em Manguinhos, hospitais destinados a estudar clinicamente a doença (Imagens 9, 10 e 11 ). ${ }^{46}$ Neste ano, em que Chagas conquistou uma importante distinção no cenário internacional com o Prêmio Schaudinn de protozoologia (pelo Instituto de Doenças Marítimas e Tropicais de Hamburgo), o percurso discursivo que fazia da tripanossomíase o emblema das doenças do Brasil teve um importante marco. Em discurso na inauguração do VII Congresso Brasileiro de Medicina e Cirurgia, em abril, em Belo Horizonte, Chagas formulou o argumento que, em 1918, se condensaria na imagem da "trindade maldita” (Penna, 1918b: 12), cunhada por Belisário Penna como selo do movimento sanitarista: "os três grandes problemas sanitários do interior do Brasil”, responsáveis pelo atraso social e, sobretudo, pelo atraso econômico do país, eram a malária, a ancilostomose e a "tripanossomíase brasileira” (Chagas, 1912a: 12). Numa operação discursiva eloqüente, passou a adotar tal denominação, explicitando a dimensão nacional que pretendia imprimir à doença ${ }^{47} \mathrm{O}$ próprio Penna (1918b: 105) reconheceria, anos mais tarde, que Chagas havia sido uma voz pioneira da campanha pelo saneamento do Brasil. Ao citar este discurso de 1912, ele declarou: “(...) é todo ele a revelação dessa desgraça e um apelo patriótico ao governo para salvar a nossa gente" (Penna, 1918b: 105).

Neste pronunciamento, ao mesmo tempo em que declarou sua filiação à tradição da "medicina científica" de Oswaldo Cruz, Chagas imprimiu o sentido do 'novo' ao seu papel neste processo, alertando para a "urgência de se ir além". Se o diretor de Manguinhos havia 'reabilitado' o país mediante o saneamento da capital, o desafio para a ciência - e a política - dizia respeito, naquele momento, aos problemas sanitários do interior, "onde nem sempre tem sido possível chegar os benefícios de uma ação bem dirigida" (Chagas, 1912a: 8) ${ }^{48} \mathrm{Com}$ vistas a caracterizar a 
doença por ele descoberta como um destes problemas, Chagas a associou à malária e à ancilostomose, duas enfermidades que, desde o século XIX, assumiam centralidade no discurso médico-higienista sobre a nosologia brasileira, e que, ganhando projeção internacional no contexto da medicina tropical mansoniana, contavam, naquele momento, com recursos e experiências concretas de profilaxia. Como traço a unir as três endemias rurais, estaria o obstáculo que representariam à economia, ao progresso nacional e, mais concretamente, à produtividade do trabalho agrícola.

Sobre a malária, destacou sua forte presença em Minas e na Amazônia, salientando que se tratava de um problema das populações rurais em todo o território nacional, "mesmo ali nas proximidades da Capital da República” (Chagas, 1912a: 10). ${ }^{49}$

Em contraste saliente com a majestade de uma natureza sempre nova, com a exuberância de uma flora sempre verde, com a variedade de uma fauna das mais ricas, encontrareis uma população de definhados, de anêmicos e de caquéticos, homens sem energia produtiva, numa condição de quase incapacidade vital (...). Aí permanecem votados à morbidez, deixando inaproveitado um solo fértil e representando um coeficiente negativo no engrandecimento econômico do país. Pior é que os destinados a esta sorte precária são, de regra, homens do trabalho agrícola, aqueles a quem deveriam sobrar as qualidades de robustez que lhes são imprescindíveis. (Chagas, 1912a: 8) ${ }^{50}$

Sobre a ancilostomose, enfatizou também os "incalculáveis prejuízos" em zonas agrícolas e a urgência de se adotar, de modo sistemático, ações de profilaxia, "hoje de uso habitual e obrigatório entre os povos cultos” (Chagas, 1912a: 12). A chamada 'doença da preguiça', emblemática da associação entre doenças endêmicas e improdutividade/incapacitação para o trabalho, era um tema proeminente no cenário internacional. ${ }^{51}$ Em 1909, a família Rockefeller (que vinha financiando ações e instituições no campo da saúde e educação) estabeleceu uma comissão sanitária para combater a doença no sul dos Estados Unidos, mediante o estímulo à construção de latrinas, ao uso de sapatos e à aplicação de vermífugos. Esta campanha foi a origem da International Health Comission (transformada, em 1916, em International Health Board) da Fundação Rockefeller, criada em 1913 em Nova York, e que, a partir de então, empreenderia ações/programas de combate à ancilostomose, à malária e a outras enfermidades em vários países do mundo, entre os quais o Brasil 
(Farley, 1991, 2004; Cueto, 1994; Castro-Santos \& Faria, 2003; Faria, $1995,2007) .^{52}$

Quanto à tripanossomíase brasileira, salientou Chagas, era a endemia "de efeitos sociais mais desastrosos". Atacando o indivíduo, em geral, no início da vida, produzia uma verdadeira "população de monstros, pela forma exterior e pela inteligência” (Chagas, 1912a: 10). Neste discurso em Belo Horizonte e na conferência que faria depois em São Paulo, apesar de manter a centralidade dos distúrbios endócrinos e de prosseguir afirmando a importância da forma cardíaca,,${ }^{53}$ os elementos da forma nervosa passaram a assumir especial destaque na caracterização da dramaticidade da doença. Se o seu 'selo' era o 'papo' ${ }^{54}$ as paralisias e as desordens mentais conferiam concretude à noção de ‘degeneração', tão presente no debate intelectual da época (Stepan, 2005) e utilizada por Chagas de modo recorrente em seus textos e pronunciamentos, sobretudo por se tratar de uma doença que afetava crianças e que, segundo ele, poderia ser hereditária. ${ }^{55}$ Este era o caminho pelo qual se realçava, naquela condição mórbida essencialmente crônica e endêmica (que, portanto, não se expressava com a mesma materialidade dramática das epidemias), os atributos que lhe conferiam maior visibilidade e impacto como objeto médico-social.

No artigo publicado no Arquivo da Sociedade de Medicina e Cirurgia de São Paulo (que corresponde à sua conferência naquele estado), percebe-se tal movimento na forma pela qual a doença foi visualmente apresentada por meio de fotografias, recurso persuasivo particularmente poderoso no sentido de concretizar os objetos aos quais se referem os enunciados científicos. Dos sete doentes cujas imagens foram apresentadas no texto (Chagas, 1912b), seis eram casos de forma nervosa (quatro deles crianças), com evidentes sinais de deformidades físicas e retardo mental. ${ }^{56}$

Na ênfase aos efeitos degenerativos produzidos pelo T. cruzi sobre o sistema nervoso, Chagas valia-se da comparação com a temida sífilis, à qual se associavam distúrbios neurológicos derivados da ação do Treponema pallidum:

Nem a infecção luética [siflilítica] nos grandes centros populosos onde ela grassa com maior intensidade apresenta determinações nervosas tão numerosas. É de interesse referirmos que no campo de nossos estudos realizados numa zona de população difusa possuímos mais de cem casos bem típicos de diplegia cerebral, em 
crianças definitivamente condenadas a uma existência de inatividade e sofrimento. (Chagas, 1912b: 58-59) ${ }^{57}$

Além do sentido estritamente científico da associação com a sífilis - "que dela [tripanossomíase] muito se aproxima no quadro clínico" (Chagas, 1912b: 64) -, há que se considerar a importância conferida a tal doença no debate médico sobre a identidade nacional (Carrara, 1996, 2004).$^{58} \mathrm{O}$ intuito do paralelo também era o de diferenciação, visando a afirmar que a infecção pelo T. cruzi, "que atinge zonas extensas do interior do país e nelas afeta a quase totalidade de seus habitantes", tinha "efeitos maléficos" mais extensos do que aquela doença que incidia preferencialmente nos núcleos urbanos do litoral (Chagas, 1912b: 64).

Cabe lembrar que, entre os médicos que integraram a delegação da ANM que foi a Lassance em 1910, estava Juliano Moreira, que dedicava à sífilis particular atenção. Assim como esta, outras doenças infecciosas, como a malária, a varíola e a febre amarela, constituíam temas de interesse no campo da psiquiatria, classificadas como "psicoses infecciosas" (Moreira \& Peixoto, 1906: 230). ${ }^{59}$ Este pode ter sido mais um fator a justificar o interesse pelos elementos neurológicos da moléstia de Chagas. Em 1913, a convite de Miguel Couto, Chagas publicou um trabalho dedicado à forma nervosa da tripanossomíase, num periódico associado ao Hospital da Salpêtrière, de Paris, um dos mais antigos e renomados centros de estudos psiquiátricos e neurológicos. Trazendo 12 fotografias de doentes desta forma clínica, afirmava ser aquela a doença humana que, talvez, provocasse mais distúrbios orgânicos no sistema nervoso central (Chagas, 1913a).

O período de 1910 e 1913 corresponde a um primeiro ciclo na construção/definição clínica da tripanossomíase, num processo em que o organismo humano foi esquadrinhado em busca de sinais específicos da ação patogênica do T. cruzi. O enquadramento impresso àquele novo objeto médico ocorreu tanto mediante elementos de regularidade, capazes de estabelecer um padrão definidor de um dado conjunto, quanto pela particularização de distintos aspectos, que, justamente pela diferença entre si, corroboravam o conjunto numa relação de pertencimento ao todo. Estes dois movimentos, estruturados na estreita relação entre a pesquisa clínica e a pesquisa anatomopatológica, foram explicitados pelo próprio Chagas. 
Para ele, a nova entidade era marcada por uma "uniformidade do conjunto" (Chagas, 1912b: 50), resultante da "unidade etiológica e conseqüente uniformidade de processos patogênicos" (Chagas, 1912b: 48), típicas das doenças infecciosas. Ou seja: uma causa única (o parasito) produzia certos efeitos por meio de um mecanismo regular. Isso era o que fazia com que a doença, mais do que formas clínicas distintas, fosse compreendida como um conjunto de "agrupamentos sintomáticos" (Chagas, 1912b:50). Apesar das diferenças, as várias formas clínicas derivavam-se todas da ação do T. cruzi em sua localização nos sistemas orgânicos. Segundo Vianna, as lesões macroscópicas eram sinais desta uniformidade: "O quadro patológico varia de intensidade de uma forma a outra, mas não se modifica qualitativamente". Entre as características deste "quadro geral", deduzido dos dez casos por ele autopsiados, salientou a "existência infalível de lesões tireoidianas escleróticas”. Contudo, dizia Vianna, "aos sinais constantes observados sempre por Chagas, outros se juntam conforme a sede da principal lesão observada em vida" (Vianna: 1911: 277; grifo do autor).

Além das diferenças em função da localização parasitária, a própria necessidade de sistematização exigida no domínio da nosologia implicava o estabelecimento de variantes clínicas, que imprimiam àquele quadro um aspecto de multiplicidade e 'polimorfismo'. Segundo Chagas (1912b: 50), a tripanossomíase brasileira era, provavelmente, "a entidade mais multiforme" em patologia humana. Foi no âmbito destas variantes que, ao longo das operações discursivas conformadoras dos enunciados, certos elementos se sobressaíam em relação aos demais. Assim, embora concedesse importância aos três conjuntos sintomatológicos (endócrinos, neurológicos e cardíacos), a doença era caracterizada, sobretudo nos enunciados que ressaltavam sua importância médico-social, fundamentalmente pelos dois primeiros.

Os traços primordiais deste desenho serviram de 'mapa' a orientar os médicos nas estimativas e na procura de 'pistas' da doença pelo país. No âmbito do IOC, isso foi feito, em grande parte, pelas expedições científicas que, desde a década anterior, o instituto enviava a diversas regiões para realizar estudos que subsidiassem órgãos públicos e privados envolvidos com a modernização econômica do país. De setembro de 1911 a fevereiro de 1912, Astrogildo Machado e Antonio Machado viajaram ao vale do São Francisco e do Tocantins para realizar a profilaxia da malária junto a obras da Estrada de Ferro Central do Brasil. Entre abril 
e julho de 1912, por solicitação da Inspetoria de Obras contra a Seca, Adolpho Lutz e Astrogildo Machado percorreram o rio São Francisco e alguns de seus afluentes. De janeiro a outubro do mesmo ano, Arthur Neiva e Belisário Penna viajaram pelos estados da Bahia, Pernambuco, Piauí e Goiás, por requisição da mesma repartição federal. Entre os objetivos destas expedições - que estavam referidos não apenas aos interesses de seus contratantes, mas também às diversas questões de pesquisa que compunham a agenda da medicina tropical em Manguinhos -, estava o de verificar a ocorrência da doença de Chagas. Nos relatórios que as duas últimas expedições produziram (Lutz \& Machado, 1915; Neiva \& Penna, 1916), percebe-se que, além da presença dos transmissores (assunto em que tanto Neiva quanto Lutz eram especialistas), o principal elemento clínico pelo qual se estimou a existência da doença foi o bócio. ${ }^{60}$

Semelhante busca foi feita no estado de São Paulo por pesquisadores dos institutos Butantan, Pasteur e Bacteriológico, num indício de que a mobilização empreendida por Chagas conquistava aliados em outros espaços da ciência médica. A conferência na Sociedade de Medicina e Cirurgia daquele estado, em 1912, havia sido um evento marcante e, na ocasião, Chagas foi homenageado com um grande banquete, no qual Vital Brazil, diretor do Butantan, fez um longo discurso exaltando a importância dos estudos feitos "por um dos maiores protozoologistas do mundo e certamente o maior do Brasil”, como um marco do início de "nossa independência” em relação à "ciência d'além mar" e da "cruzada da ciência contra as causas destruidoras", presentes nos "diferentes recantos do Brasil" (O Estado de S. Paulo, 1912: 5) ${ }^{61}$ Como salienta Luiz Jacintho da Silva (1999), os interesses de ordem econômica foram um fator decisivo para o estudo da doença de Chagas em São Paulo, em função da grande preocupação do governo estadual com o incremento da produção cafeeira, num contexto de grande dinamismo na ocupação do território. ${ }^{62}$ Em 1913, ano em que Juan Carlos Segovia descreveu, em El Salvador, o primeiro caso da nova tripanossomíase fora do Brasil, Theodoro Bayma, assistente do Instituto Bacteriológico de São Paulo, foi encarregado de procurar a infecção humana no estado.

Divulgados, em São Paulo, os notáveis trabalhos do Dr. Carlos Chagas (...), trataram os nossos institutos experimentais de investigar a existência da nova tripanose no território do Estado. (...) Não foi difícil encontrar os transmissores da moléstia - os triatomas. (...) Daí o arraigar-se nos laboratórios a convicção de que concomitante 
devia existir a infecção humana, cujos resquícios de antigos focos talvez sejam hoje representados por pequenos e raros núcleos de população cognominados arraiais de papudos. (Bayma, 1914a: 3)

Ao examinar, em Ribeirão Preto, crianças portadoras de hipertrofia da tireóide, e obter resultados positivos com a inoculação, em cobaias, do sangue de uma destas crianças, Bayma anunciou, em 1914, a primeira verificação de infecção humana pelo T. cruzi no estado (Bayma, 1914a). ${ }^{63}$ Disse Bayma (1914a: 3): "A não ser esse reduzido bócio, o selo da moléstia, na feliz expressão do prof. Miguel Couto, nenhum outro sinal da esquizotripanose apresentavam as pessoas suspeitas”.

Também neste ano, Carini e Maciel, do Instituto Pasteur de São Paulo, relataram mais um caso da infecção, expressando sua convicção de que a tripanossomíase humana descrita por Chagas em Minas Gerais "não está limitada a esta região; ela se estende, ao contrário, a uma vasta zona que se verifica cada vez mais considerável" (Carini \& Maciel, 1914a: 75). Apesar de sublinharem os muitos indícios da ocorrência de casos da doença, os autores assinalaram as dificuldades da confirmação experimental do diagnóstico clínico, já que “a constatação microscópica direta dos tripanossomas no sangue ocorre raramente e apenas em casos agudos" (Carini \& Maciel, 1914a: 76).

Carini e Maciel apresentaram, também, um levantamento detalhado da distribuição dos transmissores no território paulista. ${ }^{64}$ Segundo eles, "a difusão dessa praga se tem feito à custa dos trabalhadores nômades, colonos etc., que procedem de localidades já infectadas, transportando quase sempre nas vestes e mesmo em pequenos objetos as larvas do inseto (...)" (Carini \& Maciel, 1914b: 78-79). Este era um poderoso argumento para salientar a importância social e econômica daquela endemia num estado preocupado com a expansão da fronteira agrícola.$^{65}$ Fazendo um balanço de seus estudos, Neiva reiterava a dimensão americana da enfermidade, uma vez que seus transmissores - dos quais já havia identificado dezenas de diferentes espécies - estendiam-se do sul dos Estados Unidos até o norte da Argentina (Neiva, 1914). ${ }^{66}$

Nesses primeiros anos de produção de conhecimentos, a estreita associação entre as definições científica e social da doença expressou-se na própria tessitura dos textos e conferências de Chagas, por meio do entrelaçamento entre os enunciados de natureza médica, relativos aos processos cognitivos em curso, e as sentenças de natureza política e social 
que 'modalizavam' tais enunciados de maneira a conferir-lhes força no percurso de sua transformação em 'fatos' (Latour, 2000). Durante essa primeira fase, tal processo transcorreu basicamente nos espaços específicos da medicina e da ciência (os laboratórios, a literatura especializada, os congressos e, sobretudo, as associações médicas), ainda que com pretensões de atingir domínios mais amplos. Além da presença nas aulas de Miguel Couto, Miguel Pereira e outros aliados de Chagas, a inclusão da doença, em 1913, no manual de autoria do catedrático de higiene da Faculdade de Medicina do Rio de Janeiro (FMRJ), Afrânio Peixoto, indicava um caminho importante de propagação: o ensino médico. ${ }^{67}$

Entre 1916 e 1918, o processo de construção e legitimação da doença envolveria novas audiências, projetando-se em outros espaços do campo intelectual e, sobretudo, na arena política. Este foi o período em que, alcançando sua máxima visibilidade pública, a tripanossomíase passou também a ser objeto de dúvidas e questionamentos, lançados em 1914/ 1916 na Argentina e intensificados no Brasil entre 1919 e 1923.

O ano de 1913 foi um marco importante na configuração de certos elementos cognitivos que abririam espaço para tais dúvidas, conduzindo a um significativo redirecionamento nas estratégias de definição/afirmação da doença. Em setembro de 1912, o pesquisador do IOC Henrique Aragão, fazendo estudos em ratos, cobaias e coelhos, observou, no pulmão de animais que não estavam infectados pelo T. cruzi, as mesmas formas parasitárias (formas esquizogônicas) que Chagas considerava estágios evolutivos deste parasito, encontradas no pulmão das cobaias que ele infectara experimentalmente (Aragão, 1913). ${ }^{68}$ Diante disso, Chagas admitiu: "Somos levados a acreditar que as formas de protozoários referidas representam um outro parasito e não fazem parte do ciclo do $S$. cruzi” (Chagas, 1913b: 225).

Tal revisão teve um grande impacto. Num momento em que outras formulações sobre o parasito vinham sendo questionadas, ${ }^{69}$ ela invalidou o método utilizado por Chagas para diagnosticar parasitologicamente casos crônicos da doença (a detecção das formas esquizogônicas no pulmão das cobaias). Diante da situação, por incumbência de Oswaldo Cruz, Astrogildo Machado e César Guerreiro, pesquisadores de Manguinhos, apresentaram, neste mesmo ano, um novo método de diagnóstico, desta vez sorológico. ${ }^{70}$ Apesar de promissora, a chamada 'reação de Guerreiro e Machado' ainda dependia, entretanto, do esclarecimento e do aperfeiçoamento de vários aspectos técnicos relacionados à sua especificidade e 
à sua sensibilidade. Além disso, era um método que não identificava diretamente o parasito, mas apenas seus 'rastros' imunológicos. ${ }^{71}$

Chagas encontrava-se, assim, diante do desafio de recompor a credibilidade de seus enunciados clínicos, sobretudo quanto aos casos crônicos da doença (que, como vimos, eram a maioria). Ele não contava mais, nestes casos, com a base fundamental que, sob o paradigma microbiológico da chamada 'medicina de laboratório', garantia a certeza do diagnóstico: a comprovação da presença do agente etiológico. ${ }^{72}$ Como indicou Andrew Cunningham (1992: 216), "for infeccious diseases in general, without the pertinent micro-organism present there can be no instance of disease!". ${ }^{73}$ A ausência desta demonstração cancelava a própria idéia de uma doença específica. Nas palavras deste autor: "even if a patient appears do have all the symptoms of plague, yet they cannot be said to have plague until the laboratory has spoken" (Cunningham, 1992: $218) \cdot{ }^{74}$

Sob esta nova perspectiva imposta à pesquisa, o enquadramento da nova entidade nosológica seria marcado por novos contornos, novas ênfases e novas estratégias, não apenas cognitivas, mas também políticas, num momento em que, no contexto nacionalista da Primeira Guerra Mundial, as endemias rurais alcançariam grande repercussão no debate nacional.

\section{Notas}

1 Sobre o conceito de representação e os debates no campo da história cultural, ver Chartier (1990).

2 Chagas também adotava a denominação esquizotripanose em função do gênero Schizotrypanum, que havia proposto para o novo parasito (denominado então Schizotrypanum cruzi ou $S$. cruzi), em função de certas características de seu ciclo evolutivo. Para fins de uniformidade, manteremos a designação de Trypanosoma cruzi, à qual o próprio Chagas retornaria posteriormente.

3 Tratava-se de um inchaço/edema difuso, sobretudo da face, que foi considerado por Chagas como um sinal de hipotireoidismo, a evidenciar a ação patogênica do $T$. cruzi sobre a tireóide na fase aguda (Chagas, 1910a).

4 Chagas já estabeleceu, neste trabalho, a diferença entre os sintomas cardíacos da fase aguda e da fase crônica, observando que na primeira não havia alterações do ritmo cardíaco, como acontecia na segunda (Chagas, 1910a). É importante destacar este ponto, assim como outros aspectos relativos aos elementos cardíacos da doença, em função da importância que tais enunciados teriam, na década de 1940, para as pesquisas do grupo do Instituto Oswaldo Cruz (IOC) em Bambuí, conforme analisado no capítulo 7 . 
5 O bócio é uma doença associada ao aumento da região do pescoço, da qual há registros desde a Antiguidade. Com a descrição da tireóide no século XVI, passou a significar o crescimento incomum desta glândula e foi progressivamente associado a distúrbios como o hipertireoidismo e o hipotireoidismo. O bócio 'endêmico' (em contraposição ao bócio 'esporádico') diz respeito à situação em que a doença atinge expressiva porcentagem de uma população, numa dada região. Portadores de bócio endêmico também são acometidos de grave retardo físico e mental, sendo por isso denominados 'cretinos'. No século XVII, a definição de bócio como aumento anormal da tireóide e sua associação com o cretinismo endêmico estavam razoavelmente estabelecidas. A doença era descrita, sobretudo, nas regiões montanhosas dos Alpes europeus. Existem gradações na conformação física do bócio, sendo alguns casos percebidos apenas pela palpação e outros que se manifestam por grandes volumes no pescoço. Ao longo dos séculos, muitas teorias foram propostas para sua etiologia. Foi atribuída a condições geográficas e climáticas, como altas altitudes e intensa umidade e luminosidade. Tal concepção foi progressivamente abandonada a partir de finais do século XIX. Suspeitava-se também das águas consumidas e de fatores hereditários. Durante o século XIX, a maior parte das teorias sugeria alguma peculiaridade da água, fosse por contaminação ou pela deficiência de elementos químicos, como o iodo. A adição deste elemento ao sal de cozinha era testada como recurso profilático, mas permaneceria objeto de controvérsias. Ao final do século, cogitou-se que o bócio era uma doença infecciosa, provocada por algum agente ou toxina bacteriana. A deteç̧ão de iodo na própria tireóide, na década de 1890, recolocou a crença na deficiência química deste elemento, tese que só seria definitivamente aceita a partir da década de 1920, quando tiveram início campanhas de profilaxia baseadas na iodação. Em 1914, foi isolado o hormônio específico da tireóide, a tireoidina, que passou a ser administrado como recurso terapêutico (Sawin, 1999). A hipótese de Chagas seria duramente contestada a partir de meados da década de 1910 e, posteriormente, abandonada. Na década de 1950, teve início a primeira campanha de profilaxia do bócio endêmico no Brasil mediante iodação do sal de cozinha.

${ }_{6}$ Henrique de Figueiredo de Vasconcellos, pesquisador de Manguinhos, acompanhou Oswaldo Cruz nesta viagem a Minas e relatou que, em Belo Horizonte, o diretor de Manguinhos extraiu de alguns 'papudos' material para meios de cultura e outros exames, que, no entanto, não produziram resultados importantes. Tal relato encontra-se em ANM (1923d).

7 Neste trabalho, Chagas destacou que as extra-sístoles poderiam constituir uma arritmia particularmente evidenciadora desta condição clínica da doença: "Em alguns casos desta categoria [modalidade crônica], especialmente em adultos, são muito freqüentes as perturbações do ritmo cardíaco), sendo delas a mais constante o ritmo couplé (bi ou trigeminismo cardíaco, com extra-sístoles e repousos compensadores que bem caracterizam a natureza exata do fenômeno" (Chagas, 1910a: 264; grifo do autor). Esta é a primeira enunciação de Chagas sobre a forma cardíaca crônica da doença. Além dos distúrbios do ritmo, o coração pode sofrer alterações na circulação coronariana, provocando, por exemplo, o infarto do miocárdio.

8 Diplegia é uma paralisia bilateral dos braços e das pernas; disartria, articulação defeituosa da fala; afasia, perda da fala. 
9 Dizia Neiva: "Este hemíptero é conhecido em algumas zonas do Brasil (Minas, São Paulo, Mato-Grosso), pelo nome vulgar de 'barbeiro' e em outras (Mato-Grosso do Sul e em algumas localidades de S. Paulo) pela designação de 'chupança' ou mais raramente de 'chupão', nome pelo qual é conhecido em Goiás; no Rio Grande do Sul, segundo nos afirmaram, é o Conorhinus denominado vulgarmente 'fincão' e em alguns estados do Norte 'bicho de parede'. A área de disseminação parece cobrir todo o país, possuindo o Instituto exemplares provindos dos confins da Guiana Inglesa, de Minas, S. Paulo, Mato-Grosso e Goiás, e tendo ainda informações que lhe denunciam a presença nos estados de Sergipe, Piauí e Pernambuco" (Neiva, 1910: 206-207).

10 Gaspar Vianna (1885-1914) nasceu em Belém do Pará e interessou-se pela histologia já durante o curso médico. Logo depois de formado pela Faculdade de Medicina do Rio de Janeiro (FMRJ), em 1909, foi contratado como pesquisador de Manguinhos para substituir Rocha Lima nos estudos de anatomia patológica. Além das pesquisas sobre a doença de Chagas, destacou-se ao descrever, em 1911, a Leishmania braziliensis, parasito causador da leishmaniose tegumentar americana, e por estabelecer a ação do tártaro emético no seu tratamento. Em 1913, tornou-se livre-docente de anatomia patológica da FMRJ. Faleceu prematuramente, aos 29 anos, vítima de infecção tuberculosa aguda, contraída em acidente durante a realização de uma autópsia (Lacaz, 1963).

11 Ver Vianna (1911). Chagas praticava as autópsias em Lassance e enviava as vísceras para Vianna realizar os exames histopatológicos. A primeira foi feita em junho de 1910 com a ajuda de Belisário Penna (que trouxe os 'despojos preciosos' para Manguinhos pessoalmente). Para um relato das estratégias utilizadas por Chagas para conseguir proceder a estas autópsias, vencendo as resistências impostas pelas famílias, ver Discurso pronunciado pelo Dr. Belisário Penna na Academia Nacional de Medicina, em 15 de setembro de 1921. Fundo Belisário Penna, Série Trajetória Profissional (19210915).

12 Um reforço ao argumento anatomopatológico era sua confirmação por necropsias praticadas em cobaias experimentalmente infectadas (Chagas, 1911c; Vianna, 1911).

13 Em 1912, Chagas apontaria como um dos fatores a explicar "a raridade das infecções agudas" a possível "transmissão da infecção por herança ab ovo ou pelo contágio in utero" (Chagas, 1912b: 46).

14 Não abordarei a última forma, que diz respeito a sinais da fase aguda que voltariam a ocorrer na fase crônica, pois ela não teve grande impacto no quadro clínico e abrangia aspectos não aprofundados e pouco claros para Chagas, que se perguntava se expressariam "a revivescência do germe preexistente ou uma nova infecção, na hipótese de ter ele desaparecido" (Chagas, 1910b: 445).

15 O termo 'pseudomixedematosa' advinha, conforme Chagas, do fato de que o hipotireoidismo não assumia a intensidade característica dos casos em que a função da glândula é seriamente abalada (Chagas, 1910b: 433).

16 Chagas atribuiu este aspecto à maior virulência do parasito ou à menor resistência individual (Chagas, 1910b: 434).

17 Além destas duas formas clínicas tireoidianas, Chagas referiu-se como "fenômenos pára-esquizotripanósicos" aos adultos portadores de infantilismo (atrofia nos caracteres sexuais) ou de 'bócio antigo', que não apresentavam disfunção glandular 
e nenhum outro sinal, anatômico ou funcional, da doença. Tratava-se, segundo ele, de "conseqüências remotas da moléstia" (Chagas, 1910b: 445) - o que mais tarde denominou "estados consecutivos à esquizotripanose"-, resultantes de "lesões anatômicas definitivas ocorridas na fase do desenvolvimento" (Chagas, 1911c: 266).

18 Lesões ou processos inflamatórios atribuídos à ação do T. cruzi foram verificados não apenas na tireóide, mas também nas cápsulas supra-renais, nos ovários e nos testículos (Vianna, 1911).

19 Para Chagas, o cretinismo endêmico, associado ao bócio endêmico na Europa desde o século XIX, não fazia parte das manifestações clínicas da doença de Chagas. Os fenômenos neurológicos que integrariam o quadro sintomatológico da tripanossomíase eram, segundo ele, derivados não dos problemas endócrinos, mas da ação parasitária sobre o sistema nervoso central. Este era mais um aspecto que evidenciaria as diferenças entre o bócio parasitário, tal como acontecia em Minas Gerais, e o 'bócio europeu' (Chagas, 1910b: 434-435, 446).

20 No trabalho em que sistematizou os resultados de dez autópsias, Vianna destacou as alterações cardíacas, afirmando que "o coração é uma das vísceras de predileção do esquizotripano, quer no homem, quer nos animais" (Vianna, 1911: 278). Enfatizando a observação do parasito nos músculos estriados, assinalou: “(...) o músculo e o coração formam a pedra de toque para o diagnóstico histopatológico da moléstia de Chagas" (Vianna, 1911: 281).

${ }^{21}$ As três propriedades do coração são: excitabilidade (geração do estímulo elétrico), condutibilidade (condução do estímulo) e contratibilidade (bombeamento do sangue).

22 Sobre o bócio, os debates e as representações médicas acerca da degeneração do interior argentino no final do século XIX e início do século XX, ver Di Liscia (2005).

23 Sobre Miguel Couto, ver capítulo 1, nota 51. Miguel da Silva Pereira (1871-1918) nasceu em São Paulo e diplomou-se pela FMRJ em 1897. Professor substituto de clínica médica desta faculdade em 1907, tornou-se catedrático de patologia interna em 1908 e de clínica médica em 1910. Foi médico do Hospital Nacional dos Alienados (1904-1907). Presidiu a Academia Nacional de Medicina (ANM) de 1910 a 1911. Antonio Austregésilo Rodrigues Lima (1876-1960) nasceu em Recife e diplomou-se pela FMRJ em 1899. Em 1904, passou a trabalhar no Hospital Nacional dos Alienados e, em 1909, tornou-se professor substituto de clínica médica da FMRJ. Em 1912, assumiu a então criada cadeira de clínica neurológica desta escola. É considerado, juntamente com Juliano Moreira, um dos fundadores da neurologia brasileira. Foi eleito para a Academia Brasileira de Letras em 1914. Foi diretor do Instituto de Neuropatologia e Assistência a Psicopatas, presidente da ANM (1934-1937, 1945-1947, 1949-1951) e da Sociedade Brasileira de Neurologia, Psiquiatria e Medicina Legal. Antonio Fernandes Figueira (1863-1928) nasceu no Rio de Janeiro e formou-se pela FMRJ em 1887. Durante a administração de Oswaldo Cruz na Diretoria Geral de Saúde Pública (DGSP), dirigiu a enfermaria de doenças infecciosas de crianças no Hospital São Sebastião. Foi médico do Hospital Nacional dos Alienados. Presidiu a ANM entre 1907 e 1908. Em 1909, assumiu a direção da Policlínica das Crianças da Santa Casa da Misericórdia do Rio de Janeiro. Foi fundador, em 1910, da Sociedade Brasileira de Pediatria, tornando-se seu presidente perpétuo. Juliano Moreira (1873-1933) nasceu em Salvador, formando-se 
pela Faculdade de Medicina da Bahia naquela cidade em 1891, com uma tese sobre sífilis. Realizou vários cursos na Europa sobre doenças mentais e, em 1903, foi nomeado diretor do Hospital Nacional dos Alienados, permanecendo no cargo até 1930 e ali formando gerações de médicos psiquiatras. No mesmo ano, incentivou a promulgação da primeira lei brasileira de assistência a alienados. Em 1905, fundou com outros 'alienistas' e médicos legistas brasileiros a Sociedade de Psiquiatria, Neurologia e Medicina Legal, da qual foi presidente. Em 1910, participou da comissão encarregada da elaboração da primeira classificação psiquiátrica brasileira de doenças mentais e, em 1911, foi nomeado para a Diretoria Geral da Assistência a Alienados. Foi presidente de honra da Academia Brasileira de Ciências e vicepresidente da ANM. Ver Arquivo do Dicionário Histórico-Biográfico das Ciências da Saúde no Brasil (COC/Fiocruz), ANM (2006) e Lacaz (1963, 1966).

24 Na sessão de 13 de outubro de 1910 da ANM, Miguel Pereira relatou a viagem a Lassance e propôs que Chagas se tornasse membro titular da associação, em caráter extraordinário, já que não havia vaga. Alguns acadêmicos protestaram devido à falta de precedentes para a situação, propondo a concessão do título de membro honorário. Depois de intenso debate, a indicação de Pereira foi aceita (ANM, 1910a). Antonio Austregésilo, em entrevista ao Jornal do Commercio (1910a: 4), deu também o seu depoimento sobre a viagem, feita para que "a observação clínica do Dr. Chagas recebesse a nossa sanção".

25 Bruno Latour (1984: 95) usa a expressão "teatro da prova" para referir-se à estratégia de Pasteur de promover demonstrações públicas e dramatizadas de suas experiências científicas, cujo emblema foi a aplicação da vacina anticarbunculosa em carneiros feita, em 1881, em Pouilly-le-Fort.

26 Em seu depoimento sobre a ida a Lassance, Miguel Pereira apresentou, na ANM, desenhos sobre o ciclo evolutivo do T. cruzi e "uma preparação fornecida pelo Instituto de Manguinhos (...) em que se vêem o inseto, a larva, a ninfa e os ovos" (ANM, 1910a: 194). Quanto ao quadro clínico da moléstia, segundo ele "complexo, rico, opulento", comentou as formas cardíaca e nervosa, mas ressaltou: "Mais comuns são, porém, as formas mixedematosas e as formas de bócio. Quase nenhum doente deixa de apresentar o bócio. (...) É essa a forma que domina" (ANM, 1910a: 193; grifos meus).

27 Miguel Pereira, Antonio Austregésilo e Fernandes Figueira faziam parte do corpo clínico do Hospital Nacional dos Alienados, dirigido por Juliano Moreira. Miguel Couto também tinha interesse nesse campo e em 1917 se tornaria membro da Sociedade de Neurologia, Psiquiatria e Medicina Legal, vindo posteriormente a tornar-se presidente de honra da Liga Brasileira de Higiene Mental.

28 Além dos membros da ANM, outros médicos foram a Lassance conhecer de perto as pesquisas sobre a nova doença. Também por convite de Oswaldo Cruz, o professor da Faculdade de Medicina da Bahia, Clementino Fraga, esteve lá em novembro de 1910 e, no ano seguinte, em conferência na Sociedade de Medicina da Bahia, divulgou os enunciados de Chagas num importante espaço da tradição médica brasileira. Fraga realçou o papel de destaque de Oswaldo Cruz na orientação dos trabalhos desenvolvidos por Chagas. Além de propor que a doença se chamasse "moléstia de Cruz e Chagas", sugeriu que Cruz havia sido responsável pela hipótese sobre o bócio, reforçando ainda mais a relevância deste elemento no desenho da 
nova doença: "não me é estranho que foi Oswaldo Cruz quem teve a prioridade da etiologia parasitária do bócio, tendo no interior de Minas, vai, talvez, para mais de dez anos, levado a efeito pesquisas hematológicas nesse sentido" (Fraga, 1911: 474).

29 Conforme Nísia Trindade Lima (1999), como recurso metafórico para pensar o Brasil, o sertão - em oposição ao litoral - era concebido como um dos pólos de uma visão dualista que contrapunha o atraso ao moderno, a natureza à civilização, e que, remetendo à obra de Euclides da Cunha (1902), se tornaria estruturante de uma certa maneira de interpretar o Brasil.

30 Este filme foi doado por Carlos Chagas Filho ao acervo histórico da COC. Chagas em Lassance, 1910. (Setor de Imagem em Movimento, LVH 269 - COC/Fiocruz)

31 O médico militar Ismael da Rocha era grande entusiasta das doutrinas da medicina experimental e foi idealizador e diretor do Laboratório de Microscopia Clínica e Bacteriológica, inaugurado no Rio de Janeiro em 1896. Sob a jurisdição da Inspetoria Geral do Serviço Sanitário do Exército, este laboratório foi uma das primeiras instituições de microbiologia do país. Para uma análise desta reportagem publicada em $O$ País como exemplo emblemático de como os enunciados de Chagas circularam junto ao público mais amplo na época, ver Kropf (2008a). Também sobre a conferência de Chagas na ANM, ver Jornal do Commercio (1910b).

32 Anne-Marie Moulin (1996: 174) chama a atenção para esta "perspectiva global" da medicina tropical, que se traduzia numa "abordagem mais holista da doença", em contraposição a uma visão mais restrita implicada no modelo da microbiologia. Ao abordar os estudos e os programas de controle da tripanossomíase africana nas primeiras décadas do século XX, Helen Tilley (2004) analisa como a ecologia, em diálogo com a epidemiologia e a medicina tropical, introduziu, especialmente no período entre-guerras, novas questões e perspectivas quanto à complexidade das relações entre doenças e ambiente. A respeito da emergência de uma visão ecológica das doenças infecciosas, tributária dos estudos da medicina tropical sobre as intricadas relações entre patógenos, vetores/hospedeiros e ambiente e em contraposição à perspectiva reducionista dos 'caçadores de micróbios', ver Warwick Anderson (1994).

33 Paul Ehrlich vinha testando compostos contra tripanossomas. O marco principal de seus estudos - que se tornaria o símbolo das 'balas mágicas' da quimioterapia foi o Salvarsan, usado em 1910 para o tratamento da sífilis (Porter, R., 1999). Astrogildo Machado, pesquisador de Manguinhos, se dedicaria a testar diversos compostos químicos contra tripanossomas, na busca de algum que fosse eficaz para o T. cruzi. Em 1915, Oswaldo Cruz manifestou entusiasmo em relação a suas pesquisas nesse sentido (Cruz, 1972).

34 Em seu relato sobre a estadia em Lassance, Miguel Pereira comentou: "As casas cujas paredes são bem feitas não os hospedam [os barbeiros], como acontece com a do engenheiro residente, talvez a única nessas condições ali” (ANM, 1910a: 194). Neiva mencionava, além das melhorias habitacionais, a possibilidade de desinsetização: "O expurgo pelo emprego do gás sulfuroso deverá ser de grande utilidade" (Neiva, 1910: 211). Em 1915, Oswaldo Cruz reiterou que "encontra-se na modernização das construções e na supressão das chamadas 'cafuas', o meio seguro de extirpação da moléstia” (Cruz, 1915: 335).

35 O Correio da Manhã havia se destacado nas críticas às medidas implementadas para o embelezamento e saneamento da capital federal durante a gestão do prefeito 
Pereira Passos (1902-1906), que, segundo o jornal, prejudicavam, sobretudo, os setores sociais mais pobres da cidade (Beloch \& Abreu, 1984).

36 Para uma discussão que usa o conceito de intelligentsia (Mannheim, 1974) com o objetivo de analisar o discurso médico (especialmente o discurso sanitarista) como veículo de pensamento e interpretação do Brasil, ver Lima (1999). Como indicou Angela Alonso (2002), a análise da geração de 1870 implica o entendimento da estreita relação entre as idéias/teorias preconizadas por estes intelectuais e suas práticas no domínio da política, em seu sentido mais amplo, de ação/intervenção sobre o mundo, sob circunstâncias históricas específicas. Considero que esta é uma chave interpretativa interessante para se pensar os cientistas que atuaram em Manguinhos nas primeiras décadas do século XX.

${ }_{37}$ Neste trabalho, Chagas afirmou contar com 16 casos agudos nos quais identificou o parasito no sangue periférico. Nas inoculações em cobaias, declarou ter obtido, nos exames feitos com sangue de crianças, 40,8\% de resultados positivos. Nos exames feitos com sangue de adultos, este percentual foi de $42,1 \%$. Não foram fornecidas observações individualizadas destes casos (Chagas, 1911c: 274).

38 Sobre a repercussão da conferência na imprensa mineira, ver Diário de Minas (1911).

39 Desde o início do século XX, as elites mineiras compartilhavam de um diagnóstico pessimista quanto à estagnação e à decadência econômica e social do estado, com o declínio progressivo da posição relativa que este ocupava no cenário nacional, sobretudo em comparação ao vizinho paulista. O tema da 'recuperação econômica' passou a ser dominante na agenda política estadual. A consciência do atraso mineiro já havia se manifestado no final do Império, como evidencia o debate em torno da criação de uma nova capital, destinada a representar a retomada do progresso regional. Um marco importante destes debates foi o Congresso Agrícola, Industrial e Comercial, de 1903, onde se preconizou a diversificação da economia mineira, mediante a introdução de novas culturas para atender ao mercado interno, em contraponto à monocultura de exportação. Ainda que suas recomendações não tenham sido totalmente implementadas, esta orientação permaneceria como diretriz para a restauração econômica do estado, sendo reforçada na década de 1920 com a crise do modelo agrário-exportador e a Revolução de 1930 (Dulci, 1992, 1999; Borges, 1997).

40 Em 1912, Chagas apresentaria seus estudos sobre a doença também em São Paulo (Chagas, 1912b), outro estado em que os interesses de ordem econômica, associados ao incremento da produção cafeeira, seriam evocados como motivo de especial atenção da classe médica para o assunto, que logo se tornaria objeto de estudo por parte dos médicos locais. Ver Silva (1999).

${ }^{41}$ Neiva havia observado que os arreios dos cavalos serviam como um meio particularmente propício para que os barbeiros fossem levados a infestar novas localidades (Neiva, 1910: 212).

42 Além das perturbações tireoidianas, Chagas apontou deficiências ovarianas e supra-renais, propondo, para este último aspecto, a criação de uma forma clínica específica, o que seria formalizado em 1912 (Chagas, 1911b: 353-355).

43 Esta foi a primeira ocasião em que Chagas mencionou a possibilidade de a doença ser transmitida por herança, aspecto que reforçaria em seus trabalhos posteriores (Chagas, 1912b: 46). A descoberta, por Vianna (1911), do parasito no ovário e nos 
testículos de cobaias infectadas experimentalmente (num caso, junto a um espermatozóide) corroborava a hipótese.

44 Os doentes trazidos por Chagas de Lassance foram apresentados em aulas de Miguel Couto na FMRJ.

45 Esta primeira indicação ao Nobel foi feita pelo médico e pesquisador baiano Manuel Augusto Pirajá da Silva, que em 1908 publicara um trabalho identificando o Schistosoma mansoni (agente etiológico da esquistossomose intestinal) no Brasil. Sobre os detalhes desta e da segunda indicação de Chagas ao Nobel (feita para o ano de 1921), ver Coutinho et al. (1999).

46 O decreto n. 9.346, de 24 de janeiro de 1912, destinou também uma verba para combater e para prestar assistência aos doentes nas zonas atingidas pela doença, mediante a criação, no IOC, da Comissão de Profilaxia e Assistência Médica da Moléstia de Chagas. A idéia de Oswaldo Cruz era estabelecer "abarracamentos hospitalares móveis nos pontos mais assolados pela moléstia” (Benchimol, 1990a: 47) e enviar pesquisadores a várias regiões do país para mapear sua distribuição geográfica. Em 1913, os recursos não foram renovados, reaparecendo em 1914, ainda que num montante menor. A partir de então, a manutenção do hospital de Lassance (que foi incorporado ao patrimônio do IOC em 1918) e as obras do hospital de Manguinhos foram financiadas com a renda proveniente da venda da vacina da manqueira (Benchimol, 1990a; Benchimol \& Teixeira, 1993). O Hospital Oswaldo Cruz foi inaugurado em 1918 e, em 1941, receberia o nome de Hospital Evandro Chagas (atual Instituto de Pesquisa Clínica Evandro Chagas/Fiocruz). Ele constituiu, desde sua inauguração, a principal sede das investigações clínicas sobre a tripanossomíase em Manguinhos e hoje é um centro de referência nacional em doença de Chagas.

47 Em 1911, Chagas propôs o retorno do Schizotrypanum cruzi ao gênero Trypanosoma, em função de pesquisas de Astrogildo Machado, segundo as quais a esquizogonia era característica de outros tripanossomas além do cruzi. Desaparecendo assim a expressão esquizotripanose, Chagas mencionou como "muito apreciável" a sugestão de Lutz para que a doença passasse a ser chamada de coreotripanose, derivada de coris (percevejo), mas o termo não viria a ser, de fato, utilizado (Chagas, 1911c: 59).

48 Neste congresso de 1912, foi proposta a criação de um "comitê central de luta contra as moléstias tropicais", com sede no Rio de Janeiro, destinado a coordenar o combate à ancilostomose, à moléstia de Chagas, ao impaludismo e a outras endemias, em condições que ultrapassassem "o quadro estreito dos interesses locais e regionais", ou seja, em todo o território nacional. Esta seria a base de um "departamento geral e oficial de luta contra as endemias que nos assolam" (Congresso Brasileiro de Medicina e Cirurgia, 1912: 66).

49 Vale lembrar que Chagas havia comandado uma campanha de combate à malária em Xerém, na Baixada Fluminense (Rio de Janeiro), em 1907, e que Oswaldo Cruz, em 1910, fez o mesmo na Amazônia, onde a doença devastou os trabalhadores da ferrovia Madeira-Mamoré. A formulação citada de Chagas - que se aproxima da declaração, feita em 1918 pelo médico Afrânio Peixoto, de que o sertão começava ao final da avenida Central (Hochman, 1998: 70) - evidencia o quanto a noção de rural/interior/sertão assumia um sentido além de sua dimensão estritamente geográfica (Lima, 1999). 
50 Entre outubro de 1912 e março de 1913, por solicitação da Superintendência de Defesa da Borracha e nomeado por Oswaldo Cruz, Chagas percorreu o vale do rio Amazonas para estudar as condições de salubridade da região e indicar ao governo federal meios de combater a crise no extrativismo da borracha (ver Cruz, 1913). No Senado, ele expôs os resultados da expedição, denunciando o abandono médico e social em que viviam as populações da Amazônia e reiterando a necessidade de medidas sanitárias para viabilizar o desenvolvimento da região. Ao apontar os prejuízos econômicos trazidos, sobretudo, pela malária, fez especial menção à questão da fixação do homem ao solo: "Aquela Amazônia maravilhosa, que constitui uma das mais sólidas garantias do nosso futuro econômico, vai, no momento, irradiando de si malefícios incalculáveis, transformada num grande centro de decadência da nossa raça e de extermínio dos nossos irmãos. (...) O ideal daquelas gentes, do seringueiro infeliz, é a mais curta permanência naquele solo, dele desamado, porque lhe vai amesquinhando a vida e matando os filhos! Nada mais querem da terra, sempre madrasta, além da borracha" (Chagas, 1935e: 133). O argumento de que a malária produzia perdas econômicas substantivas foi amplamente utilizado pelos malariologistas no sul dos Estados Unidos, a partir da década de 1910, para convencer os negociantes, administradores de estradas de ferro e proprietários de terras quanto à necessidade de programas de combate à doença, que afetava diretamente o cultivo do algodão (Humphreys, 2001). Sobre as origens e implicações da concepção de que a malária constitui um obstáculo ao desenvolvimento econômico, ver Brown (1997). Sobre as expedições de Oswaldo Cruz e Carlos Chagas à Amazônia, ver Stepan (2003) e Schweickardt e Lima (2007).

51 Como mostra Alan Marcus (1988), a ancilostomose havia assumido grande importância no discurso médico norte-americano ao final da guerra civil, em um contexto de ampla discussão sobre a identidade da nação e de sua população, mais especificamente sobre as condições que faziam do sul uma região 'atrasada' e 'desviante' em relação ao norte do país. Afirmando que tais condições resultavam da decadência orgânica produzida pela verminose (ou seja, reinterpretando a situação social da região a partir de sua compreensão como problema de saúde), os médicos reivindicaram a possibilidade de 'regeneração' e incorporação do sul aos padrões da nacionalidade, legitimando sua própria identidade e seu papel social como agentes desta transformação. Outro interessante estudo sobre os sentidos atribuídos a uma enfermidade como elemento organizador de representações sobre a nação, estruturadas a partir de recortes/dualidades regionais, é o de Frank Snowden (2006: 7) sobre a malária como "doença nacional" na Itália, associada particularmente ao sul.

52 No Brasil, a Fundação Rockefeller criou, em 1917, o primeiro posto de tratamento e profilaxia da ancilostomose, em Rio Bonito, interior do estado do Rio de Janeiro (Faria, 1995, 2007; Castro-Santos \& Faria, 2003).

53 Na conferência em São Paulo, Chagas destacou o grande número de "mortes rápidas", especialmente em indivíduos jovens, "sendo realmente impressionante, nas estatísticas de letalidade, o número de pessoas falecidas repentinamente por síncope cardíaca". Este aspecto seria bastante valorizado, a partir de então, como elemento de especificidade e do impacto social da forma cardíaca crônica. Além disso, ele fez na ocasião a primeira referência ao uso do eletrocardiograma, ainda que sem dar mais detalhes (Chagas, 1912b: 53-54). Até então, seus trabalhos 
mencionavam traçados cardíacos obtidos mediante exames de natureza mecânica e não pelo registro elétrico dos batimentos. O eletrocardiógrafo - um galvanômetro de corda - foi desenvolvido entre 1901 e 1903 pelo holandês William Einthoven (ver Burnett, 1985). Cid Leme, com base em depoimento pessoal de Edgard Magalhães Gomes (um importante cardiologista dos anos 1940) atribui a Carlos Chagas "a prioridade do primeiro trabalho em eletrocardiografia publicado no Brasil" e afirma ter este adquirido, em 1910, o primeiro eletrocardiógrafo do país (Leme, 1981: 179).

54 A partir de 1912, Chagas deslocou a ênfase que vinha concedendo aos aspectos tireoidianos para fortalecer a idéia de uma "síndrome pluriglandular", em que a tireóide passava a ser uma dentre as várias glândulas afetadas pelo T. cruzi (Chagas, 1912b: 62).

55 Na conferência em São Paulo, afirmou: "Não conseguimos ainda, é certo, demonstrar de modo irrecusável a transmissão da infecção por herança ab ovo ou pelo contágio in utero. Temos, porém, diversas observações, que nos levam irrecusavelmente à convicção de que a tripanossomíase seja uma doença hereditária” (Chagas, 1912b: 46).

56 Como assinala Latour (2000), além das citações e referências, uma manobra poderosa utilizada pelos cientistas para fortalecer seus enunciados diante dos leitores é justamente 'mostrar' aquilo a que o enunciado se refere, através de figuras, gráficos, tabelas etc. Para uma discussão sobre o uso de fotografias e de outros procedimentos de representação visual na prática científica, ver Woolgar e Lynch (1990). Sobre o uso de fotografias e de imagens como fontes para a história da medicina e da saúde pública, ver Lacerda e Mello (2003). Sobre a importância das fotografias para a representação da doença de Chagas, ver Stepan (2001).

${ }^{57}$ O paralelo com a sífilis esteve presente desde os primeiros trabalhos de Chagas sobre a tripanossomíase. Ver Chagas (1910b: 425).

58 Associando o discurso médico sobre a sífilis ao projeto político-social de construção da nação, Sérgio Carrara (1996, 2004) analisa o processo pelo qual os sifilógrafos, na primeira metade do século XX, proclamaram a importância social da doença como fator de degeneração da população brasileira e objeto a ser contemplado por políticas públicas, ao mesmo tempo que forjavam sua própria legitimidade e seu campo de atuação profissional como especialistas responsáveis por este tema.

59 Havia um debate, no campo da psiquiatria, sobre a existência ou não de doenças mentais específicas de certas zonas climáticas, entre as quais os trópicos (Moreira \& Peixoto, 1906). Este é um aspecto particularmente interessante a ser estudado: o impacto que as questões trazidas pela medicina tropical tiveram sobre as discussões em torno da especificidade dos processos patológicos em campos de conhecimento médico não diretamente referidos àquela especialidade.

60 Documento encontrado no arquivo pessoal de Carlos Chagas, intitulado "Instruções para o estudo da distribuição geográfica da tireoidite parasitária”, orienta sobre o que observar em relação tanto ao inseto transmissor quanto aos possíveis casos da doença. Sobre a coleta de informações acerca das diversas formas clínicas, destaca: "Em todos os casos clínicos procurar as lesões da glândula tireóide". Apesar de não estar datado, pode-se presumir que tenha servido às expedições do IOC. Ver: "Instruções para o estudo da distribuição geográfica da tireoidite parasitária". FCC, grupo: pesquisa; subgrupo: doença de Chagas; atividade: formalização de procedimentos técnicos e métodos. 
Chagas, que recebeu o título de lente honorário da Faculdade de Medicina de São Paulo, foi agraciado com um busto em bronze de Pasteur, a partir de subscrição pública feita entre os médicos da capital e do interior do estado $(O$ Estado de $S$. Paulo, 1912).

62 Ver também Buralli (1985).

63 Sobre os critérios de diagnóstico empregados, ver Bayma (1914b).

64 Para a coleta do material, eles escreveram cartas aos moradores das principais cidades e localidades, solicitando que enviassem insetos conhecidos popularmente como 'chupança' (Carini \& Maciel, 1914b).

65 Num indício da preocupação com a dimensão econômica da doença em São Paulo, a revista paulista Chácaras e Quintais, que publicava trabalhos de divulgação científica de interesse para os fazendeiros e pequenos sitiantes, divulgou trabalhos de Rodolpho von Ihering (1911a, 1911b) sobre os principais conhecimentos a respeito dos barbeiros bem como sobre os meios de defesa possíveis contra "tão inoportuno e principalmente perigoso hóspede das casas dos colonos e caipiras" (Ihering, 1911b: 4).

66 Em 1912, Chagas havia comunicado uma importante descoberta para a compreensão dos aspectos epidemiológicos e da história natural da tripanossomíase americana: o tatu era um hospedeiro natural do T. cruzi e era a partir dele que o Triatoma geniculata adquiria e transmitia o parasito. Além de confirmar a hipótese de que outras espécies de barbeiros eram vetores do T. cruzi, o dado era importante por estabelecer a idéia de um ciclo silvestre da doença, que vinha se somar ao ciclo doméstico/domiciliar. A existência de barbeiros infectados no ambiente silvestre reforçava a apreensão de que o processo de povoamento do território fosse um meio de 'colonização' de novas áreas pelos vetores da doença, que sairiam das matas para domiciliar-se (Chagas, 1912c).

67 Também aqui, os principais traços definidores da doença eram o bócio e os aspectos neurológicos, ambos convergindo para a noção de 'degeneração': "tireoidite parasitária estudada em Minas recentemente (1911) por Carlos Chagas. Parece que é espalhada por vastas regiões, produzindo a papeira ou bócio endêmico do sertão, que definha e mata o indivíduo, degrada-lhe a geração, produzindo inválidos e cretinos muito numerosos" (Peixoto, 1913: 603). Sobre a profilaxia, Peixoto assinalava que deveria basear-se na substituição das "choupanas rudimentares" por casas "de revestimento uniforme, alisado o barro, senão caiado, de sorte a não dar guarida ao inseto transmissor". Quanto ao ataque direto ao barbeiro, mencionou o inconveniente, apontado por Neiva, da longevidade e da grande fecundidade do inseto, e concluiu: "sobre este assunto haverá muito ainda a investigar" (Peixoto, 1913: 604).

68 Carini, diretor do Instituto Pasteur de São Paulo, observara em ratos parasitados pelo T. lewisi as mesmas formas parasitárias. O casal Delanoe, no Instituto Pasteur de Paris, encontrou o mesmo protozoário em ratos livres de infecção pelo T. lewisii. Criaram então o gênero Pneumocystis e denominaram a espécie $P$. carinii.

${ }^{69}$ Conforme Delaporte (2003), a protozoologia alemã - sobre a qual se apoiavam os enunciados de Chagas - começou a sofrer nesta época vários questionamentos feitos por autores que estabeleciam novos preceitos para a compreensão do ciclo evolutivo dos tripanossomas. Entre eles estava Emile Brumpt, parasitologista francês que, em 1912, foi contratado para organizar o Departamento de Parasitologia 
da Faculdade de Medicina de São Paulo e passou a estudar o T. cruzi, sobretudo em sua evolução no vetor. Seus trabalhos contestariam vários aspectos da concepção de Chagas, entre os quais aquele referente ao mecanismo de transmissão da infecção. Brumpt (1912) afirmou que esta se dava não pela picada (como acontecia com grande parte das doenças transmitidas por insetos hematófagos), mas por contaminação mediante as fezes do inseto que continham o parasito (ao fazer suas refeições de sangue, o inseto deposita suas fezes, que penetram pela pele e pelas mucosas quando o indivíduo se coça). Este aspecto seria confirmado por Neiva e, de modo definitivo, por Emmanuel Dias. Sobre os estudos de Emile Brumpt a respeito da doença de Chagas, ver Opinel e Gachelin (2005).

70 Astrogildo Machado (1885-1945) foi um dos mais próximos colaboradores de Chagas nos estudos da tripanossomíase em Lassance, aos quais se integrou ainda como estudante do curso médico. Dedicou-se a investigações sobre a evolução dos protozoários (entre os quais o T. cruzi) e a pesquisas na área de química, testando produtos terapêuticos contra doenças provocadas por este e por outros parasitos. No campo da imunologia, além do método sorológico para o diagnóstico da doença de Chagas, produziu importantes aperfeiçoamentos na técnica de preparo dos soros produzidos em Manguinhos. Em colaboração com Alcides Godoy, desenvolveu em 1918 uma vacina contra o carbúnculo hemático. Era casado com a irmã da esposa de Chagas, com quem mantinha estreitas relações pessoais (Lacaz, 1966).

71 O método baseava-se na técnica da fixação do complemento, desenvolvida no Instituto Pasteur de Paris e que servira de base para o diagnóstico de diversas doenças, entre as quais a sífilis. Consistia na colocação de um antígeno do parasito no soro do indivíduo para, uma vez constatadas certas reações imunológicas (fixação do complemento) contra este antígeno, evidenciar a infecção pelo T. cruzi. O desafio era a escolha e o preparo do antígeno. Depois de vários testes, Guerreiro e Machado concluíram que o mais indicado era o extrato de baço de cães infectados. Diante da possibilidade de reação cruzada com a sífilis, era preciso realizar também um teste específico para esta doença (reação de Wasserman), para excluir a dúvida (Guerreiro \& Machado, 1913).

72 Em 1914, Brumpt aplicou o método do xenodiagnóstico para a infecção pelo $T$. cruzi. A nova técnica para a verificação parasitológica consistia em colocar barbeiros criados em laboratório (livres da infecção) para sugar o indivíduo e depois verificar, nas fezes do inseto ou mediante dissecação, a presença do parasito. O método podia ser aplicado tanto na fase aguda (nos casos em que o exame direto do sangue fosse negativo ou de difícil realização) quanto nos primeiros estágios da fase crônica (ainda que com menos sucesso nestes casos, já que, apesar da grande capacidade de sucção do barbeiro, a quantidade de parasitos no sangue torna-se mínima). Segundo Brumpt, pela familiaridade com o barbeiro e por ser sua picada indolor, seria mais fácil para a população rural submeter-se a este método do que permitir a coleta de sangue, tanto para o exame direto quanto para a inoculação em cobaias. Além disso, enfatizava o pesquisador francês, o transporte de um microscópio, geralmente a cavalo, para a realização destes exames de sangue em regiões remotas do interior "apresenta muitos inconvenientes" (Brumpt, 1914: 101). O xenodiagóstico só passou a ser usado sistematicamente a partir da década de 1930 (ver Emmanuel Dias, 1940). Não há referência ao seu emprego nos principais trabalhos de Chagas. 
73 “(...) para as doenças infecciosas em geral, sem a presença do microorganismo específico não há prova da doença!” - Tradução livre.

74 “(...) mesmo se um paciente parecer ter todos os sintomas da peste, ainda não se pode considerar que ele tenha peste até que o laboratório tenha falado” - Tradução livre. 


\section{Entre Dúvidas e Glórias: a tripanossomíase americana no foco da ciência e da política (1914-1918)}

Entre 1914 e 1918, a tripanossomíase brasileira foi posta no centro do debate científico e político, em distintos contextos. Pesquisas realizadas na Argentina trouxeram objeções importantes à caracterização clínica proposta por Carlos Chagas (sobretudo em relação às formas crônicas e à associação com o bócio) e à tese da vasta extensão da endemia. Apesar das vinchucas (barbeiros) infectadas com o Trypanosoma cruzi, os argentinos não conseguiam encontrar casos da doença naquele país e apontavam que, mesmo no Brasil, eram poucos os que poderiam ser efetivamente comprovados pela demonstração parasitológica. Em decorrência desta controvérsia, Chagas propôs, em 1916, uma expressiva revisão de seus estudos, diminuindo o peso que os elementos endócrinos tinham no quadro clínico da doença e esboçando novos caminhos de enquadramento para este objeto.

Também em 1916, teve início no Brasil um movimento que, numa direção oposta às incertezas no país vizinho, intensificaria como nunca a visibilidade e a força simbólica da doença, em meio à atmosfera nacionalista da Primeira Guerra Mundial. Ela tornou-se a bandeira de uma campanha que punha na ordem do dia o que Chagas já vinha propagando desde 1910: a centralidade das endemias rurais no debate sobre a nação. Entretanto, na retórica combativa do movimento pelo saneamento do 
país, a tripanossomíase americana foi disseminada - textual e visualmente - por meio dos elementos que vinham sendo postos em questão no terreno das discussões científicas: o bócio e as deformidades neurológicas, que atingiriam 'milhões' de indivíduos. Como uma conseqüência não prevista, a ampliação dos espaços sociais em que circulavam os enunciados sobre a doença e o sentido político que a fazia enquadrar, simbolicamente, a própria nação conformariam um terreno propício para que, entre 1919 e 1923, as dúvidas lançadas na Argentina fossem reeditadas, no campo médico brasileiro, com novos significados e motivações referidos às implicações assumidas pela 'doença do Brasil' no debate mais amplo sobre o país.

\section{Bociosos, Vinchucas e Nenhum Caso da Tripanossomíase: a controvérsia na Argentina (1914-1916)}

A Argentina foi um dos primeiros países a se interessar pelos trabalhos de Chagas. ${ }^{1}$ Em 1912, Carlos Maggio e Francisco Rosenbusch, do Departamento Nacional de Higiene, publicaram um breve trabalho relatando os estudos de uma comissão - da qual fazia parte também Nicolas Lozzano, que visitara o Instituto Oswaldo Cruz (IOC) para conhecer os estudos sobre a nova tripanossomíase - formada para investigar a presença da enfermidade naquele país. Destes estudos, contudo, derivariam as primeiras críticas à classificação clínica estabelecida para a tireoidite parasitária. Elas foram levantadas a partir das investigações lideradas pelo microbiologista Rudolf Kraus, da Universidade de Viena, que realizava pesquisas na Argentina desde 1913, e que, em 1916, assumiria a direção do então criado Instituto Bacteriológico do Departamento Nacional de Higiene, em Buenos Aires. ${ }^{2}$

Segundo Sandra Caponi (2002), os médicos argentinos, desde o século XIX, consideravam que, em função do clima temperado predominante, em especial, na região de Buenos Aires, as doenças mais importantes do país eram as mesmas das latitudes européias, daí sua resistência à incorporação da medicina tropical. Os estudos, assim, restringiam-se a identificar a presença de enfermidades infecciosas já conhecidas de autores europeus e referidas ao domínio da microbiologia. 
A criação do Instituto Bacteriológico, em 1916, teria significado, segundo a autora, uma tentativa de mudança em relação a este padrão, impulsionando estudos sistemáticos sobre as especificidades da nosologia argentina. O Primeiro Congresso Médico Nacional, realizado naquele ano, foi um marco importante nesse sentido. Segundo Araoz Alfaro, presidente do evento, até então só haviam ocorrido no país congressos internacionais, em que apenas os médicos de Buenos Aires se faziam representar, com trabalhos sobre os mesmos temas já discutidos na Europa. Como declarou na ocasião, este era o primeiro congresso "genuinamente argentino", com o objetivo de "investigar nuestras necesidades en materia de salubridad e higiene y estudiar nuestra patologia y nuestra climatologia (...)" (La Prensa Médica Argentina, 1916: 102; grifos do autor). ${ }^{3}$ O estudo do bócio na Argentina era uma preocupação central do Instituto Bacteriológico, que tinha como objetivo realizar um mapa sanitário do país. ${ }^{4}$ Kraus já havia estudado o tema na Europa.

Em junho de 1915, Kraus, Maggio e Rosenbusch publicaram um trabalho opondo-se à tese de Chagas segundo a qual o bócio endêmico, em regiões de infecção pelo T. cruzi, seria diferente daquele verificado na Europa e constituiria uma manifestação clínica da tripanossomíase. Em 1914, a partir de rastreamento feito pelo Departamento Nacional de Higiene em colaboração com médicos rurais, Maggio e Rosenbusch haviam indicado as áreas de maior ocorrência de vinchucas infectadas com o $T$. cruzi no território argentino. Na província de Salta, norte do país, que concentrava muitos casos de coto ('papo'), realizaram experimentos com animais de laboratório e, por meio de necropsias, encontraram o parasito no coração e em fibras musculares destes animais. Contudo, estudando o sangue de 13 indivíduos portadores de bócio e de outros sintomas descritos por Chagas (idiotia, aspecto mixedematoso), não obtiveram resultados positivos: nas cobaias inoculadas com o sangue destas pessoas, não encontraram o parasito nem no sangue, nem mediante necropsia. Cautelosos, observaram: tais "escasas investigaciones" ainda não podiam levar a excluir-se a ocorrência da tripanossomíase na Argentina, já que não haviam examinado casos agudos, nem realizado autópsias em supostos casos crônicos (apud Kraus, Maggio \& Rosenbusch, 1915: 2).

O que inquietava os pesquisadores era que, em certas províncias, havia vinchucas infectadas, mas nenhum bocioso (portador de bócio). Porém, nos doentes de bócio que examinou em áreas onde havia o vetor, Kraus não conseguiu identificar a presença do T. cruzi. Isso o levou, 
juntamente com aqueles dois pesquisadores, a "someter a un análisis la relación planteada por Chagas entre el bocio y las vinchucas". ${ }^{5} \mathrm{O}$ argumento fundamental da crítica que empreenderam era o de que o 'papo', bem como as manifestações tireoidianas e neurológicas consideradas como formas clínicas da tripanossomíase, não tinham qualquer relação com a infecção pelo T. cruzi, sendo sintomas do bócio e do cretinismo endêmicos descritos na Europa: "El punto principal (...) se refiere a la posibilidad de una distinción clínica segura entre bocio, cretinismo endémico y el cuadro clínico de las formas agudas y crónicas establecidas por Chagas (...)" (Kraus, Maggio \& Rosenbusch, 1915: 2).

O primeiro problema que indicaram nas pesquisas de Chagas foi o fato de terem sido feitas sempre em zonas montanhosas, onde o bócio é muito freqüente.

Para establecer un nuevo tipo de enfermedad que presenta mucha semejanza con el bocio endémico y cretinismo, hubiese sido necesario desde el principio buscar vinchucas infectadas, como también la enfermedad de zonas donde el bócio y el cretinismo endêmico es raro, o no existe, y no donde se les observa comumente, es decir, en las regiones montañosas. A consecuencia de eso se origina una causa de error, encontrandose así dificuldad a la distinción clínica entre la enfermedad de Chagas y el bocio endémico y el cretinismo. (Kraus, Maggio \& Rosenbusch, 1915: 2)

A escassez de evidências numéricas quanto à disseminação da doença foi detectada pelos autores nos estudos do próprio Chagas, nos quais não existiam referências à proporção de resultados positivos, obtidos para casos agudos, em relação ao conjunto das crianças examinadas. Isso não havia sido feito para os casos que apresentaram os sintomas tidos como típicos da fase aguda, nem para os 16 casos em relação aos quais Chagas afirmou, em 1911, ter verificado o parasito no sangue (Kraus, Maggio \& Rosenbusch, 1915).

Segundo Kraus e seus colaboradores, não se podia contestar a existência dos casos agudos estudados no Brasil. Uma vez excluídos os sintomas tireoidianos (como o mixedema e a hipertrofia da tireóide), as outras manifestações clínicas observadas por Chagas nesta fase (febre e tumefação ganglionar generalizada) poderiam ser, de fato, causadas pelo T. cruzi, já que o encontro do parasito no sangue "por si sola ya permite el diagnóstico" (Kraus, Maggio \& Rosenbusch, 1915: 3). 
A grande dificuldade residia na definição clínica proposta por Chagas para a fase crônica. Primeiramente, apontavam, "falta en la forma crónica la observación típica de los tripanosomas en la sangre, como se observa en las formas agudas" (Kraus, Maggio \& Rosenbusch, 1915: 3; grifos dos autores). Além disso, o método para verificação parasitológica, utilizado por Chagas para a fase crônica desde o início de seus trabalhos, havia sido refutado em 1913, quando se comprovou que as formas parasitárias encontradas no pulmão de cobaias infectadas experimentalmente pertenciam não ao T. cruzi, mas a outro protozoário (Aragão, 1913; Chagas, 1913b). Numa demonstração de como era primordial o diagnóstico etiológico, baseado na comprovação do parasito, os autores fazem uma pergunta que sintetiza o desafio enfrentado por Chagas: “Un nuevo problema se plantea al hacer la revisión de la descripción clínica de los casos crónicos. ¿Es posible, basado exclusivamente en la sintomatología clínica, efectuar el diagnóstico de la enfermedad de Chagas y diferenciar a esta del bocio endémico?" (Kraus, Maggio \& Rosenbusch, 1915: 4). ${ }^{6}$

Para Chagas, uma evidência das diferenças entre o bócio causado pelo T. cruzi e o bócio europeu era que, no primeiro, não havia a associação com o cretinismo endêmico, tão freqüente no segundo. De acordo com ele, as perturbações da inteligência e demais fenômenos neurológicos provocados pelo T. cruzi eram resultantes de lesões orgânicas no sistema nervoso e não dos distúrbios tireoidianos. Kraus e seus colaboradores questionaram tal argumento afirmando que a idiotia e outros sintomas atribuídos por Chagas à 'forma nervosa' (retardo físico e mental, paralisias, distúrbios da fala) eram encontrados em casos de cretinismo endêmico, que, conforme estudiosos europeus vinham indicando, englobava sintomas múltiplos e em graus bastante variáveis. Além disso, investigações começavam a identificar, em casos de cretinismo, lesões não apenas na tireóide, mas também no sistema nervoso, o que era mais um indício de que as desordens neurológicas descritas por Chagas não deveriam ser diferenciadas do cretinismo endêmico tal como encontrado na Europa (Kraus, Maggio \& Rosenbusch, 1915). ${ }^{7}$

Porém, Kraus, Maggio e Rosenbusch afirmavam que as autópsias praticadas por Vianna não haviam demonstrado a presença direta do parasito na glândula tireóide em nenhum caso, mas apenas lesões consideradas causadas por ele. Assim, o que Chagas via como indício seguro da ação do parasito não seria suficiente, pois não havia a demonstração da localização parasitária 'em si'. Esta só havia sido feita, de fato, no 
coração. "Las observaciones de Vianna, quien encuentra en órganos, por exemplo en el corazón y músculos, formas quísticas del tipo leishmania, explican las formas cardíacas, pero no los otros síntomas complejos de los casos crónicos, especialmente también por no encontrarse parásitos en las tiroideas" (Kraus, Maggio \& Rosenbusch, 1915: 5). ${ }^{8}$

Os autores lembraram ainda que Vianna só fizera referência ao encontro do parasito no sistema nervoso em uma autópsia de caso agudo e não em casos crônicos. ${ }^{9} \mathrm{E}$, para completar seu ceticismo, observaram que o número reduzido de autópsias e o fato de se tratar, em sua maioria, de casos agudos não permitiam deduzir conclusões gerais e não garantiam fundamento à descrição das formas crônicas (Kraus, Maggio \& Rosenbusch, 1915: 5).

Além de questionar o argumento epidemiológico da coincidência entre a distribuição dos vetores infectados e os doentes com hipertrofia da tireóide, Kraus, Maggio e Rosenbusch também puseram sob suspeição um outro pilar importante de sustentação dos enunciados de Chagas: o argumento anatomoclínico. A partir disso, argumentavam: "Nosotros llegamos a la conclusión, basados en este análisis, que la existencia de una enfermedad crónica, producida por el Schizotrypanum cruzi, con síntomas de bocio, mixedema, idiotez y diplegia, no ha sido demonstrada todavía en una forma irrefutable" (Kraus, Maggio \& Rosenbusch, 1915: 5). ${ }^{10}$

Em suma: os fenômenos tireoidianos e neurológicos que Chagas acreditava comporem a fase crônica da tireoidite parasitária corresponderiam, na realidade, a uma outra enfermidade já descrita. O bócio endêmico e o cretinismo a ele associado, afirmavam Kraus, Maggio e Rosenbusch, nada tinham a ver com o T. cruzi. Este era um assunto de "gran importancia práctica para el país", na medida em que "una lucha racional contra el bocio y el cretinismo en la República Argentina es sólo posible cuando la etiología se encuentre completamente aclarada" (Kraus, Maggio \& Rosenbusch, 1915: 5).

Kraus, Maggio e Rosenbusch, portanto, contestaram não apenas a descrição clínica das formas crônicas da doença de Chagas, mas também o principal critério usado para orientar a estimativa e a busca de casos. Tanto o conceito de tireoidite parasitária quanto a noção do 'selo da doença' foram confrontados. Impunha-se, assim, uma redefinição substantiva no desenho clínico da nova entidade mórbida: pelo menos até aquele momento, só se podia afirmar que esta era uma doença aguda e, mesmo assim, descartando-se os elementos tireoidianos que Chagas identificara nesta fase 
(como o mixedema). Isto posto, cabia então determinar a ocorrência destes casos agudos. O problema era que, na Argentina, a pesquisa do parasito no sangue de indivíduos nas localidades onde havia vinchucas infectadas continuaria a produzir resultados negativos. ${ }^{11}$

Em 1916, Kraus e Rosenbusch publicaram novo estudo, reiterando suas dúvidas e sugerindo uma hipótese que daria origem a muitas discussões no Brasil, alguns anos à frente: "la vinchuca infectada en la República Argentina, con mucha probabilidad, no produce la enfermedad de Chagas. La causa pode ser una atenuación del Trypanosoma por el clima” (Kraus \& Rosenbusch, 1916: 180). Em sua conclusão, salientaram, mais uma vez, a importância prática da questão. Uma vez afastada a etiologia parasitária do bócio e cretinismo endêmicos, não haveria motivo para que as autoridades sanitárias não iniciassem prontamente uma ampla campanha contra tais doenças, mediante os meios já adotados em outros países, como a administração do hormônio tireoidiano: “El tratamiento del bocio endémico y cretinismo con tiroidea prometeria una lucha eficaz" (Kraus \& Rosenbusch, 1916: 179).

A discussão em torno do bócio tinha significados peculiares no debate médico argentino. Di Liscia (2005) mostra que, num contexto internacional de 'confusão nosológica', no qual as fronteiras que definiam bócio, cretinismo e idiotia (e outras doenças mentais) como doenças específicas eram bastante fluidas, estas enfermidades eram investidas, desde o século XIX, de grande importância nas discussões sobre a identidade nacional e o papel da medicina na construção de um projeto de civilização na Argentina.

As categorizações médicas sobre as enfermidades mais proeminentes naquele país estavam diretamente referidas à caracterização das desigualdades econômicas, políticas e culturais que subordinavam o interior (vinculado às áreas rurais) ao litoral (associado ao urbano e, sobretudo, a Buenos Aires). Com base em dados estatísticos produzidos por censos nacionais, iniciados em 1869, passou-se a afirmar que, enquanto os imigrantes estrangeiros estabelecidos no litoral eram mais acometidos de 'neuroses e demência' (atribuídas, sobretudo, ao vício do alcoolismo), o bócio, o cretinismo e a idiotia eram enfermidades típicas dos 'nativos' do interior, particularmente dos mestiços. Esta classificação nosológica, apoiada em fatores ambientais, raciais e de gênero, levava à qualificação do interior e do rural como espaço do atraso, da incapacidade e da inferioridade (Di Liscia, 2005). ${ }^{12}$ 
A percepção desta situação gerou maior interesse no estudo de tais doenças e também um intenso debate, no campo científico e intelectual, sobre os destinos da população argentina. Este foi um caminho importante para afirmar a relevância da medicina e da ciência como responsáveis pela superação dos obstáculos ao progresso da nação. ${ }^{13}$ Ao final do século XIX, o surgimento, sobretudo na psiquiatria, de teorias sobre herança e degeneração trouxe a discussão sobre a possível natureza hereditária do bócio, do cretinismo e da idiotia, que passaram a despertar atenção entre os que se preocupavam com o 'futuro da raça'. Nas primeiras décadas do século $\mathrm{XX}$, o tema das deformidades físicas e mentais seria tratado nos marcos das teorias eugênicas, provocando intenso debate sobre a possibilidade de 'recuperar', mediante uma ação estatal assessorada pela medicina, aquela massa de população 'incapaz' e 'improdutiva' que poderia conduzir a nação à ruína. ${ }^{14}$

Contudo, assinala Di Liscia (2005), se o discurso médico enfatizava a importância de se estudar e enfrentar as doenças que comprometiam o progresso nacional, este era um assunto embaraçoso para os que enfatizavam os benefícios trazidos pela modernização e pela higiene na passagem do século e que, por isso, desejavam 'apagar' os estigmas da 'degeneração', mostrando o país como exemplo de salubridade e de civilização. Assim, o censo de 1914 eliminou de seus questionários a categoria de bócio e de outras enfermidades, como a idiotia e a demência, justificando que as melhorias sanitárias haviam feito diminuir substantivamente a sua ocorrência. Nesta tensão entre os que denunciavam os flagelos sanitários do país e aqueles que, em nome de uma visão mais 'otimista' e 'patriótica', opunham-se a expor tais mazelas (tensão esta que seria igualmente explicitada no debate brasileiro sobre a relação entre endemias rurais e identidade nacional), pode-se perceber, como assinala a autora, que, para além dos aspectos científicos que envolviam a pesquisa sobre o bócio na Argentina, esta era uma doença que mobilizava a classe médica também no que dizia respeito à sua inserção no debate político mais amplo sobre a nação (Di Liscia, 2005). ${ }^{15}$

Ironicamente, a mesma associação entre doença, degeneração, atraso, interior e identidade nacional, promovida na Argentina e no Brasil num período de grande debate nacionalista em ambos os países, gerou, a partir de 1916, dois movimentos opostos quanto à caracterização da doença de Chagas. Lá, ela foi questionada. Aqui, foi propagada intensamente na cena pública, no âmbito do movimento sanitarista. 


\section{A Resposta aos Argentinos}

Em setembro de 1916, Carlos Chagas posicionou-se publicamente diante das críticas de Kraus, em conferência no Primeiro Congresso Médico Nacional, realizado na capital argentina, anexo ao qual foi realizada a 1ํ Conferência Sul-Americana de Higiene, Microbiologia e Patologia. ${ }^{16}$ Depois de três anos sem publicações, Chagas faria veicular, além do artigo correspondente a esta apresentação, publicado numa revista argentina (Chagas, 1916a), dois alentados trabalhos sobre a classificação clínica da doença, sendo um deles exclusivamente dedicado à forma aguda (Chagas, 1916b, 1916c). ${ }^{17}$

A preocupação em responder às objeções e em reafirmar sua compreensão da doença pode ser percebida, de início, pelo fato de que, nestes textos, a designação de 'tripanossomíase brasileira' deu lugar à de 'tripanossomíase americana'. Numa ampliação semântica eloqüente, ressaltava-se que, contrariamente ao que sugeriam aqueles que apontavam sua ausência na Argentina, tratava-se de uma enfermidade que não se restringia ao país de sua descoberta. Entretanto, apesar de reiterar os conteúdos essenciais de suas principais formulações e hipóteses, a ênfase impressa por Chagas aos diferentes traços definidores da doença já não seria a mesma.

Em sua conferência na Argentina, reafirmou dispor de "un inmenso caudal de datos clínicos y experimentales" a fundamentar seus estudos e sublinhou que, mesmo no caso de revisão de alguns aspectos, nenhuma das dúvidas lançadas ameaçava o conceito geral da doença: “No importa la permanencia de puntos dudosos: la tripanosomiasis debe ser definida en aquellos aspectos etio-patogénicos y sintomáticos constantes que le son fundamentales y hacen de ella una de las humanas enfermedades de historia clínica mejor determinada" (Chagas, 1916a: 125-126).

Uma primeira questão dizia respeito às evidências anatomopatológicas da localização e da ação patogênica do T. cruzi. Rebatendo seus críticos, Chagas afirmou que havia verificado, tanto em casos agudos como crônicos, a presença direta do parasito nos diversos órgãos e sistemas orgânicos aos quais se relacionavam as formas clínicas da doença. A corroborar tal alegação, apresentou imagens de cortes histológicos do coração, da tireóide e do cérebro com indicação da presença do parasito. Uma ênfase particular foi dada à localização do protozoário no músculo cardíaco, não apenas em termos da quantidade 
de observações, mas também da natureza do processo patogênico: "Esta localización es quizá constante; por lo menos la hemos verificado siempre en todas las autopsias de casos agudos y en gran número de casos crónicos" (Chagas, 1916a: 126). Além disso, ressaltou, a ação do T. cruzi provocava processos inflamatórios tão intensos que chegavam a destruir completamente a fibra cardíaca.

Embora declarando ter feito a verificação parasitológica no aparelho endócrino, Chagas reconheceu algumas dificuldades importantes neste processo, num primeiro sinal de reversão da ênfase que até então concedera a este aspecto. Na tireóide, por exemplo, disse ter realizado tal verificação "en distintas necropsias de casos agudos", mas admitiu que a localização não representava "un hecho tan constante", ou não era tão facilmente identificável, uma vez que, por razão ainda incerta, os parasitos eram menos abundantes naquela glândula. Entretanto, isso não implicava desconsiderar a importância da ação parasitária sobre a tireóide, pois as alterações funcionais poderiam ser resultantes não da "acción directa irritativa" do T. cruzi, mas de toxinas por ele secretadas (Chagas, 1916a: 127)..$^{18}$

Este raciocínio fundamentava sua conviç̧ão quanto à especificidade dos sinais clínicos de deficiência tireoidiana na fase aguda da infecção (como o mixedema). Para Kraus, Maggio e Rosenbusch (1915), estes eram sintomas de distúrbios endócrinos 'simultâneos' à infecção pelo T. cruzi e não causados por ele. Já para Chagas, o mixedema era um dos sintomas clínicos mais freqüentes, se não constantes, nas formas agudas da tripanossomíase, apresentando-se de maneira "jamás observada en otra entidad patológica del hombre” (Chagas, 1916a: 138). Por esse motivo, era um dos principais critérios para o diagnóstico clínico diferencial da doença. Além disso, o mixedema não era o único sinal da fase aguda: "además de ese síndrome figuran otros para caracterizar la enfermedad y diferenciarla, con absoluta nitidez, de cualquier otra entidad nosológica” (Chagas, 1916a: 153). Assim, mesmo os que negavam a ação do tripanossoma sobre a tireóide (atribuindo o mixedema a outra causa) não poderiam negar a existência de outros sintomas que tornavam as formas agudas "fácilmente diagnosticables, aún antes de la verificación parasitaria" (Chagas, 1916a: 137). ${ }^{19}$

No trabalho publicado nas Memórias do Instituto Oswaldo Cruz sobre a fase inicial da infecção, Chagas (1916c: 39) detalhou tais sintomas, que tornavam "a facies de um caso agudo de tripanossomíase (...) quase 
sempre característica". Reiterou dispor de evidências anatomopatológicas que permitiam correlacionar tais sintomas à localização do parasito e às lesões por este provocadas. Como "sintomas constantes", classificou, além do mixedema: esplenomegalia, hepatomegalia, engurgitamento ganglionar generalizado, sinais cardíacos, febre e sinais de meningoencefalite nos casos graves. Como "sinais de exceção", enumerou: inflamações nos olhos, processos cutâneos, alterações nos testículos, decadência nutritiva progressiva e disfagia para alimentos sólidos e líquidos. Quanto a este último aspecto, especulou que a enfermidade popularmente conhecida como 'mal de engasgo' talvez fosse decorrência da ação parasitária do T. cruzi sobre o aparelho digestivo. ${ }^{20}$ Neste trabalho, em que aprofundou as considerações feitas na Argentina, foi apresentada a descrição de 29 casos agudos da doença, alguns documentados também por fotografias. ${ }^{21}$

No que diz respeito à caracterização da fase posterior ao período agudo, sobre a qual incidiam as contestações mais enfáticas de seus críticos, Chagas reafirmou, na Argentina, sua convicção de que a enfermidade por ele descoberta era de natureza essencialmente crônica. Excluídos os casos agudos mais graves e fatais, a grande maioria dos que contraem a tripanossomíase evoluem para esta segunda fase, em que, mesmo com a atenuação dos sintomas do período inicial, o organismo humano continua sofrendo permanentemente a ação do parasito, a partir de então abrigado no interior dos tecidos. Ao reforçar este enunciado sobre a evolução progressiva e irreversível da infecção, Chagas introduziu uma nova maneira de caracterizar sua importância médica: tratava-se de um mal que, contraído logo após o nascimento (e até mesmo antes dele, por transmissão hereditária), acompanhava os indivíduos por "toda sua existência”, mesmo que não se manifestassem sintomas muito pronunciados (Chagas, 1916a: 126).

Sobre as distintas formas clínicas que compunham a infecção crônica, apesar de reiterar o critério geral pelo qual havia formulado sua classificação original, anunciou, perante os argentinos, que havia feito algumas modificações. Ainda que sem dar mais detalhes, o que prometeu para "una próxima publicación", apresentou o que considerava "Ios sindromes crónicos más importantes" (Chagas, 1916a: 154). Anunciando um deslocamento fundamental na apresentação do quadro clínico da doença, que aprofundaria nos trabalhos seguintes, o destaque foi conferido aos aspectos cardíacos. 
Pode-se ver neste movimento uma simples estratégia de defesa diante dos argentinos, uma vez que a cardíaca era a única das formas crônicas sobre a qual não haviam sido lançadas dúvidas. Contudo, ainda que Chagas não abandonasse as outras formas clínicas (síndromes glandulares e forma nervosa), não mais as trataria como traços fortes no desenho da doença. Num rearranjo substantivo na hierarquia dos elementos constitutivos deste desenho, os aspectos cardíacos iriam, progressivamente, assumindo maior relevo. Este novo enquadramento da doença (definitivamente estabelecido e reconhecido na década de 1940) teve início, portanto, nesta conferência de 1916, mesmo que de modo ainda sutil, expresso sob uma ênfase discursiva. Disse Chagas:

Relacionada con las profundas alteraciones del miocardio, debido a las localizaciones del protozoario, el sindrome cardíaco constituye, en esa enfermedad, una de las más notables características sintomáticas y de la más notables curiosidades fisiopatológicas. (Chagas, 1916a:154)

Apresentando os conteúdos essenciais do que assegurou ser um 'capítulo definitivamente esclarecido' da doença, ressaltou tanto a confiabilidade dos dados experimentais que possuía a respeito como a relevância médico-social da questão. As arritmias produzidas pela ação do T. cruzi sobre o miocárdio, por sua freqüência incomum e por certas características não encontradas em outras cardiopatias (como a incidência de bloqueio do coração entre pessoas jovens, mesmo crianças), poderiam servir de importante critério diferencial para o diagnóstico clínico. Além disso, tratava-se de distúrbios que conduziam à morte repentina indivíduos jovens, aparentemente saudáveis. Este aspecto recebeu particular destaque como expressão da especificidade e das implicações médico-sociais desta forma clínica: mesmo quando não se exteriorizava em sinais mórbidos fisicamente explícitos, a forma cardíaca era responsável por elevado coeficiente de letalidade entre pessoas em idade produtiva.

En la zona contagiada, son pocas las familias que no hayan perdido alguno de los suyos. Mueren aún jóvenes, en plena actividad, con aparencia de buena salud. De este hecho poseemos abundantes observaciones: enfermos que fallecieron repentinamente en nuestros servicios, en los hospitales, sin que pudiésemos prever, en los síntomas físicos tan rápido desenlace. (Chagas, 1916a: 155) 
Em seguida à forma cardíaca, Chagas apresentou, nesta conferência na Argentina, suas formulações sobre as alterações neurológicas. Estas eram, juntamente com as formas tireoidianas, bastante contestadas. Quanto à fase aguda, afirmou que várias necropsias demonstraram a presença do parasito na "substancia nerviosa", estabelecendo, "de un modo definitivo", a patogenia dos processos inflamatórios. Já para a fase crônica, reiterou que em "varias autopsias" foram observados "focos parasitários y procesos inflamatorios en el encéfalo". Contudo, bem como no caso da tireóide, reconheceu dificuldades nesta verificação: "en las formas nerviosas antiguas (...) no siempre abundan focos parasitarios en los centros nerviosos, lo cual dificulta, no pocas veces, su observación”. Ainda assim, enfatizou, "los procesos histopatológicos, sin embargo, idénticos a los observados simultáneamente con la presencia de parásitos, son constantes y demuestran ser el tripanosoma Cruzi el factor etiológico indiscutible" (Chagas, 1916a: 155). ${ }^{22}$ Ou seja, tais distúrbios neurológicos não poderiam ser atribuídos ao cretinismo endêmico (ou à idiotia derivada do hipotireoidismo, descrita por autores europeus), como sugeriam seus críticos. A conclusão foi categórica: "Describiendo, en la enfermedad, alteraciones nerviosas, de ningún modo incurrimos en el error de considerar, como tales, simples aspectos clínicos del cretinismo" (Chagas, 1916a: 156; grifos do autor). ${ }^{23}$

Declarando que a análise das síndromes endócrinas crônicas seria feita em trabalho posterior, Chagas abordou então a controvertida questão da etiologia do bócio endêmico. Ao admitir que esta era uma 'questão discutível', reafirmou os argumentos essenciais de sua hipótese: a presença constante do mixedema na fase aguda (evidenciando o ataque do parasito à tireóide nos primeiros momentos da infecção), seu conceito geral sobre a evolução da doença (segundo o qual os processos iniciados na fase aguda se prolongam durante a fase crônica), os sinais clínicos que evidenciavam comprometimento da tireóide na fase crônica e, por fim, a coexistência destes sintomas com a presença de vetores infectados. Quanto a este último aspecto, deu destaque a relatos de expedições científicas do IOC:

(...) en los datos obtenidos en las excursiones científicas del Instituto 'Oswaldo Cruz', en todas las regiones, se observa la existencia simultánea de la endemia de bocio y de la triatoma megistus. Las observaciones de ARTURO NEIVA y de PENNA en Goyaz, Bahía y Piauhy y las de LUTZ y MACHADO en Minas y Bahía así la atestiguan. (Chagas, 1916a: 157) 
Apesar de manter sua interpretação sobre o bócio, minimizou, entretanto, o relevo deste sinal na fisionomia clínica geral da tripanossomíase. Apontou que a hipertrofia da tireóide era observada "en la casi totalidad de los enfermos", mas reconheceu que "no pocas veces es pequeno el aumento del volumen, a veces inapreciable” (Chagas, 1916a: 157).

Perante seus críticos na Argentina, Chagas anunciou sua disposição em não permitir que possíveis reformulações em alguns de seus enunciados comprometessem o conceito geral da tripanossomíase americana. Declarou: " $Y$ sí de aspectos dudosos, de interpretación indecisa de acuerdo con la divergencia de doctrinas existen en la historia de esta enfermedad, haremos con ellos otros problemas anexos, discutiéndolos por separado (...)" (Chagas, 1916a: 126). Em sua conclusão, enfatizou que, quaisquer que fossem os pontos de vista relativos à etiologia do bócio endêmico, permanecia "inconmovible, fundamentada en demostraciones indestructibles, la concepción clínica y parasitaria de la enfermedad" (Chagas, 1916a: 158).

\section{A Revisão: um novo desenho clínico para a tripanossomíase americana}

Em extenso artigo publicado, nas Memórias do Instituto Oswaldo Cruz, sobre os processos patogênicos da tripanossomíase americana, Chagas (1916b) procedeu a uma ampla revisão de seus enunciados sobre a fisionomia clínica da doença, com vistas a dirimir dúvidas e a estabelecer, definitivamente, a certeza sobre sua caracterização como entidade nosológica distinta.

Desejamos (...) eliminar do critério clínico toda confusão, acaso trazida pela deficiência de publicações anteriores. Nestas, (...) é possível tenham faltado a algumas interpretações elementos demonstrativos convincentes. Agora não; o acervo de fatos adquiridos autoriza considerar definitivas as principais conclusões, a que vamos chegar, ficando assim nitidamente individualizada a moléstia, no conjunto de síndromes que a observação e o estudo experimental evidenciaram. (Chagas, 1916b: 5)

O principal aspecto desta revisão foi apresentar um novo arranjo para as formas crônicas. Apesar de manter os procedimentos e conteúdos 
essenciais de seu esquema interpretativo, foi empreendida uma substancial reordenação na hierarquia e na visibilidade conferida aos distintos elementos conformadores daquela entidade 'multiforme'. Este arranjo foi o esboço de um novo enquadramento da doença, que se aprofundaria nos anos subseqüentes.

Um primeiro indício desta reordenação aparece na própria apresentação do sistema classificatório. Recolocando um princípio ao qual já havia feito referência, Chagas enfatizou que a divisão da doença em formas clínicas expressava "uma exigência didática", uma vez que, em função da unidade etiológica e da uniformidade dos processos patogênicos, não existiam diferenças essenciais entre elas. A distinção se justificava pelo fato de que, no organismo do doente, a ação do parasito se faz mais intensa sobre determinado órgão ou aparelho, gerando a predominância de determinados sintomas. Mas considerava "inconteste que nenhuma de tais formas nitidamente se separa das outras, pelo exclusivismo de alguma síndrome" (Chagas, 1916b: 6).

Porém, especulou: “(...) haverá exceções para invalidar essa doutrina?” (Chagas, 1916b: 7). Muitas vezes, os doentes não manifestavam sinais recorrentes no quadro clínico da doença. Ou seja, indivíduos em que predominavam alterações cardíacas não manifestavam sinais de comprometimento do sistema nervoso, assim como havia aqueles que exibiam sintomas cardíacos ou neurológicos "com ausência aparente de sinais indicando anomalias do sistema glandular" (Chagas, 1916b: 7). Contudo - e este é o ponto a ser ressaltado-, afirmou Chagas: "A recíproca, porém, não se verifica, isto é, nos doentes da forma nervosa ou naqueles da forma pluriglandular, a pesquisa minuciosa revela sempre alterações cardíacas" (Chagas, 1916b: 7; grifos meus). Ou seja: só a forma cardíaca poderia ser, ainda que raramente, autônoma. A afirmação foi feita com cautela, pois, segundo ele, os distúrbios neurológicos e endócrinos poderiam ter, nestes casos, escapado à observação.

O que importa reter desta passagem não é a discussão estrita sobre a possível autonomia das formas clínicas, mas o novo valor e a importância que passam a assumir os aspectos cardíacos. Neste trabalho, são eles (e não mais os aspectos endócrinos) que se destacam como elementos constantes. ${ }^{24} \mathrm{O}$ esvaziamento na centralidade até então conferida aos distúrbios glandulares - ainda que Chagas não os descartasse - pode ser observado também na própria mudança dos termos pelos quais ele os situou em sua nova classificação. 
Admitindo a necessidade de "interpretar de modo diverso as variantes da moléstia, ou, pelo menos, sistematizá-la com outros fundamentos”, Chagas decidiu conservar as formas cardíaca, nervosa e supra-renal, "definidas pela existência de síndromes clínicas bem salientes" (Chagas, 1916b: 18). No entanto, as formas pseudomixedematosa e mixedematosa, propostas em 1910, foram substituídas, respectivamente, pelas formas "indeterminada" e "hipotireoidiana".

Na forma indeterminada, estariam os casos crônicos relativamente recentes, "nos quais os grandes processos patogênicos apenas se iniciaram, não tendo ainda ocasionado as alterações anatômicas profundas, determinantes de síndromes clínicas definitivas" (Chagas, 1916b: 19). Em suas palavras:

(...) passam os doentes para uma condição crônica em que faltam ainda as grandes síndromes dos casos antigos. Só predominam aí sinais leves de insuficiência tireóide. No ponto de vista de alterações funcionais, essa condição (...) vai aos poucos experimentando modificações sensíveis, de modo a quase desaparecer, no fim de algum tempo. Por outro lado, algumas das síndromes notáveis na moléstia, como a cardíaca e a nervosa, já esboçadas neste período das formas crônicas, vão melhor se acentuando e acabam por dominar a feição clínica do doente. Assim, porque representam os pseudo-mixedematosos formas clínicas de passagem, devidas a processos patogênicos ainda em evolução e, sobretudo, sendo aí transitória essa hipofunção glandular que nos servia para caracterizar o aspeto clínico, pensamos acertado abandonar a denominação anterior. Melhor definindo os casos dessa natureza deles faremos a forma crônica indeterminada, para indicar a ausência de síndrome clínica predominante. (Chagas, 1916b: 19; grifo do autor)

A longa citação evidencia elementos discursivos significativos da minimização dos elementos endócrinos. Em 1910, Chagas já havia afirmado que, nesta fase, os sinais de hipotireoidismo eram 'leves', mas aqui ele acrescentou que eles tenderiam a desaparecer rapidamente. Além disso, é simbolicamente sugestivo que a forma na qual estaria reunida a maioria dos doentes tenha deixado de ter, como designação, uma expressão referida aos distúrbios endócrinos (forma 'pseudomixedematosa') para ser denominada 'indeterminada' ou 'de passagem'. Se, na definição desta forma clínica entre 1910 e 1913, enfatizava-se a presença (ainda que incipiente) do 'selo da doença' (o bócio), agora se salientava justamente o seu caráter 'inespecífico'. Se, até então, a hipofunção da tireóide era vista como sinal 'constante', agora seria referida como 'transitória'. 
Ao apresentar os motivos pelos quais mudou a designação de forma mixedematosa para hipotireoidiana, ${ }^{25}$ Chagas sintetizou o sentido de sua revisão: "na tripanossomíase a insuficiência tireoidiana é somente um dos elementos da moléstia e não constitui, por si só, a entidade nosológica" (Chagas, 1916b: 19). Esta é mais uma formulação a explicitar o movimento pelo qual os elementos tireoidianos passavam a constituir apenas 'uma parte' daquela entidade nosológica, que não apenas não se confundia com o todo, mas que poderia, inclusive, vir a ser descartada.

Outra modificação implementada neste trabalho foi a supressão da categoria 'fenômenos metatriponossômicos', entre os quais Chagas havia, em seus trabalhos iniciais, incluído o bócio antigo e o infantilismo. ${ }^{26}$ Declarando-se disposto a excluir "qualquer assunto passível de objeção e tudo quanto oferece campo à diversificação de doutrinas", apresentou tais questões como "problemas anexos à história clínica da doença". Tratava-se, segundo ele, de "conseqüências remotas" ou "síndromes tardias" da tripanossomíase, ocasionadas pela ação do parasito, durante as primeiras idades, sobre sistemas orgânicos vitais para o desenvolvimento do indivíduo (Chagas, 1916b: 20). Deste grupo passou, então, a constar a discussão da etiologia do bócio endêmico. Mantendo a posição expressa na Argentina, declarou:

A tripanossomíase é uma moléstia autônoma, de evolução ora aguda ora crônica, caracterizada por sintomatologia bem determinada e bem fundamentada em lesões histopatológicas. (...) O bócio endêmico, nas zonas infestadas pela tripanossomíase, é condição simultânea ou um elemento da infecção, segundo nosso conceito? Seja como for, a concepção clínica da moléstia não depende desse ponto, que será, quando muito, um problema discutível, anexo à história clínica da tripanossomíase. (Chagas, 1916b: 35; grifos meus)

Há que se esclarecer uma possível fonte de confusão: em seus trabalhos iniciais, Chagas havia considerado casos de bócio sob a designação de 'fenômenos metaesquizotripanósicos' ou 'estados consecutivos' à doença. É importante ressaltar, contudo, que isso dizia respeito ao que ele chamou de 'bócio antigo', ou seja, o aumento da tireóide em adultos que não apresentavam qualquer sinal da moléstia, gozando de boa saúde, o que não acontecia com os casos de 'bócio endêmico', em especial nas crianças e nos jovens. Naqueles trabalhos, a etiologia do bócio endêmico era discutida ao final dos textos como ponto separado, mas isso era feito 
de forma justamente a enfatizar tal aspecto. A questão não era desvinculada dos itens essenciais de sua caracterização clínica, mas ao contrário: a hipertrofia da tireóide era um dos sinais clínicos tidos como mais constantes e tangíveis, ainda que muitas vezes não se exteriorizasse em 'papos' volumosos.

Nesta reclassificação de 1916, o movimento é outro. O objetivo era, de fato, diminuir a força e o impacto dos traços endócrinos, particularmente tireoidianos, no quadro geral da doença crônica. Por um lado, isto era feito por um movimento de desvinculação: os pontos mais sujeitos a objeções, como a etiologia do bócio endêmico, eram deixados à margem, 'em anexo'. Por outro lado, de maneira mais sutil, tal efeito era obtido mediante operações discursivas de esvaziamento, como na adoção da expressão 'indeterminada’. Em suma, o objetivo era criar um novo quadro clínico que, apesar de trazer tais traços, não dependesse essencialmente deles e, portanto, pudesse ser mantido caso viessem a ser retirados.

Estes trabalhos de 1916, produzidos no contexto de uma controvérsia científica, representaram o início de um deslocamento substantivo no enquadramento da doença. Mesmo mantendo suas convicções sobre o comprometimento tireoidiano na infecção pelo T. cruzi, Chagas fez retroceder a ênfase que havia sido impressa aos sinais físicos que o expressavam. Numa operação discursiva bastante significativa deste esvaziamento, a partir de então, a doença deixou de ser referida, nos seus trabalhos e pronunciamentos, como 'tireoidite parasitária' ${ }^{27}$

\section{A Doença do Brasil e o Movimento pelo Saneamento dos Sertões: "três milhões de idiotas e papudos' (1916-1918)}

Ao retornar do congresso em Buenos Aires, Carlos Chagas e a delegação brasileira foram recebidos com grandes homenagens da classe médica do Rio de Janeiro. Tais deferências serviriam não apenas como manifestação de apoio e reconhecimento aos que haviam representado a ciência brasileira no exterior, mas como ocasião para conferir nova força e visibilidade à tripanossomíase americana como emblema dos males da nação. Na Faculdade de Medicina do Rio de Janeiro (FMRJ), aos 11 de outubro de 1916, em solenidade em homenagem a seu diretor, Aloísio 
de Castro, pela participação no encontro na Argentina, Miguel Pereira pronunciou um discurso em que afirmou: 'O Brasil é um imenso hospital.' Suas palavras ecoaram não apenas no meio médico, repercutindo também fortemente no debate político e intelectual mais amplo.

No contexto da Primeira Guerra Mundial, o momento era de grande fervor nacionalista e temas como a questão racial, a imigração, a educação e, sobretudo, o recrutamento militar, entrecruzavam-se na perspectiva de identificar as mazelas e as chances de 'regeneração' do país (Oliveira, 1990). Pereira fez das condições sanitárias dos sertões o eixo de sua crítica "[às] nossas desditas políticas e [às] nossas misérias administrativas" (Jornal do Commercio, 1916a: 4) e ironizou os que exortavam a população brasileira a engajar-se na defesa dos valores cívicos e patrióticos sem considerarem as reais condições de vida e de saúde no interior do país. ${ }^{28}$ Referindo-se a um discurso do deputado mineiro Carlos Peixoto, que declarara estar disposto a convocar os sertanejos de seu estado para servirem ao Exército brasileiro, ele ironizou:

É bem que se organizem milícias, que se armem legiões, que se cerrem fileiras em torno da bandeira, mas melhor seria que se não esquecessem nesse paroxismo do entusiasmo que, fora do Rio ou de S. Paulo, capitais mais ou menos saneadas, e de algumas outras cidades em que a providência superintende a higiene, o Brasil ainda é um vasto hospital. Num impressionante arroubo de oratória, já perorou na Câmara ilustre parlamentar que, se fosse mister, iria ele de montanha em montanha, despertar os caboclos desses sertões. Em chegando a tal extremo de zelo patriótico uma grande decepção acolheria sua generosa e nobre iniciativa. Parte, e parte ponderável, dessa brava gente não se levantaria; inválidos, exangues, esgotados pela ancilostomíase e pela malária; estropiados e arrasados pela moléstia de Chagas; corroídos pela sífilis e pela lepra (...). Não carrego as cores ao quadro. É isso sem exagero a nossa população do interior. Uma legião de doentes e de imprestáveis. Quais os soldados que o orador iria equipar? Os do seu estado natal? Mas foi exatamente ali que o descobrimento genial de Chagas, numa zona que se alonga e se dilata por centenas de quilômetros, revelou ao país, sem nenhum resultado prático ou conseqüência profilática, espetáculo dantesco de uma morbilidade fatal e progressiva que amontoa gerações sobre gerações de disformes e paralíticos, de cretinos e idiotas. (Jornal do Commercio, 1916a: 4)

Dias depois, Pereira fez novo discurso, em banquete oferecido a Chagas, no restaurante do Teatro Municipal. Dessa vez, sua denúncia 
sobre a calamidade sanitária dos sertões apareceu como corolário da louvação ao descobridor da enfermidade considerada uma das mais graves causas desta 'hecatombe'. Entre os sentidos desta louvação, estava o de desagravo. Em alusão ao embate de Chagas com Kraus, Pereira se referiu aos que "(...) em nome da ciência alemã, numa investida compacta, [começavam] a roer e esbrugar a vossa pirâmide, até achatá-la aos socos, onde apenas resistiria imune um pequeno acervo de formas agudas, produzidas por um parasito de discreta virulência" (Jornal do Commercio, 1916b: 3).

Como resposta aos que duvidavam da doença cuja designação mais conhecida - tireoidite parasitária - havia sido por ele próprio cunhada, Pereira acentuou a missão social dos "homens de ciência" que, como Chagas, haviam ido ao interior e revelado a realidade: um Brasil desconhecido, abandonado, doente, que só poderia responder aos clamores patrióticos por meio de "um exército de sombras". Na retórica política impressa ao discurso, a estimativa da disseminação da tripanossomíase ganhava números crescentes e tons hiperbólicos, reforçando a dualidade litoral/interior como eixo do olhar sobre a nação:

Da vossa moléstia, da tireoidite parasitária, continuam (...) a tombar as vítimas às centenas, aos milhares, aos milhões. (...) Ide, pastor sublime desse rebanho avariado, desenfurná-las todas e, rufando o tambor da misericórdia, em nome da Pátria, num apelo desesperado, formai as vossas densas legiões disciplinadas na regra do sofrimento e, à frente delas, numa marcha macabra, batei a todas as portas para que em cada lar desta capital, onde vivemos num egoísmo impiedoso, penetre o eco de um soluço, o vasquejo de uma agonia, a demência de um delírio, o riso de um cretino, a lamentação de um aleijado, a hediondez de um monstro. Seria esta a vanguarda espectral de um exército de sombras que não acabaria de desfilar, diante do país atônito, tanto que o grosso dele, arrastando-se do norte como do sul, de leste como de oeste, alimentado pelas endemias que nos devastam sem peias, à revelia de providências de qualquer ordem, não desertasse em massa, desde o Inferno Verde, de Alberto Rangel, até o extremo sul do país, as paragens varridas pela inclemência das lufadas mortíferas. Dizem que exagero (...). Não, meus caros colegas, não é através das vidraças de um hospital que todos nós, médicos e patriotas, trememos pelo futuro da Pátria. (Jornal do Commercio, 1916b: 3)

A denúncia, que desde o primeiro discurso na FMRJ já provocava polêmica, reconhecia em Chagas uma fonte primordial de inspiração e 
fundamento. Dirigindo a ele versos cunhados para Pasteur, Pereira sintetizou tal reconhecimento: “On n'aurait rien compris avant qu'il n'eut parlé". ${ }^{29}$ Agradecendo a homenagem, Chagas reiterou, enfaticamente, as declarações do colega, que qualificou como "magnífico painel de verdades melancólicas". Defendendo-o dos que condenavam como pessimista ou exagerada a imagem do país como "vasto hospital", apresentou seu próprio testemunho como estudioso daquele que representava, como vinha afirmando desde 1910, um dos grandes problemas sanitários do interior do Brasil.

Conheço, muito de perto, aqueles aspectos angustiosos da vida dos campos, fotografados na palavra do mestre. (...) Quanto à tripanossomíase brasileira, dela vos tenho falado muitas vezes, sempre com o objetivo de beneficiar as extensas zonas do interior do meu país, devastadas pela mortífera doença. Duvidais das cores negras com que descrevemos seus malefícios? Temos muito próximo a documentação conveniente, que evidencia a maior calamidade de nossos sertões. (...) Será acaso antipatriótico, meus ilustres amigos, evidenciar assim, com amplitude e sem reservas, a realidade de uma condição prejudicial ao nosso progresso? Cumpre salientar que nem Miguel Pereira, nem qualquer de nós, experimenta desalento ou dúvidas dos felizes destinos de nossa terra, quando desse modo nos expressamos. (...) Apontamos o mal para dele cuidar com maior presteza e todas as energias. Trabalhamos, desse modo, pelas gerações futuras, a quem poderemos legar nossa pátria cada vez mais gloriosa e enaltecida, além das belezas de uma consciência moral privilegiada, as perfeições de uma raça forte, capaz de grandiosos destinos. (Chagas 1935a: 7-8) ${ }^{30}$

O discurso de Miguel Pereira na FMRJ foi considerado, pela historiografia, o marco de origem da campanha pelo saneamento do interior do Brasil (Labra, 1985; Castro-Santos, 1985, 1987; Lima \& Britto, 1996; Lima \& Hochman, 1996, 2004; Hochman, 1998; Lima, 1999). Entre 1916 e 1920, o movimento reuniu médicos, cientistas, intelectuais e políticos em torno da idéia de que o atraso do país face às nações consideradas civilizadas não era resultado do clima tropical ou da composição racial de sua população, mas dos prejuízos causados pelas endemias rurais à produtividade do trabalho e do descaso do Estado com as populações do interior. Tal diagnóstico - fundamentado, sobretudo, nos relatos produzidos pelas expedições científicas do IOC - contrapunha-se à visão idílica do interior do país e de seus habitantes propugnada pela literatura 
romântica e mesmo pelo discurso médico. Como movimento de construção da nacionalidade, traduziu-se, politicamente, na reivindicação de que o Estado brasileiro aumentasse o poder e a amplitude de sua ação e regulação no campo da saúde pública. Com grande repercussão na imprensa, nos meios intelectuais e no Congresso Nacional, o movimento sanitarista, formalizado com a criação, em 1918, da Liga Pró-Saneamento do Brasil, conduziria a uma ampla reforma dos serviços sanitários, com a criação, em janeiro de 1920, do Departamento Nacional de Saúde Pública (DNSP), do qual Chagas seria o primeiro diretor. Como assinalaram Lima e Hochman (1996: 23):

Os conhecimentos dos médicos-higienistas sobre a saúde dos brasileiros e sobre as condições sanitárias em grande parte do território nacional, revelados ao público em meados da década de 1910, nos absolviam enquanto povo e encontravam um novo réu. O brasileiro era indolente, preguiçoso e improdutivo porque estava doente e abandonado pelas elites políticas. Redimir o Brasil seria saneá-lo, higienizá-lo, uma tarefa obrigatória dos governos.

Em diálogo com tais autores, argumento que tal concepção - de que as doenças dos sertões eram grandes obstáculos ao progresso econômico e social do país e à construção da nacionalidade - havia sido formulada já a partir de 1910, no contexto específico do processo de construção científica e social da tripanossomíase americana. Ainda que pautadas pelo debate nacionalista deflagrado, em meados da década, pelo conflito mundial, as declarações de Miguel Pereira também estavam referidas aos marcos particulares daquele processo, no qual o renomado médico havia desempenhado papel de destaque.

A historiografia aponta que o relatório da expedição de Arthur Neiva e Belisário Penna ao interior do país foi a motivação e base primordial para as declarações de Miguel Pereira. No entanto, o volume das Memórias do Instituto Oswaldo Cruz que divulgou este relato, apesar de referir-se ao ano de 1916, só seria editado quase dois anos depois. ${ }^{31} \mathrm{Em}$ carta a Penna, em 7 novembro de 1917, Neiva se queixou quanto à demora para que o relatório saísse da gráfica de Manguinhos. ${ }^{32}$ É certo que, ao fazer seu discurso, Pereira poderia já ter conhecimento do relatório, uma vez que o texto estava pronto desde meados de 1915. De todo modo, importa salientar que os traços essenciais do diagnóstico de Neiva e Penna já eram de conhecimento de Pereira, uma vez que já circulavam no meio 
médico, desde 1910, a partir das declarações de Chagas sobre a tripanossomíase e as demais endemias rurais.

No contexto do forte debate nacionalista de 1916, a denúncia do 'Brasil imenso hospital' se nutriu dos conteúdos e dos significados acionados pela doença que, posta em dúvida naquele momento na Argentina, havia sido referência essencial para esta noção de 'país doente', num processo acompanhado de perto por Miguel Pereira desde 1910. Tal associação foi indicada pelo próprio Belisário Penna, que salientou que Pereira "já estava perfeitamente informado" da extensão de várias outras endemias pelo país, inclusive por sua própria experiência clínica (A Noite, 1920b: 2). Segundo Penna, "a descoberta notável de Chagas (...) foi a gota que fez transbordar o cálice de indignação do grande mestre e levou-o à coragem de externá-la com a frase célebre, porque é dolorosa e profundamente verdadeira" (A Noite, 1920b: 2). ${ }^{33}$

A repercussão do discurso de Pereira reforçou, por sua vez, o processo pelo qual a doença de Chagas, 'emoldurada' como fato científico e social, servia de 'moldura' para a sociedade brasileira, gerando representações desta sociedade e também ações efetivas sobre ela. É nesse sentido que o discurso de 1916 deve ser considerado um marco: não por inaugurar a noção de 'Brasil doente', mas por conferir-lhe nova amplitude, para além dos círculos médicos e científicos, fazendo com que a partir dela se formulasse um programa concreto de intervenção e reforma social. Em dezembro de 1916, a Academia Nacional de Medicina (ANM) formou uma comissão para estudar e para promover os meios de saneamento contra as endemias do interior do Brasil, subsidiando o governo para tanto. Era composta por Carlos Seidl - diretor da Diretoria Geral de Saúde Pública (DGSP) -, Miguel Pereira, Miguel Couto, Afrânio Peixoto, Aloísio de Castro e Carlos Chagas. ${ }^{34}$ Em maio de 1918, um decreto assinado pelo presidente Wenceslau Braz criou o Serviço de Profilaxia Rural (Brasil, 1919b), para atuar, mediante comissões médicas formadas no Distrito Federal e nos estados, no combate às "três grandes endemias dos campos - uncinariose [ancilostomose], impaludismo e doença de Chagas" (Brasil, 1919c: 527). ${ }^{35}$ Sua direção coube a Belisário Penna, que, destacando-se desde fins de 1916 como liderança da campanha sanitarista, fundou, em 11 de fevereiro de 1918 (um ano após a morte de Oswaldo Cruz), a Liga Pró-Saneamento do Brasil, órgão oficial do movimento e que atuaria por dois anos, sendo suas atividades e diretrizes incorporadas ao DNSP em 1920. ${ }^{36}$ 
Os documentos de divulgação das idéias do movimento pelo saneamento rural do país tiveram um impacto decisivo sobre a trajetória de construção/legitimação da tripanossomíase americana. Neles, observamos uma configuração interessante do entrelaçamento das dimensões cognitiva e social implicadas na definição daquele objeto. Se, por um lado, num contexto de controvérsia científica, o desenho clínico da tripanossomíase americana passava por um reenquadramento, em que os traços que lhe tinham sido mais destacados (como os distúrbios endócrinos) perdiam sua centralidade, por outro lado o movimento político que, a partir de 1916, projetou a doença no debate nacional reforçava, justamente, um dos principais elementos que Chagas buscava minimizar: o bócio. No discurso sanitarista, ele continuaria a ser o 'selo da doença', por representar, juntamente com as desordens neurológicas, os efeitos dramáticos não apenas da tripanossomíase americana, mas da condição mórbida de todos os que pereciam no interior do país.

Um veículo decisivo para propagar esta representação foi o relatório da expedição científica de Neiva e Penna (1916). Para além de seu objetivo precípuo de mapear o quadro nosológico das localidades percorridas, a viagem produziu um amplo e detalhado inventário do ambiente físico e social de uma região inóspita e desconhecida do 'Brasil Central'. Revelando um quadro de doenças, miséria e ausência do poder público, os cientistas atualizaram a denúncia de Euclides da Cunha quanto ao isolamento e ao abandono que marcavam os sertões do país. O relatório constituiu, como acentua Lima (2003: 187), um "documento histórico referido à percepção dos intelectuais sobre a sociedade brasileira e seus contrastes", expressando a importância das viagens médicas e a participação ativa destes cientistas na formulação de interpretações do país. ${ }^{37}$ A tripanossomíase americana mereceu expressiva atenção na viagem e no relato de Neiva e Penna, como marco de referência tanto do que era buscado pelos cientistas quanto no que dizia respeito à dimensão política e social do quadro sanitário identificado ao longo do percurso.

Um dos objetivos da viagem havia sido encontrar evidências da importância epidemiológica da doença de Chagas. Com base nos estudos de Neiva sobre a presença dos vetores em outros pontos do Brasil e do continente americano (Neiva, 1910, 1914), esta era uma enfermidade, destacava o relatório, da qual há "toda a probabilidade de existir em outros países da América do Sul” (Neiva \& Penna, 1916: 117). Ao longo do trajeto, os cientistas localizaram diferentes espécies de barbeiros, 
realizaram exames para ver se estavam infectados pelo T. cruzi e descreveram suas características biológicas. ${ }^{38} \mathrm{~A}$ presença constante de cafuas indicava a existência de condições epidemiológicas propícias para a disseminação da doença transmitida por aqueles insetos: "Quase todos os domicílios, em todo o trajeto, ofereciam todas as condições para permitir a reprodução dos triatomas; a maioria é constituída por casas de adobe não rebocadas (...)" (Neiva \& Penna, 1916: 100-101). Reiterando observações já feitas por Neiva, o relatório registra que o trânsito dos viajantes contribuía para a disseminação dos barbeiros, "pelas cangalhas e outros acessórios de montaria, guardados dentro das moradias onde se hospedam" (Neiva \& Penna, 1916: 126).

Juntamente com as cafuas e os insetos transmissores, o bócio - que, em 1912 (ano da viagem), era visto como o principal sinal para a suspeita clínica de casos da doença de Chagas - foi o critério privilegiado para estimar a ocorrência da enfermidade. Os próprios autores explicitamno: "As indagações para obter informações visavam principalmente saber da existência ou não do 'papo' e da presença de 'bichos de parede', a fim de nos guiarmos sobre a relação de causa e efeito entre o bócio e os reduvidas hematófagos" (Neiva \& Penna, 1916: 118-119). ${ }^{39}$

Ao obter informações no Piauí de que a "moléstia de Chagas "pintava', isto é, dava esporadicamente no pitoresco dizer daquelas zonas”, Neiva e Penna seguiram procurando pistas da doença até que, "à medida (...) que nos aproximávamos de Goiás, os casos iam-se tornando mais freqüentes" (Neiva \& Penna, 1916: 119). Neste estado, eles encontraram o maior número de evidências da presença concomitante do bócio e dos triatomas (barbeiros) nos domicílios. Referenciando-se a textos de naturalistas e a relatos médicos sobre a ocorrência do 'papo' naquela região nos quais se apontava a ausência desta afecção entre as populações indígenas -, Neiva e Penna defenderam a idéia de que o bócio no Brasil, ou pelo menos em Goiás, era um mal posterior ao seu descobrimento, que "se propagou à medida que uma civilização atrasada ia substituindo uma condição social primitiva” (Neiva \& Penna, 1916: 123).

Segundo eles, naquelas regiões, o bócio não era decorrência nem da água, nem da alimentação, mas representava "uma relação qualquer entre o homem e o domicílio". Nas moradias dos índios e nas "residências bem construídas de civilizados", argumentavam, não há casos de bócio nem barbeiros. As observações sobre o 'papo' na capital de Goiás - de onde tal condição havia desaparecido com a modernização das casas, mas 
permanecia nas habitações de taipa dos subúrbios - também corroboravam a hipótese de que a habitação das "vilas sertanejas atrasadas" garantia o nexo entre o bócio e os transmissores da tripanossomíase (Neiva \& Penna, 1916: 123-124). ${ }^{40}$ Esta associação sustentava, por sua vez, a etiologia parasitária do bócio endêmico, proposta por Chagas. Os autores a defenderam, ainda que com reservas. ${ }^{41}$ Vale ressaltar que, por ocasião da redação do relatório (finalizada em julho de 1915), já circulavam dúvidas em torno deste enunciado de Chagas, sobretudo a partir dos trabalhos de Kraus, Maggio e Rosenbusch na Argentina. Assim, concluíam Neiva e Penna: "Ora, qualquer que queira achar uma relação de causa e efeito entre a presença de barbeiros e o bócio não deixará de encontrar bons argumentos em favor desta hipótese" (Neiva \& Penna, 1916: 123). ${ }^{42}$

Apesar da cautela, o bócio foi o critério clínico primordial a definir a presença da doença de Chagas no percurso da viagem..$^{43}$ Foi justamente ao descrever as localidades onde ela foi identificada por meio deste sinal-como em Goiás, nas quais "flagela em proporções nem de longe suspeitadas da Nação” (Neiva \& Penna, 1916: 117) - que os autores extraíram da 'tireoidite' todas as suas implicações como símbolo da degradação física e social das populações do interior, devastadas pelas endemias rurais. Sobre Porto Nacional, por exemplo, observaram:

(...) toda essa vasta região quase desabitada e com os costumes de três séculos atrás [é] habitada por uma raça cretinizada, na sua maioria, por cruel enfermidade evitável, incapaz e inaproveitável. Em palestras com os inteligentes frades dominicanos aqui residentes, os quais percorrem todo o Estado em propaganda religiosa, verificando a universalidade da terrível moléstia no Estado, sacrificando, de modo incurável, a inteligência, a virilidade e a saúde de milhares de infelizes, eles, apesar de toda a sua beatitude e santidade, concordam que Deus faria uma obra de misericórdia se chamasse todos esses infelizes à sua mansão celeste. (Neiva \& Penna, 1916: 212)

Dali para a capital de Goiás, a paisagem foi descrita em imagens que evocavam o abandono e a miséria dos sertanejos de todo o país. Mais uma vez a doença de Chagas foi a moldura para a triste composição:

A mesma solidão. Em todo o longo percurso, apenas três núcleos de população - Descoberto, Amaro Leite e Pilar, extremamente decadentes, com suas populações, na totalidade, constituídas de negros e mestiços, inutilizada pelo terrível flagelo que é a moléstia de Chagas, não atingindo nenhuma delas a 400 habitantes. Além 
desses arraiais, pequenos lugarejos de meia dúzia de habitações, algumas fazendas e pobres casebres esparsos à margem da estrada e à beira dos riachos, cujos habitantes são também, na sua maioria, pobres vítimas da tireoidite, da ancilostomose e do impaludismo. Enfim, a solidão, a miséria, o analfabetismo universal, o abandono completo dessa pobre gente, devastada moralmente pelo obscurantismo, pelas abusões e feitiçarias, e física e intelectualmente por terríveis moléstias endêmicas. A raça atual dessa região é inaproveitável. É habitual dizer-se, e nós mesmos já temos cometido esse pecado, que o povo sertanejo é indolente e sem iniciativa. A verdade, porém, é outra. A ausência de esforço e iniciativa dessa pobre gente é proveniente do abandono em que vive e da incapacidade física e intelectual resultante de moléstias deprimentes e aniquiladoras, cabendo nessas regiões à moléstia de Chagas a primazia desse malefício. (Neiva \& Penna, 1916: 220-201; grifos meus)

As fotografias tiradas ao longo da expedição, ao focalizarem variados aspectos físicos e sociais das regiões percorridas, potencializaram ainda mais a riqueza documental do relatório, funcionando como poderoso recurso persuasivo pela prerrogativa de reproduzir a 'realidade' flagrada pelos cientistas. Elas seriam decisivas para firmar 'uma certa maneira de ver' a tripanossomíase. Das 24 fotografias de doentes, 18 são referidas a esta enfermidade, o que expressa a centralidade que lhe foi conferida no painel das patologias do Brasil Central. ${ }^{44} \mathrm{O}$ 'papo', assumindo em alguns casos enormes volumes, é o traço mais saliente em praticamente todas estas imagens, associado ou não a perturbações nervosas (Imagens 13 a 16). Além disso, na medida em que somavam, aos retratos de Lassance, os rostos de doentes em outra região do país, tais fotografias atendiam ao objetivo que norteava os cientistas: demonstrar a amplitude e o impacto do mal de Chagas (Stepan, 2001).

Neiva e Penna, ao apresentarem dados que seriam vistos como fortes evidências da vasta distribuição da doença, trouxeram elementos decisivos para o desenho clínico e social desta entidade mórbida. Ao fixar e, sobretudo, ao difundir os traços pelos quais ela era reconhecida, o relatório imprimiu-lhe novo alcance no âmbito do debate mais geral sobre a nação. Com uma repercussão que ultrapassou as fronteiras do campo médico, num contexto em que ecoava o 'brado' de Miguel Pereira, o texto foi evocado como a base documental por excelência a legitimar as concepções e as reivindicações da campanha pelo saneamento do Brasil, que ganhavam as páginas dos jornais e a tribuna do Congresso. 
Entre novembro de 1916 e janeiro de 1917, Belisário Penna publicou, no Correio da Manhã, uma série de artigos em que expôs "sem subterfúgios, a dolorosa situação mórbida da população brasileira” (Penna, 1918b: 1). Eles deram origem ao livro Saneamento do Brasil, editado em 1918, como base para a fundação, neste mesmo ano, da Liga Pró-Saneamento do Brasil, entidade que, criada e dirigida por Penna, institucionalizou o movimento e à qual se filiaram vários intelectuais, médicos e políticos, inclusive o presidente da República Wenceslau Braz. ${ }^{45}$ Ainda em 1918, igualmente como coletânea de textos escritos para a imprensa diária, circulou o livro Problema Vital, em que Monteiro Lobato expressou sua adesão ao ideário sanitarista, sintetizando-o no célebre personagem do Jeca Tatu, como exemplo do impacto das doenças sobre os sertanejos e das possibilidades de sua redenção.

Sob uma retórica exaltada, Penna apresentou seu livro como "um brado veemente de protesto contra o abandono da gente e da terra patrícia, um ferro em brasa aplicado na úlcera corrosiva que se vai alastrando a todos os membros da nação" (Penna, 1918b: 4). O contexto da guerra trazia, como ele destacou, uma urgência ainda maior a que os poderes públicos se alertassem face à situação deste "país de doentes e analfabetos" (Penna, 1918b: 7) e tomassem providências para garantir "uma era de regeneração de sua gente, de reabilitação de sua terra e de moralização de sua política" (Penna, 1918b: 4), propiciando os meios de "salvação da nossa nacionalidade" (Penna, 1918b: 13). Entre as causas da "hecatombe" (Penna, 1918b: 13) em que se encontrava o Brasil, Penna destacou a desestruturação da produção agrícola, provocada pela abrupta abolição do trabalho escravo e pelo descaso de um regime republicano que privilegiava o "artificialismo" da indústria e do mundo urbano e preferia importar mão-de-obra estrangeira a investir na força de trabalho nacional. Além disso, rompendo com a unidade nacional garantida pelo Império, o regime federativo iniciado em 1891 teria, segundo ele, esfacelado a nação em "pequenas satrápias oligárquicas" (Penna, 1918b: 75) e, pelos vícios da "politicalha" (Penna, 1918b: 3), a mergulhara em profunda "falência moral e material" (Penna, 1918b: 79).

Declarando total apoio à "linguagem vibrante de verdade e de patriotismo revoltado de Miguel Pereira” (Penna, 1918b: 7), Penna conclamava a que se juntassem àquela campanha todos os

(...) que não se deixam mais iludir pelas fantasias e devaneios mentirosos de romancistas e poetas, descrevendo os nossos sertões 
como pedaços da terra da promissão, onde reinam a fartura, a saúde e a alegria, quando ao contrário são eles a sede da miséria, da doença, da tristeza e do aniquilamento físico e moral do homem, embora cercado às vezes de terras promissoras, de florestas viçosas e rios fertilizantes. (Penna, 1918b: 7-8)

Afirmando uma noção que a medicina social européia vinha enfatizando desde meados do século XIX, Penna (1918b: 36) assinalava que "economicamente o homem é um valor", pela sua capacidade de produção. Assim, a saúde deveria ser uma prioridade não apenas por razões de ordem humanitária e moral, mas por sua dimensão econômica. Considerando, na tradição de Alberto Torres, que a terra era "a única fonte de produção positiva e real do Brasil” (Penna, 1918b: 49), o líder da campanha sanitarista pontificava: "O problema econômico do Brasil está contido na necessidade inadiável de curar o homem rural, instruílo, fixá-lo e dar-lhe meios de alimentar-se convenientemente para que possa produzir o que produz um homem de saúde normal” (Penna, 1918b: 51).

Em outro livro, também publicado em 1918, Penna analisou, em contraponto ao Rio Grande do Sul, a "situação dolorosíssima de atraso e penúria” de Minas Gerais, seu estado natal, visto como maior representante da tradicional vocação agrícola do país, mas que se apresentava, antes de tudo, como o "estado da doença". O destaque conferido ao impacto da tripanossomíase, que, segundo ele, contaminaria "mais de uma terça parte" (Penna, 1918a: 11) dos cinco milhões de habitantes do estado, evidenciava o quanto esta era uma doença que servia de metáfora para o país e também para a região em que havia sido descoberta. O "cataclisma das endemias" era, conforme Penna (1918a: 6), uma das principais causas da decadência econômica mineira:

Dada a sua importância política, resultante de brilhante tradição; do peso do seu enorme eleitorado; do valor numérico da sua representação na Câmara Federal, igual às reunidas de S. Paulo e Rio Grande do Sul, da sua população de um quinto da de todo o país; e dada ainda mais a circunstância da excelência do seu clima, em geral, da riqueza do seu solo, da fertilidade das suas terras, da vastidão dos seus campos salubérrimos, da sua riqueza mineral, Minas é, sob o ponto de vista da precariedade da saúde, do definhamento da raça e da pobreza dos seus habitantes, o mais infeliz dos Estados da Federação Brasileira. (Penna, 1918a: 6-7) ${ }^{46}$ 
Um dos elementos de grande força discursiva dos textos de Penna era a autoridade evocada por alguém que se dizia fundamentado não em “informações escritas ou faladas”, mas em "verificação pessoal no norte, no centro e no sul do país" (Penna, 1918b: 7). Era com o tom incisivo desta fala autorizada que Penna imprimia à representação médica e social da doença de Chagas, por ele testemunhada desde a descoberta em Lassance, grande força persuasiva e efeito retórico. Nas suas descrições, esta era uma doença cujos contornos médicos revelavam um drama que ia muito além. A miséria da habitação que lhe servia de cenário era a síntese da miséria dos sertões que Penna e seus partidários desejavam denunciar e combater. Referindo-se à tripanossomíase, em Saneamento do Brasil, como "o mais temeroso dos flagelos endêmicos dos sertões" (Penna, 1918b: 9), asseverava:

Pobres párias, que vegetam na mais sórdida miséria, em ranchos de palha ou de taipa, inçados de barbeiros, de percevejos e piolhos, dormindo promiscuamente pais e filhos em giraus de paus roliços, sobre enxergas de palhas de buriti, sem noção de asseio rudimentar, sem utensis $[$ sic $]$ dos mais comezinhos até entre a gente pobre dos povoados, alimentando-se deficientemente (...). Esse é o quadro banal nas regiões do barbeiro. O Dr. Neiva e eu vimos no norte de Goiás quadros infernais, que só o grande poeta florentino poderia descrever, criando mais algum ciclo no seu famoso inferno. (Penna, 1918b: 10)

O enquadramento da enfermidade como a 'doença do Brasil' se fazia não apenas do ponto de vista do diagnóstico dos males da nação, mas das possibilidades de superá-los. Penna afirmava que, apesar de incurável, havia meios de preveni-la. Reiterando as colocações do próprio Chagas, afirmava: "Basta dar combate aos 'barbeiros', e esse combate consiste em construir as habitações de modo a não lhes dar abrigo, com paredes lisas, rebocadas e emboçadas, que sejam claras e arejadas, onde não haja frestas e esconderijos" (Penna, 1918b: 145). ${ }^{47}$ Este era um exemplo de como os poderes públicos poderiam, por meio da promulgação de "leis rigorosas sobre construção de casas rurais" e da destinação de verbas para "auxiliar os pobres nessas construções", intervir para solucionar os problemas das populações do interior (Penna, 1918b: 145, 147). ${ }^{48}$

Na narrativa de Penna, o testemunho pessoal, além do efeito de credibilidade, realçava a dimensão dramática do texto. Relatando os três anos que passou em "zona de barbeiro", ele lembrava: 
Certa ocasião apanhei em flagrante de sucção sangüínea, sobre o corpo de uma criança de quatro anos, 16 ninfas e oito barbeiros adultos, além de cinco, na cama, já repletos de sangue. Todos esses exemplares estavam infectados. (...) Sabendo-se que eles abrigamse aos milhares nas 'cafuas', pode-se imaginar a sangria diária a que estão sujeitos os habitantes de tais antros, já não levando em conta a inoculação do terrível parasito (...). (Penna, 1918b: 142-143)

Ao descrever o quadro clínico da doença, Penna afirmava que, das três formas crônicas, a forma cardíaca era a mais freqüente e de mais elevada letalidade, num indício de que já acompanhava a nova ênfase sob a qual Chagas apresentava o quadro clínico da enfermidade. Contudo, não deixava de realçar os outros elementos, como as perturbações da tireóide. A despeito das tentativas de Chagas de minimizar a força deste elemento, o bócio (acompanhado dos distúrbios neurológicos) permanecia, num contexto em que a dimensão política do assunto assumia sua máxima intensidade, o caminho mais direto para fazer 'aparecer', como salientou Stepan (2001), a realidade que se queria realçar. A seguinte passagem, em que Penna se remete à expedição de 1912, é exemplar:

Em todas as cidades de Goiás (inclusive a capital) e nas vastas regiões de Minas (...) onde abundam os 'barbeiros' contam-se às dezenas e às centenas os papudos, os idiotas e os aleijados, para só citar os doentes à vista de todo mundo, sem contar os numerosos atacados da forma cardíaca, com a existência presa por um fio, os quais nem sempre apresentam algum estigma exterior da moléstia. (Penna, 1918b: 145; grifos meus)

A inclusão, no livro, de fotografias de doentes contribuía para fixar e realçar esses traços. Uma delas focalizava os rostos de dois portadores de volumosos 'papos'. A outra trazia três indivíduos encostados na parede de barro de uma 'cafua', com pernas e braços atrofiados e visível aspecto de deficiência mental. Numa espécie de painel geral do quadro mórbido da doença, outra fotografia reunia, sob a legenda "grupo de doentes de várias formas”, enfermos do Asilo S. Francisco, em Goiás, nos quais se identificavam facilmente o bócio e/ou distúrbios mentais (Penna, 1918b: 141, 144, 96) (Imagem 16). ${ }^{49}$

Realçar os elementos que estavam "à vista de todo mundo" (Penna, 1918b: 145) era fundamental para garantir um dos principais objetivos que, tendo orientado a expedição que realizou com Neiva, encontrava-se presente também no livro de Penna: corroborar a noção de que a 
tripanossomíase ocorria em "vastíssima região do Brasil” (Penna, 1918b: 22). Citando as formulações de Chagas, ele acentuou: "Não há nenhum exagero nesses conceitos que vimos Neiva e eu, absolutamente e vastamente confirmados em Goiás. (...) Há localidades (arraiais) em que ninguém do lugar, literalmente, escapa à tremenda infecção” (Penna, 1918b: 144-145). Uma estratégia importante utilizada por Penna para a legitimação desta idéia - que, por sua vez, fortalecia a denúncia de que o Brasil era, de fato, um enorme hospital - foi traduzi-la em números. Segundo ele, cerca de $15 \%$ da população nacional estariam afetados pela tripanossomíase, ou seja, aproximadamente três milhões de brasileiros (Penna, 1918b: 96, 145). ${ }^{50}$

Contrastando com a escassa casuística documentada nos textos científicos, a escala da política colocava a dimensão epidemiológica e a dimensão social da doença sob um novo patamar. ${ }^{51}$ Num momento em que os pesquisadores na Argentina enfatizavam, justamente, a dificuldade em identificar novos casos da doença, estas cifras 'alarmantes' funcionavam como contraprova, ainda que o contexto que lhes desse sentido fosse o da política. Os interesses em torno da propagação, na cena pública, da idéia da onipresença das endemias no território nacional conformavam uma ocasião particularmente propícia para confrontar o enfraquecimento que a controvérsia científica com Kraus havia imputado aos enunciados de Chagas.

Penna fez menção às dúvidas existentes sobre a tripanossomíase, mas, num indício de como elas assumiam, no contexto brasileiro, uma dimensão política, tratou-as como questionamentos à própria campanha pelo saneamento do Brasil e àqueles que empunhavam tais bandeiras. Esta é mais uma evidência de como a moléstia de Chagas era o emblema não apenas das doenças do Brasil, mas daqueles que, em nome da ciência, diagnosticavam-nas e denunciavam-nas como problema nacional. Referindo-se às autoridades que não se impressionavam com os flagelos da população sertaneja e consideravam-nos conseqüência de "clima, raça e cachaça”, Penna (1918b: 146) ironizou:

Nem é para estranhar muito o fato, porque mesmo na capital do país, há conselheiros do governo, médicos com a responsabilidade de cargos muito elevados (...), os quais, por motivos inconfessáveis, dizem, não abertamente, mas por vias tortuosas, que a tripanossomíase americana é moléstia banal, sem gravidade, sem importância, e sem a extensão que lhe indicam os que percorrem o interior do país. Oswaldo Cruz, Gaspar Vianna, Carlos Chagas, 
Adolfo Lutz, Arthur Neiva, Astrogildo Machado, Leocádio Chaves, Eurico Villela e o autor deste livro são uns tipos exagerados, sem probidade científica ou profissional, e portanto sem probidade individual. Essas probidades todas, e mais a ciência e o poder de interpretação, constituem privilégio desse grupinho de vestais, demolidoras, por trás das cortinas, de reputações solidamente firmadas no trabalho árduo, constante, profícuo e patriótico, de uma instituição cuja reputação científica e produtiva ganhou a estima e o respeito de todos os países cultos do mundo.

A acentuação da face social e política da tripanossomíase americana encontrou outro importante veículo no livro de Monteiro Lobato. Em Problema Vital, publicado em 1918, os números apontados por Penna para o ‘cataclisma' sanitário do país ganharam ainda mais destaque, sendo estampados nos títulos dos artigos em que o escritor abordou as endemias da 'trindade maldita': "dezessete milhões de opilados", "três milhões de idiotas", "dez milhões de impaludados", (Lobato, 1956: 231, 239, 247). ${ }^{52}$ Sob a verve literária, a moléstia de Chagas ganhou cores ainda mais vibrantes como metáfora do Brasil. O barbeiro, "nojento percevejo tamanho como a barata", foi retratado como inimigo a atacar, insidiosamente, o sertanejo em sua própria casa, exaurindo-lhe as forças e energia vital:

Bebedor do sangue humano e de outros animais, o horripilante inseto noturno sai com as trevas da sua toca, aproxima-se das vítimas, distende o 'fincão' - tromba sugadora de fio navalhante espeta-o na carne do adormecido e suga-lhe o sangue até cair para um lado de panturra cheia. (Lobato, 1956: 239)

Citando a passagem em que Penna relatou o ataque de vários barbeiros a uma criança em Lassance, disse Lobato: "essa criança não é 'uma' criança, mas a criança do sertão brasileiro..." (Lobato, 1956: 240; grifos do autor). Sintetizando o cortejo clínico da doença tal como apresentado em Saneamento do Brasil, o escritor proclamou, em estilo a combinar o trágico e o cômico:

Três milhões - três milhões! - de criaturas atoladas na mais lúgubre miséria mental e fisiológica por artes de um baratão! (...) Três milhões de quantidades negativas, incapazes de produzir, roendo, famintas, as sobras da produção alheia - o que é pior, condenadas ao mau fado de viveiros do parasito letal para que bem assegurada fique a fartura e permanente contaminação dos sadios... (Lobato, 1956: 241-242) 
Lobato corroborou a ácida crítica de Penna à indiferença dos políticos e literatos quanto às conseqüências econômicas deste "deperecimento progressivo da população" (Lobato, 1956: 242). Pregava o fim do poder dos bacharéis ("Triatoma bacalaureatus", dizia, comparando-os, em sua ação 'vampírica', ao próprio barbeiro) e sua substituição, nos mais altos cargos da nação, pelos que de fato poderiam orientá-la: os cientistas. Se a 'doença do barbeiro' metaforizava a doença do Brasil, os que a haviam descoberto e a estudavam eram o símbolo do protagonismo público a ser desempenhado pela ciência nacional. De acordo com Lobato (1956: 244),

Manguinhos (...) já fez mais pelo Brasil do que um século inteiro de bacharelice onipotente. A salvação está lá. De lá tem vindo, vem, e virá a verdade que salva - essa verdade científica que sai nua de arrebiques do campo do microscópio, como a verdade antiga saía do poço.

As observações de Lobato evidenciam em que medida a amplitude assumida pelo movimento sanitarista teve como fator decisivo, como sugere Nara Britto (1995), a sacralização da figura de Oswaldo Cruz (falecido em fevereiro de 1917) como símbolo maior da ciência nacional, em sua imagem de porta-voz dos destinos da nação. Este processo certamente contribuiu para reforçar a centralidade que a doença de Chagas (considerada a grande vitrine da escola de Manguinhos) assumiu na campanha liderada por Penna.

Neste ano de máxima proeminência do discurso sanitarista, Chagas publicou, na Revista do Brasil, um artigo sobre a tripanossomíase americana (Chagas, 1918b). ${ }^{53} \mathrm{~A}$ ênfase incidia justamente no aspecto mais propagado pela campanha em prol do saneamento do Brasil: a importância econômica da profilaxia rural, que, no caso do combate à 'doença do barbeiro', deveria ser feita mediante a melhoria nas condições de habitação. Numa frase que seria reproduzida em vários artigos científicos e folhetos de divulgação da doença na década de 1940 e 1950 (quando o tema da profilaxia alcançaria grande projeção), Chagas afirmou: "o combate à tripanossomíase americana representa, em nosso país, um dos problemas sanitários de maior relevância, ligado aos mais altos interesses econômicos e ao aperfeiçoamento progressivo da nossa raça, nas zonas rurais" (Chagas, 1918b: 385)..$^{54}$

Se os médicos e cientistas brasileiros vinham, desde o século XIX, auferindo legitimidade pública mediante seu compromisso de responder às questões consideradas de importância para a sociedade, neste 
momento eles eram reconhecidos por sua capacidade de apontar tais problemas e também por suas aspirações de ocuparem um lugar junto ao Estado, a partir do qual, com autonomia, pudessem, de fato, ditar os rumos da nação. ${ }^{55}$ A trajetória de Carlos Chagas na vida pública, seguindo os passos de Oswaldo Cruz, foi um exemplo deste momento particular na institucionalização da ciência nacional e do papel que a descoberta e os estudos sobre a nova doença tropical empreendidos por Manguinhos desempenharam neste processo.

\section{Carlos Chagas na Cena Pública}

Nestes anos da campanha pelo saneamento do Brasil, não apenas a tripanossomíase americana alcançou grande visibilidade, mas o próprio Chagas foi alçado a uma posição de destaque no cenário nacional. Em 14 de fevereiro de 1917, três dias após a morte de Oswaldo Cruz, foi nomeado pelo presidente da República Wenceslau Braz para a direção do IOC, cargo que ocuparia até seu falecimento, em novembro de 1934. Em consonância com o modelo institucional estabelecido por Cruz, os vínculos das múltiplas atividades de pesquisa, ensino e produção com a saúde pública seriam fortalecidos, como expressão do compromisso social da ciência de Manguinhos. Esta associação personificava-se na própria figura de Chagas, que já no início de sua gestão tomou parte diretamente nas discussões visando a propor ao governo uma reforma dos serviços sanitários.

Em sua gestão no IOC, as investigações científicas continuaram privilegiando o campo da protozoologia, com ênfase nas endemias brasileiras e, em menor escala, nas doenças veterinárias. Para conferir maior formalidade às áreas de trabalho, Chagas criou seções científicas, definidas por campos do conhecimento, como química aplicada, micologia, bacteriologia e imunidade, zoologia médica, anatomia patológica, protozoologia e fisiologia. No que se refere ao ensino, ampliou o programa do Curso de Aplicação do instituto, voltado para a formação de pesquisadores no campo da microbiologia e da medicina tropical. Quanto à área de produção, diversificou a pauta de medicamentos e produtos biológicos, estimulando sua comercialização de forma a ampliar a renda própria do instituto, que, desde seus primeiros anos, era fundamental para garantir autonomia face ao orçamento do governo federal. Expressando o protagonismo do IOC na implementação de medidas preconiza- 
das pelo movimento sanitarista, organizou, em Manguinhos, o Serviço de Medicamentos Oficiais (Brasil, 1919a), criado por decreto de maio de 1918, mesma data em que se estabeleceu o Serviço de Profilaxia Rural (Brasil, 1919b). Destinava-se a fabricar e a fornecer quinina (para a prevenção e o tratamento da malária) e outros produtos terapêuticos, gratuitamente ou a preços subsidiados, aos postos de profilaxia rural, aos governos estaduais, às Forças Armadas e a empresas públicas e privadas. Em 1920, o instituto assumiria também a responsabilidade pelo controle da qualidade dos imunobiológicos fabricados ou importados pelos laboratórios nacionais e o Instituto Vacinogênico Municipal, responsável pela fabricação da vacina antivariólica, seria incorporado a Manguinhos. ${ }^{56}$

Chagas projetou-se na cena política também no terreno da saúde pública. Em fins de 1918, foi aclamado herói pela imprensa por sua dedicação ao combate à epidemia de gripe espanhola, cujos efeitos devastadores na capital federal contribuíram para amplificar ainda mais as denúncias quanto ao despreparo dos poderes públicos no campo da saúde. ${ }^{57}$ Tal repercussão pesou decisivamente na escolha de seu nome para dirigir a nova agência sanitária federal, o DNSP, criado pelo decreto n. 3.987, de 2 de janeiro de 1920, depois de intenso debate no Congresso Nacional. ${ }^{58}$ À semelhança de Oswaldo Cruz, Chagas acumularia a direção da saúde pública federal com a direção de Manguinhos. Ao concretizar a intenção de Epitácio Pessoa de fazer da reforma sanitária uma prioridade de seu governo, o novo órgão atendia as aspirações do movimento sanitarista. Tinha como diretriz ampliar a intervenção e a regulação do governo central na saúde pública, contrapondo-se ao modelo descentralizado baseado na autonomia dos estados, vigente até então (Hochman, 1998).

Da administração de Chagas no DNSP, que se estendeu até 1926, destaca-se a criação de um complexo e amplo código sanitário, que organizou e modernizou a legislação sanitária de saúde brasileira. Outra inovação foi a extensão das ações de saúde, até então concentradas nas áreas urbanas, ao interior do país, com o objetivo de promover, em especial, o combate às endemias rurais. Penna assumiu a então criada Diretoria de Saneamento e Profilaxia Rural. Chagas contou com a decisiva atuação da International Health Board (IHB) da Fundação Rockefeller, que, tendo enviado uma primeira comissão ao país em 1915, criou, a partir de então, postos de profilaxia da ancilostomose e da febre amarela em vários estados brasileiros e, em 1923, firmou um acordo de cooperação com o DNSP para ampliar esta atuação. Os cuidados com a maternidade e a 
infância, a assistência hospitalar e o combate à tuberculose, às doenças venéreas e à lepra foram também contemplados com a criação de órgãos e instituições especializadas. ${ }^{59}$

Outro aspecto importante da administração de Chagas foi o investimento na formação de profissionais especializados no campo da saúde pública, para o qual também contou com a colaboração e a influência da Fundação Rockefeller. Em 1923, foi fundada, na capital federal, a Escola de Enfermagem Anna Nery, primeira instituição para formação de enfermeiras em saúde pública do país (cujos cursos foram organizados por profissionais norte-americanas daquela fundação), e estabeleceu-se um sistema profissionalizado de enfermagem hospitalar no então criado Hospital São Francisco de Assis. Sob inspiração dos preceitos da Escola de Higiene e Saúde Pública da Universidade Johns Hopkins, criada com recursos da Rockefeller, Carlos Chagas organizou, em 1926, o Curso Especial de Higiene e Saúde Pública, como especialização anexa à cadeira de higiene da FMRJ. A responsabilidade técnica, didática e administrativa caberia ao IOC e a direção do curso ficou a cargo de Chagas. ${ }^{60}$ O objetivo era preparar médicos especializados em ações sanitárias, de modo a fornecer técnicos ao DNSP. Aos aprovados, estaria garantido o acesso direto, independentemente de concurso, aos cargos da administração sanitária federal. Este curso foi um marco importante na institucionalização e na profissionalização da carreira de sanitarista no Brasil e na afirmação de um tipo de sanitarismo voltado não apenas para o estudo e o combate às doenças, mas para o enfrentamento de problemas sociais (Fonseca, 2006, 2007; Castro-Santos \& Faria, 2006). ${ }^{61}$

A nomeação de Chagas para estes importantes cargos da ciência e da saúde pública federal reforçava sua consagração como cientista que, desde a descoberta em Lassance, tinha sua trajetória direcionada, com o apoio sistemático de Oswaldo Cruz, a trilhar o caminho que o tornaria herdeiro, não apenas da direção de Manguinhos, mas do que esta pretendia representar como projeto de ciência articulado a um projeto de nação. Contudo, a máxima projeção, assumida por Chagas e pela tripanossomíase americana, no domínio da política, ao mesmo tempo que expressava reconhecimento e legitimidade, impunha maior susceptibilidade e exposição a críticas, controvérsias e tensões.

Se por um lado servia de moldura ao brado dos sanitaristas, por outro a 'doença do Brasil' se tornaria o centro de uma intensa controvérsia, que recuperou as questões científicas debatidas na Argentina, mas 
lhes conferiu novos significados e implicações. No famoso episódio da 'polêmica na ANM', que marcou decisivamente as trajetórias da doença e de seu descobridor, a dimensão científica esteve imbricada, numa complexa trama de questões e intenções, aos conteúdos políticos que envolviam aquelas trajetórias. Também neste momento, a nova entidade mórbida identificada em Lassance evocaria sentidos muito além de seus contornos médicos. Os traços que estabeleceram de forma mais estreita a associação entre a doença e uma determinada maneira de pensar a sociedade brasileira foram o cerne dos questionamentos dos que colocavam em xeque sua própria existência como objeto científico e social.

\section{Notas}

1 Para uma análise sociológica da produção de conhecimentos científicos sobre a doença de Chagas e sua emergência/reconhecimento como problema social na Argentina, em distintos momentos históricos no século XX, ver Kreimer e Zabala (2006) e Zabala (2007).

2 Para instalar, neste instituto, a Seção de Zoologia Médica e Parasitologia, Kraus recrutou, em fins de 1915, Arthur Neiva, que permaneceria na Argentina até outubro de 1916. Sobre Kraus, ver Aquino (1921).

3 "Investigar nossas necessidades em matéria de salubridade e higiene e estudar nossa patologia e nossa climatologia" - Tradução livre.

4 Sobre a importância deste instituto para o desenvolvimento da ciência na Argentina, sobretudo no que diz respeito à associação entre pesquisas bacteriológicas e questões de saúde pública do país, ver Zabala (2007: 89-93).

5 No caso de citações extraídas dos artigos de Kraus e seus colaboradores, e também do artigo em que Chagas responde a tais críticas na Argentina, publicados originalmente em espanhol, não utilizarei o recurso da tradução livre, já que isso implicaria uma grande quantidade de notas, o que dificultaria a leitura.

6 Além da refutação deste método de diagnóstico da infecção crônica, o falecimento prematuro de Gaspar Vianna, em 1914, foi mais um fator de instabilidade para os estudos de Chagas, já que ele era o principal responsável pelas pesquisas histopatológicas sobre a ação e os 'rastros' do parasito nos distintos órgãos e tecidos.

7 A dificuldade na classificação dessas manifestações neurológicas, sintomatologicamente tão semelhantes, gerava, de fato, muita confusão na época. Era bastante comum, por exemplo, nas referências à doença de Chagas feitas por médicos e, sobretudo, por leigos, o uso de termos como 'idiotas', 'cretinos', 'imbecis' e 'retardados' como sinônimos de 'distúrbios mentais'. Desde o século XIX, a psiquiatria buscava estabelecer distinções entre tais categorias, ainda que com muitas dificuldades. Como aponta María Silvia Di Liscia (2005), ao analisar o discurso médico argentino nas últimas décadas daquele século, enquanto o retardo mental dos idiotas era classificado como a falta de condições básicas de desenvolvimento, tornando-os incapazes e improdutivos, os atributos específicos dos cretinos diziam 
respeito à degradação provocada por deficiências motoras, dificuldades de expressão lingüística e falta de respeito geral pelos costumes. Muitos incluíam esta anomalia entre as que caracterizavam os criminosos. Contudo, na prática, a distinção entre cretinos e idiotas era bastante sutil. Esta confusa terminologia predominou até a década de 1950, quando foi substituída por nomenclaturas baseadas no cálculo do coeficiente de inteligência.

8 Em 1914, Mayer e Rocha Lima já haviam levantado dúvidas quanto à presença do parasito na tireóide (Delaporte, 2003: 74). Além de observações do parasito no coração e nos músculos, Vianna fez referência à verificação do T. cruzi no sistema nervoso central em um caso agudo. Quanto às glândulas de secreção interna (tireóide, ovários, testículos e cápsulas supra-renais), identificou apenas lesões ou processos inflamatórios atribuídos ao parasito. Observou: "Não nos foi possível levar o nosso estudo a cabo neste assunto, deixando perfeitamente elucidadas as lesões de todas as glândulas" (Vianna, 1911: 287).

9 Chagas (1911c: 264), no entanto, referiu-se à verificação parasitária na "massa nervosa" em casos crônicos da doença e citou uma autópsia em que "o exame microscópico mostra: localizações parasitárias e focos múltiplos de infiltração no córtex" (Chagas, 1911c: 262).

10 Em trabalho publicado em 1913, o inglês Robert McCarrison, estudioso do bócio e que havia formulado a hipótese de ser este causado pela toxina de um germe intestinal, foi o primeiro a suspeitar da descrição clínica da tireoidite parasitária, sugerindo que a infecção pelo T. cruzi e o bócio endêmico eram duas entidades que poderiam estar correlacionadas, mas eram distintas (Delaporte, 2003).

1 Em 1924, uma comissão do Instituto de Doenças Tropicais de Hamburgo, convidada pelo Departamento Nacional de Higiene para estudar a malária na Argentina e chefiada por Peter Mühlens, identificaria os dois primeiros casos agudos da tripanossomíase americana naquele país (Mülhens, 1924).

12 Assim como no Brasil, os viajantes estrangeiros do século XIX já assinalavam uma alta incidência de 'cotudos' ('papudos') e cretinos no norte da Argentina, especialmente em Salta, o que era atribuído pelos médicos, entre outras causas, a fatores ambientais típicos das regiões montanhosas. Num contexto em que eram muitas as teorias européias para explicar as causas destas doenças, acreditava-se que o bócio era mais comum entre as mulheres - o que muitos atribuíam ao desgaste da tireóide sofrido com o 'trauma' do parto -, enquanto o cretinismo e a idiotia afetariam em sua maioria os homens, em função do maior tamanho de seu cérebro, que assim sofreria mais lesões derivadas da compressão dentro do crânio. Quanto à composição étnica/racial da população, as patologias caracterizadas pelo retardo mental, como a idiotia e o cretinismo, eram consideradas mais prevalentes entre mestiços ou índios do interior. Segundo Di Liscia (2005: 47), “(...) en las distintas menciones acerca de un número alto de personas com bocio así como de otras con disminuición mental, quizás estuviera latente una oposición 'histórica' a la campaña, a un 'interior' vagamente esbozado pero que se percibía peligroso, contrario al desarrollo económico y social propio de las grandes urbes del Litoral, junto con el estigma racial que acompañaria a esta caracterización".

13 Observando que os imigrantes estrangeiros do litoral nunca apresentavam o bócio, sendo esta uma doença comum entre os 'nativos', alguns médicos a consideravam 
uma doença própria do país, cujo estudo deveria ser priorizado, como base para a construção de uma "medicina patriótica" (Di Liscia, 2005: 41).

14 Neste contexto, intensificou-se a discussão sobre os direitos civis e políticos dos portadores de tais afecções mentais, como o de votar, servir ao Exército e, inclusive, o direito a reproduzir-se. Enquanto em alguns países europeus os portadores de bócio e cretinismo eram dispensados de servir às Forças Armadas, os médicos argentinos concluíram que o bócio só isentava do serviço militar os casos mais graves, mas que os cretinos não tinham condições psíquicas e físicas de obedecer a ordens (Di Liscia, 2005).

15 Dessa forma, ao ser contratado pelo Departamento Nacional de Higiene para mapear o quadro sanitário do país e propor soluções para enfrentar seus principais problemas, não por acaso Kraus conferiu especial atenção à questão do bócio e do cretinismo. Cabe lembrar que, em 1914, a tireoidina foi isolada e, como ele declarou, em seu trabalho com Rosenbusch, a perspectiva da profilaxia por meio da opoterapia (terapia hormonal) era uma cogitação naquele momento (Kraus \& Rosenbusch, 1916).

16 Sobre a participação brasileira no congresso, ver A Noite (1916a).

17 Na sessão preparatória do referido congresso, realizada no dia 18 de setembro, foram aprovados os estatutos da Sociedade Sul-Americana de Higiene, Microbiologia e Patologia. Entre outros objetivos, esta associação publicaria uma revista simultânea no Rio de Janeiro e em Buenos Aires, em espanhol, português, francês, inglês e alemão, tendo por diretores Rudolf Kraus e Oswaldo Cruz (Brazil Medico, 1916: 320).

18 Chagas já havia, em trabalhos anteriores, feito menção à possível ação de toxinas do parasito no caso do sistema nervoso central (Chagas, 1911c: 48), mas, nesta conferência na Argentina, realçou este aspecto, de modo a justificar que atribuísse as lesões observadas na tireóide à ação parasitária, mesmo nos casos em que o T. cruzi não era encontrado nesta glândula.

19 Ao mesmo tempo que insistia na confiabilidade dos critérios do diagnóstico clínico de casos agudos, Chagas apontava dificuldades no diagnóstico parasitológico mesmo nesta fase, em contraste com o que afirmara em seus trabalhos iniciais, quando salientou ser relativamente fácil observar o T. cruzi no sangue. Esta era uma forma de responder aos que acenavam com resultados negativos na busca daqueles casos: "Resulta de nuestra observación que en la gran mayoría de los casos clínicos solo podemos verificar flagelados en la sangre durante el período de tiempo menor de treinta días; y en muchos enfermos, después de ocho o diez días, los más demorados exámenes al fresco son negativos" (Chagas, 1916a: 126).

20 "Este sinal, de patogenia ainda mal esclarecida, relaciona-se talvez com a condição de disfagia conhecida pelo nome de 'mal de engasgo', endemia extensa em regiões do interior do Brasil e, segundo nossas observações, verificada principalmente naquelas zonas, onde é encontrada a tripanossomíase. Será o mal de engasgo um elemento mais da tripanossomíase brasileira (...)? (...) tornam-se precisas novas pesquisas que autorizem, de modo irrecusável, incluir o mal de engasgo na sintomatologia multiforme da infecção pelo Trypanosoma cruzi” (Chagas, 1916c: 43). No relatório da viagem que realizaram em 1912, publicado no mesmo volume da revista que editou este trabalho de Chagas, Neiva e Penna (1916) dedicaram particular atenção ao 'mal de engasgo' ou 'entalação', ainda que sem emitir a 
hipótese da etiologia parasitária. Chagas, entretanto, não prosseguiu nesta linha de investigação. A partir da década de 1950, o médico Joffre Marcondes de Rezende, que viu nas descrições de Neiva e Penna um reforço à sua conviç̧ão quanto à correlação entre 'mal de engasgo' e doença de Chagas, forneceria dados clínicos, epidemiológicos e sorológicos convincentes de que o megaesôfago e o megacólon eram causados pela infecção pelo T. cruzi na fase crônica (Rezende, 1956a). Sobre as resistências ao reconhecimento da etiologia chagásica do megaesôfago e megacólon endêmicos, ver Rezende (2001a).

${ }^{21}$ Antes disso, Chagas só havia apresentado a descrição individualizada de três casos clínicos (Chagas, 1909d).

22 Sobre a natureza, ainda não esclarecida, das lesões observadas nesta forma crônica, Chagas especulou se elas seriam resíduos da fase aguda ou conseqüências da ação do parasito num período posterior. Caso se verificasse esta última hipótese, a tripanossomíase seria similar à sífilis, em que as manifestações nervosas resultantes da localização do Treponema pallidum no sistema nervoso eram consideradas um fenômeno tardio, iniciadas em época distante da infecção inicial (Chagas, 1916a: 155).

23 O paralelismo com a sífilis, presente aqui com grande destaque, fortalecia a defesa diante das dúvidas em questão: “(...) ¿podrá subsistir la duda respecto de la etiopatogenia de los grandes sindromes nerviosos que hemos indicado en la enfermedad? Si así fuese, no nos damos cuenta del criterio exacto para interpretar los hechos en patología ni sabríamos donde hallar la lógica científica. Debemos aún llamar la atención sobre que ni siquiera los aspectos discutidos constituyen anomalías patogénicas, inaceptables por la ausencia de fenómenos similares. No: en la sífilis vamos a hallar hechos comparables en un gran sindrome resultante de la acción del treponema sobre los centros nerviosos" (Chagas, 1916a: 156).

24 Um indício da crescente importância conferida aos elementos cardíacos a partir de então foi o fato de que Carlos Bastos de Magarinos Torres - que havia se incorporado, ainda como estudante, à equipe do IOC que investigava a doença em Lassance e se tornaria um importante colaborador de Chagas - defendeu, em 1917, sob a sua orientação, tese de doutoramento na Faculdade de Medicina do Rio de Janeiro (FMRJ) sobre a forma cardíaca da tripanossomíase na fase aguda (Torres, 1917).

25 A nova 'forma hipotireoidiana' seria constituída pelos casos, menos comuns, de insuficiência da tireóide mais acentuada (Chagas, 1916b).

26 Infantilismo é uma condição em que persistem, no adulto, certos caracteres próprios da infância, com retardo no desenvolvimento, com ou sem nanismo, aparecimento tardio ou ausência de caracteres sexuais e, por vezes, retardo mental. O hipotireoidismo é uma de suas causas. Ver Rey (1999: 428).

27 Nos três trabalhos de 1916, o termo só foi usado uma única vez (Chagas, 1916b: 34).

28 A Liga da Defesa Nacional havia sido criada em 7 de setembro daquele ano, sob a liderança de Olavo Bilac. O poeta vinha, desde 1915, proferindo diversos discursos sobre a importância dos valores miltares - e, em especial, do serviço militar obrigatório - como caminho para a redenção moral e a coesão da nação brasileira. Em pronunciamento na Faculdade de Direito de São Paulo, em 5 de outubro de 1915, afirmou aos estudantes: "A caserna é um filtro admirável, em que os homens se depuram e apuram; dela sairiam conscientes, dignos, brasileiros (...)" (Bilac, 1917: 7). O discurso de Miguel Pereira e a repercussão que provocou estiveram 
diretamente associados a este debate. Os partidários do movimento sanitarista também endossariam a idéia de que os "corpos arregimentados" (Penna, 1920: 56) na caserna seriam um meio privilegiado de aplicação dos preceitos e das práticas da higiene. Para uma análise do intenso debate, no contexto da Primeira Guerra Mundial, em torno da questão militar e das representações e valores associados à figura do soldado como expressão da nacionalidade, bem como das relações entre este debate e a campanha sanitarista da década de 1910, ver Beattie (2001). "Nada teria sido compreendido antes que ele tivesse falado" - Tradução livre.

Para comentários de Chagas, na imprensa, sobre a repercussão da frase de Miguel Pereira, ver A Noite (1916b).

31 Dominichi Miranda de Sá (2004, 2009), ao analisar a repercussão pública do relatório de Neiva e Penna, indica que o texto começou a ser comentado na imprensa a partir de agosto de 1917 .

32 A carta encontra-se reproduzida por Cassiano Nunes (1999: XIII-XIV) na apresentação à reedição do relatório da viagem de Neiva e Penna, pelo Senado Federal, em 1999.

33 Reconhecendo a importância de Chagas na mobilização que culminaria na criação da Liga Pró-Saneamento do Brasil, Belisário Penna (1918b: 104) citou seu discurso no VII Congresso Brasileiro de Medicina e Cirurgia, de 1912 (Chagas, 1912a), e afirmou: "Avisos, de gente autorizada, já haviam sido dados ao governo, relativamente à precariedade de saúde da população rural".

34 A comissão se reuniu pela primeira vez em janeiro de 1917, elegendo, para seu presidente, Oswaldo Cruz. Falecendo um mês depois, ele não chegou a colaborar com o grupo (Hochman, 1998). O relatório da comissão, de setembro de 1917, encontra-se reproduzido em Souza-Araújo (1956: 256-257).

35 O serviço foi reorganizado e ampliado mediante decreto de abril de 1919. Ver Brasil (1920).

36 Belisário Penna (1868-1939) nasceu em Barbacena, Minas Gerais, e formou-se pela Faculdade de Medicina da Bahia em 1890. Vereador em Juiz de Fora até 1903, assumiu, no Rio de Janeiro, o cargo de inspetor sanitário da DGSP, sendo designado, em 1905, para a Inspetoria de Profilaxia da Febre Amarela. Depois de tomar parte em várias comissões científicas para estudar e para combater doenças em distintas regiões do país (como a que o levou a Lassance juntamente com Chagas), voltou a atuar, em 1914, como inspetor sanitário no Rio de Janeiro, instalando um posto de profilaxia rural no subúrbio carioca de Vigário Geral. Em 1918, ano em que criou a Liga Pró-Saneamento do Brasil, assumiu a direção do Serviço de Profilaxia Rural (criado pelo presidente Wenceslau Braz pelo decreto n. 13.001, de $1^{\circ}$ de maior de 1918, no âmbito da DGSP). A criação deste serviço era um indício de que as reivindicações daquela campanha já redundavam em medidas concretas importantes. Em 1920, passou a dirigir os serviços de saneamento rural do DNSP, instalando postos de profilaxia em vários estados brasileiros. Dois anos depois, deixaria o serviço por divergir de Chagas, com quem rompeu relações, quanto à orientação política a ser impressa ao DNSP. Em 1924, apoiou a revolta tenentista em São Paulo com o objetivo de derrubar o governo de Arthur Bernardes, sendo por isso preso. Em 1928, ocupou a chefia do Serviço de Propaganda e Educação Sanitária do DNSP, já sob o comando de Clementino Fraga, a quem substituiu na 
direção deste órgão em 1930. Exonerando-se do DNSP em finais de 1932, filiou-se então à Ação Integralista Brasileira (Lacaz, 1963; Hochman, 1998; Fonseca, 2007). $\mathrm{O}$ arquivo pessoal de Penna encontra-se sob a guarda da COC/Fiocruz.

37 Além das questões relativas às condições sanitárias, Lima (2003) chama a atenção para aspectos menos lembrados do relatório, ao analisar também os outros temas relacionados às condições de vida das populações do Brasil Central, como a desertificação - que revelava o impacto das intervenções humanas sobre a natureza -, os meios de comunicação, a propriedade fundiária, a violência, as atividades econômicas, os costumes e as tradições. Ver também Sá (2009).

38 Entre as experiências realizadas com o Triatoma sordida, que indicaram como uma importante espécie vetora, os autores encontraram evidências de que, como havia sugerido Brumpt (1912), a transmissão não se efetuava pela picada, mas pelas fezes contaminadas do barbeiro (Neiva \& Penna, 1916).

39 Neiva e Penna (1916) não fazem menção a exames de sangue nos possíveis casos da doença.

40 Lima (2003) chama a atenção para que, ao caracterizar o sertanejo como uma posição intermediária entre o indígena e o 'civilizado', Neiva e Penna corroboravam a idéia de um estágio inferior de civilização (entre a natureza e o estado regido pela higiene) presente em muitos textos médicos e em ensaios sociais do final do século XIX e início do século XX.

${ }^{41}$ Como dado que permitiria "fugir à conclusão que o bócio está ligado à moléstia de Chagas", os autores citaram "a circunstância da nula ou pequena proporção de triatomas infectadas em localidades onde o bócio é muito abundante, como Duro, Porto Nacional e Descoberto" (Neiva \& Penna: 1916: 124-125). No diário da viagem escrito por Neiva, ele registra, referindo-se à passagem por Peri-peri, município de Formosa (Goiás): "Por toda parte existe o bócio endêmico, contudo força é confessar que a doença de Chagas é por estas plagas benigna”. Diário e itinerário da excursão científica pelo interior do Brasil. Fundo Arthur Neiva, caixa 3, pastas 1 e 2. Este arquivo encontra-se sob a guarda da Casa de Oswaldo Cruz/Fiocruz.

42 No relatório da expedição de Adolpho Lutz e Astrogildo Machado, estas dúvidas também foram expressas. Em suas observações sobre o 'papo endêmico' (destacado como "problema dos mais interessantes na patologia desta região") e as distintas hipóteses sobre sua etiologia (entre as quais a de Chagas), os cientistas concluíram: "em todo o caso as nossas observações não permitem decidir estas questões, enquanto que continua incerta a etiologia do papo comum, endêmico em regiões onde não há coreotripanose" (Lutz \& Machado, 1915: 6).

43 Os autores indicaram também a ocorrência das outras manifestações clínicas atribuídas à doença: "Quer o bócio, quer as modalidades nervosas e cardíacas registradas por Chagas foram verificadas presentes nas localidades dos municípios de Remanso, Santa Rita do Rio Preto e Barra do Rio Grande pertencentes ao Estado da Bahia e em toda a zona goiana. (...) Além das formas citadas, são muito comuns em Goiás os casos de cretinismo, infantilismo e surdo-mudez" (Neiva \& Penna, 1916: 125). Contudo, o sinal tireoidiano tinha franca primazia no conjunto do relato.

4 Dentre as doenças abordadas no relatório, a moléstia de Chagas foi a que ocupou maior extensão no texto (dez páginas). Entre as outras enfermidades, a febre 
amarela, a ancilostomose e o impaludismo foram abordados, respectivamente, em cinco, uma e cinco páginas (Lima, 2003: 194).

45 Para uma análise das matérias publicadas na revista Saúde, órgão oficial da Liga, ver Lima e Britto (1996).

46 Sobre a preocupação das elites mineiras com o atraso e as possibilidades de recuperação econômica, ver Dulci $(1992,1999)$ e Borges (1997).

47 Na edição de Saneamento do Brasil, publicada em 1923, Penna incluiu imagens representando a casa do Jeca Tatu 'antes' e depois' do saneamento. Na primeira, lêse: "imundície, doença e pobreza". Na segunda: "saúde, conforto, prosperidade".

48 O decreto n. 779, de 8 de outubro de 1918, que criou o Serviço de Profilaxia Rural no Estado do Paraná, sob a responsabilidade de Heráclides César de Souza Araújo (pesquisador do IOC), estabeleceu medidas profiláticas para a tripanossomíase americana exatamente sob tal perspectiva. Independentemente de sua efetividade, esta iniciativa seria evocada, a partir de então, como exemplo.

49 Esta última fotografia havia sido publicada no relatório de Neiva e Penna (1916).

50 As outras duas integrantes da "trindade maldita", a malária e a ancilostomose, afetariam, respectivamente, $40 \%$ e $70 \%$ da população nacional (Penna, 1918b: 9596). Apesar de Penna afirmar que "Chagas avaliou em 2 milhões o número de indivíduos inutilizados pela tripanossomíase americana” (Penna, 1918b: 23), Chagas declararia, alguns anos mais tarde, não ter qualquer responsabilidade por tais cifras, uma vez que não havia sido feito um levantamento sistemático a respeito (Jornal do Commercio, 1922). Ao comentar a situação da doença de Chagas em Minas Gerais, Penna estimou em 1/3 a população acometida no estado (Penna, 1918a).

51 Apesar das recorrentes referências de Chagas à 'vasta extensão da doença', 'centenas de verificações' etc., os números concretos da pesquisa eram, até então, os de 29 casos agudos descritos por ele (Chagas, 1916c), os quatro casos identificados em São Paulo por Bayma, Carini e Maciel em 1914 (em 1918, Eurico Villela relatou mais um caso neste estado) e um caso em El Salvador, registrado em 1913. Ao analisar o discurso médico sobre a hanseníase na Colômbia, que, ao final do século XIX, foi considerado o maior foco mundial da doença, Diana Obregón (2002) chama a atenção para o uso retórico que os médicos fizeram dos dados existentes sobre a dimensão da enfermidade no país, exagerando-os com vistas a firmar a idéia da necessidade urgente de medidas de controle e a autoridade da medicina nacional como responsável por indicá-las.

52 Na primeira edição, de 1918, o título do capítulo relativo à doença de Chagas era "três milhões de idiotas e papudos". Na edição de 1956, quando a correlação com o bócio já havia sido plenamente refutada, o termo 'papudo' foi suprimido, sendo o título original informado ao leitor em nota (Lobato, 1956: 239). Assim como Penna, Lobato também atribuiu a estimativa de três milhões de doentes a Carlos Chagas.

53. A Revista do Brasil, criada em São Paulo, em 1916, por Júlio de Mesquita, vinha, desde 1917, publicando com regularidade artigos sobre o tema do saneamento. Em maio de 1918, foi comprada por Monteiro Lobato.

${ }^{54}$ Entre as várias fotografias publicadas neste texto, encontra-se a mesma que havia sido publicada em Saneamento do Brasil (Penna, 1918b), exibindo três doentes, 
paralíticos e com retardo mental, à frente de uma cafua. Ao fim do artigo, numa alusão implícita aos que consideravam não haver casos da doença em outros países, Chagas insistia em afirmar que "a tripanossomíase americana não é uma doença exclusiva do Brasil” (Chagas, 1918b: 386).

55 Um indício significativo deste reconhecimento foi o fato de que, no decreto de criação do Serviço de Profilaxia Rural, de 1ำ de maio de 1918, estabelecia-se que as comissões sanitárias instituídas com este fim seriam chefiadas, preferencialmente, por funcionários da DGSP ou do IOC.

56 Durante sua gestão, o IOC teve dois novos regulamentos, em 1919 e 1926. Ver Brasil (1919d) e IOC (1926). Sobre a administração de Chagas em Manguinhos, ver Chaves (1936), Aragão (1953), Chagas Filho (1993) e Benchimol (1990a). Sobre a repercussão de sua nomeação na imprensa, ver A Ephoca (1917), O Imparcial (1917), A Noite (1917), Penna (1917).

57 Convocado pelo presidente da República para comandar a assistência à população, Chagas instalou hospitais e postos de atendimento emergenciais em diferentes pontos da cidade e convocou a classe médica a colaborar no socorro aos doentes. Neste contexto, aproveitou para salientar a necessidade de hospitais regionais nas zonas do interior do país atingidas pelas endemias, desguarnecidas, em geral, de quaisquer serviços de assistência médico-hospitalar. Seguindo as posições do movimento sanitarista, enfatizava que esta deveria ser uma atribuição da administração federal. Ver A Rua (1919a) e outras reportagens no FCC, grupo: vida pessoal; atividade: relações familiares e produção de retratos do titular (livros de recorte de jornal). Ver ainda Chagas (1919). Sobre a atuação de Chagas neste episódio, ver Chagas Filho (1993) e Goulart (2005). Sobre a importância desta epidemia para as discussões em torno da reforma da saúde pública federal, ver Hochman (1998).

58 Em 4 de outubro de 1919, Chagas tomou posse na DGSP, que logo depois se transformaria no DNSP. Sobre as novas diretrizes que procurou implantar neste órgão, ver Jornal do Commercio (1921a). Sobre a repercussão da nomeação de Chagas na imprensa, ver A Rua (1919b), Jornal do Brasil (1920), O Paiz (1920a, 1920b, 1920c).

59 As idéias e os projetos de Chagas para a saúde pública foram divulgados internacionalmente a partir de sua nomeação, em 1922, como membro do Comitê de Saúde da Liga das Nações.

60 A estreita vinculação com Manguinhos estava expressa também no fato de que, entre as exigências para cursar a especialização, além de ser diplomado em medicina, estava a de que o aluno tivesse concluído o Curso de Aplicação do IOC (CastroSantos \& Faria, 2006).

${ }^{61}$ O primeiro passo para a introdução de um ensino especializado em saúde pública na FMRJ foi dado em 1917, quando se criou, sob a liderança de Afrânio Peixoto e outros médicos, o Curso de Medicina Pública, que cobria um ano letivo e era destinado a formar médicos-legistas e médicos higienistas. O curso funcionou até 1920 e, em 1925, foi reestruturado por ocasião da reforma do ensino promovida pelo Ministério da Justiça e Negócios Interiores, dando origem ao Curso Especial de Higiene e Saúde Pública, organizado por Chagas (Castro-Santos \& Faria, 2006). 



\section{Calamidade Nacional ou Mal de Lassance? A doença do Brasil em questão (1919-1934)}

Em 1919, médicos e pesquisadores brasileiros confrontaram certas concepções sobre a doença de Chagas, num processo que culminaria em aguerrida polêmica na Academia Nacional de Medicina (ANM), nos anos de 1922 e 1923. Atualizando as críticas levantadas na Argentina em 1916, tais questionamentos incidiram sobre a caracterização clínica da doença e a dimensão epidemiológica e social que lhe era atribuída e colocaram sob suspeição sua identidade (até mesmo sua realidade) e seu estatuto de doença símbolo do Brasil.

Chagas teve não apenas os enunciados, mas sua própria idoneidade posta em dúvida, acusado de reivindicar a descoberta do Trypanosoma cruzi que, segundo seus 'antagonistas', caberia a Oswaldo Cruz. Esta é uma polêmica da qual muito se falou nos textos biográficos de Chagas e nos relatos históricos sobre a doença. Contudo, via de regra, isto foi feito sem um acompanhamento aprofundado do processo pelo qual ela se desenrolou, em seus discursos e contradiscursos articuladores de uma gama complexa de argumentos e motivações. Este olhar mais atento se faz necessário tanto pela narrativa histórica quanto pela perspectiva de revelar os meandros de uma controvérsia exemplar no que diz respeito à natureza sociocognitiva da produção e estabilização dos fatos científicos. ${ }^{1}$ 
Se a afirmação e a legitimação da doença de Chagas se fizeram ao mesmo tempo que se lhe conferiu uma dimensão simbólica e política, também as dúvidas e os questionamentos sobre ela se dariam em referência a esta dimensão. Se o movimento sanitarista realçou os significados da tripanossomíase americana como 'doença do Brasil' e símbolo da ciência que o 'curaria', as alegações científicas de Kraus e dos argentinos de que os casos de tripanossomíase talvez se restringissem ao Brasil seriam usadas, no contexto médico brasileiro, justamente para refutar a magnitude do problema reivindicada por Chagas e pelos partidários da campanha pelo saneamento rural. Na luta nacionalista deflagrada em torno da saúde pública brasileira a partir de 1916, os que se opunham às teses ditas exageradas e antipatrióticas de Miguel Pereira, Belisário Penna e Carlos Chagas manifestavam apreensão com a imagem do Brasil como 'o único país' no qual reinasse uma doença cujos efeitos seriam tão dramáticos. A preocupação em firmar outra visão da nação, que fugisse à sua qualificação como nação doente, fez recuar ainda mais os limites geográficos retoricamente expressos nas designações da moléstia: nem tripanossomíase americana, nem doença do Brasil, mas, simplesmente, 'mal de Lassance', diriam os críticos na 'tribuna' da ANM.

Os vários sentidos atribuídos à doença de Chagas, por grupos distintos e em contextos diversos, revelam como as faces científica e política deste objeto em construção se intricavam em vínculos complexos, e muitas vezes tensos, com conseqüências não previstas por aqueles que os puseram em marcha. Em seus traços mais fortes e visíveis, a tripanossomíase expressava uma dada compreensão da relação entre medicina tropical e identidade da nação brasileira. As dúvidas sobre ela e o redirecionamento imposto aos seus enunciados também.

\section{Os Primeiros Movimentos da Contenda (1919-1920)}

Em 15 de julho de 1919, Henrique Aragão, em discurso de posse na Sociedade de Medicina e Cirurgia do Rio de Janeiro (SMCRJ), corroborou as incertezas de Kraus sobre a doença de Chagas. No auge da campanha pelo saneamento do Brasil, o pesquisador de Manguinhos enfatizou a importância do debate sobre os problemas sanitários do interior, mas afirmou que algumas questões relativas a estas endemias 
vinham sendo revistas, como a associação entre a tripanossomíase americana, o bócio e o cretinismo endêmicos, "que já começam a ser afastados pelo Dr. Carlos Chagas do quadro clínico da moléstia”. Uma vez descartada esta associação "absolutamente insustentável", dizia Aragão, a moléstia permanecia "ainda muito importantíssima e digna de estudo, de um ponto de vista científico"; no entanto, tornava-se "diminuída de valor sob o seu aspecto prático como endemia rural " (Aragão, 1919: 8-9). Em mais um indício da importância da presença do agente etiológico como critério final de diagnóstico, o ponto central era o reduzido número de casos comprovados.

É ainda relativamente pequeno o número de casos autênticos dessa moléstia com verificação do tripanossoma nos doentes (...). Em 10 anos de estudos, não foram citados 4 dezenas de casos do mal e mesmo que o número fosse 10 vezes maior ainda seria mínimo comparado ao que se sabe em relação às dezenas e centenas de milhares com que são apresentadas muitas outras doenças que nos assolam. (Aragão, 1919: 8-9)²

Ao tentar explicar tal situação, ele tocou numa questão que, a partir dali, constituiria um importante aspecto da controvérsia. Com base no raciocínio de Kraus quanto à ausência de casos agudos na Argentina (apesar da presença de vinchucas infectadas), Aragão pôs em dúvida a intensidade da ação patogênica do T. cruzi para os humanos.

A explicação talvez se encontre em que o Trypanosoma cruzi não seja facilmente transmitido pelo triatoma ou por uma difícil adaptação do parasito ao organismo humano, especialmente no adulto, sendo a maioria dos casos observada em crianças. Na verdade, o $T$. cruzi é, antes de tudo, um parasito dos animais silvestres, como os tatus, os gambás etc., para os quais parece ser bastante inócuo, como assinalou o professor Horta. Nas crianças e nos animais novos o parasito se manifesta com o poder patogênico aumentado e em contraposição o Dr. Arthur Neiva assinala não poucos insucessos na obtenção da infecção experimental em cães velhos. É muito provável, portanto, que o homem sadio se infecte com menos facilidade ou evolua nele a moléstia para a cura espontânea em muitos casos. (Aragão, 1919: 9) ${ }^{3}$

A princípio, estas formulações poderiam encontrar algum respaldo em afirmativas do próprio Chagas. Em 1918, a confirmação de que o tatu era um hospedeiro natural do T. cruzi demonstrava a existência de 
um ciclo silvestre na evolução do parasito (em que este não é patogênico para os animais que o hospedam). ${ }^{4}$ Este ciclo, num processo posterior de adaptação (ocorrido mediante a domiciliação dos transmissores), teria se expandido para o ambiente doméstico e para os hospedeiros humanos (sobre os quais o parasito tem ação patogênica). Tal percurso poderia explicar a ausência de casos humanos em certas regiões nas quais houvesse barbeiros infectados: seriam locais onde o T. cruzi ainda não havia 'atingido' o homem (Chagas, 1918a). ${ }^{5}$ Chagas (1912b: 49) já havia salientado que os adultos pareciam ter "maior resistência à ação do parasito", pois, quando contaminados, não exibiam os elementos agudos observados nas crianças. Isso não significava dizer, todavia, que estes indivíduos não sofressem sua ação patogênica.

O fato é que Aragão apresentou tais questões em referência às dúvidas de Kraus. Este introduzira a questão da 'não existência' da doença, ainda que, vale ressaltar, estivesse se referindo ao caso da Argentina (onde o parasito teria sua virulência atenuada) e não à ocorrência da doença de modo geral. Além disso, Aragão lançou tal hipótese depois de afirmar que, em vista de tais incertezas, a doença era 'diminuída' em seu valor prático face às outras endemias rurais. Tais circunstâncias faziam com que seus enunciados, expressos como alegações estritamente científicas de um eminente parasitologista, tivessem um sentido para além desta dimensão, 'modalizando' negativamente - para usar o termo de Latour (2000) - as formulações de Chagas e, por isso, provocando grande repercussão.

Outro ponto a despertar polêmica foi a afirmação de que Oswaldo Cruz - e não Chagas - havia sido o descobridor do T. cruzi. Por isso, lembrando designação proposta em 1911 por Clementino Fraga, Aragão referiu-se à tripanossomíase como "moléstia de Cruz e Chagas" (Aragão, 1919: 8). Num momento inflamado pelas bandeiras políticas da campanha sanitarista e de grande visibilidade pública de Chagas, o discurso de Aragão equivalia a colocar sob suspeita todos os elementos do 'grande feito’ científico produzido pelo então diretor do Instituto Oswaldo Cruz (IOC): a doença, o parasito e a própria descoberta.

A atribuição da descoberta do T. cruzi a Oswaldo Cruz foi corroborada, em discurso na mesma sessão da SMCRJ, por Henrique Figueiredo de Vasconcellos, pesquisador de Manguinhos desde sua criação, contemporâneo de Cruz na Faculdade de Medicina do Rio de Janeiro (FMRJ) e seu sucessor na Diretoria Geral de Saúde Pública (DGSP). Na sessão seguinte, Belisário Penna desafiou Vasconcellos a discutir o assunto, 
afirmando que ninguém melhor do que ele, Penna, que acompanhara Chagas em Lassance, para atestar sua autoria naquele processo. ${ }^{6}$

Cerca de duas semanas depois, em discurso proferido na ANM e publicado no Correio da Manhã (1919: 3), Chagas respondeu aos questionamentos de que era alvo. Mesmo admitindo haver "pontos obscuros e outros discutíveis nessa doença”, enfatizou que não podia aceitar as contestações dos colegas, uma vez que estes tinham incorrido na "inadvertência de não se haverem demorado, um momento sequer, na apreciação de fatos concretos", como os casos clínicos estudados em Lassance e as experiências de laboratório que comprovavam a patogenicidade do parasito para diversos animais. Declarou ainda não admitir a posição dos que pretendiam "destruir os fatos, na sua totalidade, pela alegação de erros parciais", ao contrário de se engajarem no objetivo comum de esclarecer, mediante novas pesquisas, as questões em aberto, tornando-se colaboradores daquele "capítulo da literatura médica nacional" (Correio da Manhã, 1919: p. 3)

No mês seguinte, Figueiredo de Vasconcelos pronunciou conferência na SMCRJ, publicada pelo Jornal do Commercio, destinada a responder ao desafio de Belisário Penna. Reafirmou que, por ter sido o autor da infecção experimental nos sagüis que revelara o novo parasito, Oswaldo Cruz deveria ser considerado "quem realmente descobriu o Trypanosoma cruzi e guiou com verdadeiro carinho paternal ao Dr. Chagas no estudo da nova entidade mórbida", a qual, por isso, deveria ser chamada "moléstia de Cruz e Chagas" (Vasconcellos, 1919a: 6). ${ }^{7}$ Apesar de declarar que não desmerecia "o valor científico do Dr. Chagas", Vasconcellos enfatizou que as glórias da descoberta e, sobretudo, do estudo da doença advinham de um trabalho coletivo em Manguinhos: “(...) não pode dizer que a moléstia de Chagas tenha sido estudada só por ele do princípio a fim. Para o seu estudo concorreram vários membros do IOC com contribuições valiosíssimas e a estes pertencem, igualmente, e com toda a justiça, uma parte das glórias" (Vasconcellos, 1919a: 6). ${ }^{8}$

Outro ponto em discussão - o essencial e de maiores implicações era a importância médico-social da doença. Respondendo a Penna, que o havia acusado de afirmar que o T. cruzi era inofensivo, Vasconcellos esclareceu sua posição: não duvidava de que o T. cruzi causasse uma doença, apesar de acreditar que ele fosse "mais patógeno para as crianças em baixa idade do que para os adultos". O fato para o qual alertava era o de não ter esta enfermidade "a extensão que se lhe quer dar, e que, pelo fato, 
de se manifestar em regiões nas quais reinam o bócio endêmico e outras entidades mórbidas, superpõe-se em certas localidades a estas, de modo que se torna difícil a diferenciação nítida (...)" (Vasconcellos, 1919a: 6). ${ }^{9}$

Segundo Vasconcellos, assim como na Argentina, em estados brasileiros onde havia abundante presença de barbeiros infectados (como a Bahia e o Rio Grande do Sul), a busca de casos da doença tinha sido infrutífera, e a verificação microscópica do parasito só fora obtida em São Paulo, em poucos casos. Dessa forma, as estimativas, estampadas nos textos de Penna e Monteiro Lobato, de que eram 'milhões' os afetados pela doença, estariam em flagrante contraste com a pequena quantidade de casos registrados pela literatura. Depois dos 29 descritos por Chagas em 1916, afirmava Vasconcellos, "o número de casos não atinge meia dúzia" e, além das dez necropsias referidas por Gaspar Vianna em 1911, "não sabemos se há outras, mas caso existam não foram publicadas" (Vasconcellos, 1919b: 6). Vasconcellos resumiu seu argumento numa operação discursiva interessante e irônica:

$$
\begin{aligned}
& \text { Anofelina + hematozoário }+ \text { homem }=\text { impaludismo. } \\
& \text { Stegomia }+ \text { vírus }+ \text { homem }=\text { febre amarela. } \\
& \text { Glossina + tripanossoma }+ \text { homem }=\text { moléstia do sono. } \\
& \text { Triatoma + tripanossoma }+ \text { homem }=\text { nem sempre moléstia de } \\
& \text { Chagas. (Vasconcellos, 1919b: } 6 \text {; grifos meus) }
\end{aligned}
$$

A nova tripanossomíase, consagrada como emblema da patologia tropical brasileira, aparecia fragilizada numa equação que era a antítese das fórmulas da ciência. Estas dúvidas científicas vinham acompanhadas de um claro sentido político, referido aos debates em torno da relação entre saúde e identidade nacional. Ao citar as declarações de Chagas, corroboradas por Miguel Pereira e Belisário Penna, sobre o terrível e vasto flagelo provocado pela enfermidade no interior do país, Vasconcellos sintetizou na SMCRJ o cerne da polêmica que três anos depois seria intensificada na ANM:

Sr. Presidente, se realmente já estivesse perfeitamente estabelecido que o bócio endêmico e que todas as manifestações mórbidas, que apresentam esses doentes, habitantes dessas regiões, fossem causadas pelo T. cruzi, eu compreendo que se pudesse assim falar, que fossem pintados com essas cores negras, tétricas, os quadros que são vistos. Mas, ainda não está provada a evidência que seja a tripanossomíase brasileira a causadora de tudo isto. E, assim sendo, é necessário, é indispensável que haja uma reação, não para des- 
truir a obra do Dr. Carlos Chagas, por que esta está assegurada, a nova entidade mórbida continua de pé, o seu brilho e o seu valor não ficaram diminuídos, mas para colocá-la dentro dos seus verdadeiros limites (...). Seria um crime de nossa parte, Sr. Presidente, se, convencidos como estamos disto, nos calássemos e deixássemos correr urbi et orbe afirmativas como estas que, em pouco tempo, trariam o descrédito sobre a nossa Pátria e dela afugentariam todos os que para ela se quisessem dirigir (...). Ora, nossa terra necessita urgentemente de imigrantes, e, creio que não será o melhor meio de atraí-los, fazê-los saber da existência de uma moléstia terrível nos lugares onde terão que ir trabalhar, e que não tem de fato sua existência cientificamente comprovada. (Vasconcellos, 1919b: 6; grifos meus)

Alguns dias depois da publicação da conferência de Vasconcellos, o Jornal do Commercio divulgou uma carta na qual Chagas declarou jamais ter reivindicado para si a totalidade das glórias a que se referia seu colega do IOC e que sempre fizera questão de atribuí-las à "escola de Oswaldo Cruz", sobretudo a seu mestre. Contudo, enfatizou que de modo algum poderia aceitar a tese de que cabia a este a autoria da descoberta do T. cruzi (Jornal do Commercio, 1919: 6). ${ }^{10}$

Num indício de que as objeções em jogo começavam a se configurar como dois lados de uma batalha, mesclando diversos elementos nacionalistas, outro jornal publicou reportagem manifestando surpresa e revolta ao saber que "há no nosso meio científico alguém que viesse repetir contra o nome consagrado do Dr. Carlos Chagas os botes do 'furor teutonicus' do professor Kraus, já rebatidos vitoriosamente pelo nosso eminente patrício”. A idéia de que eram 'detratores' todos os que lançavam críticas a Chagas, fossem elas no campo do "sofisma científico" ou expressas na acusação de "enfeitar-se com plumagens alheias", começava a se fortalecer. ${ }^{11}$ Em 1920, o assunto continuou nas páginas dos jornais, acompanhando os debates em torno da reforma sanitária implementada com a criação do Departamento Nacional de Saúde Pública, para o qual Chagas foi nomeado diretor. Numa evidência da imbricação entre a doença de Chagas e a imagem do país preconizada pela campanha sanitarista, reportagem de A Noite declarava: "Latente, mas violenta, vai lavrando nos meios médicos uma questão da maior importância para todo o Brasil: a de que houve grande exagero na primitiva concepção da doença de Chagas, servindo tal exagero como base fundamental ao conceito pessimista de que o Brasil é um vasto hospital”. 
Mais uma vez, os estudos de Kraus serviam de base para afirmar que a caracterização da moléstia de Chagas como "cataclisma nacional" havia sido decorrente, na realidade, de "uma generalização precipitada" ( $A$ Noite, 1920a: 1). A reportagem, em atitude conciliatória, alegou os motivos para tanto: a coexistência de 'papudos' nas zonas mineiras nas quais foram assinalados os casos da doença de Chagas teria induzido o raciocínio a "seguir uma seqüência inevitável" e, sendo assim, "no espírito de todos se estabeleceu a equação: tripanossoma produz a moléstia de Chagas, esta produz bócio, este produz cretinos”. A partir daí, onde havia "degenerados", deduziu-se haver aquela doença: "Grupá-los em fotografia e denominar vítimas da doença de Chagas foi um hábito que facilmente se generalizou" (A Noite, 1920a: 1). Ainda que sob uma ótica mais positiva, a reportagem extraía do tema as mesmas implicações políticas contidas na fala de Vasconcellos:

'O Brasil é um vasto hospital!' Hoje se verifica que as coisas se reduzem a fatores muito diferentes. Tira isso valor à descoberta de Carlos Chagas? Não. O seu esforço foi útil e proveitoso. Se as suas primeiras induções o levaram longe demais na concepção da moléstia, a todo o tempo pode-se corrigir o excesso. A própria exclamação de Miguel Pereira, impressionado pelas pesquisas de Chagas, produziu o seu efeito benéfico. Imprensa, governo e parlamento pensaram em melhorar as condições sanitárias do país. Mas o bom senso manda que se modifique o tom dessa imprecação. Papudos e cretinos, há-os na Argentina, como no Brasil. Uma alta compreensão de patriotismo não os levou ainda a um autojulgamento tão pessimista... (A Noite, 1920a: 1)

Como era de se esperar, a reportagem provocou indignação em Penna, que, no mesmo jornal, reafirmou a declaração de Miguel Pereira, dando seu testemunho quanto à extensão e à gravidade das endemias rurais, particularmente da tripanossomíase americana. O diretor da Liga Pró-Saneamento do Brasil desafiava os que pretendiam "empanar o brilho da descoberta de Carlos Chagas", desconsiderando que ela se constituía como "um patrimônio nacional, de que temos justificado orgulho" (A Noite, 1920b: 2). Ao rebater os que se fiavam nos dados de Kraus, afirmava:

Os estudos do professor Kraus não infirmam, nem de longe, as conclusões de Chagas. Se a doença não existe na Argentina, que tem isso com a patologia nacional? Por acaso há quem conteste a 
sua existência entre nós, na Venezuela e no Peru, onde o microscópio a demonstrou cabalmente? Além disso, o próprio Kraus não nega a sua existência na Argentina. Ele refere apenas que ainda não a encontrou (...). Por que, ao invés de andarem levantando dúvidas pelas sociedades médicas e pelos jornais, não vão os contestantes da notável descoberta às regiões infectadas verificar os fatos, estudálos, aprofundá-los, conhecer a sua extensão, ver as dezenas, ou melhor as centenas de milhares de desgraçados, que vegetam animalizados pela terrível doença nos sertões de Minas, de Goiás, de Mato Grosso e de outros Estados? Isso o que fizeram o autor da descoberta e o subscritor desta. (A Noite, 1920b: 2$)^{12}$

A mesma idéia, que opunha os médicos que conheciam os sertões àqueles que pretendiam contestá-los sem nunca ter ido ao interior do país, foi expressa em outra reportagem, em formulação sugestiva do contraponto estabelecido entre os dados da observação clínica e as 'provas' laboratoriais como instância de decisão do diagnóstico:

Se a clínica desvenda a doença de Chagas em muitos pontos onde só mais tarde o laboratório a vem confirmar, isso não admira a quem conhece o 'a' 'b' 'c' da epidemiologia de um flagelo, que é exclusivamente rural, que ataca de preferência as crianças, e cujo germe só aparece no sangue por pouco tempo, e não pode ficar esperando indefinidamente que elegantes sábios da Avenida vão encontrá-lo. (A Rua, 1920: 1; grifos meus)

Numa clara sobreposição da controvérsia científica sobre a tripanossomíase com as divergências e as tensões no âmbito do movimento pelo saneamento do Brasil, este debate, que tinha como vértices Belisário Penna, Carlos Chagas e seus críticos, atingiria sua máxima intensidade e visibilidade dois anos depois.

\section{A Polêmica na Academia Nacional de Medicina (1922-1923)}

O ano de 1922 foi particularmente rico de significados para os debates sobre a nação. O centenário da Independência foi comemorado com uma grande exposição no coração da capital, a qual havia passado por novas obras de remodelação para exibir suas credenciais de símbolo do progresso brasileiro. Outros movimentos, desta vez sob a marca da 
contestação, propunham novos arranjos estéticos e políticos para a identidade nacional, como a Semana de Arte Moderna e o movimento tenentista. Em 30 de novembro daquele ano, no discurso com que recebeu Figueiredo de Vasconcellos como membro honorário da ANM, o literato e catedrático de higiene da FMRJ, Afrânio Peixoto (que, em 1918, integrava as hostes do movimento sanitarista e havia alertado que, logo além da avenida Central, o Brasil era um outro país, o país do sertão, das endemias rurais), lançou o estopim de uma aguerrida contenda em torno do símbolo maior daquelas endemias. ${ }^{13}$ Ao referir-se aos serviços prestados por Vasconcellos ao Instituto de Manguinhos, Peixoto, famoso pelos dotes oratórios, ironizou:

Durante o vosso consulado poderíeis ter feito mais (...). Poderíeis ter achado alguns mosquitos, inventado uma doença rara e desconhecida, doença de que se falasse muito, mas quase ninguém conhecesse os doentes, encantoada lá num viveiro sertanejo de vossa província, que magnanimamente distribuiríeis por alguns milhões de vossos patrícios, acusados de cretinos. Poderíeis ter feito uma reforma suntuária, gastando cinco vezes mais que Oswaldo Cruz, para fazer cinqüenta vezes menos, mas vos ficariam, tempos e saldos, para a crítica mercenária aos inimigos que houvésseis provocado. Poderíeis além das injúrias dos dependentes e agradecidos, ter tido o jogo dos incautos e cobiçosos, ao vosso serviço. Poderíeis mais, e tudo o que a vaidade sem escrúpulo e a imprudência provocante podem fazer tentar. (ANM, 1922a: 723-724; grifos meus)

Suas ácidas palavras não deixaram dúvidas quanto ao alvo. Associando a crítica a Chagas como diretor da saúde pública ao ataque à entidade nosológica que levava seu nome, o golpe mais forte foi desferido pelo uso do verbo 'inventar', que trazia a insinuação de que, além de não ser importante, a doença de Chagas talvez nem mesmo existisse. Instituindo uma guerra de números, que opunha quarenta casos da 'papeira parasitária' de Lassance aos três milhões de doentes que Penna e Lobato afirmavam existir por todo o país, o discurso de Peixoto tornou a ANM que havia sido o locus privilegiado do reconhecimento conferido à tripanossomíase americana e ao seu descobridor - o palco de uma intensa querela sobre a 'doença do Brasil'. ${ }^{14}$

Em carta a Miguel Couto, presidente da ANM, Chagas declarou-se atingido em sua honra pessoal e profissional, tratado como "embusteiro”. Disse não aceitar as explicações de Peixoto, que em carta a Couto 
afirmara não ter tido a intenção de negar a existência da doença, mas apenas de questionar a dimensão que se lhe atribuía e de alertar para a necessidade de ampla revisão do assunto. Chagas insistiu: "Ora, Sr. Presidente, doença inventada e desconhecida, a menos que me falhe o entendimento, é, por isso mesmo, doença inexistente" (Jornal do Commercio, 1922: 5). Sendo assim, solicitou que fosse nomeada uma comissão para avaliar o assunto, com base em alguns quesitos por ele formulados. Do parecer desta comissão, dependeria sua permanência naquela casa. ${ }^{15} \mathrm{Num}$ confronto aberto com o professor de higiene, Chagas assegurou não temer uma revisão de seus estudos e afirmou que seus críticos pretendiam "confundir para iludir", ao fazerem depender do tema da etiologia do bócio a verdade de seus enunciados. Como vinha repetindo desde 1916, enfatizou que considerava este aspecto "uma questão aberta, na qual seriam possíveis ainda divergências honestas”. Igualmente lançando mão da ironia, ele escreveu a Couto: "Papeira endêmica não é tripanossomíase (...) e nem tripanossomíase é papeira endêmica. (...) Sejam esclarecidas de modo diverso a etiopatogenia do bócio, observado nas regiões de barbeiro, e nem por isso a tripanossomíase desaparecerá como doença autônoma, bem caracterizada" (Jornal do Commercio, 1922: 5; grifos meus).

Em relação tanto à primazia clínica do 'papo’ quanto ao cálculo de que seriam 'milhões' os brasileiros acometidos pela doença (ambos os aspectos intensamente propagados pelo discurso sanitarista), Chagas esclareceu que não endossava tais enunciados. Apesar de convicto quanto à vasta difusão da endemia, declarou não ter qualquer responsabilidade por tais estimativas e que nunca realizara estatísticas sobre a doença, "trabalho que oferece grande dificuldade e só poderá ser executado de modo demorado e progressivo" (Jornal do Commercio, 1922: 5).

Na sessão de 14 de dezembro de 1922, Miguel Couto submeteu à votação a proposta de criação da comissão requisitada por Chagas. Paulo de Figueiredo Parreiras Horta, catedrático da Escola Superior de Agricultura e Medicina Veterinária do Rio de Janeiro, apresentou outra carta em que Peixoto o investia, e também a Figueiredo de Vasconcellos, como seus representantes. Segundo ele, deveria ser aberto um amplo debate público na ANM, por meio de sessões extraordinárias, e não uma discussão restrita a uma comissão especial. Contudo, a proposta de Chagas foi aprovada e a comissão constituída, estabelecendo-se que, uma vez concluído o seu relatório, este seria debatido pelos membros da associação. 
Eduardo Rabello, diretor da Inspetoria de Profilaxia da Lepra e Doenças Venéreas e amigo pessoal de Chagas, sugeriu que Miguel Couto presidisse a referida comissão, mas este não aceitou, declarando "razões de afinidade, de parentesco com a pessoa de um dos contendores" (ANM, 1922b: 774). Apesar do tom elevado que envolvia a disputa desde o seu início, Couto comprometeu-se a conduzi-la como um debate de "questões essencialmente científicas”, não envolvendo "questões pessoais” (ANM, 1922b: 769). ${ }^{16}$

$\mathrm{O}$ assunto era acompanhado pelos jornais. Artigo assinado por um "curioso" arrolou uma série de questões e desafiou:

Está na berlinda esta entidade nosológica que permanece bastante confusa, em muitos pontos, mal grado os esforços e desejos de alguns interessados. Pelas 10 perguntas lançadas ao acaso, ficase convencido que essa entidade está mergulhada num mar de incógnitas e que o Dr. Chagas tem muita coisa a estudar para sair do domínio das hipóteses. (O Jornal, 1922: 6; grifos meus) ${ }^{17}$

Cerca de um ano depois, a querela voltou ao plenário da ANM. Em ofício a Miguel Couto, apresentado na sessão de 8 de novembro de 1923, o presidente da comissão, Alfredo Nascimento Silva, informou que, estando "em última demão o seu relatório" (ANM, 1923a: 635), havia acabado de receber uma carta em que Chagas expressava sua contrariedade em saber que a comissão declarara não ter condições de realizar excursão ao interior do país para verificar "a difusão e o elevado índice endêmico" da doença, o que, em sua opinião, tornaria "insolúvel um dos objetos de maior monta na pendência". Chagas assegurava que não era o caso de "repetir pesquisas extensas e demoradas", já que se prontificava em apresentar "numerosos doentes" para avaliação. Se isso não fosse feito, acentuava, não poderia aceitar "um parecer deficiente, ao qual faltarão elementos essenciais de convicção” (ANM, 1923a: 637), e, sendo assim, estava disposto a renunciar a seu título de membro da Academia. ${ }^{18}$

A comissão, por sua vez, reafirmou estar "absolutamente impossibilitada de satisfazer a este requisito", alegando que, para dar parecer seguro sobre a zona afetada, "que se diz estender-se por uma vastidão de muitas léguas de raio, em torno do foco principal, abrangendo regiões remotas de difícil acesso", seria preciso longa permanência e "penosas excursões nessas zonas" (ANM, 1923a: 636). Diante do impasse, Alfredo Nascimento Silva declarou que a comissão renunciava de sua incumbência, 
antes mesmo da conclusão do relatório. Couto considerou justas as alegações da comissão, dizendo que o objetivo de estabelecer a geografia médica da doença no país consumiria anos e implicaria despesas com as quais a ANM não poderia arcar, além de um "sacrifício" que não tinha "o direito de exigir dos seus colegas" (ANM, 1923a: 639). Contudo, ponderou que as respostas aos outros quesitos deveriam ser apresentadas, já que o relatório estava praticamente pronto. $\mathrm{O}$ assunto foi posto em debate.

Parreiras Horta e Figueiredo de Vasconcellos, lembrando que a intenção de Peixoto era a de que ocorresse uma ampla discussão do tema, defenderam que o parecer da comissão era indispensável e que esta não deveria renunciar. O acadêmico Carlos Werneck, acentuando que "o interesse científico verdadeiro está em discutir amplamente a moléstia de Chagas" (ANM, 1923a: 641), propôs que o tema fosse tratado, a partir de então, por todos os membros da Academia. No decorrer dos debates, se a comissão julgasse conveniente, apresentaria suas considerações. A proposta foi aceita. A doença de Chagas entrou na ordem do dia das sessões (ANM, 1923a: 642).

Em 16 de novembro, Figueiredo de Vasconcellos pronunciou conferência em que expôs detalhadamente o argumento que defendia desde 1919. Afirmando ter sido "testemunha ocular" e acompanhado "todas as peripécias" relativas à descoberta, em Manguinhos, do novo parasito no intestino dos barbeiros de Lassance, reafirmou: "Tenho plena consciência e absoluta convicção de que o descobridor do Trypanosoma cruzi foi Oswaldo Cruz" (ANM, 1923b: 658-659). Diante dos acadêmicos, examinou e comparou pormenorizadamente todos os trabalhos em que Chagas relatara os momentos da descoberta, detectando ambigüidades, inconsistências e contradições. Argumentou que, apesar de Chagas declarar, desde 1918 (Chagas, 1918b), que havia sido ele o autor da infecção experimental nos sagüis, as notas prévias em que anunciou a descoberta não deixavam dúvidas quanto à responsabilidade de Cruz naquela experiência. Tendo sido este quem primeiro viu ao microscópio as formas de tripanossoma no sangue dos macacos, cabia-lhe, portanto, a prioridade de sua descoberta. ${ }^{19}$

Nesta sessão, Couto apresentou outra carta que lhe fora enviada por Chagas, insistindo, mais uma vez, que a comissão não fosse dispensada das pesquisas no interior. Ao reiterar estar disposto a providenciar todos os meios para tal investigação, o pesquisador do IOC destacou justamente o elemento que, desde 1916, vinha enfatizando no quadro clínico da doença, mas que permanecia em segundo plano face à visibilidade 
assumida pela questão do bócio: “(...) eu me prontifiquei, e ainda me prontifico, a apresentar num mesmo dia, e em diversas regiões, dezenas e dezenas de enfermos com a mesma síndrome cardíaca, todos eles afetados de arritmia típica, verdadeiras epidemias de alterações do ritmo cardíaco!” (ANM, 1923b: 679; grifo do autor) Num apelo dramático, recorreu àquele que, em 1910, havia tomado parte na excursão que levara aquela mesma Academia ao sertão para verificar seus estudos. Solicitou a Couto sua "interferência amistosa" para convencer a comissão a reconsiderar sua decisão. Uma alternativa seria nomear outros colegas para prover o "esclarecimento definitivo" que todos procuravam e para preservar o que havia sido reconhecido como "um patrimônio real das letras médicas da nossa terra" (ANM, 1923b: 680). ${ }^{20}$

Couto, entretanto, negou o pedido. Em carta a Chagas, lida em plenário, o presidente da Academia declarou que a verificação requisitada, por implicar prazo indeterminado, constituiria uma "perda de tempo", e que, como presidente da ANM, sentia-se "embaraçado e sem ânimo" para insistir com a comissão a respeito. Além disso, enfatizou que, de forma alguma, a honra profissional de Chagas havia sido posta em dúvida ou ameaçada, e proferiu, em seu apoio, uma sentença bastante ambígua: "ainda que realizada num só caso, a doença de Chagas confere farta glória científica a quem a descobriu" (ANM, 1923b: 680). ${ }^{21}$

Elevando ainda mais o tom da contenda, Peixoto protestou, também mediante carta enviada ao presidente da Academia e lida nesta mesma sessão, contra a decisão de Chagas de não aceitar o parecer da comissão antes mesmo de o conhecer, "como que adivinhando a sentença". Isto vinha, em sua opinião, corroborar ainda mais as dúvidas sobre "a doença de Lassance, que se pretendia transformar em doença do Brasil” (ANM, 1923b: 681).

Subsiste, pois, Sr. Presidente, a minha dúvida sobre o mal de Lassance, raridade nosográfica, sem importância epidemiológica; subsiste agora, e não por minha intervenção, pelo procedimento do próprio autor dispensado a mais das horas o laudo da comissão, que promoverá dúvidas muito mais graves... (ANM, 1923b: 681).

O professor da Faculdade de Medicina da Bahia e amigo pessoal de Chagas, Clementino Fraga, encarregou-se de sua defesa. No plenário da Academia, enfatizou ter testemunhado "doentes em farta cópia” (ANM, 1923b: 683) em Lassance, assim como o fizera a notável comissão enviada 
pela Academia em 1910, acompanhada pelo próprio Vasconcellos. Quanto à "tese precária" que este defendia sobre a autoria da descoberta do $T$. cruzi, Fraga observou que, antes mesmo da infecção experimental, havia sido Chagas o responsável pelo "achado inicial", colocando-se "frente a frente com a novidade", ao surpreender, ainda no sertão mineiro, os flagelados no interior do barbeiro (ANM, 1923b: 685-686). ${ }^{22}$

Em réplica a Fraga, Vasconcellos lembrou, a respeito da excursão a Lassance, que os exames parasitológicos que serviram de comprovação dos casos clínicos, por ele próprio endossados com entusiasmo na época, haviam sido invalidados, anos depois, pelas pesquisas de Aragão. "Em ciência tudo evolui", disse ele. Ao requerer que se fizesse "uma revisão séria dessa entidade mórbida, que se retirem os exageros, que se verifiquem os pontos controversos, não se lhe dando a latitude que se lhe quer dar" (ANM, 1923b: 687), Vasconcellos recolocou, como fizera em 1919, a dimensão política do tema. O que estava em jogo era a imagem do país e as maneiras conflitantes de conceber o significado da 'doença do Brasil': "Não desejo que a nossa terra seja considerada como o único país do mundo em que, de norte a sul, de leste a oeste, grasse uma moléstia terrível, horrorosa, não conhecida em nenhuma outra parte do mundo" (ANM, 1923b: 687-688). ${ }^{23}$

Ao encerrar a sessão, Miguel Couto, que havia sido citado por Vasconcellos em sua conferência, deixou a posição de presidente e, como acadêmico, posicionou-se diante da questão da autoria da descoberta. Declarou que ainda encarava a doença de Chagas "com o mesmo intenso orgulho patriótico" que o dominara por ocasião da célebre viagem a Lassance e que não tinha qualquer dúvida de que "a descoberta científica é de Chagas” (ANM, 1923b: 689; grifo do autor).

Os jornais registravam cada etapa da polêmica. Reportagem de título "Tripanosomas... e ciumadas" resumia a interpretação conferida à disputa, lamentava o episódio e manifestava preocupação com a imagem da ciência nacional: "E que idéia ficarão fazendo de nós, dos nossos cientistas, os luminares da medicina estrangeira, ao constatarem que no Brasil nem se sabe quem fez a descoberta importante, negando-se ao médico tido como descobridor as glórias de um caso líquido?"24

Na sessão do dia 22 de novembro, os debates prosseguiram. Desta vez, na conferência de Parreiras Horta, estavam na berlinda a natureza do parasito e a difusão da doença. Antes mesmo de expor suas apreciações, o orador expressou sua apreensão (a mesma de Vasconcellos e de 
Peixoto) de que a imagem do país estivesse sendo prejudicada ao ter, como elemento distintivo, uma doença extremamente grave e que só aqui ocorresse.$^{25}$ A negação da dimensão que a tripanossomíase assumia como representação da nacionalidade equivalia à sua afirmação ao avesso. Desfazer estes vínculos era a outra face da moeda que os havia estabelecido e propagado. Lembrando a repercussão da conferência feita por Chagas em 1911, na ANM, diante do presidente e de vários ministros da República, Horta relatou que o ministro da Agricultura, Pedro de Toledo, teria feito o seguinte comentário: "É uma grande desgraça nacional. Temos uma moléstia capaz de nos entorpecer o progresso, e, nós, que somos um povo que precisamos de imigração, ficamos em situação inferior. Será isso exclusivamente do Brasil?” (ANM, 1923c: 696). Ao apresentar tais declarações num contexto bem diferente daquele momento de consagração de Chagas no qual elas teriam sido proferidas, Horta sublinhou o sentido negativo e 'antipatriótico' que ele e outros imputavam aos que acentuavam as 'mazelas' da nação.

O ponto central da argumentação de Parreiras Horta foi o mesmo do questionamento na Argentina. Declarou que, em suas viagens pelo Brasil, tinha observado a disseminação de barbeiros em vários estados, nos quais, apesar das buscas feitas por médicos locais, não se havia conseguido comprovar parasitologicamente casos clínicos da doença. Mesmo em São Paulo, onde há "um corpo clínico ilustradíssimo, (...) laboratórios de primeira ordem e (...) um serviço sanitário modelarmente organizado", apenas cinco casos foram identificados, disse ele, a despeito da "existência abundantíssima de triatomas" (ANM, 1923c: 699). A mesma situação se reproduzia para o continente americano. Horta defendeu, então, o argumento de que o T. cruzi poderia ser um parasito saprófita (inofensivo); apresentou observações feitas em bovinos, em cujo sangue era abundante uma outra espécie de tripanossoma (Trypanosoma theileri), sem que, no entanto, tais animais revelassem qualquer sintoma que expressasse a ação patogênica deste parasito; citou outros exemplos de tripanossomas inofensivos para os animais que os abrigam, sugerindo que o mesmo pudesse se aplicar ao T. cruzi ou então que sua virulência fosse menor do que se pretendia, provocando infecções fundamentalmente benignas e esporádicas (ANM, 1923c: 709-710). ${ }^{26}$

Outro problema seria a falta de informações sistematizadas sobre a doença no Brasil. Mesmo no caso de Minas Gerais, acentuou Horta, não havia dados oficiais sobre o assunto, nem qualquer menção nos relatórios 
da Diretoria Estadual de Higiene. Assim sendo, reivindicou: "Julgo da maior necessidade, ano por ano, mês por mês, caso por caso, seja tudo registrado e documentado, de modo a se estabelecer a geografia exata, não somente dos barbeiros infectados, como também de qualquer caso humano em que se encontre o tripanossoma" (ANM, 1923c: 713). Sua conferência foi concluída com o ponto para o qual convergiam todas as críticas: "Pois bem: os casos de tripanossomíase humana autênticos, já assinalados, são poucos e limitados a uma zona do país. É a incógnita que fica” (ANM, 1923c: 714).

Nesta mesma sessão, Clementino Fraga fez sua comunicação formal em defesa de Chagas. Antes disso, comentou brevemente a fala de Horta. Num indício de como a polêmica punha em jogo posições e sentimentos conflitantes em relação à associação entre 'doença', 'sertão' e 'atraso', tanto em termos simbólicos quanto das ações políticas envolvidas, Fraga indignou-se, em nome da Bahia (seu estado natal, no qual havia assumido diversos postos nos serviços sanitários), com o "acento sombrio" e o "aspecto catastrófico" (ANM, 1923c: 715) impostos pelo professor da escola de agricultura e veterinária, quando este disse que aquele estado encontrava-se 'inteiro' infestado por barbeiros. Segundo Horta, isso acontecia mesmo nas ruas centrais e nas "habitações estragadas" (ANM, 1923c: 701) de Salvador. Incomodado com as "palavras cáusticas" com que se imputava àquela cidade as imagens negativas do 'sertão', tratando-a como uma nova 'Lassance do norte', Fraga ironizou: "Como S. Ex. pintou o quadro, até o próprio Palácio da Aclamação estaria atingido... Mas, força é convir, que os indígenas de S. Salvador, já um tanto civilizados, habitam casas de paredes lisas, inóspitas para os barbeiros...” (ANM, 1923c: 715).

O objetivo central do médico baiano era, no entanto, refutar os argumentos de Vasconcellos quanto à identificação do T. cruzi, afirmando estar claro, nos próprios trabalhos de Chagas, seu protagonismo nas investigações que conduziram àquela descoberta. A autoridade maior de Oswaldo Cruz foi então evocada mediante a voz de seu próprio filho. Fraga apresentou, em plenário, a carta que recebera de Bento Oswaldo Cruz, atestando, em nome de sua família, que "Oswaldo Cruz sempre atribuiu essa descoberta integralmente ao Dr. Carlos Chagas". Ao caracterizar a "espoliação" imposta a Chagas como um desrespeito à memória de seu pai, manifestou seu "protesto profundamente magoado ante esta disputa ingrata e odiosa" e declarou: "Só alguns anos depois de sua morte é que pessoas, possuídas de súbito e exagerado zelo pelo seu nome, mas 
pouco preocupadas com a desconsideração que infligiam à sua memória, resolveram contestar tudo quanto fora por ele proclamado e por todos aceito" (ANM, 1923c: 721).

Além disso, Bento Oswaldo Cruz enfatizou ser inadmissível que, caso seu pai tivesse sido de fato o autor da descoberta, ele consentisse com o "ato pouco digno" (ANM, 1923c: 721) de dar a sua paternidade a um discípulo, rompendo com a hierarquia e a disciplina pelas quais tanto zelava em Manguinhos. Fraga apoiou as palavras do filho de Oswaldo Cruz e concluiu sua apresentação dizendo estar certo de que, se Oswaldo estivesse vivo, "(...) não conheceríamos esta dissensão, que à medicina brasileira principalmente fere, porque revolve fatos de seu patrimônio científico, criando dúvidas a respeito da palavra de um dos nossos maiores nomes atuais" (ANM, 1923c: 722). Esta foi uma dimensão importante da polêmica, que, como será visto adiante, deve ser acionada para sua compreensão. A contenda expressava as fissuras e as rivalidades internas no IOC, cujas origens remontavam ao processo de sua expansão e profissionalização a partir de 1908, e que, uma vez falecido seu árbitro maior, eclodiam com maior visibilidade (Benchimol \& Teixeira, 1993; Britto, 1995).

\section{A Sentença: mérito reconhecido, questões em aberto}

Na noite de 23 de novembro de 1923, perante o auditório cheio da ANM, foi lido o tão aguardado parecer da comissão. ${ }^{27} O$ Jornal saudou os membros da agremiação pelo "serviço" que iria prestar ao Brasil, o de rever "serenamente, sem paixões" o tema da doença de Chagas, "a fim de que se venha a saber, dentro e fora do país, o que ela realmente é: se essa grande calamidade nacional, na opinião de uns, ou se essa grande incógnita, essa doença de Lassance, limitada e misteriosa, na opinião de outros" (O Jornal, 1923: 6).

A primeira questão abordada pelo parecer foi a solicitação de Peixoto para que a ANM reexaminasse todos os trabalhos de Chagas desde 1911, tendo em vista, nas palavras do professor de higiene, "a revisão do problema que afeta o bom nome nacional” (ANM, 1923d: 730). Declarando não dispor de condições para tanto, a comissão posicionou-se, então, sobre o episódio que dera origem à controvérsia, ou seja, o discurso em que Peixoto usara o verbo 'inventar' para aludir à tripanossomíase. Citando carta 
remetida a Miguel Couto, em dezembro de 1922, por Peixoto, em que este esclarecia que o alvo de suas dúvidas não havia sido a 'existência' da parasitose, mas sim a 'extensão' que lhe era atribuída, a comissão julgou que a frase proferida por Peixoto não tivera, embora assim o parecesse, $o$ sentido "que magoara o Dr. Chagas", ou seja, o de sugerir que ele havia "fantasiado doença inexistente" (ANM, 1923d: 730). Prova disso, acentuou o parecer, era que o próprio professor de higiene, em seu tratado de 1922, reconhecera haver cerca de quarenta casos em Lassance (ANM, 1923d: 730).

Por reconhecer, na solicitação de Chagas, um "objetivo mais preciso" (ANM, 1923d: 731), ou seja, considerando os seis quesitos por ele formulados e mais as questões da autoria da descoberta do T. cruzi e do bócio, a comissão apresentou, então, suas conclusões. Como elementos para a investigação, "postos à sua disposição pelo Dr. Chagas", o grupo teve acesso a artigos científicos, peças anatômicas, preparações histológicas, amostras do parasito em preparados e in vivo e quarenta doentes, trazidos de Lassance para o hospital de Manguinhos, "apresentados como afetados do mal em suas várias formas” (ANM, 1923d: 732).

Sobre a questão da prioridade da descoberta do T. cruzi, o parecer foi favorável a Chagas, ainda que admitisse que a "falta de clareza" em alguns documentos desse "margem a dúbio entendimento" (ANM, 1923d: 734). A comissão enalteceu o valor e a lógica de seu raciocínio, desde os primeiros passos de suas pesquisas em Lassance e concluiu: "No correr dessa série coordenada de fatos, o descobridor do parasito, que não foi achado por acaso, mas procurado numa ilação lógica, não seria, portanto, quem por ventura primeiro o visse, mas forçosamente quem nessa concatenação tudo dispusera para que fosse encontrado" (ANM, 1923d: 737).

Negadas as alegações de Horta quanto à inocuidade do T. cruzi para o homem, o parecer passou a tratar de um dos principais pontos da querela, expresso no primeiro quesito formulado por Chagas: a tripanossomíase americana era ou não uma entidade mórbida bem caracterizada e individualizada clinicamente? As considerações da comissão a este respeito são reveladoras não apenas por suas conclusões, mas pela avaliação dos métodos e critérios de diagnóstico utilizados e reconhecidos para comprovar a infecção pelo T. cruzi nas formas crônicas.

Apesar de reconhecer que o método sorológico de Guerreiro e Machado (reação de fixação do complemento) vinha merecendo, por parte 
dos especialistas, "uma certa confiança para o diagnóstico das causas das formas crônicas", a comissão salientou: "é problema que ainda aguarda solução o diagnóstico da forma crônica da doença de Chagas pelas pesquisas parasitológicas". Sendo assim, o diagnóstico clínico de um caso crônico só poderia ser "confirmado pelo laboratório pelo exame postmortem" (ANM, 1923d: 740). Contudo, mesmo neste procedimento, havia dificuldades. Nas quarenta necropsias que Magarinos Torres (pesquisador de Manguinhos) declarou terem sido realizadas em casos crônicos, nem sempre se conseguira encontrar o parasito, em virtude de sua escassez nos tecidos. O sucessor de Gaspar Vianna na Seção de Anatomia Patológica do IOC, o norte-americano Bowman Crowell, asssegurava que, nos casos de forma cardíaca, a especificidade das lesões poderia dispensar a verificação do T. cruzi. De toda maneira, citando os próprios colaboradores de Chagas, o que o parecer destacou foi que, apesar dos avanços, ${ }^{28}$ havia grande dificuldade em se obter, para a comprovação dos casos crônicos da doença, o que todos exigiam: a presença do parasito (ANM, 1923d). ${ }^{29}$ Estas eram as circunstâncias sob as quais se indicava a fragilidade dos enunciados sobre os sinais clínicos da fase crônica: “(...) o diagnóstico inicial desta parasitose, nas formas crônicas, é via de regra falho e a pesquisa parasitológica atual, quase sempre, negativa" (ANM, 1923d: 742)..$^{30}$

Com base nestas considerações, a comissão chegou à conclusão de que não tinha condições plenamente satisfatórias para responder ao primeiro quesito de Chagas, o qual correspondia justamente à questão da especificidade clínica da doença e, conseqüentemente, de sua definição como entidade nosológica. Vale a pena acompanhar os termos do parecer:

Para responder com toda precisão ao $1^{\circ}$ quesito, seria indispensável um longo e pertinaz trabalho minucioso de controle, uma larga permanência na zona mais conhecidamente afetada, daí se irradiando por extensão indefinida a multiplicar estudos clínicos diferenciais, precisando as condições nosológicas de cada localidade, apreciando os doentes no seu meio permanente e repetindo experiências múltiplas com o parasito incriminado de patogênico. Seria preciso, em suma, refazer com uma competência múltipla e especializada, que à Comissão falece, e com possibilidades de que não dispõe, todo o longo trabalho de 15 anos do operoso e idôneo pesquisador e de seus hábeis e especializados auxiliares. Demais eles mesmos, continuando os estudos, reconhecem dúvidas a resolver e detalhes a esclarecer e pontos em que a questão está aberta, 
tendo sido algumas conclusões primitivas já alteradas por achados ulteriores. Está neste caso a relação de causa e efeito, que a princípio parecia impor-se, entre o bócio endêmico e as infestações do tripanossoma, e que hoje constitui um problema a re-estudar, sendo desde 1916, segundo as próprias declarações do Dr. Carlos Chagas, uma questão aberta. (ANM, 1923d: 744; grifos meus)

Numa difícil tentativa de contemporização, a comissão considerou ter "respondido positivamente" àquele ponto formulado por Chagas, "com as restritivas decorrentes da natureza mesma do assunto, ainda em estudo" e que "os trabalhos realizados sobre o assunto (...) merecem crédito quanto às suas conclusões essenciais” (ANM, 1923d: 745).

Em relação à controvertida distribuição geográfica da doença, também buscando uma conciliação, o parecer afirmou:

(...) a nova doença, cuja extensão geográfica, bem como o coeficiente de morbidade escapam aos meios de sindicância de que a Comissão dispõe, mas a cujo respeito há documentos indicativos de outros focos no continente americano, representa, qualquer que seja a sua difusão no interior do país, um problema de ordem social da maior relevância, merecedor da atenção do Estado. (ANM, 1923d: 745 ; grifos meus)

Finalmente, quanto ao valor científico e à idoneidade dos trabalhos de Chagas, numa decisão certamente mais fácil, a resposta foi enfaticamente positiva: "A Academia Nacional de Medicina não pode deixar de conservar integral o conceito que determinou a inclusão do Dr. Carlos Chagas no seu grêmio" (ANM, 1923d: 745).

A leitura do parecer foi seguida de comentários em plenário, levando a sessão às últimas horas do dia. Fraga, considerando-o "uma página brilhante e sincera projetada sobre o estudo dessa doença" (ANM, 1923d: 753), apresentou ainda mais dois testemunhos a favor de Chagas: cartas de Olympio da Fonseca e Magarinos Torres contestando a "divagação médico-geográfica" (ANM, 1923d: 757) de Parreiras Horta e mostrando-lhe "erros e omissões" (ANM, 1923d: 755). ${ }^{31}$ Ao final da polêmica, aprofundava-se o processo pelo qual a retórica polida dos debates científicos dava lugar ao uso de termos acusatórios explícitos. ${ }^{32}$

Defendendo, mais uma vez, seu ponto de vista - "em ciência quem vê pela primeira vez é quem descobre!” (ANM, 1923d: 767) -, Vasconcellos, num último recurso de argumentação, citou a contradição de quem fazia a defesa de Chagas. Lembrou que o próprio Fraga propusera, em 1911, a 
prioridade da descoberta do T. cruzi a Oswaldo Cruz. Em resposta, o médico baiano afirmou já ter publicamente 'confessado' haver feito a formulação sobre a "moléstia de Cruz e Chagas", mas que, depois de ouvir a palavra autorizada de Chagas, voltou atrás e reconheceu que "andou errado na penetração e no sentido dos informes em que se baseou” (ANM, 1923d: 781). ${ }^{33}$ Ao rebater a acusação de antipatriotismo que lhe fizera Fraga, por 'difamar' um símbolo da ciência nacional, Vasconcellos novamente deixou antever que, entremeadas às objeções científicas, estavam disputas em torno da imagem da nação e do interior, e do sentido que o diagnóstico do 'Brasil vasto hospital' assumia na perspectiva do seu desenvolvimento. Ao reafirmar o que dissera em 1919, declarou:

O Brasil, país novo, necessitando do braço estrangeiro, não pode ficar com a pecha de possuir no seu interior, justamente para onde devem ir os imigrantes, uma doença desconhecida para o resto do mundo, de conseqüências horrorosas, o que fatalmente, no fim de algum tempo será sabido e, portanto, será causa do afastamento de trabalhadores, que queiram vir colaborar conosco, (...) o que será de conseqüências funestas para o engrandecimento da Pátria. (...) ainda não está provada a enorme extensão e a extrema gravidade da moléstia de Chagas, mas querem a todo o custo que o esteja e que o sertão do Brasil, por este fato, seja inabitável. Singular patriotismo. (ANM, 1923d: 768)

As disputas de natureza nacionalista encaminhavam-se também no domínio concreto das decisões da saúde pública. Afirmou Vasconcelos, aludindo à cooperação entre o Departamento Nacional de Saúde Pública (DNSP) e a Fundação Rockefeller:

(...) acima da ciência brasileira, que não pretendo destruir de modo algum, coloco a nossa Pátria. (...) Falta de patriotismo, Sr. Prof. Fraga, é mandar-se vir uma missão americana para extinguir a febre amarela no norte do Brasil, porque de todas as moléstias transmissíveis é a febre amarela, indiscutivelmente, aquela cuja profilaxia é mais fácil e está perfeitamente bem estabelecida. (...) Devia ser para o Departamento Nacional de Saúde Pública uma questão de honra erradicar a febre amarela do solo brasileiro, mas, não sei porquê, de repente, para isto conseguir submete-se à tutela americana... Questão de honra, Sr. Presidente, devia ser essa, porque a técnica da profilaxia empregada por Oswaldo foi criação dele, é genuinamente nacional, e devia ser praticada exclusivamente por brasileiros. (...) O Departamento Nacional de Saúde Pública tem tudo, nada lhe falta... Não, enganei-me, falta-lhe uma coisa, 
essencial, aliás: a vontade de fazer... E este era o segredo do grande Oswaldo Cruz. (ANM, 1923d: 767-769; grifos meus)

A atuação sanitária da Fundação Rockefeller no país vinha sendo alvo de críticas por parte de alguns médicos brasileiros, contrariados com a intervenção estrangeira num domínio que Oswaldo Cruz havia tornado a grande vitrine da competência nacional em saúde pública: o combate à febre amarela. As divergências de caráter técnico reforçavam as reações nacionalistas: os norte-americanos eram contrários ao método que havia sido usado por Cruz (fumigação com inseticidas nas habitações para eliminar os mosquitos adultos) e consideravam mais eficaz e barato atacá-los em sua fase larvária. Nos últimos dias de 1923, justamente, seria selado o acordo de cooperação entre aquela instituição e o DNSP, de modo a ampliar as ações que a Rockefeller já implementava em cidades do nordeste brasileiro (Benchimol, 2001).

Em vários discursos na época, Chagas condenou os que questionavam a doença por ele descoberta como meio de atacar sua gestão no DNSP, acusado de ser um "escoadouro dos dinheiros do Estado". Numa alusão a Peixoto, disse ele:

É certo que em algumas páginas do compêndio de higiene, em períodos dubitativos e em interrogações a perder de vista, vem a sentença condenatória da tripanossomíase americana e vem recusada, ao descobridor do respectivo parasita, a precedência da descoberta (...). Entretanto, os estudos sobre a tripanossomíase americana nada têm a ver com os serviços do Departamento Nacional de Saúde Publica e constituem um patrimônio exclusivo do IOC. (Chagas, 1922b: 12-13) ${ }^{34}$

Em 1923, por ocasião da fundação da Sociedade Brasileira de Higiene, cuja presidência assumiu, Chagas dedicou seu discurso a rebater as acusações dos que consideravam antipatriótica a posição dos médicos que defendiam o saneamento rural do país, sobretudo dos que, numa "reviravolta, quase súbita, do conceito médico" (Chagas, 1923a: 6), contradiziam o apoio que haviam dado àquele movimento. ${ }^{35}$ Mais uma vez a alusão a Peixoto foi ácida. Dirigindo-se aos sanitaristas presentes na solenidade, ele declarou:

Não recueis, senhores, da vossa convicção benfazeja, e nem vos desalente aí a incoerência de alguns e o negativismo de outros. (...) Acaso será esse assunto passível de ser decidido em aprimorados 
discursos acadêmicos? Nestes, quando muito, conseguirá a gentileza de expressão bem recomendar o cavalherismo e as maneiras fidalgas de quem, à míngua de argumentos técnicos, procura no humorismo gaiato e na dubiedade de frases a ilusão da vitória em divergências científicas. Chegaremos até admitir a superioridade e eficiência na ironia jocosa e na versatilidade fácil, quando visam impressionar as galerias, e convencê-las de que a verdade única é aquela de última hora, decretada pelas conveniências e predileções profissionais. (Chagas, 1923: 6)

O último ato da polêmica na ANM aconteceu com uma conferência de Chagas, na noite de 6 de dezembro, com forte presença dos acadêmicos e outros médicos, além de estudantes de medicina e "pessoas de alta representação social" (Correio da Manhã, 1923: 3). Antes de subir à tribuna, Chagas testemunhou ainda uma última investida de Peixoto, por intermédio de carta, lida por Miguel Couto. O professor de higiene acentuou as críticas à gestão de Chagas no DNSP, acusando-o de 'importar' americanos "para nos substituírem no nosso dever" e de ser inoperante, até em relação à própria doença por ele descoberta:

Que fez, nestes 15 anos de gritaria contra tal perigo público, o governo da União e o de Minas, a região mais interessada? Que nos dizem os [relatórios] do Dr. Carlos Chagas, que além de inventor, é o diretor de saúde nacional há tanto tempo e com as províncias contratantes da profilaxia rural? Que há, pergunto, feito até este ano da graça de 1923? (ANM, 1923e: 788-789). ${ }^{36}$

O lance mais agressivo veio da recorrente batalha dos números. Peixoto ironizou o fato de que, diante de estimativas de que a tripanossomíase americana atingia cerca de 4,5 milhões de brasileiros, a comissão da Academia havia se baseado em apenas quarenta casos apresentados por Chagas (por cujo diagnóstico ela "sabiamente" se absteve de se responsabilizar) para concluir que se tratava de um "um problema social da maior importância”. Disse ele:

(...) na próxima 4⿳a a Edição de meu livro de Higiene, tão benevolamente citado, direi o que foi, que se conhecem mais 40 casos, fornecidos também pelo Dr. Chagas, isto é, agora 80, o que nos deixa ainda com o pequeno déficit de 4.499 .920 casos a demonstrar (...). De pé está, Exm. Sr. Presidente, a minha dúvida, que é a certeza de todos nós... Oito ou oitenta, não vai muito além o perigo social do mal de Lassance. (ANM, 1923e: 789) 
Em seu aguardado pronunciamento, Chagas declarou-se empenhado em "sintetizar os fundamentos de uma conviç̧ão inabalável adquirida no demorado estudo e na persistência do trabalho", mas não escondeu a mágoa: "Não valera a todos a palavra de quem, para salvaguardar o patrimônio científico de uma escola, hoje se encontra na atitude de réu, autuado de improbidade e de demolidor das prerrogativas de robustez e resistência da nossa gente dos campos" (ANM, 1923e: 791).

O diretor de Manguinhos e do DNSP rebateu as objeções que recebera, num prólogo para a exposição de suas convicções sobre a doença que levava seu nome. ${ }^{37}$ Em seguida, usando o habitual recurso de "projeções luminosas", discorreu sobre a caracterização clínica da tripanossomíase, enfatizando haver "sinais iniludíveis" de suas formas, tanto agudas quanto crônicas. Em conformidade com tendência já expressa em seus trabalhos de 1916, deu especial ênfase à forma cardíaca como o elemento mais forte da doença crônica:

A forma cardíaca constitui, sem dúvida, o aspecto mais interessante e característico da tripanossomíase americana e dela possuímos numerosas observações clínicas, todas ilustradas pelas pesquisas semióticas que determinaram a natureza exata das alterações de ritmo" (ANM, 1923e: 804).

Além disso, apresentou as evidências que a anatomia patológica trazia à comprovação etiológica dos elementos clínicos (pela constância das lesões e presença do parasito nas fibras cardíacas) e ressaltou o que já havia afirmado: a forma cardíaca era o principal caminho para a afirmação da especificidade da doença e de sua extensão geográfica e social.

É de acentuar, Sr. Presidente, que se trata, no caso, de verdadeiras epidemias de alterações do ritmo, só explicáveis pela ocorrência de um único fator etiológico e nunca observadas, sob tais modalidades, fora das zonas infestadas pelo triatoma. E numerosos, como são, os casos da forma cardíaca, devo ou não 'sustentar' elevadíssimo o índice endêmico da tripanossomíase americana? (ANM, 1923e: 805). ${ }^{38}$

Destacou ainda que, apesar das tão enfatizadas restrições no diagnóstico parasitológico dos casos crônicos, não se devia desqualificar a apreciação clínica, "sempre possível, por quem saiba realizá-la" (ANM, 1923e: 808). Além disso, assinalou que os últimos aperfeiçoamentos das técnicas laboratoriais traziam uma perspectiva bastante promissora, tal como registrado no próprio parecer da comissão: 
(...) eu devo informar à Academia que o diagnóstico das formas crônicas é hoje exeqüível, de acordo com as conclusões do trabalho que tenho em mãos, de Villela e Bicalho, pelo desvio do complemento [reação de Guerreiro e Machado] (...) (ANM, 1923e: 808) (9 $^{39}$

Chagas encerrou sua conferência com uma forte crítica ao "falso nacionalismo" de Peixoto e seus porta-vozes. Afirmou que o estudo das doenças tropicais existentes no país era um caminho fundamental para alertar o poder público quanto à importância social das endemias rurais e subsidiá-lo com as medidas necessárias para combatê-las. Em protesto contra os que o acusavam de "desamor à nossa terra, [de] desapreço pelos predicados nativos de sua gente”, declarou:

(...) não me posso capacitar, Sr. Presidente, de que constitua nacionalismo sincero e verdadeiro esse empenho em desviar as providências do Estado de um dos assuntos que mais se impõem ao nosso zelo de brasileiros (...). É possível, Sr. Presidente, que os dois ilustrados professores [Peixoto e Horta] consigam criar prosélitos e fazer opinião em torno de suas doutrinas otimistas; só o conseguirão, porém, entre os desavisados de assuntos médicos, porque os da nossa classe já estão instruídos de sobra, no que respeita às condições sanitárias do nosso interior, e se orientam por um otimismo diverso (...), que não contesta a existência do mal, mas confia no método científico e prevê, em futuro próximo, a redenção sanitária das nossas populações rurais. (ANM, 1923e: 809-810)

Em desafio a Peixoto, Chagas evocou o compromisso do "ilustre professor de Higiene" na formação dos futuros médicos e convidou-o a "verificar pessoalmente", numa viagem ao interior do país em sua companhia, a verdade ou o erro de suas conclusões, apreciando "a difusão da doença e a sua importância como fator de decadência do trabalhador rural". O presidente da ANM faria a intermediação entre os contendores, acompanhando-os na qualidade de "supremo árbitro" (ANM, 1923e: 792). O apelo a Couto, mais uma vez, foi dramático. Em "súplica” à sua autoridade, que havia sido tão decisiva nos primeiros momentos da descoberta e dos estudos que ali eram postos em suspeição, Chagas dirigiu-se ao mestre e amigo:

(...) julgo-me autorizado a implorar de V. Ex. que dedique alguns dias de sua atividade à solução dessa divergência, e venha trazer ao país, na autoridade de um conceito irrevogável, a solução dessa contenda. Sei do quanto seria penoso a V. Ex. uma excursão pelo nosso interior, acompanhado de alguns acadêmicos, a fim de colher 
elementos que o habilitem a juízo acertado; mas também sei o quanto esse sacrifício valeria aos interesses sanitários e ao prestígio científico da Nação. (ANM, 1923e: 797)

No entanto, ao contrário do que acontecera em 1910, a Academia não foi ao sertão.

\section{Uma Polêmica para a História}

A conferência de Chagas contou com grande cobertura da imprensa, que esteve presente "entre a assistência das galerias" e a divulgou ao grande público, com “vozes pró e contra” (A Notícia, 1923: 2). Reportagem de A Notícia (1923: 2) louvou o empenho do cientista em 'embrenharse' "pelo sertão adentro" e o serviço que prestara à ciência e à pátria, desvendando uma doença que "a flagelava e lhe depauperava as populações rurais". O que estava em jogo, foi afirmado no artigo, eram "sentimentos subalternos", em que o patriotismo era sacrificado "ao despeito, à inveja, às questiúnculas pessoais", numa "vergonhosa e inoportuna" campanha que feria a imagem do país, sobretudo no exterior (A Notícia, 1923: 2). Desqualificando o principal opositor de Chagas, foram ironizados os atributos de Peixoto:

(...) como médico, um homem... que se veste muito bem; como cientista e professor... um cavalheiro de aparência muito simpática, um palestrador maneiroso. Mas havermos de convir que é muito pouco. Donde as suas obras? Um tratado de medicina legal, compilado em português duvidoso, suspeito como o de alguns romances da sua lavra, não pode ser credencial que o credite perante os homens de ciência e lhe empreste autoridade para destruir a obra do seu grande antagonista. (A Notícia, 1923: 2)

Outras reportagens usaram um tom mais moderado, mas, via de regra, reiteravam que Chagas havia sido bem-sucedido em rebater seus críticos. ${ }^{40}$ Artigo de $O$ Imparcial (1923b: 2) descreveu de modo a contemporizador o confronto pelo qual "se interessou, tão vivamente, a opinião pública de todo o país". Afirmou que "o desafio lançado ao Dr. Chagas foi plenamente correspondido pela galhardia com que se ouve o discípulo de Oswaldo Cruz ao defender seus brios profissionais, inesperada e perigosamente postos em cheque". Contudo, rendeu 'justiça' a Afrânio Peixoto, "pela oportunidade que ao país ofereceu de ratificar o 
conceito que sempre formou de seus homens de ciência" (O Imparcial, 1923b: 2).

A memorialística médica produziu uma narrativa em que o famoso 'episódio da Academia', remontando ao debate na Argentina, foi apresentado como divisor de águas na biografia de Chagas e na trajetória da doença por ele descoberta. Sobre a contenda com Kraus, muitos contemporâneos, próximos a Chagas, a viram como controvérsia eminentemente científica, ainda que menosprezando as objeções levantadas. Eurico Villela (1936: 298) afirmou, por exemplo, que o diretor do Instituto Bacteriológico de Buenos Aires "chegara a conclusões verdadeiramente desapontadoras: a ação patogênica do Trypanosoma cruzi era uma ilusão, a tripanossomíase americana como doença era um mito, a doença de Chagas não existia”. O pesquisador de Manguinhos ressaltou também o "triunfo" de Chagas na resposta aos críticos, o que teria sido reconhecido pelo próprio Kraus, que, depois da conferência de Chagas, "foi dos primeiros a felicitar o orador, confessando-se nobremente satisfeito e convencido diante da documentação apresentada" (Villela, 1936: 298). ${ }^{41}$

O próprio Chagas, em 1920, reconheceu a natureza científica das objeções do colega austríaco: "Ele é um pesquisador e as suas observações têm, naturalmente, procedência. Mas, como cientista que é, tem a sua doutrina. Eu tenho a minha firmada em virtude dos estudos que fiz e do que constatei a respeito do mal". Contudo, acentuou que aqueles que, como Vasconcellos e Peixoto, faziam-se porta-vozes de Kraus tinham, na realidade, "intuitos secundários" (A Rua, 1920: 1). Assim, apesar das declarações quanto à isenção de Kraus, o uso de suas posições pelos que confrontavam Chagas no Brasil, a partir de 1919, fez com que ele fosse visto por muitos como seu primeiro 'detrator'. Em reportagem já citada, ao aludir às críticas de Vasconcellos, o redator indignou-se com os que aderiam "aos botes do "furor teutonicus" de Kraus. ${ }^{42}$

Ao longo da polêmica na ANM, a idéia de que Chagas enfrentava detratores, num embate movido por rivalidades e sentimentos de inveja $\mathrm{e}$ despeito, foi se consolidando. Esta imagem aparecia não apenas na imprensa, mas era corroborada por várias personalidades, como o próprio ex-presidente da República Epitácio Pessoa. Ele enviou a Chagas uma matéria de jornal que o elogiava e tecia críticas a Peixoto e redigiu, de próprio punho, a mensagem: "a mediocridade não perdoa ao talento, como a treva não perdoa a luz". ${ }^{43}$ 
Com o falecimento de Chagas, em 1934, tal interpretação foi ainda mais reforçada nas homenagens a ele prestadas e passaria a ser reproduzida por médicos e cientistas que reverenciam sua memória. Emile Marchoux (1934: 7), do Instituto Pasteur de Paris, declarou: "Jamais il ne céda un pouce du terrain qu'il avait scientifiquement conquis (...). Par sa courageuse attitude autant que par la force de ses arguments, il finit par imposer le respect de ses idées à ses pires détracteurs". ${ }^{4}{ }^{4}$

O professor da Faculdade de Medicina de Belo Horizonte, Octavio de Magalhães, que havia colaborado com Chagas nos estudos em Lassance, também manifestou tal posição:

No fueron, sin embargo, sólo cielos azules y mar de bonanza, los que probó el mayor de los discípulos de Oswaldo. Vió de cerca las aguas encrespadas, los aullidos tenebrosos de la tempestad de las bajas pasiones humanas. Vosotros, jóvenes, necesitáis saber con pormenores esta trágica comedia, que socavó la vida y amargó los dias de uno de nuestros mayores patricios. Tal vez podáis extraer altos ejemplos y prácticas lecciones para el presente y lo futuro. Toda vez que oigo la expresión enfática, de que 'la escuela es la vida', recuerdo las vidas de Oswaldo y de Chagas, ambos flagelados en el via crucis de sus empeños por el bien colectivo, martirizados en las cumbres de sus Gólgotas. (Magalhães, 1944: 13) (5 $^{45}$

A noção de que Chagas foi vítima de um processo de 'difamação', movido por rancores pessoais, continua até hoje presente na memorialística médica. Alguns autores, em tons exaltados que parecem ecoar diretamente da própria polêmica, chegam a afirmar que nenhuma questão científica relevante havia de fato por trás daquela 'campanha hostil'. Segundo Rachel Lewinsohn (2003: 543-544), por exemplo, "the campaing against Chagas was a long-drawn-out attempt by an envious clique to blanken the name of Brazil's greatest scientist. There were never any question of a truly scientific inquiry, which - far from disturbing or vexing Chagas - would certainly have been welcoming by him". ${ }^{46}$ Tem-se alegado que tal 'conspiração' foi a causa de se lhe ter sido negado o Prêmio Nobel, para o qual fora indicado em 1921, e que não seria concedido a ninguém naquele ano (Coutinho, Freire Jr. \& Dias, 1999; Lewinshon, 2003). ${ }^{47}$

Como aconteceu com Oswaldo Cruz (Britto, 1995), a imagem do cientista que enfrenta ataques, incompreensões e injustiças em nome de uma 'causa maior' tornou-se um ingrediente decisivo do processo de sacralização da memória de Carlos Chagas, dimensão do próprio processo 
histórico de afirmação e de legitimação da ciência à qual ele estava referido como personagem emblemático. A contenda na Academia passou, assim, a constituir um traço primordial das narrativas históricas sobre a tripanossomíase americana, que, como seu descobridor, teria sido vítima de uma grande 'injustiça' e ingressaria, a partir de então, num período de 'esquecimento'. Como afirmou Magalhães (1944: 14),

A todo esto, Chagas asistió impasible, defendiendo palmo a palmo las grandes verdades nuevas que aportó a la ciencia, conservando fijo en la mente que, para sanear Rio de Janeiro, Oswaldo Cruz tuvo contra sí una gran revolución. Fué esa campaña personal contra Carlos Chagas, la que permitió, para nuestra suprema vergüenza, que después del descubrimiento y los primeros trabajos sobre la Tripanosomiasis americana, la enfermedad pudiese permanecer abandonada durante casi dos décadas. ${ }^{48}$

Ao reconstituir a trajetória da pesquisa sobre a doença descoberta por seu pai, Carlos Chagas Filho $(1968,1993)$ aprofundou e difundiu tal interpretação, munido não apenas do testemunho pessoal, mas das fontes documentais que lhe haviam sido legadas e que constituem o arquivo pessoal de Carlos Chagas. ${ }^{49}$ Em 1968, ele propôs a seguinte demarcação naquela trajetória: depois de um "período heróico" (Chagas Filho, 1968: 7), correspondente ao reconhecimento nacional e internacional conferido aos estudos sobre a nova doença, as dúvidas iniciadas na Argentina e, sobretudo, a "grande luta" (Chagas Filho, 1968: 12) na ANM teriam instaurado uma "fase de desencanto e desentendimento" (Chagas Filho, 1968: 7).$^{50}$ Chagas Filho reconhece que o debate era inicialmente de caráter científico, mas se "desvirtuou", dando origem a "ataques menos aceitáveis", motivados por interesses que fizeram a discussão ultrapassar "os limites da colegiada acadêmica" (Chagas Filho, 1968: 13-14). Segundo ele, a contenda teve conseqüências "desastrosas":

(...) trouxe ele [o episódio] consigo onda de suspeição e de descrédito à própria doença de Chagas. Nessas condições, gerações de médicos brasileiros se formaram sem que se lhes tivesse sido focalizada devidamente a importância da doença, do ponto de vista do próprio desenvolvimento nacional, centenas de milhares de doentes não foram diagnosticados e a ação governamental de saneamento se fez retardada. (Chagas Filho, 1968: 14)

Segundo Chagas Filho (1968: 8), somente com os estudos realizados após a morte de Chagas (por pesquisadores argentinos e por um 
grupo de seguidores no IOC, liderados por Evandro Chagas e Emmanuel Dias) seria renovado o interesse pelo assunto, possibilitando que, ao final da década de 1950, fosse produzida a "perfeita compreensão nacional e internacional do problema representado pela doença de Chagas”. Na biografia de seu pai, Chagas Filho (1993: 226) reafirmou e aprofundou esta interpretação. Referindo-se à controvérsia como "o embate da mediocridade e da inveja contra a genialidade e o esforço", destacou seu efeito "dramático": "Em nada (...) atingiu o renome de meu pai. Mas, na verdade, durante algum tempo, poucos foram os centros científicos brasileiros que continuaram a estudar a doença de Chagas".

O principal fator da 'animosidade' a sustentar a disputa, que "seria para Chagas um drama íntimo de grandes proporções”, teria sido, segundo Chagas Filho (1968: 12), a inveja pelo reconhecimento nacional e internacional que seu pai obtivera, em sua atuação tanto na ciência como na saúde pública. ${ }^{51}$ Justamente nos anos que precederam à discussão na Academia, Chagas alcançara o auge de seu prestígio científico. Em 1921, foi indicado ao Prêmio Nobel . Também neste ano, a convite da Fundação Rockefeller, percorreu várias instituições acadêmicas nos Estados Unidos, tendo sido o primeiro brasileiro a receber o título de doutor honoris causa da Universidade de Harvard; no ano seguinte, foi nomeado membro do Comitê de Saúde da Liga das Nações (Chagas Filho, 1993).

Contudo, segundo Chagas Filho (1993), havia razões concretas para os 'ressentimentos' em jogo. Peixoto havia sido preterido para o cargo de diretor do órgão federal de saúde pública, assumido por Chagas em 1919. ${ }^{52}$ Outra fonte de conflito teria sido a ascensão de Chagas na hierarquia do IOC, que remontava ao concurso para 'chefe de serviço' em 1910 (quando competiu com Aragão) e que se completaria, em 1917, com sua nomeação para diretor, fato que "certamente agastou Vasconcellos" (Chagas Filho, 1993: 189), que era o pesquisador mais antigo e que aspirava ao cargo. Além disso, tensões com o establishment médico da FMRJ teriam também motivado 'desafetos', que se intensificariam com a criação do Curso Especial de Saúde Pública e da cadeira de medicina tropical. ${ }^{53}$

Os historiadores (Benchimol \& Teixeira, 1993; Britto, 1995) também enfatizam que a sucessão de Cruz foi um aspecto central das desavenças entre Chagas e os pesquisadores de Manguinhos, tanto aqueles envolvidos diretamente na polêmica, como Vasconcellos e Aragão, ${ }^{54}$ quanto os que davam a estes seu apoio. ${ }^{55}$ Segundo Britto (1995), o falecimento de Oswaldo Cruz retirou a principal instância de 'controle' das rivalidades 
e das disputas internas que marcavam Manguinhos desde seus primeiros movimentos de expansão, a partir de 1908. Tais dissensos se aglutinavam em torno da figura de Chagas, eleito por Cruz, desde o conturbado concurso de 1910, como seu herdeiro. Criou-se, então, um impasse para a sobrevivência da própria instituição. Segundo a autora, o processo de mitificação da figura de Cruz veio justamente sedimentar a produção deste consenso, pacificando as dissensões que ameaçavam a estabilidade do IOC. Contudo, apesar da efetividade deste consenso no sentido de garantir a unidade necessária à sobrevivência da instituição, Benchimol e Teixeira (1993: 103) citam que os herdeiros mais próximos de Oswaldo Cruz travariam "uma luta sem tréguas" em seus projetos pessoais e em suas aspirações políticas.

Além das rivalidades por conta de posições políticas e prestígio, Chagas enfrentou, desde os primeiros anos de sua administração em Manguinhos, muitas críticas, sobretudo com a situação de crise que se abateu sobre o instituto ao longo da conturbada década de 1920. ${ }^{56}$ Segundo Benchimol (1990a, 2001), o estrangulamento financeiro que passou a assombrar Manguinhos - provocado pela concorrência com outros laboratórios produtores de imunobiológicos, pela insuficiência das dotações orçamentárias e pela inflação, intensificada com a Primeira Guerra Mundial - levou ao progressivo desgaste da sua infra-estrutura física e tecnológica e ao declínio dos vencimentos de seus funcionários, com a conseqüente evasão de pesquisadores e a generalização do duplo emprego. Tudo isso provocou prejuízos ao rendimento e à qualidade das pesquisas. Além disso, as disputas políticas no âmbito da administração de Chagas no DNSP, especialmente durante a presidência de Arthur Bernardes (1922-1926) - que governou o país sob estado de sítio e de quem Chagas era amigo pessoal -, contribuíram para o seu desgaste. ${ }^{57}$

Outra dimensão do conflito que envolveu a tripanossomíase americana diz respeito às divergências quanto à percepção dos elos entre medicina tropical e identidade nacional. Ao analisar a polêmica em torno da doença de Chagas como parte de sua reflexão mais geral sobre os processos de representação dos trópicos, Nancy Stepan (2001: 180-207) sublinha que a especialidade criada por Manson na Inglaterra trouxe desafios específicos para os médicos que atuavam nos países tropicais, na medida em que, na visão de alguns, acionava velhos preconceitos e estereótipos em torno da idéia de 'trópicos', que não era precisa nem consensual e 
que, como admitia o próprio Manson, estabelecia-se numa estreita interface entre ciência e política. O peso da designação de 'país tropical', sujeito a doenças 'exóticas', teria levado alguns médicos a negar o conceito de doenças tropicais e a necessidade de tal especialidade médica. É sob tal perspectiva que a autora examina a história da doença de Chagas e as contestações que lhe foram feitas, as quais teriam produzido um declínio do interesse sobre o tema. Segundo Stepan (2001), este 'desaparecimento', histórico e conceitual, deve ser compreendido em razão da própria maneira pela qual a doença 'apareceu' e foi originalmente compreendida e interpretada num contexto cultural particular.

Seu argumento é o de que os conflitos em torno da tripanossomíase estavam referidos aos significados simbólicos e ideológicos que as doenças tropicais, especificamente a doença de Chagas, assumiam naquele contexto histórico, e às maneiras pelas quais esta enfermidade foi parte de um discurso mais amplo sobre a nacionalidade (Stepan, 2001). A representação visual da doença, mediante fotografias médicas que revelavam a dimensão 'monstruosa' dos trópicos, difundida especialmente pelo relatório de Neiva e Penna (1916), foi, na perspectiva de Stepan, um elemento central tanto do reconhecimento quanto das críticas àquele objeto, despertando reações negativas entre os que não aceitavam qualificar a identidade nacional pelos traços da deformação e da incapacidade (materializados no bócio e no retardo mental), considerados típicos da nosologia tropical. Os elementos visuais da doença tornaram-se particularmente incômodos, sobretudo quando a campanha pelo saneamento rural do país passou a divulgá-la a olhos não médicos. ${ }^{58}$ Assim, nas reações de Afrânio Peixoto à representação do Brasil como uma nação de 'degenerados', estava expressa a condenação à própria idéia da especificidade da medicina tropical, que, segundo este e outros médicos, introduzia estereótipos que afrontavam o orgulho nacional, além de um determinismo climático incompatível com as perspectivas intervencionistas e redentoras da higiene (Stepan, 2001).

Tais historiadores, em suma, ainda que com distintas ênfases, convergem para a compreensão das rivalidades enfrentadas por Chagas como dimensão constitutiva da própria atividade científica, sobretudo quando se trata de trajetórias que adquirem visibilidade no campo da política, seja ela institucional ou no seu sentido mais amplo, das ações e debates no espaço público da nação. Desta forma, esses autores contextualizam tais conflitos no processo geral de institucionalização da ciência no qual 
Chagas e seu 'objeto' estavam inseridos e no qual desempenhavam importante papel.

Benchimol e Teixeira (1993) e Coutinho (1999, 2003), seguindo a interpretação e a periodização de Carlos Chagas Filho, defendem que o episódio da ANM teria acarretado a 'desconstrução' da doença como fato científico e como tema de relevância médico-social no país. Este processo teria significado uma descontinuidade na institucionalização da pesquisa, só revertida após a morte de Carlos Chagas, quando teve início uma fase de 'reconstrução'. Uma primeira ressalva a esta interpretação é que, ao enfatizar os aspectos políticos envolvidos nos questionamentos a Chagas, deixa-se em segundo plano outra dimensão decisiva destes questionamentos: as incertezas e os limites de natureza científica que de fato existiam em torno de certos enunciados pelos quais Chagas vinha definindo a enfermidade que leva seu nome. Além disso, o termo 'desconstrução', usado por Coutinho (1999) como conceito referido à noção sociológica de construção dos fatos científicos, é problemático. Ele sugere a idéia de que tais dúvidas, críticas e objeções fizeram retroceder e desfazer o que já estava 'pronto', quando, na própria perspectiva teórica acionada pela autora, esta dimensão do dissenso e da controvérsia é considerada parte do próprio processo de construção dos fatos científicos. Assim, não estou de acordo com Coutinho (1999: 524) quando esta afirma, usando os termos de Bruno Latour, que, a partir do episódio na Academia, a doença "perdeu seu estatuto de fato estabilizado". Os processos em curso naquele período, que iam além dos marcos específicos da polêmica e que mesclavam dúvidas e certezas numa trama que envolvia múltiplos atores e interesses em torno daquele objeto em si mesmo multifacetado, foram parte da longa trajetória de construção da tripanossomíase americana, que não havia alcançado o estatuto de fato científico inquestionável..$^{59}$ No caso de Benchimol e Teixeira (1993), o uso da noção de 'desconstrução' é menos central e pode ser dispensado, até porque a análise que os autores desenvolvem não corrobora o que o termo sugere, mas, ao contrário, mostra em que medida aquele episódio foi parte do próprio percurso de produção do fato científico constituído pela doença de Chagas, percurso este intimamente associado ao projeto científico e político do IOC. ${ }^{60}$

Não se pretende negar a dimensão política do embate na Academia (tanto nas condições que o propiciaram quanto em suas conseqüências), mas ressaltar que, ainda que motivado pela política (em suas várias 
dimensões, de rivalidades pessoais, de conflito de interesses e de conflito ideológico), este embate se mesclou a uma controvérsia científica real em torno de certos enunciados de Chagas. A evidência de que ele próprio reconhecia a legitimidade desta controvérsia foi a importante revisão que realizou em seus trabalhos. Também não se deve menosprezar o impacto negativo trazido pelo episódio. De fato, a polêmica acentuou as incertezas em torno da doença, na medida em que lhes conferiu maior visibilidade; mas não foi responsável por tais dúvidas. Apesar de ter modificado substantivamente sua caracterização clínica, deixando os enunciados mais controvertidos como 'questões anexas', Chagas enfrentou dificuldades concretas, relacionadas, sobretudo, aos métodos de diagnóstico, para comprovar a dimensão epidemiológica da doença, antes da polêmica na ANM e depois dela.

A dimensão política (em seus vários sentidos) presente no embate na Academia não foi algo que se sobrepôs, circunstancialmente, à dimensão científica naquele momento, levando a uma 'reversão' na construção da doença de Chagas, mas foi uma dimensão constitutiva deste objeto no decorrer de todo o seu processo de construção. A controvérsia, ao fragilizar a credibilidade científica e social da doença, não interrompeu sua trajetória de construção, ainda que a tenha modificado, num contexto em que Chagas não contava mais com os aliados que lhe haviam sido tão decisivos: Oswaldo Cruz e Miguel Pereira haviam falecido, Belisário Penna estava rompido com ele e Miguel Couto não havia atendido suas solicitações durante o embate na ANM.

Em suma, argumento que, constituindo uma fase específica da trajetória de enquadramento da doença de Chagas, a controvérsia na Academia teve como fator determinante a dimensão política do confronto entre distintas posições no debate nacionalista da época, às quais se associavam distintas maneiras de conceber a doença de Chagas como símbolo da identidade nacional, na condição de 'doença do Brasil'. Os que questionavam o 'mal de Lassance' como objeto científico e problema social contestavam diretamente aqueles que qualificavam o Brasil como 'vasto hospital'.

Saindo da cena pública, a doença seguiu seu percurso no laboratório. As investigações de Chagas prosseguiram. As novas trilhas que ele havia tomado a partir de 1916 seriam reforçadas, progressivamente, e levariam, após a sua morte, sob novas circunstâncias institucionais, sociais e políticas, a uma nova etapa daquela trajetória. Isso se daria não 
como 'reconstrução', como pretendem os partidários da idéia da 'desconstrução', mas como parte de um mesmo processo longo e coletivo de produção de significados e de consenso, que mobilizou diferentes atores, instituições e interesses, envolveu acordos e disputas e exibiu, em cada momento e em cada contexto, suas peculiaridades no arranjo destes elementos.

\section{Os Caminhos de Chagas e da Doença após a Polêmica (1923-1934)}

Diante de tantas dúvidas, eram esperadas respostas asseguradoras. É bastante significativo que Chagas, na conferência que encerrou a polêmica na ANM, tenha sublinhado a importância da forma cardíaca. Tratava-se, como vimos, de um caminho que vinha sendo trilhado desde 1916, não apenas em termos das operações discursivas que lhe realçavam os enunciados, mas como orientação efetiva de pesquisa. Este caminho foi aprofundado na década de 1920, época em que a cardiologia vivia, no cenário internacional, um momento de particular desenvolvimento e institucionalização.

Conforme Bynum, Lawrence e Nutton (1985), boa parte do trabalho que gerou as concepções modernas sobre a atividade e as doenças do coração foi produzida na passagem do século XIX para o XX, especialmente nas duas primeiras décadas do século XX. O desenvolvimento do eletrocardiógrafo, pelo holandês William Einthoven, entre 1901 e 1903, foi decisivo neste processo. ${ }^{61}$ Em contraposição a uma tradição que via o coração sobretudo em seus aspectos anatômicos e estruturais, a nova cardiologia, em estreita associação com a fisiologia experimental, passou a privilegiar o estudo de suas características dinâmicas, ou seja, o seu funcionamento. Um dos focos deste novo olhar foi o estudo da atividade rítmica do órgão. Na década de 1910, o galvanômetro de corda de Einthovem (que teve seu primeiro modelo comercial vendido pela inglesa Cambridge Scientific Instrument Company em 1908) passaria por vários aperfeiçoamentos técnicos de modo a tornar-se um instrumento clínico, para além da pesquisa em eletrofisiologia. Em 1912, ano em que Chagas fez a primeira menção ao eletrocardiograma em suas pesquisas (Chagas, 1912b), o tamanho do eletrocardiógrafo (que em 1903 ocupava dois quartos e requeria várias pessoas para operá-lo) havia sido reduzido 
substancialmente, permitindo sua instalação num hospital ou consultório (Burnett, 1985). Outro fator importante para atrair interesse pela área foi a experiência da Primeira Guerra Mundial, quando reconheceuse que expressivo número de soldados sofria de afecções cardíacas. Como assinalou Lawrence (1985: 32), ao analisar a institucionalização da cardiologia na Inglaterra: "By the 1920s, cardiology was a perfectly reputable speciality for a physician to follow in his consulting rooms (...). There was a journal, a club, a recognized leadership, a technology, and most important of all, a coherent intellectual discipline" ${ }^{62}$ Em 1924, Einthoven foi laureado com o Nobel pela invenção do eletrocardiógrafo.

Chagas publicou, em 1922, com Eurico Villela (pesquisador de Manguinhos que, desde 1912, integrava a equipe que estudava a doença em Lassance), um extenso trabalho sobre a forma cardíaca da tripanossomíase, explicitando a importância que vinha conferindo a esta diretriz no estudo e na definição clínica da doença. O artigo aprofundou formulações anteriores e expressou a preocupação em fortalecer a noção de que as arritmias derivadas da ação do parasito no miocárdio eram o meio privilegiado para a avaliação da dimensão e da importância epidemiológica da doença. Substituindo o papel anteriormente conferido aos sinais tireoidianos, tais arritmias foram alçadas, pela especificidade de sua ocorrência em relação a outros tipos de cardiopatias, à condição de 'guias' primordiais para a suspeita clínica e o diagnóstico diferencial da enfermidade. Eram estes os traços que lhe garantiriam existência como entidade conceitualmente específica.

Referindo-se às lesões no miocárdio observadas nos casos crônicos, Chagas e Villela (1922: 8) acentuaram: "Estas, na multiplicidade de suas variantes e na freqüência com que são observadas em quase todos os casos clínicos, expressam uma condição patológica exclusiva da doença, e evidenciam as maiores curiosidades deste novo capítulo da patologia humana". Sobre as alterações na condutibilidade, em especial o bloqueio cardíaco, destacaram:

Em outras doenças essas alterações têm sido verificadas; em nenhuma, porém, com a freqüência aqui registrada e com os aspectos múltiplos e evolutivos que podem ser surpreendidos na tripanossomíase. E de tal modo assim é que poderíamos caracterizar essa entidade como a doença, por excelência, das alterações do ritmo, e especialmente do pulso lento (Chagas \& Villela, 1922: 8; grifos meus). 
Quanto às alterações na excitabilidade, enfatizaram que existiam em grande número "ou talvez na totalidade dos casos crônicos". Seria tal a freqüência das extra-sístoles, que este sintoma poderia ser visto como "o melhor elemento para avaliar o índice endêmico da doença”" (Chagas \& Villela, 1922: 10).

Chagas e Villela (1922: 12) detalharam os principais indícios físicos do "esgotamento progressivo" da atividade do órgão (como sinais de insuficiência cardíaca e aumento no volume do coração, entre outros), os sintomas subjetivos referidos pelos pacientes, a evolução dos processos patológicos - como a grande ocorrência de mortes súbitas - e as experiências com drogas para tratamento daquelas arritmias. ${ }^{63}$ Numa estratégia bastante persuasiva, apresentaram 63 observações de doentes com sinais desta forma clínica, descrevendo os procedimentos de diagnóstico, entre eles os traçados cardíacos tomados por procedimentos tanto mecânicos quanto, em alguns casos, por meio do eletrocardiógrafo. ${ }^{64}$

A conclusão do trabalho foi enfática e constituiu a base do que Chagas diria em sua conferência na ANM, no ano seguinte: a tripanossomíase americana deveria ser vista como uma doença crônica essencialmente cardíaca, com elementos clínicos suficientemente individualizados para dispensar a comprovação parasitária. ${ }^{65}$ Vinte anos depois, o grupo de pesquisadores do IOC em Bambuí citaria esta formulação sistematicamente em seus trabalhos, como argumento central dos estudos que realizavam com o objetivo de legitimar este novo enquadramento da tripanossomíase americana. Segundo Chagas e Villela, as observações clínicas então apresentadas

(...) evidenciam, na uniformidade da síndrome cardíaca nelas manifesta, a unidade etiológica do processo mórbido localizado no músculo cardíaco. Essa condição da doença na qual predominam, sobre quaisquer outros, os sintomas cardíacos, é generalizada nas zonas de tripanossomíase endêmica, e aí observada com intensidade e extensão máximas, constituindo assim a característica clínica por excelência da tripanossomíase americana. Não há como contestar a razão etiológica de todas as observações clínicas aqui apresentadas, embora de muitos doentes não tenha sido feito nem o diagnóstico parasitário nem a verificação necroscópica. (Chagas \& Villela, 1922: 17; grifos meus ${ }^{66}$

Em 1927, Chagas voltou à ANM para outra conferência, na qual novamente abordou os aspectos cardíacos da doença. Salientou que, embora já tivesse apresentado àquela associação vários trabalhos sobre a 
“expressão clínica multiforme da tripanossomíase americana”, tratava-se então de iniciar "o relato de indagações demoradas, referentes aos processos mórbidos essenciais e às formas clínicas predominantes nessa tripanossomíase" (ANM, 1927: 597). ${ }^{67}$ No ano seguinte, foi publicado novo trabalho a respeito, desta vez em revista francesa especializada em doenças do coração (Chagas, 1928).

Outra evidência dos investimentos neste caminho de pesquisa foi a trajetória de seu filho mais velho, Evandro. Tendo se formado na FMRJ em 1926, ele dedicou-se de pronto ao estudo deste aspecto clínico da tripanossomíase, no âmbito do Serviço de Radiologia e Eletrocardiografia (por ele chefiado) do Hospital Oswaldo Cruz. Por meio destas modernas técnicas, sua principal preocupação era definir as características peculiares e a freqüência relativa das alterações cardíacas provocadas pela infecção pelo T. cruzi, sobretudo na fase aguda (Chagas, E., 1930). Em 1931, Evandro Chagas assumiu a livre-docência da cadeira de clínica de doenças tropicais e infecciosas da FMRJ, ministrada por seu pai. Na ocasião, defendeu tese sobre a forma cardíaca da tripanossomíase americana (Chagas, E., 1932). ${ }^{68}$

As investigações sobre a 'forma nervosa' também ganharam novo impulso. A partir de 1923, experiências de Eurico Villela e outros pesquisadores, que reproduziram paralisias e outros distúrbios neurológicos em cães inoculados com o T. cruzi, geraram novos elementos para fundamentar a tese da especial 'predileção' desse protozoário pelo sistema nervoso, pelo menos de algumas cepas dele (que foram chamadas de 'neurotrópicas'). Estudos com animais demonstravam também a transmissão congênita, intraútero, do T. cruzi, que passava de mãe para filho pela placenta. Num momento em que as doutrinas em neurologia afirmavam que as infecções congênitas eram mais propícias ao ataque ao sistema nervoso, tais pesquisas fortaleciam a idéia de que a ação patogênica daquele parasito sobre tal sistema orgânico se dava desde a vida embrionária, derivando daí as síndromes clínicas posteriores. Em 1925 e em 1930, Chagas pronunciou conferências em Paris, respectivamente no Instituto Pasteur e no Hospital da Salpetrière, sobre estes aspectos (Chagas, 1926, 1930).

Em 1932, em comunicação feita em São Paulo, Chagas apresentou uma sistematização do 'estado atual da tripanossomíase americana', cujo objetivo era salientar justamente os avanços na compreensão da forma nervosa (Chagas, 1934). Suas primeiras afirmativas foram uma clara resposta aos questionamentos de que havia sido alvo. Insistia que, contrariamente 
ao que muitos sugeriam, "essa tripanossomíase humana não é doença exclusiva de nosso território, porquanto foi também reconhecida em outros países da América do Sul e da América Central” (Chagas, 1934: 58), inclusive na Argentina. ${ }^{69} \mathrm{Na}$ apresentação do quadro geral da doença, destacou, como aspecto de grande importância, a comprovação da transmissão congênita, intra-útero. ${ }^{70}$ Quanto às pesquisas sobre os elementos neurológicos, expôs que a presença do parasito vinha sendo demonstrada dentro da própria "célula nervosa” (Chagas, 1934: 60), o que constituía achado de máxima importância para fundamentar a ação patogênica do T. cruzi sobre o sistema nervoso central. Tais estudos histopatológicos revelavam também certas características desta encefalopatia comparáveis a outras encefalopatias infecciosas, como ocorria na malária, por exemplo. Todos estes novos elementos reforçavam, de acordo com Chagas, ainda que com certas adaptações, suas convicções sobre as síndromes neurológicas na tripanossomíase americana (Chagas, 1934: 58-61).

Depois de manifestar entusiasmo com o impulso conferido a esta vertente, o trabalho abordou a forma cardíaca, afirmando ser este "outro aspecto da tripanossomíase amplamente esclarecido e largamente interpretado" (Chagas, 1934: 62). As outras modalidades clínicas da doença, entre as quais as síndromes endócrinas e o bócio, constituiriam “aspectos menos esclarecidos, (...) largos domínios nos quais deverão se exercitar a inteligência e o engenho técnico dos nossos experimentadores" (Chagas, 1934: 63). Apesar de manter sua hipótese original, Chagas intensificou ainda mais as incertezas que vinha indicando desde 1916:

Discutíveis são as relações de causa e efeito, acaso existentes, entre o bócio e a infecção pelo Trypanosoma cruzi. (...). Razões diversas, e algumas altamente valiosas, levaram-nos àquela convicção. Mas, em ciência não existem dogmas e conceito de tanto alcance doutrinário (...) não dispensa o fundamento de fatos irrecusáveis. Embora persistente na convicção anterior, devemos confessar que o assunto oferece margem a divergências, sendo passível de contestação à doutrina formulada. (...) É uma questão aberta, a merecer estudo e perspicácia. (Chagas, 1934: 63) (11 $^{71}$

Depois de explicitar os elementos mais frágeis de sua concepção, Chagas concluiu suas apreciações, nesta que seria sua última comunicação científica, com afirmações sobre os enunciados que considerava mais fortes e, conseqüentemente, mais promissores do ponto de vista da continuidade das pesquisas: 
As alterações cardíacas e nervosas da tripanossomíase americana acham-se amplamente esclarecidas e autorizam admitir, como definitivas e em sistematização nosográfica bem baseada, as formas cardíaca e nervosa dessa espécie mórbida; (...) As alterações variadas do ritmo cardíaco constituem a característica sintomática de maior valia para o diagnóstico clínico dessa infecção; (...) o índice endêmico da tripanossomíase americana deverá ser apreciado, principalmente, pela percentagem, sempre muito elevada, de indivíduos com alterações do ritmo cardíaco. (Chagas, 1934: 64)

No Manual de Doenças Tropicais e Infectuosas, editado por Evandro Chagas em 1935 e que reunia os temas lecionados por ele e por seu pai (então falecido), na cátedra de mesmo nome na FMRJ, encontra-se o mesmo retrato clínico da doença, além de outros aspectos interessantes. O manual informa que as designações de "moléstia de Cruz e Chagas, tireoidite parasitária, doença do barbeiro" foram "completamente abandonadas", em benefício de tripanossomíase americana, ou brasileira, ou doença de Chagas (Chagas \& Chagas, 1935: 110). Além disso, dá-se destaque à notícia de casos localizados em diferentes países do continente americano (sobretudo na Argentina), em reforço à tese da ampla distribuição geográfica da doença. ${ }^{72}$ Cauteloso diante das estimativas que tanto foram questionadas pelos adversários de Chagas, o texto salienta que, todavia, nenhum estudo sistemático sobre o assunto havia sido feito, nem mesmo no Brasil, o que exigiria esforços demorados. Outro indício do cuidado em evitar perspectivas demasiado otimistas é encontrado no tópico relativo à profilaxia: "A prevenção da doença é extremamente difícil, pois que para a destruição do inseto seria necessário o expurgo, ou mesmo a destruição de milhares de habitações, esparsas pelo interior dos países em que grassa a doença” (Chagas \& Chagas, 1935: 144). O mesmo tom é adotado quanto às perspectivas de tratamento: "Medicamentos de ação tripanossomicida têm sido experimentados por numerosos pesquisadores sem qualquer êxito. Algumas síndromes clínicas podem experimentar ação terapêutica sintomática realizada de acordo com suas manifestações e evolução" (Chagas \& Chagas, 1935: 144).

Este trabalho constitui importante evidência das transformações implementadas no quadro clínico da tripanossomíase, num processo em que se abandonou a principal trilha cognitiva e social que havia presidido a sua definição entre 1910 e 1916. Ainda que conservasse o mesmo esquema interpretativo quanto ao processo etiopatogênico (uma infecção 
adquirida nas primeiras idades, muitas vezes antes do nascimento, de quadro essencialmente crônico, caracterizada por distúrbios decorrentes da ação parasitária sobre órgãos e sistemas orgânicos), a feição assumida pelo desenho clínico era outra: tratava-se não mais de uma afecção endócrina em seus caracteres mais salientes, mas de uma doença essencialmente cardíaca e neurológica. ${ }^{73}$

Contudo, apesar da confiança nestas duas vertentes, muitas dúvidas permaneciam. Na própria tessitura do texto, observa-se o quanto a tripanossomíase americana era ainda um objeto científico não estável, não consensual. Contradizendo a própria natureza dos manuais - em que, como sublinhou Latour (2000), os enunciados não se apresentam como hipóteses, associados a suas condições de produção e a seus autores, mas, ao contrário, aparecem como afirmativas atemporais a expressar a verdade dos fatos -, é freqüente encontrar-se, neste caso, junto aos enunciados (sobretudo nos aspectos mais controversos), indicações de quem os formulou, dados sobre as experiências realizadas e indicações de hipóteses contrárias. Mesmo os enunciados mais fortes ainda não eram 'caixas-pretas'.

Em revisão publicada em 1937, Warrington Yorke, professor de parasitologia da prestigiosa Liverpool School of Tropical Medicine e um dos editores da revista Tropical Diseases Bulletin, sintetizou as incertezas que ainda pairavam sobre a doença tropical descoberta no Brasil. Mais uma vez, a questão essencial era o número de casos:

In view of this wide distribution of infected vectors, it is remarkable that it is still a matter of considerable doubt how far South American trypanosomiasis is a disease of grave significance. The number of human beings hitherto found to be actually infected with the trypanosome is remarkably small. The only district from which any considerable number of cases has been recorded is that of the State of Minas Gerais in Brazil. (Yorke, 1937: 275) ${ }^{74}$

Sistematizando os dados da literatura até então, Yorke contabilizou: além dos 29 casos agudos estudados por Chagas em Lassance e de quatro casos identificados em São Paulo, haveria 113 casos descritos fora do Brasil. Citando trabalhos sobre casos crônicos da doença no país (como os 63 de forma cardíaca estudados por Chagas e Villela em 1922), o autor reconheceu que o número de portadores da infecção chagásica deveria ser, especialmente em Minas, bem maior. Contudo, num indício da força 
do critério etiológico como elemento para a 'demonstração' da doença, declarou estar se atendo àqueles nos quais um 'diagnóstico definitivo' foi feito com base na demonstração do tripanossoma, ou seja, 146 casos. Mesmo considerando que, deste total, quase uma centena de casos haviam sido identificados na Argentina nos quatro últimos anos, o que expressava uma nova perspectiva bem promissora, o parasitologista acrescentou que o número ainda era muito reduzido. ${ }^{75}$

Yorke enfatizou também as incertezas quanto à definição clínica da doença, sobretudo em relação às formas crônicas. Segundo o autor, apesar do novo encaminhamento que conferiu à questão a partir de 1916, ao relativizar o peso dos elementos endócrinos, Chagas permaneceu convencido de que a doença era responsável por "various forms of myocardial disease, of nervous disease, of infantilism, of hypothyroidism and goiter met with so commonly in Minas Gerais" ${ }^{76}$ E observou: "If Chagas' views are correct, then the disease which bears his name is unquestionable of very great pathological significance. Recent work, however, has raised considerable doubt whether many of the conditions included by Chagas among the chronic forms of his disease are in any way the result of infection with Trypanosoma cruzi" (Yorke, 1937: 284). ${ }^{77}$

Mesmo reconhecendo as dificuldades nos métodos de diagnóstico e que o estudo da forma cardíaca despertava boas expectativas entre os especialistas, ao fim e ao cabo, a questão era decidida pelos números. Sobre os critérios para estabelecê-los, a revisão de Yorke foi taxativa: apesar de toda a importância que pudesse ser conferida ao diagnóstico clínico, o encontro do parasito fazia-se, inescapavelmente, a instância obrigatória para definir e para certificar o que seria um caso positivo de uma dada entidade nosológica.

Sob tal perspectiva, embora Chagas afirmasse ser a tripanossomíase uma infecção crônica por excelência, era a fase aguda a que assumia maior relevo e maior legitimidade. Este era o terreno onde, desde 1913 (quando se abandonou o método de verificação parasitológica inicialmente formulado para os casos crônicos), os enunciados clínicos estavam menos expostos a objeções. Ao mesmo tempo, era para este domínio que convergia a procura dos casos, guiada pela exigência da comprovação parasitária. Como num círculo vicioso, os investimentos de pesquisa dirigiam-se aos casos agudos, em detrimento de investigações sobre a fase crônica, que era onde justamente se faziam necessários mais esforços para dirimir as dúvidas. ${ }^{78} \mathrm{O}$ impasse - que expressava um contraponto entre 
laboratório e clínica como instâncias de produção e de certificação dos conhecimentos sobre as doenças - marcava o processo de definição da doença de Chagas na época do falecimento de seu descobridor e orientaria a sua continuidade dali para frente. ${ }^{79}$

\section{Uma Doença a ser Procurada pelos Clínicos}

Em 1923, após a leitura do parecer que encerrou a polêmica na ANM, Alfredo Nascimento Silva fez algumas considerações sobre a questão que, a despeito dos protestos de Chagas, permanecia 'em aberto' na avaliação daquela comissão: a dimensão epidemiológica e social da doença. Seu raciocínio traz elementos valiosos para a reflexão sobre o processo de construção da tripanossomíase americana e os desafios que se impunham para sua continuidade. Comentando a apresentação de Parreiras Horta, em que este reiterou as dúvidas de Afrânio Peixoto sobre o 'mal de Lassance', o relator reconheceu que o colega apresentara "avultado cabedal demonstrador da vastíssima extensão geográfica em que tem sido encontrado o inseto sugador, o barbeiro, como os tripanossomas", não só no Brasil, como no continente americano. Mas, acentuou, a questão em foco era de "natureza clínica", relacionada à apuração "da existência de casos da doença". O que se impunha era "ligar estes dois fatos", ou seja, demonstrar a concomitância do inseto infectado e dos doentes cuja sintomatologia pudesse ser atribuída à ação do T. cruzi (ANM, 1923d: 746). Em suas buscas pelo país, Horta teria produzido farta documentação parasitológica sobre o primeiro aspecto, mas, ainda que seu objetivo fosse atestar a ausência de casos da doença, perguntou Nascimento Silva: "onde está a documentação clínica relativa à existência ou não nessas mesmas localidades? Não há, não foi dada” (ANM, 1923d: 749). Ou seja: Horta não teria encontrado os doentes porque 'eles não foram devidamente procurados'. Disse Nascimento Silva:

A zona de Lassance é abundante em doentes, porque ali eles são minuciosamente procurados por quem tem especial competência para encontrá-los. Fora dali, as formas clínicas, de difícil diagnóstico e de muito possível confusão com outras modalidades, ou mesmo de natureza a passarem despercebidas, podem existir indiagnosticadas, até que sindicância especializada e dirigida venha pô-las em evidência. (ANM, 1923d: 747; grifos meus) 
Para o relator, era fundamental que tal sindicância fosse "armada dos precisos elementos técnicos" adequados. Mas, reconhecia, esta era uma tarefa difícil, a começar pela dificuldade na demonstração do parasito, tanto nas formas agudas quanto, principalmente, nas "polimorfas formas crônicas” (ANM, 1923d: 749). Se o diagnóstico etiológico era limitado, a própria possibilidade da suspeita clínica diante de um eventual caso da doença também era restrita. A despeito de Chagas afirmar que, independentemente do bócio, havia sinais claros para o diagnóstico clínico, o assunto estava, de fato, envolto em dúvidas. Mesmo abandonada a certeza, até então dominante, quanto ao 'papo', não se conseguira firmar um outro traço a guiar o olhar de quem quisesse procurar a doença. Além disso, o conhecimento sobre o tema era, conforme Nascimento Silva, restrito a um grupo de especialistas.

(...) fora de um número limitado de profissionais, quase todos homens de laboratório, quem é que clinicamente conhece a doença de Chagas, de modo a que aí por todos os nossos estados e pelos sertões a dentro, esteja em condições de diagnosticá-la quando a encontrar? (...) A doença de Chagas ainda não é suficientemente conhecida e divulgada de modo que tal diagnóstico se proponha em localidades onde não lhe tenha sido demonstrada a existência; sua caracterização não é tão nítida e individual que se imponha ao clínico desprovido dos precisos recursos para a diferenciação necessária. (ANM, 1923d: 750; grifos meus)

Em suas últimas palavras, Nascimento Silva reforçou seu argumento com uma convocação que, sob uma leitura retrospectiva, impressiona pela anunciação de um processo que se iniciaria nas décadas seguintes:

(...) logicamente é de esperar que, procurando clinicamente o doente como se procurou o parasito, há de evidenciar-se a concomitância de causa e efeito. Quando assim for, a doença de Chagas surgirá triunfante de todas as dúvidas que ainda se lhe opõem; e então, sem que se possa mais chamá-la de doença de Lassance, confirmará o nome que desde o começo lhe foi dado de tripanossomíase americana. Para responder ao quesito tão importante da extensão geográfica do mal, que o relatório da comissão não pôde esclarecer, a parasitologia trouxe metade do contingente preciso; cabe à clínica trazer o resto, com o empenho com que se deve abordar tão alto problema de ciência e tão elevada questão de patriotismo. (ANM, 1923d: 753; grifos meus)

Este ponto, concernente às relações e às hierarquias entre a 'ciência de laboratório’ e a prática clínica, foi um dos principais temas da aula 
inaugural que Carlos Chagas pronunciou ao tomar posse na cátedra de medicina tropical da FMRJ, em setembro de 1926. Esta disciplina seria um espaço importante para propagar a idéia de que as endemias rurais, em especial a tripanossomíase americana, constituíam questão central para os médicos brasileiros, tanto do ponto de vista estrito do saber científico quanto por ser um caminho de legitimação social da ciência médica em seus compromissos públicos e políticos com a nação. Se, no âmbito do movimento sanitarista e à frente do DNSP, a dimensão política da atuação de Chagas era explícita, o ensino médico tornava-se outro espaço estratégico, pela possibilidade de mobilizar as 'futuras gerações' para as 'bandeiras' que vinha desfraldando desde o início da década de 1910. A própria existência deste espaço era uma vitória para o IOC, em termos teóricos (pela implantação daquela especialidade no currículo médico, há tempos pretendida, e que sempre enfrentara franca resistência) e também políticos (pela prerrogativa de interferir na formação oferecida por aquela importante escola médica). ${ }^{80}$

O principal objetivo da aula de Chagas, em 1926, foi justificar a criação daquela cadeira na FMRJ, não apenas como especialidade do saber médico, mas pela importância que adquiria no contexto nacional. As enfermidades tropicais deveriam ser estudadas porque "representam tais doenças o mais relevante de nossos problemas médico-sociais" (Chagas, 1935f: 138). Se a medicina tropical havia sido criada na Europa em virtude dos interesses colonialistas, no Brasil “(...) deveres do mais exaltado e previdente nacionalismo nos obrigam ao estudo e à pesquisa da nosologia brasileira, a fim de promover o aperfeiçoamento de nossa raça, de raros predicados nativos, e de realizar, pelo método profilático, a redenção sanitária de nosso vasto território" (Chagas, 1935f: 138).

Ao apresentar aos estudantes o conceito de medicina tropical - o clima cria variantes na nosologia na medida em que produz condições específicas para a ocorrência dos patógenos e dos vetores -, Chagas justificou o recorte que, segundo ele, associava os traços específicos da nosologia brasileira à identidade nacional: as endemias rurais, concebidas, em seu sentido simbólico e político, como 'doenças do Brasil'. Sob tal recorte, a categoria de 'trópicos' assumia concretude e era ressignificada no ambiente físico e social dos 'sertões'. Sob os argumentos teóricos da especialidade, Chagas expressava o sentido de sua própria trajetória como cientista. A tripanossomíase americana era, acima de qualquer outra, "uma entidade mórbida essencialmente brasileira" (Chagas, 1935f: 163). Não porque 
fosse exclusiva do país, mas porque o representava, numa justaposição de sentidos: foi descoberta e estudada aqui, era um emblema das condições de saúde do interior do país e um símbolo da competência médica e científica nacional. Deste modo, declarou: "Será ela, por isso mesmo, o assunto inicial deste curso" (Chagas, 1935f: 163).

O ponto fundamental que pretendia fixar entre os estudantes - $\mathrm{e}$ que ganhava significados peculiares em razão dos dilemas em torno da tripanossomíase americana - era a necessidade de estreitas relações entre a ciência de laboratório (no caso, a parasitologia) e a clínica. A medicina tropical seria o exemplo típico desta associação. Se "do microscópio não podem (...) prescindir os que estudam e praticam a medicina nos países quentes, porque é de seu manejo que resultam indicações essenciais à finalidade do nosso mister", como as informações sobre os parasitos e os vetores, Chagas sublinhou que o laboratório não substitui a clínica: "O laboratório apenas prolonga a enfermaria, e vem prosseguir ou completar a indagação etiopatogênica, sempre orientada pelo conceito clínico inicial, que a todas as pesquisas antecede". Tal articulação deveria, pois, presidir o aprendizado e o estudo das "espécies nosológicas peculiares ao nosso país" (Chagas, 1935f: 165).

O argumento seria novamente enfatizado em 1928, na abertura dos cursos da FMRJ:

É do passado essa dualidade de tendências, na orientação do ensino, ou para o leito do hospital ou para os laboratórios de pesquisas, assim definindo, uma escola clínica, que mais demorava na indagação dos sintomas, e uma escola científica que mais insistia na pesquisa experimental. (...) A enfermaria, o laboratório e o instituto anátomo-patológico hoje se penetram e se completam, e constituem uma só unidade técnica, na qual se aplicam inteligência, perspicácia e discernimento para esclarecer a doença. (Chagas, 1935g: 171-172)

Sob tal afirmação, Chagas atualizava um lema fundador da chamada 'medicina científica', traço distintivo da 'escola de Oswaldo Cruz': a necessidade de que o ensino médico fosse um espaço de pesquisa e não apenas de treinamento profissional. ${ }^{81}$ Contudo, mais do que a uma diretriz para a formação médica, tal formulação tinha um sentido muito particular no contexto das pesquisas e dos desafios em torno da doença de Chagas. Por ela, era possível afirmar: o conhecimento do parasito pelo 
laboratório é importante, mas também a competência clínica para reconhecer a doença. Foi com base neste princípio que Chagas, em sua aula inaugural de 1926, comemorando as múltiplas possibilidades que o "método científico" apresentava para "dominar as doenças nos trópicos", concluiu sua conferência com uma conclamação aos futuros médicos: "Atentai bem nessa missão de patriotismo e estudai com esforço a doença do Brasil” (Chagas, 1935f: 166; grifos meus). Numa mensagem de duplo significado, talvez não conscientemente, Chagas expressava suas expectativas não apenas em relação ao futuro dos problemas médicos nacionais, mas em relação à própria doença por ele descoberta, a fim de que esta despertasse o interesse das novas gerações.

Foi com base numa nova articulação entre laboratório e clínica que as palavras de Nascimento Silva e a exortação de Chagas seriam 'atendidas', logo em seguida ao falecimento deste, com o trabalho realizado por uma nova geração de médicos e pesquisadores. Se a controvérsia científica e política em torno do bócio havia desfeito o 'selo' que norteava a busca da doença, um novo sinal, identificado por um clínico do interior da Argentina, em 1935, refaria o 'mapa' para o encontro de casos agudos. Em relação às controvertidas formas crônicas, o mesmo ocorreria na década de 1940, com a definição de um quadro eletrocardiográfico a aprofundar a trilha que o próprio Chagas havia aberto em 1916, quando apostou no estudo da forma cardíaca.

Nesta nova fase de produção de conhecimentos sobre a doença, ela se tornaria um objeto construído e legitimado fundamentalmente no campo da experiência e da pesquisa clínica. A confiança nos dados produzidos neste campo funcionaria como alternativa à tão exigida comprovação do parasito como traço primordial da materialidade da doença. Se, como havia dito Chagas em sua tese de doutoramento (1903), cabia ao laboratório assessorar a clínica e garantir-lhe os "elementos de convicção", o processo de definição/validação da enfermidade por ele descoberta exigiu uma inversão destes termos, já que o laboratório, neste caso, encontrava limites para prover o critério de prova que ele mesmo havia instituído: a verificação parasitária. Diante disso, como afirmara Nascimento Silva, cabia à clínica completar o trabalho da parasitologia e do laboratório. ${ }^{82}$

Este processo significaria uma mudança não apenas nos referenciais cognitivos e interpretativos, mas também no que diz respeito ao terreno social privilegiado para a circulação e a legitimação dos enunciados sobre a doença: os aliados essenciais não mais seriam os 'notáveis' das 
associações médicas e científicas das capitais, dos fóruns especializados da medicina tropical (ainda que não fossem, absolutamente, descartados). Eles seriam arregimentados no domínio da clínica, especialmente daquela enraizada no próprio ambiente social em que se pretendia encontrar a doença: o interior.

Como será visto nos próximos capítulos, um novo encontro estava por acontecer. Se a Academia havia ido ao sertão na década de 1910, e se tais laços haviam sido desfeitos (ou fragilizados) na década de 1920, os cientistas novamente se dirigiriam ao 'coração do Brasil', mas desta vez para disseminar, entre os médicos do sertão, a imagem de uma doença que caberia a eles próprios encontrar. Acenando-lhes com novos 'mapas' para esta busca e com o otimismo de uma época em que se comemoravam novos recursos e novas possibilidades para o combate às doenças infecciosas em todo o mundo, os seguidores de Chagas reuniriam elementos para, num novo contexto, estabelecer um outro enquadramento e um novo consenso em torno da tripanossomíase americana.

\section{Notas}

1 O estudo das controvérsias científicas, como meio de analisar as disputas e negociações envolvidas na produção do consenso e na certificação do conhecimento científico, foi uma das importantes frentes dos chamados estudos sociais da ciência, a partir da década de 1970, e teve em Harry Collins, da Universidade de Bath, um de seus principais representantes. Ver Kreimer (1999).

2 Henrique de Beaurepaire Rohan Aragão (1879-1956) nasceu na cidade de Niterói, Rio de Janeiro. Ingressou no Instituto de Manguinhos em 1903, ainda estudante, para preparar sua tese de doutoramento, concluída em 1905. Em 1907, publicou importante estudo sobre o ciclo do parasito causador da malária aviária, que recebeu grande destaque no Congresso Internacional de Higiene e Demografia, em Berlim, naquele ano. Também em 1907, desenvolveu a vacina contra a espirilose das galinhas, que passou a ser comercializada por Manguinhos. Em 1908, efetivouse como pesquisador assistente. Nos dois anos seguintes, aperfeiçoou sua formação na Universidade de Munique, Alemanha. Sua produção científica abordou diversos aspectos da biologia, sistemática, epidemiologia e profilaxia de doenças parasitárias, humanas e animais. Demonstrou a transmissão da Leishmania braziliensis, parasito causador da leishmaniose tegumentar, por mosquitos flebótomos. No campo da virologia, destacam-se suas investigações sobre a varíola, o alastrim, a varicela, a mixomatose dos coelhos e, em particular, seus estudos sobre a transmissão da febre amarela e as técnicas de vacinação contra essa doença. Foi chefe de serviço do Instituto Oswaldo Cruz (IOC) a partir de 1919, assumindo, entre 1942 e 1949, a direção do instituto. Foi membro da Société de Pathologie Exotique de Paris e da Royal Society of Tropical Medicine de Londres, além de várias outras 
associações médicas e científicas no Brasil e no exterior. Em 1950, aposentou-se do IOC (Guimarães, 1955).

3 O catedrático de microbiologia e parasitologia da Escola Superior de Agricultura e Medicina Veterinária do Rio de Janeiro, Paulo de Figueiredo Parreiras Horta, que vinha sugerindo a possível inocuidade do T. cruzi, seria o porta-voz dessa tese na polêmica que aconteceria anos depois na Academia Nacional de Medicina (ANM).

4 Chagas publicou o primeiro trabalho sobre o tatu como hospedeiro silvestre do $T$. cruzi em 1912 (Chagas, 1912c).

5 Provavelmente pela resposta que tal achado poderia representar em face da questão lançada por Kraus, este trabalho foi amplamente divulgado, tendo sido publicado em diversas revistas e apresentado na ANM em 24 de maio de 1918.

6 Este 'desafio' de Belisário Penna foi relatado por Vasconcellos em ANM (1923b: 657).

7 Como testemunha do envolvimento pessoal de Cruz na realização das experiências com os barbeiros enviados por Chagas, Vasconcellos relatou: “(...) era no seu próprio quarto que guardava as gaiolas onde estavam encerrados os sagüis, ficando na parte inferior, separada da superior por tela de arame, os blocos de barro, em cujos buracos se encontravam os barbeiros. Ao chegar uma manhã ao Instituto, encontrei Oswaldo com os olhos avermelhados, com a fisionomia cansada. Indagando se sentia alguma coisa, disse que não dormira quase toda a noite, porque um dos barbeiros tinha fugido, e para que não fosse picado, fora forçado a caçá-lo, e que só o tinha conseguido apanhar alta madrugada. Examinava diariamente o sangue dos sagüis, que serviam de pasto aos barbeiros, e um belo dia encontra no sangue de um deles um tripanossoma, que mais tarde foi descrito pelo Dr. C. Chagas como Trypanosoma cruzi' (Vasconcellos, 1919a: 6). Delaporte (2003) chama a atenção para um aspecto interessante do conflito: a disputa pela condição de testemunhas dos grandes 'feitos' e personagens da ciência. Enquanto Penna se vangloriava de ter visto pessoalmente Chagas realizar sua descoberta, Vasconcellos afirmava sua proximidade com Oswaldo Cruz por tê-lo acompanhado nas experiências com os barbeiros.

8 A idéia de que Chagas, além da descoberta, havia sido o grande responsável pelo estudo de todos os aspectos da doença foi disseminada pelo próprio Oswaldo Cruz (1915). Contudo, o alvo de Vasconcellos era o significado que esta narrativa assumia naquele momento de ascensão política de Chagas, no contexto do movimento sanitarista, propagada especialmente por Belisário Penna, que em seu livro afirmara: "Orientado pelo gênio de Oswaldo Cruz, ele, sozinho, e em poucos anos, descobriu a causa, o transmissor, o processo de transmissão, a patologia e a profilaxia do terrível flagelo, caracterizou-o e discriminou todas as suas modalidades, caso único na história da medicina" (Penna, 1918b: 22; grifos meus).

$9 \quad$ Indignando-se contra os que defendiam a possibilidade de o T. cruzi não ser tão patogênico como se afirmava, ou mesmo ser inofensivo, Belisário Penna lançou um desafio: ele se deixaria inocular por um tripanossoma não patogênico ao homem, como o Trypanosoma lewisi, desde que um dos que questionavam o T. cruzi fizesse o mesmo com este parasito (A Noite, 1920b: 2).

10 Chagas relatou com detalhes os momentos que o conduziram à identificação do novo parasito e da nova doença. Como prova de que a reivindicação de Vasconcellos era descabida, citou as declarações do próprio Cruz enaltecendo seu protagonismo em todo o processo da descoberta (Jornal do Commercio, 1919). 
"Dr. Carlos Chagas e a tripanossomíase americana. Um ataque injusto. A Ephoca, Rio de Janeiro, 24 agosto de 1919. Fundo Carlos Chagas, grupo: vida pessoal; atividade: relações familiares e produção de retratos do titular (livro de recortes de jornais, v. 3, p. 97).

12 Em 1919, a doença foi verificada no Peru por E. Escomel e na Venezuela por Enrique Tejera.

13 Em 1918, em discurso em homenagem a Miguel Pereira, então falecido, Peixoto declarou: “(...) não nos iludamos, o 'nosso sertão' começa para os lados da Avenida” (citado por Hochman, 1998: 70). Júlio Afrânio Peixoto (1876-1947) nasceu em Lençóis, na Bahia, e formou-se em medicina em Salvador, em 1897, com uma tese sobre a relação entre epilepsia e crime. A convite de Juliano Moreira, mudou-se para o Rio, onde foi inspetor de saúde pública em 1902. Foi professor de medicina legal e de higiene da Faculdade de Medicina do Rio de Janeiro (FMRJ) a partir de 1906, tornando-se, em 1916, titular desta última cadeira. Em 1907, fundou, com Juliano Moreira, a Sociedade de Psiquiatria, Neurologia e Medicina Legal. Neste mesmo ano, assumiu a direção do Serviço Médico-Legal no Rio de Janeiro. Em 1910, foi eleito para a Academia Brasileira de Letras, da qual foi presidente em 1923. Teve atuação de destaque também no campo da educação, sendo diretor da Escola Normal do Rio de Janeiro (1915) e da Instrução Pública do Distrito Federal (1916) e reitor da Universidade do Distrito Federal (1935). Foi deputado federal pela Bahia entre 1924 e 1930. Ver Academia Brasileira de Letras (2006) e Lacaz (1963: 40).

14 Na edição de 1922 de seu manual sobre higiene, Peixoto afirmou sobre a "papeira parasitária": "conhecem-se autenticados cerca de 40 casos, se é que, ainda nesses, o bócio e a decadência mental têm relação com a infecção verificada. Entretanto, mal entendida propaganda sanitária já calculou em mais de $15 \%$ da população do Brasil os atacados do mal" (apud ANM, 1923d: 730).

15 Os pontos formulados por Chagas para serem respondidos pela comissão eram: “1ㅇ- A tripanossomíase americana (doença de Chagas, doença de Cruz e Chagas) é ou não uma nova entidade mórbida de etiopatogenia bem determinada, de sintomas bem característicos, de síndromes clínicas bem definidas? $2^{\mathrm{o}}-$ Os trabalhos sobre o assunto, realizados, por mim e por alguns pesquisadores de Manguinhos, obedeceram ou não ao mais rigoroso escrúpulo e merecem ou não merecem crédito as nossas conclusões essenciais? $3^{\mathfrak{0}}-\mathrm{A}$ descoberta da tripanossomíase americana, doença em cuja etiologia foi verificado, pela primeira vez, o papel transmissor de um inseto, do gênero Triatoma, representa ou não representa um fato do mais alto alcance científico? $4^{\mathrm{o}}$ - Os estudos que esclareceram a doença em seus principais aspectos etiológicos, patogênicos e clínicos, e as conclusões a que nos conduziram aqueles estudos, importam ou não importam em conquista científica da mais alta valia? $5^{\underline{0}}$ - Finalmente, a Academia, após a verificação que venha a realizar, conserva integral o conceito que determinou minha conclusão em seu grêmio, ou possui elementos para modificá-lo?” (ANM, 1922b: 768-769). Chagas solicitava ainda que fossem discutidas a relação entre a doença e o bócio endêmico no Brasil e a questão da autoria da descoberta do T. cruzi.

16 Couto era casado com uma prima-irmã da esposa de Chagas. Foram nomeados para a comissão Alfredo Nascimento Silva, Eduardo Meirelles (que renunciou à função logo em seguida), Henrique Duque, Afonso Mac Dowell e Joaquim Moreira 
da Fonseca (ANM, 1922b: 773). Alfredo Nascimento Silva nasceu no Rio de Janeiro em 1866. Doutor em medicina pela FMRJ em 1888, ocupou vários cargos na diretoria da ANM, sendo seu presidente entre 1908 e 1909. Foi professor catedrático da Escola Superior de Guerra Militar, das Escolas Militares da Praia Vermelha e de Realengo, e lente substituto de medicina legal e higiene da Faculdade Livre de Ciências Jurídicas e Sociais. Dirigiu a Escola Normal do Distrito Federal (1920). Foi presidente da Liga Brasileira Contra a Tuberculose, em 1915, e vice-presidente do Instituto Histórico e Geográfico Brasileiro. Henrique Dias Duque Estrada (18711951) nasceu em Magé, Rio de Janeiro, e formou-se pela FMRJ em 1898. Foi assistente de Miguel Couto na 7a Enfermaria da Santa Casa da Misericórdia e livredocente de clínica médica daquela escola. Afonso da Gama e Costa Mac Dowell (1881-1958) nasceu em Belém do Pará e diplomou-se pela FMRJ em 1904, com tese sobre aspectos do soro dos anêmicos por ancilostomose. Tornou-se professor desta escola em 1919. Joaquim Moreira da Fonseca (1886-1970) nasceu na cidade do Rio de Janeiro e formou-se, em 1910, pela FMRJ. Assistente de Miguel Couto na cadeira de clínica médica desta escola, tornou-se livre-docente desta cadeira em 1913. Foi membro da Sociedade de Neurologia, Psiquiatria e Medicina Legal do Rio de Janeiro e um dos fundadores da Liga Brasileira de Higiene Mental. Em 1935, substituiria Carlos Chagas na cadeira de Doenças Tropicais e Infectuosas (antiga cadeira de Medicina Tropical) da FMRJ. Arquivo do Dicionário HistóricoBiográfico das Ciências da Saúde no Brasil, COC/Fiocruz.

17 Tais perguntas diziam respeito ao ciclo evolutivo do parasito, seu modo de transmissão e às dificuldades de se verificar sua presença no organismo, em especial na fase crônica. A este respeito, o "curioso" ironizava: "onde se escondem eles?” (O Jornal, 1922: 6).

18 A referida carta de Chagas foi lida nesta sessão da Academia (ANM, 1923a: 637-638).

19 Vasconcellos (ANM, 1923b: 671) ironizou: “(...) só no fim de 9 anos é que S.S., esquecendo tudo o que tinha publicado, lembra-se que foi ele quem verificou a existência do tripanossoma no sangue do sagüi. E vem a fazer isso em um jornal profano, a "Revista do Brasil".

20 Esta carta de Chagas foi publicada na Gazeta de Notícias (1923).

${ }_{21}$ É curioso que, apesar de constar, na ata da referida sessão, como uma transcrição literal da carta de Couto, no original manuscrito (que se encontra no arquivo pessoal de Chagas), o respectivo trecho aparece sob outra formulação, bem menos incisiva: "Qualquer que seja o índice endêmico da doença de Chagas, ela dá farta glória científica a quem a descobriu". Carta de Miguel Couto a Carlos Chagas. Rio de Janeiro, 14 de novembro de 1923. Fundo Carlos Chagas; grupo: pesquisa; subgrupo: doença de Chagas; função: pesquisador do IOC; atividade: debate sobre doença de Chagas; série: cartas.

22 Corroborando esta ponderação, Olympio da Fonseca, pesquisador de Manguinhos, tomou a palavra e salientou que, em ciência, o autor da descoberta é quem tem a idéia original, detecta as incógnitas, raciocina e busca respostas para os fenômenos inexplicados e não quem, por incumbência deste, simplesmente 'vê' ou atesta o objeto considerado novo (ANM, 1923b: 688).

23 Vasconcellos, assim como os outros críticos de Chagas, vinculava suas assertivas, em grande parte, às afirmações de Kraus. Em 1916, este havia afirmado em seu traba- 
lho: "La enfermedad de Chagas existe en el Brasil' (Kraus, Maggio \& Rosenbusch, 1916: 180). O que enfatizava era que, apesar de aparentemente não ocorrer na Argentina, ela 'de fato' existia no Brasil. Nas falas de Vasconcellos e de Peixoto, aquela declaração sofria um fundamental deslizamento discursivo: a doença de Chagas existiria 'só' no Brasil!

24 "Tripanosomas e... ciumadas", O Brasil, Rio de Janeiro, 18 de novembro de 1923. Fundo Carlos Chagas, grupo: vida pessoal; atividade: relações familiares e produção de retratos do titular (livro de recortes de jornais v. 5, p. 6).

25 A acusação de que Chagas difamava a imagem do Brasil no exterior já havia sido feita por alguns jornais, em setembro daquele ano, por ocasião da exposição comemorativa ao centenário de Louis Pasteur, realizada em Estrasburgo, da qual o Brasil, representado por Chagas, participou com uma mostra científica em que se apresentaram várias estátuas e imagens de portadores de doenças tropicais existentes no Brasil (apud Chagas Filho, 1993: 123).

26. Horta se referiu ainda ao debate sobre as variações encontradas na tripanossomíase africana, que, quando causada pelo Trypanosoma rhodesiense, assumiria uma forma mais benigna. Este era, segundo ele, um exemplo da grande 'confusão' reinante na classificação geral dos tripanossomas e na sua relação com as doenças provocadas em animais e em humanos (ANM, 1923c: 709-710).

27 Depois de intenso debate sobre se a Academia deveria ou não tornar público este parecer, que, na véspera, havia sido enviado a Miguel Couto lacrado, com o pedido para ser arquivado, a palavra final de Couto decidiu que ele deveria ser lido publicamente (ANM, 1923c).

28 Para divulgar os recentes avanços nos conhecimentos sobre a doença e em seus métodos de diagnóstico, a Folha Médica publicou, naquele ano, vários trabalhos de pesquisadores de Manguinhos sobre o tema, sendo alguns deles citados pelo parecer (Cunha, 1923; Torres, 1923).

29 Segundo o parecer, o xenodiagnóstico, método proposto por por Emile Brumpt, tinha o seu valor "posto em dúvida e (...) não logrou ainda entrar na prática corrente" (ANM, 1923d: 740). Villela e Bicalho (1923: 15) comentaram as restrições no método: "Exige manobras complicadas e demoradas, como a criação de barbeiros, fazê-los picar os doentes, e esperar o desenvolvimento do parasito no tubo digestivo do inseto. Demais, as pesquisas recentes de Mayer, que provam a possibilidade de transmissão hereditária da infecção nos triatomas, tiram muito do seu rigor".

30 A apreciação, na época, de um suposto caso crônico de forma cardíaca, vindo de Lassance, foi particularmente elucidativo da barreira imposta ao diagnóstico clínico das formas crônicas, pela não demonstração do parasito. Tendo sido encontrado o T. cruzi no sangue de um gato inoculado com o sangue deste doente, o indivíduo veio a falecer. Os membros da comissão foram convidados a assistir à necropsia e a enviar, a um patologista de sua confiança, parte das vísceras para exames. Estes, contudo, deram negativo para a verificação do parasito, ainda que revelando "um processo congestivo visceral resultante, sem dúvida, da insuficiência cardíaca" (ANM, 1923d: 743). Magarinos Torres, por sua vez, mesmo sem achar o parasito, considerou o caso positivo. Contudo, para a comissão, não se podia ter absoluta certeza quanto a este diagnóstico, já que os "caracteres histopatológicos da miocardite crônica assinalada são, também, comuns a outros processos infectuosos" 
(ANM, 1923d: 744).

31 Fraga comentou, com ironia, a profusão de cartas que marcava aquela "polêmica científica”, na qual não haviam se pronunciado, de viva voz, os principais contendores: "Em verdade os personagens principais do entrechoque acadêmico, desde o primeiro momento, manifestaram franca simpatia pelo gênero epistolar, e, de permeio à paciência apostólica de V. Ex., Chagas e Afrânio, os dois, em vôos de águia, trocam bicados nas alturas..." (ANM, 1923d: 754).

32 Magarinos Torres, por exemplo, provocou Horta: "Ninguém melhor que S. Ex. deve ser cauteloso em fazer afirmativas categóricas, devendo-se recordar de uma circunstância ocorrida em sua carreira científica, e que, ainda hoje, em Manguinhos, é citada como exemplo de como é fácil o engano em ciência experimental e quão difícil evitar as interpretações erradas. Quem sabe se agora o eminente Professor não passou por casos da moléstia de Chagas como certa vez pelos corpúsculos de Negri?” O próprio Fraga, apesar de salientar que não encontrava nestas cartas "agressões pessoais", mas apenas "termos de polêmica", admitiu, perante o plenário, que havia suprimido das referidas cartas "uma ou outra frase, acaso mais ácida" (ANM, 1923d: 764).

33 Vasconcellos, provocando Fraga, ironizou o momento em que este voltou atrás em sua convicção, para fazer coro à reação veemente de Chagas ao discurso de Vasconcelos na SMCRJ em 1919: "Clementino Fraga diz que foi Oswaldo Cruz, em pessoa, quem descobriu o tripanossoma. O Dr. Carlos Chagas diz que foi ele próprio... (...) O professor Clementino Fraga ouve-o... Horas duras e amargas deviam ser essas, em que luta terrível devia passar-se no seu íntimo, a ouvir de um lado a voz do amigo vivo, que, súplice, lhe estendia os braços e de outro a memória do grande amigo morto... Mas V. Ex. não hesitou e correu para o vivo..." (ANM, 1923d: 776).

34 Em setembro de 1923, ao regressar da França, onde havia representado o Brasil nas comemorações do centenário de Pasteur, Chagas abordou as principais realizações do DNSP, declarando-se confiante no compromisso do recém-empossado Arthur Bernardes de dar continuidade à orientação de seu antecessor. Em mais uma alusão a seus críticos, afirmou: "Deveremos, é certo, corrigir e ampliar, mas nunca retroceder de um avanço em que se prestigiaram, com a ação dos médicos, as normas de alta política. (...) Uma vez (...) levados à atividade da administração pública e aí forçados à defesa de altos interesses do país, tenhamos tolerância para a injustiça e serenidade bastante para avivar na crítica, embora apaixonada, o nosso espírito de zelo e de previdência" (Chagas, 1935c: 42, 45).

35 Em 1923, Pacheco Leão, Raul Penna, Lafayette de Freitas e Mario Pinotti, apresentando-se como "intérpretes de um numeroso grupo de entusiastas dos serviços de higiene" (Leão et al., 1922: 5), publicaram o opúsculo Afranio versus Afranio. Ele continha dois discursos do catedrático de higiene da FMRJ (um deles proferido em maio de 1918, em homenagem a Miguel Pereira e à promulgação dos decretos que criaram o Serviço de Profilaxia Rural e o Serviço de Quinina Oficial, e o outro em dezembro de 1919, como paraninfo de uma turma de doutorandos daquela escola) e uma conferência de Belisário Penna, em fevereiro de 1920, na Sociedade Nacional de Agricultura, no qual o presidente da Liga Pró-Saneamento do Brasil (que então completava dois anos) comentou a "incoerência injustificável" (Leão et al., 1922:13) destes dois discursos de Peixoto. No primeiro deles, este posicionou-se como entusiasta da Liga Pró-Saneamento do Brasil, da qual era membro, enquanto 
no segundo criticou duramente os partidários desta campanha, condenando-os como pessimistas e antipatrióticos. Denunciando a "deserção" de Peixoto, os organizadores da publicação argumentam que esta "completa reviravolta de idéias" veio "deixar perplexa toda a gente, sem saber qual a sua verdadeira profissão de fé" e ironizam: "cabe aos amantes das ciências ocultas a decifração do interessante enigma" (Leão et al., 1922: 5).

36 De fato, é intrigante que, apesar de ser uma das bandeiras do movimento sanitarista e de constar formalmente das diretrizes do Serviço de Profilaxia Rural criado em 1918, não haja registro de ações de profilaxia da tripanossomíase americana no período em que Chagas foi diretor da saúde pública. Provavelmente, essa situação, além de possíveis questões de natureza técnica, foi derivada sobretudo do próprio ambiente de incertezas que pairava sobre a doença, especialmente a partir de 1919.

37 Em relação a Parreiras Horta, Chagas denunciou-lhe a falta de documentação clínica que fundamentasse sua afirmativa de que não havia casos da doença em regiões infestadas por barbeiros, por ele percorridas. Admitiu a possibilidade de que ainda não houvesse acontecido, em tais regiões, a adaptação necessária para que o parasito, inicialmente em reservatórios silvestres, viesse a tornar-se um agente infeccioso no organismo humano. Mas enfatizou ser esta apenas uma hipótese e que nada havia provado tal ausência de casos. Quanto à comparação do T. cruzi com parasitos inofensivos, reiterou a impropriedade lógica daquele raciocínio e, afirmando que provavelmente Horta sequer havia lido os seus trabalhos clínicos, salientou: "quase adivinho o pasmo em que ficaram os cardiologistas desta Academia quando ouviram recusado qualquer valor semiológico às arritmias da nova doença” (ANM, 1923e: 798-803).

38 Chagas também afirmou serem incontestáveis seus enunciados sobre a forma nervosa, mas concedeu a eles menos ênfase. Quanto ao bócio, manteve o que já vinha afirmando: "Considerei desde muito uma questão aberta e passível de divergências (...). Entretanto, persisto na interpretação primitiva” (ANM, 1923e: 807).

39 Além do estudo da forma cardíaca, outra linha de pesquisa impulsionada pelas dúvidas que cercavam a doença a partir de 1916 foi o estudo dos métodos de diagnóstico das formas crônicas, em especial da reação de Guerreiro e Machado, que mobilizou, além destes, outros pesquisadores do IOC, como Aristides Marques da Cunha, Antonio Eugênio de Arêa Leão, Eurico Villela e Chagas Bicalho. Ver Villela e Bicalho (1923).

40 Ver, entre outros, O Imparcial (1923a)

${ }^{4}$ Segundo Villela (1936), depois das sessões do congresso, Kraus ofereceu uma homenagem a Chagas em sua residência e o convidou para realizarem colaborações no estudo da tripanossomíase americana. Chagas e Kraus, que na ocasião participaram da criação da Sociedade Sul-Americana de Higiene, Microbiologia e Patologia, manteriam relações nos anos seguintes. Em 1918, por exemplo, Chagas enviou carta ao colega na Argentina relatando seus esforços por conquistar sócios brasileiros para a "nossa sociedade de higiene, microbiologia e patologia sul-americana", que realizaria, naquele ano, um encontro no Rio de Janeiro. Carta de Carlos Chagas a R. Kraus. Rio de Janeiro, 18 de abril de 1918. Fundo Carlos Chagas, grupo relações interinstitucionais e intergrupos.

42 Dr. Carlos Chagas e a tripanossomíase americana. Um ataque injusto. A Época, Rio 
de Janeiro, 24 agosto de 1919. Fundo Carlos Chagas, grupo: vida pessoal; atividade: relações familiares e produção de retratos do titular (livro de recortes de jornais, v. 3, p. 97).

43 "Tripanosomas e... ciumadas", $O$ Brasil, Rio de Janeiro, 18 de novembro de 1923. Fundo Carlos Chagas, grupo: vida pessoal; atividade: relações familiares e produção de retratos do titular (livro de recortes de jornais, v. 5, p. 6). O fato foi lembrado por Chagas Filho (1993) na biografia de seu pai.

4 "Ele jamais cedeu um milímetro do terreno que havia cientificamente conquistado (...). Por sua atitude corajosa assim como pela força de seus argumentos, ele acabou por impor, a seus piores detratores, o respeito a suas idéias" - Tradução livre.

45 "Não foram, entretanto, somente céus azuis e de bonança que experimentou o maior dos discípulos de Oswaldo Cruz. Ele viu de perto águas tormentosas, os bramidos da tempestade das baixas paixões humanas. Vocês, jovens, necessitam saber com detalhes desta trágica comédia, que abalou a vida e amargou os dias de um dos nossos maiores conterrâneos. Talvez possam extrair altos exemplos e lições práticas para o presente e o futuro. Toda vez que ouço a expressão enfática de que 'a escola é a vida', recordo as vidas de Oswaldo Cruz e de Carlos Chagas, ambos açoitados na via crucis de sua dedicação pelo bem coletivo, martirizados no cume de seus Gólgotas" - Tradução livre.

46 "a campanha contra Chagas foi uma frustrada tentativa de um pequeno grupo de apagar o nome do maior cientista do Brasil. Nunca houve questão derivada de genuína pesquisa científica, a qual, se fosse feita, ao invés de perturbar ou de ser vexatória para Chagas, certamente teria sido bem-vinda por ele" - Tradução livre.

47 Desta vez, a indicação oficial foi feita pelo médico Hilário de Gouvêa.

48 "A tudo isso assistiu Chagas impassível, defendendo palmo a palmo as grandes novas verdades que trouxe à ciência, conservando fixo na sua mente que, para sanear o Rio de Janeiro, Oswaldo Cruz teve contra si uma grande revolução. Foi essa campanha pessoal contra Carlos Chagas que permitiu, para nossa suprema vergonha, que depois da descoberta e dos primeiros trabalhos sobre a tripanossomíase americana, a doença pudesse permanecer abandonada durante quase duas décadas" - Tradução livre.

49 Trata-se do Fundo Carlos Chagas, sob a guarda da COC/Fiocruz.

50 Fritz Köeberle, pesquisador austríaco que produziu, na Faculdade de Medicina de Ribeirão Preto, importantes contribuições sobre a patogenia da doença de Chagas na década de 1950, qualificou esta fase, decorrente da polêmica na Academia, como 'oblivion', um termo que se tornaria freqüente entre os médicos que corroborariam tal periodização. Ver Dias (1988).

51 Chagas Filho (1993: 229), referindo-se ao desgaste emocional vivido pelo pai, afirmou: "não é exagero admitir que os primeiros sinais da doença cardíaca, que o mataria, começaram com a consternação íntima que lhe trouxe a contestação de seu trabalho durante a polêmica de 1922-23".

52 Deve-se notar que o discurso em que Peixoto expôs suas críticas ao movimento sanitarista, em contraste com sua filiação anterior a esta campanha, ocorreu em dezembro de 1919, quando Chagas já era diretor da DGSP e tramitava no Congresso Federal o projeto de criação do Departamento Nacional de Saúde Pública (DNSP), cuja direção foi também entregue a ele (Leão et al., 1923). 
53 Alguns professores da FMRJ, como Peixoto, eram contrários à noção de uma especialidade em medicina tropical, vendo-a como um reforço ao estereótipo de país tropical inviável à civilização (Stepan, 2001). Além disso, Chagas sofreria críticas de seus colegas naquela escola em função da ingerência que teria na implementação dos cursos de higiene e saúde pública e de medicina tropical. Ver Castro-Santos e Faria (2006). Sobre as disputas entre os pesquisadores do Instituto de Manguinhos e alguns professores da FMRJ, ver Labra (1985).

54 No concurso para 'chefe de serviço' de 1910, Aragão era considerado por muitos o candidato com mais atributos científicos (sobretudo em virtude de sua descoberta do ciclo da malária aviária, publicada em 1907), em especial por Rocha Lima, que, tendo então rompido relações com Oswaldo Cruz, manifestava veementemente seu desacordo com as preferências deste em relação a Chagas (Benchimol \& Teixeira, 1993).

55 Antonio Cardoso Fontes e Arthur Neiva não aparecem diretamente na polêmica com Chagas, mas eram citados, por Vasconcellos (1919b), como partidários das críticas que lhe eram feitas. Cardoso Fontes, que, como Vasconcellos, era um dos pesquisadores mais antigos de Manguinhos, provavelmente também se sentira contrariado diante do prestígio de Chagas perante Oswaldo Cruz. Em relação a Neiva, Chagas Filho (1993: 190) sugere (ainda que sem citar seu nome) que teria sido Neiva, que estava em Buenos Aires em missão científica no instituto dirigido por Kraus, quem o 'municiou' com material de Manguinhos sem o conhecimento de Chagas, que teria ficado profundamente contrariado com o fato. Segundo Benchimol e Teixeira (1993), além das disputas no ambiente de Manguinhos, a concorrência entre os dois cientistas ocorreu no campo da saúde pública. Em dezembro de 1916, ao regressar da Argentina, Neiva tornou-se diretor do Serviço Sanitário do Estado de São Paulo, onde promoveu importante reforma. Sua movimentação para fazer do Instituto Butantan um competidor de Manguinhos precipitou o rompimento com Chagas, em 1917. Outro motivo foi a competição pelo comando da reforma sanitária federal que levaria à criação do DNSP. Em 1918, Neiva apresentou ao recém-eleito presidente da República, Rodrigues Alves, um projeto de reestruturação dos serviços sanitários federais, que chegou a ser aprovado, mas foi inviabilizado pelo falecimento de Alves, em janeiro de 1919, vítima da gripe espanhola.

56 Em resposta aos que o acusavam de desfazer a obra de seu antecessor, Chagas afirmou, em 1921, que tal obra “(...) em nada diminuiu de sua grandeza e do seu prestígio, e poderá ser hoje, apreciada e aplaudida pelo nosso orgulho patriótico como o fora no tempo do grande morto. (...) Não desconheço, meus caros amigos, os conceitos isolados que procuram contrariar a verdade desse conceito, e proclamam convencidos a desagregação irremediável da obra do mestre, na incapacidade de quem o substituiu. Acato, quanto me cumpre, o critério que assim se exterioriza; dele, porém, não me poderá agora advir o menor dos dissabores, um minuto sequer de desconforto, porque fala mais alto a autoridade dos maiores centros de ciência do universo, e fala principalmente o apreço da classe médica do meu país, a opinião valiosa e imparcial dos homens cultos de minha terra" (Jornal do Commercio, 1921: 3).

57 Em 1926, ano em que Chagas deixou o DNSP, ele foi duramente atacado na imprensa por conta de um surto de varíola na cidade e do risco de uma epidemia de febre amarela. As freqüentes viagens que fazia ao exterior também foram alvo de 
intensa oposição (Benchimol \& Teixeira, 1993; Chagas Filho, 1993). Ver também FCC; grupo: gestão de ciência e saúde pública; atividade: administração institucional; função: diretor do Departamento Nacional de Saúde Pública; série: clipping.

58 Segundo Stepan (2001), por um lado, estas representações visuais foram parte de um inventário médico que propiciou maior consciência pública quanto ao sofrimento dos pobres e doentes no interior do país. Por outro, elas propiciaram a visão 'desagradável' de um 'outro' característico de uma nação tropical que muitos preferiam não ver. A autora enfatiza que a feição racial dos doentes exibidos nestas fotografias, em grande parte negros ou mestiços, foi um elemento a mais para a rejeição que provocaram, num contexto particularmente sensível do debate racial por conta dos movimentos eugênicos.

59 François Delaporte $(1995,2003)$ opõe-se à idéia de 'desconstrução' por considerar que os historiadores misturam, como parte de um mesmo processo de conspiração voltado a "acabar com os méritos dos trabalhos de Chagas" (Delaporte, 2003: 73), o embate travado na Argentina - que, segundo ele, girou em torno de "refutações de ordem científica" (Delaporte, 2003: 75) - e a polêmica na ANM, que teria sido, de fato, "um violento requisitório" derivado de um acerto de contas (Delaporte, 2003: 95). A tese da desconstrução seria, assim, mais uma evidência da "ilusão retrospectiva" (Delaporte, 2003: 75) dos historiadores comprometidos com o mito de Carlos Chagas. Embora concordando que se deva diferenciar aqueles dois momentos da controvérsia, devemos observar que o próprio Delaporte faz uma 'confusão' entre dois aspectos absolutamente distintos. Incorrendo no mesmo equívoco de seu argumento sobre a descoberta de Chagas (Delaporte, 1995), ele se refere aos 'historiadores' citando, indiscriminadamente, os médicos contemporâneos a Chagas (e os memorialistas) e os autores que, de fato, produziram análises no campo da história. Se os primeiros se engajaram na produção do mito, fizeram-no e continuam a fazê-lo com legitimidade, em consonância com sua própria identidade socioprofissional como médicos. Já os historiadores - no caso, Benchimol e Teixeira, os únicos por ele citados - não assumem esta perspectiva. Portanto, ainda que a noção de desconstrução possa ser questionada, não implica, pelo menos no caso destes dois autores, uma perspectiva meramente conspiratória, bastante questionada no terreno da historiografia. Outro motivo pelo qual Delaporte não aceita a idéia de desconstrução é o fato de que, em sua interpretação, a construção do conceito de tripanossomíase americana só ocorreria na década de 1930, uma vez afastados os 'equívocos' de Chagas em seu conceito de tireoidite parasitária. Este argumento, do qual discordo, será analisado mais adiante.

60 O termo 'desconstrução' acabou sendo usado num sentido mais lato, como movimento de negação, de fragilização, de reversão de um processo. Este é o caso também em Stepan (2001: 198).

${ }^{61}$ A primeira tentativa bem-sucedida de produzir um eletrocardiograma humano foi feita no Hospital de São Bartolomeu, em Londres, em 1869/70. Na década de 1890, a crescente indústria da energia elétrica (e também do telégrafo) levou os engenheiros a desenvolveram vários instrumentos para registrar as variações na corrente elétrica. Estes instrumentos (como o oscilógrafo, de 1893) foram os precursores do galvanômetro de corda desenvolvido por Einthoven. A introdução do eletrocardiógrafo, como indica Burnett (1985), marcou uma mudança expressiva 
na natureza e na engenhosidade dos instrumentos de diagnóstico médico, condensando várias e intricadas idéias e dispositivos técnicos.

62 "No início da década de 1920, a cardiologia era uma especialidade perfeitamente respeitável para ser adotada por médico em seu consultório (...). Existiam uma revista, uma associação, uma liderança reconhecida, uma tecnologia e, acima de tudo, uma disciplina intelectual coerente" - Tradução livre.

63 Entre os sintomas subjetivos, destacaram o "avexame", expressão popular usada para referir "sensações as mais variadas" relacionadas ao aparelho circulatório, como palpitações, tonteiras, sensação de "baticum" e outros sinais inespecíficos (Chagas \& Villela, 1922: 13). Quanto ao prognóstico da forma cardíaca, embora muitos doentes permanecessem em "estado de tolerância durante longos anos" (Chagas \& Villela, 1922: 14), acentuaram que esta era a forma da doença a ocasionar maior letalidade, sendo o mais comum a morte por assistolia (parada cardíaca), causada por insuficiência progressiva do miocárdio. Além do impacto social deste aspecto, reforçaram o enunciado quanto à importância da morte súbita como elemento diagnóstico: "A morte súbita constitui o apanágio das regiões de tripanossomíase endêmica. Tivemos oportunidade de verificá-la em diversos casos da forma cardíaca, na sede de nossos trabalhos, e mais falam de sua freqüência as referências unânimes dos habitantes de tais regiões, onde grande número de famílias lastimam a morte súbita de um ou de vários membros. Falecem os indivíduos, não raro, em plena mocidade e no gozo de uma condição hígida aparente (...). E não sabemos de outra condição, em patologia humana, que ocasione a morte súbita em percentagem tão elevada" (Chagas \& Villela, 1922: 14).

64 As observações correspondem a pacientes examinados desde 1910. Em duas delas, feitas em 1921, os autores referem-se ao emprego da reação de fixação de complemento, com resultado positivo (Chagas \& Villela, 1922).

6̋ No discurso que antecedeu sua conferência na ANM em 1919 sobre a forma cardíaca, Chagas (Correio da Manhã, 1919: 3) já havia insistido sobre este ponto, afirmando que, embora fosse "certo que o parasito não tem sido visto em todos os infectados", isso não invalidava a individualização clínica da entidade. Em comparação com a sífilis, salientava que, também nesta doença, era difícil surpreender o agente causal, mas nem por isso se duvidava dos outros procedimentos para firmar o diagnóstico. Ou seja: o diagnóstico clínico bem fundamentado tornava possível "prescindir da verificação parasitária".

66 Num forte indício de que, apesar de tudo, o critério clínico ainda não conseguia sobrepujar o critério parasitológico, estas 63 observações clínicas não seriam citadas na polêmica da ANM, em que justamente a contagem dos casos presumidos e comprovados da doença assumiu tanta proeminência.

67 O trabalho foi publicado no Brazil-Medico (Chagas, 1927).

68 Segundo Carlos Chagas Filho (1987: fita 1, lado A), ainda como estudante, seu irmão destacava-se no manejo do eletrocardiógrafo: "Naquela ocasião havia dois eletrocardiógrafos no Rio. Um, do Roberto Duque Estrada, outro de Manguinhos. Era um aparelho complicadíssimo, fabricado pela Fábrica Bolite, francesa, que consistia no seguinte: você tinha um fio de quartzo (finíssimo), pelo qual atravessava a corrente produzida pelo eletrocardiógrafo. (...) Era raríssimo o eletrocardiograma naquela época. O fio se rompia com muita facilidade. E colocar o fio era uma arte. 
O fio fazia um movimento na presença de imãs. Esse movimento é que era registrado e dava as ondas que você vê hoje nos eletrocardiógrafos comuns". Sobre a importância dos trabalhos de Evandro Chagas sobre a forma cardíaca, ver Laranja (1949). Sobre Evandro Chagas, ver Sodré (1940). O arquivo pessoal de Evandro Chagas encontra-se sob a guarda da COC/Fiocruz.

${ }_{69}$ Especialmente na Argentina, os trabalhos do grupo liderado pelo médico Salvador Mazza, que será analisado no capítulo 6, vinham identificando, desde 1926, vários casos agudos. Ver Zabala (2007).

70 Descartava-se assim a hipótese de infecção ab ovo (por 'herança verdadeira'), como havia sido cogitado depois que Vianna (1911) identificou o parasito nos testículos, nos ovários e num espermatozóide de animais experimentalmente infectados. Quanto à transmissão vetorial, mesmo admitindo ser possível a contaminação pelas fezes através das mucosas e da pele, como formulara Emile Brumpt, Chagas defendeu, neste trabalho, com base em experiências de Magarinos Torres, que ela se dava pela picada, como havia afirmado originalmente (Chagas, 1934).

71 Em 1931, o pesquisador mineiro José Baeta Vianna, realizando estudos de campo mediante técnicas de bioquímica, defendeu que a carência de iodo era a causa do bócio endêmico em Minas Gerais, mas não excluiu totalmente a hipótese defendida por Chagas (Vianna, 1931). Em 1933, A. Penna de Azevedo, pesquisador de Manguinhos, publicou seus estudos sobre as lesões tireoidianas em casos agudos de tripanossomíase americana, pelos quais constatou serem elas semelhantes àquelas ocorrentes em casos de bócio endêmico na Europa e em outras regiões isentas da infecção pelo T. cruzi. Em 1939, Álvaro Lobo Leite, também pesquisador do IOC, mediante estudos epidemiológicos feitos em Minas, afirmou não haver dúvidas de que se tratava de endemias sobrepostas: “(...) parece-nos que a ocorrência do bócio na tripanossomíase americana não deve ser considerada como fazendo parte essencial do quadro mórbido da moléstia” (Lobo Leite, 1939: 1.033).

72 O texto faz referência a casos observados na Argentina, no Peru, na Bolívia, na Venezuela, em El Salvador, no Panamá e na Guatemala, a insetos infectados no Uruguai e no Paraguai, a gambás infectados em Honduras e à probabilidade de insetos infectados nos Estados Unidos e nas Ilhas Maurício (Chagas \& Chagas, 1935).

73 Expressando o interesse particular de Evandro Chagas nesta linha de investigação, a forma cardíaca assume, no texto, maior proeminência em relação à nervosa. $\mathrm{Na}$ sua definição, afirma-se: "seguramente [é] a mais freqüente das formas clínicas da doença. Encontra-se habitualmente associada a outros sintomas, especialmente sintomas nervosos, mas bem se define em um tipo à parte, pela intensidade dos processos patogênicos e pela evidência dos sintomas (...). (...) em geral, não vivem os indivíduos afetados além dos 50 anos (...). Em quaisquer das modalidades da forma cardíaca é o indivíduo um mioprágico [incapacitado] no que respeita à atividade produtiva, mas é também um degradado em todas as funções orgânicas (...). É seguramente a doença que porcentagem mais alta apresenta de mortes súbitas" (Chagas \& Chagas, 1935: 135-138).

74 "Diante desta vasta distribuição de vetores infectados, é digno de nota que ainda haja considerável dúvida sobre até que ponto a tripanossomíase sul-americana é uma doença de grave dimensão. O número de seres humanos realmente infectados com o tripanossoma, até o momento encontrados, é notavelmente pequeno. $\mathrm{O}$ 
único estado em que um considerável número de casos foi registrado é o de Minas Gerais, no Brasil" - Tradução livre.

75 Em revisão feita em 1934, Reichenow referiu-se a 36 casos comprovados fora ao país (21 na Argentina, cinco no Panamá, três na Venezuela, três na Guatemala, dois em Salvador e dois no Peru). Citado por Dias (1939: 966).

76 "diversas formas de doença miocárdica, de doença nervosa, de infantilismo, de hipotireoidismo e bócio encontrados tão comumente em Minas Gerais" - Tradução livre.

$\pi$ "Se as concepções de Chagas estiverem corretas, então a doença que leva seu nome é inquestionavelmente de grande significado patológico. Trabalhos recentes, contudo, têm levantado consideráveis dúvidas se muitas das condições incluídas por Chagas entre as formas crônicas da doença são em alguma medida decorrentes da infecção pelo Trypanosoma cruzi" - Tradução livre.

78 João Carlos Pinto Dias (1988) enfatiza esta tendência à concentração dos estudos na fase aguda, durante as primeiras décadas das pesquisas sobre a doença de Chagas.

79 Carlos Chagas faleceu subitamente, aos 56 anos, em sua residência, depois de haver se queixado de dores no coração. Muitos especularam que poderia tratar-se de problemas cardíacos derivados da tripanossomíase. Segundo Carlos Chagas Filho (1993: 264-265), "esta é uma questão que nunca poderá ser respondida".

so A cadeira de medicina tropical foi criada pela reforma educacional promovida pelo Ministério da Justiça e Negócios Interiores (decreto n. 16.782-A, de 13 de janeiro de 1925) e conduzida, na FMRJ, por seu então diretor, Juvenil da Rocha Vaz. A disciplina foi estabelecida como complemento obrigatório para a conclusão do curso. Caberiam à direção do IOC as decisões sobre os conteúdos programáticos, a nomeação de professores e as questões regimentais. Para ministrá-lo, Chagas foi nomeado catedrático, em maio de 1925, mediante decreto presidencial que, instituindo o critério de 'notório saber', o dispensou da realização de concurso. O início efetivo do curso ocorreu em setembro de 1926. Ver Jornal do Commercio (1925) e Chagas (1935f). O Curso Especial de Higiene e Saúde Pública, anexo à FMRJ e cuja direção caberia também a Chagas, foi criado igualmente no âmbito desta reforma. Ver Labra (1985) e Castro-Santos e Faria (2006).

81 Dizia Chagas (1935g: 175): “(...) as faculdades médicas de hoje não se podem destinar ao objetivo único de ensinar um ofício, embora alto e de tanta dignidade, qual esse de zelar a saúde e de defender a vida. Não pode ser assim, porque é nelas (...) que se organiza, principalmente, a evolução renovadora da medicina, e aí se há de pretender agora, na conquista de verdades novas, firmar conceitos e criar doutrinas, instituir princípios e sistemas definitivos, aperfeiçoar o método e dilatar suas possibilidades práticas, e assim, dia a dia, melhor aparelhar a ciência para dominar a doença e vigiar os altos destinos humanos".

82 Em notícia sobre estudo de Eurico Villela publicado em 1930 sobre casos da doença de Chagas em hospitais em Belo Horizonte, o Boletim da Oficina Sanitária PanAmericana (RSPA, 1930: 1.398) reforçava o mesmo ponto, num indício de que esta concepção se disseminava. Chamando a atenção para o número crescente de casos identificados em vários países do continente sul-americano, o texto alertava: “(...) os estudos clínicos não têm sido feitos com cuidado. Quase todos têm se contentado com a verificação do laboratório". 



\section{Manguinhos e a Saúde Pública a partir de 1930: novos caminhos para o estudo das endemias rurais}

\section{O Instituto Oswaldo Cruz e as Novas Estruturas da Saúde Pública Pós-1930}

A perspectiva de dar continuidade à agenda de pesquisa sobre a tripanossomíase americana após a morte de Carlos Chagas exigia não somente investimentos individuais no estudo do tema, mas um empreendimento coletivo capaz de atrair novos interesses e novos grupos para este campo de investigação profundamente marcado pela liderança de seu fundador. O desafio aos seus herdeiros tornava-se ainda maior pelo fato de que, além da doença, a própria instituição à qual ela estava referida encontrava-se cercada por indefinições. No início da década de 1930, o Instituto Oswaldo Cruz (IOC) buscava novos caminhos numa sociedade que vivia o contexto de instabilidade e imprevisibilidade dos primeiros anos do governo Getúlio Vargas; vislumbrava-se uma série de transformações que, ainda que não significassem uma ruptura com a ordem vigente, constituíam uma importante inflexão em sua história, sob vários aspectos (D’Araújo, 1999a; Ferreira \& Delgado, 2003a, 2003b).

O falecimento de Chagas, em novembro de 1934, é tradicionalmente referido pela historiografia como um divisor de águas na trajetória de Manguinhos, representativo do fim da chamada 'fase heróica' da 
instituição, relativa às gestões de Oswaldo Cruz e de seu sucessor. Ao longo daquele período, a instituição construiu sua proeminência na ciência biomédica brasileira em virtude de um determinado modelo de organização de suas práticas de pesquisa e de legitimação de suas atividades na vida pública nacional, para o qual a descoberta e os estudos da doença de Chagas contribuíram de modo decisivo. A liderança científica e política assumida por Oswaldo Cruz e Carlos Chagas na formulação e na realização de campanhas sanitárias pelo país, na veiculação pública da importância do saneamento e na própria gestão dos serviços de saúde foi a face mais visível de um projeto institucional que, pretendendo constituir um centro de excelência internacional em medicina tropical, orientava a competência acadêmica em certas disciplinas biomédicas - como entomologia, parasitologia e anatomia patológica - para o enfrentamento de temas considerados de importância social (Stepan, 1976; Schwartzman, 1979; Benchimol, 1990b, 2001; Benchimol \& Teixeira, 1993; Britto, 1995).

Conforme tal historiografia, a perda da liderança (ainda que controvertida) de Carlos Chagas aprofundou o progressivo enfraquecimento deste modelo. Desde a década de 1920, o IOC vivia uma situação de crise, marcada por dificuldades financeiras que impunham crescentes restrições às atividades da instituição, e por disputas políticas advindas, entre outros fatores, das dissensões em torno da atuação de Chagas como diretor do Departamento Nacional de Saúde Pública (DNSP), em especial durante o governo de Arthur Bernardes. Para Benchimol (1990a), esta crise institucional expressava as tensões políticas e sociais em que se encontrava o país e que levariam à eclosão do movimento político-militar que poria fim à República Velha.

A Revolução de 1930 resultou da composição de forças políticas e econômicas heterogêneas, contrapostas, por distintos motivos, ao modelo oligárquico agrário-exportador firmado na República Velha, cujas fraturas nos anos 20 chegaram ao ápice, agravando-se com a crise mundial de 1929. Tais forças abrangiam frações das oligarquias agrárias não centrais naquele modelo, setores das classes médias urbanas, militares descontentes com o regime político-eleitoral imposto pelas oligarquias e organizados no movimento tenentista e trabalhadores ansiosos por conquistar direitos políticos e sociais. O novo Estado que deu início à chamada Era Vargas definiu-se pelo formato centralizador, pelo forte poder de intervenção na economia e na sociedade e pela disposição em criar condições para um novo modelo de desenvolvimento econômico, orientado para a 
industrialização e a produção para o mercado interno. Do ponto de vista ideológico, foi marcado pela preocupação em identificar a nova ordem com o início da construção de uma nação centrada no valor do trabalho, na modernização econômica e no protagonismo do Estado, personificado na figura paternalista de Vargas como instância suprema de mediação dos interesses diversos da sociedade (Fausto, 1995; Mendonça, 1986; Oliveira, Velloso \& Gomes, 1982; Pandolfi, 2003).

A nova correlação de forças políticas e sociais alçada ao poder em 1930 teve impacto direto sobre Manguinhos. A instabilidade econômica dos primeiros anos do governo Vargas reforçou os problemas financeiros enfrentados pela instituição, que persistiriam durante a gestão do sucessor de Chagas, o gaúcho Antonio Cardoso Fontes. Sua nomeação foi, em si mesma, um indício das fraturas internas no instituto naquele momento e da nova ingerência do Estado sobre as instituições públicas federais. Segundo Carlos Chagas Filho (1987, fita 17, lado b), a maioria dos pesquisadores não concordava com a escolha de Fontes, que estava afastado da vida institucional e ao qual muitos não atribuíam prestígio acadêmico. Em abaixo-assinado a Vargas, solicitou-se a indicação de Figueiredo de Vasconcellos, mas a opção por Fontes prevaleceu. ${ }^{1}$

Além das restrições orçamentárias, a orientação centralizadora da nova administração federal, intensificada com a decretação do Estado Novo em 1937, cancelou um dos sustentáculos essenciais do modelo construído por Oswaldo Cruz: a autonomia administrativa e financeira de Manguinhos. Em novembro de 1930, o IOC foi transferido da pasta da Justiça para o então criado Ministério da Educação e Saúde Pública (Mesp), mas ainda permaneceu subordinado diretamente ao ministro. Contudo, com a reforma do ministério (mediante projeto apresentado, em fins de 1935, por Gustavo Capanema - que assumira a pasta em julho de 1934 -, discutido pelo Congresso Federal e sancionado em janeiro de 1937), o IOC viu-se 'rebaixado' a uma divisão do então criado Departamento Nacional de Saúde (DNS). ${ }^{2}$ Estabeleceu-se, ainda, que os recursos produzidos pela venda dos produtos fabricados pelo instituto fossem transferidos para a receita geral da União e que todos os serviços de Manguinhos deveriam ser custeados exclusivamente pelas dotações orçamentárias do ministério. Ao mesmo tempo, o instituto ficava proibido de fabricar produtos veterinários. As mudanças representaram um sério golpe para o financiamento das atividades da instituição, na medida em que a venda da vacina contra o carbúnculo sintomático (conhecida como 'vacina 
da manqueira') era uma de suas principais fontes de recursos. O Departamento Administrativo do Serviço Público (Dasp), criado em 1938, assumiu a responsabilidade pela elaboração do orçamento anual do IOC e de todos os órgãos federais. Entre as medidas destinadas a profissionalizar o serviço público, a obrigatoriedade de concursos e a proibição de acumulação de cargos contribuíram para aumentar a evasão de pesquisadores de Manguinhos, e muitos deles optaram pela universidade (Benchimol, 1990a, 2001). Na visão de Fontes, estas mudanças impunham graves restrições ao funcionamento do instituto: “(...) a perda da autonomia financeira, que sempre fruiu com vantagens desde a sua fundação, (...) será um fator de grandes embaraços à execução e ao desenvolvimento dos serviços, determinando brusco desequilíbrio em sua economia". ${ }^{3}$

Segundo Benchimol (1990a: 73), as medidas tomadas por Capanema "puseram fim ao modelo institucional arquitetado por Oswaldo Cruz". Apesar do grande impacto que tiveram, há que se considerar que elas constituem a conseqüência de um processo mais amplo pelo qual a própria identidade social de Manguinhos foi posta em questão, em função das novas expectativas que o Estado brasileiro e as forças sociais e políticas por ele representadas tinham em relação à ciência que se fazia em Manguinhos. Considero que tal situação conduziu não ao encerramento do modelo dos 'tempos heróicos', mas à sua redefinição. Este modelo, para além de um arranjo burocrático-administrativo, dizia respeito fundamentalmente a uma certa maneira de conceber a destinação social da ciência. O que o IOC enfrentou naquele momento foi o desafio de restabelecer o elo entre suas atividades científicas e os interesses de uma sociedade em transformação, mais especificamente no novo campo da saúde pública que tomava forma naquele momento. ${ }^{4}$

Mais importante do que a autonomia financeira e administrativa, o que o IOC perdeu a partir de 1930 foi a atribuição de definir e conduzir, mediante seus diretores, a política de saúde pública do país, que passaria para a esfera de estruturas administrativas especializadas então no âmbito do Executivo Federal. Em função da própria natureza do Estado oligárquico na Primeira República, a capacidade da instituição de se relacionar com os interesses sociais se materializava no atendimento a interesses e a demandas imediatas de grupos econômicos associados ao modelo agrário-exportador, preocupados, por exemplo, em combater pragas ou enfermidades vistas como ameaças para a produção agropecuária ou para as grandes 
obras de modernização, como ferrovias, represas e portos. O Estado atuava, sobretudo, como mediador desta relação. No pós-1930, a presença e o protagonismo assumidos pelo Estado na vida pública o levariam a chamar para si a responsabilidade não apenas de representar os interesses dos diversos grupos econômicos, mas de organizar tais interesses com vistas à implementação de um projeto de desenvolvimento para o país. ${ }^{5}$ Foi esta perspectiva que o fez encarregar-se da formulação de um conjunto de políticas sociais destinadas a subsidiar tal projeto, entre elas as políticas de saúde pública. ${ }^{6}$ Este aspecto da nova situação social que se instaurou em 1930 gerou transformações substantivas na forma pela qual o IOC estabeleceria sua relação com a sociedade e com a saúde pública. Ainda que herdando da Primeira República um intenso processo de formação do poder público no campo da administração sanitária (Hochman, 1998), o primeiro governo de Vargas produziu inovações políticas e institucionais que diziam respeito à constituição de um arcabouço administrativo destinado a promover a centralização, a normatização e a burocratização dos serviços de saúde, e, sobretudo, a expansão da intervenção do Estado no território nacional, integrando as esferas federal, estadual e municipal num projeto político unificado. ${ }^{7}$ O principal marco deste processo foi a reforma preconizada por Gustavo Capanema no início de sua gestão no Mesp (1934-1945) e posta em ação pelo médico João de Barros Barreto, que, como diretor do DNS, seria o principal responsável pelas diretrizes da política sanitária federal. ${ }^{8}$

A chamada Reforma Capanema, efetivada pela lei n. 378, de 13 de janeiro de 1937, definiu os rumos da política nacional de saúde pública e adequou a estrutura do ministério - que ganhou o nome de Ministério da Educação e Saúde (MES) - às diretrizes básicas da política social do governo Vargas. ${ }^{9}$ Como principal inovação institucional para promover a expansão e a interiorização das ações do ministério, foram criadas as delegacias federais de saúde, instaladas em oito regiões do território nacional. Comandadas por médicos sanitaristas, seriam responsáveis por coordenar e supervisionar as atividades nos estados, assegurando a normatização e a uniformização das ações de saúde em todo o país. ${ }^{10}$ Outra inovação importante foi a instituição das conferências nacionais de saúde, destinadas a reunir, periodicamente, administradores e técnicos de órgãos públicos de saúde nas esferas federal e estadual, para discutir e firmar diretrizes técnicas e administrativas para as principais questões do setor, sob a coordenação direta do Executivo (Fonseca, 2007). 
Na tendência de profissionalização e burocratização do serviço público brasileiro, e em conformidade com as diretrizes preconizadas nos fóruns internacionais do campo da saúde pública da época, um aspecto importante da Reforma Capanema foi a preocupação em formar e recrutar quadros técnicos especializados para atuar nos serviços do DNS (Fonseca, 2007). Reforçava-se assim um processo iniciado na Primeira República, pelo qual as ações públicas da saúde passavam a ser formuladas e executadas por profissionais especialmente preparados: os médicos sanitaristas. ${ }^{11}$ A diversificação e a complexificação da estrutura administrativa do MES ao longo da gestão Capanema favoreceriam a estruturação desta carreira (Lima \& Fonseca, 2004; Castro Santos \& Faria, 2006; Fonseca, 2007).

Os debates sobre qual deveria ser a inserção do IOC na nova estrutura do ministério, travados durante a tramitação do projeto da Reforma Capanema no Congresso Nacional (entre dezembro de 1935 e janeiro de 1937), expressam como tais transformações impunham ao instituto novas perspectivas e a necessidade de redefinir seus rumos. Entre as medidas propostas pelo ministro, constava a criação do Instituto Nacional de Saúde Pública (Insp) e a transferência do IOC para o Departamento Nacional de Educação (DNE), passando a figurar entre "as instituições de desenvolvimento cultural”, no segmento de educação extraescolar, entre as quais estavam o Observatório Nacional, a Biblioteca Nacional e o Museu Nacional (Brasil, 1935: 36). ${ }^{12}$ A proposta de modificar a denominação do Mesp para Ministério da Cultura Nacional - alterada para MES em dezembro de 1936 - demonstra a importância que Capanema concedia à cultura como elemento central de constituição da nacionalidade (Schwartzman, Bomeny \& Costa, 1984; Gomes, 2000; Williams, 2000). Conforme tal diretriz - cujo ponto central era a criação da Universidade do Brasil -, a inserção do IOC na esfera da educação se justificaria pela necessidade de criar no país um sistema de ensino superior qualificado, para formar uma elite intelectual capacitada, entre outras funções, a ocupar cargos no Estado. Pretendia-se, assim, reforçar o programa de pesquisa de Manguinhos, que, segundo Capanema, era "essencialmente uma casa de ciência", destinada a investigações "no campo da biologia, naquilo em que esta se relaciona com a medicina” (Brasil, 1935: 36).

Sob tal orientação, o IOC perderia formalmente os laços com a saúde pública. As funções que até então lhe cabiam nesse campo passariam ao 
Insp, que, vinculado diretamente ao MES, se incumbiria de "realizar, de modo sistemático e permanente, pesquisas as mais completas e rigorosas de todos os problemas sanitários do Brasil", tendo em vista "suas causas, suas manifestações, os horizontes de sua propagação [e] os processos de debelá-las”. Ele também se encarregaria da formação de recursos humanos especializados para os serviços de saúde pública federal, estadual e municipal (Brasil, 1935: 20). ${ }^{13}$ Com exceção de José Antonio de Figueiredo Rodrigues (médico e deputado federal pelo Ceará, um dos mais sistemáticos críticos da reforma), que foi contra a proposta por considerar que as funções que caberiam ao Insp já eram desempenhadas por Manguinhos, os membros da Comissão de Saúde Pública da Câmara Federal aprovaram a criação do novo instituto. $\mathrm{O}$ debate sobre o assunto dizia respeito não apenas a decisões de natureza burocrática ou administrativa, mas a distintas visões sobre a relação de Manguinhos com o Estado e com a sociedade brasileira. ${ }^{14}$

Em julho de 1936, à medida que a reforma estava sendo discutida no Congresso, Fontes enviou a Capanema, a partir de solicitação deste, um anteprojeto para a remodelação de Manguinhos, prevendo a recuperação e a ampliação das instalações, a reorganização do quadro de pessoal e uma nova estrutura de atividades. ${ }^{15}$ Contudo, o diretor do IOC ficaria surpreso e descontente com o encaminhamento dado ao assunto. No relatório daquele ano, registrou:

Estavam escritas estas linhas quando chegou ao conhecimento desta Diretoria, pela publicação no Diário Oficial de 13 de janeiro de 1937, a reforma no Ministério da Educação e da Saúde Pública. Há nesta reforma dispositivos que favorecem ao Instituto Oswaldo Cruz, concedendo-lhe recursos para o prosseguimento de sua remodelação e para a manutenção do pessoal contratado. Ao lado destes, outros afetam profundamente a vida da instituição, de modo que, de momento, não se pode prever todos os seus efeitos, tal a posição que eles deram ao Instituto na hierarquia administrativa. ${ }^{16}$

Nomeado diretor do DNS em fevereiro de 1937, um mês após a aprovação da reforma, João de Barros Barreto encarregou-se de implementá-la, no que foi favorecido pela decretação do Estado Novo, em novembro daquele ano. Sobre o Insp, defendeu, junto ao ministro, o início imediato de seus trabalhos:

Enquanto V. Ex. não decide prosseguir as obras dos novos edifícios que irão constituir o INSP, penso ser possível iniciar seus 
trabalhos nas dependências do Ministério, destacando para sua realização técnicos dos Serviços de Saúde e contratados (...). Espero da clarividência de V. Ex., o deferimento a essa pretensão das mais justas e instantes do sanitarismo brasileiro, com o que continuará V. Ex. a sua obra de úteis realizações, a culminar na instalação do INSP, cujas altas finalidades em nada colidem com as de outros Institutos existentes no Rio de Janeiro, mantidos pelo governo federal. ${ }^{17}$

No entanto, diante de várias divergências quanto ao formato que deveria assumir o novo instituto, em fins de 1937, o governo extinguiu o Insp, incorporando suas atribuições ao IOC. Com esta medida, o IOC teria como "finalidade primordial promover investigações científicas relacionadas com o problema da saúde humana" e atender "às constantes necessidades de aplicação (aos problemas sanitários), mediante solicitação do Departamento Nacional de Saúde, com aprovação do ministro” (Brasil, 1937, 1938: 410-411). Sua remodelação seria projetada por uma comissão da qual, além de Fontes, fez parte Barros Barreto. Capanema foi categórico na negação da autonomia financeira: “(...) por tantos anos observada, não impediu que o nível de eficiência do Instituto baixasse. A autonomia financeira não trará, portanto, vantagem”. ${ }^{18}$

Cabe ressaltar no debate em torno do Insp a falta de consenso sobre o papel social de Manguinhos, além do fato de que nem o ministro, nem o diretor do DNS, o viam como instituição que deveria estar vinculada à saúde pública. O episódio mostra que o instituto já não detinha a mesma capacidade de afirmar seu projeto institucional no cenário político nacional. Além de não possuir a proeminência de Oswaldo Cruz e Carlos Chagas nos organismos sanitários federais, a direção do IOC não se apresentou como força política expressiva na discussão sobre seu próprio projeto. Ainda assim, o resultado final da reforma mostra que, apesar da falta de consenso, havia algum espaço para que a instituição mantivesse sua identidade como instituto de pesquisa associado aos temas e às ações da saúde pública.

Dois marcos importantes, em 1937, sinalizavam a perspectiva de que a recriação desta tradição fosse algo além do que uma diretriz formal expressa na lei. Em março, inaugurou-se, em Manguinhos, o Laboratório do Serviço Especial de Profilaxia da Febre Amarela, da Fundação Rockefeller, para produzir a vacina então desenvolvida, nos Estados Unidos, por técnicos daquela instituição e para realizar exames e estudos 
necessários à campanha de combate à doença empreendida em todo o país (Benchimol, 2001). A perspectiva de manter os vínculos do IOC com a saúde se apresentaria, contudo, de maneira mais ampla, justamente no campo em que tal associação havia alcançado sua máxima visibilidade nos 'tempos heróicos': o estudo e o combate às endemias rurais, tema cuja proeminência na agenda política da saúde brasileira foi reafirmada pelo Estado varguista. ${ }^{19}$ De modo simbolicamente sugestivo, isso seria feito sob a liderança do filho mais velho de Carlos Chagas, Evandro.

\section{O Serviço de Estudo das Grandes Endemias (Sege)}

O Serviço de Estudo das Grandes Endemias (Sege) foi decorrência de um projeto formulado ainda na gestão de Carlos Chagas, em 1934: estudar a possibilidade de ocorrência no Brasil da leishmaniose visceral, aventada quando técnicos da Fundação Rockefeller identificaram o parasito causador da doença em órgãos humanos examinados para diagnóstico da febre amarela, no norte do país. Em função do falecimento de Chagas, as investigações tiveram início somente em fins de 1935, chefiadas por Evandro Chagas, que, com ajuda do Correio Aéreo Militar, empreendeu uma série de viagens ao Norte e ao Nordeste. Depois de registrar o primeiro caso humano, em abril de 1936, em Sergipe, ele passou a estudar a doença em seguidas excursões a várias regiões. ${ }^{20}$

Em novembro de 1936, mediante acordo com o governo do Pará, Evandro Chagas criou, em Belém, o Instituto de Patologia Experimental do Norte (Ipen), que mais tarde receberia seu nome. O objetivo era realizar pesquisas sistemáticas sobre a leishmaniose visceral americana e demais doenças endêmicas da região, bem como formar técnicos especializados neste campo de investigação. Evandro Chagas pretendia criar institutos congêneres em outros estados do país. O projeto, contudo, não ficaria restrito ao estudo da leishmaniose. Já nas viagens feitas em 1936, ele colheu informações sobre outras enfermidades que ocorriam nas várias regiões que percorrera. Em 1937, decidiu incorporar a seu programa de pesquisas temas como a tripanossomíase americana, a malária e a esquistossomose, entre outras endemias. Criava-se assim o Sege, no âmbito da Seção de Doenças Tropicais e Infectuosas do IOC, 
chefiada por Evandro Chagas e que funcionava no Hospital de Manguinhos, também dirigido por ele, onde o serviço instalou seus laboratórios e demais estruturas.

O Sege exibia uma clara filiação ao ideário dos que, na década de 1910, levantaram a bandeira do saneamento rural do Brasil. Perante o ministro da Educação e Saúde, Evandro Chagas salientava que seus objetivos eram "estender ao interior do país as atividades do Instituto [de Manguinhos] e assim esclarecer os principais problemas da patologia regional do Brasil". ${ }^{21}$ Entre as muitas viagens empreendidas por ele e pelos técnicos do Sege por todo o país - que reeditavam, em certa medida, as expedições científicas do IOC nas décadas anteriores - merece destaque a que foi realizada com Walter Oswaldo Cruz (filho de Oswaldo Cruz e pesquisador de Manguinhos que estudava a relação entre anemia e ancilostomose), em julho e agosto de 1938, aos estados do Ceará, do Rio Grande do Norte, da Paraíba e de Pernambuco. O objetivo foi dar início a um levantamento sistemático das endemias do Nordeste brasileiro e averiguar a possibilidade de instalar, na região, institutos ou postos de pesquisa. Os resultados da expedição, bem como os objetivos do Sege, foram apresentados na Academia Nacional de Medicina (ANM) em setembro de 1938 (Chagas, 1938). ${ }^{22}$

A preocupação em produzir novos conhecimentos científicos sobre as doenças regionais do Brasil estava diretamente associada à perspectiva de propiciar ações concretas para o enfrentamento dos problemas sanitários por elas constituídos. ${ }^{23}$ Buscava-se formar "uma organização especialmente orientada no sentido da utilização dos métodos da pesquisa científica aplicada, (...) [com] técnicos especializados em trabalhos a um tempo de investigação clínica, de laboratório e de campo". ${ }^{24}$ Ao ressaltar uma dimensão essencial da identidade institucional de Manguinhos em suas três primeiras décadas, tratava-se, nos propósitos de Evandro Chagas, de um empreendimento científico em que a agenda de pesquisa, além de gerar conhecimentos dotados de utilidade social, subsidiaria um projeto de nação no qual a saúde, especialmente das populações rurais, era condição fundamental para a superação do 'atraso' e a promoção do desenvolvimento econômico e social.

A apresentação do Sege como projeto em continuidade à tradição de Oswaldo Cruz e de Carlos Chagas era constante nos pronunciamentos de Evandro Chagas. Em discurso perante os alunos de um curso de especialização em doenças tropicais, oferecido em 1936, ele sintetizou 
esta dimensão pública que imprimiria ao serviço a ser formalizado no ano seguinte. Como credencial primeira a conferir-lhe legitimidade, recorria à figura da qual era herdeiro em vários sentidos:

Carlos Chagas foi o apóstolo da redenção sanitária do homem dos campos e fiel às suas normas, (...) outro não foi o meu intuito senão o de, em apagadas lições, vos instruir nas condições precárias de nossas populações rurais, e despertar em cada um de vós o desejo da luta em prol daqueles que são a verdadeira gente de nossa terra. Veria cumprida a minha missão de médico, e satisfeitos os meus deveres para com um pai que foi um exemplo, se vos visse partir dispersos para as longínquas e desoladoras regiões do Brasil, onde os agentes da doença acompanham o homem como o espectro da morte e onde a miséria orgânica implora a piedade humana. Ao povo e aos governos chegou já a noção de que da integridade física do camponês depende a grandeza das nações, e por toda parte multiplicam-se no continente os núcleos de pesquisa experimental destinados à orientação das campanhas sanitárias. $^{25}$

Para implementar tal projeto, Evandro Chagas definiu como diretriz central o estabelecimento de vínculos estreitos com os serviços sanitários federais e estaduais. Em 1940, reiterou, perante o ministro, que a principal finalidade do serviço era:

(...) estudar as doenças endêmicas rurais do Brasil, especialmente as que têm maior importância médico-social, de modo a que aos serviços executivos de saúde pública pudessem ser fornecidos dados e elementos que permitissem a aplicação de métodos e processos racionais de terapêutica e prevenção das moléstias endêmicas rurais. ${ }^{26}$

Uma particularidade importante da experiência do Sege foi o fato de se realizar num momento em que as estruturas federais da saúde pública se fortaleciam e ganhavam maior capacidade operacional. Se os defensores da campanha sanitarista durante a Primeira República reivindicaram a existência de uma organização sanitária capaz de implementar as ações preconizadas pelos cientistas - e deram os primeiros passos para criar tal organização -, na década de 1930 o Estado assumia cada vez mais um formato que expressava a concretização deste objetivo, ou seja, uma estrutura centralizada e burocratizada, com capacidade operacional para estender-se pelo território nacional e gerida por quadros técnicos especializados. Em conformidade com a redefinição que o novo modelo 
de saúde pública impunha às atribuições de Manguinhos neste campo, o desenho preconizado pelo Sege estabelecia claramente uma divisão de tarefas com os serviços sanitários: a estes caberia a execução dos planos e das campanhas de combate às endemias e aos cientistas caberia orientar tecnicamente tais ações.

Para concretizar tais objetivos, Evandro Chagas preconizava o estabelecimento de acordos com os estados, destinados a fundar institutos ou postos de pesquisas que, subordinados administrativa e financeiramente aos governos locais e em associação com os serviços sanitários estaduais, desenvolvessem, sob a orientação técnico-científica do Sege, pesquisas sobre os problemas de maior relevância médico-social em cada região. $\mathrm{O}$ corpo técnico destes institutos seria recrutado e treinado pelo Sege. Embora em nenhum outro estado conseguisse repetir a experiência do Ipen, que constituía a referência exemplar desta perspectiva, Evandro Chagas procurou todo o tempo sensibilizar os interventores e outras autoridades públicas para o projeto. Ao final de 1939, submeteu a Capanema um plano para a ampliação desta cooperação com os estados. ${ }^{27}$

Nesta ocasião, o Sege já contava com algumas iniciativas implementadas. ${ }^{28}$ No Ceará, mantinha, desde 1938, junto à Fundação Rockefeller e ao Serviço de Malária do Nordeste (criado pelo governo federal em 1939), laboratórios especiais para estudar e para auxiliar o combate à intensa epidemia desta doença que grassava na região, cuja extensão e gravidade Evandro Chagas contribuiu para determinar em suas viagens ao estado em 1936. A campanha contra o Anopheles gambiae, concluída em 1940 com a erradicação do mosquito, teve grande visibilidade e importância não só no país, mas internacionalmente. Ela viria conferir grande prestígio e visibilidade ao serviço dirigido por Evandro Chagas (Packard \& Gadelha, 1994). Em Pernambuco, foi organizada, em 1939, a Comissão de Estudos de Patologia do Nordeste, no intuito de estudar, sobretudo, a esquistossomose, endemia de grande importância na região. Em Minas Gerais, em outubro daquele ano, o Sege firmou acordo com o Instituto Biológico Ezequiel Dias (Ibed) - antiga filial do IOC em Belo Horizonte, e que, em 1936, se transferiu para o governo estadual-, com o objetivo de realizar estudos sistemáticos sobre a doença de Chagas naquele estado. ${ }^{29}$ Esta iniciativa, como será visto no capítulo seguinte, teria grande impacto nas pesquisas sobre o tema no Brasil.

Além da atividade de pesquisa, outro objetivo do Sege era a realização de cursos de especialização em doenças tropicais e infecciosas, visando 
a proporcionar um treinamento específico para aqueles que pretendessem direcionar os conhecimentos científicos neste campo a ações de saúde pública. Tais cursos, oferecidos no Hospital de Manguinhos e no Ipen, tinham em geral a duração de três meses e eram constituídos de "lições teórico-práticas, prática de laboratório e clínica, e trabalhos de campo". ${ }^{30}$ Destinavam-se tanto a médicos e a estudantes dos últimos anos de medicina quanto a farmacêuticos, enfermeiras e outros profissionais dos serviços sanitários. Os cursos do Ipen, que ocorriam anualmente, abordavam especialmente a malária. Muitos médicos que, mais tarde, se destacariam como importantes sanitaristas do Ministério da Saúde, como Fausto Magalhães da Silveira e Aristides Limaverde, foram alunos de cursos oferecidos pelo Sege. Também nesse sentido, o Sege ia ao encontro das expectativas e das diretrizes das novas estruturas sanitárias que investiam cada vez mais no recrutamento de profissionais especializados.

Se, associando pesquisa científica, ensino e interesses sociais no campo da saúde pública, o Sege dava continuidade ao modelo firmado por Oswaldo Cruz e Carlos Chagas para a organização e a legitimação social da ciência, o lugar assumido pelo serviço no IOC, entretanto, indica que, naquele momento, tal projeto não era fruto de uma política institucional clara e prioritária da direção do instituto. Tratava-se de uma experiência viabilizada e conduzida sob a marca pessoal de Evandro Chagas. Cientistas que atuaram na instituição na época ressaltam que o Sege tinha grande autonomia e funcionava praticamente à parte da estrutura formal do IOC, reportando-se mais a Capanema, com quem Evandro Chagas tinha relações pessoais, do que a Cardoso Fontes. Segundo Wladimir Lobato Paraense (1987-1989) e Carlos Chagas Filho (1987), tal situação, somada ao prestígio pessoal e político de Evandro Chagas, despertava entre alguns pesquisadores forte oposição ao serviço. ${ }^{31}$

Fator determinante para tal autonomia era o fato de que, embora contasse com a verba orçamentária do IOC, esta era minoritária diante dos recursos obtidos por Evandro Chagas junto ao governo federal (que, desde 1937, destinava uma "verba especial para o estudo das grandes endemias”) e aos governos estaduais associados (sobretudo o do Pará), além de vultosas doações do empresário Guilherme Guinle, com quem a família Chagas mantinha vínculos pessoais (Sanglard, 2008). ${ }^{32}$ A 'verba Guinle', utilizada sobretudo para contratação de pessoal, permitia grande liberdade de ação ao Sege, que podia assim prescindir dos trâmites burocráticos da administração de Manguinhos. ${ }^{33}$ Numa época em que 
eram reduzidas as chances de incorporação formal ao quadro de funcionários do IOC, tais recursos eram preciosos.

Uma forte evidência do isolamento do Sege foi a solicitação feita por Evandro Chagas a Capanema, em agosto de 1940, de que o serviço se desligasse formalmente do IOC. Mediante a ampliação de instalações, de recursos, de quadro de pessoal e do escopo de suas atividades, deveria se transformar em Instituto Nacional de Doenças Tropicais, subordinado diretamente ao ministério, garantindo, assim, melhores condições para estabelecer "a mais ampla ação em todo o território nacional e relações muito íntimas com os serviços sanitários federais". ${ }^{34}$ Apesar da proposta não ter se concretizado, ela expressa claramente que, durante a primeira gestão que sucedeu a de Carlos Chagas em Manguinhos, a perspectiva de reconfigurar os vínculos entre ciência e saúde pública apresentou-se como um projeto fundamentalmente de seu filho, e não como diretriz institucional mais ampla.

A experiência do Sege é reveladora das fragilidades que, como assinala Schwartzman (1979), marcavam o processo de institucionalização da ciência naquela época. O IOC não tinha mais a identidade 'aplicada' e a articulação a um projeto nacional que o haviam marcado em suas três primeiras décadas. Contudo, no pós-1930, a instituição ainda não tinha sido capaz de construir sua legitimidade com base num projeto de ciência que gozasse de autonomia suficiente para ser reconhecida e valorizada independentemente da aplicação a demandas e a interesses sociais concretos. Embora a relação entre pesquisa e saúde pública ainda continuasse a existir dentro de Manguinhos, este modelo não mais lhe garantia sua face pública. Ao mesmo tempo, um novo modelo de legitimidade para a ciência, pelo qual ela fosse reconhecida por seu valor intrínseco como atividade de produção de conhecimento, ainda não dispunha de instrumentos para imprimir sua marca ao projeto institucional.

De todo modo, ainda que sob as peculiaridades do lugar que assumia numa instituição em transição, o Sege foi o caminho pelo qual Manguinhos redefiniu seus laços com a saúde pública e recolocou, no contexto histórico da década de 1930, o tema das endemias rurais como bandeira para o papel da ciência e da saúde na implementação de projetos de desenvolvimento. Decisiva para tanto foi a campanha de erradicação do A. gambiae no Nordeste (Packard \& Gadelha, 1994; Farley 2004), da qual o Sege participou diretamente. Esta campanha expressou a nova capacidade do Estado de estabelecer organismos especializados no campo 
da saúde pública, bem como as novas relações entre tais estruturas e os institutos de pesquisa; além disso, marcou o início de um progressivo otimismo, no cenário internacional, quanto às novas possibilidades na luta contra as doenças transmissíveis, consagrando uma dada abordagem da relação entre saúde e desenvolvimento que, hegemônica no decorrer da Segunda Guerra Mundial, teria grande impacto sobre os rumos do IOC.

\section{Uma Guerra Mundial contra as Doenças: o otimismo da 'era DDT'}

A idéia da relação entre saúde e desenvolvimento/riqueza (ou, em termos equivalentes, entre doença e atraso/pobreza) assumiu distintos significados ao longo da história. Para John Farley (2004: 284-285), o século XX foi marcado pela oscilação, como num 'pêndulo', entre dois modos de se estabelecer os nexos causais entre os termos desta equação e, conseqüentemente, dela derivar ações concretas na vida social. Por um lado, a concepção de que a melhoria nas condições de saúde, mediante intervenções técnicas e específicas contra as doenças, é um pré-requisito essencial para o desenvolvimento econômico-social. Por outro lado, uma concepção que inverte o sentido da relação, afirmando que, embora a elevação dos padrões sanitários de uma sociedade seja importante, o desenvolvimento econômico-social mais amplo é a condição indispensável para que se estabeleçam níveis adequados de saúde.

Num balanço das diferentes abordagens acerca do combate à malária - enfermidade à qual se atribuía grande impacto socioeconômico e era um dos principais temas para a discussão das relações entre saúde e desenvolvimento -, Nájera (1994) também apresenta dois paradigmas/ modelos contrapostos, que produziram oscilações cíclicas nas políticas de saúde durante o século XX. O grupo ‘antiparasito’ corresponderia aos que priorizavam intervenções imediatas destinadas a interromper a transmissão da doença (por meio do controle ou da erradicação do vetor ou de medidas de tratamento), independentemente de fatores sociais mais amplos. O grupo 'antidoença' abrangeria os que julgavam que a própria efetividade daquelas medidas exigia que viessem acompanhadas de ações mais gerais voltadas para o desenvolvimento econômico-social. ${ }^{35} \mathrm{~A}$ despeito de possíveis nuances, os modelos mencionados por Farley e Nájera 
se equivalem; ambos recorrem à imagem de uma oscilação entre duas abordagens.

O final da década de 1930 foi decisivo para conduzir o 'pêndulo' à primeira destas posições, em que o foco residia nas intervenções diretas nos 'alvos' representados pelas doenças. Conforme Randall Packard e Peter Brown (1997: 184), esta era uma 'concepção biomédica estrita' da relação entre saúde e desenvolvimento, construída desde a emergência da microbiologia ao final do século XIX, com base na idéia de que os fenômenos da doença poderiam ser enfrentados pela competência médica de forma relativamente independente de processos sociais e econômicos mais amplos. ${ }^{36}$ No caso da malária, tal concepção traduziu-se no chamado modelo 'malária bloqueia o desenvolvimento' (malaria blocks development model ), ou seja, na visão de que a doença era a grande responsável pela baixa produtividade do trabalho e que qualquer perspectiva de desenvolvimento econômico exigia, antes de tudo, a remoção deste obstáculo (Brown, 1997). ${ }^{37}$

A crescente importância econômica concedida às questões de saúde (especialmente às doenças infectocontagiosas) no contexto de fortalecimento do capitalismo industrial na segunda metade do século XIX e a difusão da microbiologia e da medicina tropical, que proporcionaram distintos meios para se intervir diretamente sobre os agentes causais e transmissores daquelas doenças, foram fatores a reforçar a hegemonia deste modelo no âmbito da saúde internacional (Rosen, 1994). Nas primeiras décadas do século XX, este processo se intensificou com os debates nos Estados Unidos sobre as perdas econômicas produzidas pela ancilostomose e com a atuação da International Health Board (IHB) da Fundação Rockefeller. Essa instituição passaria a ser, sobretudo com suas campanhas contra os transmissores da febre amarela e da malária, a principal representante de uma abordagem que preconizava o ataque aos vetores como estratégia prioritária para 'quebrar' a 'cadeia' da doença e do atraso. ${ }^{38}$

Apesar do entusiasmo que os técnicos da Rockefeller conferiam à perspectiva de controlar e até mesmo de erradicar os transmissores das doenças infecciosas, a abordagem centrada nos vetores sofreria, durante a década de 1920, pesadas críticas vindas, sobretudo, dos malariologistas da escola italiana. ${ }^{39}$ Eles apresentavam inconsistências e insucessos nas tentativas de combater os mosquitos da malária, e afirmavam que esta e outras doenças só seriam vencidas mediante a melhoria nas condições de vida das pessoas, ou seja, pela reforma social. Os relatórios da Comissão 
de Malária da Liga das Nações, de 1924 e 1927, corroboraram este ceticismo quanto à vitória sobre os vetores e recomendaram investimentos em políticas sociais e medidas associadas a planos de desenvolvimento (Nájera, 1994; Packard \& Gadelha, 1994).

Contudo, o movimento que parecia levar o 'pêndulo' para a posição contrária à abordagem centrada nas intervenções sanitárias seria revertido ao final da década de 1930, quando o Brasil, que já vinha contando com ações da Fundação Rockefeller desde a década de 1910, foi palco daquele que seria o grande marco na afirmação desta abordagem: a campanha de erradicação do Anopheles gambiae. Esta espécie de mosquito, proveniente da África, foi constatada em Natal, em 1930, e provocou uma epidemia de malária que ressurgiria com grande intensidade em 1938, atingindo duramente o Rio Grande do Norte e o Ceará. O Sege desempenhou papel importante neste episódio, realizando, entre 1936 e 1938, estudos epidemiológicos que chamaram a atenção do governo federal para o problema, que decidiu criar um órgão especial para enfrentá-lo. O risco de o mosquito se propagar pela Amazônia e alcançar o canal do Panamá despertou também o interesse dos Estados Unidos (Packard \& Gadelha, 1994; Farley, 2004).

Em 1939, o então criado Serviço de Malária do Nordeste (SMN), do MES, passou a se responsabilizar pelo combate à doença, em ação conjunta com a Fundação Rockefeller. Como assinalam Packard e Gadelha (1994), a organização do SNM estava diretamente referida às diretrizes da reforma da saúde pública promovida pela gestão Capanema. Também expressava a ascensão, dentro do aparato federal nesta área, de profissionais especialmente treinados no planejamento e na implementação de campanhas sanitárias, como Manoel José Ferreira, que assumiu a direção do novo serviço. Além de constituir uma oportunidade de projetar publicamente a nova capacidade política e técnica do Estado para lidar com os problemas de saúde da população, a epidemia atraiu os interesses de Fred Soper, da International Health Division (IHD) - designação do IHB a partir de 1927 -, da Fundação Rockefeller, e diretor do Serviço de Profilaxia da Febre Amarela (SPFA). Ele estava empenhado em demonstrar a viabilidade da eliminação total de uma espécie vetora, desde que assumira, em 1930, a direção da campanha de erradicação do Aedes aegypti, vetor da febre amarela, no Brasil. ${ }^{40}$

A estratégia utilizada por Soper para convencer as autoridades envolvidas de que o caso do $A$. gambiae exigia a total eliminação do mosquito 
foi caracterizar a epidemia como uma ameaça a todo o continente americano, inclusive aos Estados Unidos. Para reforçar este argumento, ele recorreu a Evandro Chagas como aliado, citando suas declarações de que a epidemia trazia grande impacto econômico para a região, comprometendo a produção agrícola. Aprovado seu plano, que seria implementado mediante o esquema militarizado do SPFA, foi feita a aplicação de larvicidas nos reservatórios de água e a fumigação de inseticidas nas construções. ${ }^{41}$ A vitória foi comemorada em novembro de 1940, quando se localizou o último $A$. gambiae no Brasil. ${ }^{42}$ Difundido, de forma grandiloqüente, como prova da viabilidade da erradicação de vetores, o sucesso da campanha do A. gambiae correria o mundo e, apesar de os críticos afirmarem que tal resultado só havia sido possível porque se tratava de uma espécie exógena (e, portanto, não adaptada), esta seria a grande credencial dos que advogavam que a luta contra as doenças transmissíveis - e conseqüentemente a superação dos danos econômicos e sociais por elas provocados - dependia de intervenções técnicas focadas no combate sistemático aos seus transmissores (Packard \& Gadelha, 1994; Farley, 2004). ${ }^{43}$

A Segunda Guerra Mundial veio consolidar tal abordagem da relação entre saúde e desenvolvimento. Pelo interesse estratégico e militar que conferia às enfermidades infectocontagiosas - especialmente a malária e o tifo, que causavam pesadas baixas aos soldados das forças aliadas -, tornou premente a necessidade de se desenvolver ações para interromper a transmissão destas doenças. Técnicos e cientistas passaram a se empenhar fortemente em viabilizá-las. Em julho de 1940, a IHD da Fundação Rockefeller criou a Health Comission (HC), na Europa, para implementar, em ajuda às organizações sanitárias governamentais, ações relativas a questões de saúde surgidas no contexto da guerra, entre as quais o combate a doenças que atingissem os soldados nas frentes de batalha (Farley, 2004).

Conforme sugestivo título de um livro publicado em 1943 - The Chemical Front -, a Segunda Guerra Mundial foi travada, e decidida, não apenas pelo poderio das armas e estratégias nas frentes de batalha, mas também no campo da química:

From the first shot of vaccine in the recruit's arm to the grease paint he smears on his face before he joints the raiding-party, the American soldier is clothed, equipped, armed, kept comfortable, dry and in good health, all thanks to many chemicals (...). There is 
a great deal more than poison gas in the story of modern warfare on the chemical front. (Haynes, 1943: VI) ${ }^{44}$

Uma primeira frente importante na produção destas 'balas mágicas' criadas pela química foram os produtos terapêuticos. ${ }^{45}$ Desenvolvida em 1928 por Alexander Fleming e aperfeiçoada em 1939 por pesquisadores ingleses - que, com recursos da Rockefeller, testaram a droga em seres humanos -, a penicilina foi o primeiro de uma série de antibióticos utilizados em larga escala a partir de então. Ela seria o símbolo maior da grande euforia desencadeada, na época, pela perspectiva de cura para temidas doenças, como a tuberculose (Porter, R., 1999). Ao mesmo tempo, buscavam-se novas drogas antiparasitárias. Foi o caso da cloroquina, produto antimalárico que, sintetizado em 1937 na Alemanha, foi obtido pelos Aliados em 1942 e passou a ser usado como substituto da quinina no tratamento da doença entre as tropas. ${ }^{46}$

Os produtos profiláticos também eram recursos fundamentais naquele momento. A vacina contra a febre amarela, por exemplo, desenvolvida pela Fundação Rockefeller e produzida no IOC desde 1937, foi usada em larga escala para proteger os soldados nas regiões tropicais (Benchimol, 2001). Grande expectativa incidia sobre os inseticidas, e o desafio era buscar produtos que tivessem maior efeito residual, ou seja, durabilidade e efetividade depois do momento da aplicação. Substituindo os tradicionais pós à base de piretro, o dicloro-difenil-tricloroetano (DDT) tornou-se a grande arma neste terreno e o marco de uma 'nova era' nas perspectivas mundiais de combate às doenças transmitidas por insetos, em especial a malária (Stapleton, 1998). O desenvolvimento deste produto mobilizou diversas instituições norte-americanas, num exemplo dos investimentos que, numa estreita interface entre política e ciência, o esforço de guerra legou às questões de saúde.

Em março de 1942, a Fundação Rockefeller criou um programa especial em seu laboratório de Nova York para testar inseticidas contra os piolhos transmissores do tifo epidêmico. Conhecido como 'louse-lab', o laboratório mantinha estreitos contatos com o Commitee of Medical Research (vinculado ao U.S. Office of Scientific Research and Development, criado em função da guerra), as empresas produtoras de inseticidas, as agências de saúde pública norte-americanas e o Bureau of Entomology and Plant Quarantine, divisão do Departamento de Agricultura, que também vinha realizando testes com inseticidas para serem 
usados na guerra. Em novembro, este escritório recebeu amostras de DDT, sintetizado em 1874, cujas propriedades inseticidas haviam sido descobertas pelo químico suíço Paul Muller, da empresa Geigy, em 1939. Em pouco tempo, ele revelou-se um dos produtos mais potentes contra os vetores do tifo. No início de 1943, por solicitação daquela divisão e com financiamento do US Office of Scientific Research and Development e do US Departament of the Army, a Fundação Rockefeller iniciou testes com o novo inseticida no México. Em janeiro deste ano, dois meses após a entrada dos Aliados na Argélia e no Marrocos, representantes da Comissão de Tifo dos Estados Unidos (criada no ano anterior pelo presidente Roosevelt) chegaram ao Egito para testar a eficácia de uma vacina e de repelentes à base de piretro contra os piolhos, uma vez que a doença ameaçava seriamente as movimentações militares para expulsar os alemães no norte da África. Técnicos da Rockefeller, entre eles Fred Soper, foram convidados a associarem-se à comissão. Ao passo que se desenrolavam os testes no Egito, a Rockefeller decidiu criar um grupo de trabalho para testar medidas de controle do tifo na Argélia, sob os auspícios da Cruz Vermelha e do Instituto Pasteur de Argel. Soper transferiu-se para a nova unidade e foi nesta ocasião que teve conhecimento do DDT. Ao testar o produto, percebeu que tinha um poder residual bem mais efetivo do que os pós de piretro. Sob o seu comando também foram desenvolvidos equipamentos mais eficazes e práticos para a aplicação do produto, o que permitia operações de larga escala junto à população civil.

Em outubro de 1943, as tropas aliadas, que haviam invadido a Sicília em rota para a liberação da Itália e do continente, encontraram em Nápoles uma grande epidemia de tifo. Diante da gravidade da situação, os militares norte-americanos e ingleses responsáveis pela administração dos territórios ocupados convocaram a Rockefeller a transferir para a cidade italiana sua unidade de tifo da Argélia. O objetivo era organizar, sob o comando de Soper, um amplo programa contra os transmissores, usando, sobretudo, o DDT. A epidemia foi debelada no início de 1944.

A consagração da nova arma química viria com o seu uso no combate aos vetores da malária, naquele ano. Durante a campanha da Sicília, os soldados aliados percorreram zonas fortemente malarígenas e, diante da falta de condições básicas de proteção contra os mosquitos, sofreram pesadas baixas. ${ }^{47} \mathrm{~A}$ despeito das medidas tradicionais de controle, a doença continuava atacando em graves proporções. A pedido do Exército 
dos Estados Unidos, a Fundação Rockefeller foi incumbida de aplicar sua experiência com o DDT numa ampla campanha. Soper assumiu o controle de uma unidade de malária no sul da Itália, que passou a borrifar o novo inseticida nas casas. Também em 1944, o Departamento de Agricultura norte-americano testou o método de aspersão de DDT em domicílios no Arkansas, a fim de examinar como os resíduos do produto, aplicado sobre as superfícies, mantinham sua toxicidade e ação contra os mosquitos. O método, estudado ao longo de 1942 e 1943, não havia sido até então empregado em campanhas mais extensas. Os ensaios no Arkansas e, sobretudo, os resultados positivos no sul da Itália comprovaram a eficácia da estratégia, fundada no poder residual do DDT aplicado em superfícies. ${ }^{48}$

O ano de 1944, que entrara para a história pelo desembarque dos Aliados na Normandia, chegou ao fim trazendo a perspectiva de também liberar o mundo do fardo de doenças como a malária (Stapleton, 1998; Farley, 2004). Em 1945, as Forças Armadas norte-americanas começaram a usar o produto extensivamente para combatê-la no Pacífico. Entre os malariologistas, difundia-se cada vez mais a crença de que o DDT havia alterado significativamente os procedimentos de controle da doença. Nos Congressos Internacionais de Medicina Tropical e Malária realizados em 1948, o especialista argentino Carlos Alberto Alvarado declarou que o ano de 1945 dividia a história da malária em 'antes' e 'depois' da introdução do DDT (Stapleton, 1998). Segundo Farley (2004: 135), "the world looked forward - naively as it turned out - to a world free from the disease". ${ }^{49}$

Esta perspectiva fazia parte de um clima geral de entusiasmo em relação a vários aspectos da vida social, que, acentuando-se no pós-guerra, constituía o que Laurie Garret (1995) chamou de "era do otimismo". Duas campanhas antimaláricas conduzidas pela Fundação Rockefeller, no México e na Sardenha, iniciadas respectivamente em 1943 e 1946, foram emblemáticas do grande impulso que o DDT trouxe ao combate às doenças infectocontagiosas em todo o mundo, fortalecendo a concepção de que campanhas sanitárias contra os transmissores destas enfermidades eram a base para os avanços econômicos, sobretudo do ponto de vista da produtividade agrícola (Stapleton, 1998; Brown, 1997).

A visibilidade que o tema do controle das doenças transmissíveis alcançava no contexto da guerra dizia respeito também aos interesses em relação ao desenvolvimento econômico-social dos países latino-americanos. 
A preocupação dos Estados Unidos com a expansão econômica e política da Alemanha nazista nestes países chamava a atenção dos estrategistas do Departamento de Estado norte-americano desde meados da década de 1930 para a necessidade de programas de apoio na região, articulados sob uma política geral de cooperação entre os países do hemisfério. O objetivo era garantir o suprimento de matérias-primas produzidas pelos países latino-americanos que pudessem servir aos interesses militares (impedindo que tais produtos fossem comercializados com os países do Eixo) e, ao mesmo tempo, evitar a disseminação da propaganda nazifascista nestes países. Com a tomada da França em 1940 e a invasão do norte da África pelos alemães, a preocupação aumentou, e os norte-americanos passaram a temer que o poder aéreo alemão atingisse o nordeste brasileiro. Como sintetiza Campos (2000: 199), "ante essa ameaça, o foco da política externa norte-americana reorientou-se para a 'cooperação e defesa do hemisfério"'. Em agosto de 1940, a Casa Branca criou o Escritório para a Coordenação das Relações Culturais e Comerciais entre as Repúblicas Americanas, a cargo de Nelson Rockefeller. A partir da decisão, em 1941, de instalar bases militares norte-americanas no litoral brasileiro, este escritório passaria a investir em programas de saúde pública na América Latina, tanto para assegurar o suprimento de matérias-primas estratégicas, como a borracha amazônica e os minérios de Minas Gerais, quanto para proteger as tropas sediadas naquelas bases. Organizavam-se os interesses e as decisões que levariam, em 1942, à criação do Serviço Especial de Saúde Pública (Sesp), órgão bilateral dos governos norteamericano e brasileiro, que implementaria importantes programas de saneamento em distintas regiões brasileiras (Campos, 2000, 2006).

A movimentação de Evandro Chagas, em 1940, tendo em vista expandir substancialmente as atividades do Sege, mediante sua transformação num instituto ligado diretamente ao MES, estava diretamente referida a este contexto. Tanto no Brasil quanto no cenário internacional intensificavam-se os interesses em torno da perspectiva de vencer a batalha contra as doenças e de afastar esses obstáculos que, naquele momento, eram vistos como ameaças não apenas ao desenvolvimento social e econômico das nações, mas à própria possibilidade de um mundo livre do nazifascismo. O diretor do Sege beneficiou-se das circunstâncias deste cenário de distintas maneiras. Diante do uso intensivo de inseticidas nas frentes de batalha na Europa, afirmava que a idéia de que as doenças seriam vencidas mediante aplicação de produtos químicos nos domicílios 
havia sido proposta originalmente por seu pai, nas campanhas contra a malária que coordenara no início do século. Esta era mais uma forma de associar o projeto do Sege à tradição das 'glórias de Manguinhos' e aos princípios e valores por esta representados. ${ }^{50}$

Assumindo publicamente a defesa deste método profilático, Evandro Chagas se movimentava politicamente para viabilizar uma campanha de grande envergadura no Brasil sob esta perspectiva. ${ }^{51}$ Em meados de 1940, passou a se dedicar, mediante solicitação do MES, à formulação de um plano sistemático de levantamento e de combate à malária na região amazônica, a ser orientado tecnicamente pelo Sege e implementado pelo DNS. Em outubro daquele ano, o presidente Getúlio Vargas, em visita ao Ipen, declarou seu apoio ao projeto e nomeou uma comissão com representantes do MES e do Sege para encarregar-se do plano a ser iniciado no ano seguinte.$^{52} \mathrm{Na}$ ocasião, a produção da borracha na região despertava atenção do governo brasileiro, interessado em expandir a capacidade produtiva do país para compensar a queda nas importações devido à guerra, e também dos norte-americanos, preocupados com o suprimento de matérias-primas estratégicas (Campos, 2006). A trajetória ascendente do Sege, no entanto, enfrentaria uma grande reviravolta. Em 8 de novembro de 1940, faleceu Evandro Chagas, vítima de um desastre aéreo na enseada de Botafogo.

\section{O Instituto Oswaldo Cruz entre Dois Projetos}

O falecimento de Evandro Chagas impôs ao Sege um grande desafio: como sobreviver sem sua liderança, se o serviço funcionava como um projeto pessoal seu, sob a forte marca de seus vínculos com autoridades políticas e forças econômicas? As conseqüências daquele evento dramático seriam decisivas não apenas para a história do Sege, mas para o próprio IOC.

Se, até aquele momento, a perspectiva de reconstruir em Manguinhos o modelo de sua 'fase heróica' havia se estabelecido como um caminho 'à parte', que conduzia para fora dos muros da casa de Oswaldo Cruz, a partir de então a instituição teria de definir seus rumos optando entre dois projetos claramente distintos.

Num confronto simbolicamente expressivo, a sucessão de Antonio Cardoso Fontes colocaria em disputa dois modelos de ciência, associados, 
justamente, aos dois filhos de Carlos Chagas. Por um lado, havia a possibilidade de transformar a orientação que Evandro Chagas imprimira ao Sege - o reforço dos vínculos com a saúde pública - em diretriz prioritária da instituição. Por outro, surgia a alternativa de recuperar as 'glórias de Manguinhos' não pelo caminho da saúde pública, mas mediante a transformação do instituto num centro de pesquisa voltado, acima de tudo, a acompanhar os avanços no conhecimento que então se processavam nas ciências biológicas. Retomando, de certa maneira, o espírito da proposta que Capanema formulara para o IOC por ocasião da reforma do ministério, este era o projeto de Carlos Chagas Filho que foi trazido de volta a Manguinhos em virtude da morte de seu irmão. ${ }^{53}$

Em mais um indício de que o Sege constituía uma organização à parte no IOC e que a marca da família Chagas era decisiva para sua existência, Capanema nomeou para substituir Evandro Chagas na superintendência do serviço, em caráter provisório, o outro filho de Carlos Chagas. Segundo depoimento do próprio Carlos Chagas Filho (1987), esta indicação foi fruto de solicitação pessoal do presidente Vargas, que temia que, com a morte de Evandro Chagas, o Sege se desativasse, em função das oposições internas no IOC.

Apesar de nunca ter feito pesquisas sobre endemias, Chagas Filho assumiu o compromisso de dar continuidade aos trabalhos e planos do irmão. Para isso, passou a reivindicar a incorporação do Sege à estrutura do IOC, sob a forma de um novo departamento. ${ }^{54}$ No entanto, a volta de Carlos Chagas Filho teria um sentido bem maior do que o empenho em conferir ao serviço criado por Evandro Chagas uma inserção mais orgânica no IOC. Valendo-se do prestígio e da proximidade com Capanema, ele tentaria implementar uma transformação substantiva na própria organização e identidade social de Manguinhos, num episódio bastante significativo dos diferentes caminhos que poderiam ser trilhados pelo instituto e, sobretudo, dos valores, significados e expectativas conferidos à ciência biomédica naquele contexto histórico. Assim, o ano de 1941 foi marcado pela disputa entre duas concepções diferentes a respeito de qual deveria ser a destinação social da ciência produzida em Manguinhos. O caminho que o IOC seguiria, a partir de então, e o lugar assumido pelas endemias rurais na agenda de pesquisa da instituição ao longo da década que se iniciava seriam determinados, em grande parte, pelos acontecimentos em curso naquele momento, em sua relação com o cenário da saúde pública nacional e internacional. 
Carlos Chagas Filho (1987) relata que, na ocasião em que assumiu a direção do Sege, manifestou em conversa com Capanema séria preocupação quanto à 'indefinição’ sob a qual vivia o IOC. Em resposta, o ministro convidou-o a assumir a direção do instituto, sugerindo que apresentasse uma proposta formal de novas diretrizes para Manguinhos. Aceito o convite, Chagas Filho encaminhou ao ministro um documento com tal objetivo, no início de 1941. Ressaltando a 'revolução radical' ocorrida, nas últimas décadas, nos princípios teóricos e metodológicos da ciência, particularmente das ciências biológicas, e citando as principais tendências desta renovação e complexificação da biologia, Chagas Filho queria fazer do IOC uma instituição afinada com tal processo, ou seja, engajada na pesquisa de ponta destinada a expandir as fronteiras do conhecimento.

Ainda que não de forma explícita, a proposta deixa antever a concepção de que, ao assumir esta nova identidade, Manguinhos deveria deixar de se pautar pela necessidade de aplicação de suas pesquisas a demandas do campo da saúde pública. Ou seja, para Carlos Chagas Filho, a legitimidade social da ciência residia em seu propósito essencial de busca pelo avanço do conhecimento. Para isso, reivindicava a "autonomia científica integral do diretor" e a "transferência de alguns serviços do instituto para outras repartições mais adequadas, de modo a que o Instituto possa se limitar à pesquisa científica e restringir suas atividades" ${ }^{55}$ Com o intuito de conferir maior organicidade às distintas áreas de pesquisa, propunha a criação de divisões, dentre as quais a Divisão de Estudos das Grandes Endemias, que absorveria o serviço criado por seu irmão. Apesar de enfatizar a importância da incorporação do Sege à estrutura do IOC, esta era uma concepção de ciência bastante diferente daquela que norteava o projeto de Evandro Chagas. ${ }^{56}$

Embora contasse com o apoio político do ministro, a proposta de Chagas Filho entrou em conflito com a orientação do diretor do DNS, Barros Barreto, a qual acabou prevalecendo e levou à nomeação de Henrique Aragão para a direção do IOC, em 1942. ${ }^{57}$ Conforme Chagas Filho (1987: fita 5, lado b), o principal motivo do embate foi justamente a divergência na maneira de conceber a finalidade social da ciência de Manguinhos: “(...) eu queria um instituto liberado, embora com compromissos da saúde pública. Parece que o Barros Barreto queria essencialmente um instituto de saúde pública”. Uma evidência dos atritos entre estas duas visões - e da importância especial que Barros Barreto conferia ao Sege como espaço por excelência para que Manguinhos atendesse às 
expectativas do MES - foi o ofício enviado pelo diretor do DNS a Cardoso Fontes, pedindo esclarecimentos sobre o programa que estava sendo implementado no Sege e afirmando, em tom de cobrança, que este deveria manter seus vínculos com o ministério, "atendendo a finalidades práticas cujos resultados pudessem ter imediata aplicação pelos Serviços de Saúde". ${ }^{58}$ Se, durante a discussão da Reforma Capanema, não se tinha muita clareza das atribuições e da função social que o IOC deveria ter (se deveria ser um instituto de pesquisa científica 'desinteressada' ou um instituto ‘aplicado’ à saúde pública), neste momento a decisão pela segunda opção foi explícita, por parte daquele que efetivamente conduzia as políticas do ministério. Barros Barreto, que em 1937 não havia compartilhado desta orientação, agora a defendia com toda a força.

Muito além das rivalidades políticas e pessoais inerentes a momentos de sucessão, o episódio expressa não apenas duas maneiras de conceber a identidade do IOC, mas concepções distintas sobre a própria ciência. E o desfecho da disputa, que teria conseqüências diretas e decisivas para os rumos da pesquisa sobre a doença de Chagas na instituição, foi uma evidência de como a prática e a organização da ciência estão sujeitas à influência de circunstâncias históricas específicas, que dizem respeito ao ambiente social mais geral no qual esta atividade se insere. A decisão de institucionalizar o modelo de Evandro Chagas como diretriz essencial do IOC, em detrimento da proposta de Carlos Chagas Filho, esteve diretamente referida ao mesmo processo histórico que vinha impulsionando e dando visibilidade ao Sege e produzindo condições cada vez mais favoráveis para que a ciência de Manguinhos reforçasse seus vínculos à saúde pública.

Numa conjuntura internacional em que se intensificavam os investimentos no combate às doenças infectocontagiosas - tanto no front propriamente dito quanto nos países latino-americanos que forneciam subsídios econômicos e políticos para as Forças Aliadas - e surgiam sinais de que a ciência e a técnica produziriam instrumentos sem precedentes para vencêlas, o projeto político de construção de uma nova estrutura sanitária federal no Brasil vivia um momento crucial, no sentido de sua consagração e concretização. Respaldado pela autonomia garantida pelo regime político ditatorial, Capanema empreendeu uma reforma administrativa no DNS, aprovada em abril de 1941, destinada a conferir maior poder de coordenação e de atuação ao órgão, mediante novas e mais poderosas estruturas para viabilizar a nacionalização da saúde pública preconizada em 1935 
(Fonseca, 2007). Entre elas, estavam os serviços nacionais de saúde. ${ }^{59} \mathrm{Em}$ associação com as delegacias federais de saúde (criadas em 1937), eles constituiriam a face mais concreta do processo de expansão do poder de intervenção do Estado no campo da saúde pública. Os serviços nacionais instituiriam - tendo como prioridade o combate às doenças infectocontagiosas, especialmente as endemias rurais - campanhas verticalizadas, definidas por doença e orientadas, sempre que possível, para o ataque aos vetores, conforme a abordagem consagrada, em 1940, pela campanha contra a malária no Nordeste. A criação destes serviços foi a expressão máxima da força política de Barros Barreto como idealizador e gestor deste modelo. A reforma de 1941 - ano em que se realizou a I Conferência Nacional de Saúde (Hochman \& Fonseca, 2000) - proporcionou, além de instrumentos mais eficazes, maior visibilidade ao projeto político-ideológico do novo Estado brasileiro para a área da saúde, conferindo-lhe significados particulares como projeto de construção da nacionalidade. Este processo deve ser compreendido em função do lugar que o tema da saúde vinha assumindo no âmbito da política social e de desenvolvimento econômico promovida pelo Estado pós-1930 (Hochman, 2001; Fonseca, 2007).

Como analisa Angela de Castro Gomes (1982, 1988, 1999), o projeto político de Vargas, especialmente durante o Estado Novo, estruturouse em torno da meta fundamental de equacionar os problemas econômicos e culturais resultantes da pobreza mediante a construção de um 'novo homem brasileiro', cujo atributo essencial como cidadão era constituir-se como um 'trabalhador', reabilitado e valorizado em seu compromisso de servir à pátria e de gerar a riqueza nacional. A centralidade assumida pelo tema do capital humano nacional como maneira de enfrentar a questão social no país expressou-se não apenas pelas medidas concretas de incorporação formal e de regulação do mundo do trabalho, com a criação de uma legislação social específica, mas pela propagação de um discurso afirmativo do trabalho como valor essencial a legitimar a própria pretensão renovadora do regime.

No intuito de garantir condições para que esses novos trabalhadores nacionais pudessem desempenhar seu papel como 'soldados da produção’ e, ao mesmo tempo, mantivessem-se disciplinados sob o controle do Estado, o governo estabeleceu suas políticas de previdência e de assistência social, bem como programas diversos destinados à melhoria nas condições de vida dos trabalhadores. Entre tais preocupações, a saúde 
assumiu significado importante: "No próprio interesse do progresso do país, deviam-se vincular estreitamente as legislações social e sanitária, já que o objetivo de ambas era construir trabalhadores fortes e sãos, com capacidade produtiva ampliada" (Gomes, 1982: 157). ${ }^{60}$

Esta dimensão do contexto nacional é um elemento relevante para que se compreendam tanto os sentidos e formatos da política de saúde pública quanto as expectativas e as redefinições que esta política colocou para as instituições de pesquisa biomédica, como o IOC. Ao mesmo tempo, tal conjuntura histórica proporcionou aos cientistas elementos materiais e discursivos particulares para reivindicar a legitimidade de seus projetos. A articulação entre ciência, saúde e desenvolvimento nacional encontrou, nesta particular centralidade conferida ao tema do trabalho, nova força retórica e novas potencialidades, tanto de se transformar em ações concretas por parte do Estado quanto de dar sentido ao projeto dos cientistas, especialmente no que dizia respeito ao tema das endemias rurais.

Foi sob tais condições que, aproveitando os ventos favoráveis da saúde pública nacional e internacional, Henrique Aragão transformaria o programa de Evandro Chagas em grande bandeira e vitrine para que se reconstruíssem o prestígio e a tradição de Manguinhos como instituição comprometida com as demandas e os interesses da sociedade. Carlos Chagas Filho deixou a superintendência do Sege em setembro de 1942, no mês seguinte à aprovação do novo regimento que, formulado por Aragão, marcava o início de uma nova fase na trajetória do instituto. Ironicamente, aquele que, em 1919, havia confrontado a caracterização clínica e a importância social atribuída à doença de Chagas vinha a ser o principal responsável pelas condições institucionais sob as quais, na década de 1940, seriam realizados os estudos que levariam à superação daquelas dúvidas. ${ }^{61}$

\section{Manguinhos Vai à Guerra: o reencontro com a saúde pública}

Sob a gestão de Henrique Aragão (1942-1949), sobretudo em seus primeiros anos, Manguinhos funcionou como instituição voltada essencialmente para as demandas da saúde pública, em conformidade com as 
diretrizes da reforma do DNS em 1941. O novo regimento, aprovado em 14 de agosto de 1942, formalizou tal orientação em seu artigo primeiro:

O Instituto Oswaldo Cruz (IOC), órgão integrante do Departamento Nacional de Saúde, tem como finalidade o estudo de problemas de biologia humana e particularmente de higiene e nosologia do Brasil, devendo para este fim realizar inquéritos, pesquisas e estudos sobre as condições da saúde, sobre a epidemiologia das doenças existentes no país e seus métodos de profilaxia e tratamento. (Brasil, 1942: 360)

As atividades de pesquisa ganharam novo arranjo interno e passaram a ser organizadas em divisões, e não mais em seções. Ainda que, segundo os cientistas, o trabalho continuasse a ser feito, na prática, de forma independente de rótulos formais - fossem eles referentes à natureza das atividades (pesquisa ou produção) ou relativos a campos disciplinares -, a medida vinha reforçar a antiga disposição de Carlos Chagas de imprimir maior organicidade e formalidade às áreas de pesquisa. Foram criadas as divisões de Bacteriologia e Imunologia, Vírus, Zoologia Médica, Fisiologia e Endocrinologia, Química e Farmacologia, Patologia, Higiene e Estudo de Endemias. Esta última incorporou as atividades do Sege e sua direção coube a Aristides Marques da Cunha, chefe da antiga Seção de Protozoologia.

Continuando a funcionar no hospital, que recebeu então o nome de Evandro Chagas (atual Instituto de Pesquisa Clínica Evandro Chagas/ Fiocruz), a Divisão de Estudo das Endemias (DEE) tinha como objetivos: realizar estudos sobre "as doenças endêmicas e endemo-epidêmicas que grassam no país", especialmente destinados à profilaxia e ao tratamento; organizar e manter, para tal fim, centros regionais de pesquisa, por si mesma ou em colaboração com outros órgãos técnico-científicos, especialmente o DNS; “colaborar na confecção do mapa nosográfico brasileiro"; e, no âmbito do Hospital Evandro Chagas, realizar estudos clínicos e terapêuticos (Brasil, 1942, artigo 14). A DEE era composta pelas seções de Epidemiologia e de Inquéritos e Trabalhos de Campo, cujas chefias couberam respectivamente a Octavio de Magalhães e a Emmanuel Dias. Desde a morte de Evandro Chagas, o filho de Ezequiel Dias, que era muito amigo e havia sido colega de Carlos Chagas Filho na Faculdade de Medicina do Rio de Janeiro (FMRJ), vinha se destacando à frente do Sege, respondendo pelo expediente do serviço na ausência de Chagas 
Filho. ${ }^{62} \mathrm{~A}$ DEE receberia de Aragão grande atenção, como espaço privilegiado para produzir conhecimentos voltados às necessidades sanitárias do país.

Ainda que a associação com a saúde pública fosse uma expectativa imposta pelas instâncias superiores às quais o IOC estava subordinado, $\mathrm{o}$ fato é que circunstâncias históricas muito particulares neste início da gestão de Aragão possibilitaram que tal diretriz se concretizasse, num período que, como assinala Benchimol (2001), foi de prestígio e de prosperidade para Manguinhos. ${ }^{63}$ Tais circunstâncias diziam respeito fundamentalmente às novas e crescentes demandas que passaram a ser apresentadas ao IOC, tanto pela expansão do aparato sanitário estatal quanto, sobretudo, pelas expectativas que a experiência da guerra trazia para instituições de ciência biomédica como Manguinhos.

Com os compromissos assumidos pelo Brasil para o fornecimento de materiais estratégicos aos Aliados e a entrada oficial do país no conflito (em 22 de agosto de 1942), o IOC tornou-se uma das instituições a servir ao esforço de guerra. Tal situação teve um impacto decisivo sobre a pauta de atividades do instituto e também sobre sua imagem pública, como instituição a serviço dos 'mais elevados' interesses da nação, tendo em vista seu desenvolvimento social e a defesa de sua soberania. Tal imagem ganhava proeminência no contexto ideológico do Estado Novo.

Manguinhos viu-se diante da necessidade de intensificar substantivamente a fabricação de produtos biológicos - como soros, vacinas e quimioterápicos -, para atender às requisições das Forças Armadas, dos serviços públicos de saúde federais, estaduais e municipais, e para formar estoques que servissem às autoridades militares e civis em quaisquer eventualidades. A escassez de materiais e de equipamentos importados e a alta generalizada nos preços, provocadas pela situação mundial, exigiam a ampliação do setor produtivo de Manguinhos em termos quantitativos e em relação à pauta de produtos fabricados. ${ }^{64}$ Reportando-se à então criada Comissão de Segurança Nacional do MES, Aragão listou, em setembro de 1942, as múltiplas atividades pelas quais o IOC poderia colaborar ao "aparelhamento de guerra e à defesa do País" ${ }^{65}$ Entre os itens cuja produção já vinha sendo intensificada, e poderia sê-lo ainda mais, de modo que garantisse quantidades suficientes para atender a quaisquer solicitações do DNS e das Forças Armadas, citou: soros contra tétano, gangrena, peste, difteria, disenteria, infecções estreptocócicas, pneumonia e meningite; anatoxinas tetânica e diftérica; óleos de 
chalmoogra e de sapucainha, para tratamento da lepra; vacinas antitífica, antipestosa, antipiógena, antiestafilocócica, antiestreptocócica e antivariólica ${ }^{66}$ Entre os produtos que ainda estavam em estudo e que eram "de extrema utilidade para a defesa nacional", destacavam-se o plasma humano, ${ }^{67}$ a vitamina A concentrada, "de tão grande utilidade para os aviadores e soldados que tenham que realizar esforços especiais", ${ }^{68}$ a vacina antidisentérica e a penicilina.

No que diz respeito às necessidades imediatas em vista do esforço de guerra, Aragão salientava, naquele momento, as contribuições da Divisão de Patologia, com estudos sobre técnicas de cirurgia asséptica; da Divisão de Química e Farmacologia, por suas investigações sobre problemas técnicos relativos à preparação de diversos produtos e de medicamentos; da Divisão de Vírus, pelas pesquisas e ensaios necessários ao desenvolvimento de uma vacina contra a gripe; e das divisões de Zoologia Médica e de Estudo de Endemias, pelo estudo das doenças transmitidas por insetos. Mesmo nas áreas de pesquisa não diretamente associadas à perspectiva de aplicação, como a fisiologia, Aragão destacava trabalhos que poderiam se mostrar relevantes no contexto da guerra, como, por exemplo, o estudo sobre os distúrbios do labirinto, "de importância para as reações com que se defrontam os aviadores em seus arrojados mergulhos". ${ }^{69}$

Além daqueles diversos produtos, outros seriam fabricados em Manguinhos nos anos subseqüentes, como as vacinas contra a gripe e contra o cólera, ambas produzidas a partir de 1944, e produtos para diagnóstico, como soros aglutinantes e antígenos para serem usados em reações sorológicas para sífilis, tuberculose e lepra, a serem fornecidos aos serviços nacionais respectivos. ${ }^{70}$ Ao mesmo tempo, havia o empenho em desenvolver novos produtos profiláticos, como vacinas contra o sarampo, o tifo exantemático e a leishmaniose cutânea. ${ }^{71}$ Outro setor que se desenvolveu particularmente neste período foi o de prestação de serviços de análises e de fiscalização de medicamentos e produtos diversos, pela então criada Seção de Ensaios Biológicos e Controle, da Divisão de Química e Farmacologia, para atender a requisições do Serviço Nacional de Fiscalização da Medicina, do DNS. Entre os objetivos destes exames, estavam o licenciamento de produtos biológicos para venda, sobretudo vitaminas e hormônios, e a concessão de pareceres sobre pedidos de patentes. ${ }^{72}$ A criação dos serviços nacionais do MES também intensificou as demandas por outros serviços tradicionalmente prestados pelo IOC, como exames histopatológicos e autópsias, para diagnóstico de diversas doenças 
(requisitados, principalmente, pelos serviços nacionais de Lepra e Tuberculose), e exames de animais e insetos para atestar sua não contaminação por microorganismos patogênicos, como solicitado pelo Serviço Nacional da Peste (IOC, 1945).

A grande vitrine da contribuição do IOC às necessidades sanitárias nacionais e às 'causas patrióticas' do momento foi a produção de penicilina. Aragão decidiu, logo em 1942, iniciar o preparo do produto em Manguinhos. ${ }^{73}$ Com verbas especiais do governo e doações do Banco do Brasil, montou-se, em 1944, uma instalação completa, ainda que pequena, totalmente aparelhada para o complicado processo de sua fabricação. A penicilina preparada no IOC era utilizada para tratamento de pneumonias, otites, mastoidites, erisipelas, antrazes, furunculoses, infecções puerperais, complicações blenorrágicas, cancros sifilíticos e bouba, uma doença endêmica causada por um treponema bastante semelhante ao da sífilis e cuja crescente incidência no Nordeste passou a chamar a atenção das autoridades sanitárias naquele período. Em 1944, Aragão comemorou o sucesso da iniciativa: “(...) nossa instalação tem agradado muito aos técnicos americanos em Penicilina e já está servindo de modelo a outras que estão sendo planejadas no Brasil e na Argentina. (...) esperamos que nossa produção no próximo ano seja dez a vinte vezes maior" (IOC, 1945: 17). ${ }^{74}$

O produto era fornecido gratuitamente a hospitais civis e militares, à Legião Brasileira de Assistência, a clínicas no Rio de Janeiro e mesmo a "pessoas de poucos recursos" (IOC, 1946: 16). Era também exportado para países sul-americanos e para Portugal e Espanha. Além disso, o IOC realizou estudos que mostravam que o medicamento poderia ser administrado em doses menores do que habitualmente preconizado por autores estrangeiros, o que significava uma economia preciosa, em se tratando de produção dispendiosa e escassa naquelas circunstâncias. Esta nova metodologia foi ensaiada, sobretudo nos trabalhos do posto aplicado do IOC em Rio Bonito, estado do Rio de Janeiro, para o combate à bouba. Além da penicilina, outros antibióticos seriam, a partir de 1945, estudados e produzidos no instituto (IOC, 1945, 1946). ${ }^{75}$

No amplo rol de demandas apresentadas ao IOC neste período, constavam solicitações diretamente referidas à política social e ao projeto de modernização econômica do Estado varguista. Foi o caso dos estudos desenvolvidos pela Divisão de Higiene, a respeito das condições de vida e de trabalho nas minas do Rio Grande do Sul, a pedido do Ministério 
do Trabalho, Indústria e Comércio, e das pesquisas da então criada Seção de Hidrobiologia sobre a fauna e a flora marinha, tendo em vista estabelecer métodos de criação de animais rentáveis do ponto de vista comercial e servir à crescente indústria da pesca no Brasil (IOC, 1945). ${ }^{76}$

O engajamento da instituição no esforço de guerra constituiu, por sua vez, uma ótima oportunidade para obter, junto ao governo, melhores condições físicas e materiais para a instituição. Desde maio de 1942, Aragão já utilizava este argumento para pleitear benfeitorias, como a criação de novas instalações e a remodelação das já existentes, a aquisição de novos equipamentos, o reforço no fornecimento de insumos para pesquisa e produção, a contratação de pessoal técnico e melhorias nas condições de trabalho. Além disso, reivindicava autonomia para movimentar as verbas, "evitando delongas muito prejudiciais aos serviços, em momentos de premência como o atual”. Segundo dizia,

É preciso agora, mais do que nunca, ser atendida sua situação material para que ainda melhor venha a servir ao Brasil (...). Há em Manguinhos (...) uma necessidade urgente de renovação e remodelação de muita coisa que se acha desproporcionada para o seu desenvolvimento atual e as suas crescentes atividades futuras. ${ }^{77}$

O aumento substantivo da produção, em termos quantitativos e no que se refere à sua pauta, imprimia ao IOC o reforço não apenas da utilidade social de suas atividades, mas também de seu valor comercial/ econômico. Isso seria utilizado por Aragão como um poderoso argumento para reivindicar benefícios materiais para a instituição. Numa contabilidade repetida nos relatórios dos anos subseqüentes, o diretor ressaltou que, caso os soros e as vacinas produzidos por Manguinhos em 1942 fossem postos à venda, isso geraria uma renda equivalente a mais da metade da verba orçamentária que o governo lhe destinara para custear todos os seus serviços. ${ }^{78}$

A conjuntura internacional da guerra e da reorganização das estruturas sanitárias federais no Brasil, neste início dos anos 1940, constituiu um contexto favorável para que Manguinhos encontrasse um novo rumo em sua relação com a saúde pública não apenas pelas demandas imediatas e pontuais. A perspectiva de Aragão foi aproveitar tais circunstâncias a fim de tornar esta relação bem mais ampla do que uma vinculação pragmática de fornecimento de produtos e serviços. Vislumbrava-se uma nova forma de associar a ciência feita em Manguinhos aos interesses de 
um projeto nacional. A via preferencial para isso seriam novos investimentos no tema que melhor representava a tradição de Oswaldo Cruz e de Carlos Chagas: as endemias do interior do país.

\section{Uma Nova Agenda para o Saneamento do Interior}

A perspectiva de novos recursos terapêuticos e profiláticos contra as doenças infecciosas - na ordem do dia tanto para as agências sanitárias e os organismos governamentais envolvidos com a guerra quanto para as instituições de pesquisa biomédica - foi fundamental para a decisão de Aragão de conferir centralidade às investigações sobre as doenças endêmicas do país. Ao sintetizar, perante o ministro da Educação e Saúde, os meios pelos quais o IOC responderia "a uma larga cooperação nos trabalhos relacionados com a defesa nacional", ele indicou justamente este outro sentido pelo qual a guerra impunha novos caminhos ao IOC, para além do fornecimento de produtos e serviços:

Este imperativo está indicando, ao Instituto Oswaldo Cruz, o rumo a seguir, na esfera de sua ação, que é o de se aparelhar, desde já, nas mais eficientes condições, para fornecer à população e às suas classes armadas os produtos profiláticos e curativos de uso humano e intensificar seus trabalhos e pesquisas no sentido de esclarecer os problemas nosológicos brasileiros. ${ }^{79}$

Com base nesta orientação, foram criados, no âmbito da DEE, postos aplicados para estudar e para combater doenças específicas em distintas regiões do país, como a bouba, a esquistossomose, o bócio endêmico, a leishmaniose e a doença de Chagas. Tais enfermidades não haviam sido contempladas com a criação de serviços nacionais no MES. Aragão buscava, assim, investir em áreas que não constituíam objeto de ações sistemáticas do Estado.

Em 1943, em Catende, Pernambuco, foi criado um posto para estudo e ensaio de métodos de controle da esquistossomose, sob a coordenação de Geth Jansen. A doença, transmitida por caramujos, era de grande prevalência no Nordeste e começava a se alastrar pelo país, no rastro das crescentes migrações, oriundas, sobretudo, daquela região, em direção ao Sul e Sudeste. ${ }^{80}$ No mesmo ano, foi criado o Centro de Estudos e 
Profilaxia da Moléstia de Chagas (CEPMC) em Bambuí, sob a direção de Emmanuel Dias, foco da análise nos próximos capítulos (IOC, 1945). Também em Minas, o IOC realizaria pesquisas sistemáticas, em Conselheiro Lafayette, sobre o bócio endêmico, implementando ações de profilaxia baseadas na adição de iodo ao sal e a outros alimentos consumidos pela população. ${ }^{81}$ No início de 1945, os estudos sobre a bouba deram origem a um posto especial em Rio Bonito, estado do Rio de Janeiro, sob a coordenação de Felipe Nery Guimarães, que se destacaria, além dos estudos clínicos, pelo uso da penicilina para tratamento da doença (IOC, 1946). Dias, Jansen e Guimarães haviam trabalhado no Sege. Outras "moléstias que grassam nas zonas rurais e sertões brasileiros" seriam objeto de investigações na DEE, como a ancilostomose, a leishmaniose, o fogo selvagem e o tifo exantemático. ${ }^{82}$ Estes postos reeditavam o movimento de interiorização da pesquisa preconizado pelo Sege, num contexto que reforçava o caráter aplicado das pesquisas sobre as endemias rurais. O objetivo era, sobretudo, estabelecer procedimentos para sua profilaxia, a ser implementada por campanhas do MES. Recriava-se, assim, uma agenda em prol do saneamento do Brasil.

Luiz Antonio de Castro-Santos (1985: 210) considera que o processo de nation-building iniciado em 1930 teria levado a um "esvaziamento definitivo da ideologia de redenção dos sertões" e inviabilizado a continuidade do movimento sanitarista, "sob o peso crescente da burocratização das atividades de saúde durante a vigência do 'Estado administrativo' de Vargas”. Para o autor, Vargas deslocou o projeto de construção da nacionalidade para a fronteira, de modo que poupasse o novo regime do enfrentamento com as oligarquias do grande sertão. Pode-se argumentar, entretanto, que ainda que em termos ideológicos o discurso do saneamento não tivesse mais a intensidade com que se manifestara na década de 1910, as novas estruturas administravas da saúde pública brasileira proporcionaram justamente a criação de condições institucionais e políticas concretas para a viabilização e o aprofundamento do projeto sanitarista. Além disso, este ganhava nova força simbólica mediante os significados que, a partir da Segunda Guerra Mundial, vinham sendo conferidos à relação entre saúde e desenvolvimento. Segundo Hochman (2001) e Fonseca (2007), um dos sentidos em que se pode afirmar uma continuidade entre a reforma sanitária promovida pela gestão de Capanema no MES e a agenda do movimento sanitarista da Primeira República foi a orientação pela qual se conferia à política de saúde pública um caráter de 
construção da nacionalidade. ${ }^{83}$ A mesma afirmação pode ser feita em relação à perspectiva de Evandro Chagas e Henrique Aragão, na medida em que buscava reconfigurar a associação entre combate às endemias rurais e desenvolvimento nacional como diretriz prioritária de Manguinhos. Contudo, a possibilidade de identificar, entre estes distintos projetos, uma proximidade substantiva ou continuidade - em termos das orientações tomadas e dos princípios e valores que os legitimavam implica que sejam percebidas as maneiras pelas quais este projeto de retomar as bandeiras do sanitarismo nas décadas de 1930 e 1940 foi ressignificado nas condições históricas específicas desta nova temporalidade. Se as bandeiras do movimento pelo saneamento rural persistiram no pós-1930, cabe observar em que medida seus elementos discursivos essenciais - o tema do interior, de sua articulação com o progresso/desenvolvimento nacional e, conseqüentemente, do papel das endemias rurais como obstáculo a este desenvolvimento - assumiram novos contornos numa sociedade que passava por importantes transformações.

Um primeiro e fundamental aspecto a ser considerado em relação aos novos significados atribuídos ao mundo rural neste período é que, embora os projetos de desenvolvimento no pós-1930 se direcionassem para a construção de um Brasil essencialmente industrial e urbano, em contraponto ao modelo agrário-exportador das oligarquias rurais, o setor agropecuário não ficou relegado a um segundo plano no novo arranjo da economia brasileira. Segundo Tamás Szmrecsányi (1995), ele assumiu importância estratégica, até como forma de garantir a viabilidade do processo de industrialização e urbanização. Na transição para um novo padrão de acumulação da economia brasileira, um dos grandes desafios era fazer com que a produção agropecuária deixasse de atender apenas às exportações e ao autoconsumo e se tornasse capaz de suprir as demandas do mercado consumidor interno, que cresciam à medida que se expandiam a população urbana e as necessidades de um parque industrial em progressiva diversificação. Entre as demandas deste mercado interno, estava o fornecimento de gêneros alimentícios a baixo preço, fundamental para manter sob controle os custos de reprodução da força de trabalho urbana.

Os próprios interesses do projeto industrialista, portanto, pressupunham dotar a economia rural de condições e investimentos para o aumento de sua produtividade. Isso implicava não apenas a mudança dos padrões produtivos (como a introdução de novas culturas e processos téc- 
nicos de produção), mas também a fixação do homem no campo, de maneira a conter o êxodo rural decorrente das migrações internas, intensificadas pelos limites que a Constituição Federal de 1934 impôs à imigração estrangeira e, sobretudo, pelo processo de expansão urbano-industrial. ${ }^{84}$ O deslocamento dos trabalhadores rurais para as cidades, além de produzir esvaziamento na capacidade produtiva do setor agropecuário, era motivo de preocupação, na medida em que poderia introduzir problemas nestes novos pólos do desenvolvimento, como a disseminação de favelas, da mendicância e de doenças. Como afirma Gomes (1982: 163), os poderes públicos começaram a atentar para o fato de que "a solução do problema da cidade residia na solução do problema do campo".

A preocupação com a produtividade do trabalho rural era dada por motivos econômicos, mas também dizia respeito aos horizontes ideológicos do período, sobretudo pelo valor conferido à noção de trabalho como viga-mestra da nova ordem criada em 1930. De acordo com Gomes (1982, 1988, 1999), embora a ênfase recaísse sobre o trabalho urbano, em função do próprio direcionamento assumido pelo processo de modernização do período, a preocupação com a produtividade do trabalho rural também estava presente, na medida em que se afirmava que a riqueza nacional dependia de uma vigorosa conquista do campo e do aumento de sua produtividade.

Ainda que a extensão da legislação social ao campo permanecesse como promessa, a 'marcha para o oeste' implementada por Vargas, destinada a expandir as fronteiras agrícolas, a ocupar os vazios territoriais do país e a promover a exploração racional da terra, foi uma das formas de se encaminhar, pelo menos como projeto, a incorporação do interior e do setor agropecuário a esta grande 'cruzada' de valorização do trabalho e da produtividade nacional. Neste processo, o tema do saneamento rural apresentava-se como meta relevante para a política de povoamento. ${ }^{85}$ No contexto histórico-social de Minas Gerais, no qual o Sege e o CEPMC inscreviam seus esforços de pesquisa e de combate à doença de Chagas, as condições também eram particularmente favoráveis à perspectiva do saneamento como condição para o desenvolvimento social e econômico. 


\section{Combatendo Endemias em Minas Gerais: as preocupações com a superação do atraso econômico}

Se a afirmação da importância do estudo e do combate da doença de Chagas e outras endemias rurais se beneficiava dos valores e significados conferidos, no âmbito do projeto de modernização do país, ao tema da produtividade do trabalho rural, este era um assunto particularmente em evidência em Minas Gerais. O estado, tradicionalmente conhecido por sua 'vocação agrícola', vivia o desafio de adequar-se à transição para uma ordem urbano-industrial. Como mostram Otavio Dulci $(1992,1999)$ e Maria Eliza Linhares Borges (1997), a estagnação econômica do estado e os meios para sua recuperação econômica preocupavam as elites mineiras e eram hegemônicos na agenda política estadual. ${ }^{86}$

Um fator considerado determinante da desestruturação da agricultura mineira era o intenso êxodo que, especialmente a partir da década de 1920, produzia o que então se qualificou como uma verdadeira 'diáspora' dos operários agrícolas mineiros (Borges, 1997). Com a intensificação das migrações internas, estes trabalhadores eram atraídos para as cidades e as indústrias, não apenas dentro do estado, mas principalmente em outras regiões do país. ${ }^{87}$ Além do interesse econômico, a fixação da mão-de-obra nas fazendas mineiras assumia também importância política, na medida em que a mobilidade dos trabalhadores favorecia o questionamento das normas que regiam as relações tradicionais de dominação no campo e a perda do controle sobre a força de trabalho. Além disso, migração dos trabalhadores rurais significava perda de votos e enfraquecimento do poder local das elites agrárias. Quando este deslocamento levava os eleitores para outros estados, o risco era para o próprio poder de barganha das elites mineiras no cenário nacional, já que um dos fatores do peso político de Minas na federação, desde a Primeira República, era o fato de ser o estado mais populoso do país (Borges, 1997).

A perspectiva, surgida no final da década de 1920 e intensificada a partir da década de 1930, de que o estado deveria rever sua estrutura agroexportadora e ter um projeto de industrialização focado, sobretudo, na siderurgia, adequando-se ao movimento nacional de construção de uma ordem urbano-industrial, não significou o deslocamento dos interesses e das preocupações quanto à superação dos problemas da economia agrária. 
Seguindo a tendência nacional, os próprios grupos envolvidos na criação de uma nova vocação industrial para Minas reconheciam a necessidade de modernização da produção agropecuária, de modo a gerar capitais que viabilizassem os investimentos na indústria. Assim, as tradicionais elites agrárias mineiras buscaram redefinir suas relações com o novo arranjo político-econômico firmado a partir de 1930, de modo a garantir a continuidade de seu poder e seus privilégios.

O modelo de modernização implementado pelo governo de Benedito Valladares (1933-1945) - que significou o avanço do poder estatal como agente privilegiado para o planejamento da modernização - preconizava que o pré-requisito fundamental para um programa de superação do atraso e de industrialização era a modernização da agricultura. Isso se daria, principalmente, por meio da policultura, a fim de diminuir a dependência da produção cafeeira e de promover o abastecimento do mercado consumidor interno. Sob a atuação de Israel Pinheiro como secretário de Agricultura (1933-1942), firmou-se a idéia de que seria justamente mediante novos investimentos em sua tradicional vocação agrícola que Minas assumiria proeminência no processo de industrialização nacional. Como 'celeiro do Brasil', seria o grande fornecedor de gêneros básicos para o mercado interno nacional (Borges, 1997).

Contudo, apesar dos esforços de Valladares em promover a recuperação econômica, o estado enfrentava, no início da década de 1940, uma crise generalizada, amplificada diante do crescimento de São Paulo e da expansão das fronteiras agrícolas rumo ao Paraná e a Goiás, o que contribuía para intensificar o processo de migração (Diniz, 2002). Neste cenário, as elites mineiras tornavam-se particularmente sensíveis a projetos que pretendessem promover melhorias nas condições de vida e de trabalho, como o combate a endemias que significassem prejuízos à produtividade rural, sobretudo nas regiões mais promissoras do ponto de vista econômico. O interesse norte-americano pelas matérias-primas brasileiras estratégicas às operações de guerra - entre as quais os minérios a serem explorados nas jazidas daquele estado - constituía um elemento a mais a impulsionar a perspectiva de modernização em Minas e, conseqüentemente, a gerar interesse por medidas sanitárias tidas como necessárias a esta modernização. Apesar de terem perdido para o Rio de Janeiro a Companhia Siderúrgica Nacional, os mineiros foram contemplados com a criação, em 1942, da Companhia Vale do Rio Doce. A fim de garantir condições sanitárias para a instalação da nova empresa e para a renovação 
da Estrada de Ferro Vitória-Minas, o Serviço Especial de Saúde Pública (Sesp), criado em agosto daquele ano mediante acordo entre os governos brasileiro e norte-americano, encarregou-se do saneamento da região por meio do combate à malária e da implantação de postos de saúde. No ano seguinte, o Sesp daria início ao Programa da Mica, igualmente com o objetivo de criar uma infra-estrutura sanitária básica nas regiões produtoras de mica e quartzo em Minas e em Goiás (Campos, 2006).

Esta particular centralidade atribuída ao tema da produtividade do trabalho - tanto no cenário nacional como no caso mineiro, em particular - conferia à articulação entre saúde e desenvolvimento nacional uma nova força discursiva e política, além de novas potencialidades para que tal bandeira se transformasse em ações concretas por parte do Estado brasileiro. Foi neste contexto que o Sege deu início às pesquisas sobre a doença de Chagas no estado em que ela fora descoberta, que levariam à criação, em novembro de 1943, em Bambuí, do CEPMC, responsável por nova fase no processo de construção e legitimação daquela enfermidade.

Os elementos históricos apresentados neste capítulo, articulando dimensões relativas aos cenários internacional e nacional e ao ambiente específico de Manguinhos, constituem mais do que um pano de fundo para esta trajetória, focalizada nos próximos capítulos. Eles nos fornecem chaves importantes para compreendermos como os processos sociais em curso - sobretudo os valores e significados que temas como ciência, saúde e desenvolvimento assumiam no imaginário político-cultural da época - influenciaram as ações dos cientistas, seja como condições de possibilidade, seja como elementos discursivamente utilizados por eles para legitimarem seus próprios projetos.

\section{Notas}

1 Ambos os cientistas, em especial Vasconcellos, haviam sido antagonistas de Chagas por ocasião da polêmica sobre a tripanossomíase americana entre 1919 e 1923. Fontes, segundo Chagas Filho, foi uma das lideranças do grupo que se opunha a seu pai em Manguinhos e, no terreno da política, havia se aliado a Belisário Penna na oposição a Chagas durante a Revolução de 1930 (Chagas Filho, 1987, fita 17, lado b).

2 Para mais detalhes sobre a organização do Ministério da Educação e Saúde Pública (Mesp) a partir de 1930 e sobre sua reestruturação a partir da Reforma Capanema, ver Fonseca (2007). 
3 Fontes, Antonio Cardoso. Relatório dos serviços executados pelo Instituto Oswaldo Cruz no exercício de 1936, p. XXI. Fundo Instituto Oswaldo Cruz, Seção Serviço de Administração, Série Administração Geral (doravante FIOC/SSA/SAG), caixa 26, maço 4. Este arquivo encontra-se sob a guarda da COC/Fiocruz.

4 Este argumento foi formulado e desenvolvido no âmbito do projeto "Entre o básico e o aplicado: práticas e tradições de pesquisa no Instituto Oswaldo Cruz (1935-1970)", realizado na COC/Fiocruz entre 2000 e 2002 sob a coordenação de Luiz Otávio Ferreira, do qual participei juntamente com Nara Azevedo e Wanda Hamilton.

5 'Projeto de desenvolvimento' é aqui considerado no sentido mais amplo de programa geral de modernização, uma vez que, até o pós-guerra, as políticas de desenvolvimento no Brasil ainda não se constituíam como um plano acabado, baseado em metas e em mecanismos de financiamento, de controle e de coordenação formalmente estabelecidos (Corsi, 2000; Leopoldi, 2003).

6 Sobre a política de saúde na Era Vargas, ver Hochman e Fonseca (1999, 2000), Hochman (2001), Fonseca (2007) e Campos (2006).

7 A preocupação do Estado em expandir os serviços de saúde em todo o país expressou-se num intenso processo de interiorização que imprimiu aos médicos sanitaristas uma identidade que, de acordo com o depoimento de um destes médicos, Celso Arcoverde, era a de profissionais "longe do asfalto e do ar-condicionado" (apud Fonseca, 2007: 171). Sobre a saúde pública pós-1930, ver também Hochman e Fonseca (1999, 2000) e Hochman (2001).

8 João de Barros Barreto (1890-1956) nasceu no Rio de Janeiro e formou-se pela Faculdade de Medicina do Rio de Janeiro (FMRJ) em 1912. Em 1914, tornou-se inspetor sanitário da Diretoria de Higiene do Estado do Rio de Janeiro, passando a atuar na Diretoria Geral de Saúde Pública (DGSP) no ano seguinte. Com a criação dos serviços federais de profilaxia rural em 1918, passou a organizar e a dirigir postos sanitários e obras de saneamento em áreas suburbanas da cidade do Rio de Janeiro e em vários estados brasileiros. Com bolsa de estudos da Fundação Rockefeller, realizou cursos na Johns Hopkins School of Hygiene and Public Health e na Harvard School of Public Health (1924-1925). Teve destacada atuação no campo da higiene industrial e foi um dos pioneiros na institucionalização da medicina do trabalho no país. Foi eleito membro da Academia Nacional de Medicina (ANM) em 1925. De 1925 a 1936, foi professor da cadeira de higiene da FMRJ. Em 1936, tornou-se professor catedrático de higiene da Faculdade de Ciências Médicas. Entre 1926 e 1929, foi assistente de Clementino Fraga, diretor do Departamento Nacional de Saúde Pública (DNSP). Como diretor do Departamento Nacional de Saúde (DNS), nos períodos de 1937 a 1939 e de 1941 a 1945, comandou a reorganização dos serviços sanitários brasileiros, em sintonia com as diretrizes do processo mais geral de reforma do Estado (Hochman, 2007a).

9 Ao reforçar a separação política e institucional entre saúde pública e assistência médica, que havia se desenhado ao longo dos anos 1920, o governo Vargas instituiu dois formatos distintos para a prestação de serviços de saúde relativos aos dois ministérios então criados, o Ministério do Trabalho, Indústria e Comércio (MTIC) e o Mesp. Assim, à medida que a assistência médica ficaria a cargo da estrutura previdenciária montada por Vargas em torno de categorias funcionais específicas e 
regulada pelo MTIC, ao Mesp caberiam ações de saúde pública de caráter universalista, referidas aos interesses de clientelas mais amplas, que não haviam sido incluídas no processo de regulação estatal da força de trabalho. Ver Hochman e Fonseca (1999), Hochman (2001) e Fonseca (2007).

10 Como indica Fonseca (2007: 150-151), a proposta "foi uma das mais importantes inovações institucionais promovidas pela reforma do Mesp, para os propósitos de expansão dos órgãos federais de saúde". Para uma descrição da estrutura organizacional assumida pela saúde pública durante o Estado Novo, ver Barreto (1942).

11 Esta formação era feita em cursos de especialização oferecidos pelo Instituto de Higiene (embrião da atual Faculdade de Saúde Pública da Universidade de São Paulo), pelo Curso de Medicina Pública da FMRJ (embrião do Curso Especial de Higiene e Saúde Pública, dirigido pelo IOC nesta escola) e por instituições norteamericanas, como a Johns Hopkins School of Hygiene and Public Health e a Fundação Rockefeller (Castro-Santos \& Faria, 2006).

12 O projeto de reorganização do Mesp foi apresentado ao Congresso Nacional em 15 de dezembro de 1935 (Brasil, 1935).

13 Sobre a Reforma Capanema e o debate sobre o Insp no que concerne ao ensino especializado em saúde pública, ver Castro-Santos e Faria (2006).

14 A posição de Rodrigues foi compartilhada por Ernani Agrícola, médico do DNS, em parecer criticando o caráter burocrático e corporativo que o Insp iria assumir se fosse efetivamente instalado no formato proposto pela Comissão de Saúde Pública. Afirmava que seria preferível a criação no IOC de algumas seções para estudos, inquéritos e pesquisas sobre temas de interesse prático para a saúde, principalmente as endemias rurais. Parecer de Ernani Agrícola encaminhado ao ministro Gustavo Capanema, em 15 de janeiro de 1937. Arquivo Gustavo Capanema, Série Ministério da Educação e Saúde/Saúde e Serviço Social (doravante AGC/SMES/SSS), GC h 1935.05.27. Este arquivo encontra-se sob a guarda do CPDOC/ Fundação Getulio Vargas

15 Fontes, Antonio Cardoso. Bases para a remodelação de Manguinhos. Fundo Carlos Chagas Filho (em organização). Este arquivo encontra-se sob a guarda da COC/ Fiocruz.

16 Fontes, Antonio Cardoso. Relatório dos serviços executados pelo Instituto Oswaldo Cruz (IOC) durante o exercício de 1936, p. XXI. FIOC/SSA/SAG, caixa 26, maço 4.

17 Carta de João de Barros Barreto a Gustavo Capanema. Rio de Janeiro, 1 de junho de 1937. AGC, GC h 1935.02.19, rolo 59, fotograma 101; grifos meus.

18 Parecer do ministro da Educação e Saúde na questão da autonomia financeira do IOC. Rio de Janeiro, 30 de novembro de 1937. Fundo Carlos Chagas Filho (em organização).

19 O artigo 140 da Constituição Federal de 1934 atribuía à União a responsabilidade pela organização de um "Serviço Nacional de combate às grandes endemias". Esta diretriz, reafirmada no decorrer dos debates em torno da Reforma Capanema, foi incorporada à lei que a sancionou, em 1937, mediante o artigo 65 (Fonseca, 2007: $156,169)$.

20 As informações sobre o Sege apresentadas nesta seção foram colhidas nos seguintes documentos: Relatórios do Serviço de Estudo das Grandes Endemias, apresentados 
em 1936, 1937 e 1938; Ofício de Evandro Chagas ao ministro da Educação e Saúde Gustavo Capanema, Rio de Janeiro, 8 de dezembro de 1938; Serviço de Estudo das Grandes Endemias - Exposição ao Sr. ministro da Educação e Saúde, destinada a modificar o orçamento para o Serviço em 1940. Rio de Janeiro, 9 de novembro de 1939; Chagas Filho, Carlos. Exposição sobre o Serviço de Estudo das Grandes Endemias. Rio de Janeiro, 31 de dezembro de 1940; Carlos Chagas Júnior [sic], Serviço de Estudos das Grandes Endemias e a obra de Evandro Chagas. AGC/ SMES/SSS, GC h 1935.05.27; Relatório das atividades do Sege, encaminhado por Carlos Chagas Filho ao diretor do IOC. Rio de Janeiro, 22 de agosto de 1941. Fundo Carlos Chagas Filho (em organização).

${ }^{21} \quad$ Ofício de Evandro Chagas ao ministro da Educação e Saúde Gustavo Capanema. Rio de Janeiro, 8 de dezembro de 1938. AGC/ SMES/SSS, GC h 1935.05.27.

22 No Ceará, os pesquisadores encontraram barbeiros infectados com o Trypanosoma cruzi e sinais clínicos da tripanossomíase americana. Chagas, Evandro; Cruz, Walter Oswaldo. "Inquérito preliminar sobre algumas endemias do Nordeste", 1938. AGC/ SMES/SSS, GC h 1935.05.27. Para uma lista das expedições realizadas pelo Sege entre 1936 e 1941, ver: Ofício encaminhado por Carlos Chagas Filho ao diretor do IOC, Rio de Janeiro, 22 de agosto de 1941. Fundo Carlos Chagas Filho (em organização).

23 As constantes viagens feitas pelos pesquisadores associados ao Sege proporcionaram abundante material de pesquisa (insetos, parasitos, plantas, animais, amostras de sangue etc.) para várias seções do IOC, como as de protozoologia, entomologia e helmintologia, viabilizando linhas de pesquisa que não tinham necessariamente objetivos médicos e aplicados. O Sege patrocinou pesquisadores daquelas seções para que realizassem viagens de investigação e, além de seus objetivos específicos de estudo, coletassem materiais de interesse ao serviço, como possíveis transmissores ou animais reservatórios de doenças. Tais viagens foram fundamentais para formar e/ou enriquecer as célebres coleções científicas do IOC. Ver Fundo Instituto Oswaldo Cruz: inventário dos documentos das coleções científicas. Este fundo encontra-se sob a guarda da COC/Fiocruz.

24 Ofício de Evandro Chagas ao ministro da Educação e Saúde Gustavo Capanema, em 19 de agosto de 1940. AGC/SMES/SSS, GC h 1935.05.27.

25 "Instituto Oswaldo Cruz", s/n, [1936]. Fundo Evandro Chagas (doravante FEC), grupo: vida pessoal; atividade: relações familiares e de sociabilidade (livro de recortes de jornais, p. 55). Esta associação com a tradição sanitarista de Manguinhos foi um traço marcante na forma com que o Sege era apresentado também perante o grande público, como bem expressa o título desta reportagem: "Continuador de uma das glórias da Medicina Brasileira. A ação saneadora do professor Evandro Chagas no sertão - Importantes inquéritos nosológicos no vale do Amazonas, no Nordeste e no pantanal de Mato-Grosso" (Correio da Noite, março de 1940). FEC, grupo: vida pessoal; atividade: relações familiares e de sociabilidade (livro de recortes de jornais, p. 96-97)

26 Serviço de Estudo das Grandes Endemias. Exposição ao Sr. ministro da Educação e Saúde, destinada a modificar o orçamento para o serviço em 1940. Rio de Janeiro, 9 de novembro de 1939. AGC, GC 35.05.27.

27 Plano para os trabalhos de cooperação do Serviço de Estudo das Grandes Endemias com os Estados. Rio de Janeiro, 11 de novembro de 1939. AGC/SMES/SSS, GC h 1935.05.27. 
28 Evandro Chagas pretendia que o Sege, além dos serviços especiais de epidemiologia, zoologia, hospital, patologia e entomologia, e dos serviços gerais (como biblioteca, biotério etc.), que funcionavam no Hospital de Manguinhos, fosse composto de 'divisões' referentes às regiões Sul, Nordeste, Norte e Centro, às quais estariam vinculados os institutos criados nos estados. Nos estados em que não fosse possível estabelecer um instituto, seriam organizados laboratórios nas principais cidades, sob a responsabilidade das respectivas divisões. Ver organograma em: Serviço de Estudo das Grandes Endemias. Exposição ao Sr. ministro da Educação e Saúde destinada a modificar o orçamento para o serviço em 1940. Rio de Janeiro, de 9 de novembro de 1939. Para um relato dos acordos e das tentativas de cooperação realizados por Evandro desde o início do serviço, ver: Plano para os trabalhos de cooperação do Serviço de Estudo das Grandes Endemias com os Estados. Rio de Janeiro, 11 de novembro de 1939. AGC/SMES/SSS, GC h 1935.05.27.

29 O Ibed foi criado em 1907 como filial do IOC em Belo Horizonte para abrigar as investigações de Ezequiel Dias, transferido àquela cidade para tratamento de saúde, como muitos outros médicos e pesquisadores atraídos pelo clima, considerado benéfico à cura da tuberculose. Transformando-se rapidamente num importante centro de ciências biomédicas e biológicas da cidade, o pequeno posto do IOC desenvolvia pesquisas sobre os principais temas de saúde pública em Minas Gerais (como o escorpionismo), fabricava produtos imunobiológicos requeridos pelo Estado, como a linfa antivariólica, e antídotos contra o veneno de escorpiões e de serpentes, além de realizar exames microbiológicos para atender à população. A cooperação e o intercâmbio com a Faculdade de Medicina de Belo Horizonte (FMBH), de cuja criação Ezequiel Dias participou em 1911, formaram uma característica marcante da instituição. Procurando reproduzir o modelo de pesquisa científica da matriz, Dias permaneceu à sua frente até falecer, em 1922. O Ibed ficou vinculado a Manguinhos até 1936, quando, em função da medida federal que proibia o IOC de ter filiais regionais, passou a ser administrado pelo estado de Minas Gerais. Em 1941, foi denominado Instituto Químico e Biológico de Minas Gerais. Ainda assim, continuaria sendo conhecido como Instituto Ezequiel Dias. A instituição constitui a atual Fundação Ezequiel Dias (Benchimol, 1990a; Klein \& Thielen, 2003; Starling, Germano \& Marques, 2007).

30 "Doenças regionais no Brasil" (1936). FEC; grupo: vida pessoal; atividade: relações familiares e de sociabilidade (livro de recortes de jornais, v. VII, p. 47).

31 Em seu depoimento, Paraense (1987-1989, fita 12), pesquisador do Sege, conta que Capanema teria convidado Evandro várias vezes para assumir a direção de Manguinhos.

32 Para o ano de 1940, por exemplo, o orçamento do Sege compreendia: verba especial do governo federal para as pesquisas sobre as grandes endemias no país, 400:000\$000; Guilherme Guinle, 96:000\$000; Fundação Rockefeller, 75:000\$000; estado do Pará, 200:000\$000; verba orçamentária ordinária do IOC, 189:000\$000; total, 960:000\$000. Ofício de Evandro Chagas ao ministro da Educação e Saúde Gustavo Capanema. Rio de Janeiro, 19 de agosto de 1940. AGC/SMES/SSS, GC h1935.05.27.

33 Na época em que foi combater a malária em Itatinga, São Paulo, Carlos Chagas conheceu Eduardo Guinle (pai de Guilherme) e Cândido Gafrée, sócios da Companhia Docas de Santos, que havia requisitado providências contra a doença. Como 
mostra Gisele Sanglard (2008), foi a partir deste episódio que a família Guinle passou a se dedicar ao mecenato científico e à filantropia, investindo, por exemplo, no laboratório privado de fisiologia dos irmãos Ozório de Almeida, importantes nomes da ciência biomédica brasileira, e na manutenção e construção de hospitais. O depoimento de Wladimir Lobato Paraense é revelador de como as relações pessoais e familiares mantidas pela família Chagas foram determinantes para a experiência do Sege: "Um filho de Carlos Chagas vai onde quer. Ele [Evandro] procurou o Guinle, e este lhe deu uma verba, de mais ou menos 240 contos de réis. Nesse tempo, isso dava para se trabalhar bem. Mesmo que o instituto desse esse recurso, não se ia poder fazer as coisas do mesmo jeito, por causa da burocracia. $\mathrm{O}$ dinheiro do Guinle era para fazer o que precisasse fazer, era direto na mão. Não havia burocracia nenhuma. (...) A secretária do Evandro recebia todo mês o dinheiro direto da secretária do Guinle" (Paraense, 1987-1989, fita 13, lado A).

34 Segundo o projeto de Evandro Chagas, o orçamento da nova instituição seria, para 1941 , de 2.335.800\$000, cerca de duas vezes e meia maior do que o orçamento do Sege em 1940. Ofício de Evandro Chagas para o ministro da Educação e Saúde. Rio de Janeiro, 19 de agosto de 1940. AGC/SMES/SSS, GC 35.05.27.

35 As idéias de 'antiparasito' e de 'antidoença', segundo Nájera (1994), devem-se ao fato de que, no primeiro caso, as intervenções preconizadas visavam, em última instância, a eliminar o parasito da malária e, no segundo paradigma, o principal objetivo era elevar os níveis de saúde da população, num sentido mais amplo. A nosso ver, entretanto, estas designações mais confundem do que sintetizam as interessantes formulações de Nájera.

36 Worboys (1997) opõe-se à visão de que a teoria dos germes teria conduzido a uma visão de saúde reducionista, em que as circunstâncias socioeconômicas e políticas seriam irrelevantes para a prática médica. Segundo ele, a metáfora da 'semente' e do 'solo' (ou seja, que o germe somente 'floresce' em condições favoráveis), recorrente ao final do século XIX, expressou a vinculação entre a visão bacteriológica e uma concepção de saúde que articulava múltiplos fatores relativos ao ambiente, à economia e à constituição individual.

37 Randall Packard e Peter Brown (Packard \& Brown, 1997; Brown, 1997), valendo-se de uma perspectiva antropológica, afirmam que esta forma de conceber o papel da saúde na promoção do desenvolvimento econômico-social deve ser vista como uma espécie de modelo cultural, uma ferramenta cognitiva que os membros de uma sociedade usam para pensá-la. No caso do modelo 'malária bloqueia o desenvolvimento', ao analisar a campanha implementada pela Fundação Rockefeller na Sardenha a partir de 1946, Brown chama a atenção para a necessidade de analisar como tal concepção foi sendo historicamente construída valendo-se de maneiras específicas de se atribuir sentido tanto ao conceito de malária quanto ao de desenvolvimento.

38 A designação de "abordagem centrada no vetor", utilizada por Packard e Gadelha (1994: 197), sintetiza os principais elementos das formulações de Farley (2004), Nájera (1994) e Packard e Brown (1997) sobre este modelo que concebe as intervenções sanitárias como pré-requisito para o desenvolvimento.

39 O principal representante desta escola foi Angelo Celli que, na década de 1910, afirmava ser a malária uma doença social resultante da exploração e das péssimas condições de vida dos operários e camponeses. Para ele, de nada adiantaria comba- 
ter mosquitos enquanto persistissem os interesses políticos e econômicos que determinavam tal exploração. O conflito entre os italianos e os que preconizavam o combate ao vetor, especialmente os malariologistas e entomologistas norte-americanos e britânicos, levaria à fundação da Comissão de Malária da Liga das Nações, no início da década de 1920 (Packard \& Gadelha, 1994). Sobre a malária na Itália, ver Snowden (2006).

40 Em 1914, a Fundação Rockefeller começou a delinear um plano mundial de combate à febre amarela. Nesta ocasião, William Gorgas (que havia liderado as campanhas de Cuba e para a abertura do canal do Panamá) argumentou em favor da erradicação mundial da doença, fundamentado na teoria dos 'focos-chave', segundo a qual deveriam ser eliminadas as condições de procriação do vetor nos centros endêmicos que constituíssem 'sementeiras' de epidemias. A erradicação da febre amarela (juntamente com a ancilostomose) foi um dos principais objetivos da Rockefeller no Brasil, na sua primeira fase de atuação, a partir de 1916. Em 1923, um acordo de cooperação com o governo brasileiro formalizou a responsabilidade conjunta do DNSP e do International Health Board (IHB) para a eliminação do Aedes aegypti das cidades litorâneas do Norte e Nordeste. As ações foram marcadas, contudo, por conflitos entre os norte-americanos e os sanitaristas brasileiros quanto à eficácia da metodologia antilarvária e à teoria dos focos-chave. A grande epidemia na capital federal, em 1928, intensificou as críticas às fragilidades do programa e derrubou a crença de que a erradicação seria uma tarefa simples. Em 1930, a direção da campanha foi assumida por Fred Soper, que a reestruturou completamente. Com total liberdade de gerenciamento e lançando mão de um esquema fortemente militarizado e disciplinado, ele dedicou-se a mapear a extensão da doença em todo o país. A comprovação, em 1932, de que havia uma forma silvestre da febre amarela e de que o A. aegypti não era o único transmissor exigiu uma revisão em sua epidemiologia. Em 1933, verificou-se ser possível eliminar o vetor nas áreas urbanas e, a partir daí, a meta passou a ser o índice larvário zero. Em 1938, tal resultado parecia ter sido alcançado nas cidades brasileiras mais importantes, e Soper propôs um programa continental de erradicação, projeto que seria estimulado pelo sucesso contra o Anopheles gambiae em 1940. Naquele ano, o combate à febre amarela no Brasil foi transferido da Rockefeller para o Serviço Nacional de Febre Amarela, do MES. O uso do DDT, na década de 1940, impulsionaria as ações contra o mosquito e, em 1947, a Repartição Sanitária Pan-Americana, dirigida por Soper, aprovou um plano para a erradicação continental do A. aegypti. Em 1950, a campanha no Brasil alcançou seu auge e vários estados foram declarados livres desta espécie vetora. Em 1958, o Brasil e outros países do continente consideraram erradicado este mosquito transmissor da febre amarela de seus territórios (Benchimol, 2001).

${ }^{41}$ Ainda não se utilizavam inseticidas de ação residual, que seriam desenvolvidos somente a partir da Segunda Guerra Mundial. Naquela época, eram usados, sobretudo, produtos à base de piretro.

42 Em outubro de 1941, o encontro de mosquitos mortos em aviões norte-americanos vindos da África para Natal, seguido da identificação de exemplares vivos do A. gambiae na região da base naval desta cidade, provocou preocupações quanto à reinfestação e ao retorno da epidemia. A ação do Serviço Nacional de Malária, em 1943, evitou que isso acontecesse (Campos, 1999). 
43 Em 1944 e 1945, Soper repetiria a experiência combatendo o A. gambiae no Egito (Farley, 2004).

44 "Da primeira vacina aplicada no braço do recruta até a graxa com que ele besunta seu rosto antes de juntar-se à tropa de ataque, o soldado norte-americano está vestido, equipado, armado, mantido confortável, seco e em bom estado de saúde, tudo graças a muitos produtos químicos (...) Na história da guerra moderna, há, no front químico, muito mais além de gás venenoso" - Tradução livre.

45 O termo 'bala mágica' foi cunhado pelo alemão Paul Ehrlich para designar os quimioterápicos que produzia para combater agentes infecciosos específicos, como o Salvarsan, usado a partir de 1910, contra o causador da sífilis (Porter, R., 1999). Em 1940, a Warner Bros. produziu um filme chamado Dr. Ehrlich's magic bullet, popularizando o termo, no contexto da guerra, como expressão da confiança vivida na época em relação ao desenvolvimento de novos recursos terapêuticos e profiláticos contra as doenças infectocontagiosas.

46 Desde a Primeira Guerra Mundial, os Estados Unidos e países europeus buscavam desenvolver antimaláricos sintéticos que viessem a substituir a quinina. Ver Poser e Bruyn (1999).

47 Os britânicos estimaram em duzentos mil os casos de malária entre as Forças Aliadas na campanha da Sicília, uma perda em capacidade de luta equivalente a duas divisões de infantaria (Farley, 2004: 134).

48 Até 1944, todo o trabalho com o DDT nos Estados Unidos foi mantido em sigilo sob os auspícios do Comitê de Pesquisa Médica, do Office of Scientific Research and Development (Stapleton, 1998; Farley, 2004).

49 "o mundo ansiava - ingenuamente, como se perceberia depois - por um mundo livre de doenças" - Tradução livre.

50 Ao noticiar a participação de Evandro Chagas num congresso científico em Washington, o Correio da Manhã (1940a: 3) afirmou: “(...) o interesse principal da assembléia se concentrou na aplicação, em larga escala, de inseticidas para o combate ao mosquito nos domicílios. Foi essa a primeira vez em que, na América, se deu uma demonstração da eficiência do processo e melhor se fundamentou a doutrina sustentada por Carlos Chagas, em 1905, de que a malária é uma infecção essencialmente domiciliar e que a base da campanha contra ela reside no combate ao transmissor no interior da habitação".

51 Sobre a conferência em que abordou o assunto, na FMBH, ver Folha de Minas (1940).

52 A comissão era formada por Barros Barreto, diretor do DNS; Ernani Agrícola, diretor da Divisão de Saúde Pública do DNS; e por Evandro Chagas (Correio da Manhã, 1940b). Cecilio Romaña, que estava na Amazônia na ocasião realizando pesquisas em colaboração com o Sege, comentou: "Yo vi cómo el presidente Vargas era arrastado pela palabra de Chagas hacia la realización de ese programa". ["Eu vi como o presidente Vargas era arrastado pela palavra de Chagas na direção da realização desse programa" - Tradução livre]. Romaña, Cecilio. "En memoria del Dr. Evandro Chagas". Catedra y Clinica, (Buenos Aires, 1940: 521-522, texto escrito em 10 de novembro de 1940). Fundo Carlos Chagas Filho (em organização). 
53 Carlos Chagas Filho (1910-2000) formou-se pela FMRJ em 1931 e, em 1935, tornou-se livre-docente da cadeira de física biológica desta escola. Neste mesmo ano, efetivou-se como pesquisador do IOC. Dois anos depois, passou a dedicar-se à organização do laboratório de biofísica (que, em 1945, se transformaria no Instituto de Biofísica), da Faculdade Nacional de Medicina da então criada Universidade do Brasil. Por imposição da lei de desacumulação de cargos, deixou suas atividades em Manguinhos, permanecendo na universidade. Teve uma destacada carreira científica, assumindo, entre outros cargos, a direção do Setor de Pesquisas Biológicas do Conselho Nacional de Pesquisas (CNPq), entre 1951 e 1954, e a presidência da Academia Brasileira de Ciências, entre 1964 e 1966. Foi delegado permanente do Brasil na Organização das Nações Unidas para a Educação, a Ciência e a Cultura (Unesco) e presidente da Academia Pontifícia de Ciências do Vaticano (Chagas Filho, 1987). Para uma autobiografia, ver Chagas Filho (2000).

${ }^{54}$ Além de prosseguir nos estudos que o serviço vinha desenvolvendo sobre a doença de Chagas em Minas Gerais, cabe destacar, na atuação de Chagas Filho à frente do Sege, o acordo estabelecido entre o Instituto de Patologia Experimental do Norte (Ipen) e a $2^{a}$ Delegacia Federal de Saúde, com o objetivo de concretizar o plano de combate à malária no vale do Amazonas, idealizado por Evandro Chagas pouco antes de seu falecimento. Carta de Carlos Chagas Filho a Antonio Cardoso Fontes. Rio de Janeiro, 3 de outubro de 1941. FIOC/SSA/SAG, caixa 10.1, maço 4, pasta 1; Carlos Chagas Junior [sic], Serviço de Estudos das Grandes Endemias e a obra de Evandro Chagas, AGC/SMES/SSS, GC h 1935.05.27.

55 Chagas Filho, Carlos. Novas diretrizes da pesquisa científica. Exposição de motivos apresentada ao Sr. ministro da Educação e Saúde. Rio de Janeiro, 14 de janeiro de 1941. AGC/SMES/SSS, GC 1935.05.27.

56 Chagas Filho, Carlos. Novas diretrizes da pesquisa científica. Exposição de motivos apresentada ao Sr. ministro da Educação e Saúde. Rio de Janeiro, 14 de janeiro de 1941. AGC/SMES/SSS, GC 1935.05.27. A transformação nas ciências biológicas na época, segundo Chagas Filho, dizia respeito basicamente à passagem de uma biologia calcada na morfologia para uma biologia fundamentada pelos conhecimentos bioquímicos e, conseqüentemente, pelo recurso a metodologias físicas e biofísicas. Estes eram os princípios que, na ocasião, ele tentava implementar no laboratório de biofísica da Universidade do Brasil.

${ }^{57}$ Aragão assumiu interinamente a direção do IOC em janeiro de 1942, em virtude de viagens realizadas por Cardoso Fontes, e foi efetivado no cargo em julho daquele ano, por causa do agravamento das condições de saúde de seu antecessor. Ver relatório de atividades do IOC relativo ao ano de 1942 em: Ofício de Henrique Aragão a João de Barros Barreto. Rio de Janeiro, 23 de janeiro de 1943. Fundo IOC, Seção Direção, Cópias de Ofícios (doravante FIOC/SD/CO), ofício n. 66.

58 Ofício de João de Barros Barreto a Antonio Cardoso Fontes. Rio de Janeiro, 22 de setembro de 1941. FIOC/SSA/SAG, caixa 10.1, maço 4, pasta 1.

59 Foram 12 os serviços nacionais de saúde estabelecidos por esta reforma no DNS, cada um contando com uma estrutura administrativa específica: Serviço Nacional de Febre Amarela (criado no ano anterior), Serviço Nacional de Tuberculose, Serviço Nacional de Peste, Serviço Nacional do Câncer, Serviço Nacional de Lepra, Serviço Nacional de Malária, Serviço Nacional de Doenças Mentais, Serviço Nacio- 
nal de Educação Sanitária, Serviço Nacional de Fiscalização da Medicina, Serviço Nacional de Saúde dos Portos, Serviço Nacional de Bio-Estatística, Serviço Nacional de Águas e Esgotos. Ver Barreto (1942).

60 Embora a autora se refira, com mais ênfase, à política de assistência médica previdenciária, terreno de maior visibilidade da política sanitária sob a gestão de Capanema, suas formulações contemplam todas as iniciativas voltadas para garantir melhores condições de vida e bem-estar, numa concepção geral de saúde como capital para o desenvolvimento nacional (Gomes, 1982, 1988).

${ }^{61}$ Sobre Henrique Aragão, ver Guimarães (1955).

62 O fato de Dias não ter sido contemplado com a direção da Divisão de Estudo das Endemias (DEE), conforme expectativa de Chagas Filho, gerou constrangimento entre este e Aragão. Justificando suas opções, o diretor do IOC afirmou que o caso era de natureza puramente administrativa e que reservara para Dias uma posição de grande prestígio. Nos anos subseqüentes, Dias assumiria, de fato, grande projeção na DEE, sobretudo em razão de seus trabalhos no posto criado para estudar a doença de Chagas em Bambuí. Carta n. 63 de H. Aragão a Carlos Chagas Filho. Rio de Janeiro, 14 de outubro de 1942. Fundo Instituto Oswaldo Cruz, Seção Direção, Cópias de Cartas (doravante FIOC/SD/CC).

63 Sobre a gestão de Aragão no IOC, ver Benchimol (2001: 86-96).

${ }^{64}$ Para uma lista dos produtos fabricados em Manguinhos, com as respectivas quantidades produzidas nas décadas de 1930 e 1940, ver Benchimol (2001: 92-95).

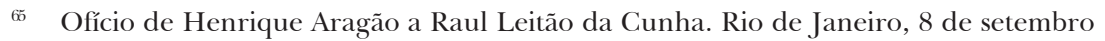
de 1942. FIOC/SD/CO, ofício 635.

66 Ofício de Henrique Aragão a Raul Leitão da Cunha. Rio de Janeiro, 8 de setembro de 1942. FIOC/SD/CO, ofício 635. Ver também: Ofício de Henrique Aragão a João de Barros Barreto. Rio de Janeiro, 23 de janeiro de 1943, p.2. FIOC/SD/CO, ofício 66. A sapucainha era uma planta brasileira usada para substituir o óleo de chalmoogra, de difícil importação naquele momento, no tratamento da lepra. Para um quadro comparativo da produção do IOC entre 1941 e 1945, ver Instituto Oswaldo Cruz (1946: 58).

67 Ao longo de 1942, estabeleceu-se uma técnica mais econômica para a preparação do plasma seco, que poderia assim ser fabricado em grande escala a qualquer momento que fosse solicitado pelas autoridades militares. Em 1945, com equipamentos fornecidos pelo Ministério da Guerra, Manguinhos passaria a preparar o produto para uso do Exército brasileiro. Ofício de Henrique Aragão a João de Barros Barreto. Rio de Janeiro, 23 de janeiro de 1943. FIOC/SD/CO, ofício n.66, p.2; Instituto Oswaldo Cruz (1946: 27).

${ }_{68}$ O IOC desenvolveu estudos sobre dosagens de vitamina A nos óleos de cação, visando substituir o de fígado de bacalhau, em função das dificuldades de importação do momento. Os estudos sobre vitaminas extraídas de animais e vegetais brasileiros constituíam uma área de particular interesse comercial na agenda de pesquisa do IOC nesta época. Ofício de Henrique Aragão a João de Barros Barreto. Rio de Janeiro, 23 de janeiro de 1943. FIOC/SD/CO, ofício n. 66, p. 9.

${ }^{\theta}$ Ofício de Henrique Aragão a Raul Leitão da Cunha. Rio de Janeiro, 8 de setembro de 1942. FIOC/SD/CO, ofício n. 635, p. 5. 
70 Desenvolvida em parceria com a Fundação Rockefeller, a prefeitura do Distrito Federal e a Cooperativa Nacional de Avicultura, a vacina contra a gripe foi testada num surto ocorrido no Rio de Janeiro em 1945, tendo sido fornecida aos serviços de saúde pública, ministérios da Guerra, da Aeronáutica e da Agricultura, Banco do Brasil, prefeitura do Distrito Federal e diversas instituições civis. Ver IOC (1945: 20); Ofício de Henrique Aragão a Clemente Mariani Bittencourt (encaminhando relatório de atividades no decurso de 1946), Rio de Janeiro, 29 de janeiro de 1947. FIOC/SD/CO, ofício n. 121. A tuberculose e a lepra eram objetos de grande preocupação e prioridade por parte dos serviços públicos de saúde brasileiros, tendo constado entre os principais temas da I Conferência Nacional de Saúde, em 1941 (Hochman \& Fonseca, 2000).

71 Ver Ofício de Henrique Aragão a João de Barros Barreto. Rio de Janeiro, 23 de janeiro de 1943. FIOC/SD/CO, ofício n.66.

72 Já em 1942, Aragão reivindicava aumento no número de funcionários e instalações destinadas a estas atividades de rotina. Nos anos seguintes, passou a manifestar descontentamento com o peso que tais serviços assumiam no IOC, comprometendo excessivamente o tempo dos técnicos das diversas divisões, "com certo prejuízo para suas pesquisas". Segundo ele, cabia ao DNS retirar tal atribuição de Manguinhos e criar um órgão especialmente dedicado a tais objetivos. Instituto Oswaldo Cruz (1945: 28).

73 Em 1943, para atender a fins militares, a penicilina já era produzida em grande escala pela indústria privada em convênio com o governo norte-americano. Contudo, a exportação do produto era proibida. Somente em 1945 sua venda foi liberada (Benchimol, 2001).

74 A cultura do Penicilum era feita na Divisão de Microbiologia e Imunologia e os trabalhos de extração, concentração, purificação e secagem da penicilina na Divisão de Química. Em 1942, o IOC produziu 2.500 ampolas do produto ainda em estado bruto. Dois anos depois, o fornecimento subiu para 67 mil ampolas de penicilina purificada injetável e 21 mil ampolas do produto em estado bruto. Em 1945, a produção iria dobrar em relação às quantidades fabricadas no ano anterior, atingindo cerca de 150 mil ampolas do produto injetável e 20 mil do produto bruto, quantidades que seriam mantidas no ano seguinte, quando o IOC receberia a visita de Flemming e Florey, para conhecer as instalações para preparo do produto. Ver: Ofício de Henrique Aragão a João de Barros Barreto, Rio de Janeiro, 23 de janeiro de 1943. FIOC/SD/CO, ofício n.66; Instituto Oswaldo Cruz (1945, 1946); Ofício de Henrique Aragão a Clemente Mariani Bittencourt, Rio de Janeiro, 29 de janeiro de 1947. FIOC/SD/CO, ofício 121, p. 10.

75 Ver: Ofício de Henrique Aragão a Clemente Mariani Bittencourt, Rio de Janeiro, 29 de janeiro de 1947. FIOC/SD/CO, ofício 121, p. 10. Apesar do sucesso na fabricação da penicilina e outros quimioterápicos, o IOC não teve condições de manter a produção no pós-guerra, em função do grande desenvolvimento então assumido pela indústria farmacêutica (Benchimol, 2001).

76 Ver: Ofício de Henrique Aragão a João de Barros Barreto. Rio de Janeiro, 23 de janeiro de 1943. FIOC/SD/CO, ofício n.66, p. 15.

7 Ofício de Henrique Aragão a João de Barros Barreto. Rio de Janeiro, 12 de maio de 1942, p. 3. FIOC/SD/CO, ofício n. 278, p. 3-4. Aragão encaminhou, anexo a este ofício, texto de exposição a ser encaminhado a Capanema a respeito dos principais 
problemas do IOC e suas considerações sobre como superá-los. Entre as principais obras e melhorias a serem feitas na instituição, citava a ampliação do Hospital Evandro Chagas, "para ampliação dos seus serviços e estudos de moléstias infectuosas" (Ofício n. 278, 7). Em setembro, Aragão solicitou ao MES uma 'verba de guerra' de 2 mil contos, que, em apenas um ano, segundo ele, seria compensada pelo fornecimento de "produtos destinados ao Departamento Nacional de saúde e às Forças Armadas do país". Ofício de Henrique Aragão a Raul Leitão da Cunha. Rio de Janeiro, 8 de setembro de 1942, FIOC/SD/CO, ofício n. 635, p. 4. Em termos de melhorias nas condições de trabalho, Aragão chegou a solicitar ao MES que fossem sanadas as dificuldades de transporte enfrentadas pelos técnicos mediante um ônibus especial que os levasse do centro da cidade a Manguinhos. Ofício de H. Aragão a Heitor de Farias, presidente da Comissão de Eficiência do Ministério da Educação e Saúde. Rio de Janeiro, 10 de setembro de 1942. FIOC/SD/CO, ofício n. 644.

78 Ofício de Henrique Aragão a João de Barros Barreto. Rio de Janeiro, 23 de janeiro de 1943. FIOC/SD/CO, ofício n.66, p. 2.

79 Ofício de Henrique Aragão a Gustavo Capanema. Rio de Janeiro, 12 de maio de 1942. FIOC/SD/CO, ofício n. 278, p. 1; grifos meus.

80 Criado em convênio com a Divisão de Organização Sanitária do MES, o posto seria transferido definitivamente para este serviço em 1946, embora a DEE continuasse a desenvolver trabalhos sobre a endemia (IOC, 1945). Ofício de Henrique Aragão para Clemente Mariani Bittencourt, Rio de Janeiro, 29 de janeiro de 1947. FIOC/ SD/CO, ofício n. 121, p. 20.

${ }_{81}$ Desde 1939, o pesquisador Álvaro Lobo Leite estudava a doença nesta cidade, onde montou, em 1940, com apoio da prefeitura, um pequeno serviço de prevenção entre a população escolar. Ver Lobo Leite (1943). Em 1945, seria feito um acordo com a Fundação Brasil Central (criada em 1943 pelo governo Vargas com o objetivo de promover a chamada 'marcha para o oeste') para que seus técnicos implementassem, sob a orientação do IOC, a aplicação em larga escala deste método profilático e terapêutico, já utilizado em outros países. Ver IOC (1946).

82 Ofício de Henrique Aragão a Clemente Mariani Bittencourt. Rio de Janeiro, 29 de janeiro de 1947. FIOC/SD/CO, ofício 121, p. 20.

83 Fonseca (2007: 29) afirma que a política pública de saúde no governo Vargas também constituiu um instrumento de construção da nacionalidade, sem o 'deslocamento' indicado por Castro-Santos. "A bandeira do saneamento foi incorporada e reelaborada no projeto político-ideológico do governo e, independente da existência ou não de mobilização social, ela atendeu ao governo federal em seu interesse de garantir presença no interior do país (...)".

${ }^{84}$ Sobre as modificações na dinâmica populacional brasileira a partir de 1930, ver Patarra (1995).

85 Segundo Vargas (1938: 31), os espaços despovoados do país "não atingiram o necessário clima renovador pela falta de densidade da população e pela ausência de toda uma série de medidas elementares, cuja execução figura no programa de Governo e nos propósitos da administração, destacando-se dentre elas o saneamento, a educação e os transportes. No dia em que dispuserem todos desses elementos, os espaços vazios se povoarão. Teremos densidade demográfica e desenvolvimento industrial". 
86 Para uma análise dos processos de modernização/desenvolvimento em Minas Gerais, sob várias perspectivas, ver Gomes (2005).

87 Conforme dados do Censo de 1940, os migrantes para a região Sul provinham sobretudo de Minas Gerais. Naquele ano, $12 \%$ da população mineira vivia fora do estado. A partir de então, esta tendência se aprofundaria, e, entre 1940 e 1970, Minas Gerais seria o único estado brasileiro a sofrer decréscimo, em números absolutos, da população rural (Patarra, 1995; Diniz, 2002). 


\section{Os Estudos sobre a Doença após Carlos Chagas (1935-1943)}

Por ocasião do encerramento dos debates sobre a tripanossomíase americana na Academia Nacional de Medicina (ANM), em 1923, Alfredo Nascimento Silva afirmou que, de modo a resolver as incertezas que pairavam sobre o tema, aquela era uma doença cujos casos deveriam ser sistematicamente procurados pelos clínicos, municiados com os elementos técnicos necessários para diagnosticá-los. O problema, contudo, era que, dentre os critérios clínicos estabelecidos por Chagas, alguns eram objeto de fortes críticas e outros permaneciam sob o impacto das dúvidas explicitadas na polêmica da Academia. Como num círculo vicioso, o escasso número de casos consensualmente reconhecidos como comprovados enfraquecia a convicção sobre os enunciados clínicos definidores da doença, mas, justamente para que esse número pudesse aumentar, era fundamental que se impusesse algum grau de confiança em torno de sinais clínicos passíveis de fazer os médicos suspeitarem de sua ocorrência e, pela localização do parasito ou pelo teste sorológico, completarem o diagnóstico.

O fio para desatar este nó seria puxado justamente no país de onde provieram os primeiros questionamentos à doença. Na década de 1930, foram estabelecidos, na Argentina, não apenas um novo sinal para o diagnóstico clínico da fase aguda, mas também novas estratégias para que 
este sinal fosse disseminado como 'pista' daquilo que se pretendia encontrar. O estudo da doença no país vizinho, inscrito num projeto institucional que chamava a atenção para a importância da patologia regional argentina, impulsionou fortemente aqueles que, no Brasil, apresentavam-se como os dois principais herdeiros, em vários sentidos, de Carlos Chagas em Manguinhos. Evandro Chagas, seu filho mais velho, e Emmanuel Dias, seu afilhado de batismo, ambos formados sob sua orientação nas pesquisas em Lassance, seriam os principais responsáveis por dar continuidade às investigações e por produzir as condições para um consenso em torno daquela entidade nosológica, de modo a superar as incertezas existentes sobre o assunto desde 1916, em especial depois do confronto na ANM.

\section{Novo Encontro com os Argentinos: um sinal clínico para os médicos do interior}

Em 1926, o médico argentino Salvador Mazza, professor de bacteriologia da Universidade de Buenos Aires, criou a Misión de Estudios de Patología Regional Argentina (Mepra), como órgão vinculado àquela universidade e com sede na cidade de Jujuy. O objetivo era desenvolver estudos sobre os problemas sanitários do interior do país, sobretudo das províncias do norte, tradicionalmente vistas como típicas do 'atraso' do interior argentino. Mazza considerava imprescindível ultrapassar os limites da capital e criar postos de pesquisa nas províncias, estabelecendo uma cooperação direta com os profissionais locais, sobretudo os médicos do interior, para quem os problemas da nosografia regional eram material de trabalho diário. Para isso, criou a Sociedad Argentina de Patología Regional del Norte (SAPRN) que, sediada em Jujuy e com filiais nas diversas províncias, promoveria o intercâmbio entre os colaboradores da Mepra (Sierra-Iglesias, 1990; Zabala, 2007). ${ }^{1}$

Como assinalou Sandra Caponi (2002), desde a criação do Instituto Bacteriológico do Departamento Nacional de Higiene, em 1916, impulsionou-se a preocupação dos médicos argentinos com o mapeamento e o estudo das doenças e problemas sanitários típicos do país, em contraposição a uma tendência, dominante até então, de privilegiar as doenças já descritas e estudadas na Europa, em especial as que se faziam 
mais presentes na região de Buenos Aires. A iniciativa de Mazza pode ser vista em consonância com este movimento. Se, no Brasil, o estudo das endemias rurais havia sido a tradução local da medicina tropical européia sob as condições e os sentidos específicos do contexto e da ciência nacional, o mesmo pode ser pensado em relação à idéia de "patologia regional', eixo do projeto médico-político de Mazza, em que a busca pelas doenças 'típicas' do país assumia uma dimensão diretamente associada a uma dada percepção da identidade nacional argentina. ${ }^{2}$ Nos dois países, tal diretriz expressou-se num movimento de ida ao interior, representado como 'âmago' da nação, em contraponto a um mundo urbano/ litorâneo 'mimetizador' da Europa. ${ }^{3}$ Em ambos os casos, ainda que com especificidades, a doença de Chagas assumiu protagonismo como emblema de uma ciência comprometida com o estudo da patologia rural/regional.

Na época de criação da Mepra, apesar de já ter ocorrido o primeiro registro da doença de Chagas na Argentina (Mülhens, 1924), ainda havia muitas incertezas sobre a existência da enfermidade no país. Em 1926, Mazza diagnosticou o quinto caso da doença. No início da década de 1930, os estudos clínicos e epidemiológicos intensificaram-se em várias regiões da Argentina e novos casos começaram a ser detectados pela Mepra (Mazza, 1949; Sierra-Iglesias, 1990; Zabala, 2007).

Em 1935, realizou-se, na cidade de Mendoza, a XIX Reunião da Sociedad de Patología Regional Argentina, em homenagem a Carlos Chagas, falecido no ano anterior. ${ }^{4} \mathrm{O}$ encontro tinha como objetivo divulgar, com especial ênfase, os progressos produzidos pela Mepra no estudo da doença de Chagas. Entre os presentes, estavam Evandro Chagas e Emmanuel Dias, convidados especiais. Na solenidade de inauguração, com a presença do governador, ministros e autoridades diversas, o presidente da Sociedade Médica de Mendoza deu as boas-vindas em nome dos médicos da região, orgulhosos de serem os anfitriões deste tipo de evento normalmente ocorrido nos grandes centros acadêmicos. Entre os elogios a Chagas, o orador declarou: "(...) con verdadera clarividencia, descubrió que lo que hasta entonces se titulaba bocio endémico, denominación que obedecía a uno de los síntomas que suelen presentar los que padecen de esa afección, era una enfermedad infecto contagiosa" (Gainza, 1935: 25). ${ }^{5}$

O médico de Mendoza utilizava para caracterizar o 'grande feito' do cientista brasileiro seu enunciado mais frágil, cerne das controvérsias que haviam surgido justamente na Argentina. Sua percepção evidenciava 
a 'encruzilhada' em que se encontrava a pesquisa sobre a doença naquele momento. Apesar de já ser reconhecido, sobretudo no Brasil, que a tripanossomíase americana e o bócio endêmico eram entidades distintas, para boa parte dos médicos que tinham ouvido falar do mal de Chagas sua expressão clínica mais concreta ainda era o 'papo'. Para Mazza, a Mepra tinha como objetivo primordial levar àqueles médicos do interior, que lidavam diariamente com as doenças regionais, os 'verdadeiros' conhecimentos sobre tais problemas, de modo que pudessem auxiliar nas pesquisas sobre os mesmos. Em seu discurso na ocasião, ele enfatizou que o elemento indispensável para o trabalho dos investigadores da Mepra era

(...) la colaboración del médico de la región, especialmente del rural, obtenida mediante un estímulo de su tarea diaria, siempre ardua, armándolo de los elementos de juicio para apreciar o sospechar la verdadera naturaleza de procesos encubiertos por apariencias de vulgares padecimientos que simulan entidades morbosas comunes. (Mazza, 1935: 31)

Se os cientistas pretendiam estudar as doenças do interior e demonstrar sua importância epidemiológica e social, era fundamental que dispusessem de casos destas doenças, de preferência muitos casos. No que concernia à tripanossomíase americana, estes constituiriam não apenas material indispensável ao avanço das pesquisas, mas as principais provas em favor da tese de que a doença, que muitos consideravam restrita aos rincões de Minas Gerais, atingia, como afirmara Chagas, vastas regiões do Brasil e de outros países do continente americano. Contudo, para que os médicos do interior pudessem efetuar o diagnóstico destes casos, precisavam dispor de elementos para distinguir, no emaranhado de sintomas e queixas dos doentes, indícios que os levassem a suspeitar que estavam diante de uma enfermidade específica. Ao examinarem os indivíduos que os procuravam cotidianamente, deveriam ver não simplesmente 'doentes', mas possíveis 'casos' de alguma doença. Era preciso destacar das ‘aparências', como dizia Mazza, a ‘verdadeira natureza' daqueles distúrbios. Cabia aos cientistas, portanto, ensinar os médicos a ‘verem' as pistas daquilo que eles próprios estavam procurando.

Mazza (1935: 31) apresentou, naquela reunião, resultados importantes desta empreitada: 35 casos agudos de infecção pelo Trypanosoma cruzi, identificados pela Mepra somente nos últimos meses que antecederam ao encontro. Em tom de comemoração, declarou, na sessão de abertura, que este número superava a cifra total dos casos demonstrados no 
país desde a descoberta de Chagas. ${ }^{7}$ À exceção de dois casos, todos os demais haviam sido identificados mediante 'fenômenos evidentes' e receberam o diagnóstico clínico antes da 'demonstração microscópica' (Mazza, 1935: 31). As questões que se colocavam, no entanto, eram: como garantir que 'fenômenos clínicos evidentes' para os especialistas também o fossem para os clínicos locais, muitos dos quais sequer tinham ouvido falar da doença de Chagas? Como orientar estes clínicos em relação aos critérios de diagnóstico que deveriam adotar? Quais sinais deveriam ser considerados 'pistas' de uma doença cujo quadro clínico era tão controverso?

Chegamos então ao acontecimento que tornaria a reunião de Mendoza um marco na história da doença de Chagas, a expressar já os resultados da propalada associação com os médicos do interior: a descrição, por Cecilio Romaña (1935), de um novo sinal clínico, de fácil e imediata identificação, indicativo da fase aguda da infecção chagásica. O jovem clínico da cidade de Resistência era um dos colaboradores de Mazza, que o enviara a Manguinhos, em 1934, para realizar estudos com o próprio Chagas. Tratava-se da 'conjuntivite esquizotripanósica unilateral', um inchaço das pálpebras superior e inferior do olho que, segundo Romaña (1935), indicava a 'porta de entrada' da infecção, ao constituir uma reação inflamatória à penetração do parasito na conjuntiva, mediante as fezes contaminadas do barbeiro. ${ }^{8} \mathrm{O}$ 'sinal de Romana' (Imagem 18) - denominação proposta na ocasião por Emmanuel Dias e Evandro Chagas - se tornaria fundamental para induzir, mediante a observação clínica, a suspeita diagnóstica de casos agudos da doença, cujas cifras aumentariam vertiginosamente a partir de então. ${ }^{9} \mathrm{Em}$ apenas três anos a partir da publicação do trabalho de Romaña, a Mepra chegaria a trezentos casos da doença na Argentina, sendo a maioria identificada mediante o "ojo en compota". ${ }^{10} \mathrm{O}$ entusiasmo foi sintetizado por Emmanuel Dias (1939: 969): "O sinal de Romaña, permitindo à distância e num relance a suspeita da moléstia de Chagas, tornou o diagnóstico de probabilidade uma simples questão de propaganda, que não tardará a dar os seus frutos onde quer que seja empreendida". ${ }^{11}$

Para François Delaporte (2003), a descrição do sinal de Romaña significou uma 'reorganização epistemológica' radical na definição da doença descrita por Chagas e uma ruptura com o sistema médico que até então a sustentava. O inchaço na face que, para Chagas, constituía o sinal de uma desordem tireoidiana (mixedema) foi visto por Romaña como 'porta de entrada' da infecção. Esta diferença na percepção do mesmo 
fenômeno físico foi resultante, para o autor, de esquemas conceituais totalmente diferentes. Chagas tinha por referência uma medicina experimental calcada, por um lado, na relação entre microbiologia e endocrinologia e, por outro, na protozoologia alemã de Schaudinn, que, entre outros 'equívocos', assinala Delaporte, o impediu de aceitar a tese do francês Emile Brumpt de que a transmissão do parasito se processava não pela picada do barbeiro, mas pela contaminação com as fezes através das mucosas, tese esta que foi fundamental para o raciocínio de Romaña. ${ }^{12}$ Já o médico argentino situava-se cognitiva e institucionalmente no terreno da medicina clínica, o que lhe permitiu um novo olhar sobre o quadro sintomatológico.

Delaporte (2003: 113) argumenta que, ao proceder a esta "reconversão" dos significados atribuídos ao sinal clínico mais evidente e específico da fase aguda da doença, Romaña teria estabelecido as condições para que "emergisse", pela primeira vez, o conceito de tripanossomíase americana (ou seja, uma parasitose de dimensão continental). O conceito médico de Chagas quanto à tireodite parasitária - pelo qual a doença era essencialmente uma afecção tireoidiana - teria representado "um obstáculo à elucidação da natureza da tripanossomíase americana" (Delaporte, 2003: 72). Assim, segundo o autor, 1935 não foi a data de uma "redescoberta", como muitos (sobretudo o próprio Mazza) proclamaram, mas "o momento no qual se diagnostica a tripanossomíase americana" (Delaporte, 2003: 101).

A interpretação de Delaporte incorre no anacronismo ao tomar a formulação de Romaña como base para o 'verdadeiro' conceito de tripanossomíase americana, resultante da depuração de 'obstáculos' e de 'desvios' antecedentes. É certo que houve, como cita o autor, um deslocamento expressivo na conceituação daquela entidade nosológica, decorrente, em sua perspectiva, da transformação nas 'condições de possibilidade' para a formulação dos enunciados. Contudo, do ponto de vista de uma história social da ciência, a contribuição de Romaña e a transformação que ele representou constituem o produto de um longo e coletivo processo, estabelecido não como 'depuração', mas mediante uma intricada composição de continuidades e descontinuidades entre enunciados legítimos sob as circunstâncias próprias que os geraram. Nesse sentido, Romaña não 'fundou' o conceito de tripanossomíase americana, pois o que havia antes, apesar das diferenças, já era a tripanossomíase americana 'tal qual foi concebida por Chagas', e enriquecida por vários 
outros investigadores que dedicaram-se a aspectos diversos da questão e, por meio de relevantes contribuições, deram ao problema a configuração que tinha à época em que Romana se debruçou sobre ele. ${ }^{13}$

Delaporte compreende a história da doença de Chagas como a história de um constructo epistemológico (das 'condições de possibilidade' para sua formulação), e indica, a partir de um certo arranjo assumido por este constructo, desvios e aproximações no percurso que o antecedeu. Ao meu ver, indissociável da dimensão cognitiva/experimental que gerou as distintas configurações conceituais desta entidade nosológica está a dimensão social e política pela qual ela foi produzida em contextos históricos particulares, num exemplo emblemático da natureza sociocognitiva dos fatos científicos. ${ }^{14} \mathrm{~A}$ despeito das mudanças conceituais que separam a doença descrita por Chagas e o enquadramento que a ela viria a ser conferido a partir da década de 1930, os significados que assumiu como doença-símbolo de uma dada visão da nação e da relação entre ciência, saúde pública e sociedade foi o fio que perpassou todo este processo de construção e que, inclusive, propiciou o projeto que Mazza concebeu para a Mepra. Romaña produziu conhecimentos que iriam reorientar o desenho desta enfermidade não por ter se 'desvencilhado' do legado de Chagas, mas por estar inserido nesta trajetória, ao integrar um projeto cuja diretriz era, justamente, superar as dúvidas e produzir evidências sobre a existência da doença. ${ }^{15}$

A descrição e, principalmente, a divulgação do sinal de Romaña impulsionada, sobretudo, pelos brasileiros - foram um evento cognitivo e social de grande impacto na trajetória da doença de Chagas, por propiciar uma espécie de 'conversão' do olhar entre os que buscavam a enfermidade. Se antes o principal traço que materializava, no organismo humano, a imagem da doença era o 'papo', a partir de então aquilo que usualmente seria classificado como uma conjuntivite, ou simplesmente um olho inchado, passaria a ser visto como a pista por excelência da 'doença do barbeiro'. Esta conversão dependia, entretanto, de que os cientistas fossem capazes de convencer os médicos e a própria população das regiões onde pudesse haver indícios da doença (como a presença de barbeiros ou de habitações passíveis de abrigá-los) não apenas a enxergar o novo sinal, mas a atribuir-lhe este novo significado. Esta foi a grande tarefa à qual se lançaram muitos pesquisadores em vários países, especialmente no Brasil. As palavras de um médico do interior do Rio Grande do Sul, que registrou em seu consultório um caso agudo de doença de Chagas, 
após ter lido, em trabalho de Emmanuel Dias, a respeito do significado do 'olho inchado', são emblemáticas da importância que este novo critério de diagnóstico teve na descrição de novos casos da enfermidade:

No caso em estudo, a constatação do sinal de Romaña orientou imediatamente o interrogatório, bem como o exame clínico e laboratorial, no sentido da verdadeira etiologia. É evidente que os demais sintomas (...) são típicos da tripanosomose americana e concordantes com a descrição fundamental de Chagas. Não obstante, na ausência do sinal de Romaña, seriam facilmente confundidos com os de tantas enfermidades comuns às zonas rurais porque, é óbvio, não se pode exigir de um clínico prático o tirocínio e a intuição de um especialista, mormente quando os próprios especialistas reconhecem o quanto a sintomatologia escassa de certos casos dificulta o diagnóstico. (Falcão, 1943: 181; grifos meus)

Outro aspecto importante do trabalho da Mepra foi impulsionar e dar maior visibilidade a uma linha de pesquisa clínica que, aberta pelo próprio Chagas e particularmente valorizada a partir de 1916, vinha se desenvolvendo no Brasil, sobretudo com os trabalhos de Evandro Chagas: os estudos sobre a forma cardíaca, que, como assinalado na revisão de Yorke (1937), eram considerados uma via promissora para a elucidação dos aspectos clínicos essenciais da doença. Em 1929, depois de observar no hospital do IOC as investigações de Evandro Chagas, o cardiologista argentino Rafael Bullrich divulgou em seu país os principais conhecimentos sobre esta forma clínica. Em 1934, Romaña descreveu os primeiros casos de forma cardíaca fora do Brasil. Ao estudar as alterações cardíacas, sobretudo da fase aguda, o grupo de Mazza apresentou alguns trabalhos sobre o assunto na reunião de 1935, ano em que foi assinalado o primeiro caso desta forma clínica na Venezuela. ${ }^{16}$

Os argentinos aderiam, assim, não apenas a uma linha de investigação, mas ao grande desafio posto desde os estudos de Carlos Chagas, que vinha motivando seu filho e que seria um dos principais objetivos de pesquisa do posto do IOC em Bambuí, ao longo da década de 1940. Como transformar determinadas alterações cardíacas atribuídas à ação do T. cruzi - já enunciadas por Chagas - em critérios indiscutíveis para o diagnóstico clínico da tripanossomíase? Em outras palavras: como garantir que estas alterações, detectadas eletrocardiograficamente, fossem reconhecidas consensualmente como 'provas' da ação patogênica do T. cruzi e não sinais de outros tipos de cardiopatias? 
Se os pesquisadores haviam descrito os traços específicos que transformavam o que poderia ser visto como simples conjuntivite numa 'conjuntivite causada pela doença de Chagas', no caso da forma cardíaca o desafio era equivalente e mais complexo: como enxergar, em certos traçados do eletrocardiograma (ECG), sinais de uma entidade clínica particular? A detecção de alterações eletrocardiográficas não era suficiente: era preciso que os cientistas produzissem um acordo sobre como 'ler' tais alterações, em termos de suas características, de sua freqüência e das possibilidades de combinação entre elas. Era necessário estabelecer um 'padrão', para definir o que seria um 'caso típico' de cardiopatia chagásica. E, o mais importante, era preciso ensinar e convencer os médicos a reconhecê-lo e a aceitá-lo como tal. ${ }^{17}$

O trabalho da Mepra, ao divulgar os conhecimentos básicos sobre a forma cardíaca da doença e as técnicas para seu estudo e diagnóstico (e ao mesmo tempo aprofundar o estudo da questão nos novos casos que identificava), contribuía para ampliar os conhecimentos e o interesse sobre o assunto, atraindo novos pesquisadores e, conseqüentemente, aumentando as possibilidades de que este caminho de pesquisa levasse aos objetivos desejados.

Em síntese, a contribuição dos argentinos constitui um marco importante para a construção e a certificação da doença de Chagas não apenas por ter produzido novos conhecimentos sobre suas características clínicas, gerando uma 'reviravolta' na epidemiologia da doença, pelo grande número de casos diagnosticados a partir de então. Outro aspecto fundamental foi ter proporcionado novos instrumentos de persuasão e de propaganda em torno da necessidade de se estudar aquele problema e fortalecido as vias de pesquisa consideradas mais promissoras para fazê-lo. ${ }^{18}$

Além disso, a Mepra foi um passo importante para conferir à pesquisa sobre o assunto uma nova diretriz, do ponto de vista de seus marcos disciplinares, da natureza socioinstitucional do projeto pelo qual tais estudos seriam desenvolvidos e do perfil dos atores que o viabilizariam. Se os trabalhos feitos por Chagas e por seus colaboradores em Manguinhos estavam essencialmente referidos ao campo da medicina tropical, em especial da parasitologia, a partir de então a investigação sobre a doença iria adquirir uma natureza essencialmente médica. Os principais problemas a serem enfrentados pelos pesquisadores, bem como as estratégias e os caminhos para equacioná-los, estariam situados, em larga medida, no domínio da pesquisa clínica. Em suma: como Alfredo Nascimento Silva e 
o próprio Chagas reconheceram, para alargar os interesses sobre a doença e para institucionalizar este campo de pesquisa, era preciso tornar o assunto, antes de tudo, 'um problema para os médicos'. Esta nova diretriz encontraria, no Brasil, um espaço privilegiado para sua implementação no Serviço de Estudo das Grandes Endemias (Sege), criado por Evandro Chagas logo após a reunião de Mendoza e em muito inspirado no que ele observou entre seus colegas argentinos.

O encontro de Mendoza, realizado numa temporalidade e num espaço simbolicamente eloqüentes - o primeiro aniversário de falecimento de Carlos Chagas e no país onde tiveram início os questionamentos sobre seus trabalhos -, expressou publicamente as fronteiras que demarcavam o que se conhecia, o que não se conhecia e, principalmente, o que se pretendia vir a conhecer sobre a doença de Chagas. Nesse sentido, ele nos revela os traços e os contornos, alguns já apagados, outros mais nítidos, de um objeto que estava sendo 'desenhado'. Mais importante do que o novo traço introduzido neste quadro - que se materializava na imagem de uma criança com o olho inchado - foi o encontro entre os vários personagens e os caminhos que, entrecruzando-se naquele momento, determinavam o itinerário que ia sendo trilhado neste processo de enquadramento. Estavam ali presentes os 'herdeiros' de Carlos Chagas (entre os quais os que introduziam modificações substantivas na 'tradição' por ele iniciada) e os principais aliados que estes cientistas recrutariam nesta empreitada, os médicos do interior. Evandro Chagas e Emmanuel Dias trouxeram da Argentina não apenas um sinal clínico para a busca da doença de Chagas, mas o exemplo de um projeto e uma estratégia a partir da qual empreendê-lo. Se, na década de 1910, os cientistas foram até os sertões e de lá voltaram para revelar ao litoral um país marcado pelo abandono e pelas doenças, e para pressionar o Estado em prol da criação de estruturas concretas para combater tal situação, os discípulos desta tradição, nas circunstâncias particulares da nova conjuntura nacional e internacional do pós-1930, incorporariam ao seu projeto os atores e os espaços locais deste interior. Eles seriam aliados importantes não apenas para os desafios a serem enfrentados no laboratório, mas para o desafio da política, de se reivindicar perante este novo Estado, empenhado na implementação de novas estruturas sanitárias, que estas fossem utilizadas no combate à doença descoberta por um dos principais 'apóstolos' do saneamento dos sertões. 


\section{O Sege e as Pesquisas sobre a Tripanossomíase Americana}

Desde as primeiras viagens que realizou para estudar a leishmaniose no Norte e no Nordeste do país, Evandro Chagas se preocupava em investigar, nas localidades que percorria, os barbeiros e as características biológicas das diferentes cepas de T. cruzi, além de buscar indícios clínicos de possíveis casos humanos da tripanossomíase americana. Em 1939, decidiu pôr em marcha um plano sistemático de investigação sobre a doença no estado de Minas Gerais. Implementado mediante cooperação com o Instituto Biológico Ezequiel Dias (Ibed), o plano seria conduzido por Amilcar Vianna Martins, pesquisador deste instituto e professor de parasitologia da Faculdade de Medicina de Belo Horizonte, além de dois assistentes por ele designados - Valdemar Versiani e Antonio Tupinambá -, com os quais vinha realizando estudos, desde 1937, sobre os vetores da doença no Estado. ${ }^{19}$ A expectativa de Evandro Chagas era a de que, ampliado para outras regiões, este empreendimento deveria "dentro de prazo relativamente curto, fornecer noção exata da distribuição geográfica da tripanossomíase americana no Brasil e idéia precisa do verdadeiro significado médico-social desta moléstia no país". ${ }^{20}$

Associando trabalhos de campo e de laboratório, o plano compreendia as seguintes atividades: levantamento das diferentes espécies de 'barbeiros' e de seu índice de infecção pelo T. cruzi, visando a mapear a distribuição dos vetores e a estudar a capacidade de transmissão de cada espécie; realização de exames laboratoriais e clínicos para diagnosticar casos da doença; e isolamento de diferentes cepas de parasitos, de modo a estabelecer variações em seu poder patogênico. No que diz respeito aos aspectos clínicos, é interessante observar que, além da forma cardíaca, o plano previa a busca de sinais relacionados também à forma nervosa e inclusive ao bócio. Das fichas para registro dos dados da pesquisa, constavam questões relativas aos sintomas destas três formas, ainda que com maior detalhamento no caso dos sintomas cardíacos. ${ }^{21}$

Em julho de 1940, Martins e seus colaboradores publicaram os primeiros resultados das investigações. A busca da doença era feita especialmente com base na identificação do vetor infectado e da presença de sinais clínicos, especialmente cardíacos. Ao analisar dados procedentes de 118 municípios, suas conclusões foram as de que "os barbeiros parecem existir em todo o território do Estado com exceção de pequenas 
áreas (...)" (Martins, Versiani \& Tupinambá, 1940: 290), e que, no caso das espécies mais freqüentes, era alta a percentagem de presença do parasito causador da doença, o que indicava que a ocorrência de casos humanos era bastante provável em grande parte do território. Na pequena localidade de Alagoas de D. Inácia, município de Jaboticatubas - uma região que, segundo os autores, tinha "o aspecto típico do "sertão" (Martins, Versiani \& Tupinambá, 1940: 299) -, os cientistas examinaram todos os moradores. Constataram que: "os exames clínicos feitos até agora mostram (...) uma percentagem anormalmente alta de perturbações do ritmo cardíaco” (Martins, Versiani \& Tupinambá, 1940: 300). Decidiram, então, realizar eletrocardiogramas no maior número possível de moradores da região. Segundo Evandro Chagas, este trabalho constituía "o primeiro passo no sentido do estudo racional da epidemiologia da doença de Chagas no Brasil”. ${ }^{22}$

Alguns meses depois, os pesquisadores do Ibed viriam a encontrar dois casos agudos, os primeiros registrados em Minas Gerais depois dos estudos de Chagas publicados em 1916 (Martins \& Tupinambá, 1940). Ao comentarem a dificuldade de diagnosticar a doença num estado em que sua presença sempre havia sido estimada como extremamente alta, os autores reforçaram a importância da nova orientação que, desde as contribuições de Mazza e Romaña, vinha permitindo superar tal dificuldade: a preocupação de que a doença deixasse de ser um tema para especialistas e passasse a atrair o interesse também dos médicos, sobretudo os do interior, de modo a que estes colaborassem no mapeamento da sua ocorrência. Numa alusão à polêmica na ANM, apesar de mencionarem a "campanha de desmoralização" movida contra Chagas por seus "inimigos pessoais" como um dos elementos que teria dificultado o interesse e, conseqüentemente, o diagnóstico da doença neste período, Martins e Tupinambá (1940: 839) afirmaram que “(...) a principal causa desse desconhecimento consistia na ausência de sistematização de sinais clínicos que permitissem o diagnóstico da moléstia, quer nas formas agudas, quer nas formas crônicas, pelos clínicos do interior, tornando esse diagnóstico apanágio de laboratoristas".

Um aspecto decisivo da atuação do Sege foi justamente o empenho em divulgar amplamente os procedimentos de identificação da doença (sobretudo os métodos de diagnóstico clínico mais simples, como o sinal de Romaña) junto à comunidade médica brasileira, em especial nas regiões rurais. Além dos clínicos e dos profissionais da saúde, outros grupos 
sociais seriam alvo desta mobilização empreendida pelos cientistas, que muitas vezes visava a proporcionar material para a própria pesquisa que eles realizavam. Em seu estudo sobre a distribuição geográfica dos vetores em Minas Gerais, Martins e seus colaboradores enviaram circulares para "médicos, organizações sanitárias, professores, prefeitos municipais e fazendeiros do interior", solicitando que lhes remetessem barbeiros para exame (Martins, Versiani \& Tupinambá, 1940: 287). Como relatam os autores, a resposta em geral foi muito favorável e, no caso das escolas primárias, estas se revelaram uma "uma ótima fonte de abastecimento de barbeiros” (Martins, Versiani \& Tupinambá, 1940: 287). A exemplo do que faziam seus colegas argentinos, os cientistas brasileiros, interessados em produzir o reconhecimento científico e social da doença de Chagas, foram 'ao campo' não apenas com objetivos de pesquisa, mas para mobilizar a sociedade, ampliando a associação de interesses em torno do tema. Esta orientação determinaria decisivamente os rumos da pesquisa, intensificada a partir da década de 1940 com a criação do Centro de Estudos e Profilaxia da Moléstia de Chagas (CEPMC), em Bambuí.

O maior exemplo das conseqüências da divulgação do sinal de Romaña entre os médicos do interior foi justamente a descoberta de um foco da doença nesta cidade, no oeste de Minas, onde o IOC instalaria este posto. Em 1940, Antonio Torres Sobrinho, clínico daquela região, foi consultar-se em Belo Horizonte com Amilcar Martins, que lhe falou a respeito do 'sinal do olho' e da importância de buscar casos agudos da doença no estado. Martins disse ao médico que, em função das pesquisas que o Ibed vinha realizando, já havia sido examinado um barbeiro proveniente de Bambuí, estando o inseto infectado pelo T. cruzi. Sobrinho retornou à sua cidade disposto a procurar a doença. Em outubro daquele ano, esteve em seu consultório uma menina com as características clínicas da fase aguda, entre elas o inchaço no olho, conforme Martins havia informado. Remetidos os dados a Belo Horizonte, a resposta não tardou: era o primeiro caso confirmado da doença em Bambuí (Imagem 18). Sobre aqueles dias, relembra Sobrinho:

O movimento de casos que se seguiu foi tão grande que, de 9 de outubro de 1940 a 21 de março de 1941, apenas em seis meses e meio, só pelas minhas mãos passaram dezesseis casos agudos, fora os que foram observados pelos colegas do Hospital. E quase todos foram remetidos para o devido estudo aos Institutos Oswaldo Cruz no Rio e Ezequiel Dias em Belo Horizonte. ${ }^{23}$ 
Em dezembro de 1941, este número subiria para 25, dando origem a um importante artigo de Martins, Versiani e Tupinambá (19391940), com a descrição minuciosa de cada caso. ${ }^{24}$ Este trabalho é particularmente revelador do processo de construção, por parte dos cientistas, de uma narrativa pela qual se colocava o trabalho do Sege, em continuidade com o impulso dado pelos argentinos, como marco de retomada do interesse pela doença e, sobretudo, da demonstração de que Chagas estava certo ao afirmar a extensa distribuição geográfica da tripanossomíase americana. A volta aos sertões mineiros tinha, assim, o intuito de responder aos que haviam duvidado da doença e questionado seu descobridor. Ou seja, a perspectiva de dar prosseguimento à agenda de pesquisa de Chagas revestia-se, também, do sentido de promover a "integral confirmação da sua obra, nas suas partes básicas e essenciais" (Martins, Versiani \& Tupinambá, 1939-1940: 10). Para os pesquisadores, o caminho que garantiria tais objetivos, firmados pelo acordo entre o Ibed e o Sege, era a produção de mais informações e consenso, entre os médicos, em torno dos critérios de diagnóstico, especialmente do diagnóstico clínico.

Já começa a moléstia a chamar novamente a atenção dos poderes públicos e a entrar na cogitação dos clínicos, principalmente os do interior. Consideramos urgente mostrar a verdadeira importância da moléstia de Chagas, provar objetivamente, por meio de observações numerosas, de que não se trata de moléstia rara, curiosidade nosológica, que ataca esporadicamente sertanejos de baixo nível econômico. Para isso não basta fazer cálculos teóricos sobre o número de cafuas existentes no Brasil e sobre a percentagem de seus habitantes que devem estar infectados. É preciso demonstrar a existência do inseto transmissor na maior parte do território nacional; verificar a percentagem de indivíduos doentes, com a forma crônica, em diferentes regiões; esclarecer os clínicos, a fim de que sejam diagnosticados e devidamente registrados os casos agudos, no maior número possível. É necessário divulgar amplamente que o diagnóstico da moléstia, pelo menos em sua fase aguda, não é apanágio de laboratoristas (...). É esse o programa que em Minas Gerais vem sendo executado, em cooperação e o apoio do governo estadual, pelo Serviço de Estudo das Grandes Endemias do Instituto Oswaldo Cruz. Os resultados obtidos têm sido absolutamente animadores. Na zona mais trabalhada - o município de Bambuí - já o diagnóstico clínico e mesmo a sua confirmação pelas provas de laboratório, é feito com a maior segurança pelos médicos locais. (Martins, Versiani \& Tupinambá, 19391940: 7-8; grifos meus) 
Desde o início das pesquisas, Evandro Chagas veiculava, também pela imprensa, a disposição do Sege de demonstrar a tese de seu pai de que aquela era uma doença de vasta dimensão no continente americano. Apesar de serem ainda poucos e concentrados em Minas Gerais os novos casos que estavam sendo identificados, ele afirmava já haver indícios concretos de que poderiam ser muito mais numerosos, desde que devidamente procurados. Em entrevista a um jornal, declarou que estava sendo "verificado que a doença existe em muitas regiões do país onde não havia ainda sido assinalada, podendo ocorrer na maior parte do território nacional". ${ }^{25}$

A partir da descoberta do foco de Bambuí, intensificou-se a preocupação dos pesquisadores vinculados ao Sege em divulgar o sinal de Romaña entre os clínicos do interior. Eles lançariam mão da publicação, nas principais revistas médicas, de artigos explicitamente orientados para este fim. Emmanuel Dias, que estudava aspectos da transmissão da doença, foi o principal responsável por estes textos. Já tendo publicado, antes mesmo de colaborar com o Sege, um trabalho salientando a importância do novo elemento de diagnóstico descrito por Romaña (Dias, 1939), ele escreveu, em co-autoria com Evandro Chagas, um artigo sobre o tema. Ao se referirem ao encontro dos casos agudos em Bambuí por um médico local, graças ao 'sinal do olho', eles enfatizaram que a campanha do Sege já começava a “dar seus frutos” (Chagas \& Dias, 1941: 189).

Mais do que uma continuidade 'natural' dos estudos iniciados em Lassance, o Sege estabeleceu as bases que viabilizaram esta continuidade, cujo sentido maior era comprovar a importância médico-social que Chagas atribuía à doença por ele descoberta. As condições institucionais peculiares oferecidas pelo Sege - condições financeiras, de pessoal e de infra-estrutura - foram determinantes não apenas para garantir a execução de um plano de estudo sistemático sobre a doença, mas para o próprio rumo assumido pelas pesquisas no âmbito deste plano. Em carta a Evandro Chagas, Martins afirmou, por exemplo, que, sem os recursos do Sege, o Ibed não teria condições de custear os trabalhos de campo necessários para uma linha de investigação mais aprofundada sobre a doença no estado. ${ }^{26}$

Foi graças a estas condições que os pesquisadores e os médicos envolvidos com o Sege puderam realizar exames eletrocardiográficos nos habitantes de diversas localidades em Minas Gerais e, assim, impulsionar os estudos sobre a forma cardíaca da doença. Uma carta enviada a Evandro 
Chagas por Aristóteles Brasil, "especialista em corações e vasos" 27 de Belo Horizonte e que fora convidado por Martins para participar das excursões destinadas a mapear a doença no estado, é bastante ilustrativa. O médico relatava os vários problemas enfrentados no uso do eletrocardiógrafo que havia sido levado a Alagoas de D. Inácia, onde os pesquisadores estudavam alguns casos com alterações cardíacas. Tratavase de um aparelho, segundo ele, com muitas restrições de natureza técnica, como largura de fita (papel onde se imprimem os traçados) inapropriada e suscetibilidade a interferências, quando utilizado próximo a correntes elétricas ou outros aparelhos. Além disso, era muito pesado, aspecto particularmente problemático quando se tinha que percorrer grandes distâncias a pé. Ou seja: não era qualquer equipamento utilizado pelos médicos nas cidades que poderia ser usado nos sertões mineiros. Afirmando conhecer todos os modelos disponíveis no mercado, Aristóteles Brasil solicitou que o Sege comprasse um determinado equipamento que era o único "de molde a poder satisfazer ao que se pede de um tal aparelho, para trabalho tão especial". Ele se dizia disposto a realizar exames eletrocardiográficos duas vezes ao ano nos doentes selecionados para estudo, de modo a acompanhar as alterações cardíacas por um período longo de tempo e assim identificar certos padrões em sua ocorrência. Reiterava: "um aparelho próprio, um eletrocardiógrafo adequado, é indispensável a esse serviço". ${ }^{28}$

A solicitação de Brasil foi corroborada por Martins, que, também em carta a Evandro Chagas, encaminhou orçamento para a compra de dois eletrocardiógrafos. Em anexo, enviou folheto de propaganda em que um dos aspectos mais enfatizados quanto ao caráter moderno e avançado do aparelho era o fato de ser portátil, de simples manuseio, a ponto de ser operado por "pessoas que não tenham nenhum conhecimento prévio de eletrocardiografia” (Imagem 19). Garantia a propaganda que, a partir de então, os exames de coração não ficariam mais confinados ao hospital ou ao consultório médico. ${ }^{29}$

As cartas de Brasil e de Martins são bastante ilustrativas de como a produção do conhecimento científico se dá e se viabiliza sob certas circunstâncias institucionais específicas. O projeto do Sege, não apenas por colocar a doença como objeto de pesquisa, mas, sobretudo, por garantir condições concretas para isso, foi o que sustentou - em todos os sentidos - a idéia de se prosseguir, de maneira sistemática, no estudo da forma cardíaca da doença, mediante os instrumentos e as metodologias 
especializadas necessários para tanto. ${ }^{30}$ Além de propiciar condições para a produção de novos conhecimentos científicos sobre a tripanossomíase, a experiência do Sege foi importante por recolocar o tema das endemias como questão associada a um projeto nacional. Reiterando, em seus discursos, a importância das doenças endêmicas rurais como obstáculo ao desenvolvimento, Evandro Chagas associava-se explicitamente aos ideais sanitaristas do pai, num contexto histórico que conferia ao seu projeto novos significados e nova dimensão.

Depois do falecimento do irmão, em novembro de 1940, Carlos Chagas Filho deu prosseguimento, como novo superintendente do Sege, aos estudos realizados em Minas Gerais, especialmente na região de Bambuí. A pesquisa também foi continuada em outros estados em que o Sege vinha realizando atividades, como no Pará e no Ceará. Nos laboratórios do Rio de Janeiro, Emmanuel Dias e Cecilio Romaña prosseguiram suas investigações sobre as diferentes cepas de T. cruzi e seus níveis de infectabilidade. ${ }^{31}$ Em 1941, estudos sobre a doença feitos sob a orientação técnica do Sege passaram a ser realizados e/ou intensificados em localidades de outros estados, como São Paulo, Goiás, Rio Grande do Sul, Pernambuco e Bahia. ${ }^{32}$

A mobilização em torno do assunto já começava a despertar algum interesse entre as autoridades sanitárias estaduais e federais. Em agosto de 1941, a partir de solicitação do secretário de Saúde de Minas Gerais, foi promovido, em Belo Horizonte, um curso de extensão universitária sobre a doença, mediante convênio entre a Universidade do Brasil e a universidade daquele estado, e que envolveu também o IOC e o Instituto Biológico de São Paulo. ${ }^{33}$ Em outubro, o Sege providenciou, atendendo ao Departamento Nacional de Saúde (DNS), o envio de dois técnicos, Álvaro Pinho Simões e Antonio Tupinambá, ao Rio Grande do Sul, onde, mediante estudos epidemiológicos realizados por César Pinto, pesquisador do IOC, com a colaboração do Laboratório de Parasitologia do Departamento Estadual de Saúde e de médicos locais, haviam sido identificados casos agudos. O objetivo do Ministério da Educação e Saúde (MES) era fazer um levantamento semelhante ao que estava sendo realizado em Minas. Igualmente em Goiás, onde também haviam sido registrados casos da doença, o DNS solicitou uma inspeção. ${ }^{34}$

Ao mesmo tempo que dava prosseguimento às linhas de trabalho de seu irmão, Carlos Chagas Filho começou a imprimir sua marca pessoal na agenda de pesquisa, estimulando estudos de natureza básica sobre o 
tema. Por iniciativa sua, foi estabelecida uma cooperação do Sege com o Instituto de Biofísica da Universidade do Brasil, por ele dirigido, para estudar, entre outras questões, novos métodos de cultivo do T. cruzi. ${ }^{35}$

\section{Um Front para a Luta: a criação do Centro de Estudos e Profilaxia da Moléstia de Chagas (CEPMC) em Bambuí}

O início da gestão de Henrique Aragão no IOC e sua intenção de tornar o estudo das endemias uma prioridade da instituição conduziram, sob as condições favoráveis das novas estruturas sanitárias do MES e da guerra, à institucionalização das atividades em Bambuí num posto permanente para as investigações sobre a doença de Chagas.

Aragão vinha concedendo especial importância aos estudos sobre a doença de Chagas desde o período em que assumiu interinamente a direção do IOC, em janeiro de 1942. Além de constituir um tema de grande força simbólica como emblema das 'glórias de Manguinhos', este se tornou um campo promissor diante das tendências internacionais, em que a confiança no desenvolvimento de inseticidas irradiava-se dos laboratórios empenhados em produzir novas armas contra as doenças nos campos de batalha na Europa e na África.

Em junho daquele ano, Aragão decidiu impulsionar o levantamento da presença de barbeiros em vários estados do país, solicitando ao então diretor do Serviço Nacional da Peste, Mário Pinotti, que enviasse a Manguinhos insetos vivos ou mortos coletados por técnicos daquele serviço. De todo modo, a ênfase continuou sendo sobre os estudos em Minas Gerais, e Aragão empenhou-se em dar continuidade à cooperação com o Ibed - que, em 1941, assumiu a designação de Instituto Químico e Biológico de Minas Gerais (IQBMG) -, para intensificar as pesquisas especialmente na região de Bambuí. ${ }^{36}$ A decisão de fundar um posto especial para o estudo e a profilaxia da tripanossomíase americana nesta cidade foi tomada por Aragão quando formulou, já como diretor efetivo do IOC, o programa para a Divisão de Estudo de Endemias (DEE), criada pelo novo regimento aprovado em agosto de 1942. Como medida preparatória, foram realizados, sob o comando de Emmanuel Dias (que vinha se destacando nos estudos sobre a enfermidade no IOC), os primeiros 
testes com produtos químicos contra os vetores naquela região do oeste mineiro. Suas declarações a Amilcar Vianna Martins explicitavam a nova perspectiva para os trabalhos sobre a doença:

Daqui por diante, devemos ter sempre em mente o estudo de medidas contra os triatomíneos, pois já é mais que tempo de tentar-se a execução de medidas de profilaxia da doença. Parece que com a implantação do Posto em Bambuí, teremos condições muito favoráveis para os primeiros ensaios. Por sugestão do Dr. Soper poderemos experimentar desde logo a realização de aspersões de inseticidas por meio do aparelho portátil De Vilbiss. Um que me foi cedido por ele vai se mandado para aí; as instruções para o seu uso vão em anexo a esta (...). O essencial por ora é procurarmos estabelecer as medidas práticas, cuja adoção possamos recomendar como úteis. Esta parte deve tomar lugar destacado em nosso programa de trabalho e as experiências devem ser multiplicadas com o fim de chegarmos o mais rapidamente possível a uma conclusão. ${ }^{37}$

A referência a Soper é bastante significativa de como o projeto do CEPMC nascia sob a influência direta da abordagem centrada no controle dos vetores (Packard \& Gadelha, 1994), que ia cada vez mais se consolidando no cenário internacional e tinha em Soper seu principal entusiasta.

Na ocasião, a doença começava a chamar alguma atenção nos fóruns da saúde pública internacional, como as Conferências Sanitárias PanAmericanas. Em sua 11 $1 \underline{a}$ reunião, realizada no Rio de Janeiro em setembro de 1942, foram apresentados trabalhos sobre a ocorrência da enfermidade no México, Uruguai, Chile e Paraguai. Assumiram a relatoria do tema Carlos Chagas Filho, que destacou as contribuições do Sege, e Samuel Pessoa, catedrático de parasitologia da Faculdade de Medicina da Universidade de São Paulo e liderança na conscientização política em torno das endemias rurais naquele estado. ${ }^{38}$ Apesar de terem sido apresentados poucos trabalhos sobre o tema, a conferência aprovou uma resolução recomendando a "realização de estudos relativos à doença de Chagas sob o duplo ponto de vista médico e social” (RSPA, 1942: 1.081).

Ao longo de 1943, Aragão conduziu negociações com o IQBMG para estreitar a colaboração que as duas instituições mantinham desde a época do Sege e para direcioná-la para o projeto do posto. ${ }^{39} \mathrm{O}$ diretor do IOC manifestava seu otimismo quanto à perspectiva de desenvolver, pela primeira vez, métodos concretos de combate à doença: "Se tudo correr bem, como espero, julgo possível que se consigam desses trabalhos não 
só resultados teóricos de grande importância como práticos, na erradicação do mal pela destruição sistemática dos transmissores".${ }^{40}$ As investidas para a criação do CEPMC envolveram, além dos diretores do IQBMG e do Departamento Estadual de Saúde, o secretário de Agricultura de Minas Gerais, o que indica que a busca de apoio se dava em esferas relacionadas não apenas à saúde pública, mas aos interesses econômicos do estado. ${ }^{41} \mathrm{~A}$ idéia inicial era a de que os trabalhos fossem conduzidos, no IQBMG, por Amilcar Vianna Martins e Valdemar Versiani, e, no IOC, por técnicos da DEE, entre os quais Dias. A incorporação de Martins à Força Expedicionária Brasileira, contudo, afastou-o do projeto. ${ }^{42}$ Dias, que na ocasião era chefe da Seção de Inquéritos e Trabalhos de Campo da DEE, assumiu a direção do posto em novembro de $1943 .{ }^{43}$

As atividades do CEPMC tiveram início em 2 de dezembro, Dia Pan-Americano da Saúde, e foram divulgadas como a primeira iniciativa para enfrentar, de maneira sistemática, o problema da profilaxia da tripanossomíase americana. Ao comentar os eventos relacionados àquela data em seu boletim de maio de 1944, a Repartição Sanitária Pan-Americana registrou que o IOC dava início ao primeiro ensaio experimental de campanha contra a doença de Chagas. Nas primeiras semanas, os trabalhos transcorreram em laboratório cedido pelo diretor do Hospital Nossa Senhora do Brasil, Antonio Torres, que logo se tornou colaborador do projeto. Logo depois, ao final de dezembro, passaram a uma casa alugada na rua dos Expedicionários, onde o posto funcionaria por sete anos. ${ }^{44}$ A primeira providência foi montar o 'teatro de operações', ou seja, proceder ao estudo detalhado das características do foco, inclusive com o recenseamento das habitações e dos habitantes na área delimitada para os trabalhos, conforme modelo estabelecido pelo Serviço Nacional de Febre Amarela (SNFA). ${ }^{45}$

Situada no oeste de Minas, a cerca de 250 quilômetros de Belo Horizonte, a cidade de Bambuí era sede do município de mesmo nome, criado em 1881. Tinha, na ocasião, por volta de $3.000 \mathrm{~km}^{2} \mathrm{e}$ uma população de 26.913 habitantes. Servida pela Rede Mineira de Viação, possuía iluminação elétrica e a rede de esgoto estava em construção. As casas ainda não haviam sido numeradas pela prefeitura. A zona a ser trabalhada pelo CEPMC foi delimitada numa área de $4 \mathrm{~km}^{2}$, que incluía a cidade propriamente dita e os bairros periféricos. Seguindo o critério do SNFA, que classificava as habitações em mocambo (ou cafua), térreo e sobrado, o levantamento apurou 432 térreos e duas cafuas na cidade e 98 
térreos e 195 cafuas nos bairros periféricos (Dias, 1945). ${ }^{46}$ Para cada morador, foram registradas, em fichas domiciliares, informações como: nome, idade, cor e parentesco com o dono da casa, características da habitação, presença de animais domésticos (possíveis reservatórios do T. cruzi) e relatos sobre existência de barbeiros na casa ou na região. O levantamento indicou um total de 2.956 moradores na área delimitada para a atuação do posto (Dias, 1945).

Deu-se início, prontamente, ao levantamento da incidência dos insetos transmissores na região, mediante um disciplinado esquema de captura (realizado por guardas contratados ou pelos próprios moradores) e de exames, para verificar o índice de contaminação pelo parasito. Estes dados eram cuidadosamente registrados em fichas. Os barbeiros capturados serviam, por sua vez, para criação (com vistas à realização do xenodiagnóstico) ou para as diversas experiências de laboratório, sobretudo os testes de inseticidas e outros métodos de profilaxia. Conforme dados de 31 de maio de 1944, verificou-se que a espécie predominante era o Triatoma infestans e que $2 / 3$ das habitações dos bairros periféricos estavam infestadas por barbeiros (na parte urbana da cidade, esta proporção era de $20 \%$ ), sendo que $70 \%$ deles estavam parasitados pelo $T$. cruzi. Em suma: "das 727 habitações de toda a zona trabalhada em Bambuí, o Centro já comprovou a existência de triatomas em 282, o que dá a elevada percentagem de 38,79\%" (Dias, 1945: 24). Apesar de não se ter examinado na ocasião todos os barbeiros capturados, chegava-se a uma percentagem de $32 \%$ dos insetos infectados com o T. cruzi. Além das capturas, o posto realizava exames em reservatórios silvestres do parasito (como gambás e tatus), com a ajuda dos próprios moradores, que se incumbiam de procurar barbeiros em tocas, ninhos e quaisquer abrigos de animais (Dias, 1945).

Uma das características essenciais da direção que Dias imprimiu, desde o início, aos trabalhos do posto foi a preocupação com o registro e o acompanhamento detalhado de todas as informações. Assim, além dos vários modelos de fichas e livros de registro e anotações, podia-se controlar cotidianamente o fluxo de dados sobre o foco por meio de um grande mapa da cidade, onde cada casa recebia uma marcação específica, com alfinetes coloridos: ${ }^{47}$

Todas as casas com barbeiros infectados estão assinaladas com alfinetes vermelhos, as de que provieram barbeiros não examinados, ou negativos, estão marcadas com alfinetes verdes. (...) 
Sabe-se logo, portanto, qual a situação de cada casa, relativamente à presença das espécies domiciliares de barbeiro e à sua infecção pelo $S$. cruzi. ${ }^{48}$ (Dias, 1945: 42)

O procedimento sintetiza, numa imagem bastante eloqüente, sobretudo naquela época, a natureza do empreendimento que se estava montando: os cientistas, de fato, preparavam o terreno para uma guerra contra a doença.

Ainda que a profilaxia fosse o objetivo mais imediato para a criação do CEPMC, outra área de investigação mereceria atenção especial na sua agenda de trabalho: o estudo clínico da doença. Também sob este aspecto, pretendia-se fazer de Bambuí o "primeiro grande foco da endemia a ser intensivamente investigado no Brasil, mesmo independentemente do objetivo preventivo de que se reveste este estudo" (Dias, 1945: 45). Esta dimensão do trabalho científico era vista como fundamental não apenas para produzir novos conhecimentos sobre os aspectos clínicos da doença, mas também para viabilizar que esta se tornasse um assunto a despertar o interesse de outros grupos, sobretudo nos meios médicos e científicos e entre os profissionais da saúde pública. Dias (1945: 45) salientava:

Um dos importantes resultados dos trabalhos em realização naquela cidade mineira é o grande aumento que farão advir para a casuística da moléstia de Chagas em nosso país, o que certamente contribuirá para o melhor conhecimento da infecção pelos clínicos e cientistas brasileiros, que vimos há alguns anos procurando incrementar. E o que é extremamente desejável, aqueles trabalhos poderão vir a despertar a atenção das autoridades sanitárias e do Governo para o problema, e facilitar sua ação no sentido de enfrentá-lo.

Estas foram, assim, as duas principais vertentes de pesquisa às quais os cientistas associados ao CEPMC se dedicariam ao longo da década de 1940. Ao mesmo tempo que buscavam os meios de combater, mediante os novos recursos tecnológicos do momento, uma endemia que, segundo eles, era socialmente importante por comprometer o desenvolvimento econômico de Minas e do país, Dias e seus colaboradores se engajariam em produzir evidências para o seu reconhecimento como entidade nosológica definida e individualizada clinicamente. O processo de construção da doença de Chagas como fato científico e social entraria numa nova e importante fase, com permanências e diferenças em relação à época de Carlos Chagas. 


\section{Notas}

1 Como indica Zabala (2007), o projeto Mepra foi decorrência direta da missão científica chefiada pelo bacteriologista francês e diretor do Instituto Pasteur de Tunis Charles Nicolle (que Mazza havia conhecido em suas viagens pela Europa e pelo norte da África entre 1922 e 1924, e que receberia o Prêmio Nobel em 1929), para estudar a patologia do norte argentino. Tal missão, da qual fez parte Mazza, foi designada pelo Departamento Nacional de Higiene argentino em fins de 1925. Ver Sierra-Iglesias (1990), Ramacciotti (2007) e Zabala (2007).

2 A opção por "patologia regional" vinha substituir a designação de doenças "tropicais, exóticas ou coloniais”, como afirmava Mazza (1935: 30), indicando um contraponto a terminologias referidas à ótica da medicina européia.

3 Sobre a dualidade interior/litoral nos estudos médicos na Argentina, ver Di Liscia (2005).

4 Por considerar que o norte do país não 'monopolizava' a ocorrência de certos 'flagelos' que lhe eram considerados típicos, Mazza declarou, na ocasião, a ampliação da abrangência da sociedade, retirando a palavra "norte" de seu título (Mazza, 1935: 30).

5 “(...) com verdadeira clarividência, descobriu que o que até então se chamava bócio endêmico, denominação referida a um dos sintomas que apresentam os que padecem desta infecção, era uma enfermidade infectocontagiosa" - Tradução livre.

6 “(...) a colaboração do médico da região, especialmente do médico rural, obtida mediante um estímulo à sua tarefa diária, sempre árdua, armando-o com os elementos de juízo para apreciar ou antever a verdadeira natureza de processos encobertos pelas aparências de padecimentos comuns que simulam entidades mórbidas comuns" - Tradução livre.

7 Em entrevista a um jornal da capital brasileira (Jornal do Commercio, 1935), Mazza ressaltou a importância da Mepra para comprovar a extensão e a relevância social da tripanossomíase americana no continente.

8 O inchaço no olho inicia-se nas pálpebras e na conjuntiva e se expande pelo mesmo lado da face, acompanhado de reação nos gânglios (pré-auriculares, parótidos e submaxilares). Esta síndrome (edema palpebral e reação ganglionar) é denominada 'complexo oftálmico-ganglionar'. Sobre a contribuição de Romaña, ver Dias (1939), Chagas e Dias (1941), Dias (1997), Delaporte (1997, 2003) e Zabala (2007).

9 A eponimia provocou forte reação de Mazza, dando início a uma intensa disputa por prioridade. $\mathrm{O}$ diretor da Mepra afirmou que quem realmente descobrira o sinal havia sido o próprio Chagas (ao referir-se, sobretudo em seu trabalho sobre a forma aguda de 1916, a 'afecções oculares e palpebrais') e que ele, Mazza, havia retomado o assunto, divulgando sua importância e viabilizando, portanto, a descoberta de Romaña. Emmanuel Dias (1939: 969), por sua vez, defendendo a prioridade de Romaña, afirmou que não se podia atribuir a Chagas a descrição do 'sinal do olho' porque, para este, o edema facial era um sinal de natureza endócrina. As afecções oculares, mencionadas de modo isolado em alguns de seus trabalhos, haviam sido consideradas por Chagas, como afirmou Dias, ‘sinais de exceção’ e não constituíram objeto de aprofundamento. Depois da revisão de Dias (1939), Mazza passou a diminuir a importância do valor semiológico do achado de Romaña. 
Sobre a controvérsia e o rompimento das relações entre Mazza e Romaña, ver Sierra-Iglesias (1990) e Zabala (2007). No VI Congresso Nacional de Medicina realizado na Argentina, o pesquisador uruguaio Rodolfo Tálice propôs que a doença passasse a se chamar enfermedad de Chagas-Mazza, em virtude das fundamentais contribuições de Mazza ao estudo da doença (ver Zabala, 2007: 118). Até hoje, tal designação é utilizada na Argentina.

10 No Uruguai, o encontro de casos agudos da doença também foi uma decorrência direta da divulgação do sinal de Romaña. Após a descrição do primeiro caso em 1937, em 1939 já se havia identificado cerca de uma centena neste país (Dias, 1997, 1939). Em 1936, Mazza, Romaña e colaboradores identificaram outro sinal de 'porta de entrada' da infecção, o chagoma de inoculação, que é uma reação inflamatória na pele, com o aspecto de um furúnculo, que indica a penetração do parasito (pelas fezes do barbeiro) no local lesionado pela coceira provocada pela picada do inseto.

11 Segundo Zabala (2007), o reconhecimento da Mepra como pólo de estudos sobre a doença de Chagas, a partir de 1929, foi impulsionado em boa medida pelos pesquisadores brasileiros do Instituto Oswaldo Cruz (IOC), que viam os trabalhos de Mazza e, sobretudo, Romaña como confirmação das teses de Carlos Chagas quanto à extensão da doença.

12 Sobre os estudos de Emile Brumpt, ver Opinel e Gachelin (2005).

13 Ao comentar as diferenças entre o saber clínico acionado por Chagas (uma "clínica de laboratório") e o de Romaña (institucionalmente referido à prática hospitalar), Delaporte (2003: 111) chama a atenção para um aspecto interessante, mas incorre no anacronismo, ao afirmar: “(...) a moda dessa medicina experimental [de Chagas] era a contrapartida de um fracasso: a impossibilidade de colocar-se no campo da medicina clínica excluía a constituição de uma semiologia”. O fato de que aspectos centrais do desenho clínico de Chagas tenham sido descartados não significa que ele não indicou sinais clínicos efetivos para o diagnóstico da doença. Tanto o fez que, durante muito tempo, a 'tireoidite' foi diagnosticada clinicamente pelo bócio, amplamente aceito como ‘selo’ da doença. O próprio Delaporte assinala os fortes motivos teóricos que Chagas teve para propor este esquema. Trata-se, de fato, de modelos de conhecimento clínico diferentes. Mas a pretensa 'superioridade' da clínica de Romaña, no sentido de 'revelar' a tripanossomíase americana, só faz sentido no momento em que o quadro da tireoidite já havia sido afastado, ou pelo menos era duramente contestado.

14 Inscrito na tradição epistemológica francesa, Delaporte compreende a história das ciências como a análise das estruturas e das condições teóricas que permitem a emergência e a aplicação de conceitos. Como observa Löwy (2006: 24), que se contrapõe à análise deste autor sobre a história da febre amarela, "o estudo da ciência pode também ser considerado de uma outra maneira, que veria a ciência não como um sistema coerente de enunciados sobre a estrutura do mundo natural, mas como o conjunto indivisível das práticas materiais, sociais e discursivas dos cientistas". Sobre as diferenças entre as perspectivas teóricas de Delaporte e dos historiadores brasileiros que abordaram a história da doença de Chagas, ver Löwy (2005).

15 Para usar as formulações de Thomas Kuhn (1962), poderíamos dizer que o que garantiu a mudança na percepção/conceituação daquela entidade não foi uma 
posição externa à tradição/paradigma vigente, mas o reconhecimento de uma 'anomalia' produzido mediante um intenso empenho por parte de uma dada coletividade para manter esta tradição, solucionando seus 'quebra-cabeças'.

16 Sobre os casos de forma cardíaca da doença de Chagas descritos fora do Brasil entre 1934 e 1948, ver Laranja (1949). Para uma análise das importantes contribuições de Mazza para a compreensão da doença de Chagas aguda, ver Zabala (2007).

17 Evandro Chagas e os argentinos estudaram especialmente a forma cardíaca aguda. A questão se tornava mais complicada no caso da forma cardíaca crônica, quando não se tinha o recurso à detecção do parasito no organismo do doente como critério confirmador do caso. Este seria o desafio enfrentado pelos pesquisadores associados ao posto de Bambuí. Para um interessante estudo em torno da idéia de 'caso típico' no processo de construção social das doenças, ver English (1992).

18 No início da década de 1940, a Mepra começou a mostrar sinais de declínio, o que se agravou em 1946 com sua transferência para a cidade de Buenos Aires e a morte de Mazza, e, em seguida, a intervenção do peronismo na Universidade de Buenos Aires. Em 1959, ela foi desativada (ver Zabala, 2007). Romaña, depois de uma estadia de dois anos no IOC, foi convidado, em 1942, para organizar e dirigir o Instituto de Medicina Regional da Universidade de Tucumán. À frente desta instituição, ele se tornou a principal referência dos estudos sobre a doença de Chagas na Argentina e assumiu a liderança dos esforços por institucionalizá-la como problema nacional neste país, processo implementado entre fins da década de $1940 \mathrm{e}$ meados da década de 1950 (Zabala, 2007). Romaña seguiu em estreito contato com os pesquisadores brasileiros, em especial Emmanuel Dias. O arquivo do posto de Bambuí possui numerosas cartas trocadas entre estes cientistas, que tiveram trajetórias muito semelhantes, por associarem suas investigações científicas à intensa militância em busca do reconhecimento da doença de Chagas como problema sanitário de dimensão continental. Ver Fundo Centro de Pesquisas René Rachou, Seção Posto Avançado de Pesquisas Emmanuel Dias (doravante FCPqRR/SPAPED), Série Correspondência.

19 Amilcar Vianna Martins (1907-1990) nasceu em Belo Horizonte e foi uma das grandes lideranças da parasitologia mineira. Ingressou, em 1924, na Faculdade de Medicina de Belo Horizonte (FMBH), trabalhando no Instituto Biológico Ezequiel Dias (Ibed) como auxiliar acadêmico e, depois, pesquisador. Em 1930, tornou-se professor assistente de fisiologia daquela faculdade. Em 1939, foi aprovado em concurso para livre-docente da cadeira de parasitologia. Um ano depois, tornou-se professor catedrático de zoologia e de parasitologia da Faculdade de Odontologia e Farmácia da Universidade de Minas Gerais. Em 1943, serviu à Força Expedicionária Brasileira na Itália. Em 1947, desligou-se do Instituto Químico Biológico (antigo Ibed), para chefiar o Serviço de Endemias Rurais da Secretaria de Saúde de Minas Gerais, no qual permaneceu até 1949. Em 1952, passou a atuar como perito em doenças parasitárias da Organização Mundial da Saúde (OMS). Entre 1956 e 1958, foi diretor do Instituto Nacional de Endemias Rurais (INERu), órgão de pesquisas do então criado Departamento Nacional de Endemias Rurais (DNERu), do Ministério da Saúde. O Centro de Pesquisas de Belo Horizonte, origem do atual Centro de Pesquisas René Rachou, da Fundação Oswaldo Cruz (Fiocruz), e em cuja criação Martins desempenhou papel decisivo, foi um dos órgãos do INERu. Entre 1958 e 1960, assumiu a direção do IOC e, entre 1960 e 1961, esteve à frente 
do DNERu. Em 1966, assumiu a direção do Instituto de Ciências Biológicas da Universidade Federal de Minas Gerais e, no ano seguinte, tornou-se diretor do Departamento de Parasitologia deste instituto. Em 1969, foi aposentado compulsoriamente pelo Ato Institucional n. 5 (AI-5), retornando às suas funções docentes em 1979. Faleceu em 1990 (Martins, 1987; Azevedo \& Kropf, 2007).

20 Serviço de Estudo das Grandes Endemias. Exposição ao Sr. Ministro da Educação e Saúde destinada a modificar o orçamento para o serviço em 1940. Rio de Janeiro, 9 de novembro de 1939. Arquivo Gustavo Capanema, Série Ministério da Educação e Saúde/Saúde e Serviço Social (doravante AGC/SMES/SSS), GC h 1935.05.27. O plano encontra-se publicado em Martins, Versiani e Tupinambá (1940: 286-287).

${ }^{21}$ Tais fichas encontram-se anexadas ao diário de Evandro Chagas, no trecho relativo ao dia 12 de setembro de 1939, quando reporta conversa com Martins sobre o plano de estudos. Fundo Evandro Chagas (doravante FEC), grupo: pesquisa; atividade: coordenação científica de pesquisa; função: diretor do Hospital Oswaldo Cruz/superintendente do SEGE/orientação técnica e científica do IPEN.

22 Carta de Evandro Chagas a Amilcar Vianna Martins, Rio de Janeiro, 20 de fevereiro de 1940. FEC, grupo: pesquisa; atividade: divulgação de resultados; função: diretor do Hospital Oswaldo Cruz/superintendente do Sege/orientação técnica e científica do IPEN.

23 Discurso de Antonio Torres Sobrinho no Hospital Nossa Senhora do Brasil, em Bambuí. Bambuí, 21 de dezembro de 1979, p. 2-3. FCPqRR/SPAPED, caixa 03, maço 7. O episódio é narrado também por Martins (1987: fita 5, lado A).

24 Embora o referido trabalho tenha sido publicado nos volumes relativos aos anos de 1939/1940 das Memórias do Instituto Ezequiel Dias, ele corresponde às observações feitas pelos autores até dezembro de 1941, como é informado no próprio trabalho (Martins, Versiani \& Tupinambá, 1939-1940: 5).

${ }_{25}$ "A doença de Chagas incidindo em todos os países americanos! Sucedem-se com freqüência, no México, os casos de mortes repentinas, principalmente entre camponeses. O Dr. Evandro Chagas, chefe do Serviço de Estudos das Grandes Endemias, do Instituto Oswaldo Cruz, esclarece a extensão do mal, no continente". FEC, grupo: vida pessoal; atividade: relações familiares e de sociabilidade (livro de recortes de jornais, v. 7, p. 92).

26 Carta de Amilcar Vianna Martins a Evandro Chagas. Belo Horizonte, 26 de abril de 1940. FEC, grupo: pesquisa; atividade: cooperação técnico-científica; função: diretor do Hospital Oswaldo Cruz/superintendente do SEGE/orientação técnica e científica do IPEN.

27 Carta de Aristóteles Brasil a Evandro Chagas. Belo Horizonte, 7 de maio de 1940. FEC, grupo: pesquisa; atividade: intercâmbio com cientistas; função: diretor do Hospital Oswaldo Cruz/superintendente do SEGE/orientação técnica e científica do IPEN.

28 Carta de Aristóteles Brasil a Evandro Chagas. Belo Horizonte, 7 de maio de 1940. FEC, grupo: pesquisa; atividade: intercâmbio com cientistas; função: diretor do Hospital Oswaldo Cruz/superintendente do SEGE/orientação técnica e científica do IPEN.

29 Carta de Amilcar Viana Martins a Evandro Chagas. Belo Horizonte, 25 de maio de 1940. FEC, grupo: pesquisa; atividade: cooperação técnico-científica; função: dire- 
tor do Hospital Oswaldo Cruz/superintendente do SEGE/orientação técnica e científica do IPEN.

30 Outra condição fundamental para uma pesquisa sistemática sobre a doença, proporcionada pelos recursos do Sege, foi a criação de barbeiros em laboratório para a realização de exames de xenodiagnóstico, implantada inicialmente no Ibed e em seguida no IOC, e que exigia condições particulares de instalações e de acompanhamento técnico. Carta de Amilcar Vianna Martins a Evandro Chagas, 2 de setembro de 1940. FEC, gupo: pesquisa; atividade: cooperação técnico-científica; função: diretor do Hospital Oswaldo Cruz/superintendente do SEGE/orientação técnica e científica do IPEN.

31 Ver Chagas Filho, Carlos. Exposição sobre o Serviço de Estudo das Grandes Endemias. Rio de Janeiro, 31 de dezembro de 1940. AGC/SMES/SSS, GC h 1935.05.27.

32 Relatório das atividades do Sege, encaminhado por Carlos Chagas Filho ao diretor do IOC Cardoso Fontes. 22 de agosto de 1941. Fundo Carlos Chagas Filho (em organização); Relatório de Atividades do Sege, anexo ao ofício de Carlos Chagas Filho a Antonio Cardoso Fontes. Rio de Janeiro, 3 de outubro de 1941. Fundo Instituto Oswaldo Cruz, Seção Serviço de Administração, Série Administração Geral (doravante FIOC/SSA/SAG), caixa 10.1, maço 4, pasta n. 1.

33 Com aula inaugural de Eurico Villela, antigo colaborador de Carlos Chagas, participaram como professores no curso Herman Lent, pesquisador de Manguinhos especializado em entomologia, Octavio de Magalhães e Valdemar Versiani, do Ibed, e Emmanuel Dias. Relatório de atividades do Sege, anexo ao ofício de Carlos Chagas Filho a Antonio Cardoso Fontes. Rio de Janeiro, 3 de outubro de 1941. FIOC/SSA/ SAG, caixa 10.1, maço 4, pasta n. 1.

34 Relatório de atividades do Sege, anexo ao ofício de Carlos Chagas Filho a Antonio Cardoso Fontes. Rio de Janeiro, 3 de outubro de 1941. FIOC/SSA/SAG, caixa 10.1, maço 4, pasta n. 1. Entre 1939 e 1942, foram registrados 15 casos da doença no Rio Grande do Sul, a maioria mediante o sinal de Romaña. Em cinco deles, submetidos a exames clínicos mais aprofundados, foram constatados sintomas cardíacos. Ver Pinto (1942).

35 Os trabalhos da pesquisadora Herta Meyer, deste instituto, que utilizava as modernas técnicas da bioquímica e da microscopia eletrônica, contribuiriam para a elucidação de importantes aspectos da biologia do parasito. Relatório de atividades do Sege encaminhado por Carlos Chagas Filho ao diretor do IOC. Rio de Janeiro, 22 de agosto de 1941. Fundo Carlos Chagas Filho (em organização).

36 Ofício de Henrique Aragão a Mário Pinotti. Rio de Janeiro, 11 de junho de 1942. Fundo Instituto Oswaldo Cruz, Seção Direção, Cópias de ofícios (doravante FIOC/ SD/CO), ofício n. 362. Ofício de Henrique Aragão a Israel Pinheiro. Rio de Janeiro, 9 de maio de 1942. FIOC/SD/CO, ofício n. 273.

37 Carta de Emmanuel Dias a Amilcar Vianna Martins. [s. 1.], 4 de junho de 1942. FCPqRR/SPAPED, caixa 15, maço 01. A recomendação de Dias era a de que se usasse uma mistura composta por extrato de piretro, tetracloreto de carbono e óleo diesel ou querosene. As primeiras experiências de laboratório para testar a ação de inseticidas contra os barbeiros haviam sido feitas, na década de 1920, na filial do IOC em Belo Horizonte, pelo pai de Emmanuel, Ezequiel Dias, em traba- 
lho cujo objetivo era investigar meios de combate aos escorpiões (Dias, Libânio \& Lisboa, 1924).

38 Em entrevista a um jornal, Carlos Chagas Filho ressaltou, ao comentar a atuação do Sege, a divulgação da doença entre os médicos das áreas rurais, que já havia produzido importantes resultados: "Está sendo distribuída aos clínicos do interior literatura sobre diagnóstico da 'Moléstia de Chagas' a fim de que os mesmos colaborem no despistamento de casos agudos e crônicos" (A Notícia, 1942). O grupo liderado por Samuel Pessoa na Universidade de São Paulo (USP) constituiria uma importante tradição na área de parasitologia, sobretudo na década de 1950, sob a qual seriam formados pesquisadores que trariam destacadas contribuições às pesquisas sobre a tripanossomíase americana.

39 A idéia do posto ganhou reforço quando Heráclides de Souza Araújo, pesquisador do IOC, visitou um leprosário em Bambuí e, ouvindo falar da alta incidência da doença de Chagas na região, enviou, em março de 1943, um memorial ao ministro Capanema, enfatizando a necessidade de medidas concretas para estudar e para combater o problema. Este episódio é relatado em: Carta de Heráclides de Souza Araújo a José Pellegrino. Belo Horizonte, 5 de abril de 1955. FCPqRR/SPAPED, caixa 3, maço 2 .

40 Carta de Henrique Aragão a Antonio Valladares Bahia, diretor do Instituto Químico Biológico de Minas Gerais. Rio de Janeiro, 19 de junho de 1943, FIOC/SD/CC, carta n. 89.

41 Carta de Henrique Aragão a José Castilho Júnior, diretor do Departamento de Saúde do Estado de Minas Gerais. Rio de Janeiro, 19 de junho de 1943; Carta de Henrique Aragão a Lucas Lopes, secretário de Agricultura do estado de Minas Gerais. Rio de Janeiro, 19 de junho de 1943. FIOC/SD,CC, cartas n. 88 e 87.

42 A ausência de Martins levou a um esvaziamento da participação do IQBMG no projeto, que passaria a ser fundamentalmente um programa do IOC, ainda que com a forte colaboração de pesquisadores mineiros, entre os quais Versiani. Carta de Henrique Aragão a A. Cerqueira da Luz, diretor do Instituto Químico Biológico de Minas Gerais Rio de Janeiro, 14 de outubro de 1943. FIOC/SD/CC, carta n. 156.

43. Nascido na cidade do Rio de Janeiro em 27 de julho de 1908, Emmanuel Dias começou a trabalhar no IOC em 1929, como voluntário, ainda estudante, sob a supervisão direta de Carlos Chagas. Tendo feito o Curso de Aplicação de Manguinhos em 1932, formou-se pela Faculdade de Medicina do Rio de Janeiro (FMRJ) em 1933, com tese de doutoramento (Dias, 1934) que elucidava importantes aspectos do ciclo evolutivo do T. cruzi, como sua transmissão ao homem pelas fezes contaminadas do barbeiro, como havia postulado Emile Brumpt. Neste ano, foi contratado por Chagas, diretor do IOC, como adjunto de Thales Martins, chefe de laboratório da seção de fisiologia, substituindo-o neste cargo em 1934. Por ocasião da reunião em Mendoza, Argentina, em 1935, no qual apresentou quatro trabalhos, Dias continuava seus estudos sobre o T. cruzi, com especial interesse sobre a evolução deste e de outros tripanossomas em reservatórios naturais, como morcegos, estudo no qual teria, nos anos seguintes, a colaboração de Romaña. Desde sua formatura, Dias contou com o empenho de Chagas para incorporá-lo aos quadros da instituição, o que não era tarefa simples, em função das dificuldades formais de contratação. Em 1935, ele foi enviado para servir no posto do IOC em Belo Horizonte, que havia 
sido dirigido por seu pai. Lá estabeleceu contato próximo com Amilcar Martins, com quem participou, em 1937, de uma viagem de estudos aos Estados Unidos para estudar as rickettioses (doenças causadas por microorganismos do gênero Rickettsia), patrocinada pelo governo brasileiro, em função do interesse em criar no Ibed um laboratório para produção de vacina contra a febre maculosa brasileira (também chamada de tifo exantemático). No âmbito da cooperação Sege/Ibed, Dias realizou uma série de excursões, especialmente em Minas, em companhia de Romaña, para coletar diferentes espécies de barbeiros e de reservatórios do T. cruzi e para estudar questões relacionadas à transmissão da doença, como a variação na suscetibilidade à infecção pelo parasito entre diversas espécies de barbeiros. Sua trajetória a partir da criação do CEPMC será acompanhada nos capítulos seguintes. Ver: Memorial para concurso com vistas a provimento de cargo de chefe de laboratório do IOC. Rio de Janeiro, 26 de outubro de 1935, FCPqRR/SPAPED, caixa 28, maço 2; Carta de A. Fernandes a Julio Arnoldo Laender, fornecendo dados biográficos de Emmanuel Dias. [s.l.], 9 de maio de 1960. FCPqRR/SPAPED, caixa 28, maço 2; "Emmanuel Dias", Assentamento Funcional (livro 3, p. 507) (este arquivo encontra-se sob a guarda da COC/Fiocruz). Ver também o depoimento oral de seu filho, João Carlos Pinto Dias (1998) e Dias (2009).

44 Para um relato histórico do CEPMC, escrito por seu diretor em homenagem a Henrique Aragão, ver Dias (1956).

45 A descrição e os dados deste levantamento encontram-se em Dias (1945).

46 As cafuas eram definidas como construções toscas, com teto de capim geralmente, paredes de pau-a-pique, chamadas de 'sopapo' (porque o barro era batido a sopapos no madeirame) e sem revestimento de piso. Já os térreos ou sobrados possuíam teto de telha ou zinco, paredes rebocadas ou caiadas e piso revestido com tijolo ou soalho (Dias, 1945).

47 Muitos destes livros de registro e anotações diversas encontram-se no FCPqRR/ SPAPED.

48 Por motivos diversos dos que orientaram Chagas, Dias considerava o parasito causador da tripanossomíase americana como pertencente ao gênero Schizotrypanum, daí esta denominação S. cruzi. Ver Dias (1934). 



\section{Identificando o Inimigo e as Armas: as pesquisas do Instituto Oswaldo Cruz em Bambuí, Minas Gerais (1943-1949)}

Ao conferir ao projeto do Centro de Pesquisa e Profilaxia da Moléstia de Chagas (CEPMC), posto do Instituto Oswaldo Cruz (IOC) em Bambuí, o sentido de continuidade e de legitimação dos trabalhos de Carlos Chagas, Emmanuel Dias e seus colaboradores produziram, entre 1943 e 1949, conhecimentos que imprimiriam um novo consenso a esta enfermidade ainda tão envolta em dúvidas. Por um lado, produziram um instrumento concreto para o ataque aos seus vetores e, reportando-se às reivindicações de Chagas desde os primeiros anos após a descoberta, passaram a advogar a viabilidade de uma campanha de profilaxia. Por outro, aprofundando o caminho que vinha sendo trilhado no estudo clínico da doença - as pesquisas sobre a forma cardíaca -, mas fazendo-o sob uma nova perspectiva, engajaram-se em enfrentar o maior desafio posto ao reconhecimento da doença como entidade nosológica específica: a caracterização e o diagnóstico das formas crônicas. Num momento em que a cardiologia passava por importante processo de desenvolvimento técnico e de institucionalização, o recurso a profissionais e a metodologias deste campo confirmou que a pesquisa clínica era a via para superar os impasses e quebra-cabeças que o laboratório e a parasitologia haviam deixado em aberto no estudo daquela doença tropical. 


\section{Guerra aos Vetores: testando estratégias}

Em meados da década de 1940, o otimismo internacional gerado pelo início da 'era DDT' (Stapleton, 1998; Farley, 2004) fortalecia a disposição dos que, no Brasil, buscavam estabelecer o primeiro plano de profilaxia para a doença de Chagas. Com base nas detalhadas informações sobre as características e a distribuição dos vetores de Bambuí, que revelavam níveis de infestação das habitações surpreendentes (em apenas duas cafuas foram capturados 3.500 barbeiros), Dias (1945: 84) deu início, logo após a criação do posto, em dezembro de 1943, às primeiras experiências de laboratório e de campo. A expectativa era grande. Em 1944, Henrique Aragão salientou que os trabalhos realizados no oeste mineiro constituíam um "serviço que pela primeira vez é realizado de um modo sistemático e que promete resultados muito interessantes a propósito deste assunto" (IOC, 1945: 36). Num indício da importância conferida ao posto como emblema dos esforços do instituto em acompanhar a guerra química aos vetores, travada no cenário internacional, o diretor do IOC mandou publicar, pela Imprensa Nacional, o relatório das atividades do CEPMC nos seus primeiros seis meses de funcionamento (Dias, 1945).

Para Dias (1945: 87), o objetivo primordial era viabilizar a destruição completa dos vetores da tripanossomíase americana: “(...) o triatoma muito se presta ao êxito das modernas campanhas sanitárias, que visam à extinção total e não apenas à diminuição dos transmissores de doenças em determinadas regiões". O CEPMC havia recebido de Fred Soper não apenas uma bomba para aplicar inseticidas, mas, sobretudo, a concepção que a Fundação Rockefeller defendia e representava no campo da saúde internacional, reforçada com o advento do DDT: o combate aos vetores sob a perspectiva da erradicação (Farley, 2004). O diretor do posto de Bambuí reconhecia, contudo, que, naquele momento, a erradicação dos triatomíneos era ainda uma meta para o futuro, a orientar uma agenda de pesquisa que estava apenas começando.

A solução ideal para o controle das infecções propagadas por agentes intermediários animados é a eliminação total dos respectivos transmissores da face da terra. Diante dos extraordinários progressos realizados nos últimos decênios na luta contra certas infecções desse grupo, já podemos acreditar em que, talvez dentro de poucas gerações, consigamos lograr aquela solução, ao menos para 
alguns dos grandes problemas que nos afligem (...). Quanto à luta contra a moléstia de Chagas, mal estamos dando os primeiros passos no seu início e muitos anos talvez ainda transcorrerão antes que se venha a por em ação um vasto plano de combate a essa séria endemia, tão enormemente espalhada em toda a América do Sul. (Dias, 1945: 66)

Uma primeira e fundamental estratégia desta luta, preconizada pelo próprio Chagas desde 1905 em relação à malária, era a aplicação de inseticidas nos domicílios. Para isso, Dias testou várias substâncias disponíveis no comércio, como querosene, gasolina, formol, amoníaco, ácido fênico, entre outras. Eram usadas bombas aspersoras de várias marcas, como a De Vilbiss, ofertada por Soper. Além de produtos com possível ação letal sobre os barbeiros, foram testados também repelentes para desalojá-los de seus 'esconderijos', geralmente as frestas das paredes, de modo a que viessem a ter contato com o inseticida. As propriedades destes produtos eram previamente examinadas no laboratório, com vistas a determinar qual a mais baixa diluição capaz de provocar a morte do inseto. Além da aspersão de líquidos inseticidas, foram testados também a aplicação de gases tóxicos e o uso de lança-chamas (Imagens 22 e 23). ${ }^{1}$

Como subsídio a estes ensaios, o CEPMC recorria à Divisão de Defesa Sanitária Vegetal, do Departamento Nacional de Produção Vegetal do Ministério da Agricultura, que lhe fornecia informações sobre processos de combate a pragas e sobre métodos e fórmulas de preparação dos inseticidas. Com vistas a facilitar o acompanhamento e a avaliação dos expurgos experimentais, além do livro de registro geral, foram confeccionadas fichas específicas para cada ensaio, nas quais eram anotadas detalhadas informações sobre as condições em que foi realizado. As experiências de expurgo exigiam a colaboração e a anuência dos próprios moradores, ainda que os técnicos estivessem orientados a efetuá-las, por vezes, por meio de medidas bastante radicais, como expresso na recomendação de Dias, para que se procedesse à “destruição (queima) de todos os guardados inúteis que essa pobre gente do sertão é dada a conservar" (Dias, 1945: 76).

Naquele momento, o principal desafio era identificar um produto que tivesse a mais prolongada ação residual contra os barbeiros, ou seja, um poder de letalidade cujo tempo de durabilidade fosse suficiente para eliminar os insetos que eventualmente escapassem dos expurgos, evitando a reinfestação do domicílio. Se, no caso da malária, esta propriedade 
era o diferencial que consagrava o DDT entre os outros inseticidas contra os mosquitos, no caso dos transmissores da doença de Chagas, cuja característica é esconder-se nas frestas das paredes e em outros locais de difícil acesso para os jatos das bombas aspersoras, ela tornava-se ainda mais necessária. Na falta de um produto com poder residual adequado, Dias (1945: 78) recomendava a aplicação de grandes quantidades do líquido inseticida em cada expurgo, mas admitia: "Ainda assim, nunca podemos estar seguros de que todos os barbeiros foram direta ou mesmo indiretamente alcançados, ou que sofrerão os efeitos letais do preparado." Ele considerava necessário realizar aplicações sucessivas com vistas a ir diminuindo paulatinamente a colônia de triatomíneos em cada habitação. Afirmava:

Este último inconveniente, comum aliás a todos os expurgos baseados no método hit or miss, será contornado quando dispusermos de uma mistura de inseticida que alie à sua ação tóxica imediata, uma ação tóxica residual tanto quanto possível prolongada no tempo. Um agente desinfetante que reúna estas propriedades constituirá uma arma tremenda contra o barbeiro e simplificará enormemente o saneamento das vastíssimas regiões assoladas pela endemia esquizotripanósica. O DDT é uma esperança nesse sentido. (Dias, 1945: 78)

Em meados de 1944, Dias manifestou junto ao diretor do IOC que acompanhava de perto o andamento dos trabalhos do posto - seu desapontamento com os inseticidas até então testados contra o Triatoma infestans, principal espécie transmissora em Bambuí. Mas, ao mesmo tempo, demonstrou grande expectativa com o novo produto que despontava no cenário internacional. Solicitando que Aragão lhe enviasse alguns quilos de DDT para estudar seus efeitos contra os barbeiros, dizia:

Lançado em aspersão, poderá não só agir atingindo diretamente o inseto, como tardiamente, sob a forma de pó que ficará depositado nas paredes e que, como já vimos, tem ação paralisante e finalmente mortal sobre o Triatoma. Seria muito bom que pudéssemos acrescentar um ensaio com esta droga no primeiro relatório. Se assim for, na prática o DDT teria sobre os inseticidas comuns de ação por contato direto uma enormíssima vantagem. ${ }^{2}$

Seu entusiasmo alimentava-se das notícias vindas do front europeu, não só sobre o DDT, mas acerca dos vários produtos e dos aparelhos que vinham sendo testados contra os vetores: 
No Times de 3 de abril último (...) há uma notícia interessante sobre uma bomba revolucionária contra mosquitos (...) que mata todos [?] os insetos em poucos minutos. Escrevi ao Dr. Vannevar Bush, Chairman of the Army and Navy's Joint Commitee of New Weapons and Equipment, vendo se consigo mais informações sobre o assunto e perguntando se a droga e a respectiva aparelhagem são disponíveis. Tenho visto outras coisas muito interessantes de novo e tenho pensado mesmo se não valeria a pena ir aos Estados Unidos ver o que há de melhor para experimentar na profilaxia da doença de Chagas. ${ }^{3}$

A idéia de uma viagem aos Estados Unidos havia sido despertada, segundo informa nesta mesma carta, pela leitura do livro The Chemical Front, publicado no ano anterior (Haynes, 1943). Dias resolveu escrever sobre o assunto, "em caráter particular", a Carlos Drummond de Andrade, com quem mantinha relações pessoais. O chefe de gabinete do ministro Capanema lhe responderia estimulando-o a conhecer de perto a "guerra química aos insetos" que estava sendo conduzida por aquele país e dispondo-se a colaborar para tanto. Em carta a Aragão, Dias transcreveu as palavras que recebera de Drummond:

Sua idéia de fazer nos Estados Unidos um estudo aprofundado da guerra química aos insetos me parece excelente e, realizada, deverá trazer um rendimento extraordinário ao trabalho que V. vem levando a peito, com tamanha precariedade de meios no nosso interior mineiro. Aqui estou para estimulá-lo nesse empreendimento, embora a pequena valia de meus préstimos. Trate pois da coisa oficialmente, que da minha parte diligenciarei para o andamento mais acelerado do assunto no meu setor. E mande notícias, suas e de sua luta contra o barbeiro, luta que tem um tão grande interesse humano e - acredite - vale mais do que toda a nossa pobre literatura. ${ }^{4}$

A conjuntura da guerra criava condições favoráveis ao projeto do CEPMC não apenas por colocar na ordem do dia a importância do combate às doenças transmitidas por insetos, mas também porque, no bojo desta preocupação, produzia um interesse específico sobre a tripanossomíase americana no âmbito internacional, particularmente nos Estados Unidos. Um indício deste interesse foi o estudo sobre os transmissores da doença produzido pelo Serviço de Saúde Pública daquele país (Usinger, 1944). O autor, entomólogo que atuaria junto às tropas norte-americanas no combate à malária no Pacífico, apresentou revisão 
detalhada das características biológicas e epidemiológicas das diversas espécies de triatomíneos encontradas nas Américas Central e do Norte e na Ásia e também dos dados sobre a ocorrência da infecção nestas regióes. Apesar de, até então, não ter sido registrado caso humano da tripanossomíase nos Estados Unidos, a alta porcentagem de infecção pelo Trypanosoma cruzi em triatomíneos identificados no México, na Califórnia, no Arizona, no Novo México e no Texas constituía fator de grande preocupação, especialmente para os interesses militares daquele país. Dizia Usinger (1944: 5): "Hence, it would seem inevitable that human cases of 'Chagas' disease will appear and very likely that they will appear under field conditions in troop training and maneuver areas". ${ }^{5}$ Foi nestas circunstâncias que Dias começou a se corresponder com pesquisadores norte-americanos, que lhe requisitavam bibliografia especializada e o envio de barbeiros e culturas de T. cruzi. Em janeiro de 1945, por exemplo, um dos mais destacados cientistas nesta área, Ardzroony Packchanian, da Universidade do Texas, manifestou, em carta ao diretor do CEPMC, a quem agradecia a colaboração e a remessa de material para a pesquisa, $\mathrm{o}$ interesse em passar um mês no Brasil para conhecer de perto as linhas de investigação sobre o tema. ${ }^{6} \mathrm{O}$ intercâmbio com os norte-americanos reforçava a divulgação internacional dos conhecimentos que vinham sendo produzidos pelo CEPMC, tanto sobre o controle dos vetores quanto sobre os aspectos clínicos da doença.

Os ensaios com o DDT em Bambuí tiveram início em agosto de 1944. Para obter subsídios técnicos, Dias escreveu ao chefe do setor de pesquisa agrícola do Bureau of Entomology and Plant Quarantine, de Washington - divisão do Departamento de Agricultura norte-americano que vinha, desde 1942, testando inseticidas tendo em vista as necessidades militares da guerra -, solicitando remessa de trabalhos sobre ensaios feitos com o produto. ${ }^{7}$ Os resultados das primeiras experiências foram positivos e, em carta ao colega argentino Cecilio Romaña, Dias chegou a afirmar: "Parece ser a solução para os barbeiros". ${ }^{8}$ Contudo, ao longo de 1945, o DDT não correspondeu às expectativas. Dias continuaria testando outros produtos e uma nova promessa passou a ser o pó Fly-Tox, à base de piretro, que desalojava rapidamente os insetos, matando-os lentamente. Havia, porém, duas grandes desvantagens: o produto não possuía ação residual e também não era letal para os ovos dos barbeiros. O problema continuava a ser como evitar a reinfestação das casas (Dias, 1946b). ${ }^{9}$ 
Além dos expurgos com inseticidas, outro método considerado por Dias para a eliminação dos barbeiros e a conseqüente interrupção da transmissão da doença era a realização de melhorias habitacionais, com vistas a extinguir as condições para a proliferação destes insetos. O CEPMC desenvolveu ensaios com este objetivo (Dias, 1945). Logo nos primeiros meses, foi iniciado um programa experimental de reboco nas paredes das 43 cafuas existentes num bairro periférico de Bambuí (Lavapés), com a finalidade de estudar a viabilidade econômica e a eficácia da medida (Imagem 24). Numa formulação que seria usada muitas vezes em seus artigos e pronunciamentos, Dias afirmava: "Como é geralmente sabido, o problema da doença de Chagas está intimamente ligado ao problema da habitação rural e a solução deste trará quase seguramente a solução daquele. Combater a cafua é combater a tripanosomose" (Dias, 1945: 105; grifos meus). Segundo o cientista, o ideal seria empreender "medidas mais radicais", como a destruição, pelo fogo, de todas as habitações propícias à infestação pelos barbeiros e construir "casinhas adequadas, higiênicas, cobertas de telha, para a população rural de certas regiões" (Dias, 1945: 105). Além disso, os governos estaduais e municipais deveriam promulgar leis proibindo a construção de cafuas. ${ }^{10}$

Contudo, se enfrentava dificuldades para identificar inseticidas adequados contra os barbeiros, Dias admitia que a estratégia relativa às melhorias habitacionais era de difícil aplicação, "por óbvias razões de ordem econômico-social” (Dias, 1945: 103). Além disso, ela perdia sua eficácia se feita de forma isolada, sem abranger a totalidade das casas sujeitas à infestação em uma dada região (objetivo que parecia bastante improvável de ser alcançado). Sendo assim, reconhecia: "Limitar-nos à lacônica preconização da queima das cafuas infestadas e da construção das casinhas higiênicas para o pobre homem do campo, medida radical inicial, seria fugir àquele problema [da profilaxia da doença], cuja dificuldade, aliás, ninguém ignora" (Dias, 1945: 68).

O contraponto entre combater o barbeiro por meio de inseticidas e combater o ambiente propício a estes insetos mediante melhorias nas habitações rurais ganharia, ao longo da década de 1950, significados e implicações para além do domínio técnico, quando passaria a expressar diferentes maneiras de se conceber a relação entre saúde e desenvolvimento: por um lado, uma abordagem centrada no vetor e, por outro, a concepção de que o principal meio de se combater as doenças infectocontagiosas era garantir melhores condições de vida, ou seja, 
promover o desenvolvimento econômico-social. Nos primeiros anos da década de 1940, contudo, até porque se estava no início das pesquisas relativas às duas metodologias de combate ao barbeiro - e os debates sobre a articulação entre doença e pobreza não haviam ainda atingido a coloração política que passariam a ter no pós-guerra -, Dias explorava ambas as possibilidades de encaminhar a profilaxia da doença, concebendo-as num sentido eminentemente técnico. ${ }^{11}$ A própria defesa das melhorias habitacionais era vista como mais uma forma de preconizar, conforme a abordagem centrada no combate ao vetor, o objetivo que unia todos os esforços: o extermínio completo dos transmissores. Segundo Dias (1944: 12): "O barbeiro deve ser implacavelmente perseguido e destruído por todos os meios ao nosso alcance" (Imagem 25).

As dificuldades no encontro de um inseticida, contudo, acabaram levando Dias a reforçar a importância da profilaxia baseada nas melhorias habitacionais, cujos testes prosseguiam em Bambuí. Em maio de 1946, ele aventou junto ao prefeito a possibilidade de empreender a substituição das cafuas da cidade, mediante verbas que o Ministério do Trabalho estava destinando a melhorias nas moradias rurais, ou por meio de possíveis acordos com o Ministério da Educação e Saúde (MES) nesse sentido. ${ }^{12}$ Em trabalho publicado em setembro daquele ano, declarando que o objetivo continuava sendo a "morte ao barbeiro", Dias citou as resistências que os insetos vinham demonstrando contra os produtos testados e voltou a afirmar: "A cafua é a fortaleza dos barbeiros e para exterminá-los temos que destruí-la totalmente. (...). Assim, a luta contra a infecção por fim se resume na luta contra a habitação miserável, porque, como já se disse, ‘combater a cafua é combater a doença de Chagas"' (Dias, 1946c: 6-7).

Esta orientação foi formalizada no I Congresso Interamericano de Medicina, realizado em 1946, no Rio de Janeiro, quando a doença de Chagas foi um dos temas oficiais da seção de grandes endemias. Neste encontro, aprovou-se a recomendação de que as autoridades dos vários países do continente atingidos pela tripanossomíase promovessem programas de profilaxia, "tendo em conta que a medida principal é a questão da vivenda rural e que todas as demais medidas úteis são somente medidas auxiliares" (apud Dias, 1948a: 219). Em publicação de abril de 1947 , novamente a ênfase recaiu na necessidade de medidas que reformassem as habitações rurais ou evitassem a construção de cafuas, por meio de impedimentos legais ou pela divulgação de novos hábitos junto à população das áreas endêmicas (Dias, 1947). Na ocasião, Dias travava 
entendimentos com a Fundação da Casa Popular tendo em vista um plano de reforma nas moradias de Bambuí, o que seria conseguido, em julho, com a aprovação de recursos para a construção de cem casas experimentais. ${ }^{13}$

O diretor do CEPMC atuava, portanto, em várias frentes buscando estabelecer meios para o combate à doença. Além dos distintos métodos de profilaxia, ele também se preocupava em testar drogas que pudessem ter alguma ação terapêutica para a infecção pelo T. cruzi. Desde 1945, realizava ensaios, em pacientes internados no Hospital Evandro Chagas, no IOC, com produtos antimaláricos e penicilina. ${ }^{14} \mathrm{~A}$ pesquisa e a produção de medicamentos para as doenças infecciosas despertavam crescente interesse no cenário internacional, tendência que se aprofundaria no pós-guerra. ${ }^{15}$

A partir de 1947, a perspectiva de atacar os barbeiros por meio de inseticidas ganhou importantes reforços e passaria a predominar na agenda de pesquisa e de mobilização do CEPMC. Em março deste ano, o diretor do IOC, Henrique Aragão, solicitou a incorporação à equipe do CEPMC do médico José Pellegrino, vinculado ao Departamento de Saúde de Minas Gerais. ${ }^{16}$ Ele vinha desenvolvendo estudos sobre a doença de Chagas na Faculdade de Medicina da Universidade de Minas Gerais, além de realizar experiências com inseticidas em algumas localidades do interior do estado. ${ }^{17}$ Com a ajuda dos destacamentos da Polícia Militar mineira cujo hospital, em Belo Horizonte, havia sido fundado e dirigido por seu pai-, Pellegrino realizou amplo levantamento pelo qual se concluiu que 204 dos 316 municípios mineiros possuíam vetores da doença e, em 143 deles, os insetos estavam infectados pelo T. cruzi. A partir destes dados, o autor fez um mapa dos principais focos da infecção no estado - tais dados foram apresentados em artigo de Pellegrino e Borrotchin (1948).

Na mesma ocasião em que se iniciava a colaboração com Pellegrino, Dias recebeu de Aragão, para ser testado, um novo produto contra os barbeiros: "uma lata de inseticida para gafanhoto, que me foi dada pela Imperial Chemical, o qual contém gamexane, que afirmam ser mais ativo do que o DDT". ${ }^{18}$ Dias e Pellegrino passaram a aplicar o produto em ensaios em Bambuí e em Santa Juliana, no Triângulo Mineiro. Os primeiros resultados foram bastante positivos. Vários tipos de gamexane (isômero gama do hexaclorociclohexano ou $\mathrm{BHC}$ ) foram trazidos ao posto por um técnico daquela indústria inglesa de inseticidas. ${ }^{19}$ Conforme os testes prosseguiam, Pellegrino animava-se com a perspectiva de ampliar 
os ensaios para outras regiões do estado e de conseguir a adesão das autoridades sanitárias para o projeto. Em carta, sugeriu a Dias as estratégias políticas e científicas a serem tomadas nesse sentido:

Estive pensando sobre o plano de profilaxia da doença de Chagas em uma área mais ou menos extensa do Estado. Acho que o modo mais prático é conseguirmos o auxílio de vários modos: o Departamento Estadual de Saúde poderá fornecer o gamexane e as bombas; a Força Policial poderá ceder elementos destacados nas diversas cidades e distritos e nós daremos instruções a estes elementos e faremos o controle geral. Assim poderemos tomar uma área bem grande do Estado [como o] Triângulo Mineiro (...), fazendo as mesmas experiências em larga escala. (...) Amanhã vou escrever ao Dr. Aragão dando os resultados das primeiras experiências feitas em Santa Juliana; ficará muito satisfeito. Acho muito importante fazermos, logo que tivermos material suficiente, um trabalho sobre o gamexane como destruidor dos transmissores da doença de Chagas. O 'furo' neste caso não será dado por experiências de campo em larga escala (tomam muito tempo e o controle é muito difícil) mas por experiências efetuadas no laboratório bem conduzidas, que ditem normas definitivas para os trabalhos de campo (trabalho básico). ${ }^{20}$

Em nova carta, Pellegrino reforçou ainda mais seu entusiasmo com o produto:

Vou começar esta carta com uma boa notícia. Acho que o gamexane P.530 resolverá o importantíssimo problema da profilaxia da doença de Chagas. Talvez pense o Sr. que eu esteja exagerando, mas não é. Estivemos em Bambuí durante mais de uma semana e lá pude experimentar todos os preparados à base de gamexane (...). Os resultados foram fabulosos. ${ }^{21}$

Em maio de 1948, Dias e Pellegrino publicaram no Brazil-Medico o primeiro trabalho descrevendo a ação do gamexane sobre os barbeiros, tomando-se por base as experiências conduzidas em laboratório (conforme sugestão de Pellegrino), nas quais se incluiu um ensaio comparativo com o DDT (Dias \& Pellegrino, 1948). Na mesma ocasião, os argentinos também tornaram público seu otimismo quanto a este produto, que vinham igualmente testando em ensaios experimentais (Romaña \& Abalos, 1948). Apesar de reconhecerem restrições de natureza técnica, Dias e Pellegrino (1948: 191) comemoravam as perspectivas trazidas pelo produto, que, segundo eles, poderia ser a tão procurada arma contra o barbeiro: 
"Embora não seja o produto ideal pelas suas propriedades e pelo seu custo, não resta dúvida que o Gamexane constitui um novo recurso de valor para a luta contra os transmissores da doença de Chagas". ${ }^{22}$

Diante deste recurso, Dias reforçaria, então, sua crença quanto à perspectiva da erradicação e passaria a propagandeá-la. Embora continuasse reconhecendo que esta era uma "tarefa para várias gerações" (Dias, 1948b: 1.162), chamava a atenção para o fato de que a ciência vinha dando passos importantes para concretizá-la. Em comunicação à VI Conferência Pan-Americana de Diretores Nacionais de Saúde, realizada na cidade do México em outubro de 1948, este foi o principal tom de sua apresentação (Dias, 1948b). Quase quarenta anos depois da descoberta, os cientistas declaravam-se de posse de um instrumento concreto contra a tripanossomíase americana e passariam a reivindicar providências, por parte dos organismos sanitários para implementar campanhas de profilaxia com base na desinsetização dos domicílios.

\section{O Primado da Clínica: o olhar da cardiologia}

O estudo clínico da doença constituiu também uma prioridade de pesquisa do CEPMC. Desde o início, a opção foi privilegiar o estudo das formas crônicas, terreno mais 'pantanoso' no que se referia à caracterização clínica proposta por Chagas e aos métodos de diagnóstico. As dificuldades de verificação parasitológica nesta fase, tanto durante a vida do doente quanto em exames post-mortem, tornavam imperativo o diagnóstico clínico como meio para orientar a realização dos exames laboratoriais.

Na revisão em que sintetizou as dúvidas em torno das formas crônicas da tripanossomíase, o parasitologista da Escola de Medicina Tropical de Liverpool, Warrington Yorke (1937), assinalou que, dentre as formulações propostas por Chagas, a mais promissora era a que dizia respeito à forma cardíaca. Os especialistas reconheciam a alta incidência de distúrbios cardíacos, muitas vezes levando à morte, em regiões da América do Sul nas quais proliferavam barbeiros infectados com o T. cruzi e onde haviam sido identificados casos agudos da doença. Desde os trabalhos de Gaspar Vianna, as pesquisas anatomopatológicas com casos agudos e animais infectados haviam demonstrado a tendência do parasito em se localizar no músculo cardíaco durante a fase inicial da infecção, além de evidenciar as lesões por ele provocadas neste órgão. Contudo, salientou, 
não estava ainda esclarecida a evolução destas lesões cardíacas quando estes casos agudos escapavam do óbito e evoluíam para a fase crônica. Chagas e seus colaboradores haviam descrito em linhas gerais os distúrbios cardíacos que consideravam mais freqüentes nos doentes crônicos e, em algumas autópsias, haviam identificado certas alterações patológicas no coração que qualificaram como típicas à doença. Ainda assim, Yorke afirmou (1937: 289): “(...) whether these cardiac lesions are really characteristic of chronic Chagas' disease and can be distinguished from other forms of myocarditis, such as that due to syphilis, is open to doubt" ${ }^{23} \mathrm{Ou}$ seja, não se considerava comprovada a relação de causa e efeito entre os processos patológicos no miocárdio durante a fase crônica e a ação patogênica do T. cruzi. Nos termos de Charles Rosenberg (1992c), os cientistas requeriam mais pesquisas/evidências para reconhecerem tais distúrbios como definidores de uma 'entidade clínica específica'. A seguinte formulação de Yorke (1937: 290) sintetiza a percepção de que este era um caminho difícil, mas promissor, para as investigações:

There seems, on the whole, to be a prima facie case that American trypanosomiasis may actually be responsible for a good deal of the heart disease which is apparently so common in certain endemic areas in Brazil, Uruguay and the Argentine, and the cause of so many early deaths. The chronic cardiac form of the disease may be a sequel to an acute infection in infancy or the consequence of repeated infection in later life. If this should eventually prove to be the case, then American trypanosomiasis will indeed assume a pathological significance of the first magnitude. The subject is obviously one which urgently requires much further work. ${ }^{24}$

Vários dos artigos publicados pelos pesquisadores do CEPMC citariam estas palavras de Yorke. Este era o estado da arte e o principal desafio para as pesquisas sobre a tripanossomíase americana. A avaliação de que se fazia necessário um estudo aprofundado das características clínicas da doença crônica levou, desde a concepção do projeto do posto de Bambuí, à decisão de priorizar a forma cardíaca. Por orientação do próprio diretor do IOC, antes de assumir a direção do posto, Emmanuel Dias assistiu a um curso de cardiologia oferecido pelos professores Oscar Ferreira e Edgar Magalhães Gomes, na Santa Casa da Misericórdia do Rio de Janeiro. Foi nesta ocasião, em agosto de 1943, que ele encontrou aquele que seria o principal responsável pela contribuição do CEPMC ao estudo clínico da doença, sob a perspectiva citada por Yorke, ou seja, a 
de torná-la uma entidade clínica definida - e reconhecida - essencialmente como uma cardiopatia crônica específica.

Francisco Laranja era assistente do professor Magalhães Gomes, encarregando-se da parte de eletrocardiografia nos cursos que este oferecia, desde 1940, na Santa Casa. Em 1938, ainda estudante de medicina, ingressou como auxiliar administrativo no Instituto de Aposentadoria e Pensões dos Industriários (Iapi) e, a partir do ano seguinte, passou a auxiliar os médicos então concursados (entre eles Magalhães Gomes) a realizarem as perícias nos segurados que requeriam aposentadoria por problemas médicos. ${ }^{25}$

Como a principal causa de incapacitação para o trabalho eram as doenças cardiovasculares, o Iapi montou um serviço de cardiologia que, segundo Laranja (1978, 1986), era o melhor do Rio de Janeiro, sobretudo na área de eletrocardiografia, tanto do ponto de vista técnico quanto no que se referia à experiência clínica: o instituto tinha o mais moderno eletrocardiógrafo e a maior estatística de cardiologia da cidade. Os médicos que ali trabalhavam eram requisitados a dar cursos de especialização e as teses da Faculdade de Medicina eram feitas com material e equipamentos do Iapi, que teve assim um papel decisivo no processo de institucionalização da cardiologia como especialidade dentro da clínica médica. ${ }^{26}$

Laranja trabalhou inicialmente como eletrocardiografista no consultório de Magalhães Gomes no Iapi e aos poucos passou a responsabilizar-se também pela interpretação dos exames. A experiência clínica que conquistou neste serviço era bastante específica e diferente do treinamento oferecido pelo curso médico. Nas enfermarias da Santa Casa, o estudante examinava e acompanhava diariamente um grupo pequeno de doentes. No Iapi o médico via o paciente apenas uma vez, mas atendia a um número bem maior de indivíduos. Era como se fosse um ambulatório específico de cardiologia, o que proporcionava o acesso a um universo amplo e diversificado de enfermidades cardíacas e, conseqüentemente, um treinamento intensivo nos métodos de diagnóstico neste campo (Laranja, 1978, 1986). Quando conheceu Dias, em 1943, Laranja havia examinado mais de cinco mil doentes cardíacos no Iapi e estava atualizado face aos avanços que então marcavam a cardiologia, especificamente a eletrocardiografia, técnica que, na época, era "um negócio que pouca gente sabia" (Laranja, 1986: fita 4, lado B). ${ }^{27}$ 
Desde sua invenção, pelo holandês William Einthoven, nos primeiros anos do século XX, o eletrocardiógrafo passou por substantivos aperfeiçoamentos técnicos com vistas a possibilitar seu uso na prática clínica, o que ocorreu especialmente na década de 1920, momento decisivo na institucionalização da cardiologia como especialidade (Lawrence, 1985; Burnett, 1985). No Brasil, Carlos Chagas foi pioneiro ao utilizar, em seus primeiros trabalhos sobre a doença de Chagas, o método eletrocardiográfico no estudo clínico. Nos anos seguintes, outros médicos, especialmente em São Paulo, buscariam instalar eletrocardiógrafos nas faculdades de medicina e familiarizar-se com os então incipientes conhecimentos para o manejo e a interpretação de seus traçados. Em 1928, a companhia Frank Sanborn produziu uma versão portátil do aparelho, que se aperfeiçoou bastante em relação ao galvanômetro de corda de Einthoven ao funcionar com válvulas. Isso representou um avanço expressivo na possibilidade de sua difusão entre os médicos.

Do ponto de vista da qualidade e do alcance dos registros eletrocardiográficos, uma contribuição decisiva foi dada pelo norte-americano Frank Wilson. Em 1934, ele desenvolveu procedimentos técnicos (as derivações precordiais múltiplas) que, por aumentar o número de pontos onde se colocavam os eletrodos no corpo, conferiam maior precisão à capacidade de localizar e qualificar os distúrbios elétricos do coração. Com o estreitamento das relações entre Brasil e Estados Unidos em função da guerra, aumentou a ida de médicos brasileiros àquele país para realizar cursos ou estágios em hospitais americanos, facilitando a incorporação da nova metodologia. Em 1942, o paulista Dante Pazzanese, que havia feito estágio com Wilson na Universidade de Michigan, trouxe-o ao Brasil para ministrar um curso na Escola Paulista de Medicina, no qual tomaram parte médicos de várias regiões do país, entre os quais Magalhães Gomes e Francisco Laranja. Num indício do crescente interesse pela especialidade, Pazzanese fundaria, no ano seguinte, juntamente com outros médicos, a Sociedade Brasileira de Cardiologia. ${ }^{28}$

Uma evidência do "vivo interesse que as observações e pesquisas do aparelho circulatório" vinham despertando, naquela época, a partir das novas técnicas que conferiam "progressos imensos à cardiologia" (Capriglione \& Benchimol, 1941: 4), foi o livro publicado, em 1941, por Luiz Capriglione (catedrático da Faculdade de Ciências Médicas e livredocente da Universidade do Brasil) e Aarão Benchimol (assistente da mesma faculdade e cardiologista da Caixa de Aposentadoria e Pensóes 
dos Serviços Telefônicos). ${ }^{29}$ No prefácio do livro, o ex-catedrático de clínica médica da Faculdade Nacional de Medicina, Maurício de Medeiros, destacou a grande visibilidade conferida à cardiologia em função dos "novos métodos experimentais de pesquisa" e da "multiplicidade de métodos semiotécnicos" então surgidos:

(...) os métodos propedêuticos se têm aperfeiçoado sensivelmente nestes últimos tempos, permitindo penetrar em detalhes que escapavam à observação e rever conceitos e teorias clássicas, que os fatos melhor observados hoje à luz desses novos métodos não podem confirmar (...). Há 30 anos, por exemplo, a eletrocardiografia era mais uma curiosidade de laboratório de Fisiologia, do que um meio de indagação diagnóstica (...). Os anos foram se passando. As observações se foram acumulando. Hoje há toda uma ciência de Eletrocardiografia, de preciosa utilidade para o cardiologista. E, embora me pareça ainda uma ciência vacilante e incerta, nos seus detalhes, grandes linhas gerais de aquisições já foram por ela estabelecidas de tal forma que o próprio clínico não especializado precisa estar ao corrente de tais aquisições, e o experimentador precisa documentar suas experiências com os traçados eletrocardiográficos. (Capriglione \& Benchimol, 1941: 2-3)30

A decisão de Dias de investir no estudo da forma cardíaca da doença de Chagas, recrutando profissionais com treinamento clínico específico, ocorreu, portanto, num momento em que se disseminavam novos recursos institucionais e técnicos para o conhecimento e o manejo das doenças cardíacas. Além de suas credenciais profissionais, um fator extracientífico tornava Francisco Laranja ainda mais indicado ao empreendimento que Aragão e Dias estavam por iniciar: filho de fazendeiros de São Borja, o cardiologista era afilhado de batismo de Getúlio Vargas.

Quando terminou o curso na Santa Casa da Misericórdia, em 1943, Dias foi procurar Laranja em seu consultório particular, que na época já gozava de grande prestígio no meio médico. Informando-lhe sobre o posto de Bambuí, propôs que examinasse alguns chagásicos. Num indício da descrença que pairava sobre a doença na época, ao relatar o encontro, Laranja (1986: fita 5, lado A) registrou que este era um assunto que praticamente desconhecia: "Na faculdade, a gente aprendia que tinha um tal de Trypanosoma cruzi, via no microscópio, na cadeira de parasitologia, mas nunca tinha visto nenhum caso de doença de Chagas, não se falava em doença de Chagas. (...) ninguém tinha visto um caso. Era a tal doença que existe, mas ninguém viu". ${ }^{31}$ Aceito o convite, Laranja foi até o Hospital Evandro Chagas, no IOC, examinar alguns doentes 
crônicos trazidos de Bambuí, nos quais a reação sorológica de fixação do complemento havia sido positiva para infecção pelo T. cruzi. Sobre aquele momento, lembrou Laranja, numa formulação particularmente interessante:

(...) entre esses doentes tinha dois que me chamaram muito a atenção. Era uma enorme cardiopatia, completamente diferente de tudo o que eu tinha visto naqueles 4 ou 5 anos (...) no Iapi, na Santa Casa. Eu disse: 'o que é isso? Eu não sei. Mas que não é o que eu estou acostumado a ver aqui, essas doenças cardíacas comuns, não é. É diferente’. E aí eu me interessei. (Laranja, 1986: fita 5, lado A; grifos meus) ${ }^{32}$

Este foi um evento decisivo para o estudo da forma cardíaca crônica da doença de Chagas que viria a ser empreendido pelo CEPMC. No caminho cognitivo de 'estabilização' da tripanossomíase americana como fato científico, como entidade nosológica individualizada, o olhar treinado de um médico experiente no campo disciplinar específico no qual se pretendia definir aquele objeto confirmava que, antes de tudo, tratava-se de uma cardiopatia 'incomum, diferente'. Para se estabelecer a peculiaridade da cardiopatia devida à ação do T. cruzi, seria fundamental contrapor e diferenciar seus traços em relação a outras cardiopatias. Daí a importância da experiência clínica de Laranja. Este foi um movimento essencial do que se consubstanciaria como um novo frame para a doença, não apenas no sentido da conformação deste enquadramento, mas dos recursos para se lhe imprimir força persuasiva.

A partir de então, Laranja entusiasmou-se com o desafio e, juntamente com Magalhães Gomes, foi até Bambuí levando seu eletrocardiógrafo. Depois de um mês no posto, no qual examinou diversos doentes crônicos e confirmou suas impressões iniciais quanto ao caráter atípico de suas alterações eletrocardiográficas, voltou ao Rio disposto a estudá-las sistematicamente. Iniciava-se assim a participação de Laranja junto ao IOC. ${ }^{33}$ O objetivo era demonstrar que aquela 'cardiopatia diferente' era, de fato, provocada pela ação do T. cruzi no miocárdio. Ainda que Carlos Chagas tivesse salientado a importância da forma cardíaca na fase crônica e mencionando alguns sinais clínicos específicos pelos quais ela se manifestava, tratava-se de criar as condições para que esta cardiopatia fosse aceita como uma entidade clínica real e peculiar, a materializar a existência e singularidade da própria doença de Chagas. Ou seja, tratava-se de fazer daquela cardiopatia a moldura primordial a conferir à tripanossomíase americana 
a especificidade que, segundo Rosenberg (1992c), constitui o atributo essencial das doenças como categorias passíveis de serem conceituadas para além das manifestações idiossincráticas das experiências individuais.

\section{Novos Traçados para a Doença: a cardiopatia chagásica crônica}

O ato do diagnóstico constitui, segundo Rosenberg (2002), a instância fundamental do processo de constituição cognitiva e social das doenças como conceitos dotados de especificidade. Nesse sentido, os cientistas do CEPMC contavam com um poderoso instrumento: um eletrocardiógrafo moderno, a ser operado por um especialista reconhecido como tal. Desde o século XIX, estes instrumentos tecnológicos vinham sendo cada vez mais enaltecidos como meios de se estabelecer, com precisão, a natureza e as características das doenças. Na medida em que a mensuravam em unidades-padrão e as tornavam visíveis por meio de gráficos, curvas e traçados, a eles se atribuía a capacidade de revelar seus contornos 'objetivos'.

O papel que estes aparelhos desempenham na produção e na validação do conhecimento científico é tema recorrente nos estudos históricos e sociais da ciência. Latour e Woolgar (1997), por exemplo, propuseram o conceito de "inscrição literária" para caracterizar os diversos registros visuais que formalizam os fenômenos que servem de matéria-prima para a elaboração dos enunciados científicos. Os aparelhos que os produzem - os "inscritores" - assumem grande espaço e importância nos laboratórios, na medida em que são vistos como meios de conferir existência material aos fenômenos investigados e, em última instância, à própria natureza. Segundo os autores, as inscrições literárias não são indicadores ou representações da presença de uma substância 'exterior' ou 'prévia', uma vez que esta substância só se configura como tal sob a forma material de tais inscrições. É à realidade produzida pelos inscritores que os cientistas se referem quando falam das entidades 'objetivas' por eles enunciadas. Uma característica essencial da maneira como os inscritores são utilizados no laboratório é que, uma vez obtidas as inscrições, rapidamente são esquecidos os procedimentos e as etapas circunstanciais que conduziram à sua produção, sendo estes relegados ao domínio da 'pura 
técnica'. Desta forma, sublinham Latour e Woolgar (1997), alcança-se o efeito persuasivo de se considerar o fenômeno em questão um objeto 'natural', dotado de uma realidade prévia e totalmente independente.

O recurso à moderna eletrocardiografia, sob a expertise de Laranja, foi o caminho preferencial adotado pelo CEPMC para enfrentar os desafios da pesquisa clínica da doença de Chagas. Desta empreitada, participariam também Dias (que continuou seus estudos sobre cardiologia) e Genard Nóbrega, médico do Hospital Evandro Chagas, que se encarregou do acompanhamento diário dos doentes trazidos de Bambuí. Da mesma forma que nos estudos destinados à profilaxia, Dias montou uma estrutura de coleta de informações e de realização de exames necessários à investigação clínica. ${ }^{34} \mathrm{Na}$ medida em que o posto proporcionava consultas, exames e medicamentos gratuitos para a população, atraindo doentes de toda a região, potencializavam-se as chances de registro de novos casos (Imagem 20). ${ }^{35}$

O trabalho de conscientização entre os clínicos locais, feito desde a época do Serviço de Estudo das Grandes Endemias (Sege), também era fundamental, na medida em que eles vinham se familiarizando com a doença e encaminhando ao posto casos suspeitos. Assim, eram realizados exames sistemáticos em todos os possíveis portadores da doença que acorriam ao CEPMC, mediante técnicas para detecção dos casos agudos e também procedimentos de diagnóstico dos casos crônicos, como a reação de fixação do complemento e o xenodiagnóstico. Este último procedimento foi aplicado em larga escala na população da região. Para isso, eram usados os barbeiros criados no próprio CEPMC. ${ }^{36}$

Os casos humanos identificados mediante esta rotina de exames serviam não apenas para o estudo clínico, mas também para impulsionar avanços técnicos nos próprios métodos de diagnóstico laboratorial da infecção, tendo em vista que proviam material (amostras de sangue) para as pesquisas imunológicas feitas em Manguinhos. Como salientou a revisão de Yorke (1937), o aperfeiçoamento destes métodos, especialmente do teste sorológico de fixação do complemento (reação de Guerreiro e Machado), era outra vertente de investigação fundamental para superar as dúvidas sobre as formas crônicas da enfermidade. ${ }^{37}$ Em 1944, os pesquisadores do IOC Júlio Muniz e Gilberto de Freitas desenvolveram, utilizando material proveniente de Bambuí, nova maneira de preparar o antígeno necessário à reação de fixação do complemento (RFC), o que veio conferir maior sensibilidade ao método (Muniz \& Freitas, 1944a, 
1944b).$^{38}$ Este avanço facilitou o diagnóstico de novos casos crônicos, beneficiando as pesquisas clínicas.

Em junho de 1945, Dias, Laranja e Nóbrega apresentaram, na 2a Reunião da Sociedade Brasileira de Cardiologia, no Rio de Janeiro, os primeiros resultados de seu estudo eletrocardiográfico da doença de Chagas, feito com 183 casos crônicos identificados em Bambuí, num universo diversificado de faixa etária e de tempo de infecção. Este trabalho, acrescido de uma detalhada revisão dos enunciados clínicos sobre a doença, foi publicado nas Memórias do Instituto Oswaldo Cruz naquele ano e constituiria uma das principais referências da pesquisa clínica desenvolvida pelo CEPMC (Dias, Laranja \& Nóbrega, 1945).

A estrutura narrativa do texto é expressiva do objetivo sob o qual ele foi produzido. Num traço recorrente em diversas publicações do posto, os autores tomam como ponto de partida a descoberta de Carlos Chagas (descrita sob um tom épico) e suas principais formulações sobre a doença. Em seguida, apresentam os resultados das investigações em Bambuí, ressaltando o quanto elas vinham confirmar a 'grande obra' do mestre. Contudo, num percurso em que certos enunciados são deixados de lado e outros aprofundados, os autores vão construindo um novo 'retrato' da doença, diferenciado do quadro geral do qual haviam partido, pela ênfase e pelo tratamento conferido a alguns de seus traços. A primeira ênfase reveladora incide sobre a noção de que a tripanossomíase americana é, fundamentalmente, "uma infecção crônica de longa duração" (Dias, Laranja \& Nóbrega, 1945: 508) caracterizada por alterações estruturais e funcionais resultantes da localização do parasito em órgãos e tecidos. Chagas insistiu sobre este ponto desde o início de seus trabalhos, mas as dúvidas acerca das formas crônicas fizeram com que as formas agudas assumissem maior relevo no desenho da doença e muitos acreditassem que esta se restringia a tal período inicial. Este era o primeiro traço a ser fixado: tratava-se de uma enfermidade essencialmente crônica.

Após descrever rapidamente, sem muitos comentários, os enunciados de Chagas sobre os distúrbios endócrinos (o "problema do bócio") e a 'forma nervosa' - aspectos bastante controvertidos -, os autores ressaltam que, pela "predileção particular [do parasito] em localizar-se no miocárdio", a forma cardíaca constitui "a forma clínica mais freqüente da doença em sua fase de cronicidade", "a verdadeira expressão clínica da doença”, e que, portanto, é sobre este aspecto que eles se deterão em 
suas considerações (Dias, Laranja \& Nóbrega, 1945: 520-521). Estava explicitada a segunda ênfase que conformaria o fio condutor do trabalho. Se os autores pretendiam corroborar o desenho de Chagas para a doença, eles imprimiam-lhe um enquadramento particular que produzia outra figura, esboçada por Chagas em seus últimos trabalhos, mas que não se completara tendo em vista que ele não deixara totalmente de lado os outros aspectos mais frágeis daquele desenho "multiforme", para usar a expressão a que recorreu várias vezes. Efetuando, desta vez, um recorte efetivo, Dias, Laranja e Nóbrega estabelecem: a tripanossomíase americana é uma doença crônica e 'cardíaca'. É bastante sugestivo o termo usado, pela primeira vez, para caracterizar este novo 'selo' da doença: “cardiopatia chagásica crônica” (Dias, Laranja \& Nóbrega, 1945: 522). Ainda que fosse uma 'parte', esta cardiopatia apresentava-se, em si mesma, como uma entidade clínica específica, a representar a própria doença como um todo.

Tal recorte foi formalizado e expresso nos dados eletrocardiográficos: dos 183 indivíduos classificados como casos crônicos (mediante a RFC ou o xenodiagnóstico), noventa deles (49,2\%) tiveram eletrocardiogramas (ECGs) que evidenciavam lesão no miocárdio (Dias, Laranja \& Nóbrega, 1945: 521). Apesar de os exames terem sido feitos num conjunto restrito de casos, a noção de que cerca de 'metade' dos casos crônicos de doença de Chagas manifestava a forma cardíaca seria reafirmada, a partir de então, como um enunciado central nas várias publicações do grupo. Antes mesmo de detalhar tais alterações, de modo a apresentar as evidências de que elas eram específicas à tripanossomíase, Dias, Laranja e Nóbrega lançaram mão de uma manobra conceitual interessante para dar conta da outra metade dos casos que não apresentaram sinais de comprometimento cardíaco. Conforme assinalado por Chagas, a maioria dos indivíduos que evoluem para a fase crônica ingressa na chamada forma indeterminada (assintomática) da infecção e só manifestam aqueles sinais muitos anos depois. Uma vez que não há 'cura espontânea' (ou seja, o parasito continua agindo no organismo) e os dados até então produzidos comprovavam a alta incidência de perturbações cardíacas entre os casos crônicos, os autores do CEPMC afirmam: “(...) é justificado considerar-se como cardíacos potenciais todos os pacientes que contraíram a enfermidade e nos quais não se possa ainda demonstrar a presença de lesão cardíaca” (Dias, Laranja \& Nóbrega, 1945: 521; grifo meu). Ou seja, a forma indeterminada constituía uma 'passagem' para a forma cardíaca. O termo 'cardíacos potenciais' é emblemático da operação de enquadramento que se estava 
processando: mesmo que não fosse possível determinar sintomas ou sinais, o mal de Chagas deveria ser qualificado como uma doença cardíaca. Além disso, sugerindo tratar-se de uma moléstia 'insidiosa', que agia em silêncio, a noção produzia o alerta, de grande efeito persuasivo face ao objetivo dos cientistas, de ressaltar a importância médico-social do tema: a qualquer momento, o indivíduo poderia ser surpreendido pelos danos produzidos pelo parasito sobre seu coração. Em relação aos casos assintomáticos, outro enunciado de Chagas seria reforçado, neste texto de 1945 e nos subseqüentes, igualmente com o sentido de potencializar a caracterização da doença como cardiopatia à qual todos deveriam ficar atentos: a alta incidência de 'morte súbita' entre indivíduos jovens, aparentemente saudáveis, em zonas infestadas por barbeiros. O termo, já utilizado por Chagas, também era retoricamente impactante e teria grande destaque nas representações da doença junto ao público leigo, produzindo a idéia de que, nas áreas endêmicas, era comum as pessoas morrerem de repente, vitimadas por uma doença da qual não sabiam ser portadoras (Dias, Laranja \& Nóbrega, 1945). ${ }^{39}$

Quanto aos casos com sinais de cardiopatia, Dias, Laranja e Nóbrega (1945) analisam, neste trabalho, os dados produzidos em Bambuí, no intuito de qualificar tais alterações. Como havia mencionado Chagas, os sintomas da cardiopatia chagásica, em si, não tinham nada de específico, ocorrendo também em outras cardiopatias. As 'pistas' da peculiaridade da cardiopatia chagásica deveriam ser buscadas não na natureza dos sinais, mas no seu modo de apresentação, ou seja, em sua freqüência e no arranjo pelo qual se combinavam entre si. Tais sinais poderiam ser identificados de diversas maneiras: pelas queixas dos próprios doentes, pelas várias técnicas de exame físico feito pelo médico (palpação, percussão e ausculta) e pelos exames mais especializados, como as radiografias e, principalmente, os ECGs. Também aqui os autores associam suas próprias conclusões aos enunciados de Chagas. Primeiramente, reiteram a formulação geral, proposta em 1910, de que as arritmias apareciam como a principal manifestação da cardiopatia provocada pelo T. cruzi. Em seguida, destacam como outro indício de especificidade a alta incidência e importância, entre as diferentes modalidades de arritmias, dos distúrbios da condução do estímulo elétrico (83\% dos ECGs anormais) e, em menor escala, dos distúrbios em sua formação (42\%) (Dias, Laranja \& Nóbrega, 1945: 531). ${ }^{40}$ Com maior detalhamento, passam então a apontar quais tipos de distúrbios eram mais freqüentemente detectados. Apesar de ser 
possível identificar certas alterações pelo exame físico do paciente, o mais comum era que elas se mostrassem apenas pelo método eletrocardiográfico. ${ }^{41}$

Apresentando um quadro com os níveis de freqüência de cada modalidade de alterações eletrocardiográficas nos noventa casos em que elas tinham sido detectadas, e analisando cada uma sempre em referência às colocações de Chagas, os autores chegam, então, às conclusões centrais deste trabalho de 1945. As pesquisas indicavam que dois tipos de arritmias se apresentavam com freqüência particularmente alta e peculiar e, portanto, poderiam ser considerados elementos presuntivos da cardiopatia crônica chagásica (CCC). Uma das arritmias dizia respeito aos bloqueios auriculoventriculares, especialmente ao bloqueio A-V total, que já havia sido destacado por Chagas (sobretudo em seu trabalho com Villela, em 1922) como elemento diagnóstico importante da forma cardíaca crônica da tripanossomíase. Eis a formulação de Dias, Laranja e Nóbrega (1945: 535; grifos dos autores):

Bloqueio A-V total - (...) sua presença em indivíduos com menos de 40 anos deve fazer suspeitar esta etiologia, mormente se o paciente mora ou provém de zona infestada por barbeiros. Sem dúvida, chama a atenção a alta incidência (10\%) do bloqueio A-V total na miocardite crônica esquizotripanósica, incidência que é muito maior que a encontrada em qualquer outro tipo etiológico de cardiopatia. Já dizia Chagas ser esta por excelência a doença do pulso lento permanente.

Além deste, os autores se referem a outro distúrbio que aparecia com freqüência extraordinariamente alta, mas que não havia sido mencionado nos trabalhos de Chagas: o bloqueio de ramo direito (BRD). A detecção desta alteração, salientam os autores, tinha sido possível graças às novas técnicas da eletrocardiografia, como o uso das derivações precordiais estabelecidas por Wilson, nos anos 1930. Sobre este aspecto da cardiopatia chagásica, eles afirmam:

Bloqueio de ramo direito - Constitui em nossa estatística a forma mais freqüente de distúrbio da condução, estando presente em $39 \%$ dos casos com eletrocardiogramas anormais (...). É, pois, essa uma incidência muito elevada, relativamente à que ocorre nas demais cardiopatias, nas quais os bloqueios intraventriculares constituem distúrbios pouco freqüentes. (Dias, Laranja \& Nóbrega, 1945: 540$)^{42}$ 
Estes dois sinais constituíam, assim, duas importantes 'evidências sugestivas' para o diagnóstico de casos da CCC:

A presença de bloqueio de ramo direito ou bloqueio A-V total em crianças ou adultos jovens deve fazer suspeitar a etiologia esquizotripanósica da cardiopatia, uma vez que esses distúrbios da condução são raros em outras cardiopatias que incidem em indivíduos jovens, e muito freqüentes na cardiopatia crônica chagásica. (Dias, Laranja \& Nóbrega, 1945: 551)

Outro aspecto enfatizado era a incidência da CCC por faixa etária. A partir dos dados coligidos em Bambuí, Dias, Laranja e Nóbrega (1945) confirmam que, diferentemente de outras cardiopatias, esta atingia, conforme Chagas já havia indicado, sobretudo indivíduos jovens, entre 10 e 45 anos. Destes, a maioria não ultrapassava os 55 anos de vida. Também neste caso, trata-se de um enunciado que teria implicações importantes nas representações e significados atribuídos à doença junto ao público mais amplo: a enfermidade atingia as pessoas em idade produtiva. Seguindo o mesmo raciocínio usado para os indivíduos assintomáticos, os autores salientam que, em confirmação ao alerta de Chagas, "o prognóstico desta cardiopatia é sempre grave” (Dias, Laranja \& Nóbrega, 1945: 555). Devido à persistência da ação do parasito sobre o coração, e não se dispondo de tratamento para revertê-la, a tendência era o aparecimento de insuficiência cardíaca, com progressiva deficiência funcional do coração, o que podia levar à morte por assistolia (parada cardíaca). Ao final do trabalho, foram sintetizados os traços fundamentais deste novo recorte da doença de Chagas. Dos traçados da eletrocardiografia emergia a imagem de uma doença crônica que, mesmo sem sintomas aparentes, acaba por comprometer o sistema cardíaco, incidindo, sobretudo, em indivíduos jovens, na idade produtiva, e cuja evolução é sempre grave e se expressa por certas arritmias com padrão de ocorrência peculiar.

Nos anos seguintes, à medida que aumentava o número de casos identificados pelo CEPMC, os cientistas reforçavam seus enunciados sobre o quadro eletrocardiográfico da CCC. Em 1946, Dias publicou um pequeno trabalho analisando 254 casos da doença (Dias, 1946a). Enfatizou tratar-se da mais numerosa casuística até então reunida numa mesma região do país, e destacou que, dos 207 ECGs realizados, 97 haviam manifestado alterações indicativas de lesão no miocárdio, com grande incidência de distúrbios na condução do estímulo, sobretudo BRDs e 
bloqueios A-V, o que confirmava a descrição feita em 1945. Também em 1946, no II Congresso Interamericano de Cardiologia, realizado no México, Laranja, Dias e Nóbrega expuseram as informações referentes a 357 casos crônicos, dos quais 208 (58\%) apresentaram traços de lesão no miocárdio. Como nos trabalhos anteriores, os autores assinalaram a alta freqüência de BRD - "a maior incidência deste distúrbio na patologia cardíaca" (Laranja, Dias \& Nóbrega, 1948a: 51) - e dos graus mais elevados de bloqueio A-V. A partir desta publicação os autores passariam a dar ênfase a outro sinal que também havia se manifestado com alta freqüência e se tornaria mais uma evidência sugestiva importante da CCC: as extra-sístoles ventriculares, consideradas por Chagas a arritmia mais característica da tripanossomíase americana crônica.

Em 1948, o CEPMC sistematizou os conhecimentos sobre a CCC em seus aspectos clínico-eletrocardiográficos essenciais. Em outro grande trabalho de revisão, com base na análise de mais de seiscentos casos da doença, Laranja, Dias e Nóbrega (1948b) forneceram novos dados sobre o que consideravam o quadro eletrocardiográfico específico desta cardiopatia - "um dos mais variados e curiosos que se encontra em cardiopatologia” (Laranja, Dias \& Nóbrega, 1948b: 506) -, apontando as manifestações clínicas relacionadas. Segundo eles, as evidências dos ECGs permitiam comprovar: "a expressão clínica por excelência da esquizotripanose crônica é a cardiopatia. Portanto, as manifestações desta orientarão o diagnóstico clínico" (Laranja, Dias \& Nóbrega, 1948b: 511 ; grifo dos autores).$^{43}$ Nas conclusões, ficava assim estabelecida a sistematização das formas clínicas da tripanossomíase americana: “a) Forma aguda; b) Formas crônicas: 1 - Forma indeterminada (cardíacos potenciais), 2 - Forma cardíaca (cardiopatia crônica). Os autores não encontraram no material estudado em Bambuí casos classificáveis como forma nervosa crônica" (Laranja, Dias \& Nóbrega, 1948b: 519). ${ }^{44}$ O recorte do esquema classificatório proposto por Chagas, fazendo com que dele permanecessem apenas os sinais cardíacos, foi o caminho pelo qual os pesquisadores do CEPMC produziriam as condições para o reconhecimento científico da entidade nosológica por ele descoberta. ${ }^{45}$ 


\section{Convencendo os que Ainda Queriam Ver o Parasito}

Ao mesmo tempo que estabeleciam a definição eletrocardiográfica da CCC, os cientistas associados ao CEPMC desenvolveram outros argumentos para sustentar a realidade/especificidade desta entidade clínica. Como afirmou o próprio Laranja (1986), a principal dificuldade era que, mesmo com as evidências eletrocardiográficas, alguns especialistas permaneciam céticos devido às dificuldades de demonstrar a presença do parasito nas lesões observadas no coração dos pacientes crônicos. Nos casos autopsiados, o exame, muitas vezes, identificava os efeitos da ação do T. cruzi no órgão, mas não o próprio parasito, prejudicando a aceitação do diagnóstico fundado nos critérios clínico-eletrocardiográficos e no teste sorológico. Era o mesmo problema enfrentado por Chagas: como provar a positividade do caso na ausência do parasito? Nas palavras de Laranja:

Se a gente não demonstrava o parasito, eles achavam que não era [CCC], que podia ser devido a uma outra causa, uma miocardite crônica de outra natureza. (...) A dificuldade era tal para a gente encontrar o parasito em certos casos que o Departamento de Anatomia Patológica [de Manguinhos] colocou um técnico só para fazer cortes e procurar o parasito. E levava semanas, até meses, trabalhando naquilo. Às vezes só depois de seiscentos, oitocentos cortes, é que se encontrava o parasito (...). (Laranja, 1986: fita 5, lado B $)^{46}$

Para contornar esta dúvida, os cientistas enfatizavam os aspectos epidemiológicos, a confiabilidade dos métodos laboratoriais de diagnóstico e as evidências de natureza experimental para os dados clínicos. A primeira destas estratégias foi mostrar que o padrão eletrocardiográfico detectado entre os casos reunidos em Bambuí era encontrado em outros grupos de população em áreas endêmicas. Para isso, passaram a realizar inquéritos entre indivíduos não previamente selecionados. Como dizia Laranja (1978), mais importante do que uma casuística elevada em termos absolutos era estabelecer 'percentuais' que pudessem fixar a idéia da alta incidência da CCC.

Dois inquéritos importantes foram realizados. Em 1947, Dias, Laranja e Pellegrino examinaram 312 indivíduos entre trabalhadores da Rede Mineira de Viação e suas famílias. Ao realizar o ECG nos que tiveram reação sorológica positiva para a infecção chagásica e também naqueles em que o teste foi negativo, os cientistas comprovaram "importantes 
diferenças na incidência e no tipo de alterações do traçado nos dois grupos" (Dias, Laranja \& Pellegrino, 1948: 412). No grupo negativo, apenas $3,5 \%$ apresentaram alterações no miocárdio, ao passo que no grupo positivo o percentual foi de $32,5 \%$, sendo que $73,5 \%$ destas alterações eram constituídas de distúrbios da condução, especialmente o BRD. O fato de estarem analisando uma população não selecionada, além de constituir uma metodologia inovadora que seria recomendada como modelo a partir de então, era mais um fator persuasivo para a tese quanto à "importância da doença de Chagas na etiologia de cardiopatias crônicas em área infestada por triatomíneos" (Dias, Laranja \& Pellegrino, 1948: 413). O inquérito da Rede Mineira de Viação, apresentado em 1949 na Primeira Reunião sobre Doença de Chagas promovida pela Repartição Sanitária Pan-Americana na Argentina (Laranja, Dias \& Pellegrino, 1950), foi pioneiro também por utilizar o método eletrocardiográfico como critério de investigação epidemiológica. Como dizia Laranja (1986: fita 5, lado B), "o eletrocardiógrafo foi usado como instrumento de avaliação de um problema de saúde pública talvez pela primeira vez”.

Outro inquérito foi realizado, em 1948, no Hospital da Santa Casa da Misericórdia de Belo Horizonte. Entre os 181 internos examinados, sem seleção prévia, cerca de $20 \%$ apresentaram provas sorológicas positivas para a doença. Destes, $52 \%$ tinham cardiopatia, com traçados muito semelhantes ao padrão descrito pelo CEPMC. Os cientistas concluíram que "em conjunto, estes resultados confirmam a importância de certas alterações eletrocardiográficas (...) no diagnóstico da forma crônica da doença de Chagas" (Pellegrino \& Borrotchin, 1948: 446), bem como a tendência de estas alterações incidirem sobre indivíduos jovens. O inquérito, portanto, comprovava os dados produzidos em Bambuí e demonstrava que a doença de Chagas era o principal fator etiológico de problemas cardiovasculares nas áreas endêmicas. Desse modo, os autores reivindicavam que a CCC figurasse como um elemento etiológico específico entre os critérios de diagnóstico definidos pela New York Heart Association.

A ênfase discursiva nos números e nos percentuais decorrentes das pesquisas do CEPMC seria uma constante nos trabalhos de Dias, especialmente naqueles em que se enfatizavam o impacto social da doença e a necessidade de providências por parte das autoridades sanitárias, como a realização de uma campanha de profilaxia. Em artigo de 1949, ele indicou que das 2.084 reações sorológicas feitas até então por pesquisadores em Minas, São Paulo e Goiás, 959 (45\%) haviam sido positivas para 
a infecção chagásica, o que confirmava que "em cerca de metade dos casos há probabilidade da existência de lesão miocárdia, e que a outra metade é constituída de indivíduos sujeitos a neles se instalar com o tempo a cardiopatia esquizotripanósica (cardíacos potenciais)” (Dias, 1949b: 218). O ‘alerta’ vinha como complemento necessário aos números apresentados:

Atentai bem na trágica eloqüência destas cifras, senhores médicos rurais. Atentai nelas bem, senhores sanitaristas, a quem cabe a grave responsabilidade de zelar pela saúde do nosso povo. Procurai agora avaliar a significação da infecção chagásica como fator de primeira grandeza entre os que concorrem para arruinar a saúde do homem rural, reduzindo-lhe a capacidade produtora (...). (Dias, 1949b: 681-682)

Embora reiterassem que a casuística produzida, somente na região de Bambuí e adjacências, era a mais expressiva até então no país (sendo bem mais elevada do que a referida por Chagas e todos os outros pesquisadores brasileiros), Dias e seus colaboradores reconheciam que, em termos absolutos, os números permaneciam insuficientes a fim de expressar a real magnitude da endemia. ${ }^{47}$ Assim, eles se esforçavam em convencer a sociedade, especialmente os médicos e os responsáveis pelas políticas de saúde, de que os percentuais gerados pelos inquéritos eram os números que efetivamente deveriam ser levados em consideração para dimensionar a importância médico-social do problema. Na trajetória de uma doença cujas cifras haviam sido motivo de tantas polêmicas, o recurso a números expressos em porcentagens era uma forma particularmente eficaz de se lhes imprimir poder de persuasão. Na ausência de um mapeamento sistemático e extensivo a outras regiões do país, eles passavam a ser veiculados como a representação de uma 'tendência'.

Além do argumento epidemiológico proporcionado por estes inquéritos, outra estratégia importante de convencimento foi afirmar reiteradamente que, graças ao aperfeiçoamento da técnica da RFC obtido com as pesquisas de Muniz e Freitas (1944a, 1944b) em Manguinhos, este teste sorológico constituía um instrumento seguro para diagnosticar casos crônicos da doença, complementando os critérios clínicoeletrocardiográficos. Dias e seus colaboradores enfatizavam que este procedimento de diagnóstico era um método de grande confiabilidade e praticidade para ser utilizado em inquéritos como os da Rede Mineira de Viação. Assim, afirmavam os cientistas, se muitas vezes não era possível encontrar diretamente o parasito, já se podia confiar nos 'rastros' de sua 
presença, revelados pelas reações imunológicas. Diziam: "Em um caso suspeito de esquizotripanose é à reação de fixação de complemento que costumamos recorrer em primeiro lugar para esclarecimento etiológico" (Laranja, Dias \& Nóbrega, 1948b: 513).

Outro argumento que traria especial poder persuasivo aos enunciados do CEPMC sobre a especificidade da CCC, confrontando as dúvidas dos que reivindicavam a presença do parasito como único critério diagnóstico definitivo, foi de ordem experimental. Pellegrino $(1946,1947)$ conseguiu reproduzir em cães, depois de inoculá-los experimentalmente com o T. cruzi, uma cardiopatia crônica cujas características eletrocardiográficas, radiológicas e clínicas eram as mesmas encontradas nos seres humanos. ${ }^{48} \mathrm{~A}$ importância desta infecção experimental residia no fato de que tornava possível correlacionar um determinado quadro clínico e eletrocardiográfico com a presença do parasito: mesmo que ele não viesse a ser identificado no organismo do cão, nem mesmo por meio de exame em necropsia, não se podia duvidar de sua presença, uma vez que os cientistas o haviam inoculado. Assim, o "testemunho irrecusável da experimentação” (Dias, 1949a: 683) vinha reforçar os enunciados dos que pretendiam mostrar que certas características clínicas constituíam elementos suficientemente específicos para garantir o diagnóstico e a 'realidade' da doença de Chagas em sua forma crônica. Os argumentos da clínica conquistavam, desse modo, uma importante vitória no próprio domínio do laboratório, conforme suas regras e seus protocolos mais clássicos.

\section{Provas para os Enunciados do 'Mestre': novo enquadramento para a tradição}

Em 1948, os cientistas do CEPMC consideraram sistematizadas as características essenciais da cardiopatia chagásica crônica. Citando a passagem em que Yorke (1937) dissera que, se isso fosse alcançado, a doença de Chagas se constituiria de fato num problema médico-social de grande magnitude, eles concluíram:

A experiência adquirida nestes últimos anos em Bambuí, onde temos acompanhado numerosos casos, trouxe-nos a convicção de que a esquizotripanose crônica encontra expressão clínica essencialmente em uma cardiopatia bem definida em seus caracteres 
anátomo-patológicos, clínicos, radiológicos e eletrocardiográficos, permitindo-lhes individualização segura. (Laranja, Dias \& Nóbrega, 1948b: 476-477)

Em revisão publicada sobre a CCC, Laranja (1949: 606, 644) sintetizou o papel do CEPMC no que considerou o marco de uma nova fase na "história acidentada" da doença de Chagas, a superar o "ceticismo generalizado" que se impusera sobre a doença depois da fase inicial da descoberta e dos primeiros estudos de Chagas e seus colaboradores.

A descrição de um quadro eletrocardiográfico com caracteres particulares em um grupo numeroso de casos de esquizotripanose crônica, a revisão dos caracteres clínicos da cardiopatia crônica da moléstia de Chagas, com extensa confirmação dos achados descritos por Chagas, a reprodução de uma cardiopatia com caracteres clínicos e eletrocardiográficos semelhantes em animais experimentalmente infectados com o S. cruzi, afora os fatos de ordem anatômica já conhecidos desde os estudos iniciais de Chagas e seus colaboradores, colocaram esta cardiopatia em posição de entidade clínica de realidade indiscutível e imprimiram às suas manifestações importância especial no diagnóstico clínico da esquizotripanose crônica. Além disso, os progressos recentes no estudo da sorologia da moléstia de Chagas vieram facilitar consideravelmente o reconhecimento dos casos de infecção crônica. Por outro lado, uma soma apreciável de dados recentes justificam atribuir-se a esta cardiopatia importância considerável, em extensas regiões rurais, e grande interesse por este problema começa a manifestar-se nos meios clínicos de nosso país. (Laranja, 1949: 654-655; grifo meus)

O sentido fundamental que os pesquisadores do CEPMC atribuíam a seu trabalho era ter produzido 'provas' que corroboravam os enunciados de Carlos Chagas. Em vários dos seus textos, encontram-se declarações desse tipo. Segundo eles, entre os fatores determinantes neste processo, estava a possibilidade que tiveram de acompanhar, em Bambuí, um grupo expressivo e diversificado de casos crônicos, de maneira sistematizada, com a realização de exames periódicos, de modo a formar uma idéia de conjunto sobre a evolução da doença e sobre o desenvolvimento de suas manifestações, "ponto essencial à compreensão da clínica da infecção chagásica” (Laranja, Dias \& Nóbrega, 1948b: 478). Além disso, Laranja destacou o recurso a técnicas e a aparelhos bem mais sofisticados dos que os disponíveis ao tempo de Chagas. 
A análise dos distúrbios do ritmo cardíaco era, então, feita por Chagas pelo registro dos batimentos cardíacos (choque de ponta) e dos pulsos jugular e radial com o polígrafo de Jacquet. Os métodos de semiótica do coração usados na época eram insuficientes para esclarecimentos de muitos distúrbios da condutibilidade e só recentemente, com as estatísticas baseadas em elevado número de casos estudados eletrocardiograficamente em Bambuí, pôde estabelecer-se a verdadeira incidência dos distúrbios de condutibilidade (...). (Laranja, 1949: 609) ${ }^{49}$

Assim, os cientistas do CEPMC não apenas produziam novos conhecimentos sobre a CCC, mas também uma determinada forma de se qualificar o sentido histórico de sua atuação: eles teriam reunido as condições técnicas capazes de revelar uma realidade já descrita por Chagas e que jazia encoberta por dúvidas. Haviam feito 'justiça' àquela obra que se apresentara, desde o início, como a maior das 'glórias de Manguinhos' e da ciência nacional. Esta interpretação seria corroborada por médicos que, posteriormente, destacaram a contribuição de Bambuí para a renovação do interesse pela doença e para a superação da chamada 'fase de descrédito', instaurada pelas críticas na Argentina e na Academia Nacional de Medicina (ANM). ${ }^{50}$

A perspectiva de história da ciência adotada no presente trabalho apresenta as seguintes questões para uma reflexão sobre tal processo: a contribuição dos cientistas de Bambuí foi simplesmente ter produzido, mediante recursos técnicos mais sofisticados, provas mais convincentes para os enunciados originais de Chagas? Por que estas provas foram convincentes? A doença definida em Bambuí tinha os mesmos contornos da doença descoberta e estudada em Lassance?

A importância do trabalho do CEPMC para a validação dos enunciados de Chagas e para a definição da especificidade clínica da tripanossomíase americana deve ser compreendida não como evolução linear e progressiva a partir dos conhecimentos produzidos por Chagas e seus colaboradores, mas como algo que se viabilizou mediante certas diferenças substantivas em relação àquela fase de construção/definição da doença. Este foi um processo em que os recursos cognitivos para operar tais diferenças foram proporcionados com base em condições e em processos sociais também específicos e distintos. Se Dias, Laranja e seus colaboradores produziram condições para imprimir legitimidade a certas formulações de Chagas, isto se deu justamente porque impuseram à 
pesquisa sobre a doença um novo formato e a enquadraram mediante outros esquemas conceituais e sociais.

O próprio Laranja fornece elementos para esta interpretação. Segundo ele, o trabalho desenvolvido em Bambuí representou uma mudança na "orientação de pesquisa" subjacente aos estudos de Chagas e seus colaboradores, num processo que qualificou como passagem do "período parasitológico" para o "período clínico" de investigação sobre a doença (Laranja, 1986: fita 5, lado A). Na primeira fase, a pesquisa se encontrava referida fundamentalmente ao domínio da parasitologia, tanto em termos disciplinares quanto no que se referia ao perfil daqueles que a realizavam (entre os quais o próprio Chagas). Uma implicação direta disso era que a própria idéia da doença como categoria específica dependia inescapavelmente da demonstração da presença do parasito. Mediante o enquadramento da parasitologia, a existência da doença como categoria real e particular era dada fundamentalmente pelo T. cruzi. A decisão do diretor do IOC, Henrique Aragão, e de Dias de investir na pesquisa clínica das formas crônicas, recorrendo a um profissional como Laranja para enfrentar o desafio de conferir credibilidade ao diagnóstico clínico, significou uma mudança em relação a esta orientação. O relato do cardiologista expressa as implicações que esta mudança traria para os meios e as operações de percepção e de definição da doença. Diferenciando-se dos que só admitiam a positividade dos casos quando houvesse verificação parasitária, ele afirmou:

(...) eles estudaram a fase aguda, com outra metodologia, com outro conceito da doença. Não era a mesma coisa que nós. Eu encarava a doença como uma cardiopatia crônica, sem o parasito. $\mathrm{O}$ que me interessava era ver os caracteres dessa cardiopatia para ver se aquela exteriorização clínica era diferente, se me permitia distingui-la de outras cardiopatias. Esse é que foi o problema maior. (Laranja, 1986: fita 5, lado A; grifos meus)

O trabalho do posto de Bambuí, graças, sobretudo, à atuação de Francisco Laranja, colocou a pesquisa sobre a doença de Chagas sob outro esquema classificatório e outros recursos cognitivos, referidos a outro domínio profissional e disciplinar. Embora o parasito continuasse a ser elemento fundamental, o que definia a tripanossomíase americana era um determinado quadro clínico, materializado como cardiopatia crônica. Era exatamente este novo desenho que a transformava num problema capaz de interessar não apenas os especialistas no domínio da medicina tro- 
pical ou da parasitologia, mas o universo mais amplo dos médicos, dotando-a de maiores possibilidades de ser reconhecida publicamente como problema relevante no âmbito da saúde pública. Nesse sentido, a posição profissional de Laranja como cardiologista respeitado foi um elementochave não apenas pelo instrumental cognitivo que tornou possível este novo enquadramento, mas também no que se refere ao poder de persuasão assumido por seus enunciados junto a esta audiência específica dos médicos. Como dizia Laranja (1978: 11), ele não era um pesquisador, no sentido em que o eram os cientistas de Manguinhos; era um "pesquisador attaché, assim meio clandestino", "um pesquisador clínico essencialmente".

A possibilidade desta nova orientação se deu não como decorrência 'natural' da vontade e do empenho dos cientistas em dar prosseguimento ao trabalho de Chagas, ou seja, como um caminho racional, inexorável, para solucionar os 'quebra-cabeças' da doença, mas em virtude de um projeto institucional específico, viabilizado, por sua vez, por condições histórico-sociais particulares. Foi graças à importância e ao sentido que a direção do IOC conferiu às pesquisas voltadas para a profilaxia das doenças endêmicas, em conformidade com o ambiente de otimismo, no cenário internacional e no Brasil, em relação às perspectivas do desenvolvimento e à luta contra as doenças, que o CEPMC teve as condições institucionais, políticas e sociais para realizar pesquisas clínicas sistemáticas sobre a tripanossomíase. ${ }^{51}$ Assim, se houve uma decisão de tomar novo caminho de pesquisa sobre a enfermidade, ela se deu não em razão de uma lógica interna inerente e inevitável ao avanço do conhecimento, mas por meio de uma dada orientação sobre o lugar e a identidade social que a ciência praticada em Manguinhos deveria assumir naquele momento histórico. A produção das 'provas' que permitiriam enxergar a doença sob certos traços específicos não foi uma conseqüência necessária do fato de se ter melhores instrumentos técnicos para vê-los, mas se tornou possível porque, em conformidade com aquele projeto institucional, decidiu-se reconfigurar aquele tema de pesquisa como problema essencialmente médico. A eletrocardiografia utilizada por Laranja não foi a causa deste novo retrato da doença, mas uma conseqüência do projeto de construí-lo. As fronteiras cognitivas que o grupo de Bambuí imprimiu à CCC como um evento clínico regular, uma realidade clínica coerente e clara, materializada 'objetivamente' nos traços do ECG, expressam a 
realidade social deste projeto, os valores e os interesses que ele articulava e as estratégias adotadas para viabilizá-lo.

Como enfatizou David Bloor (1991), com base na formulação do sociólogo Emile Durkheim acerca do caráter coercitivo da sociedade sobre as representações simbólicas e a produção do conhecimento, a natureza social da atividade científica é dada na medida em que os arranjos pelos quais os indivíduos classificam e dão sentido às coisas e às idéias expressam os arranjos pelos quais eles se classificam e se posicionam socialmente no mundo.

O estudo de Christopher Lawrence (1992) sobre o conceito de trombose coronariana é um exemplo particularmente interessante de como a idéia do framing disease proposta por Charles Rosenberg (1992c) é passível de diálogo estreito com os estudos sociais da ciência, tal como expresso nas formulações de Bloor e dos seguidores do Programa Forte da Sociologia do Conhecimento Científico. Ele fornece algumas chaves intrepretativas bastante pertinentes ao caso aqui analisado, inclusive pela proximidade entre os objetos, entidades clínicas supostamente 'reveladas' pela eletrocardiografia. Lawrence parte da seguinte questão: os manuais de história da medicina afirmam que, somente a partir do final da década de 1920, o infarto agudo do miocárdio, resultante da formação de coágulos nas artérias do coração, passou a ser diagnosticado regularmente pelos médicos como entidade clínica definitiva e inquestionável: a trombose coronariana. A pergunta tradicionalmente feita por estes historiadores é: por que uma doença tão ‘óbvia', cuja manifestação principal é popularmente conhecida como ‘ataque do coração’ e que constitui uma das principais causas de morte nas sociedades ocidentais, não foi 'descoberta' antes? Segundo o autor, a própria formulação da pergunta expressa o anacronismo e outros limites das concepções tradicionalmente empregadas nos estudos históricos sobre as doenças, como a suposição de que estas constituem entidades não problemáticas, que podem ser apreendidas mediante linguagem objetiva, neutra, que corresponda de maneira direta aos fenômenos da natureza. Conforme tal tradição historiográfica, depois de um período de erros e/ou descrições parciais, estas entidades são finalmente desvendadas e descritas definitivamente por indivíduos notáveis. Assim, caberia ao historiador buscar os fatores responsáveis por este 'atraso', derivado dos 'erros' ou das 'crenças falsas' daqueles que precederam esta descrição definitiva (Lawrence, 1992). 
Os relatos históricos tradicionais sobre a trombose coronariana citam a eletrocardiografia como chave essencial para a definição desta entidade, inovação técnica que a sedimentou, separando-a de um conjunto de outras afecções funcionais e circulatórias. Contrapondo-se a esta abordagem, Lawrence afirma que o reconhecimento da trombose coronariana como entidade clínica específica não foi o produto necessário do progresso na competência cognitiva e técnica dos médicos com o intuito de 'decifrar' a realidade natural de certos distúrbios cardiológicos, mas sim o resultado de longo processo de negociação, no qual o sentido conferido aos traçados dos ECGs foi não o 'desfecho', mas um elemento também sob disputa. O consenso sobre a existência e as características desta 'realidade' foi construído a partir dos interesses sociais e cognitivos de médicos norte-americanos que queriam transformar a cardiologia em uma especialidade diferenciada e reforçar os espaços institucionais da medicina dita acadêmica. Segundo Lawrence (1992: 53):

In defining coronary thrombosis as a 'definite and material' disease these clinicians were also defining their own social identity. The demarcation of coronary thrombosis was a means of signaling their own medically elite status. ${ }^{52}$

Remetendo-se aos princípios estabelecidos por Bloor, o autor defende a concepção de que a apreensão e a classificação dos fenômenos físicos, dos objetos da natureza, dependem das categorias e das convenções de que os atores dispõem para organizar sua própria experiência destes fenômenos, que no caso em questão constituem os sintomas e os sinais clínicos relacionados a certas desordens do coração. Os processos de negociação e de produção de consenso sobre uma dada realidade natural dizem respeito, portanto, à formação de acordos sobre o uso destas categorias e convenções. Assim, afirma Lawrence (1992), a definição clínica da trombose coronariana foi um processo complexo no qual certos clínicos buscaram convencer seus colegas a reclassificar sua clínica experiência de outro modo. Foi com base nesta reclassificação que a trombose coronariana, antes definida como um 'estado patológico' associado a causas e a processos funcionais variados, foi elevada ao estatuto de 'doença', entidade clínica específica, constituindo-se, por sua vez, como novo elemento classificatório para a experiência clínica. Esse é o sentido em que se pode dizer que ela foi 'construída': "Coronary thrombosis was not 'discovered' or 'described', in the commom medical sense of the words, 
but was 'made' by clinicians gradually coming to agree on the conventions defining the entity whose existence they affirmed" (Lawrence, 1992: 67). ${ }^{53}$

Lawrence partilha também das abordagens recentes da história social e da sociologia da ciência no que diz respeito ao questionamento das fronteiras tradicionalmente estabelecidas entre os espaços 'internos' e 'externos' da atividade científica (Shapin, 1982b). Ele chama a atenção para o fato de que este processo coletivo de negociação - expressão da natureza social da atividade científica - envolve não apenas atores e domínios próprios ao mundo da ciência, mas também outros espaços e grupos sociais, que participam ativamente do empreendimento da ciência, no que se refere à construção e à certificação dos conteúdos dos fatos científicos. Em conformidade com tal perspectiva, argumento que o processo de certificação da CCC como traço primordial da tripanossomíase americana se deu não apenas no âmbito da produção de novos elementos cognitivos para aquela entidade, estabelecidos mediante os esquemas classificatórios particulares da pesquisa clínico-cardiológica, mas ocorreu, ao mesmo tempo, pela capacidade que os cientistas tiveram de convencer seus colegas, médicos e cientistas (e também os não especialistas), a aceitarem seus enunciados como evidências da 'realidade' que pretendiam construir: uma doença clinicamente individualizada e importante do ponto de vista médico-social. ${ }^{54}$ Se os cientistas do CEPMC tornaram reconhecidos certos enunciados de Carlos Chagas, eles o fizeram na medida em que, recolocando-os sob o enquadramento da clínica, proporcionaram condições para que tais enunciados circulassem para além do mundo restrito dos especialistas na doença, levando-os ao domínio cognitivo - e também social - dos médicos e de outros grupos e espaços sociais.

Adotar tal perspectiva não significa confrontar a interpretação dos atores históricos que participaram desse processo (corroborada por novas gerações de médicos e cientistas a partir de então), para os quais o empreendimento do CEPMC teve um sentido primordial de comprovação do trabalho do 'mestre'. Tal interpretação é parte do objeto aqui analisado. A idéia de uma continuidade em relação à obra de Chagas, sob a ótica daqueles atores, conferia identidade e sentido científico e político ao seu projeto como médicos e cientistas. Esta associação era essencial para os que pretendiam reproduzir aquela tradição, que era - e continua sendo - emblemática não apenas da ciência praticada em Manguinhos, mas da própria ciência nacional. 
Além disso, o próprio caminho que levou a uma reconfiguração no quadro clínico erigido por Chagas foi estabelecido a partir do reconhecimento de que havia problemas e impasses a serem superados no processo de certificação desta entidade nosológica. A compreensão de que se estava comprovando e ampliando a obra do descobridor da doença foi, portanto, fundamental para que se pudesse operar o seu re-enquadramento, num processo em que elementos de continuidade e de descontinuidade foram faces articuladas do mesmo projeto: garantir não apenas a reprodução daquele campo de pesquisa, mas dos significados institucionais, políticos e sociais a ele atribuídos com base no seu objeto mais representativo.

À semelhança de Chagas, os pesquisadores associados ao CEPMC se movimentariam para além das fronteiras do laboratório, empenhados em convencer a todos de que esta era a 'doença do Brasil'. Ainda que sob um novo desenho, ela permaneceria sendo propagada como tema revestido de significados para a sociedade e emblema do projeto que a ciência, em seus compromissos com a saúde pública, tinha a apresentar para a nação.

\section{Notas}

1 Estas duas técnicas não se mostrariam satisfatórias. Para a aplicação de gases tóxicos, como o ácido cianídrico, a cafua era envolta numa cobertura plástica e fumigava-se o gás em seu interior. Estas e outras experiências foram fotografadas, pelo próprio Emmanuel Dias, em mais um indício da importância que concedia ao ato de documentar todos os pormenores do trabalho do posto. Tais fotografias encontram-se no rico acervo iconográfico do Fundo Centro de Pesquisas René Rachou, Seção Posto Avançado de Pesquisas Emmanuel Dias (doravante FCPqRR/SPAPED. Algumas imagens constam do relatório publicado em 1945 e outras foram usadas em publicações para divulgar a doença e o trabalho do Centro de Pesquisa e Profilaxia da Moléstia de Chagas (CEPMC) (Dias, 1945, 1946c).

2 Carta de Emmanuel Dias a Henrique Aragão. Bambuí, 26 de julho de 1944. FCPqRR/ SPAPED, caixa 15, maço 1.

3 Carta de Emmanuel Dias a Henrique Aragão. Bambuí, 26 de julho de 1944. FCPqRR/ SPAPED, caixa 15, maço 1. Interrogação do autor.

4 Citado por Emmanuel Dias em carta a Henrique Aragão. Bambuí, 8 de outubro de 1944. FCPqRR/SPAPED, caixa 22, maço 1.

5 "Parece pois inevitável que casos humanos de doença de Chagas venham a aparecer e é muito provável que isso aconteça sob as condições de campo, em áreas de treinamento de tropas e de manobras" - Tradução livre. 
${ }^{6}$ Carta de A. Packchanian a Emmanuel Dias. [s.l.], 20 de janeiro de 1945. Na mesma ocasião, Dias recebeu carta de um pesquisador da Universidade da Califórnia agradecendo o envio de separatas e pedindo que seu nome fosse incluído na lista daqueles para quem Dias enviava seus trabalhos de entomologia médica. Carta de Edward Steinhaus a Emmanuel Dias. Berkeley, 8 de janeiro de 1945. FCPqRR/ SPAPED, caixa 31 , maço 2.

7 Carta de Emmanuel Dias a P. N. Annand. Bambuí, 3 de setembro de 1944. FCPqRR/ SPAPED, caixa 31, maço 2. Em novembro deste ano, num contexto de crescentes interesses econômicos e políticos por parte dos Estados Unidos em relação aos países latino-americanos, o Departamento de Agricultura deste país solicitou à Fundação Rockefeller, que realizava ações de controle da malária no México, que incluísse o DDT em seu programa. Como mostra Stapleton (1998), antes mesmo da comprovação científica dos efeitos do produto na interrupção (ou pelo menos na diminuição expressiva) da transmissão da doença nas localidades onde foi aplicado, o programa produziu forte onda de euforia, tanto entre as autoridades locais - que conseguiam benefícios políticos com os investimentos e as expectativas gerados por aquela 'bala mágica' tão enaltecida internacionalmente - quanto entre a população dos vilarejos rurais, satisfeita com um produto que matava não apenas os mosquitos, mas outros insetos indesejáveis à vida doméstica, como moscas e baratas.

8 Carta de Emmanuel Dias a Cecilio Romaña. Bambuí, 3 de setembro de 1944. FCPqRR/SPAPED, caixa 31, maço 2. Para um relato das experiências com o DDT, ver Carta de Emmanuel Dias a Henrique Aragão. Bambuí, 8 de outubro de 1944. FCPqRR/SPAPED, caixa 22, maço 1 .

9 Neste estudo, Dias (1946b) apresenta os trabalhos do posto realizados até 31 de dezembro de 1945 .

10 O exemplo recorrentemente citado por Dias era o decreto que criou o Serviço de Profilaxia Rural no estado do Paraná, em 1918, e estabeleceu normas para a profilaxia da doença de Chagas. Entre elas, previa-se o compromisso do poder público de realizar melhorias nas habitações rurais e de proibir a construção de "casas de tipo primitivo, de paredes barreadas (paredes de sopapo) e de coberturas de capim" (Dias, 1945: 95). Apesar de não ter sido posta em prática, a iniciativa era enaltecida como modelo para o "controle legal" da doença (Dias, 1945: 93).

11 Além destes dois eixos do plano geral de profilaxia preconizado pelo posto, previase ainda o combate aos portadores vertebrados do T. cruzi (os animais domésticos e silvestres que funcionavam como reservatórios do parasito) e medidas de educação sanitária, especialmente nas escolas, com vistas a difundir entre a população noções elementares sobre a doença e sobre como evitá-la (Dias, 1945).

12 Carta de Emmanuel Dias a Henrique Aragão. Bambuí, 4 de maio de 1946. FCPqRR/ SPAPED, caixa 31, maço 2.

13 Telegrama de Emmanuel Dias a Jadyr Britto, prefeito de Bambuí. Belo Horizonte, 14 de abril de 1947. FCPqRR/SPAPED, caixa 15, maço 01. Carta de Emmanuel Dias a Arimathéa Mourão. Bambuí, 30 de julho de 1947. FCPqRR/SPAPED, caixa 31, maço 2.

14 Centro de Estudos e Profilaxia da Moléstia de Chagas, Bambuí, Minas Gerais. Informações sumárias relativas aos seus dois anos de funcionamento, apresentadas ao Sr. Diretor do IOC, Dr. Henrique Aragão, por intermédio do Sr. Chefe da 
Divisão de Estudos de Endemias, Dr. Aristides Marques da Cunha, pelo Dr. Emmanuel Dias, em fevereiro de 1946. FCPqRR/SPAPED, caixa 3, maço 4. Ver, neste arquivo, a série "Ensaios parasitológicos e terapêuticos".

15 Em 1949, o diretor do Wellcome Laboratories of Tropical Medicine de Londres, J. S. K. Bond, propôs a Dias que realizasse ensaios clínicos com uma nova droga que vinha sendo testada em animais contra a infecção pelo T. cruzi. Citando carta publicada na revista Nature, em 1946, em que eram mencionados testes com produtos ativos contra este parasito, Bond salientava que, desde então, os laboratórios Wellcome vinham promovendo vários ensaios com este objetivo. Carta de J. S. K. Bond a Emmanuel Dias. Londres, 24 de junho de 1949. FCPqRR/SPAPED, caixa 31, maço 2. Sobre as pesquisas com o T. cruzi destinadas a desenvolver drogas contra a tripanossomíase e outras enfermidades, como o câncer, no contexto do pós-II Guerra Mundial, ver Krementsov (2002).

16 José Pellegrino (1922-1977) nasceu em Passagem de Mariana, Minas Gerais. Formado pela Faculdade de Medicina da Universidade de Minas Gerais (UMG), foi médico do serviço sanitário desse estado entre 1947 e 1961, período no qual colaborou com o CEPMC. Professor da Faculdade de Medicina da UMG, desenvolveu, além das pesquisas sobre doença de Chagas, importantes trabalhos sobre esquistossomose. Foi pesquisador do Centro de Pesquisas de Belo Horizonte, criado em 1956 e que deu origem ao Centro de Pesquisas René Rachou, incorporado, em 1970, à Fundação Oswaldo Cruz (Azevedo, Kropf \& Hamilton, 2003).

17 Pellegrino entrou em contato com Dias em maio de 1946, solicitando amostras de T. cruzi para infecção experimental em animais. Em dezembro, pediu-lhe o envio do trabalho "Ensaio de profilaxia" (Dias, 1945) e outras referências bibliográficas sobre o assunto. Cartas de José Pellegrino a Emmanuel Dias. Belo Horizonte, 20 de maio e 27 de dezembro de 1946. FCPqRR/SPAPED, caixa 31, maço 2. Carta de José Pellegrino a Emmanuel Dias. Nova Era, 28 de fevereiro de 1947. FCPqRR/SPAPED, caixa 31 , maço 2 .

18 Carta de Henrique Aragão a Emmanuel Dias. Rio de Janeiro, 3 de março de 1947. FCPqRR/SPAPED, caixa 31, maço 2.

19 Dias, Emmanuel. Resumo dos trabalhos em 1947. Bambuí, 12 de janeiro de 1948. FCPqRR/SPAPED, caixa 29, maço 1 .

20 Carta de José Pellegrino a Emmanuel Dias. Belo Horizonte, 7 de novembro de 1947. FCPqRR/SPAPED, caixa 31, maço 2.

${ }^{21}$ Carta de José Pellegrino a Emmanuel Dias. Belo Horizonte, 9 de novembro de 1947. FCPqRR/SPAPED, caixa 31, maço 2.

22 Pelo fato de o gamexane não possuir ação repelente contra os insetos e, portanto, não provocar o desalojamento destes de seus esconderijos, tornava-se necessário um expurgo associado com pós à base de piretro. Porém, seu poder residual, apesar de bem superior ao do DDT, decaía muito depois de um mês e sua toxicidade não atingia totalmente as formas jovens e os ovos dos barbeiros, o que exigia a repetição dos expurgos com um ou dois meses de intervalo. Tudo isso acabava por aumentar os custos e a complexidade das operações (Dias \& Pellegrino, 1948).

23 “(...) se tais lesões cardíacas são realmente características da doença de Chagas crônica e podem ser diferenciadas de outras formas de miocardites, como a provocada pela sífilis, é ainda uma questão aberta a dúvidas” - Tradução livre. 
24 "À primeira vista, parece que, de modo geral, a tripanossomíase americana pode de fato ser responsável por boa parte de doenças cardíacas aparentemente tão comuns em certas áreas endêmicas do Brasil, Uruguai e Argentina, e a causa de tantas mortes prematuras. A forma cardíaca crônica da doença pode ser a seqüela de uma infecção aguda na infância ou a conseqüência de repetidas infecções durante a vida. Se isso vier a ser comprovado, então a tripanossomíase americana de fato assumirá um significado patológico de primeira magnitude. Este é um tema que obviamente requer, urgentemente, muito mais estudo" - Tradução livre.

25 Francisco da Silva Laranja Filho (1916-1989) nasceu em São Borja, Rio Grande do Sul. Em 1935, iniciou o curso da Faculdade de Medicina de Porto Alegre, transferindo-se para a Faculdade Nacional de Medicina da Universidade do Brasil, no Rio de Janeiro, onde se diplomou em 1940. Desenvolvendo pesquisas no IOC a partir de 1944 sobre a doença de Chagas, foi nomeado diretor deste instituto em 1953, deixando o cargo, em 1954, por ocasião do suicídio de Vargas. Retomou então suas atividades no Instituto de Aposentadoria e Pensões dos Industriários (Iapi) e assumiu a direção do Serviço de Assistência Médica Domiciliar de Urgência (Samdu), onde permaneceria até 1961, quando se transferiu para a nova capital federal para organizar os serviços médicos e de assistência hospitalar. Em 1971, tornou-se professor titular de cardiologia da Faculdade de Ciências da Saúde da Universidade de Brasília. Nesta década, retomaria suas atividades de pesquisa clínica sobre a doença de Chagas na então criada Fundação Oswaldo Cruz (Laranja, 1986).

26 Naquela época, a cardiologia era exercida geralmente pelo clínico geral. A realização no Iapi, em 1939, de um concurso específico para a área de cardiologia, pelo qual foi contratado o professor Magalhães Gomes, foi, segundo Laranja (1986: fita 4), um importante passo para o reconhecimento oficial da especialidade.

27 Naquela ocasião, Laranja já havia sido efetivado, mediante concurso em 1941, como médico do Iapi (Laranja, 1986: fita 5, lado A).

28 Sobre a história da cardiologia no Brasil, ver Leme (1981), Reis (1986) e Rassi (2001).

29 A Faculdade de Ciências Médicas, criada em 1936, foi incorporada, em 1950, à então criada Universidade do Distrito Federal. Capriglione tornou-se titular de uma das cadeiras de Clínica Médica da Faculdade Nacional de Medicina ao final da década de 1940. Benchimol publicou vários trabalhos sobre a forma cardíaca crônica da doença de Chagas na década de 1950.

30 Medeiros (Capriglione \& Benchimol, 1941: 3) diz que o primeiro eletrocardiógrafo a ser utilizado no Brasil foi por ele instalado no Laboratório de Psicologia Experimental do Hospital Nacional dos Alienados. Tal informação contrasta com a que teria sido fornecida por Magalhães Gomes a Cid Abreu Leme, segundo a qual caberia a Chagas a prioridade da introdução do eletrocardiógrafo no país (Leme, 1981: 179).

31 Desde a inauguração, em 1926, da cadeira de medicina tropical na Faculdade de Medicina do Rio de Janeiro (FMRJ), o ensino da tripanossomíase americana passou a ser dado no âmbito das disciplinas relacionadas à parasitologia, o que certamente contribuiu - contrariamente ao que Chagas desejava - para o afastamento entre o tema e o domínio da clínica médica (Chagas Filho, 1993). 
32 As principais causas de cardiopatias eram a hipertensão, a arterioesclerose, o reumatismo e a sífilis.

33 Em início de 1947, a direção do IOC faria uma requisição oficial ao Iapi para que Laranja fosse posto à disposição de Manguinhos, de forma a dedicar-se integralmente aos trabalhos sobre a doença de Chagas. Ofício de Henrique Aragão ao presidente do Iapi, 7 de agosto de 1947. Fundo Instituto Oswaldo Cruz, Seção Direção, Cópias de Ofícios (doravante FIOC/SD/CO), ofício n. 936. O Fundo Francisco Laranja, sob a guarda da COC/Fiocruz, guarda vários eletrocardiogramas realizados por ele em indivíduos de Bambuí, além de alguns registros de suas pesquisas nas décadas de 1940 e 1950. O arquivo, todavia, é formado fundamentalmente por documentos relativos às suas investigações sobre a doença na década de 1970, na Fiocruz.

34 Ver, no arquivo do posto (FCPqRR/SPAPED), a série "Acompanhamento clínico".

35 A este respeito, Dias relatou, em 1946: "Durante nossas estadias no Centro acorrem ali diariamente dezenas de pessoas, atraídas pela consulta e distribuição de remédio gratuitas. Milhares de amostras de medicamentos têm sido fornecidas; conseguimolas com colegas do Rio e de Belo Horizonte e também dos próprios laboratórios (...). Graças a este recurso temos podido examinar pacientes das mais longínquas paragens do município de Bambuí e de outros municípios próximos (Luz, Córrego Dantas e outros). À custa da experiência auferida, é possível uma adequada seleção dos pacientes pelo exame clínico, o que muito contribuiu para um rápido e constante acréscimo de nossa casuística." Centro de Estudos e Profilaxia da Moléstia de Chagas, Bambuí, Minas Gerais. Informações sumárias relativas aos seus dois anos de funcionamento...", FCPqRR/SPAPED, caixa 3, maço 4.

36 Carta de Emmanuel Dias a Henrique Aragão. Bambuí, 25 de março de 1944. FCPqRR/SPAPED, caixa 15, maço 1. Dias foi pioneiro em utilizar, de modo sistemático, este método, proposto em 1914 por Emile Brumpt. Ver Dias (1940).

37 "The diagnosis of Chagas' disease in the absence of trypanosomes in the peripheral blood is a matter of great importance, and the more so since trypanosomes occur in the blood for so short a period and in such scanty numbers. It is conceivable that the Machado reaction may prove specific, and in this case it will assume that same importance in Chagas' disease that the Wasserman reaction has in syphilis. (...) The matter is obviously one which urgently demands through investigation". ["O diagnóstico da doença de Chagas na ausência de tripanossomas no sangue periférico é um assunto de grande importância, especialmente porque os tripanossomas aparecem no sangue por um tão curto período de tempo e em número muito escasso. É esperado que a reação de Machado possa se provar específica, e nesse caso assumirá a mesma importância na doença de Chagas do que a reação de Wasserman tem para a sífilis. (...) O assunto é claramente dos que demandam, urgentemente, mais pesquisas" - Tradução livre] (Yorke, 1937: 295).

38 Muniz e Freitas (1944a, 1944b), utilizando o antígeno preparado segundo a técnica de Davis, obtiveram melhores resultados na reação de fixação de complemento em relação à técnica de Guerreiro e Machado (1913), que extraíam o antígeno de frações de órgãos de animais infectados. O tema também mobilizava Dias, que, em parceria com Romaña, desenvolveu uma técnica de preparo de antígeno alcoólico para a RFC (Dias \& Romaña, 1942). A RFC foi sendo progressivamente abandona- 
da à medida que surgiram técnicas mais modernas e de maior sensibilidade e especificidade. Atualmente, ela não é recomendada, sobretudo em triagem em bancos de sangue, uma vez que pode dar resultados falso-negativos. Os métodos empregados no diagnóstico sorológico da infecção pelo T. cruzi são o teste Elisa (ensaio imunoenzimático), a imunofluorescência indireta e a hemaglutinação. Para comprovação parasitológica, recorre-se ao xenodiagnóstico, à hemocultura ou ao PCR (polymerase chain reaction, técnica de biologia molecular).

39 Na década de 1950, quando a doença foi veiculada com maior sistematicidade nos jornais em função da primeira campanha de profilaxia, seria comum recorrer-se a esta imagem, já utilizada por Chagas. Ver FCPqRR/SPAPED, série "Jornais".

40 Nos termos de Chagas, os distúrbios na formação do estímulo eram referidos como distúrbios na excitabilidade do miocárdio.

${ }^{4 l}$ Segundo os autores, uma dada alteração no batimento (desdobramento da segunda bulha no foco pulmonar), perceptível pela ausculta e indicativo de bloqueio intraventricular, por sua alta freqüência nos casos observados em Bambuí, poderia ser usado como "evidência presuntiva" da cardiopatia chagásica crônica, antes mesmo da realização dos ECGs (Dias, Laranja \& Nóbrega, 1945: 529).

42 Os autores citam, como termo comparativo para reforçar esta hipótese, os percentuais bem menores de incidência de bloqueios intraventriculares (de ramo direito ou de ramo esquerdo) na casuística de autores estrangeiros e nos dados do serviço de cardiologia do Iapi. Além disso, chamam a atenção para que, "na prática cardiológica comum", a incidência do bloqueio de ramo direito é aproximadamente igual à do bloqueio de ramo esquerdo. "Ao contrário, nos numerosos casos de bloqueio intraventricular verificados em nossos casos de miocardite crônica esquizotripanósica, chama desde logo a atenção a peculiaridade de só serem eles representados por curvas de BRD” (Dias, Laranja \& Nóbrega, 1945: 541; grifos dos autores).

43 Todos estes trabalhos do CEPMC traziam numerosos traçados eletrocardiográficos, além de imagens radiológicas, numa evidência de como tais "inscrições" (Latour, 2000), também já utilizadas por Chagas, sobretudo em seu trabalho com Villela em 1922, eram importantes como recurso persuasivo para os enunciados propostos.

44 Para a fase aguda, além do edema local, indicativo de 'porta de entrada', assinalado por Romaña, os autores mantiveram os sinais descritos por Chagas, citando as divergências que ainda persistiam sobre a natureza do edema generalizado, considerado por este como mixedema de origem tireoidiana. É interessante notar que a forma indeterminada, descrita originalmente por Chagas, em 1916, para abranger os indivíduos com sinais leves, ou não aparentes, das síndromes hipotireoidiana, nervosa e cardíaca, foi reformulada. Ela passava a contemplar apenas os casos assintomáticos com perspectiva de evolução dos sinais cardíacos (Laranja, Dias \& Nóbrega, 1948b). Dos enunciados propostos por Chagas para a forma nervosa, foram mantidos apenas os que diziam respeito aos fenômenos de meningoencefalite nos casos agudos em crianças, sendo descartadas, a partir da década de 1960, suas formulações sobre as síndromes nervosas crônicas.

45 Desde a morte de Chagas até este trabalho foram esparsos os estudos realizados sobre a forma cardíaca crônica da doença de Chagas, tanto no Brasil como no exterior. Ver Laranja (1949). Conforme Zabala (2007), na Argentina, processou-se, a partir de meados da década de 1940, processo semelhante de 'reconversão' da 
doença de Chagas em enfermidade crônica essencialmente cardíaca, em especial mediante os estudos realizados por Cecilio Romaña no Instituto de Medicina Regional da Universidade Nacional de Tucumán.

46 O próprio Salvador Mazza, que havia estudado a cardiopatia chagásica aguda, manifestou, até seu falecimento em 1946, dúvidas sobre a forma cardíaca crônica da doença, que considerava "entidade complexa e absolutamente ainda não bem definida clinicamente, (...) [sendo] realmente grande a confusão reinante sobre a sua natureza e o meio de comprová-la com segurança” (apud Laranja, 1949: 640$641)$.

47 Em 1949, o CEPMC contava com cerca de 1.600 casos identificados da doença (Dias, 1949a: 682). No ano anterior, Laranja, Dias e Nóbrega (1948b: 474) mencionaram 1.300 casos reunidos na Argentina pela Misión de Estudios de Patología Regional Argentina (Mepra). Segundo Laranja (1949: 655), desde 1930 - quando foram descritos os primeiros casos de cardiopatia crônica chagásica (CCC) no Brasil sem ser na região de Lassance - até 1944 (inclusive), foram descritos 45 casos, ao passo que, entre 1945 e 1948, o número já ultrapassava seiscentos. No exterior, entre 1934 e 1948, foram descritos 134 casos. Contudo, ele observava: "Por esta revisão da literatura, que acreditamos incluir a totalidade ou a quase totalidade dos casos de forma cardíaca da esquizotripanose publicados fora do Brasil, pode-se formar impressão errônea da freqüência desta forma clínica da doença de Chagas, parecendo que ela constitui raridade, cujos casos quando diagnosticados merecem um por um publicação" (Laranja, 1949: 631).

48 Antes do CEPMC, alguns autores haviam feito esta experiência, mas só havia sido observado o desenvolvimento da cardiopatia aguda (ver Pellegrino, 1946, 1947).

49 O polígrafo realizava registros mecânicos (e não eletrocardiográficos) da atividade do coração.

${ }^{50}$ Ver, entre outros: Chagas Filho (1968, 1993), Dias (1988, 1998) e Prata (1999).

${ }^{51}$ Além da infra-estrutura técnica e de pessoal proporcionada ao posto de Bambuí, crucial para a realização de exames periódicos na população e para o acompanhamento sistemático de pacientes, e de outras condições para a pesquisa, as verbas extras obtidas por Aragão junto ao Ministério da Educação e Saúde (MES) em função do esforço de guerra garantiram a ampliação das instalações e o reaparelhamento do Hospital Evandro Chagas, onde pacientes enviados de Bambuí por Dias eram acompanhados por Laranja e por Nóbrega. Este hospital recebeu, então, um novo aparelho de raios X e um novo eletrocardiógrafo. Ver IOC (1945, 1946), Ofício de Henrique Aragão a Clemente Mariani Bittencourt. Rio de Janeiro, 29 de janeiro de 1947, p. 22, FIOC/SD/CO, ofício 121.

52 "Ao definirem a trombose coronariana como doença 'definitiva e material' esses clínicos estavam também definindo sua própria identidade social. A demarcação da trombose coronariana foi um meio de indicar seu próprio status como elite médica" - Tradução livre.

53 'A trombose coronariana não foi 'descoberta' ou 'descrita' no sentido médico comum destas palavras, mas sim 'feita' pelos clínicos que gradualmente chegaram a um acordo sobre as convenções definidoras desta entidade cuja existência eles afirmavam" - Tradução livre. Numa formulação que nos remete às colocações de Bloor contra os que atribuem ao relativismo da sociologia da ciência uma posição 
radical idealista, Lawrence (1992) assinala que conceber a trombose coronariana como uma entidade clínica que existe como parte de uma rede classificatória, sustentada pelo interesse de um grupo particular, não significa afirmar que a doença 'não existe', desprezando assim a experiência concreta dos pacientes ou a efetividade do conhecimento e das práticas da comunidade médica. Segundo ele (Lawrence, 1992: 54): "Pain, collapse or any other symptom is real and terrible enough and the basic stuff of medical classification. But medical knowledge does not simply sort out such events into preexisting natural categories. Medical knowledge in general, and of heart disease in particular, exists because of its constructed and interest character, no in spite of it". ["A dor, o colapso ou quaisquer outros sintomas são bastante reais e terríveis, e são os elementos básicos da classificação médica. Mas o conhecimento médico não classifica tais eventos simplesmente a partir de categorias naturais pré-existentes. O conhecimento médico, em geral - e o que se refere às doenças cardíacas, em particular - existe na medida em que foi construído e tem uma dimensão interessada, e não a despeito disso" Tradução livre].

54 Em seu estudo sobre a "revolução copernicana", Thomas Kuhn (1973) afirma que a luneta de Galileu não forneceu provas da correção do esquema conceitual de Copérnico, mas constituiu, naquele mundo renascentista, um poderoso instrumento de propaganda e de persuasão em torno do novo cosmos construído por tal esquema. 



\section{Para Além do Laboratório: arregimentando aliados na guerra contra a doença do coração do Brasil (1942-1950)}

Ao mesmo tempo que produziam novos conhecimentos sobre a tripanossomíase americana, os pesquisadores do Centro de Estudos e Profilaxia da Moléstia de Chagas (CEPMC), particularmente Emmanuel Dias, engajaram-se numa 'cruzada' com o objetivo de disseminar publicamente a importância médico-social da doença e de conquistar, para o projeto deste posto do Instituto Oswaldo Cruz (IOC) em Bambuí, a adesão de outros grupos e interesses sociais. Foi no âmbito desta mobilização, que teria como principais aliados os chamados 'médicos do Brasil Central', que os cientistas produziram as condições para que a doença, expressa fundamentalmente na cardiopatia chagásica crônica, fosse aceita como “entidade clínica de realidade indiscutível”, como afirmou Laranja (1949: 654). Tal mobilização também foi decisiva para que, em 1950, ela fosse inserida na pauta da política de saúde pública do país, tornando-se, como Chagas e os partidários do movimento sanitarista reivindicavam desde a década de 1910, objeto de uma campanha de profilaxia.

A noção de que o processo de produção e certificação dos fatos científicos transcorre mediante um movimento coletivo de negociação e busca de consenso, que envolve distintos espaços da vida social, foi adotada, entre outros autores, por Bruno Latour (2000: 194), especialmente mediante o conceito de "associação de interesses". É sob tal perspectiva 
que, como sugere o autor no título de seu livro, pretende-se, neste capítulo, "seguir os cientistas sociedade afora", de modo a observar as estratégias e os recursos postos em ação por Dias e seus colaboradores para recolocar, sob as condições históricas específicas da década de 1940, a doença de Chagas como emblema de um projeto de desenvolvimento para a nação.

Se, durante a vida de Carlos Chagas, esta enfermidade foi 'emoldurada' (Rosenberg, 1992c) de maneira indissociada, como fato científico e social, o trabalho do CEPMC atualizaria este processo, mas com base em novo arranjo: desta vez, a representação da tripanossomíase americana como 'doença do Brasil' seria dada por meio de outra 'moldura', que a instituía como entidade nosológica fundamentalmente cardíaca. Sua dimensão simbólica e seu impacto social seriam, assim, representados não mais pelas deformações físicas e mentais associadas aos distúrbios endócrinos e neurológicos - de grande efeito dramático pela saliência e visibilidade de seus traços -, mas justamente por elementos que não se faziam visíveis, e que, justamente por isso, seriam designados como particularmente ameaçadores: a perda de vitalidade, o cansaço e a improdutividade, derivados da ação de um parasito que, como assinalavam os cientistas, ataca silenciosa e persistentemente o órgão central da vitalidade humana e, a qualquer momento, produz a morte ou a incapacitação de jovens trabalhadores rurais.

A partir desta imagem é que a doença descoberta por Chagas passou a servir de emblema para um país que, sobretudo a partir da Segunda Guerra Mundial, engajava-se no debate nacionalista em torno da idéia de desenvolvimento e de superação do "círculo vicioso da doença e da pobreza" (Winslow, 1955: 106). Este processo, iniciado na década de 1940, ganharia sua força simbólica mais evidente com a construção da nova capital no coração do país. Ao mesmo tempo, ao proclamarem a doença como símbolo não apenas dos 'males' do Brasil Central mas também da medicina que ali se praticava, os cientistas do CEPMC garantiam novos espaços para a reprodução institucional daquele objeto científico, tanto no campo da pesquisa quanto no campo da saúde pública.

\section{O Apelo aos Médicos}

Desde a época do Serviço de Estudo das Grandes Endemias (Sege), os cientistas buscavam atrair para o tema da doença de Chagas os interes- 
ses de outros grupos sociais, especialmente os médicos do interior. A estratégia foi aprofundada na ocasião em que a direção do IOC começou a pensar na criação do posto em Bambuí. Em junho de 1942, Dias publicou um artigo em que esta intenção vinha estampada já no título: "Apelo aos clínicos do interior para a colaboração no estudo da doença de Chagas". O texto trazia informações básicas sobre os principais indícios da doença - existência de barbeiros nas casas e sintomas clínicos das fases aguda e crônica - e orientava sobre como confirmar tais suspeitas mediante técnicas elementares de observação do parasito no sangue, quando se tratasse de casos agudos. Para os casos crônicos, informava-se sobre como proceder à coleta do material necessário ao diagnóstico nos laboratórios de Manguinhos. Escrito em linguagem simples, no texto eram apresentadas fotografias dos vários aspectos da doença, como o parasito, o inseto vetor e o 'sinal do olho’. Ao abordar as formas crônicas, além de salientar que o "papo' nada tem que ver com a tripanossomose”, o artigo sublinhava que "a mais importante é a cardíaca”, associando os principais sintomas às "sensações comumente designadas pelos pacientes como 'vexame' (também 'avexame' ou 'avexume’), 'baticum', ‘canseira”' (Dias, 1942: 922). O enunciado da forma cardíaca aparecia, assim, como o principal guia para a busca da doença. Além do aspecto informativo, a perspectiva de conquistar a adesão dos médicos locais era dada pela ênfase na idéia de que a enfermidade não era mais assunto de especialistas, mas estava ao alcance de qualquer clínico, inclusive daquele residente nas áreas rurais. Ou melhor: dependia diretamente da colaboração destes profissionais.

Desde que os progressos realizados no estudo da doença de Chagas facilitaram notavelmente o diagnóstico clínico desta infecção (antigamente privilégio de raros investigadores), o grande impulso dado ao conhecimento da mesma, até em países onde era ignorada, foi em grande parte devido à valiosa colaboração dos médicos que clinicam nas zonas de endemia. (...) São naturalmente os clínicos do interior os que estão em melhor posição para deparar com os enfermos, uma vez que possuam noções elementares sobre a moléstia e se capacitem de que a doença de Chagas é extremamente comum nas zonas infestadas por espécies domiciliares de barbeiro. (Dias, 1942: 921; grifos do autor)

Se, por um lado, solicitava-se aos médicos rurais que enviassem ao IOC material para investigação (como exemplares de barbeiros e amostras de sangue), por outro, os pesquisadores prontificavam-se a facilitar 
tal colaboração. Forneceriam, por correio, lâminas para observação ao microscópio, ampolas para coleta de sangue, caixas para o acondicionamento de barbeiros, publicações especializadas e demais instruções necessárias (Dias, 1943).

Uma estratégia decisiva para a conquista do apoio dos médicos do interior foi fazer com que eles vislumbrassem seus próprios interesses nesta parceria com os cientistas. Os trabalhos de Dias anunciavam, assim, o compromisso do IOC em encaminhar para publicação, nas principais revistas médicas do país, os artigos em que tais clínicos descrevessem casos da doença por eles registrados e/ou estudados. Antes mesmo da publicação do 'apelo aos clínicos' (Dias, 1942), esta estratégia do Sege já vinha produzindo resultados. Eram em geral textos curtos, em que os clínicos faziam uma narrativa pessoal de como havia sido despertado seu interesse pela doença (via de regra, agradecendo aos técnicos do IOC pelo estímulo e pela colaboração) e apresentavam as características dos doentes, os sinais clínicos que orientaram o diagnóstico e os procedimentos utilizados para a confirmação dos casos.

Em 1941, um médico de Pires do Rio, Goiás, publicou, por intermédio do Sege, um trabalho com a descrição de três casos da doença, diagnosticados clinicamente em seu consultório e confirmados por provas laboratoriais no IOC. Declarando já suspeitar da existência da doença na região havia algum tempo, expressou sua adesão ao projeto dos cientistas:

Em face das provas hoje obtidas, não padece dúvida sobre a existência de foco chagásico endêmico no Estado de Goiás. (...) À medida que os médicos do sertão se forem familiarizando com os vários aspectos da enfermidade, se levantará o véu e, então, poderse-á aquilatar da verdadeira extensão e importância que a doença de Chagas assume no hinterland brasileiro. (Romeiro, 1941: 590)

Em 1943, outro clínico do interior relatou no Brazil-Medico um caso agudo por ele estudado em Santo Ângelo das Missões, no Rio Grande do Sul. José de Barros Falcão (1943) teve contato com as investigações realizadas pelo Sege naquela localidade e leu o "apelo aos clínicos do interior" de Dias (1942). Contou que suspeitou da doença de Chagas ao atender em seu consultório uma menina de três anos com o "olho inchado", moradora de "casa de pau-a-pique, coberta de palha, onde existem em abundância os "fincões'” (Falcão, 1943: 180). Constatados alguns sintomas clínicos da fase aguda e sendo positivo o exame a fresco no sangue 
da criança, ele procurou o IOC para notificar seus achados e foi então imediatamente orientado por Dias, que lhe enviou barbeiros para a realização do xenodiagnóstico, pelo qual se comprovou a positividade da infecção. Ao final do trabalho, o médico convocou seus colegas a "atenderem ao 'apelo' do Dr. Dias, a fim de que se procure dar um patriótico impulso à investigação do grande problema da doença de Chagas no Brasil" (Falcão, 1943: 182).

A mesma exortação seria feita por um médico de Bambuí, que, ao publicar a descrição de três casos agudos da doença por ele observados naquela localidade, louvou

a campanha que a Divisão de Estudos de Endemias, do Instituto Oswaldo Cruz (Manguinhos), vem realizando com todo êxito para incrementar as pesquisas sobre a doença de Chagas, difundindo entre os clínicos do interior os conhecimentos essenciais ao seu diagnóstico e proporcionando-lhes, por meio de seus técnicos, todo auxílio e orientação, ora direta e pessoalmente, ora por correspondência. (Lasmar, 1944: 232-233)

Além de publicarem trabalhos sobre a doença, estes clínicos dispunham-se a colaborar com o IOC também mediante a influência privilegiada que exerciam junto à população rural. Em 1946, agradecendo as publicações remetidas por Dias e declarando-se pronto a prestar a colaboração que estivesse ao seu alcance, um médico de Ubá, Minas Gerais, solicitou "estampas com o barbeiro bem nítido, a fim de emprestá-las a habitantes da zona rural, que me poderão em pontos distintos desta região prestar auxílio na colheita do material". ${ }^{1}$

Outros profissionais, por sua vez, tornariam o tema objeto de seu interesse no sentido do próprio estudo da doença. Em carta a Dias, Rubem Jácomo, médico de Uberaba, comentou que já havia algum tempo que se dedicava ao assunto e que contava com mais de sessenta casos registrados em seu consultório. Solicitou o envio de folheto que Dias escrevera sobre a doença (Dias, 1944), para ser distribuído na região, especialmente entre os fazendeiros, que, segundo ele, pediam com freqüência informações a respeito. Dizia o clínico: "Tenho feito uma propaganda muito grande perante os colegas e o povo. Recebo diariamente várias caixas de barbeiros para exame." ${ }^{2}$ Em resposta, Dias o estimulou a publicar sua casuística - "será muito importante para que ela [doença] se torne melhor conhecida pelos nossos médicos" - e informou como obter antígeno para confirmação sorológica dos casos. ${ }^{3}$ Além de estudar a doença em seu 
consultório, Jácomo teria atuação de destaque na mobilização de diversos segmentos sociais no Triângulo Mineiro para a necessidade da profilaxia da doença (Jácomo, 1950).

Alguns clínicos de áreas rurais, a partir da casuística reunida em seus consultórios, contribuíram diretamente para as investigações sobre a forma cardíaca. Além de Jácomo, o médico de Uberlândia Miron de Menezes publicou, em 1949, artigo em que apresentava suas pesquisas sobre trinta casos de tripanossomíase e cerca de novecentos traçados eletrocardiográficos colhidos em "lavradores de todo o Brasil Central", que procuravam sua clínica cardiológica. Agradecendo a Dias e a Pellegrino "o estímulo que pessoalmente deram à realização deste trabalho" (Menezes, 1949: 587), o autor analisou seus dados à luz das pesquisas do CEPMC e corroborou o postulado central que as orientava: "Há fortes evidências de que a doença de Chagas representa um dos importantes fatores etiológicos de cardiopatias em amplas zonas rurais do Brasil, nas quais é responsável em grande parte pelos casos de morte súbita ou de insuficiência cardíaca, principalmente em indivíduos jovens" (Menezes, 1949: 585). Ao concluir o estudo, salientou seu apoio aos cientistas: "Estamos inteiramente de acordo com a opinião expressa por E. Dias, segundo a qual 'a pesquisa sistemática da etiologia chagásica em todas as zonas de triatomas, quando vier a ser empreendida, revelará uma terrível incidência da moléstia"” (Menezes, 1949: 587).

Além dos periódicos médicos, Dias buscou disseminar os conhecimentos básicos sobre a doença entre os clínicos e a população do interior por meio de outros veículos, como folhetos de divulgação do Ministério da Educação e Saúde (MES) e revistas de grande circulação. ${ }^{4}$ Sua disposição era a de um verdadeiro 'militante', como salientavam os que conviveram com ele. No relato de Antonio Torres Sobrinho, médico de Bambuí e colaborador do posto:

Lançava mão da imprensa, com artigos em jornais e revistas médicas e leigas. Escrevia e pedia a colegas que escrevessem opúsculos de observações sobre a doença de Chagas, dando a todos valiosa orientação. Enfim, desdobrava-se de todos os modos em favor da sua causa, que era a destruição do grande flagelo do Brasil e de grande parte do mundo. ${ }^{5}$

Um dos textos de maior circulação publicados por Dias foi um folheto editado em 1944 pelo Serviço Nacional de Educação Sanitária do 
MES. Sob a forma de perguntas e respostas, em linguagem simples e acompanhada de ilustrações e fotografias, o texto apresentava à população residente nas áreas rurais as principais noções sobre a doença. ${ }^{6} \mathrm{Se}$, junto aos médicos, a meta era estimular o diagnóstico de novos casos, naquele momento em que se iniciavam em Bambuí as pesquisas sobre a profilaxia, buscava-se conquistar a colaboração de todos para o combate à doença. Assim, o folheto indicava os vários procedimentos a serem usados contra o barbeiro. Os moradores poderiam recorrer a "meios domésticos", como queimar os insetos com lamparinas, esmagá-los com um objeto qualquer ou destruí-los com "água fervendo, pura ou com cal, soda cáustica ou sabão grosso, de que algumas donas de casa mais esclarecidas às vezes lançam mão" (Dias, 1944: 13). Poderiam também utilizar os próprios meios que vinham sendo testados no CEPMC, como expurgos com produtos químicos, como os preparados à base de piretro, querosene e vários outros "inseticidas do comércio” (Dias, 1944: 13). Além do 'combate ativo ao barbeiro', Dias pregava a realização de melhorias nas habitações e a adoção dos preceitos da educação sanitária, como a limpeza das casas, para facilitar a captura dos insetos. A população era convocada a tomar parte na grande 'cruzada' contra o barbeiro conduzida pelos cientistas do IOC (Imagem 25).

Outro importante trabalho de divulgação foi publicado na revista Eu Sei Tudo, destinada ao grande público. Prestando homenagem a Carlos Chagas, Dias (1946c: 1) exaltou-lhe as virtudes de herói da ciência enviado aos sertões para livrá-los do "espectro da doença”, um dos principais obstáculos à penetração da civilização no interior do país. Além de descrever a 'grande descoberta' em Lassance, o texto apresentava os conhecimentos fundamentais sobre a transmissão, os sinais clínicos e a evolução da tripanossomíase americana. Particular destaque foi dado à associação com a miséria da população rural, expressa nas precárias condições de suas moradias. $^{7}$ Dias (1946c: 6-7) sublinhava a importância das melhorias habitacionais para a luta contra o "mal que devasta nossos sertões" e defendia que fossem "condenadas à destruição, para não mais reaparecerem, as cafuas de pau-a-pique, em cujo lugar hão de erguer-se casinhas modestas, porém higiênicas, impróprias à pululação dos daninhos triatomas". 8

Nestes textos, a apresentação das informações sobre a doença era feita mediante estratégias retóricas que potencializavam o poder persuasivo da mobilização empreendida por Dias. Uma delas era a apresentação de fotografias, retratando os vários elementos do ciclo da doença: a cafua, 
os insetos transmissores, o parasito e os doentes. Nos trabalhos a partir de 1943, os próprios passos da pesquisa científica realizada no CEPMC eram visualmente apresentados aos leitores, como os processos testados para o combate aos barbeiros. Além do aspecto pedagógico, as fotografias contribuíam para conferir maior concretude àquela entidade que se pretendia divulgar, funcionando como recurso simbólico poderoso, sobretudo quando retratavam as 'vítimas' do flagelo.

Se, na época de Carlos Chagas, os doentes eram representados em geral pelas imagens dos portadores do bócio ou de perturbações neurológicas, nos textos a partir da década de 1940 eles eram basicamente crianças na fase aguda, com o sinal de Romaña bem evidente, ou, no caso dos pacientes crônicos, adultos portadores de distúrbios cardíacos. Neste caso, na ausência de um sinal físico aparente, enfatizava-se o aspecto de esgotamento, cansaço e improdutividade dos doentes, como na imagem emblemática de uma senhora, prostrada diante de uma cafua, sendo examinada pelo eletrocardiógrafo (Imagem 21). Na legenda, lê-se: "Mais um aspecto dramático da doença: paciente em último grau de insuficiência cardíaca, ao termo de seus tremendos sofrimentos. Das paredes de barro e pau-a-pique saíam os insetos que lhe roubavam o sangue, dando-lhe o germe que, por fim, lhe tirou a vida" (Dias, 1946c: 6). Ao lado desta imagem, há fotografias do coração dilatado de um doente necropsiado designado como "coração bovino" - e de um corte histológico deste órgão, mostrando uma fibra muscular "completamente invadida" pelo parasito.

O drama da doença estava assim representado conforme o enquadramento que os cientistas pretendiam fixar. A idéia da cardiopatia chagásica crônica como fator primordial da materialidade clínica da doença e dos prejuízos econômicos e sociais por ela causados aos trabalhadores rurais encontrava, nesta composição exemplar, um poderoso recurso de persuasão. O público não especializado ia sendo convencido de que a doença de Chagas era essencialmente uma grave cardiopatia, e que, como tal, deveria ser combatida energicamente.

Neste trabalho para a revista $\mathrm{Eu} S \mathrm{Sei}$ Tudo, as fotografias que representavam o 'grande feito' de Carlos Chagas - como sua imagem examinando um dos primeiros casos agudos em Lassance e a visão do 'castelo' mourisco do IOC com sua dedicatória manuscrita (Imagens 8 e 2) reforçavam a importância científica e social que se queria atribuir àquela enfermidade, vinculando-a à autoridade e ao prestígio da tradição de Manguinhos (Dias, 1946c). 
Os enunciados sobre a forma cardíaca crônica - como a 'predileção’ do parasito pela fibra cardíaca, a alta freqüência da morte súbita e a evolução sempre grave da doença rumo à insuficiência cardíaca expresavam-se mediante formulações de forte apelo dramático. A cardiopatia chagásica era descrita como 'mal silencioso', cujos sinais, na maioria das vezes, eram detectáveis pelos aparelhos especiais dos cientistas, vistos como 'salvadores' por revelarem o que jazia 'escondido' no coração de pessoas que sequer se imaginavam doentes:

(...) milhares de nossos compatriotas têm a existência inutilizada e finalmente roubada por esta insidiosa moléstia. (...). O eletrocardiógrafo tem que ser levado até esses condenados que morrem obscuramente nas choupanas, para registrar os misteriosos fenômenos provocados pelo tripanossoma que lesa irreparavelmente seu coração. (Dias, 1946c: 6)

Outros mecanismos discursivos recorrentemente utilizados por Dias eram a 'demonização' do barbeiro e o tom de denúncia que se imprimia ao texto, destinado a alertar as populações sertanejas que aquele inseto, aparentemente inofensivo e familiar, era na verdade um "criminoso", um "inimigo mortífero" (Dias, 1945: 9). ${ }^{9} \mathrm{Um}$ exemplo foi a fotografia de um homem dormindo com um barbeiro pousado em sua face, publicada em Eu Sei Tudo, com a legenda: "Traiçoeiro, age o inseto na escuridão da noite. O caboclo indefeso dorme tranqüilo, ignorando que o barbeiro que lhe chupa o sangue traz consigo um germe invisível que lhe roubará a saúde e a vida" (Dias, 1946c: 3). Os textos eram recheados de metáforas, a maximizar o efeito retórico:

Disputando ao homem rural sua humilde habitação, tornou-se mestre na arte de ocultar-se e traiçoeiro nos seus hábitos noturnos, guiado por poderoso instinto de conservação, que se diria inspirado na consciência dos males que pratica. Hematófago estrito, é ávido de sangue humano, gozando, ainda por cima, grande resistência e vitalidade. Mas o maior de seus malefícios, que por si só justifica e impõe a execução das medidas mais radicais que contra ele possamos tomar, é o de contaminar o organismo humano com um micróbio patogênico peculiaríssimo, de funesta predileção pelo próprio coração (...). (Dias, 1945: 65-66)

Inseto e parasito eram, assim, representados como vilóes a produzirem uma 'ação maléfica' no órgão mais precioso, o coração, tradicionalmente visto como 'centro' da vida humana. O barbeiro, mais especificamente, 
aparecia como articulador de todos os demais elementos e significados que os textos estabeleciam como constitutivos da doença: a casa do sertanejo, o micróbio, o coração do doente. Ao conferir materialidade à entidade nosológica que emergia dos enunciados científicos, e para a qual se pretendia chamar a atenção de todos, a ênfase no inseto presente no diaa-dia dos sertanejos produzia forte argumento a justificar o objetivo dos cientistas: o de que era imperioso destruir o barbeiro, quebrar a cadeia de 'malefícios' que ele articulava. Para isso, os cientistas já vinham indicando várias medidas concretas. Além disso, a natureza hematófaga do inseto e sua abundância nas moradias rurais eram destacadas de modo a reforçar ainda mais a idéia de esgotamento das forças físicas do homem do campo. Tratava-se de um círculo vicioso da miséria: a pobreza dos sertanejos, expressa na cafua, permitia a infestação pelos insetos, que por sua vez os depauperavam ainda mais, tanto por transmitir uma doença que ataca o coração quanto pelo efeito direto de suas constantes picadas. Ao descrevê-lo como "grande sugador de sangue" (Dias, 1944: 3), Dias valia-se da mesma imagem à qual Belisário Penna (1918b: 142-143), em Saneamento do Brasil, havia conferido grande força retórica. Nas palavras do diretor do posto de Bambuí:

Ao sugar, enchem-se consideravelmente, chegando a retirar boas quantidades de sangue. Em vista do grande número de triatomas que pode haver nas cafuas (já vimos algumas com mais de dois mil!), imagine-se o mal que isso representa para a pobre e desnutrida gente que mora nessa classe de habitações. (Dias, 1944: 4; grifo do autor)

O uso de metáforas bélicas - comuns nas referências a processos patológicos, sobretudo epidêmicos - era recorrente nas passagens em que Dias focalizava a necessidade de combate aos barbeiros. O procedimento discursivo adquiria efeitos ainda mais contundentes no contexto do conflito mundial:

Voando à noite, eles [barbeiros] deixam as cafuas e dirigem-se freqüentemente às boas residências do centro da cidade, cujos moradores não estão livres de serem atingidos pela sua mortífera carga de microorganismos. Data venia, prevalecemo-nos da situação atual do mundo para compará-los a verdadeiras fortalezas voadoras carregadas com milhões de bombas... Nada menos que 188 bombardeiros, quer dizer barbeiros, foram abatidos - perdoe- 
nos o lapso - foram até agora capturados na zona urbana de Bambuí. (Dias, 1945: 85)

Tais construções discursivas potencializavam o efeito de "convocação’ que Dias pretendia imprimir a seus textos. Ressaltando a ausência de qualquer tratamento eficaz contra a enfermidade, ele enfatizava que o único caminho para a 'guerra' contra a doença era o combate ao "criminoso hematófago" (Dias, 1946c: 3):

Impossibilitados de lutar diretamente contra o tripanossoma, lutemos contra o seu transmissor, o barbeiro, este 'bandoleiro sangrento', no dizer de um cronista inspirado. 'Morte ao 'barbeiro' é o lema que norteia o combate à doença; exterminemos a um tempo, antes que perpetrem sua nefasta ação, micróbio e transmissor, cúmplices criminosos no assalto às nossa populações. (Dias, 1946c: 6)

Com o início das atividades do posto de Bambuí, a preocupação em convencer que a doença de Chagas era disseminada no continente americano e que todos deviam conhecê-la melhor e, sobretudo, combatêla (com os meios desenvolvidos pelos cientistas) tornou-se o foco dos próprios trabalhos científicos nos quais Dias e seus colaboradores apresentavam seus resultados de pesquisas.

Além das Memórias do Instituto Oswaldo Cruz, grande parte destes trabalhos foi veiculada no Brazil-Medico, periódico de grande circulação entre clínicos de vários estados do país. A maioria dos textos seguia o mesmo roteiro, com maior ou menor extensão, profundidade e detalhamento dos dados, no qual o 'desfecho' era sempre a exortação para que se reconhecesse a importância da doença como problema de saúde pública e se viabilizassem medidas para sua solução.

Assim, partia-se da descrição do ambiente geográfico-social propiciador da presença do inseto transmissor, ou seja, as precárias habitações das áreas rurais, mostrando-se dados sobre os altos índices de infestação destas moradias e os elevados níveis de infecção dos insetos pelo Trypanosoma cruzi. Em seguida, na descrição do quadro clínico, reforçava-se a 'predileção' deste parasito pelo músculo cardíaco, caracterizando-se a doença como fundamentalmente uma cardiopatia crônica. Para evidenciar os graves danos às populações rurais, apresentavam-se informações referentes às elevadas taxas de mortalidade na fase aguda, geralmente entre crianças, e à ocorrência de insuficiência cardíaca e/ou morte súbita na fase crônica, especialmente em indivíduos na idade mais 
produtiva da vida. Depois de exibir dados sobre a crescente casuística reunida pelo CEPMC (que confirmavam a alta prevalência da infecção, especialmente em sua forma cardíaca, entre as populações do interior) e de salientar a ausência de recursos terapêuticos, os textos eram concluídos com o alerta sobre a urgência da profilaxia, destacando-se as possibilidades técnicas que vinham sendo testadas em Bambuí (Dias, 1946a, 1946b, 1947, 1948a, 1948b, 1949a, 1949b). Além de apresentar as pesquisas em desenvolvimento no posto, tais publicações constituíam, portanto, pela própria narrativa que fixavam e reproduziam, um poderoso instrumento retórico de convencimento.

\section{A Divulgação nos Fóruns Médico-Científicos}

A apresentação em congressos médico-científicos e as conferências e cursos em centros de pesquisa e universidades, no Brasil e no exterior, foram outro meio para divulgar o trabalho do CEPMC. Pela ênfase no estudo clínico da forma cardíaca, os eventos da área de cardiologia constituíram um espaço particularmente visado. A atuação de Francisco Laranja foi determinante para despertar o interesse dos profissionais desta especialidade, em processo de fortalecimento e institucionalização. Em 1945, os primeiros resultados do estudo eletrocardiográfico feito por Dias, Laranja e Nóbrega foram apresentados à $2^{\mathrm{a}}$ Reunião Anual da Sociedade Brasileira de Cardiologia (SBC), realizada em junho no Rio de Janeiro. Naquele mesmo ano, a doença foi debatida por Dias e Laranja em curso de cardiologia ministrado na Faculdade Nacional de Medicina, no Rio de Janeiro, pelo então catedrático de cardiologia Magalhães Gomes. ${ }^{10}$ No ano seguinte, as pesquisas foram apresentadas na $3^{\text {a }}$ Reunião Anual da Sociedade Brasileira de Cardiologia, em Belo Horizonte. A doença de Chagas constituiu um dos temas oficiais do evento, relatado por Dias e Laranja. Ao final do encontro, Gomes encaminhou, em nome da SBC, uma moção de apoio ao IOC pelos trabalhos em Bambuí. Segundo os cardiologistas,

(...) considerando que a doença de Chagas constitui um dos temas oficiais da referida reunião; considerando que pela palavra dos relatores do tema, Doutores Emmanuel Dias e Francisco Laranja, e pela de outros médicos que apresentaram trabalhos originais, ficou perfeitamente demonstrado que a esquizotripanose é uma tre- 
menda endemia existente na maior parte do território nacional, ocasionando uma cardiopatia gravíssima e incurável; considerando que o Instituto Oswaldo Cruz, sob a sábia direção do Professor Henrique Aragão, tem proporcionado notável incremento nas pesquisas relativas a esta infecção; considerando que o mesmo Instituto foi o primeiro a organizar um Centro de Estudos no interior para investigações sobre a profilaxia do mal; Resolveu [a SBC], por decisão unânime consignada em ata, enviar a presente moção de apoio e aplauso ao Instituto Oswaldo Cruz pelos importantes trabalhos que vem realizando sobre a doença de Chagas e pelas iniciativas de grande alcance que tem tomado no combate à moléstia; e dirigir-lhe um apelo no sentido de que continue auxiliando e incentivando, em escala cada vez maior, os médicos e cardiologistas que, nas cidades como no interior do país, se interessam pela pesquisa deste momentoso assunto. ${ }^{11}$

Dias utilizaria o apoio formal dos cardiologistas como importante trunfo em sua mobilização em torno da doença, solicitando ao diretor do jornal $O$ Estado de Minas que desse ampla publicidade à moção. ${ }^{12}$

Outro episódio revelador deste movimento para inserir a doença de Chagas nos espaços institucionais da clínica médica, particularmente da cardiologia, e de como a figura de Laranja era fundamental para isso, foi o convite que este recebeu para produzir um capítulo sobre o tema na edição brasileira de um manual médico alemão, organizada pelo professor de clínica médica da Faculdade Nacional de Medicina, Luiz Capriglione (Capriglione \& Strumpell, 1946). ${ }^{13}$ Pela extensão do trabalho, que tinha mais de cem páginas, Laranja recebeu críticas de alguns médicos, que consideraram desproporcional a ênfase que o tema assumiu no referido volume. Ao lembrar o episódio, ele relata que a justificou afirmando que "no futuro iria se tornar uma doença reconhecida de grande importância médica para os países sul e centro-americanos” (Laranja, 1978: 10).

A comunidade médica internacional também constituía audiência fundamental a ser conquistada. Um evento importante foi o I Congresso Interamericano de Medicina, ocorrido no Rio de Janeiro e promovido pela Academia Nacional de Medicina em setembro de 1946, no qual os trabalhos sobre a doença de Chagas tiveram grande destaque. ${ }^{14}$ Entre as resoluções oficiais, estava a recomendação de que fosse criado um centro ou uma fundação para coordenar as pesquisas e ações relativas ao assunto, com sede no IOC e representantes de diversos países do continente 
(apud Romaña, 1952). Octavio de Magalhães, da Faculdade de Medicina da Universidade de Minas Gerais, apresentou, na ocasião, a idéia de que se organizasse no país um Serviço Nacional de Combate à Doença de Chagas, para, sob a orientação do IOC, coordenar as ações da União, dos estados e dos municípios destinadas ao controle da enfermidade, e empreender uma vasta campanha para criar "a consciência cívica contra o barbeiro", além de desenvolver pesquisas sobre a doença (Magalhães, 1947: 17).

Também no plano internacional, os espaços institucionais da cardiologia foram utilizados para divulgar as pesquisas clínicas do CEPMC. Os estudos sobre a cardiopatia chagásica foram apresentados no Congresso Interamericano de Cardiologia, em suas segunda e terceira reuniões (realizadas na Cidade do México e em Chicago, respectivamente, em 1946 e 1948), e no $1^{\circ}$ Congresso Mundial de Cardiologia, em Paris, em 1950 (Laranja, Dias \& Nóbrega, 1948a; Laranja, Pellegrino \& Dias, 1948; Laranja, Dias \& Pellegrino, 1950). Em 1946, depois do evento no México, Dias e Laranja foram convidados pelo Instituto Nacional de Cardiologia daquele país a percorrer o interior, em companhia de diversos médicos e cardiologistas, para capturar barbeiros e animais silvestres, realizar exames e efetuar traçados eletrocardiográficos. ${ }^{15} \mathrm{Em}$ seguida, os pesquisadores brasileiros foram aos Estados Unidos, onde apresentaram conferências na Universidade do Texas, em Galveston, e visitaram o laboratório de Ardzroony Packchanian, que estudava a doença de Chagas naquela universidade. Depois de reuniões com cardiologistas norteamericanos em Austin, Houston e Nova Orleans, Dias partiu em viagem por países latino-americanos (Guatelama, El Salvador, Costa Rica, Panamá, Colômbia, Equador, Peru), para divulgar a cardiopatia chagásica entre estudantes de medicina, médicos (especialmente cardiologistas) e pesquisadores. Ao relatar tais viagens ao diretor do IOC, destacou que havia recebido muitas solicitações de pesquisadores, nos diversos países que visitou, para que lhes enviasse literatura sobre o assunto e antígenos para realização de exames. O diretor do CEPMC entusiasmava-se com as perspectivas de conquistar os colegas no continente americano:

(...) sou de parecer que o Instituto [Oswaldo Cruz], estabelecendo numerosos contatos, por meu intermédio, em todas as Repúblicas visitadas, acha-se em posição ímpar para estimular e colaborar nas pesquisas sobre doença de Chagas, problema de interesse verdadeiramente continental, ao qual deve continuar dando toda a sua 
atenção, atendendo de imediato a todas as solicitações, aqui veiculadas, de material e literatura, além de, sempre que possível, assistência técnica. ${ }^{16}$

Em 1947, o trabalho em que Laranja, Dias e Nóbrega (1948b) sistematizavam os principais resultados de suas pesquisas clínicas e eletrocardiográficas foi apresentado no $2^{\circ}$ Congresso Mexicano de Medicina. No ano seguinte, Laranja voltou aos Estados Unidos, onde pronunciou conferências sobre a cardiopatia chagásica no Army Institute of Pathology, Washignton; no Peter Bent Brigham Hospital (Universidade de Harvard); no Massachussets General Hospital, em Boston; e no hospital da Universidade da Pensilvânia. Em 1949, ele faria uma série de conferências na Faculdade de Ciências Médicas de Buenos Aires e na Universidade de Tucumán, Argentina. Em 1952, voltaria ao México para palestras no Instituto Nacional de Cardiologia e na Sociedade Médica de Cuernavaca. ${ }^{17}$

Outro grupo importante junto ao qual se buscava divulgar o trabalho feito em Bambuí eram os pesquisadores da área de parasitologia e medicina tropical. ${ }^{18}$ De grande repercussão foram os IV Congressos Internacionais de Medicina Tropical e Malária, realizados em Washington, em 1948, e que voltavam a se reunir depois de um período de interrupção ocasionado pela guerra. ${ }^{19}$

O encontro teve particular importância no campo médico-científico por conferir visibilidade ao entusiasmo, cada vez mais forte no pósguerra, quanto aos novos recursos tecnológicos para o combate às doenças infecciosas, como o DDT, num ambiente geral de otimismo em relação ao ‘desenvolvimento’ no cenário internacional (Escobar, 1995; Garret, 1995; Farley, 2004). Dias e Laranja (1948) apresentaram, no evento, uma comunicação sintetizando os principais aspectos das pesquisas feitas em Bambuí. Quanto à sistematização clínica da tripanossomíase americana, afirmaram que "clinically, chronic Chagas' disease is essentially represented by cardiac form, since the other chronic forms described are doubtful" (Dias \& Laranja, 1948: 1.163). ${ }^{20}$ Reiteraram os contornos essenciais do quadro clínico estabelecidos pelo CEPMC: uma infecção crônica que, mesmo sem apresentar sintomas, conduzia inevitavelmente a uma cardiopatia específica, detectada sobretudo pelo método eletrocardiográfico, e que acometia preferencialmente indivíduos jovens, conduzindo-os à insuficiência cardíaca ou à morte antes dos 55 anos. 
Quanto à profilaxia, destacaram: "Chagas disease is an extremely important social and public health problem, both for its incidente and its severity. It demands the urgent and careful attention of the public health authorities in Latin America" (Dias \& Laranja, 1948: 1.165). ${ }^{21}$ Foi então aprovada resolução solicitando à Repartição Sanitária Pan-Americana que se tornasse o centro de coordenação entre instituições e pesquisadores interessados no estudo da doença de Chagas no continente (Fourth International Congresses of Tropical Medicine and Malaria, 1948: 26).

Também em 1948, em reunião conjunta da American Society of Parasitologists, American Society of Tropical Medicine, American Academy of Tropical Medicine e National Malaria Society, realizada em Nova Orleans, o pesquidador norte-americano A. Chandler apresentou trabalho em colaboração com Dias (Dias \& Chandler, 1949).

\section{Ampliando as Articulações para Conquistar as Agências Sanitárias}

Além dos médicos e cientistas, outros grupos seriam alvo da mobilização empreendida pelo diretor do CEPMC, como as autoridades políticas, sobretudo no contexto mineiro. Para isso, Dias contou com um aliado fundamental, o diretor do IOC. Henrique Aragão atuava pessoalmente junto a tais autoridades, para obter apoio às atividades do posto em Bambuí e para convencê-las a implementar medidas para o combate à doença de Chagas. Um segmento importante eram os prefeitos. Em circular publicada em 1947, no jornal Minas Gerais, o Superintendente do Departamento de Municipalidades, Orlando de Carvalho, exortou os chefes municipais de todo o estado a atenderem à solicitação de Aragão para que colaborassem com as ações que o IOC estava desenvolvendo para o estudo e a profilaxia da doença de Chagas. Segundo o superintendente, os prefeitos deveriam enviar barbeiros para exame, promover campanhas de educação sanitária especialmente nas escolas, estimular melhorias nas habitações populares, além de “(...) procurar interessar nesta campanha os médicos, sanitaristas, laboratoristas, farmacêuticos, professoras que trabalham [no] município, enviando o quanto antes ao Instituto uma lista das pessoas que lhes pareçam com maior disposição e capacidade para colaborar nessas importantes pesquisas". ${ }^{22}$ 
A circular informava que Dias enviaria folhetos e qualquer material impresso necessário. Em matéria veiculada, em agosto, no mesmo jornal, Carvalho reforçou a importância da resposta dos prefeitos e salientou que o IOC publicaria um trabalho com base nas informações fornecidas por eles. ${ }^{23}$

Antes mesmo do apelo de Aragão, alguns prefeitos mineiros já colaboravam ativamente com o CEPMC. O prefeito de Monte Belo tomou medidas em sua cidade para o combate aos barbeiros: coleta e envio de insetos ao posto de Bambuí, numeração das cafuas para controle, registro de possíveis casos da doença pelas farmácias locais, proibição de construção de cafuas e de reparos inadequados nas habitações. Em tom entusiasmado, comemorou a "destruição espontânea", pelo próprio morador, de um casebre infestado por barbeiros. ${ }^{24}$

No âmbito da política estadual, a União Democrática Nacional (UDN), partido que elegeu em 1946 o governador Milton Campos, vinha manifestando, por ocasião desta campanha eleitoral, interesse pelo problema da doença de Chagas. Ao se referir com otimismo às perspectivas para a luta contra o 'flagelo' no estado, Dias afirmou:

Em Minas Gerais há boas perspectivas de progresso neste terreno [da profilaxia]. No programa de realizações da União Democrática Nacional figura desde o ano passado o combate à endemia chagásica, sendo portanto muito de esperar-se do governo Milton Campos. Dando início à campanha o Departamento Cultural do grande partido já fez publicar em inúmeros jornais o artigo 'A UDN e o problema da doença de Chagas', no qual se encontra utilíssimo plano de ação (...). (Dias, 1946 b: 163-164) ${ }^{25}$

A busca por uma nova sede com melhores instalações para o CEPMC, que desde a inauguração funcionava em pequena casa alugada, constituiu situação particularmente oportuna para Dias e Aragão buscarem o apoio da classe política mineira. Por intermédio de Aragão, Dias foi recebido pessoalmente pelo governador Milton Campos em julho de 1947 para tratar do assunto. Ele autorizou o início da construção, em terreno cedido pela municipalidade, de um novo prédio especialmente projetado para o posto do IOC, cuja inauguração se daria em 1951. A proximidade com o executivo estadual de Minas Gerais também se expressou na carta em que Dias comentou com Aragão suas conversas com o então secretário do Interior, Pedro Aleixo, a respeito de possíveis mudanças na legislação estadual sobre endemias. Aleixo havia sugerido 
que o mais indicado seria um deputado da UDN propor emenda à Constituição mineira, prevendo a reserva de uma percentagem das verbas municipais (5\% ou 10\%) para o combate às doenças endêmicas. Dias contou a Aragão que ele e Amilcar Martins estavam conversando sobre o assunto com vários deputados, inclusive de outros partidos, que também haviam se mostrado interessados em apresentar a matéria em plenário. Sobre Milton Campos, disse, entusiasmado: "mandou-me dizer que está inteirado dos problemas que estamos agitando e encara-os com a máxima boa vontade”. ${ }^{26}$

Além das investidas junto aos políticos, buscava-se arregimentar a colaboração da própria população das áreas rurais, sobretudo daqueles que habitavam as moradias infestadas ou sob risco de infestação pelos barbeiros, convencendo-os a notificar o posto sobre a existência destes insetos e a adotar medidas preventivas em suas residências. ${ }^{27}$ As táticas para fazer chegar a estas pessoas os conhecimentos básicos sobre a doença incluíam a circulação de folhetos, a publicação de matérias em jornais locais e o aconselhamento dos médicos que as atendiam em seus consultórios ou postos de saúde. O próprio posto de Bambuí, em razão da prestação de assistência médica e da distribuição gratuita de medicamentos, atraía os habitantes da cidade e das regiões vizinhas, facilitando a divulgação da importância da doença e o registro de novos casos..$^{28} \mathrm{O}$ apoio da população de Bambuí e regiões vizinhas foi expresso em abaixo-assinado encaminhado ao diretor do IOC, enaltecendo as atividades do CEPMC e solicitando que fossem ampliadas ao máximo, mediante a substituição das cafuas por habitações apropriadas à proteção contra os barbeiros:

Esse empreendimento memorável que repercutiu bem alto além das fronteiras, trazendo ao nosso meio técnicos de nomeada universal, não pode perecer. Como sabemos do patriótico e humanitário empenho desta casa, cuja direção foi, em boa hora, confiada à alta proficiência de V. Excia., de combater e extinguir esse terrível mal que flagela a nossa população, especialmente a menos favorecida da fortuna, vimos solicitar que se empenhe junto a quem de direito, para proporcionar ao Posto local os necessários recursos financeiros para, com a colaboração dos poderes estaduais e municipais, completar a obra tão brilhantemente encetada, com resultados tão magníficos e que falam tão alto da cultura científica desse púgilo de sábios e patriotas do Instituto Oswaldo Cruz. ${ }^{29}$

Além do prefeito da cidade, assinaram o documento: médicos, advogados, um delegado de polícia, um pároco, irmãs batistinas, farmacêuticos, 
fazendeiros, funcionários públicos, um tabelião, um coletor federal, um contador do juízo, um juiz, dentistas, bancários, um escrivão, comerciantes, o chefe do serviço de obras da prefeitura, um promotor de Justiça, um agente municipal de estatística, um engenheiro agrônomo, industriais, um corretor de seguros, industriários e professoras. Na década de 1950, quando a doença ganharia as páginas dos jornais em razão da primeira campanha de profilaxia, o interesse da população sobre o tema se apresentaria também mediante solicitações de doentes ou de seus familiares, que escreveriam a Dias em busca de tratamento e de informações. ${ }^{30}$

O apoio desses diversos grupos sociais - médicos, cientistas, políti$\cos$, moradores das áreas endêmicas - era importante para a conquista de um elo decisivo na cadeia de associações que Dias pretendia construir em torno da doença de Chagas: as autoridades sanitárias, especialmente as responsáveis pela realização de campanhas de controle de endemias. Os 'alvos' eram tanto os organismos estatais de saúde brasileiros - nos níveis federal e estadual -, quanto as agências internacionais, como a Repartição Sanitária Pan-Americana (RSPA).

A partir de 1948, quando se comprovou experimentalmente a eficácia do gamexane contra os barbeiros e, ao mesmo tempo, os pesquisadores consideraram sistematizados os conhecimentos clínicos sobre a cardiopatia chagásica crônica, o diretor do CEPMC passou a reforçar em seus textos e pronunciamentos o argumento de que era possível e urgente implementar ações de profilaxia, e que cabia àquelas autoridades, no Brasil e no continente americano, assumir o quanto antes esta responsabilidade.

Naquele ano, Dias (1949b) recebeu em Bambuí a visita do diretor do Departamento Nacional de Saúde (DNS), Heitor Praguer Froés, a quem relatou os bons resultados com o gamexane, tendo em vista convencê-lo de que já se dispunha de instrumento eficaz para a profilaxia da doença. Em outubro de 1948, graças à intermediação de Fróes, ele esteve presente na VI Conferência Pan-Americana de Diretores de Saúde, realizada na Cidade do México, onde enfatizou este argumento, afirmando que a tripanossomíase americana, "pela sua ampla distribuição nas Américas e pela gravidade de sua forma cardíaca, constitui importante problema continental cuja significação ainda não é bem compreendida" (Dias, 1948b: 160). Destacou as medidas fundamentais para a profilaxia - melhorias habitacionais, borrifação de inseticida nas moradias e educação sanitária. Reiterando que, "como acontece com todas as infecções transmitidas por artrópodes, a luta contra as doenças veiculadas por 
triatomas tem como base a erradicação dos agentes intermediários", acentuou que a experiência do posto de Bambuí havia demonstrado ser "possível a erradicação dos triatomas pelo expurgo domiciliar repetido" (Dias, 1948b: 1.160-1.161). O fato de o gamexane ainda possuir certas restrições técnicas não era, segundo ele, motivo para abandonar este ideal, que deveria ser atingido também pela promoção de melhorias habitacionais. Dias conclamou a RSPA e os diretores nacionais de Saúde dos países do continente para que organizassem "um programa com o objetivo ideal e remoto da erradicação das espécies mais perigosas de triatomas do Novo Mundo" (Dias, 1948b: 1.162).

Quanto à implementação do combate sistemático aos triatomíneos no Brasil, Dias se queixava da falta de interesse das autoridades sanitárias. Em artigo cujo título explicitava esta reivindicação - "Considerações sobre a importância da moléstia de Chagas em Minas Gerais e estados vizinhos. Necessidade urgente de ser desenvolvido o estudo dessa endemia e de serem tomadas medidas para combatê-la" -, ele denunciou a não inclusão da doença de Chagas na pauta da política de saúde pública do país:

Um fato muito lamentável ocorre em relação à doença de Chagas. (...) sabe-se que é extremamente difundida e que determina grave processo de miocardite cuja expressão clínica é uma cardiopatia incurável; conhecem-se outros fatos sugestivos da gravidade deste problema de higiene rural. Não obstante, praticamente nada se faz para combatê-la. Enquanto outras endemias consomem grandes verbas e contam com serviços nacionais de profilaxia, a esquizotripanose permanece inteiramente ignorada pelas autoridades sanitárias, que jamais lhe reservaram nos seus orçamentos qualquer soma para cumprir os dispositivos a ela referentes. (Dias, 1949b: 217)

Depois de apresentar uma série de dados sobre a distribuição dos transmissores, dos casos da doença e seu impacto médico-social entre a população rural, por se tratar de uma doença cardíaca, Dias mencionou, neste texto, o apelo que fizera à RSPA, no Congresso dos Diretores Nacionais de Saúde, no México. Ao manifestar a expectativa de que "o Departamento Nacional de Saúde não mais continuará indiferente a este problema" (Dias, 1949b: 219), fez referência aos meios de se viabilizar as medidas de profilaxia. Propôs, por exemplo, a criação, pelo DNS, de serviços especialmente destinados à doença de Chagas nos departamentos estaduais de saúde, a fim de realizar trabalhos de rotina (como exames 
sorológicos, criação de barbeiros para xenodiagnóstico, execução de expurgos), pesquisas científicas (nos campos da epidemiologia, clínica e profilaxia da doença) e atividades de educação sanitária, com equipes técnicas formadas no IOC e no posto de Bambuí. Em sua conclusão, salientou:

O ideal é que se pudesse completar este plano com o início, o mais cedo possível, de expurgos domiciliares com 'Gammexane' $[\mathrm{BHC}]$ nas zonas rurais infestadas por barbeiro. O Serviço Nacional de Malária, pela sua esplêndida organização devida à brilhante atuação do Dr. Mario Pinotti, seria o mais capaz para enfrentar este problema e poderia talvez, iniciando-a nas zonas malarígenas, estender depois sua atuação a todos os focos da endemia chagásica, prestando assim mais um colossal serviço ao Brasil. Expressamos nosso veemente desejo de que as idéias sugeridas possam ser postas em prática e reiteramos nosso apelo às altas autoridades no sentido de não pouparem esforços para encarar a solução de um magno problema de higiene rural, até agora incompreensivelmente tão descurado. (Dias, 1949b: 219)

Tendo em vista que atuava não apenas na produção de conhecimentos sobre a doença, mas também como liderança de intensa mobilização para viabilizar seu enfrentamento, Dias assumia, como cientista, o mesmo perfil de intelligentsia, no sentido proposto por Karl Mannheim (1974), que é possível identificar em Carlos Chagas. Atuava como intelectual comprometido com a intervenção no mundo da política, vendo-se como detentor de um saber capaz de contribuir diretamente para a formulação de um projeto nacional.

Como indicam vários autores (Bomeny, 2001), foi extensa, no período pós-1930, a participação de intelectuais na montagem de projetos de ação política, em diversas áreas, e na legitimação do Estado como responsável pela promoção de políticas sociais. ${ }^{31}$ Num processo que remonta ao final do século XIX, os intelectuais brasileiros concebiam a modernização do país como decorrente da combinação entre os recursos e saberes da ciência, dos quais eram os portadores, e a intervenção do Estado, como instância suprema de articulação das forças sociais (Alonso, 2002; Carvalho, 1991; Hershmann, Kropf \& Nunes, 1996).

Dias reproduzia, como cientista envolvido com a política e a construção da nação, a identidade assumida pelos médicos e cientistas que, no movimento sanitarista da década de 1910, reivindicaram a responsabilidade 
do Estado no equacionamento dos problemas que, segundo eles, comprometiam o progresso do país (Lima, 1999). O contexto da década de 1940, especialmente no pós-guerra, era particularmente favorável a esta associação entre ciência, saúde e projetos de desenvolvimento.

\section{Os Médicos do Brasil Central e a Doença do Sertão}

Aliados decisivos para que, conforme as reivindicações do diretor do CEPMC, fosse viabilizada uma ação estatal voltada para a tripanossomíase americana foram os médicos do interior, que já vinham colaborando com o posto mediante o diagnóstico de novos casos e a produção dos conhecimentos clínicos sobre a doença. ${ }^{32}$

Os chamados "Congressos Médicos do Brasil Central" surgiram como um importante espaço de representação e afirmação socioprofissional destes clínicos, tendo sido criados justamente no contexto desta associação de interesses com os cientistas. Tais eventos, voltados para a discussão de endemias e problemas sanitários típicos dos sertões do país, constituíram um fórum privilegiado para a apresentação das pesquisas realizadas pelos médicos do interior sobre a doença de Chagas, a afirmação de sua importância como obstáculo ao desenvolvimento das áreas rurais e o encaminhamento político conferido à questão. ${ }^{33}$

O $1^{\text {o }}$ Congresso Médico do Triângulo Mineiro aconteceu em Uberaba, em dezembro de 1947, por iniciativa do presidente da Sociedade de Medicina local, tendo como tema principal a doença de Chagas. Nesta cidade, núcleo do Triângulo Mineiro, vários clínicos interessavam-se pelo assunto, especialmente Rubem Jácomo. Tal interesse expressava-se no noticiário constantemente dedicado à doença em Lavoura e Comércio, principal jornal da região (Bilharinho, 1983). O Centro de Saúde, procurado por muitos pacientes em busca de tratamento para a enfermidade, já em 1947 alertara a Secretaria de Saúde do Estado para a necessidade de atendimento especial a estas famílias. ${ }^{34} \mathrm{O}$ objetivo do congresso era reunir médicos locais para discutir os problemas da região. Relembram dois destes médicos:

Ficou estabelecido, neste dezembro, um divisor de águas na História da Medicina no Brasil. Pela primeira vez, médicos do Brasil Central 
se arregimentaram num congresso desta natureza. Os congressistas não eram muitos e nem todos configuravam grandeza na medicina oficial indígena. Não eram esplendentes de juventude, eram entrados ou entrando na quarta década de vida. E eram médicos do interior. Todavia, seu papel histórico na evolução da medicina tropical possui uma significação que não pode ser minimizada. (Porto \& Porto, 1970: 117)

Ao afirmar que eram eles, e não os 'médicos do litoral', quem lidava concretamente com os flagelos do interior do país, os médicos do Brasil Central passaram a usar o tema da importância científica e social da endemia chagásica, 'doença do sertão', para maximizar seus próprios interesses e afirmar sua identidade socioprofissional diferenciada.

Uma evidência dos resultados desta poderosa aliança foi o fato de que no $3{ }^{\circ}$ Congresso Médico do Triângulo Mineiro, ocorrido em Araxá em setembro de 1949, Dias (1949a) pronunciou uma conferência emblemática dos conteúdos e das estratégias utilizados em sua militância para inserir a doença de Chagas na pauta das políticas sanitárias do país. ${ }^{35}$

A associação com os médicos do interior foi reafirmada mediante a homenagem a Carlos Chagas, representado como exemplo da tradição de Manguinhos na articulação entre ciência e saúde pública e da centralidade que os 'males do interior do Brasil' assumiam nesta tradição. Segundo Dias (1949a: 679), Chagas foi essencialmente um "filho do interior, [que] triunfou nos grandes centros mundiais, mas para ele [interior] teve sempre o espírito voltado”. Seguindo o roteiro de seus outros textos e apresentações, destacou a vasta distribuição dos barbeiros em Minas Gerais, a alta percentagem de infecção destes insetos pelo T. cruzi e os resultados dos inquéritos feitos pelo CEPMC, que revelavam "a freqüência alarmante da infecção nas populações rurais” (Dias, 1949a: 681). Segundo tais dados, em 1.920 reações de fixação de complemento praticadas em soros de indivíduos não selecionados de Bambuí, haviam sido positivas 780 , ou seja, $60,4 \%$.

O vínculo com os clínicos do Brasil Central explicitou-se também no modo de apresentar as pesquisas científicas do CEPMC, para as quais, ressaltou Dias, era fundamental a colaboração daqueles profissionais. Os trabalhos de Miron de Menezes, em Uberlândia, e de Rubem Jácomo, em Uberaba, foram incorporados, assim, como fontes importantes para os dados reunidos pelo posto sobre a dimensão geográfica e social da endemia: "Computando em conjunto estes resultados, observamos que 
num total de 2.893 reações feitas em Minas, São Paulo e Goiás, nada menos que $52,5 \%$ deram resultado positivo, o que revela portanto altíssima incidência da esquizotripanose nessas regiões do Brasil Central" (Dias, 1949a: 681). Ao trazer os aliados para dentro dos números e dados técnicos das investigações que apresentava, Dias imprimia força persuasiva a seu argumento central: a denúncia da gravidade de uma doença que, sendo uma “infecção cardiotrópica por natureza” (Dias, 1949a: 682), trazia sérios prejuízos para o desenvolvimento de Minas e de todo o interior do país. Em suas palavras: "Que outra endemia pode ser mais terrível do que esta que, assim difundida, lesa irremediavelmente o coração de milhares, senão milhões de nossos conterrâneos?" (Dias, 1949a: 683). Também aqui a contribuição dos clínicos colaboradores do IOC foi ressaltada mediante dados sobre a cardiopatia chagásica crônica produzidos nos consultórios de Menezes e Jácomo, em Minas Gerais, e por Adriano Pondé, na Bahia. ${ }^{36}$

Ao final, todos os elementos apresentados convergiam para reivindicar aos poderes públicos ações concretas de combate à doença. Mais uma vez, Dias (1949a: 684) sugeriu: “(...) a providência mais acertada no momento (...) é a de que um serviço perfeitamente organizado e que tem dado provas de máxima eficiência, qual seja o Serviço Nacional de Malária, tome a si a tarefa maior de iniciar o combate aos triatomas". Ele também chamou a atenção para a necessidade de que os departamentos e as secretarias estaduais de saúde começassem a "proceder desde já ao levantamento das áreas infestadas". Como desenlace final de sua exposição, convidou os congressistas presentes a manifestar seu apoio a este empreendimento mediante moção dirigida ao ministro da Educação e Saúde, na qual fosse

(...) solicitado dirija-se Sua Excelência ao Diretor do Departamento Nacional de Saúde e ao Diretor do Serviço Nacional de Malária, bem como a todas as autoridades que julgue necessário ou conveniente, recomendando-lhes providências para que sejam lançadas as bases efetivas de uma campanha redentora, que poderá ser longa e penosa, mas que devemos reclamar em nome de milhares e milhares de humildes compatriotas nossos. (Dias 1949a: 685)

A moção foi encaminhada pelo presidente do congresso, Sabino Vieira de Freitas, ao ministro Clemente Mariani, fato que seria muitas vezes lembrado pelos médicos do Brasil Central como evidência do papel que desempenharam para a viabilização da profilaxia da doença de Chagas no Brasil. ${ }^{37}$ 
No mês seguinte, mediante acordo firmado entre os diretores do IOC e do Serviço Nacional de Malária (SNM), Henrique Aragão e Mário Pinotti, tiveram início, na cidade de Uberaba, expurgos experimentais destinados a estabelecer procedimentos técnicos para uma campanha de desinsetização domiciliar em grandes áreas. O SNM arcou com os custos dos inseticidas e de material, oferecendo também pessoal especializado, treinado nas campanhas antimaláricas. O CEPMC enviou todos os seus guardas e técnicos, que se transferiram com Dias para Uberaba. Nesta cidade, contaram com a colaboração sistemática de médicos locais, liderados por Rubem Jácomo. Dos diversos inseticidas testados em 15 localidades, revelaram-se de maior eficácia aqueles à base de cloro, como o BHC, e os tiofosfatos, como o Rhodiatox, isolados ou associados ao DDT (destinado ao combate simultâneo dos mosquitos). ${ }^{38}$ Embora os ensaios continuassem até os primeiros meses de 1950, Dias comunicou ao prefeito da cidade, em novembro de 1949, os bons resultados preliminares, expressando seu otimismo: “(...) já dispomos de recursos técnicos eficazes e praticáveis na luta contra os barbeiros, o que justifica que seja pleiteada desde agora sua aplicação em maior escala, sem prejuízo da continuação dos trabalhos de ordem estritamente experimental". ${ }^{39}$

A movimentação política em Uberaba, em prol da campanha reivindicada por Dias, foi imediata. Logo depois deste comunicado, o vereador e médico Cláudio Moreira de Almeida, colaborador das experiências, pronunciou discurso na Câmara Municipal, no qual leu o documento de Dias ao prefeito e sugeriu que os vereadores solicitassem ao presidente da Comissão de Saúde Pública da Câmara Federal, Miguel Couto Filho, em caráter de urgência, providências destinadas à ampliação dos trabalhos iniciados, em outubro de 1949, em Uberaba, mediante recursos especiais ao IOC e ao SNM. ${ }^{40}$ Em relatório à Secretaria de Saúde do estado, o Centro de Saúde de Uberaba reiterou a gravidade do problema, afirmando ser o Triângulo Mineiro o maior foco da doença no país, e clamou por medidas profiláticas amplas. ${ }^{41}$ Além dos ensaios em Uberaba, foram feitos testes com inseticidas em Bambuí e na Cidade Industrial, próxima a Belo Horizonte, igualmente como preparação para uma campanha em maior escala (Dias \& Pinto, 1952; Pellegrino \& Brener, 1951).

O ano de 1949 havia sido de grande importância para os objetivos do CEPMC também em razão da realização, em julho, nas cidades argentinas de Tucumán, Salta e Jujuy, da Primeira Reunião Pan-Americana de Doença de Chagas, promovida pela RSPA. No ano anterior, por ocasião 
dos IV Congressos Internacionais de Medicina Tropical e Malária, a RSPA havia assumido formalmente o compromisso de promover o estudo da doença de Chagas no continente, destinado especialmente à sua profilaxia. Nesta reunião na Argentina, Dias apresentou resultados do inquérito clínico-epidemiológico realizado em 1947, com Laranja e Pellegrino, em localidades ao longo da Rede Mineira de Viação (Dias, Laranja \& Pellegrino, 1948, 1950). O evento foi um marco importante do reconhecimento científico e social da doença: era a primeira vez que pesquisadores de países do continente americano reuniam-se em fórum específico para debater a doença de Chagas, sob a chancela da RSPA.

Neste contexto de expressivas respostas à mobilização empreendida pelo CEPMC, o MES, mediante a portaria n. 577, de 6 de dezembro de 1949, atribuiu ao SNM, ao IOC e à Divisão de Organização Sanitária/ MES, o encargo de "organizarem com a máxima urgência um plano para início da profilaxia da doença de Chagas, com base na aplicação de inseticidas" (apud Pinotti, 1950b). O plano seria executado pelo SNM a partir das diretrizes técnicas firmadas nos estudos desenvolvidos, sobretudo na cidade de Uberaba, sob a orientação dos pesquisadores do IOC e com o apoio da Secretaria de Saúde e Assistência de Minas Gerais. ${ }^{42}$

Henrique Aragão, que havia garantido, como diretor do IOC, as condições institucionais e políticas para o trabalho do posto de Bambuí, não assistiria, entretanto, a esta importante conquista dos cientistas de Manguinhos. Em 1949, em atitude inédita na história da instituição, demitiu-se do cargo, diante da decisão do MES (que acabaria sendo revogada) de transferir, para o Serviço Nacional de Febre Amarela, o laboratório que desde 1937 produzia a vacina contra esta doença. Olympio da Fonseca Filho seria o diretor de Manguinhos presente na inauguração oficial da campanha.

\section{A Primeira Campanha (1950)}

"Empreendimento inédito no mundo: oficialmente inaugurada em Uberaba a campanha contra a doença de Chagas". Assim noticiou $O$ Diário, de Belo Horizonte, o início, em 7 de maio de 1950 em Uberaba, do primeiro programa de profilaxia da tripanossomíase americana no Brasil. A região escolhida para os expurgos compreendia 123 municípios de Minas Gerais, situados no Triângulo Mineiro e no sudoeste do 
estado, e 93 no norte de São Paulo, na bacia do Rio Grande, numa área de aproximadamente 213.000 quilômetros quadrados e que abrangia uma população de cerca de 3.460 .000 habitantes (Pinotti, 1953: 684). Nesta região, nas quais o Triatoma infestans era a principal espécie de transmissor, previa-se a aplicação de inseticidas em cerca de duzentas mil habitações. A vinculação entre doença de Chagas e prejuízo à produtividade rural foi um argumento central a justificar a campanha, inclusive do ponto de vista da escolha das regiões a serem beneficiadas. Conforme o diretor do SNM, Mário Pinotti (1953: 683-684), tal seleção baseara-se em "razões várias, de ordem técnica, econômica e prática”: melhor conhecimento da prevalência da infecção por parte dos pesquisadores, a oportunidade de estabelecer uma barreira contra a expansão do T. infestans para norte e para leste, e o fato de ter a região alta densidade demográfica, "possuindo grande importância econômica, pois compreende áreas altamente produtivas” (Pinotti, 1953: 684).

A inauguração da campanha, com a presença de diversas autoridades políticas e sanitárias, teve grande repercussão na imprensa, especialmente em Minas Gerais. ${ }^{43} \mathrm{O}$ evento foi filmado pelo Instituto do Cinema Educativo do MES, que já havia registrado o trabalho experimental realizado na cidade um mês antes. ${ }^{44} \mathrm{O}$ tema ocupou também as tribunas da Câmara Federal. ${ }^{45} \mathrm{O}$ otimismo quanto ao poder da ciência e à capacidade de ação do Estado como instrumentos para a 'redenção' dos sertanejos foi expresso em tom ufanista nas reportagens sobre "a campanha de preservação dos habitantes do campo contra o pior inimigo de sua saúde" (Estado de Minas, 1950b: 4). A ocasião conferiu grande projeção pública ao trabalho do CEPMC e às noções sobre a doença preconizadas pelos cientistas, sobretudo à sua caracterização como cardiopatia perigosa para o trabalhador rural, como se percebe no título de reportagem publicada na capital federal: "Descoberto o inseticida para o combate da 'doença de Chagas’. Ação do perigoso ‘barbeiro’ entre as populações rurais. Produtor de $65 \%$ das cardiopatias. Iniciada a campanha contra o triatomídeo” (Diário Carioca, 1950: 3). A conferência realizada por Francisco Laranja na Sociedade de Medicina e Cirurgia de Uberaba foi divulgada pelo jornal local:

Após discorrer sobre a forma aguda da doença, se deteve mais demoradamente no estudo de sua forma crônica, particularizando a forma cardíaca, que, a bem dizer, é que deve, de fato, ser considerada como problema social, não só pela diminuição de atividades 
do portador da moléstia, como é responsável pelo encurtamento da média de vida do nosso homem de campo. Com a autoridade que todos lhe reconhecem, o Dr. F. Laranja terminou o seu trabalho afirmando ser a Moléstia de Chagas 'uma doença essencialmente crônica, e que se exterioriza e termina por uma cardiopatia'. (Lavoura e Comércio, 1950b: 2) ${ }^{46}$

Nos anos seguintes, a campanha iniciada no Triângulo Mineiro seria estendida a outras regiões de Minas e a alguns outros estados do país. $^{47}$

Também em maio de 1950, o Serviço de Profilaxia de Malária do Estado de São Paulo (SPM-SP) lançou uma campanha semelhante à que o SNM iniciava no Triângulo Mineiro, que abrangeria as regiões do estado não contempladas por este serviço federal, especialmente a área de Ribeirão Preto. ${ }^{48}$ Como afirma Luiz Jacintho da Silva (1999), a decisão de implementar o controle da doença em São Paulo esteve relacionada diretamente às preocupações com o esgotamento da cafeicultura e das terras virgens no estado, de modo a garantir o desenvolvimento agrícola dentro das fronteiras paulistas. O programa do SPM-SP, que contou com a orientação de pesquisadores da Faculdade de Medicina da Universidade de São Paulo, como José Lima Pedreira de Freitas, teve grande apoio da classe política paulista, sobretudo de deputados, vereadores e prefeitos das áreas endêmicas. ${ }^{49}$ Este foi mais um espaço aberto, com a campanha de 1950, para a divulgação dos trabalhos do CEPMC e para a mobilização de Dias. Ele manteria, a partir de então, estreito contato com os técnicos do SPM-SP e com os pesquisadores paulistas, especialmente em Ribeirão Preto, trocando material de pesquisa, sendo várias vezes convidado a participar de debates e eventos relacionados ao tema naquele estado e recebendo-os para visitas ao CEPMC. ${ }^{50}$

Além de concretizar a idéia, defendida por Chagas desde o início de seus trabalhos, de que tal enfermidade deveria ser objeto das ações do Estado brasileiro, e de dar grande visibilidade pública aos estudos do posto de Bambuí, a articulação da campanha em Uberaba trouxe ao processo de legitimação da doença de Chagas um novo e decisivo aliado. O SNM era a mais importante organização na estrutura federal da saúde pública brasileira, com grande penetração em vários estados do país, extenso corpo de funcionários e que estava em evidência desde o pósguerra, em razão do caráter emblemático conferido internacionalmente à malária como expressão da importância social e econômica das chamadas 
'doenças de massa' e, ao mesmo tempo, do otimismo da 'era DDT'. Seu diretor, Mário Pinotti, que estava à frente do serviço desde sua criação em 1941, seria forte liderança política da saúde pública na década de 1950, tornando-se ministro da Saúde entre 1958 e $1960 .{ }^{51}$ A associação com o SNM materializava, portanto, em vários sentidos, o reconhecimento da importância médico-social da doença de Chagas.

O sucesso atribuído ao controle da malária mediante aplicações de DDT, feito desde 1947 pelo SNM, era mais um elemento a conferir credibilidade e otimismo à campanha que se iniciava em Uberaba. Como assinalou um jornal de Belo Horizonte, ao referir-se à "vitória espetacular" da campanha contra a malária, que conseguira "resolver praticamente o problema da insidiosa endemia": "Semelhante processo de borrifações domiciliares em todos os prédios rurais e urbanos localizados em áreas de incidência chagásica vai ser adotado agora (...)" (O Diário, 1950: 12).

O SNM também se beneficiava desta associação com a doença de Chagas, na medida em que ela permitia a ampliação de sua esfera de ação e, conseqüentemente, de seu poder na estrutura do MES, além de potencializar seu prestígio e sua legitimidade social mediante a vinculação com o IOC.

Tanto Dias quanto Pinotti iriam referir-se à aliança selada em Uberaba para maximizar seus interesses. No discurso que pronunciou na solenidade de inauguração da campanha, em maio de 1950, dirigindo-se ao ministro da Educação e Saúde, Clemente Mariani, ao secretário de Saúde e Assistência de Minas Gerais, Baeta Vianna, e às demais autoridades presentes, Pinotti (1950a: 4) apresentou dados detalhados sobre a "vertiginosa evolução" do SNM, com o emprego das novas armas "forjadas nas entranhas da última guerra" para combate à endemia - o DDT e a cloroquina -, e informou sobre o sucesso das campanhas que vinham possibilitando "a recuperação de milhares de impaludados, restituídos às suas atividades, em benefício de suas famílias e da economia nacional” (Pinotti, 1950a: 4). Ao enaltecer a iniciativa do MES de conferir ao SNM a atribuição de combater também a endemia chagásica, destacou a importância dos estudos promovidos pelo posto do IOC em Bambuí, com referência especial ao trabalho de Dias: "jovem e talentoso cientista da Escola de Manguinhos, uma das maiores autoridades atuais sobre doença de Chagas, que teve a gentileza de nos fornecer notas técnicas sobre o assunto, algumas das quais tomo a liberdade de reproduzir textualmente" (Pinotti, 1950b: 4). ${ }^{52}$ Em seguida, baseando-se em tais notas, o diretor do 
SNM apresentou os resultados dos ensaios realizados em Uberaba, em Bambuí e na Cidade Industrial, cuja primeira conclusão, apesar de ainda estarem em aberto algumas questões técnicas sobre a metodologia dos expurgos (como a duração do efeito residual dos inseticidas testados e qual deles se mostraria mais poderoso contra os triatomíneos), era a de que "já se dispõe de técnicas de comprovada eficácia para a luta contra os transmissores da doença de Chagas" (Pinotti, 1950b: 5). ${ }^{53}$ Dias também enfatizou, na ocasião, a importância da aliança com o SNM, afirmando que aquela data era a mais importante na história da doença de Chagas desde sua descoberta. Disse: "Senhores, nasceu com a malária, nas margens do rio das Velhas, a tripanossomíase americana. E com a malária deve ela começar a morrer aqui, nas férteis terras da beira do rio Grande" $(O$ Globo, 1950: 6).

O diretor do posto de Bambuí utilizou a associação com o SNM para afirmar a importância social da doença e para divulgar as ações do CEPMC de diversas maneiras. Uma delas foi se beneficiar do poder de propaganda que aquele serviço detinha, em razão de sua atuação em várias regiões do país. Em agosto de 1950, por exemplo, respondendo a uma solicitação de Pinotti, Dias ofereceu-lhe sugestões relativas à organização de um mostruário sobre doença de Chagas, destinado a fazer parte do material do SNM, provavelmente tendo em vista uma exposição itinerante. Deste mostruário, constariam fotografias, mapas, gráficos, quadros e objetos relacionados aos diversos aspectos da doença e de seu controle: biologia dos vetores e sua distribuição geográfica, sinais e formas clínicas, casuística do posto de Bambuí, técnicas de expurgo, dados da campanha então em curso. Entre estes materiais, seriam exibidos "eletrocardiogramas com as alterações mais sugestivas da cardiopatia chagásica: bloqueio de ramo direito, bloqueio A-V total, extra-sístoles ventriculares". ${ }^{54}$ A colaboração com o SNM se deu ainda mediante estudos realizados, desde outubro de 1949, sobre diversos aspectos das técnicas de profilaxia e da epidemiologia da doença ${ }^{55}$ Ao longo da década de 1950, Dias passou a utilizar sistematicamente a Revista Brasileira de Malariologia e Doenças Tropicais, criada em 1949 como órgão do SNM, para publicação de seus trabalhos. ${ }^{56}$

Além dos novos vínculos com os organismos sanitários, o início da profilaxia, em 1950, também reforçou os laços do CEPMC com antigos parceiros: os médicos do interior, que aproveitaram a oportunidade para reafirmar seus interesses e sua própria identidade em torno da 
tripanossomíase americana. Na reunião da Sociedade de Medicina e Cirurgia de Uberaba, realizada durante a inauguração da campanha e na qual foi proferida conferência de Francisco Laranja, o presidente daquela agremiação, Sabino Vieira de Freitas, lembrou os esforços dos clínicos da cidade em chamar a atenção das autoridades para a gravidade da endemia chagásica. Tal empenho havia culminado na moção que, em nome do $1^{\circ}$ Congresso Médico do Brasil Central e $3^{\circ}$ do Triângulo Mineiro, ocorrido em Araxá em 1949, solicitou providências ao ministro para sua profilaxia. ${ }^{57}$ Freitas, que havia presidido o referido congresso, reivindicava para os médicos locais a responsabilidade direta pela viabilização da campanha:

Depois desses insistentes e patrióticos brados, foi que as atenções dos poderes públicos e da nossa maior instituição científica, que é o Instituto Oswaldo Cruz, se voltaram para cá. E o resultado de tudo isso foi que, verificada a procedência e a veracidade dos apelos dos médicos que aqui trabalham, se iniciou essa memorável campanha, que a todos interessará. (Lavoura e Comércio, 1950b: 2)

A referência ao trabalho realizado em Bambuí no sentido de valorizar a identidade dos médicos do interior como os 'legítimos conhecedores' dos problemas rurais do país se intensificaria ao longo da década de 1950. Se no congresso de Araxá, em 1949, Dias havia enfatizado o pertencimento de Carlos Chagas a esta identidade, a partir de então os próprios clínicos do Brasil Central justificavam seu apoio a Dias por considerarem-no 'um dos seus'. ${ }^{58}$

A mobilização empreendida por Dias, em especial a partir de 1948 (quando os pesquisadores consideraram estabelecidos os conhecimentos essenciais tanto sobre os aspectos clínicos da doença quanto sobre sua profilaxia), que culminou com a campanha de 1950, transcorreu num contexto histórico marcado pelas múltiplas perspectivas que se abriam, no pós-guerra, para o que, a partir de então, seria vivido, de maneira global, como o 'sonho' do desenvolvimento. Entre tais perspectivas, estava a de uma vitória definitiva sobre as doenças tropicais. 


\section{O Otimismo do Pós-Guerra: um mundo confiante no desenvolvimento}

O período que se seguiu ao término da Segunda Guerra Mundial conferiu força e significados particulares à noção de que a saúde constitui um elemento-chave para o desenvolvimento econômico e social das populações, fortalecendo a crença de que a humanidade já dispunha de meios concretos para garantir este percurso. Além do impacto do uso do DDT, dos antibióticos e de outras 'balas mágicas' produzidas pela ciência durante o conflito, tal perspectiva intensificou-se num ambiente cultural profundamente marcado pela idéia de que todas as nações, cedo ou tarde, vivenciariam o 'encontro com o desenvolvimento'.

Segundo Arturo Escobar (1995), as condições políticas e econômicas constitutivas daquele momento particular de expansão do capitalismo - e os lugares assumidos pelas distintas nações neste processo - geraram não apenas novos mecanismos, ações e políticas para o desenvolvimento, mas criaram em torno desta categoria um poderoso 'regime de representações', a partir do qual o mundo seria ressignificado, sobretudo no que se refere a temas como pobreza, atraso, fome e doenças. A reestruturação nas relações de dominação entre os países, tanto em razão do fim do domínio colonial quanto em função da bipolaridade imposta pela Guerra Fria, foi um dos fatores essenciais que forjaram este campo discursivo, no qual países e grupos sociais passaram a ser classificados em razão de sua maior ou menor proximidade em relação a este que era considerado o grande telos da história.

The development discourse defined a perceptual field structured by grids of observation, modes of inquiry, and registration of problems, and forms of intervention; in short, it brought into existence a space defined not so much by the ensemble of objects with which it dealt but by a set of relations and a discursive practice that systematically produced interrelated objects, concepts, theories, strategies, and the like. (Escobar, 1995: 42) ${ }^{59}$

Sob a perspectiva antropológica dos estudos culturais, Escobar focaliza o desenvolvimento não apenas na condição de conjunto de práticas econômicas ou políticas, mas como uma categoria que, em si mesma vazia, toma forma e adquire o poder de organizar o mundo mediante os sentidos que lhe são atribuídos em contextos sociais e históricos específicos, por grupos sociais investidos de determinados interesses e projetos. ${ }^{60}$ Ainda 
que parecendo pairar, como idéia-força dotada de movimento próprio, acima de quaisquer particularidades, a concepção do desenvolvimento no pós-guerra como meta transnacional estava ancorada diretamente nos interesses da nação que afirmava sua hegemonia neste contexto e pretendia estendê-la sobre o planeta. Em janeiro de 1949, Harry Truman, em seu discurso inaugural como presidente dos Estados Unidos - no qual formulou o chamado Programa Ponto IV de assistência técnica aos países do Terceiro Mundo -, sintetizou os princípios e valores do que então se desenhava como o sonho de um novo mundo no pós-guerra:

More than half the people of the world live in conditions approaching misery. Their food is inadequate, they are victims of disease. Their economic life is primitive and stagnant. Their poverty is a handicap and a threat both to them and to more prosperous areas. For the first time in history humanity possesses the knowledge and the skill to relieve the suffering of these people (...). I believe that we should make available to peace-loving peoples the benefits of our store of technical knowledge in order to help them realize their aspirations for a better life (...). What we envisage is a program of development based on the concepts of democratic fair dealing (...). Greater production is the key to prosperity and peace. And the key to greater production is a wider and more vigorous application of modern scientific and technical knowledge. (apud Escobar, 1995: 3) ${ }^{61}$

Assim, 'desenvolvimento' passava a equivaler a uma marcha mundial em direção a certas características do que se considerava uma sociedade 'avançada': uma sociedade altamente industrializada e urbanizada, com elevados padrões de produtividade material e condições de vida e fundada nos valores culturais da modernidade. Este percurso, por sua vez, seria viabilizado por instrumentos específicos. Por um lado, a ciência e a tecnologia, às quais se atribuía, desde a experiência da guerra, uma capacidade de intervenção sobre o mundo sem precedentes. Por outro, aparatos específicos, governamentais ou internacionais, destinados a planejar os rumos da modernização.

Dois processos, que se intensificariam progressivamente a partir de então, serviram de base a este movimento global do desenvolvimento (Escobar, 1995). Em primeiro lugar, a afirmação social da categoria profissional do cientista como figura proeminente num mundo cujos problemas sociais passavam a ser vistos como essencialmente 'técnicos', sujeitos a decisões racionais e administrativas por parte de especialistas. ${ }^{62}$ 
Ainda que o pós-guerra viesse acelerar o processo de profissionalização da ciência, mediante o qual esta ganharia cada vez mais institucionalidade como atividade intrinsecamente legítima de produção de conhecimentos, ao mesmo tempo conferia aos cientistas um sentido de compromisso e um campo de atuação especialmente importantes e visíveis no que diz respeito às questões públicas. Foi assumindo uma identidade referida a este compromisso que os cientistas envolvidos com a pesquisa sobre a doença de Chagas construíram, no espaço discursivo do desenvolvimento, a relação entre seu objeto de pesquisa e um projeto nacional de modernização.

Em segundo lugar, o pós-guerra imprimiu grande impulso à institucionalização de aparatos específicos para a produção de conhecimentos e de ações voltados para a promoção do progresso material e do bem-estar social. Sob a égide dos então criados organismos internacionais, ou sob as configurações próprias dos Estados nacionais, reforçouse a idéia de que o desenvolvimento exigia coordenação de ações e interesses, bem como planificação de métodos e políticas sob uma instância centralizadora (Escobar, 1995: 38). A obsessão do pós-guerra com o planejamento e com o poder da ciência e da tecnologia como instrumentos para transformar o mundo manifestou-se de forma contundente no campo da saúde, com o fortalecimento da concepção segundo a qual o desenvolvimento advinha essencialmente de intervenções técnicas, planejadas e conduzidas por especialistas. A campanha global de erradicação da malária, implementada pela Organização Mundial da Saúde (OMS) a partir de 1955, foi a expressão máxima desta crença. ${ }^{63}$

Num contexto em que os interesses econômicos e políticos dos países ricos dependiam cada vez mais dos países ditos subdesenvolvidos ou do Terceiro Mundo - denominações que, como mostra Escobar, foram criadas justamente sob a formação discursiva do desenvolvimento -, a questão da pobreza e das condições a ela relacionadas passou a despertar grande preocupação internacional, com intensos debates sobre como administrála e minorar seus efeitos. A saúde foi um dos diversos campos a sofrer intervenções nesse sentido. Se, durante a guerra, o combate às doenças transmissíveis assumira importância decisiva (inclusive como estratégia militar), num mundo em reconstrução - e mais do que nunca em disputa por áreas de influência econômica e política -, a luta contra as chamadas doenças da pobreza ganhou especial proeminência, a requerer conhecimentos específicos e mecanismos adequados de planejamento. 
A preocupação com a recessão do pós-guerra, com o aumento da produtividade agrícola (a fim de suprir o fornecimento de matérias-primas centrais à industrialização e à urbanização e de garantir suprimentos alimentares num mundo em rápida expansão demográfica) e com a viabilização de novos mercados para os produtos manufaturados dos países desenvolvidos colocava na ordem do dia o aumento da produtividade nos países ditos tropicais e, conseqüentemente, a questão de como melhorar a saúde de suas populações (Escobar, 1995: 8). No pós-guerra as implicações políticas da pobreza foram recolocadas no contexto da Guerra Fria. O medo do comunismo favoreceu não apenas os investimentos em campanhas de combate às doenças transmissíveis, mas a hegemonia do modelo que preconizava prioridade às intervenções sanitárias conduzidas 'do alto', em detrimento de programas mais amplos de articulação entre medidas sanitárias e reforma social, considerados mais custosos e, sobretudo, mais 'perigosos' politicamente (Packard, 1997).

O discurso do secretário de Estado norte-americano George Marshall, na abertura dos IV Congressos Internacionais de Medicina Tropical e Malária, em 1948 em Washington, sintetizou exemplarmente como a meta da 'conquista das doenças tropicais' foi ressignificada, naquele momento, com base nos novos sentidos atribuídos à sua importância social e nos novos meios técnicos e políticos de se enfrentá-las:

The tropics are the habitation of perhaps half the human race, but a large proportion of these people lack greatly in the advantage of modern civilization. A chief factor in restricting improvement in these respects is tropical disease. Little imagination is required to visualize the great increase in the production of food and raw materials, the stimulus to world trade, and above all the improvement in living conditions, with consequent social and cultural advances, that would result from the conquest of tropical diseases. This situation presents a challenge that, like the Equator, cuts across national boundaries and local interests. It is an international problem and it should be solved by a pooling of the genius and the resource of many nations. That it is not insoluble from the medical standpoint has been demonstrated by numerous projects with which you are so familiar. The task of convincing the governments and peoples most concerned of the feasibility of controlling and eventually eradicating disease throughout the tropics will be measurably advanced by the discussions at this conference of the latest discoveries of research and the modern techniques in public health. (Marshall, 1948: 2) ${ }^{64}$ 
O otimismo do final da década de 1940 foi um campo fértil - social e simbolicamente - para a reconstrução dos significados, valores e práticas associados à relação entre saúde e desenvolvimento. Tal processo foi construído concretamente em contextos locais e é a partir das especificidades destes contextos que se pode compreendê-lo.

\section{Saúde e Desenvolvimento na Democratização Brasileira}

No Brasil do pós-guerra, a importância econômica da saúde ganhou nova ênfase nos projetos políticos destinados a promover a meta do desenvolvimento. O início do governo de Eurico Gaspar Dutra (19461951), apesar do continuísmo em relação a Vargas, recompôs, sob o valor da democracia, a imagem do Estado como agente primordial de conciliação das distintas forças sociais sob o objetivo comum do desenvolvimento. Nesse período, o país viveria as conseqüências da guerra no sentido do aprofundamento dos processos que, desde a década de 1930, vinham dando forma a um novo modelo econômico e político na sociedade brasileira. Apesar da filiação de Dutra, em seus primeiros anos de governo, a uma política econômica de cunho mais liberal, a tendência de planificação da economia (em curso no cenário internacional e defendida no Brasil por empresários, técnicos da administração governamental, intelectuais e políticos desde o Estado Novo) foi reafirmada. Reforçava-se que a concepção de que, diante da 'fraqueza' do empresariado nacional, carente de capitais e de tecnologias para sustentar a montagem de um parque industrial substantivo, cabia ao Estado intervir diretamente como promotor do desenvolvimento, em termos tanto da coordenação de programas quanto dos investimentos necessários. Ao mesmo tempo, o acúmulo de divisas, resultante do aumento das exportações durante a guerra, foi um estímulo importante à industrialização, fundada na substituição de importações e no aumento da produção para o mercado interno.

Os últimos anos do governo Dutra trouxeram resultados expressivos para o crescimento econômico. No plano ideológico, a volta ao regime constitucional e à liberdade do jogo partidário projetou ainda mais, na cena pública, os debates em torno dos caminhos do desenvolvimento. Sob diferentes formas de concebê-los, acentuava-se a tendência dos intelectuais de se colocarem como intelligentsia comprometida com a intervenção na 
política e a formulação de um projeto de construção da nação. O país vivia, sob vários aspectos, a progressiva conformação daquilo que, com o início do segundo governo Vargas (1951-1954), viria a se apresentar em seus contornos mais definidos como o chamado modelo nacionaldesenvolvimentista (Skidmore, 1975; Mendonça, 1986; Quadros da Silva, 1999; Abreu, 1999; D’Araújo, 1999a, 1999b; Ferreira \& Delgado, 2003c).

No que se refere ao lugar assumido pela saúde nos programas de desenvolvimento da época, o tema recebeu um tratamento especial no Plano Salte, elaborado por Dutra em 1948 e aprovado em 1950. Dos recursos previstos, $13 \%$ destinavam-se à saúde, 13,6\% à alimentação, 56,8\% aos transportes e 16,6\% à energia. Apesar das críticas que recebeu pela fragilidade teórica do ponto de vista do planejamento econômico e de ter sido considerado um fracasso do ponto de vista da implementação das medidas propostas, a inclusão da saúde como um dos cinco aspectos conformadores de um programa nacional de desenvolvimento foi um indício da importância que se dava à questão, pelo menos do ponto de vista das intenções do governo. ${ }^{65} \mathrm{~A}$ idéia essencial expressa no plano era a de que os baixos níveis de saúde constituíam um sério obstáculo ao desenvolvimento econômico do país, na medida em que implicavam custos extremamente elevados.

Postulava-se claramente, desta forma, que a política sanitária deveria estar submetida essencialmente aos objetivos de aumento da produtividade econômica. Em 1949, reiterando perante o Congresso Nacional a importância econômica da saúde, o presidente Dutra remeteu-se à especificidade de um ambiente tropical, derivando daí, implicitamente, o próprio recorte dos problemas sanitários que deveriam ser privilegiados num projeto de desenvolvimento.

As condições sanitárias de um país circunscrevem-lhe rigidamente o desenvolvimento econômico-social. No caso do Brasil - onde talvez se processe, como já foi assinalado por tantos estudiosos, a maior experiência conhecida de adaptação da civilização européia a um ambiente tropical - a melhoria geral das condições sanitárias e o desenvolvimento econômico-social são, verdadeiramente, termos co-extensivos do mesmo problema, isto é, a asseguração de possibilidades de progresso. (Brasil, 1949: 127)

Dutra enfatizou - destacando, entre as realizações do governo federal no campo da saúde, as campanhas promovidas pelos Serviços Nacionais - a preocupação com as doenças endêmicas: “(...) ainda são amplos e 
desastrosos para nossa vida rural os efeitos maléficos que decorrem dessas endemias. Julgo mesmo que, se há campo de defesa sanitária que nos deva merecer ainda maior atenção, é precisamente esse" (Brasil, 1949: 134).

Em consonância com a tendência internacional, a malária era tida como o maior destes problemas: "a mais perniciosa, assim pela virulência do mal, como pela amplitude das zonas de sua incidência" (Brasil, 1949: 136). Os dados apresentados pelo governo eram alarmantes. Inquéritos realizados até 1946 teriam indicado a incidência da doença em cerca de 2/3 dos municípios do país, estimando-se em 1/5 a parcela da população atingida. Em 1/3 das capitais, ela estava incluída entre as cinco primeiras causas de morte (Brasil, 1950). Contudo, sublinhava-se, aquele era o momento em que se podia lançar mão de instrumentos sem precedentes para combater a doença: “(...) os métodos clássicos de combate à malária, onerosos e inseguros, foram substituídos pelas poderosas e eficientes técnicas reveladas pela ciência nestes últimos anos" (Brasil, 1949: 136).

Em 1947, o SNM dera início a uma campanha antimalárica na Baixada Fluminense, que constituiu a primeira experiência de uso massivo do DDT, associado à cloroquina (medicamento usado a partir de 1945), contra a doença no país. A partir desta campanha, o Brasil vinha fazer coro aos que manifestavam a euforia em torno destes novos recursos legados pela guerra:

(...) o objetivo que há alguns anos atrás parecia inatingível - libertação de mais de 8.000 .000 de brasileiros vitimados pelo flagelo da malária - começa a oferecer possibilidade de ser alcançado, em virtude do desenvolvimento que teve a campanha desencadeada pelo Governo" (Brasil, 1949: 135). ${ }^{66}$

Tendo sido a idéia-força do movimento pelo saneamento dos sertões na década de 1910, a vinculação entre saúde e desenvolvimento atualizava, no contexto histórico da década de 1940, os sentidos atribuídos aos termos desta equação. 'Saúde' equivalia a combate às endemias rurais e 'desenvolvimento' significava recuperação e intensificação da produtividade do trabalho agrícola. Ao apresentar os números anteriormente citados sobre a extensão da malária como flagelo nacional, Dutra (1950: 129) afirmou: "Estes dados acentuam a significação sócio-econômica do problema, se forem associados à circunstância de sua maior prevalência nas zonas de produção agrícola e não raro nas regiões mais férteis, onde tem prejudicado seriamente o rendimento do trabalho humano". 
Sintetizando a magnitude do problema, o governo mostrava-se sintonizado com a tendência internacional, que se aprofundaria na década de 1950, de materializar a dimensão social das doenças mediante parâmetros e índices quantitativos, ditados pela ciência econômica. Segundo o presidente, a malária acarretava "prejuízos para a economia nacional de cerda de 100.000.000 homens-dia de trabalho" (Brasil, 1950: 130). Os resultados que o governo declarava estar colhendo nesta campanha assumiam, assim, significados que iam além do campo da saúde pública: eram uma vitrine do poder do Estado brasileiro como responsável primordial pelas condições necessárias ao trabalho e, conseqüentemente, ao desenvolvimento nacional.

Balanceadas as realizações do Governo federal, nestes quatro anos de exaustivos esforços, podemos orgulhar-nos dos promissores resultados obtidos através da campanha contra a malária no país. Reduzimos as proporções do flagelo a níveis de tal inferioridade que, brevemente, a incidência do mal não causará, de modo algum, efeitos perniciosos à atividade produtiva do trabalhador brasileiro. (Brasil, 1950: 132)

O otimismo quanto ao desenlace desta e de outras campanhas sanitárias equivalia às expectativas quanto ao próprio projeto político da modernização nacional.

\section{A Recuperação Econômica do 'Celeiro do Brasil'}

No contexto mineiro, o pós-guerra foi particularmente marcado pela idéia de renovação e de desenvolvimento, e o tema da produtividade do trabalho rural ganhou especial projeção e significados. Aprofundando um movimento que vinha se encaminhando desde a década de 1920, Minas Gerais vivia, neste momento, o ápice dos esforços por parte do poder público para superar a situação de atraso e estagnação econômica há tempos diagnosticada. Segundo Otavio Soares Dulci $(1992,1999)$, numa evidência da pluralidade das experiências regionais no que diz respeito a projetos de desenvolvimento, o modelo de modernização experimentado em Minas caracterizou-se fundamentalmente pelo uso de recursos políticos e pelo protagonismo do poder público como responsável maior pela indução do 
crescimento econômico, em termos de coordenação e de investimentos diretos. O Plano de Recuperação Econômica e Fomento da Produção, formulado em 1947 pelo governador Milton Campos (que, segundo Dulci, constituiu experiência pioneira no país em termos de planejamento macroeconômico), expressou de maneira exemplar esta orientação, preconizando, como caminho para o desenvolvimento, a conciliação entre expansão industrial e modernização da agricultura.

Como estratégia para alcançar este objetivo, visto como fundamental para que Minas Gerais assumisse importância no cenário nacional como estado fornecedor de gêneros básicos para o mercado interno, o plano defendia a diversificação da produção, a ser atingida, sobretudo, mediante a introdução de novas técnicas de cultivo. Na mensagem apresentada à Assembléia Legislativa de Minas Gerais em julho de 1947, Milton Campos corroborou o diagnóstico do atraso - "o que mais impressiona na atualidade mineira é o decréscimo da produção agrícola e sua conseqüência natural: carestia de vida e penúria das classes menos protegidas" (Campos, 1947: 38) - e indicou o caminho de sua superação: "Os centros populosos da Nação reclamam mais e mais produtos da agricultura. Para incentivar-lhe a produção temos que melhorar os métodos e práticas empregados, estabelecendo uma política baseada na ciência e na técnica" (Campos, 1947: 42-43).

A dimensão tecnológica deveria estar, por sua vez, associada à promoção de melhores condições de vida para os trabalhadores agrícolas, não apenas como meio de fixá-los à terra (diminuindo o êxodo rural que comprometia a força de trabalho nas fazendas mineiras havia algumas décadas), mas para evitar alternativas mais radicais, como projetos de reforma agrária ${ }^{67}$ Com este objetivo, o governo mineiro organizou dois programas de extensão rural voltados para pequenos produtores, o Ensino Agrário Ambulante (serviço de instrução técnica e atendimento sanitário que funcionava em comboios ferroviários) e a Associação de Crédito e Assistência Rural (Acar), criada em 1948 mediante convênio entre o governo estadual (com forte participação da Escola de Agricultura de Viçosa) e a American Association for Economic Development, entidade fundada por Nelson Rockefeller no pós-guerra (Dulci, 1992). Se, ao poder público, cabia planejar a recuperação econômica, fazia-se imperativo investir na "melhoria do rendimento do capital humano como fator de produção", dizia o governador (Campos, 1947: 45). Recuperar a produção exigia recuperar o trabalhador e um dos caminhos para isso era a saúde. 
O governo Milton Campos trazia, portanto, pelo menos no que diz respeito a suas diretrizes programáticas, uma perspectiva sensível a projetos destinados a promover melhores condições sanitárias no campo. Proclamava-se urgente o início do "combate às endemias que minam a energia vital do homem e acarretam considerável diminuição dos dias de trabalho" (Campos, 1947: 45). Entre os principais problemas a serem enfrentados pela Secretaria de Saúde e Assistência Social do Estado, estavam as mesmas doenças que figuravam na pauta de prioridades do governo federal: tuberculose, lepra e malária. Assim como o presidente da República, o governador de Minas também recorria a coeficientes econômicos: "Nas regiões palustres, o rendimento médio do homem nunca excede a 25\% do normal" (Campos, 1947: 45) e também se entusiasmava com a perspectiva de usar os modernos recursos profiláticos e terapêuticos, sobretudo contra a malária, mediante um plano sistemático de aplicação do DDT.

Se o governo mineiro tinha interesse em combater as endemias visando a recuperar regiões marcadas pela estagnação econômica, a preocupação saneadora também se manifestava em áreas valorizadas como frentes de expansão, a serem impulsionadas como exemplo para o conjunto do estado. A escolha dos locais onde tiveram início as ações de profilaxia para a doença de Chagas, articuladas pelo CEPMC junto ao SNM e à Secretaria de Saúde de Minas Gerais, esteve intimamente relacionada a esta orientação. Tanto a cidade de Uberaba, no Triângulo Mineiro, onde se inaugurou oficialmente a campanha, quanto a Cidade Industrial, onde foram feitos os ensaios experimentais que a antecederam, eram localidades especialmente importantes como emblemas do projeto de modernização econômica de Minas Gerais.

Em congresso de prefeitos do Triângulo Mineiro ocorrido em Uberaba, em janeiro de 1949, no âmbito de uma campanha municipalista promovida pelo Instituto Brasileiro de Geografia e Estatística (IBGE), os vários discursos pronunciados, inclusive pelo secretário do Interior de Minas Gerais, Pedro Aleixo, e pelo ministro da Justiça, Adroaldo Mesquita da Costa, proclamaram a importância econômica da região como uma das mais prósperas do interior brasileiro (IBGE, 1949). ${ }^{68} \mathrm{O}$ Triângulo representava para Minas um núcleo de modernização e em torno dele se congregavam os interesses daqueles que, em diversas regiões do país, mobilizavam-se pela valorização econômica e geopolítica do Brasil Central. O prefeito da cidade, Boulanger Pucci, destacou na ocasião a idéia 
"que se anuncia" da mudança da capital federal para o Triângulo Mineiro, o que traria grandes vantagens, segundo ele, pela facilidade de comunicação com as várias regiões do país, pela proximidade dos principais centros urbanos, pelo alto potencial hidráulico da região, mas, sobretudo, pelo significado simbólico de situar-se o centro decisório do país onde, de fato, se localizavam "o centro e o coração do Brasil" (IBGE, 1949: 11). ${ }^{69}$

O discurso municipalista vinha, assim, reafirmar os valores associados ao universo rural, contrapostos, conforme a dualidade tradicionalmente estabelecida nas narrativas sobre o Brasil, aos núcleos urbanos do litoral (Lima, 1999). Em referência àqueles valores, eram expressas as reivindicações quanto à intensificação da capacidade produtiva de Minas Gerais e de sua relevância econômica e política nos horizontes de desenvolvimento nacional. O secretário-geral do IBGE e presidente da Comissão Nacional de Organização da Associação Brasileira de Municípios, Rafael Xavier, afirmou que o município, "sinônimo de terra, interior, os largos espaços rurais", deveria ser o veículo de todos os projetos destinados a restaurar o valor da "civilização do interior". Minas Gerais, estado marcado pelo predomínio de núcleos locais e visto como grande representante do "Brasil produtor", era, segundo ele, exemplo deste caminho (IBGE, 1949: 18). ${ }^{70}$

É interessante perceber como, nesta construção discursiva, a oposição interior-litoral ganhava novos sentidos, como contraponto entre o desenvolvimento voltado para o mercado interno e o modelo exportador. Nas palavras do secretário do IBGE:

(...) o Brasil-produtor não poderá permanecer indefinidamente à mercê dos caprichos e das oscilações do mercado litorâneo, que por sua vez é mero caudatário do mercado internacional: (...) urge criar o mercado interno, e paralela e conseqüentemente - pois os dois problemas estão intimamente ligados - dar ao povo possibilidades de melhorar o nível de vida, pela abertura de mais longas perspectivas aos que sejam capazes de trabalhar. Só assim subirá o poder aquisitivo das gentes do interior, e se criará, para as atividades de produção, um mercado de consumo que absorva parte substancial das utilidades no próprio local, ou na própria região. (IBGE, 1949: 24-25)

Esta era mais uma formulação que conferia importância ao combate às endemias, mencionadas pelo secretário do IBGE como um dos aspectos da "dura servidão" do abandono a que estavam relegadas as 
populações do interior (IBGE, 1949: 30). O Triângulo Mineiro era enaltecido como exceção a este quadro e exemplo a ser seguido. Nas palavras do ministro da Justiça, Adroaldo Mesquita da Costa, era "um posto avançado na genuína marcha para o oeste", "bandeirante da civilização interior do Brasil” (IBGE, 1949: 32). ${ }^{11}$ Tratava-se, portanto, de região de importância estratégica, em termos econômicos e também em termos simbólicos, no que se referia aos projetos de desenvolvimento das áreas rurais do país.

A Cidade Industrial também era um espaço carregado de sentidos para a perspectiva de modernização em Minas Gerais. O plano de instalar um núcleo industrial próximo a Belo Horizonte (mas fora do seu núcleo urbano) e que fosse servido por um sistema energético próprio visava a superar a 'perda' do projeto siderúrgico para Volta Redonda e as dificuldades de se promover a expansão industrial na capital mineira, especialmente em razão da deficiência na oferta de energia (Diniz, 2002). Em 1941, por decreto-lei estadual, foi criada a Cidade Industrial, no município de Contagem, a cerca de dez quilômetros do centro de Belo Horizonte, e deu-se início à construção da usina hidrelétrica de Gafanhoto. ${ }^{72} \mathrm{O}$ empreendimento constituiu a maior realização do governo de Benedito Valadares e símbolo maior do projeto de modernização econômica em curso no estado, que seria continuado por seu sucessor, Milton Campos. Além de montar a infra-estrutura local para o funcionamento das indústrias, o governo acenou com muitos incentivos para estimular o interesse dos empresários. Em 1947, apesar de os resultados ainda não corresponderem ao esperado, a Cidade Industrial contava com dez indústrias, empregando cerca de mil pessoas, muitas delas instaladas, com suas famílias, em núcleos residenciais construídos pelas empresas (Diniz, 2002). ${ }^{73}$

Contudo, a área foi infestada por barbeiros, trazidos nas bagagens dos trabalhadores provenientes das regiões rurais do estado, chamando a atenção das autoridades sanitárias. A presença da doença de Chagas nos 'muros' da capital mineira, sobretudo num local que materializava a disposição do poder público em impulsionar e em coordenar a modernização no estado, conferiu ao problema dimensão política especial, reforçando os motivos pelos quais ela foi escolhida, juntamente com Bambuí, para servir de campo de ensaios para os métodos de profilaxia que os cientistas do posto do IOC pretendiam aplicar na grande campanha a ser realizada no estado. Apesar de se tratar de foco recente, com baixos índices de infecção pelo T. cruzi entre os barbeiros capturados, os 
cientistas observaram grande capacidade de proliferação dos insetos, inclusive em casas melhor construídas. Segundo eles, a situação exemplificava os riscos de expansão da endemia mediante as migrações dos trabalhadores originários de áreas endêmicas (Pellegrino \& Brener, 1951). ${ }^{74}$ A preocupação com as possibilidades de a doença se disseminar nos centros urbanos e atingir inclusive a capital aumentava em razão da presença de indivíduos infectados, provenientes de áreas endêmicas, entre os candidatos a doadores de sangue nos hospitais da cidade, conforme indicado por inquéritos feitos por José Pellegrino e outros pesquisadores (Pellegrino et al., 1951). ${ }^{75}$ Assim, tanto por atingir áreas estratégicas para a recuperação e expansão agrícola quanto pela possibilidade de espraiar-se pelos núcleos urbano-industriais, a doença de Chagas era reiteradamente qualificada pelos cientistas como ameaça às perspectivas do desenvolvimento econômico mineiro.

Estas distintas dimensões contextuais, relativas aos cenários internacional, nacional e estadual, fornecem elementos importantes para a compreensão do processo de construção e de reconhecimento social da doença de Chagas no período, na medida em que a elas estão referidas não apenas as forças políticas, econômicas e sociais que conformaram os espaços sociais concretos nos quais este processo ocorreu, mas também os valores e significados acionados pelos cientistas para conferir àquele objeto certos traços específicos como fenômeno biológico e social. Apesar das especificidades que distinguem estes contextos, pode-se afirmar, de modo geral, que foi num ambiente histórico-social marcado pela 'obsessão’ com o desenvolvimento e a vitória contra as doenças que os cientistas do CEPMC buscaram as estratégias políticas e simbólicas que os tornaram capazes de produzir o convencimento de que aquela enfermidade, definida pelos novos dados produzidos pelo eletrocardiógrafo e por outros procedimentos técnicos, fazia sentido para os interesses presentes na sociedade brasileira, naquele momento.

Se, em 1949, Dias e seus colaboradores declaravam haver produzido os conhecimentos essenciais para superar as dúvidas sobre a definição clínica da doença, e se a primeira campanha de profilaxia da doença, em 1950, foi um marco decisivo ao torná-la reconhecida como objeto de ações concretas por parte do Estado, o processo de afirmação científica e social da 'doença do Brasil' prosseguiria ao longo da década de 1950 período em que se intensificariam os debates sobre as perspectivas do desenvolvimento e o lugar da saúde como requisito para sua viabilização. 
Foi nessa década que os cientistas do posto de Bambuí reforçaram sua movimentação 'sociedade afora', buscando ampliar o processo de legitimação e de institucionalização científica e social da doença, tanto como tema de pesquisa quanto como objeto de políticas sanitárias.

\section{Notas}

1 Carta de Jacinto Soares Souza Lima a Emmanuel Dias. Ubá, 13 de abril de 1946. Fundo Centro de Pesquisas René Rachou, Seção Posto Avançado de Pesquisas Emmanuel Dias (doravante FCPqRR/SPAPED), caixa 31, maço 2. Alguns médicos também se valeriam desta associação para maximizar seus interesses políticos, como no caso de um clínico de Tupaciguara, que pediu a Dias exemplares de um folheto sobre a doença para utilizar em sua campanha política para prefeito daquela cidade. Carta de Philogonio Martins a Emmanuel Dias. Tupaciguara, 23 de setembro de 1947. FCPqRR/SPAPED, caixa 31, maço 2.

2 Carta de Rubem Jácomo a Emmanuel Dias. Uberaba, 27 de novembro de 1947. FCPqRR/SPAPED, caixa 31, maço 2.

3 Carta de Emmanuel Dias a Rubem Jácomo. Bambuí, 3 de dezembro de 1947. FCPqRR/SPAPED, caixa 31, maço 2.

4 Em carta a Aragão em 1946, comentou, por exemplo, a vinda de uma equipe dos Diários Associados a Bambuí, para fazer uma reportagem sobre o CEPMC: "Nela procurarei fazer sobretudo propaganda do assunto, mostrando de um lado a gravidade do problema da doença de Chagas e de outro a necessidade de maior estudo e combate à moléstia.” Carta de Emmanuel Dias a Henrique Aragão. Bambuí, 18 de março de 1946. FCPqRR/SPAPED, caixa 31, maço 2.

5 Discurso de Antonio Torres Sobrinho, do Hospital Nossa Senhora do Brasil em Bambuí, por ocasião da solenidade de inauguração da placa que dá nome de Centro de Pesquisas Emmanuel Dias ao posto da Fiocruz em Bambuí, em 21 de dezembro de 1979, p. 3-4. FCPqRR/SPAPED, caixa 3, maço 5.

6 Além de mandar este folheto (Dias, 1944) para vários médicos e cientistas - como fazia com separatas de suas publicações -, Dias solicitava às próprias autoridades sanitárias que se encarregassem de sua distribuição. Em carta ao diretor da Saúde Pública do estado de Minas Gerais, pediu que o folheto fosse amplamente veiculado sobretudo entre "médicos, sanitaristas e professoras das zonas rurais". Carta de Emmanuel Dias a Otto Cirne. Bambuí, 8 de junho de 1945. FCPqRR/SPAPED, caixa 31 , maço 2.

7 Segundo Dias (1946c: 6), "A miséria, que obriga a família sertaneja a morar em choças infectas, é o grande mal, gerador de tantos outros males que desgraçam a vida nos campos, que de outro modo poderia ser tão feliz e produtiva”.

8 Em suas palavras: "A cafua é a fortaleza do barbeiro e para exterminá-lo temos que destruí-la totalmente” (Dias, 1946c: 6).

9 Era comum em seus textos de divulgação a apresentação dos nomes populares conferidos aos transmissores da doença. 'Barbeiro' era a denominação mais comum em Minas Gerais. Em São Paulo e no estado do Rio, o inseto era conhecido como 
'chupança'. No Rio Grande do Sul, como 'chupão' ou 'fincão'. Nos estados do Norte e Nordeste, era chamado de 'bicudo', 'procotó', 'percevejo de parede', entre outros. Para os médicos, Dias esclarecia que "os barbeiros são hemípteros reduvídeos estritamente hematófagos, denominados de um modo genérico "triatomas" (Dias, 1944: 3).

10 Programa do $3^{\circ}$ Curso de Cardiologia pelo Professor Magalhães Gomes, Santa Casa da Misericórdia do Rio de Janeiro, Centro de Estudos do Hospital Geral. Rio de Janeiro, 1945. FCPqRR/SPAPED, caixa 38, maço 1.

11 Moção da Sociedade Brasileira de Cardiologia ao Instituto Oswaldo Cruz. Belo Horizonte, agosto de 1946. FCPqRR/SPAPED, caixa 38, maço 1.

12 Carta de Emmanuel Dias a Gregoriano Canedo. Belo Horizonte, 13 de agosto de 1946. FCPqRR/SPAPED, caixa 31, maço 2.

13 O texto era, em linhas gerais, o mesmo publicado por Dias, Laranja e Nóbrega em 1945 nas Memórias do Instituto Oswaldo Cruz. Em carta a Romaña, Dias manifestou entusiasmo com a publicação: "A parte cardiológica está um colosso e documentadíssima”. Carta de Emmanuel Dias a Cecilio Romana. Belo Horizonte, 3 de novembro de 1945. FCPqRR/SPAPED, caixa 31, maço 2.

14 Neste evento, Dias apresentou relatório das atividades do IOC no estudo e na profilaxia da doença de Chagas. Foram apresentadas ainda as seguintes comunicações, de autoria de Laranja, Dias e Nóbrega: "Estudo eletrocardiográfico de 81 casos de megaesôfago" e "Manifestações clínicas e diagnóstico da cardiopatia aguda da doença de Chagas". Citado por Dias (1956: 354-355). Não foram localizados os anais deste encontro.

15 Foi durante esta excursão que ocorreu o falecimento de Salvador Mazza, por infarto do miocárdio, presenciado por Dias. Para um relato do episódio, ver carta de Emmanuel Dias a Henrique Aragão. Belo Horizonte, 22 de março de 1947. FCPqRR/SPAPED, caixa 31, maço 2.

16 Carta de Emmanuel Dias a Henrique Aragão. Belo Horizonte, 22 de março de 1947. FCPqRR/SPAPED, caixa 31, maço 2. Em anexo a esta carta, Dias enviou a Aragão recortes de matérias publicadas sobre sua presença em vários destes países. No Galveston Tribune, de 18 de novembro de 1946, a reportagem intitulada "Brazilian scientists arrive for study of Chagas' disease" deu destaque para a caracterização da doença de Chagas como "an infection which has left over a million of Brazilians with heart ailments" ["uma infecção que deixou mais de um milhão de brasileiros com problemas cardíacos" - Tradução livre].

17 Ver Ofício de Olympio da Fonseca ao ministro da Educação e Saúde. 10 de dezembro de 1951. Fundo Instituto Oswaldo Cruz, Seção Direção, Cópia de Ofícios (doravante FIOC/SD/CO), ofício n. 1.357.

18 Enquanto a cardiopatia chagásica crônica passava a constar, em 1946, do manual de clínica médica organizado por Luiz Capriglione (Capriglione \& Strumpell, 1946), nos livros-texto de parasitologia ela ainda era vista, na mesma ocasião, como entidade clínica não totalmente comprovada. Samuel Pessoa (1946: 18), na primeira edição do que viria a constituir um importante manual da área, citou apenas os trabalhos de Evandro Chagas e Salvador Mazza e concluiu: “(...) a questão das miocardites chagásicas em países onde prevalece o Trypanosoma cruzi carece de 
mais extensas investigações. Mesmo em regiões nas quais comumente se encontram triatomas infectados e onde ocorrem infecções humanas pelo T. cruzi, não há estudos convincentes de que as degenerações do miocárdio estejam associadas a infecções prévias pelo protozoário, eis que a miocardite pode ter outras origens, como, por exemplo, a sífilis ou deficiência de vitaminas".

19 Nesta ocasião, o Congresso Internacional de Medicina Tropical e o Congresso Internacional de Malária passariam a compor o mesmo evento, daí a designação de Congressos Internacionais de Medicina Tropical e Malária.

20 "Clinicamente, a doença de Chagas crônica é fundamentalmente representada pela forma cardíaca, uma vez que as outras formas crônicas descritas são duvidosas" - Tradução livre.

${ }_{21}^{2}$ "A doença de Chagas é um problema social e de saúde pública extremamente importante, tanto por sua incidência quanto por sua severidade. Requer a atenção urgente e cuidadosa das autoridades de saúde pública na América Latina” Tradução livre.

22 "Circular aos prefeitos", transcrição de matéria publicada no jornal Minas Gerais, 25 de junho de 1947. FCPqRR/SPAPED, caixa 15, maço 1.

23 "Circular sobre doença de Chagas", transcrição de matéria publicada no jornal Minas Gerais, 15 de agosto de 1947. FCPqRR/SPAPED, caixa 3, maço 1.

24 Carta de Grimaldi Ribeiro a Emmanuel Dias. Monte Belo, 25 de fevereiro de 1947; resposta de Dias em 27 de fevereiro; carta de Grimaldi Ribeiro a Emmanuel Dias, Monte Belo, 11 de março de 1947. FCPqRR/SPAPED, caixa 15, maço 1.

25 O plano incluiria ações de educação sanitária e melhoria nas habitações rurais.

${ }_{26}$ Carta de Emmanuel Dias a Henrique Aragão. Belo Horizonte, 19 de abril de 1947. FCPqRR/SPAPED, caixa 3, maço 2.

27 Um fator que tornava importante a colaboração da população era a necessidade de realizar necropsias nos casos confirmados ou suspeitos da doença. Em 1945, Dias fez circular entre os moradores de Bambuí um folheto com instruções para convencer as famílias a permitirem, pelo menos, a retirada de alguns órgãos dos cadáveres de seus entes falecidos, sobretudo o coração. Dias, Emmanuel. Instruções para a eventualidade de morte de casos de doença de Chagas. Bambuí, 8 de junho de 1945. FCPqRR/SPAPED, caixa 24, maço 9.

28 O fato de Dias enviar ao Hospital Evandro Chagas, no Rio de Janeiro, portadores da doença de Chagas para a realização de pesquisas clínicas provavelmente também se apresentava à população como mais um motivo para apoiar os trabalhos do posto. Embora não houvesse terapêutica específica para a doença na época, o recurso poderia ser visto como oportunidade de acompanhamento por especialistas e, assim, de aumento das chances de melhoria ou sobrevivência. Ver Centro de Estudos e Profilaxia da Moléstia de Chagas, Bambuí, Minas Gerais. Informações sumárias relativas aos seus dois anos de funcionamento, FCPqRR/SPAPED, caixa 3, maço 4 .

29 Abaixo-assinado endereçado a Henrique Aragão. Bambuí, 2 de junho de 1946, FCPqRR/SPAPED, caixa 15 , maço 1 .

30 Para exemplos destas cartas, ver FCPqRR/SPAPED, caixa 31, maço 4, caixa 32, maço 8, caixa 33, maços 13 e 14 . 
31 Dois trabalhos que marcaram especialmente as discussões sobre as relações entre intelectuais e política no Brasil foram os de Sergio Miceli (1979) e Daniel Pécaut (1990).

32 Sobre a importância dos 'médicos do Brasil Central' para a legitimação e a produção de novos conhecimentos sobre a doença de Chagas, ver Kropf (2008).

33 Tais congressos foram de grande relevância para a divulgação dos estudos, realizados por médicos do interior, a respeito da etiologia chagásica do 'mal de engasgo' (megaesôfago), tema que seria emblemático da importância e da originalidade da contribuição científica feita pelos médicos do Brasil Central. Ver Porto e Porto (1970) e Rezende (2001a). Os programas e outras informações relativas a tais encontros eram publicados na Revista Goiana de Medicina, criada em 1955.

34 Relatório dos serviços executados pelo Centro de Saúde de Uberaba durante o ano de 1949, apresentado pelo dr. A. Carneiro Maciel, chefe do Centro de Saúde, à Secretaria de Saúde e Assistência. Uberaba [31 de dezembro de 1949]. FCPqRR/ SPAPED, caixa 16 , maço 1 .

35 Nesta ocasião, o evento, que até então era apenas do Triângulo Mineiro, passou a incorporar médicos de outras regiões vizinhas, como Goiás, assumindo a designação de Congresso Médico do Triângulo Mineiro e Brasil Central. A conferência de Dias foi divulgada, na íntegra, pelo Jornal do Commercio, em 12 de fevereiro de 1950 .

36 Pondé, professor de clínica médica da Faculdade de Medicina da Bahia, desenvolvia pesquisas sobre a cardiopatia chagásica no estado, publicando trabalhos sobre o tema desde 1945. Em artigo de 1948, agradeceu o auxílio prestado pelo IOC no fornecimento de antígenos para reações sorológicas em seus pacientes.

${ }_{37}$ Os participantes daquele evento também enviaram moção de reconhecimento ao IOC pelas contribuições do CEPMC ao estudo da doença de Chagas e pelos "auxílios (...) prestados pelo referido Posto a médicos que trabalham no Brasil Central, estimulando-lhes as iniciativas individuais e facilitando-lhes meios para a realização de estudos sobre esta moléstia”. Moção de reconhecimento ao Instituto Oswaldo Cruz. $1^{\circ}$ Congresso Médico do Brasil Central e $3^{\circ}$ do Triângulo Mineiro. Araxá, setembro de 1949. FCPqRR/SPAPED, caixa 39, maço 1.

38 Para um relatório dos métodos utilizados e dos resultados obtidos nestes ensaios, ver Dias et al. (1952).

39 Carta de Emmanuel Dias a Boulanger Pucci. Uberaba, 25 de novembro de 1949. FCPqRR/SPAPED, caixa 14, maço 2.

40 Discurso do vereador Cláudio Moreira de Almeida na Câmara Municipal de Uberaba, na sessão de 28 de novembro de 1949. FCPqRR/SPAPED, caixa 14, maço 2. O filho de Miguel Couto havia feito, anos antes, o estudo eletrocardiográfico de um caso de forma cardíaca da doença de Chagas, acompanhado por ele no Rio de Janeiro (Couto Filho, 1936).

${ }^{41}$ Relatório dos serviços executados pelo Centro de Saúde de Uberaba durante o ano de 1949, FCPqRR/SPAPED, caixa 16, maço 1.

42 A imprensa, especialmente a mineira, deu destaque ao acordo. Ver Minas Gerais (1950), Estado de Minas (1950a, 1950b) e Jornal do Commercio (1950). 
43 Ver, por exemplo, Folha da Manhã (1950), Estado de Minas (1950c, 1950d, 1950e), Diário da Tarde (1950), Lavoura e Comércio (1950a), Folha de Minas (1950a, 1950b). Para outras reportagens, ver FCPqRR/SPAPED, caixa 36, maço 1.

44 Roteiro de filme sobre a doença de Chagas, 1952. FCPqRR/SPAPED, caixa 16, maço 1. A idéia de fazer um filme sobre a doença de Chagas foi apresentada por Dias a Aragão em 1948. Ofício de Emmanuel Dias a Mário Pinotti, em 7 de maio de 1952. FCPqRR/SPAPED, caixa 15, maço 1.

45 Em maio de 1950, Rui Santos e Clemente Medrado, deputados pela Bahia e por Minas Gerais, pronunciaram discursos sobre a campanha que se iniciava em Uberaba. Ver O Jornal (1950).

46 A imprensa seria um veículo importante, ao longo da década de 1950, para difundir os preceitos e enunciados que os pesquisadores do CEPMC vinham afirmando sistematicamente nas revistas e congressos médicos desde a década de 1940. Dias aproveitaria também outros veículos de comunicação, pronunciando, por exemplo, palestras nas rádios Mayrink Veiga e Nacional, em 1951. Ver: Sumário das atividades científicas do dr. Emmanuel Dias durante o ano de 1951. FCPqRR/ SPAPED, caixa 3, maço 4.

47 Em abril de 1951, mediante novo acordo entre o governo de Minas Gerais e o MES, foram previstos expurgos em toda a área malarígena do estado, com combate simultâneo aos vetores da doença de Chagas. Em 1952, estabeleceu-se que o combate aos barbeiros seria feito em todas as regiões afetadas pela tripanossomíase em Minas e não apenas nas áreas de malária. A partir deste ano, o MES estenderia a campanha para outros estados do país, como Goiás, Bahia e Rio Grande do Sul. Ver Estado de Minas (1951a, 1952a, 1953) e Folha de Minas (1952). Contudo, um programa nacional de controle da tripanossomíase só seria implementado na década de 1980.

48 Ao longo da década de 1940, as estimativas quanto à incidência da endemia chagásica em São Paulo eram alarmantes. Em 1946, José Lima Pedreira de Freitas, pesquisador da Faculdade de Medicina da Universidade de São Paulo (USP), criou, por sugestão do catedrático de parasitologia Samuel Pessoa e com o apoio do Departamento de Saúde Estadual, no distrito de Cássia dos Coqueiros, um posto de estudo para investigar a distribuição da doença no estado e para propor medidas de profilaxia. Em 1950, dos 369 municípios paulistas, foram coletados barbeiros em 130, sendo a infecção dos insetos pelo T. cruzi identificada em 72 deles (ver Freitas, 1951). Pedreira de Freitas, que em 1947 defendera tese de doutoramento sobre diagnóstico laboratorial da doença de Chagas e em 1952 se tornou catedrático do Departamento de Medicina Preventiva da então criada Faculdade de Medicina de Ribeirão Preto, teria atuação de destaque na mobilização política em torno do combate à doença naquele estado, de modo semelhante a Emmanuel Dias. Sobre a doença de Chagas em São Paulo, ver Buralli (1985) e Silva (1999). Sobre a trajetória de Samuel Pessoa, ver Pessoa (1978) e Paiva (2006).

49 Em abril de 1951, esse programa foi incluído no plano quadrienal formulado pelo governador Lucas Nogueira Garcez (A Gazeta, 1951). Em 1954, o Serviço de Profilaxia de Malária do Estado de São Paulo (SPM-SP) assumiria a responsabilidade pela profilaxia no norte do estado, anteriormente incluída no programa do Serviço Nacional de Malária (SNM), no qual estava a região de Ribeirão Preto, 
que, juntamente com o oeste de Minas, eram as principais áreas de endemia chagásica identificadas no país.

50 Em julho de 1950, realizou-se em Ribeirão Preto um simpósio sobre doença de Chagas, promovido pelo Centro Médico local, com sanitaristas do SNM e do SPMSP. Dias participou como orador. Em outubro de 1951, ao apresentar, na Assembléia Legislativa de São Paulo, projeto de lei que conferia ao SPM-SP a competência formal para o controle da endemia chagásica (sancionada em dezembro), o deputado Alípio Correia Neto enfatizou a importância social da doença para as áreas rurais do país e particularmente para a economia paulista, destacando as pesquisas feitas pela Faculdade de Medicina da USP e pelo CEPMC. Ver "No Centro Médico teve grande brilho o simpósio sobre a doença de Chagas", Diário de Notícias, Ribeirão Preto, 16 de julho de 1950. FCPqRR/SPAPED, caixa 36, maço 2. O discurso do deputado Correia Neto encontra-se em: Diário Oficial do Estado de São Paulo, 23 de outubro de 1951. FCPqRR/SPAPED, caixa 36, maço 3. Para cartas trocadas entre Dias e Pedreira de Freitas, ver FCPqRR/SPAPED, caixa 31, maço 5, caixa 15 , maços 2 e 3.

51 Mário Pinotti (1894-1972) nasceu em Brotas, interior do estado de São Paulo, e diplomou-se, em 1914, pela Escola de Farmácia de Ouro Preto e, em 1918, pela Faculdade de Medicina do Rio de Janeiro (FMRJ). Ingressou em 1919 nos serviços federais de saúde pública. Entre 1924 e 1925, como bolsista da Fundação Rockefeller, estudou na Escola de Malária de Nettuno, na Itália. Em seu retorno, atuou como assistente dos serviços de combate à febre amarela sob o comando da Rockefeller. Foi diretor do SNM de 1942 até 1956, ano em que os serviços nacionais encarregados da malária, da peste e da febre amarela foram reunidos no então criado Departamento Nacional de Endemias Rurais, do Ministério da Saúde. Assumiu a direção deste departamento entre 1956 e 1958. Em 1952, Pinotti e sua equipe do Instituto de Malariologia, órgão de pesquisa e ensino do SNM inaugurado em 1949, começaram a testar técnicas terapêuticas contra a malária, tendo em vista as condições brasileiras. Em 1953, propôs a mistura de cloroquina ao sal de cozinha e sua distribuição gratuita, pelo governo, às populações das áreas endêmicas onde não fosse possível a utilização do DDT. Consagrado como 'método Pinotti', o sal cloroquinado foi difundido internacionalmente como estratégia inovadora e autóctone de profilaxia da malária. Ele foi distribuído na região amazônica de 1958 a 1960. Pinotti foi presidente da Sociedade Brasileira de Higiene e membro da Academia Nacional de Medicina (ANM) a partir de 1959. O ápice de sua trajetória pública foi a nomeação para ministro da Saúde em 1958, cargo que deixaria em 1960. Sobre Pinotti, ver Hochman (2007b). Sobre o método do sal cloroquinado, ver Hochman, Melo e Santos (2002) e Hochman (2008).

52 Ao descrever os aspectos básicos da doença em seus discursos, Pinotti se valia dos enunciados e da forma de apresentação típicos dos textos de Dias. Ver Pinotti (1950b).

53 As formulações técnicas de Pinotti sobre a campanha, reproduzidas em várias outras matérias de jornais na época, foram reiteradas por Dias e por dois técnicos do SNM no IX Congresso da Sociedade Brasileira de Higiene, realizado em 1951 em Porto Alegre (Dias et al., 1952). Em novembro de 1950, no 4⿳一 Congresso Médico do Triângulo Mineiro e 2o do Brasil Central, reunido em Uberaba, Pinotti apresentou conferência sistematizando os resultados da campanha iniciada naquela 
cidade, que deu origem a uma publicação cujo título já evidencia a importante aliança que se estabelecia, nos planos material e simbólico: "Malária e doença de Chagas: dois problemas em vias de solução" (Pinotti, 1951a, 1951b).

54 Carta de Emmanuel Dias a Mário Pinotti. Rio de Janeiro, 4 de agosto de 1950. FCPqRR/SPAPED, caixa 15, maço 1.

55 Em 1951, por exemplo, além do acompanhamento técnico dos expurgos, Dias realizou, com Francisco Laranja, Therezino Caldeira Brandt, do SNM, e Felipe Nery Guimarães, diretor do posto do IOC para combate à bouba em Rio Bonito, um inquérito clínico-epidemiológico-sorológico-eletrocardiográfico nesta região do estado do Rio de Janeiro, indene de barbeiros, cujos resultados serviriam para testar os critérios usados nos inquéritos em regiões endêmicas (Dias et al., 1953).

56 O SNM contribuiu para os trabalhos desenvolvidos pelo CEPMC também na medida em que o Instituto de Malariologia (órgão de pesquisa e ensino do SNM) foi uma das instituições a que Dias recorreria, a partir de 1951, para realização dos testes sorológicos de diagnóstico da doença de Chagas, que até então eram feitos quase que exclusivamente no IOC. Relatório dos trabalhos realizados pelo Dr. Emmanuel Dias em 1952. FCPqRR/SPAPED, caixa 3, maço 4.

${ }^{57}$ Ao reconhecer publicamente, na solenidade de inauguração da campanha, que aquela moção havia de fato contribuído para sensibilizar o ministro, Pinotti (1950b) também contribuiu para reforçar a adesão dos médicos do interior ao empreendimento que se iniciava.

58 Em carta dirigida ao ministro da Saúde em 1954, um grupo de médicos de Bambuí elogiou o trabalho do CEPMC e enalteceu a missão de Dias nos seguintes termos: "[ele] poderia estar confortavelmente instalado nos gabinetes de qualquer instituto da Capital, a fazer medicina epidemiológica de erudição livresca e de tertúlias agradáveis nas Associações Científicas”. Torres, Antonio; Sobrinho, Antonio Torres; Magalhães, João Moreira; Alves, Dilermando; Chavez, Antonio Ruy. Carta ao ministro da Saúde Miguel Couto Filho. Bambuí, 7 de junho de 1954. FCPqRR/ SPAPED, caixa 3 , maço 2.

59 "O discurso do desenvolvimento definia um campo de percepção estruturado em redes de observação, modos de questionamento e registro de problemas, e formas de intervenção. Em suma, ele trouxe à tona um espaço definido não tanto por um conjunto de objetos dos quais tratava, mas, sim, por um conjunto de relações e uma prática discursiva que produziam sistematicamente objetos, conceitos, teorias, estratégias etc., que se inter-relacionavam” - Tradução livre.

6) Conforme Escobar (1995: 44-45): "Development was a response to the problematization of poverty that took place in the years following World War II and not a natural process of knowledge that gradually uncovered problems and dealt with them; as such, it must be seen as a historical construct that provides a space in which poor countries are known, specified, and intervened upon. To speak of development as a historical construct requires an analysis of the mechanisms through which it becomes an active, real force." ["O desenvolvimento foi uma resposta à problematização da pobreza, que ocorreu nos anos que se seguiram à Segunda Guerra Mundial, e não um processo natural de conhecimento que, gradualmente, revelou problemas e lidou com eles. Como tal, deve ser visto como uma construção histórica, que oferece um espaço no qual países pobres são conhecidos, especificados 
e sofrem intervenções. Falar de desenvolvimento como uma construção histórica requer uma análise dos mecanismos através dos quais torna-se uma força real e ativa" - Tradução livre].

${ }_{61}$ "Mais da metade dos povos do mundo vive em condições que se aproximam da miséria. Sua alimentação é inadequada e eles são vítimas de enfermidades. Sua vida econômica é primitiva e estagnada. Sua pobreza é uma desvantagem e uma ameaça, tanto para eles mesmos quanto para as áreas mais prósperas. Pela primeira vez na história, a humanidade possui o conhecimento e a habilidade para aliviar o sofrimento desses povos (...). Eu acredito que nós deveríamos tornar disponíveis aos povos pacíficos os benefícios do nosso acervo de conhecimento técnico, de modo a ajudá-los a realizar as suas aspirações por uma vida melhor (...). O que visualizamos é um programa de desenvolvimento baseado nos conceitos de negociação justa e democrática (...). O aumento da produção é a chave para a prosperidade e a paz. E a chave para o aumento da produção é uma aplicação mais ampla e mais vigorosa do conhecimento técnico e científico moderno" - Tradução livre.

62 Sobre os processos de institucionalização e profissionalização da ciência brasileira no pós-guerra, ver Fernandes (1990) e Andrade (1999).

63 Sobre a campanha global de erradicação da malária, ver Packard (1998) e Cueto (2007).

64 "Os trópicos são o habitat de cerca da metade da raça humana, mas uma ampla parcela dessa gente está em grande desvantagem quanto à civilização moderna. Um dos principais fatores que restringem a melhoria dessa situação é a ocorrência das doenças tropicais. Não é necessária muita imaginação para visualizar o enorme incremento na produção de alimentos e matérias primas, o estímulo ao comércio mundial e, sobretudo, a melhoria das condições de vida, com os avanços sociais e culturais daí decorrentes, que resultariam da conquista sobre as doenças tropicais. Essa situação apresenta um desafio que, assim como o Equador, ultrapassa fronteiras nacionais e interesses locais. Trata-se de um problema internacional e deveria ser resolvido através da conjugação das capacidades e dos recursos de muitas nações. Através de inúmeros projetos com os quais vocês estão familiarizados, já ficou demonstrado que, do ponto de vista médico, isso não é insolúvel. A tarefa de convencer os governos e os povos mais interessados quanto à viabilidade de controlar e, em última instância, erradicar as doenças em todas as áreas tropicais avançará significativamente a partir das discussões, nesta conferência, sobre as mais recentes descobertas da pesquisa e sobre as modernas técnicas na saúde pública” - Tradução livre.

65 Como afirma Maria Valério Junho Pena (1977: 71), “não importa se o Plano Salte era basicamente orçamentário ou mesmo se nunca foi efetivamente implementado. O que importa (...) é que ele reflete a definição 'oficial' da realidade, tanto quando propõe caminhos que ela deve percorrer. O papel que se atribui à Saúde é aqui preponderante desta visão de mundo".

66 Neste mesmo ano, o DDT passou a ser utilizado na campanha de erradicação do Aedes aegypti do Serviço Nacional de Febre Amarela (Benchimol, 2001).

67 Dizia Campos (1947: 44): "Importa muito a Minas fixar o homem à terra. (...) Cumpre evitar a convergência da população para os centros urbanos e criar núcleos de civilização de alto sentido demográfico no Vale do São Francisco, por exemplo. A fim de promover o crescimento das populações nas várias zonas de Minas, é 
necessário levar-lhes a higiene, a instrução, o conforto, dinamizando-lhes por todos os meios as fontes de riqueza".

68 A campanha, que organizava congressos de prefeitos em várias regiões do país, tinha como objetivo chamar a atenção para a necessidade de fortalecer os municípios tanto do ponto de vista orçamentário quanto administrativo (IBGE, 1949).

6) Sobre o debate em torno da interiorização da capital do país, ver Silva (2006) e Vieira $(2007,2009)$.

70 O orador chegou a associar o estilo político dos mineiros a esta condição de estado rural por excelência: “(...) a atmosfera desses centros modestos e calmos, confundindo-se com os vagares da vida rural, propiciou a formação do caráter e da personalidade dessas austeras e dignas figuras de dirigentes, cheios de ponderação e equilíbrio, que o Brasil tem tido a felicidade de ver passar pelos mais altos postos de direção" (IBGE, 1949: 20).

${ }^{71}$ O ministro da Justiça havia sido encarregado por Dutra de organizar uma Federação dos Municípios e era presidente de honra do referido congresso de prefeitos do Triângulo Mineiro (IBGE, 1949).

72 Segundo Alisson Guimarães (1957), a localização nas proximidades da capital mineira deveu-se a vários motivos, como garantia de um mercado consumidor próximo e em expansão, facilidades na obtenção de mão-de-obra, distância relativamente pequena das principais matérias-primas, preocupação com a preservação da paisagem urbana residencial de Belo Horizonte, possibilidade de contar com um sistema energético melhor do que o que servia a capital, proximidade das principais vias de comunicação e existência de extensa rede bancária em Belo Horizonte.

73 A Cidade Industrial viria a se tornar a maior aglomeração industrial de Minas Gerais, reunindo indústrias siderúrgicas e metalúrgicas, de alimentação, químicas, têxteis, de eletricidade, de instrumentos científicos e de construção. Além de Guimarães (1957), ver também Borges (1997).

74 Na época em que começaram os trabalhos de profilaxia, no início de 1950, foram registradas, entre os 291 domicílios do Parque Industrial (que incluía núcleos residenciais construídos pelas indústrias, como a Magnesita e a Cia. Itaú), 37 cafuas, típicas das áreas rurais mais pobres do estado. A grande maioria dos barbeiros capturados foi encontrada nestas moradias, algumas delas com elevado índice de infestação (em uma cafua foram encontrados 1.189 barbeiros). Os cientistas realizaram exames sorológicos em cem servidores do estado e seus familiares e em 83 trabalhadores da Cia. Itaú. Em 11 deles, o resultado foi positivo. Todos eram casos crônicos e haviam se infectado antes de se estabelecerem na Cidade Industrial. Os expurgos destinados à eliminação dos barbeiros foram realizados em todas as habitações, mediante aplicação de $\mathrm{BHC}$ associado a um repelente à base de piretro (Pellegrino \& Brener, 1951).

75 Em seu Ensaio de Profilaxia da Moléstia de Chagas, Dias (1945: 114-115) advertiu para os riscos de transmissão da infecção via transfusão de sangue e para a necessidade do controle de doadores. No $3^{\circ}$ Congresso Médico do Triângulo Mineiro, realizado em Araxá, em 1949, e na 1ª Reunião Pan-Americana sobre Doença de Chagas, realizada em Tucumán também naquele ano, Pellegrino, Dias e Laranja apresentaram moções sobre a necessidade de se pôr em prática medidas de controle nos bancos de sangue destinadas a diagnosticar casos de infecção chagásica entre 
os candidatos a doadores. O controle da transmissão transfusional seria implementado sistematicamente no Brasil a partir da década de 1980, em função do controle dos bancos de sangue imposto pela pandemia de Aids. Ver Dias e Coura (1997) e Brasil (2005). 


\section{A Doença de Chagas em Tempos de Desenvolvimento (1951-1962)}

O processo histórico pelo qual, no pós-Segunda Guerra Mundial, a ciência e a saúde assumiram centralidade nas discussões sobre o desenvolvimento aprofundou-se na década de 1950, no cenário internacional e no contexto brasileiro. Se, em 1950, a primeira campanha de profilaxia contra a tripanossomíase americana constituiu um marco do reconhecimento desta doença como entidade nosológica específica, clinicamente individualizada e socialmente importante, a movimentação dos cientistas em prol deste reconhecimento prosseguiria, destinada a conquistar novas adesões e a ampliar os interesses sociais em torno daquele objeto, propiciando sua institucionalização como tema da ciência e da saúde pública, no Brasil e no continente latino-americano.

\section{Saúde, Desenvolvimento e Endemias Rurais na Década de 1950: o 'círculo vicioso da doença e da pobreza'}

A quinta Assembléia Mundial da Saúde, promovida pela Organização Mundial da Saúde (OMS) em maio de 1952, em Genebra, constituiu 
uma ocasião importante para o debate sobre a relação entre saúde e economia. Charles-Edward Amory Winslow (liderança da saúde pública norteamericana) e o economista sueco Karl Gunnar Myrdal (então secretárioexecutivo da Comissão Econômica para a Europa) fizeram, na nona sessão plenária, a apresentação geral do tema 'valor econômico da saúde', estabelecendo princípios que se tornariam estruturantes deste debate a partir de então. Ao afirmar que as preocupações com os vínculos entre doença e pobreza remontavam ao "grande despertar sanitário" (Winslow, 1955: 1) de meados do século XIX na Europa, quando foram discutidas as condições de trabalho nas fábricas e a expansão do capitalismo, Winslow (1955) reiterou que, mais do que nunca, este era um tema a ser enfrentado naquele momento de reconfiguração do mundo após a guerra. A "carga econômica" de doenças como a malária - que prejudicavam a produtividade não apenas pela perda do "capital-vida" (Winslow, 1955: 5), mas também pela queda da potência produtiva e pelo aumento dos custos com serviços médicos - era um problema premente para os países, marcados, cada vez mais, por estreitas relações de interdependência:

Los hombres de hoy advierten que el mundo unido que ellos anhelan edificar no puede establecerse ni mantenerse constituído con naciones trabadas por las cargas abrumadoras de la pobreza y la enfermedad (...). (...) las enfermedades que existen en Asia, en Africa o en los Mares del Sur pueden crear problemas económicos para los comerciantes de Londres o de Nueva York. (Winslow, 1955: 1, 16)

Como exemplo destas preocupações, Winslow enfatizou a necessidade de aumentar a produção agrícola para atender ao crescimento demográfico acelerado em todo o mundo. As zonas que ofereciam maiores possibilidades de incrementar o cultivo de alimentos eram, acentuou, justamente, as áreas tropicais mais afetadas por 'enfermidades evitáveis'.

Ao salientar a perspectiva otimista que a ciência vinha oferecendo para enfrentar as doenças, sendo o combate aos vetores um dos "resultados mais espetaculares" (Winslow, 1955: 12), Winslow apontou, então, elementos para a formulação de um programa de saúde internacional, a ser conduzido pela Organização das Nações Unidas (ONU) e encaminhado mediante projetos de cooperação mútua entre os países. Entre tais elementos, destacou a produção de estatísticas vitais e estudos de campo nas distintas regiões, como base para ações de planejamento, e a 
profissionalização das estruturas administrativas e técnicas dos programas de saúde. Afirmou, sintetizando os termos do debate num conceito que seria amplamente difundido a partir de então: "La pobreza es causa de enfermedad y la enfermedad origina mayor pobreza, en un círculo vicioso. Por conseguiente, la salud pública es un problema que está relacionado intimamente con el progreso económico y social que se logra en una colectividad dada" (Winslow, 1955: 106). ${ }^{2}$

Myrdall (1952) apresentou, na mesma ocasião, outra formulação que se tornaria central no campo da saúde internacional. Com base no princípio dos efeitos cumulativos e da interdependência dos fatores sociais, argumentou que o círculo vicioso assinalado por Winslow só poderia ser rompido mediante a implementação planejada de reformas que gerassem transformações cumulativas e direcionadas aos fatores responsáveis pelas desigualdades econômico-sociais. Ou seja: qualquer ação no plano da saúde deveria integrar-se a um programa mais amplo de desenvolvimento. As intervenções sanitárias eram, sem dúvida, importantes para melhorar as condições de vida das populações, mas não deveriam ser concebidas de modo isolado: deveriam fazer parte de um conjunto de transformações sociais.

Nesta nona sessão plenária da Assembléia da OMS, os brasileiros Paulo de Assis Ribeiro, Manoel Ferreira (que a presidiu) e Ernani Braga (1998 [1952]) apresentaram trabalho sobre os instrumentos para mensurar os custos e as perdas econômicas produzidos pelas doenças. ${ }^{3}$ As concepções expressas neste encontro, por sistematizarem posições que já vinham se delineando desde o final da Segunda Guerra Mundial, seriam amplamente endossadas e propagadas no debate brasileiro sobre a relação entre saúde e desenvolvimento no contexto do nacional-desenvolvimentismo do segundo governo Vargas (1951-1954) e, em especial, do governo de Juscelino Kubitschek (1956-1961) (Mendonça, 1986; Abreu, 1999; Quadros da Silva, 1999; D’Araújo, 1999a, 1999b; Gomes, 2002).

Labra (1988) propôs a designação de 'sanitarismo desenvolvimentista' para a corrente de pensamento que, desde o final do Estado Novo, uniu médicos e sanitaristas em torno dos princípios consagrados em Genebra, em 1952. ${ }^{4}$ Segundo a autora, os "sanitaristas desenvolvimentistas" contrapunham-se a um modelo de saúde campanhista e verticalizado, "centralizador e autoritário", formalizado com a reforma sanitária conduzida por Carlos Chagas na década de 1920 e que alcançara seu ápice durante a gestão de Capanema no Ministério da Educação e Saúde 
(MES), sob as diretrizes de João de Barros Barreto (Labra, 1988: 15). Esta oposição nos remete ao argumento de John Farley (2004) sobre as distintas ênfases na maneira de articular os termos da equação 'saúde e desenvolvimento', expressas na imagem de um pêndulo a oscilar entre uma posição que priorizava as intervenções sanitárias como pré-requisito do desenvolvimento e a que priorizava o desenvolvimento social como pré-requisito das melhorias na saúde. ${ }^{5}$

Contudo, ainda que críticas ao modelo ‘campanhista' estivessem na perspectiva de alguns indivíduos à época, considero que as posições em torno do ideário do 'sanitarismo desenvolvimentista' não eram tão demarcadas ou contrapostas. ${ }^{6}$ Num momento em que as discussões sobre a saúde mesclavam-se a um intenso debate político entre distintos modelos de reforma social, muitas questões estavam em jogo em torno da concepção geral que associava saúde a desenvolvimento econômico. Para além de divergências quanto às maneiras de articular estes termos, havia um acordo geral ao qual eles estavam intimamente associados (Lima, Fonseca \& Hochman, 2005). Assim, muitos dos que propugnavam e implementavam as diretrizes 'campanhistas' do MES defendiam enfaticamente as concepções gerais associadas ao 'sanitarismo desenvolvimentista'. As mensagens presidenciais e os discursos de ministros da Saúde do período foram importantes veículos de propagação dessas concepções. Em sua Mensagem ao Congresso Nacional, de 1951, Vargas declarou:

Analisando o panorama sanitário brasileiro não perderemos de vista o conceito de que o nível de saúde de um povo é corolário do seu progresso econômico, e que somente a gradual ascensão dos padrões sociais e educativos da vida nacional e a melhoria do nível de bem-estar da população poderão efetivamente conduzir ao definitivo aperfeiçoamento dos índices sanitários. (Brasil, 1951: 198)

Quanto à malária, evocada há tempos como ‘doença econômica' por excelência, o presidente assegurou que o governo continuaria o programa de profilaxia por meio do combate aos vetores, mas associando-o às atividades produtivas, principalmente agrícolas: "Reconhece o Governo a importância do trabalho em curso, porém não esquece que, no combate à malária, a vitória final só é obtida quando se completa a recuperação do solo pela agricultura, em condições técnicas adequadas" (Brasil, 1951: 205). A mesma diretriz seria endossada nas várias conferências que o ministro da Saúde Aramis Athayde pronunciou em 1955 (Athayde, 1957). 
Mário Pinotti - que, durante a década de 1940, chefiou um dos organismos sanitários que melhor expressava o modelo das campanhas verticalizadas do MES, o Serviço Nacional de Malária (SNM), e que seria ministro da Saúde durante o governo JK - produziu textos e pronunciamentos defendendo que a saúde era um bem de valor econômico e que deveria ser vista como parte de um projeto mais geral de desenvolvimento (Pinotti, 1958, 1959). Segundo ele, isso não significava descartar intervenções técnicas, focadas em problemas sanitários específicos, sobretudo tendo-se em vista as conquistas técnicas neste terreno. A importância de Pinotti na formulação das diretrizes para o campo da saúde no período é atestada pelo fato de ter sido ele o autor do prefácio ao programa de saúde pública de JK, quando este se candidatou à presidência, e, tudo indica, também o responsável pela redação do próprio programa (Kubitschek, 1955). ${ }^{7}$

O ano de 1955 foi um marco do chamado 'otimismo sanitário' internacional (Garret, 1995), com o lançamento, pela OMS, da campanha global de erradicação da malária. ${ }^{8}$ No programa de saúde de JK, podemos observar em que medida os princípios gerais da associação entre ciência, saúde e desenvolvimento, pelos quais se afirmava a necessidade de priorizar o combate às chamadas 'doenças de massa', reconfiguravam, naquele contexto histórico, os significados que, desde a década de 1910, eram atribuídos às endemias rurais como obstáculo à produtividade e à economia nacional. ${ }^{9}$ Endossando o protesto de Euclides da Cunha contra "a indiferença com que o Brasil mal civilizado deixa o Brasil verdadeiro e puro das nossas origens" (Kubitschek, 1955: 20), o texto enfatizava a importância de investimentos e ações voltados para o homem do interior, "castigado de trabalhos e de doenças, mas ainda assim rijo e resistente" (Kubitschek, 1955: 8), e assinalava, em alusão direta à dualidade litoral/sertão: "Há muito tempo que o povo brasileiro do interior espera pelo povo das cidades brasileiras. Os apelos já atravessam séculos. Dispondo dos recursos humanos e materiais de que os sucessivos governos têm disposto, não é mais possível este completo divórcio no sangue e nas energias do Brasil”" (Kubitschek, 1955: 33).

Numa referência ambivalente ao movimento sanitarista liderado por Belisário Penna na década de 1910, o programa de JK reiterava a importância do combate às doenças das populações rurais do país, mas enfatizava justamente a nova capacidade técnica e política do poder público no sentido de mudar aquela situação, afirmando que "o Brasil não 
é só doença" e, portanto, distanciando-se de "atitudes de pessimismo ou negativistas em relação ao próximo futuro do Brasil” (Kubitschek, 1955: 32). Recorrendo a uma formulação retoricamente eloqüente - "já não somos mais (...) o vasto hospital da frase de Miguel Pereira" (Kubitschek, 1955: 53) -, o candidato destacava que tal capacidade de transformação, que ele prometia intensificar "em cinco anos de trabalhos intensivos", expressava-se nas campanhas sanitárias empreendidas pelo MES (entre as quais, a de profilaxia da doença de Chagas), que permitiam "controlar (...) graves endemias que flagelavam milhões de brasileiros" (Kubitschek, 1955: 53). ${ }^{10}$ O otimismo sanitário do momento apresentava-se, assim, como parte do otimismo geral que JK tornaria a marca de seu governo.

Quando voltarmos os olhos para o nosso homem do interior, não devemos ver só um homem doente. Não existem só doenças e doentes no vasto interior do Brasil. Ao lado das grandes populações enfermas, existe uma grande população de gente sadia, bem disposta, trabalhando com resultado e esperança. (...) Só os que não conhecem o Brasil, vivem arrolhados nas cidades, podem duvidar do povo brasileiro e do seu extraordinário poder de assimilação e utilização de tudo quanto a ciência e a técnica moderna vão produzindo em benefício do homem. Mal surge no mundo uma conquista e logo o Brasil a incorpora ao seu patrimônio e ao seu arsenal de trabalho. Mal se aplicava o DDT nas campanhas norteamericanas da última guerra no Extremo-Oriente e já o Brasil em pouco tempo se tornava o maior consumidor de DDT no mundo, para combater mais de uma das suas endemias rurais. (Kubitschek, 1955: 32; grifos meus)

Num indício de que compartilhava da noção de que as campanhas sanitárias deveriam estar inseridas num projeto maior de desenvolvimento econômico, JK afirmou, por exemplo, a importância de associar o combate às endemias rurais à mecanização da agricultura. Além de sua dimensão concreta como base material para a modernização, a máquina era um símbolo eloqüente da conquista do interior pelo progresso.

Não basta combater as doenças. Pôr nas mãos vigorosas do sertanejo recuperado, lúcido, vigoroso, uma simples enxada é quase um crime contra o Brasil. Sua inteligência, sua admirável capacidade de compreender, sua aptidão para assimilar rapidamente, tudo nele está pedindo alguma coisa além do rudimentarismo da enxada, símbolo da nossa rotina, do nosso atraso, da nossa displicência, que deve ser banida do Brasil. Tudo nele pede a máquina, para 
poupar-lhe as energias, para que agora possa ele aplicá-las no sentido superior que a vida brasileira deve e necessita ter. (Kubitschek, 1955: 33$)^{11}$

Foi sob as peculiaridades históricas deste período - em que o tema do saneamento rural ganhava nova moldura na plataforma política dos que pretendiam construir, com potentes inseticidas e máquinas, uma nova nação - que a 'doença do Brasil', emoldurada desde o início como emblema dos males do interior, avançaria em seu processo de reconhecimento científico e social.

\section{A Tripanossomíase Americana em Destaque nos Eventos Médico-Sanitários}

A inclusão da doença de Chagas na pauta do MES fez com que ela passasse a despertar particular interesse nos congressos e eventos da classe médica. Em especial, os dois primeiros anos que se seguiram ao início da campanha de Uberaba foram de grande visibilidade pública para o tema, bem como para os trabalhos do Centro de Estudos e Profilaxia da Moléstia de Chagas (CEPMC), que, em 1951, teve sua nova sede inaugurada, com apoio de JK, então governador de Minas. O momento foi sintetizado por Emmanuel Dias: "O assunto vai de vento em popa, os tempos são outros..."12 Nestes eventos, a atenção era especialmente dirigida para a questão da profilaxia. Nas apresentações que Dias e Pinotti fizeram sobre o tema, foram enfatizados os resultados concretos da campanha e a necessidade de sua ampliação, bem como os avanços na elucidação de questões técnicas relativas aos métodos de combate aos vetores.

Os encontros que reuniam a classe médica em regiões diretamente afetadas pela doença, como os congressos médicos do Brasil Central e Triângulo Mineiro, foram um espaço importante de divulgação e mobilização em torno do assunto. A reunião de 1951, em que a tripanossomíase foi tema de destaque (cuja relatoria coube a Dias), foi marcada pelo entusiasmo com o "batismo científico da Nova Capital que florescia na brutalidade do sertão brasileiro" (Porto \& Porto, 1970: 126). A cidade planejada de Goiânia, inaugurada em 1933, era o símbolo do projeto de Vargas da 'marcha para o Oeste'. Na ocasião, os congressistas reforçaram, como de costume, a importância dos médicos do Brasil 
Central como 'legítimos conhecedores' dos problemas representados pelas endemias rurais. Em 1955, o 7 Congresso Médico do Brasil Central, ocorrido em Uberlândia, contou com a presença do ministro da Saúde Aramis Athayde, que destacou em sua conferência as potencialidades econômicas do Triângulo Mineiro. Enaltecido como "passagem natural das pessoas e bens das imensas regiões do Brasil Central" (Athayde, 1957: 59), a região era exemplar da marcha do desenvolvimento ao interior do país. Entre as 'doenças de massa' que a afligiam, Athayde salientou a doença de Chagas, elogiando as iniciativas do Ministério da Saúde em combatê-la.

A capital de Minas Gerais também foi palco de encontros médicos que deram grande destaque à tripanossomíase. Em 1951, ocorreu em Belo Horizonte o $1^{\circ}$ Congresso da Associação Médica de Minas Gerais, no qual José Pellegrino (1953: 611-612), colaborador do CEPMC, apresentou relatório das pesquisas feitas no estado até aquela data, considerada um divisor de águas pelo "notável impulso que tomaram recentemente os estudos sobre este importante problema de Saúde Pública”, derivado sobretudo da "individualização definitiva da cardiopatia chagásica crônica” e da verificação da eficácia dos inseticidas como método profilático. A inclusão da doença como tema oficial deste e outros eventos médicos, realizados naquele ano no país, traduzia o interesse que os poderes públicos e a classe médica devotavam ao assunto, "um dos problemas sanitários da maior relevância que afeta tão profundamente a saúde e a economia do Estado" (Pellegrino, 1953: 613). ${ }^{13}$

A ampliação do interesse médico pela doença se deu também no âmbito de especialidades particulares, como a pediatria. $\mathrm{O}$ tema 'doença de Chagas na infância' fez parte, por exemplo, da VI Jornada de Puericultura e Pediatria, realizada em Belo Horizonte em 1952, cabendo a relatoria a Pellegrino, que publicou alguns trabalhos em periódicos da área (Pellegrino, 1952; Pellegrino, Rezende \& Brener, 1952; Pellegrino \& Rezende, 1953). Naquele mesmo ano, o já renomado pediatra Rinaldo de Lamare publicou artigo sobre a doença de Chagas (De Lamare \& Aguiar, 1952). Os gastroenterologistas também se interessavam pelo assunto, sobretudo no que dizia respeito às manifestações digestivas da doença (Rezende, 1956a, 2001, 2001a). Em 1957, a Sociedade de Gastroenterologia e Nutrição da Paraíba realizou um Seminário Brasileiro sobre Doença de Chagas. ${ }^{14}$ 
O tema da doença de Chagas foi progressivamente se institucionalizando na década de 1950 igualmente no campo da saúde pública, em termos tanto das políticas ministeriais quanto das pesquisas específicas à área. No plano nacional, o mais importante espaço eram os Congressos Brasileiros de Higiene, promovidos pela principal instituição de representação dos sanitaristas, a Sociedade Brasileira de Higiene (SBH). Na nona reunião realizada em 1951, em Porto Alegre, a tripanossomíase foi o tema que reuniu maior quantidade de comunicações, sendo grande parte apresentada por técnicos dos serviços sanitários encarregados de programas de profilaxia.

Dias foi autor de cinco trabalhos, em colaboração com sanitaristas do SNM, quase todos relativos às pesquisas para padronização das técnicas de aplicação de inseticidas (SBH, 1952) ${ }^{15}$ Como conferencistas convidados, Francisco Laranja (1953) discutiu os aspectos clínicos da doença e Mário Pinotti (1952) abordou o programa de profilaxia do SNM. Cecilio Romaña apresentou, como representante da Repartição Sanitária PanAmericana (RSPA), um balanço dos conhecimentos sobre a enfermidade nos vários países. Felicitando o governo brasileiro pelo início da profilaxia e os cientistas da 'escola de Manguinhos' que compunham a 'vanguarda' das investigações sobre o tema nas Américas, o pesquisador argentino sintetizou o entusiasmo vigente e os significados que a campanha de 1950 assumia na trajetória da doença desde sua descoberta: "La era de los insecticidas de acción residual y la nueva conciencia que la medicina preventiva ha desarrollado en el mundo harán que la cruzada que inició Chagas en el Brasil tenga el noble final que todos esperamos" (Romaña, 1952: 215). ${ }^{16}$

No X Congresso Brasileiro de Higiene, realizado em 1952 na capital mineira, em homenagem a Carlos Chagas, a doença continuou em destaque, com vários trabalhos de pesquisadores vinculados ao CEPMC (SBH, 1953). Na ocasião, o governador JK enalteceu a importância das medidas voltadas a "recuperar o elemento humano para que se consiga o progresso, prosperidade e engrandecimento do Estado" (SBH, 1953: XXIV) e destacou as realizações de seu governo no combate às endemias rurais. Numa operação expressiva da dimensão simbólica que a doença de Chagas assumia neste programa, foi lançada a pedra fundamental de um monumento a Carlos Chagas, no Parque Municipal, e Kubitschek enfatizou a "dívida de gratidão" que o estado de Minas resgatava com o cientista mineiro, exemplo para todos os higienistas brasileiros, por ter 
levado a ciência para a "hinterlândia" (SBH, 1953: XXV). JK afirmou que a campanha contra a doença de Chagas em Minas Gerais era "uma das maiores e mais significativas homenagens que se poderiam prestar ao sábio" (SBH, 1953: XXV). ${ }^{17}$ Na inauguração do congresso, Pinotti, diretor do SNM e da SBH, sintetizou o sentido de "nova era" que se atribuía àquele momento, em que as campanhas contra "as doenças endêmicas e epidêmicas que assolavam o Brasil ao tempo de Miguel Pereira”, graças aos avanços técnicos produzidos especialmente a partir da guerra, assumiam características de verdadeiras “cruzadas nacionais" (SBH, 1953: XV).

Quanto à projeção da doença em eventos internacionais no campo da saúde pública, um marco importante foi o I Congresso Interamericano de Higiene, ocorrido em Havana, em outubro de 1952, em homenagem ao cinqüentenário da Repartição Sanitária Pan-Americana (RSPA) e a Carlos Juan Finlay (autor da teoria do mosquito como transmissor da malária). Por convite de Fred Soper, diretor da RSPA, Dias foi debatedor na mesa-redonda sobre doença de Chagas, onde Laranja discorreu a respeito da cardiopatia chagásica crônica (RSPA, 1953: 692-694). ${ }^{18}$ Pinotti (1953: 681), chefe da delegação brasileira e vice-presidente do congresso, ressaltou em sua conferência a importância do trabalho do CEPMC, ao qual atribuiu o "surto de interesse nacional pela doença de Chagas" e o seu "reconhecimento (...) como problema sanitário", graças às "novas e importantes aquisições de ordem clínica, epidemiológica e profiláticas" e à sua capacidade de chamar atenção para o tema nos meios médico-sanitários. A campanha contra a doença, que selava a cooperação entre o Instituto Oswaldo Cruz (IOC) e o SNM, deveria, segundo ele, ter uma dimensão nacional.

O congresso de Havana, além de divulgar internacionalmente o pioneirismo brasileiro no combate à endemia chagásica, foi uma boa ocasião para que Dias estreitasse seus contatos com pesquisadores dedicados ao assunto nos diversos países do continente americano, de modo que estes o ajudassem a pressionar a RSPA a responsabilizar-se pelo combate à doença. ${ }^{19}$ Em nome da delegação brasileira, o diretor do CEPMC propôs a recomendação oficial, unanimemente aprovada, de que a RSPA providenciasse a criação de uma comissão de especialistas de diversos países, em caráter consultivo, para tratar da tripanossomíase americana no continente (RSPA, 1953: 758-759). A imprensa deu destaque à participação dos cientistas brasileiros no evento, em especial à liderança de Dias (O Globo, 1952; Diário de Notícias, 1952; O Diário, 1952; O Jornal, 
1952; Estado de Minas, 1952c, 1952d). Em 1953, o diretor do SNM apresentou os resultados da campanha contra a doença de Chagas no Brasil nos V Congressos Internacionais de Medicina Tropical e Malária, realizados em Istambul (Pinotti, 1954).

Outra evidência de como a legitimação científica e social da doença de Chagas se beneficiou, nesta época, do interesse internacional em torno das novas perspectivas para o combate às doenças infectocontagiosas foi a publicação, na Alemanha, de um atlas com a distribuição geográfica destas enfermidades em todo o mundo. A idéia havia partido de epidemiologistas alemães durante a guerra e restringia-se a doenças e regiões consideradas de importância militar. Com o término do conflito, as forças norte-americanas que ocupavam a Alemanha resolveram ampliar e patrocinar o projeto. Em finais de 1949, Dias recebeu o convite para responsabilizar-se por um capítulo sobre a doença de Chagas. ${ }^{20}$

A elaboração do trabalho (Dias, 1954), que se estenderia até 1954 , fez crescer o intercâmbio entre Dias com os pesquisadores nos diversos países americanos, com quem ele se correspondeu sistematicamente, solicitando informações e comentários. Este foi o primeiro grande panorama sobre a tripanossomíase americana no continente, com dados e mapas relativos à distribuição geográfica dos transmissores e casos da doença. Exemplares do atlas foram entregues por Dias a diversos pesquisadores e instituições nacionais e internacionais, como mais uma estratégia em sua argumentação sobre a gravidade da endemia. ${ }^{21}$

Outra iniciativa do diretor do CEPMC para ampliar o reconhecimento internacional da doença foi sua participação, como observador do Conselho Nacional de Pesquisas (CNPq) e da Organização das Nações Unidas para a Educação, a Ciência e a Cultura (Unesco), da V Reunião do International Scientific Committee for Trypanosomiasis Research (ISCTR), realizada em Pretória, África do Sul, em 1954, destinada sobretudo a trabalhos sobre a tripanossomíase africana. Reiterando a recomendação do congresso de Havana, Dias sugeriu a criação de um comitê semelhante para orientar as pesquisas sobre a doença de Chagas nas Américas, no âmbito da RSPA. ${ }^{22}$

Em 1955, Dias divulgou as pesquisas brasileiras sobre a tripanossomíase americana junto ao público europeu, como consultor técnico-científico da exposição em homenagem à vida e à obra de Carlos Chagas, realizada no Palais de la Découverte, em Paris. Na mostra, foram exibidos o filme feito por Dias em parceria com o SNM e os mapas que 
produziu para o atlas alemão (Dias, 1954). Numa interessante representação da ciência e do Brasil nos tempos do nacional-desenvolvimentismo, a exposição destacava as riquezas e potencialidades econômicas do país e as grandes obras de modernização, como a Usina de Volta Redonda (Imagem 30). O laboratório de Chagas no IOC foi reproduzido por fotomontagem, sendo exibidos materiais que pertenceram ao cientista (Imagem 27). O ambiente do sertão foi recriado mediante a montagem de uma cafua (Imagem 23). Um dos painéis da mostra trazia um mapa do Brasil onde eram figurados os tipos humanos e as características físicas ou econômicas de suas regiões. Além da Bahia, do Rio de Janeiro, de Porto Alegre e de São Paulo, indicava-se a cidade de Bambuí, cujo ícone era uma cafua. Entre as imagens relativas à doença, fotografias mostravam pacientes submetidos a exames radiológicos e eletrocardiográficos (Imagem 29). ${ }^{23}$

A projeção da doença nos eventos médico-sanitários impulsionava, por sua vez, a disseminação, junto ao grande público, dos principais traços e imagens pelos quais ela era reconhecida como entidade clínica. Em matéria de $O$ Estado de $S$. Paulo (1951: 5) sobre a profilaxia empreendida naquele estado, lia-se que a enfermidade “(...) ataca de maneira particular a musculatura cardíaca, sendo responsável por um grande número de mortes súbitas. Nos municípios mais acometidos, observa-se um fato curioso: os negociantes evitam vender fiado”. No Jornal de Montes Claros, um médico local publicou informações destinadas a esclarecer "os homens da roça" sobre os sintomas desta que era "a maior responsável pelas mortes do coração [sic] em nosso meio”. ${ }^{24}$ Em outra reportagem, afirmava-se que, apesar de suas belezas, a cidade de Itacambira, interior de Minas Gerais, possuía um "número fantástico de cardíacos, (...) geralmente por terem sido sugados pelo barbeiro", e que era muito comum, nas festas da Igreja, pessoas morrerem fulminadas por parada cardíaca. ${ }^{25}$

As representações sobre o "terrível mal caboclo" (A Cidade, 1950) assumiam, por vezes, imagens de grande dramaticidade. $O$ Estado de Minas (1952d: 4), anunciando o congresso de Havana, afirmava: "A picada do barbeiro equivale a uma condenação à morte. (...) O coração invadido pelo tripanossoma vai sucumbindo, na passagem dos dias e das horas, como a luz que se apaga para sempre". Em entrevista ao mesmo jornal, o pesquisador de Manguinhos Eurico Villela declarou: "Carlos Chagas ressuscitou na pessoa de Emmanuel Dias. Se não fosse este moço com as suas pesquisas em Bambuí, o mundo estaria ignorando ainda 
aspectos cruciantes de uma doença das mais sérias". O reconhecimento público de que a doença de Chagas era essencialmente uma doença cardíaca crônica se ampliava e se consolidava. Villela, trinta anos depois de publicar com Carlos Chagas um dos trabalhos mais importantes sobre o assunto, acentuou: "Hoje, que a cardiopatia chagásica se acha incluída nos consultórios, devemos agradecer a Bambuí e suas pesquisas" (Estado de Minas, 1952e: 7).

\section{Pedidos ao Doutor Dias: a doença vista pela população}

A realização de campanhas de profilaxia, ainda que restritas a certas regiões, favorecia a ampliação das associações estabelecidas por Dias em torno da doença. Se, desde a década de 1940, o CEPMC buscou informar e conquistar o apoio das populações de áreas endêmicas, a partir de então os próprios doentes passariam a se dirigir a Dias, em nome de seus interesses. Nas cartas que lhe endereçaram (em alguns casos expressando grande esforço em superar as barreiras da linguagem escrita), identificamos a percepção que os próprios habitantes das áreas rurais possuíam da doença e em que medida os enunciados formulados pelos cientistas já haviam se estabilizado no senso comum de modo a orientar esta percepção. ${ }^{26}$ Via de regra, estas pessoas buscavam, junto a Dias, assistência médica, declarando terem 'ouvido falar' que o posto de Bambuí possuía 'remédios' para o mal. As notícias sobre o poder dos inseticidas utilizados no combate à doença eram, por vezes, compreendidas não como prevenção ou controle, mas como recurso terapêutico. Era recorrente a referência à doença em razão de sintomas cardíacos, quer por terem sido mencionados por um clínico local, quer pela noção já disseminada de que 'ser ofendido pelo barbeiro', como se dizia, equivalia a sofrer do coração.

Em 1954, um morador da cidade mineira de Cláudio, que ouvira dizer que Dias "era um ótimo especialista em moléstia transmitida por barbeiro", pediu-lhe ajuda para tratar a enfermidade, identificada no ano anterior. Dizia ele:

(...) pensei que aquilo não era uma doença perigosa, não encomodei [sic] de tratar, mas agora estou sentindo o coração falhando demais, ele dar [sic] uma pancada e falha outra, estou também com as pernas um pouco enchadas $[\mathrm{sic}]$. Por este motivo peço o senhor a 
caridade de enviar-me uma receita deste milagroso remédio, se for preciso eu pagarei a receita ao senhor (...). Espero que não deixe de atender o meu pedido o qual ficarei muito contente mesmo pagando a receita. Cordial saudação. ${ }^{27}$

Em resposta, Dias informou que, infelizmente, não existia o referido remédio e convidou-o a visitar o CEPMC, onde poderia examiná-lo. ${ }^{28}$ Contudo, logo em seguida, recebeu carta do genro de Francisco José informando-lhe seu falecimento, agradecendo a atenção de Dias e comunicando que a sogra também possuía a doença. Ele próprio temia ter sido contaminado: "Já morei em lugar que tem o tal inseto". ${ }^{29}$ Mais uma vez, Dias fez o convite para que fossem a Bambuí e para enviarem ao posto insetos da região, a fim de confirmar se estavam infectados. ${ }^{30}$

Em 1958, uma moradora de Belo Horizonte contou a Dias que a filha de 20 anos, levada ao hospital com problemas cardíacos, foi diagnosticada como portadora da doença de Chagas. Reproduzindo as palavras do médico que a atendeu e referindo-se ao inseticida como medicamento, ela pediu-lhe:

A doença do coração é a válvula entupida. A doença das Chagas [sic] só está no sangue, ainda não atingiu o coração. Então peço ao senhor se for possível mandar para mim uma receita para a doença das Chagas [sic] o mais breve possível, porque eu não estou com esperança no tratamento dos médicos daqui. Nós somos aquela família que a [sic] 9 anos morávamos aí na beira do rio nos terrenos do Sr. Tunico Julio, sempre o senhor mandava pôr remédio lá por causa dos barbeiros. ${ }^{31}$

O CEPMC era visto como posto de assistência médica. Uma moradora de Uberaba, "desesperada com um irmão que está desinganado [sic] por algum médico daqui”, dirigiu-se a Dias como "gerente do Hospital de Chagas da cidade de Bambuí", querendo saber "detalhadamente se é verdade que há meios de pelo menos suavizar o sofrimento de doente desta espécie". ${ }^{32}$

Algumas vezes, os indivíduos afetados pela doença solicitavam, de fato, ações de profilaxia. Em 1957, um telegrafista de Araxá enviou a Dias um barbeiro encontrado na cama de seu filho, que havia sido picado pelo referido inseto. Em "linhas que partem de um coração aflito de um pai extremoso", Joaquim Simões de Oliveira Filho reclamou da falta de combate à doença naquela cidade. Além de solicitar sua intervenção, o telegrafista declarou que ajudaria Dias em qualquer injunção necessária para chamar 
a atenção das autoridades: "Esclareço que V.S. pode fazer desta [carta] o uso que desejar, contando com minha fraca mas sincera colaboração no combate ao terrível mal". ${ }^{33}$ Em resposta, comunicando o resultado negativo do exame no barbeiro, Dias informou que havia remetido sua carta ao ministro da Saúde, como mais um meio de pressionar os serviços sanitários a empreender o combate aos vetores da doença na região. ${ }^{34}$

Em outras ocasiões, os doentes requeriam ajuda para fazerem valer seus próprios direitos civis e trabalhistas. Joaquim da Rocha, que já havia sido atendido por Dias, contou-lhe que estava na roça trabalhando quando se sentiu muito mal e decidiu ir para Uberaba "tomar remédio". Contudo, para trabalhar naquela cidade, precisava de um atestado médico. Este era o motivo de sua carta, escrita com dificuldade: "Eu peço o senhor que escreve pra mim uma carta disendo i [sic] aprovando [sic] que sou doente e que fui ofendido de barbero [sic] peço que mande pra mim um atestado de conformação [sic] que seu [sic] um rapas [sic] doente". Agradecendo o envio do atestado, o lavrador comunicou a Dias que havia feito o alistamento militar e tirado as carteiras profissional e de saúde. Aproveitava para pedir-lhe "um serviço de malária", pois precisava de "um serviço mais leve". ${ }^{35}$ Dias convidou-o, então, a trabalhar na campanha de erradicação dos barbeiros em Bambuí. ${ }^{36}$

Ao longo da década de 1950, Dias continuou a receber cartas também de clínicos das áreas endêmicas, que se mantinham como fiéis aliados da 'cruzada' do CEPMC, sobretudo em sua atuação junto à população. Em 1955, um cardiologista de Montes Claros, João Valle Maurício, escreveulhe: "Estou sempre muito interessado no problema da 'cardiopatia chagásica', tendo mesmo apresentado alguns trabalhos em congressos e em revistas. (...) Tenho procurado através de jornais locais alertar o povo sobre os perigos e gravidade desta afecção". Convidando Dias a visitar o centro de estudos no qual os médicos da região se reuniam semanalmente, solicitou o envio de material de divulgação "para ensinamento ao povo", como fotografias, coleção de triatomíneos para demonstração e publicações sobre a "condição clínica" e a profilaxia da doença. ${ }^{37}$ No XI Congresso Anual da Sociedade Brasileira de Cardiologia, em 1954, o médico apresentou trabalho sobre "a doença de Chagas como fator de despovoamento" (Maurício, 1954) e registrou indícios do processo de 'urbanização' da enfermidade, no rastro das intensas migrações internas que geravam grandes deslocamentos populacionais, sobretudo em Minas Gerais. 


\section{Novos Espaços de Pesquisa}

Além da visibilidade nos eventos públicos, um aspecto importante do processo de legitimação científica e social da doença de Chagas foi a centralidade assumida em novos espaços institucionais de pesquisa e de ensino médico criados, na década de 1950, em áreas onde a doença era endêmica e que constituíam núcleos regionais de desenvolvimento econômico. Isso foi fundamental não apenas para a estabilização científica dos enunciados que compunham aquele objeto, mas para garantir sua reprodução como tema de pesquisa, mediante a formação de novos grupos e linhas de investigação. Este foi mais um sentido em que a doença de Chagas, símbolo dos médicos do Brasil Central, atuou como 'moldura' para a sociedade, impulsionando a institucionalização da medicina em outros espaços sociais e geográficos do país.

O principal marco deste processo foi a fundação da Faculdade de Medicina de Ribeirão Preto (FMRP), em 1952, como parte da Universidade de São Paulo (USP). No contexto de profissionalização da ciência no pós-guerra, a escola foi projetada em consonância com os novos padrões de carreira reivindicados pelos cientistas paulistas, especialmente a partir da criação, em 1948, da Sociedade Brasileira para o Progresso da Ciência (SBPC), como o regime de tempo integral para os professores e o estímulo à pesquisa (Fernandes, 1990). A FMRP se tornaria, desde os primeiros anos, um dos principais centros de investigação sobre a doença de Chagas no país. Entre os professores dedicados ao tema, destacaram-se Mauro Pereira Barreto, no campo da entomologia, José Lima Pedreira de Freitas, que estudava aspectos do diagnóstico, da epidemiologia e do controle da doença, e Fritz Köeberle, na área de patologia. Os dois primeiros vinham do Departamento de Parasitologia da USP, chefiado por Samuel Pessoa. Köeberle, patologista, veio da Áustria, contratado pelo reitor Zeferino Vaz, mentor do projeto da nova instituição, e logo se interessou pela doença, apresentando contribuições inovadoras, tanto sobre a forma cardíaca quanto sobre o que viria a se tornar a forma digestiva da doença. Em torno da liderança de Freitas, a faculdade desempenharia papel decisivo na conscientização política quanto à importância social das endemias rurais e da doença de Chagas, subsidiando os organismos sanitários encarregados da profilaxia no estado. ${ }^{38}$ Além da FMRP, cabe destacar a criação da Faculdade de Medicina do Triângulo Mineiro, em Uberaba, em 1954, e da Faculdade de Medicina da Universidade Federal de Goiás, 
idealizada em 1953 pela classe médica de Goiânia e formalizada em 1960. Assim como no interior paulista, também nestas escolas a doença de Chagas seria um tema de destaque. ${ }^{39}$

Outro marco para a inserção da doença em novos espaços institucionais do campo médico do interior foi a Revista Goiana de Medicina (RGM), criada em 1955, pela Associação Médica de Goiás (AMG), no contexto do "surto de progresso" por que passava o estado, em função dos projetos de desenvolvimento econômico para a região e dos planos para a construção da nova capital federal (Mendonça, 1955: 1). A revista foi um dos principais veículos para publicação das pesquisas dos médicos do Brasil Central, com ênfase nos problemas relativos à patologia regional. ${ }^{40} \mathrm{~A}$ tripanossomíase americana ocupou, desde o início, proeminência em sua linha editorial. Em 1956, um número especial foi dedicado aos trabalhos dos representantes da AMG no Congresso Médico do Brasil Central, realizado, naquele ano, em Uberaba. Em seu editorial, afirmou-se a importância social da enfermidade na região e louvou-se o interesse dos poderes públicos em avaliar a extensão da endemia no país e promover sua profilaxia.

Muito mais grave do que a malária ou a esquistossomose, pela inexistência de qualquer terapêutica eficaz, a Doença de Chagas vem silenciosamente dizimando vidas preciosas no interior do país ou levando homens e mulheres ainda jovens a uma situação de sofrimento e improdutividade. (...) Em Goiás, (...) os reconhecimentos entomológicos realizados pelo Serviço Nacional de Endemias Rurais evidenciaram um índice de infecção natural dos triatomídeos para todo o Estado de cerca de $20 \%$, a que deve corresponder necessariamente uma incidência igualmente elevada da doença entre os habitantes da zona rural. (...) Somente o norte do Estado mostrou-se ainda livre da endemia. Não se há de estranhar, portanto, que os cardiologistas de Goiânia tenham em seus fichários clínicos maior número de casos de cardiopatia chagásica do que de hipertensão arterial (...). Que não se poupem esforços ou dinheiro nessa batalha, pois, como acentua Josué de Castro, aquilo que a Nação despende em benefício da saúde de seu povo, a ela reverte com juros em prazo relativamente curto. (Rezende, 1956b: 239-240)

Ao mesmo tempo que divulgava os avanços no conhecimento sobre a doença e propagava sua importância para o desenvolvimento do interior do país, a RGM contribuía diretamente para impulsionar as pesquisas 
científicas sobre o tema, realizadas pelos médicos do interior. ${ }^{41} \mathrm{Em} 1956$, o editor da revista, Joffre Marcondes de Rezende (clínico mineiro, formado pela Faculdade de Medicina do Rio de Janeiro em 1950 e radicado em Goiânia), publicou seu primeiro trabalho em que defendia a tese da etiologia chagásica do megaesôfago, assunto que despertava muitos debates e resistências entre os cientistas 'do litoral' e que era enaltecido nos fóruns do Brasil Central como a maior contribuição original de pesquisa dos médicos do interior (Rezende, 1956a, 2001a). A forma digestiva da doença, proposta por Rezende com base em dados clínicos, epidemiológicos e sorológicos, foi esclarecida em sua patologia por Köeberle e, reconhecida a partir da década de 1960, viria somar-se à forma cardíaca e à forma indeterminada entre as formas crônicas da doença de Chagas. ${ }^{42}$ Os médicos do Brasil Central, aliados de longa data, faziam-se, portanto, partícipes da construção científica e social da doença tanto por sua mobilização política quanto por sua atuação como pesquisadores, deixando sua marca na definição do quadro clínico da tripanossomíase americana tal como ele é consensualmente aceito até o presente (Kropf, 2008).

A revista divulgou também os estudos de cardiologistas goianos, como os de Anis Rassi, que trouxeram avanços importantes para o conhecimento e o tratamento das manifestações cardíacas da doença, contribuindo para reforçar o reconhecimento de que a importância social da endemia, como entrave ao desenvolvimento rural, estava diretamente relacionada à sua ação como fator de cardiopatias no meio rural. ${ }^{43}$

Na década de 1950, a doença de Chagas foi tema também dos novos fóruns representativos do movimento pela profissionalização da atividade científica liderado por cientistas dos grandes centros do país. Em 1951, em Belo Horizonte, foi tema oficial da terceira reunião da SBPC, criada em 1948 como expressão da luta política dos pesquisadores, sobretudo de São Paulo, para garantir, junto ao governo, condições para sua organização em novos moldes profissionais. ${ }^{44}$ Neste encontro, o governador Juscelino Kubitschek tomou parte na mesa-redonda destinada à tripanossomíase, na qual Pellegrino fez uma apresentação sobre a distribuição de barbeiros em Minas Gerais. Herman Lent, do IOC, abordou a distribuição mundial dos transmissores e Flávio da Fonseca, do Instituto Butantan, fez uma estimativa da prevalência da infecção chagásica no Brasil. Com base em dados apurados para os estados de Minas Gerais e São Paulo, calculou que três milhões de brasileiros estariam "em risco iminente de contrair a infecção" e, provavelmente, cerca de um milhão 
de casos deveria ocorrer no país (SBPC, 1951: 258). ${ }^{45}$ O governador encontrou-se, na ocasião, com o diretor do IOC para tratar, entre outros assuntos, de providências para intensificar o combate à endemia no estado (Estado de Minas, 1951b).

O processo de profissionalização da ciência no Brasil, durante a década de 1950, trouxe benefícios para o trabalho desenvolvido no CEPMC também na medida em que significou novas possibilidades de financiamento, por meio do CNPq, criado em 1951. Em 1952, o posto de Bambuí recebeu verbas desta agência para aquisição de novos equipamentos, como aparelhos de raios X, eletrocardiógrafos, aparelhos de pressão arterial, além de suprimentos para atividades de laboratório e de consultório (Estado de Minas, 1952b). ${ }^{46}$

Além do espaço universitário, a doença de Chagas passou também a ser objeto de pesquisa para os médicos sanitaristas que trabalhavam nas campanhas de profilaxia. Desde 1950, o Instituto de Malariologia do SNM realizava estudos sobre as características biológicas das distintas espécies de vetores e o efeito, sobre eles, dos vários inseticidas então utilizados, de modo a determinar, por exemplo, o melhor intervalo entre os expurgos nas moradias (Pinotti, 1954). Os profissionais daquele instituto foram colaboradores constantes de Dias em suas pesquisas neste período e co-autores em várias de suas publicações.

Neste momento em que novas frentes de pesquisa científica vinham sendo abertas para o estudo das endemias rurais e da doença de Chagas, tanto nas universidades quanto nos organismos sanitários, o IOC enfrentou uma crise associada a profundas divergências sobre sua identidade institucional. Em fase marcada por direções curtas e instáveis, reeditavamse, num novo contexto, os dilemas vividos por ocasião da reforma Capanema (1935-1937) e da sucessão de Cardoso Fontes, no início da década de $1940 .{ }^{47}$

Manguinhos viveu, na década de 1950, o embate entre os que defendiam sua permanência como instituição vinculada às demandas e questões da saúde pública e aqueles que argumentavam, sob o impacto das novas diretrizes da profissionalização da ciência e das novas expectativas da sociedade brasileira em relação à atividade científica (cujo marco fundamental foi a criação do CNPq), que o instituto deveria ser, antes de tudo, um centro de pesquisa científica, atualizado em termos dos avanços na fronteira dos conhecimentos, sem o necessário compromisso com a 'aplicação' direta destes conhecimentos. ${ }^{48}$ 
Emmanuel Dias, a despeito destas clivagens, manteria sua concepção de que a doença de Chagas era não apenas um tema da ciência, mas um exemplo do compromisso desta com a saúde pública. Contudo, não mais contando com a prioridade institucional que havia sido reservada às endemias rurais durante a gestão de Henrique Aragão (1942-1949), seus interlocutores passariam a ser as próprias organizações sanitárias (das quais receberia, até mesmo, apoio financeiro), os pesquisadores e os governos de outros países interessados na 'luta antichagásica' ${ }^{49}$

\section{A Doença do Brasil Central na Era JK}

A segunda metade da década de 1950 imprimiu novo impulso ao reconhecimento social e à institucionalização da doença de Chagas como objeto de pesquisa e de ações sanitárias, e também à mobilização política do posto do IOC em Bambuí. Foi decisiva, para tanto, a importância conferida pelo governo JK ao tema das endemias rurais, expressa na criação, em 1956, no Ministério da Saúde (MS), do Departamento Nacional de Endemias Rurais (DNERu), cuja direção foi entregue a Pinotti. Reforçando o interesse de pesquisa que a tripanossomíase já despertava no âmbito do Instituto de Malariologia do SNM, criou-se, no Instituto Nacional de Endemias Rurais (Ineru), órgão de pesquisas do DNERu, o Laboratório de Doença de Chagas do Centro de Pesquisas de Belo Horizonte. Sob a direção de José Pellegrino, este laboratório abrigaria não apenas investigações para subsidiar ações sanitárias, mas estudos científicos sobre diversos aspectos da doença, como a terapêutica. ${ }^{50}$ Tais organismos sanitários atuariam também como espaço de ensino. Em 1956, teve início a primeira turma do curso de especialização em Endemias Rurais, voltado para médicos associados a campanhas profiláticas e promovido pelo DNERu, em Belo Horizonte. Dias colaborou com sugestões referentes à parte de doença de Chagas (Estado de Minas, 1956). ${ }^{51}$

O DNERu, absorvendo as estruturas e atribuições dos Serviços Nacionais de Malária, de Peste e de Febre Amarela, encarregou-se de organizar e executar o combate às principais endemias do país, entre elas a doença de Chagas, em todo o território nacional..$^{52}$ No programa para a área de saúde pública que $\mathrm{JK}$ apresentou como candidato à presidência da República, firmou-se a disposição de incrementar o alcance dessas campanhas - "trabalho imenso, apenas iniciado, de libertar milhões de 
brasileiros de suas seculares e devastadoras doenças de massa” (Kubitschek, 1955: 1) - e enalteceu-se o exemplo do estado de Minas, durante o seu governo, no combate às endemias rurais. Já eleito, JK reafirmaria este compromisso:

Quando eu comecei a minha campanha política, visitando o Brasil em toda a sua extensão, não podia deixar de me impressionar com o aspecto terrível das endemias que assolam o Brasil, em várias de suas regiões. Adotamos então um programa de controlar no Brasil uma série de enfermidades que de uma maneira geral acometem as coletividades do Brasil. Neste é que nós estamos empenhados agora. (...) Este programa assegura (...) que neste setor o Brasil não vai andar apenas os 50 anos que eu anunciei em 5 anos, mas muito mais do que isso. ${ }^{53}$

A doença de Chagas, definida como "grave doença do coração", havia sido mencionada, no programa de saúde pública de JK (Kubitschek, 1955: 17-18), como exemplo dos prejuízos econômicos das endemias rurais: "O cardíaco de Chagas é praticamente um homem inútil para a vida e o trabalho". Numa operação discursiva que nos remete a Belisário Penna e a Monteiro Lobato, afirmava-se: "O barbeiro vive em grandes áreas do Brasil e não será exagero calcular que cinco milhões de brasileiros estejam expostos à doença de Chagas ou por ela infectados" (Kubitschek, 1955: 17-18). A solução era combatê-lo e, para isso, o programa iniciado em Minas Gerais deveria "ser estendido a todas as regiões do país atacadas" (Kubitschek, 1955: 18). ${ }^{54}$ O entusiasmo com o apoio do novo presidente - cuja condição de médico e mineiro era vista como mais um fator de sua sensibilidade ao tema das endemias rurais - foi várias vezes explicitado pelo diretor do CEPMC, como nesta carta a Cecilio Romaña: "Aqui estamos em começo de uma nova era, que acredito será de grandes realizações para o Brasil por parte do novo governo, cujo chefe é o nosso eminente colega Juscelino Kubitschek (...). Sei que faz parte de seu programa um grande impulso no combate às nossas endemias e nisso será grandemente auxiliado pelo Dr. Pinotti." ${ }^{55}$

Neste contexto, a mobilização de Dias assumiu um novo objetivo: a viabilização de uma campanha global de erradicação da doença, sob a coordenação da RSPA, à semelhança do que a OMS fazia em relação à malária. Em fins de 1955, ele apresentou aos diretores do IOC e do SNM o esboço de um projeto para testar, em Bambuí, a erradicação das duas principais espécies de triatomíneos domiciliados (Triatoma infestans e 
Panstrongylus megistus). Segundo ele, as campanhas iniciadas em 1950, pelo caráter esparso dos expurgos e os longos intervalos entre eles, haviam se revelado custosas e, apesar de proporcionarem grande redução dos barbeiros, não constituíam solução definitiva. Tendo sido informado por Pinotti do interesse do recém-eleito presidente JK em levar a efeito uma ação de grande alcance contra a tripanossomíase americana, Dias promoveu em Bambuí, entre março e abril de 1956, um pequeno ensaio a partir do qual passou a defender que duas aplicações de BHC, a um intervalo de trinta dias, promoveriam a total eliminação dos barbeiros nas moradias (Dias, 1957a).

O diretor da Comissão do Vale do São Francisco (CVSF), Assis Scaffa, tendo em vista os planos de recuperação econômica da região, interessou-se pelas idéias de Dias e dispôs-se a financiar, mediante acordo com o IOC e o DNERu, uma campanha experimental em Bambuí, como base para um programa mais amplo a ser implementado no Vale do São Francisco. ${ }^{56}$ Em agosto de 1956, teve início, naquela cidade, o "primeiro plano concreto que surge com o objetivo ideal de atingir a completa erradicação dos triatomíneos responsáveis pela propagação de tão nefasta endemia" (Dias, 1957a: 286). Dias apresentou o projeto no IOC e na Academia Nacional de Medicina (Jornal do Commercio, 1956; Dias, 1957a). ${ }^{57}$ Ao mesmo tempo, o DNERu prometia ampliar as medidas profiláticas que vinham sendo implementadas em vários estados. ${ }^{58}$

A campanha de erradicação em Bambuí, apesar de seu caráter experimental e restrito, expressava não apenas o reconhecimento da doença como assunto de saúde pública, mas a capacidade dos cientistas de mobilizar interesses econômicos relacionados diretamente às perspectivas desenvolvimentistas no cenário nacional. Ao expor as realizações do governo no Vale do São Francisco, o diretor da CVSF destacou, além dos empreendimentos voltados ao incremento produtivo da região, a preocupação com o "estado sanitário do povo" e o "vigor físico e moral das populações”, mencionando o apoio à luta contra a endemia chagásica como principal exemplo do compromisso da comissão:

(...) a Comissão não se fez indiferente à revelação de que a doença de Chagas é, como endemia, a responsável máxima, dentre as vicissitudes que avassalam o homem à contingência da miséria e degradação, em vasta área da bacia do São Francisco. (...) a Comissão prestigiou a primeira campanha experimental de erradicação do 'barbeiro', feita em Bambuí, à luz dos estudos e observações do 
eminente cientista, do Instituto Oswaldo Cruz, Dr. Emmanuel Dias.

(Scaffa, 1958: 54-55) ${ }^{59}$

Em 1956, além dos avanços na institucionalização da doença no campo da saúde pública, o CEPMC comemorou uma importante conquista na validação dos conhecimentos científicos que a haviam estabelecido como entidade clínica específica, expressa por uma cardiopatia crônica. Laranja, Dias, Nóbrega e Miranda publicaram artigo sistematizando suas pesquisas na prestigiosa revista norte-americana Circulation, da American Heart Association, que se tornaria um dos trabalhos mais citados da literatura sobre doença de Chagas (Laranja et al., 1956). Este importante marco de legitimação da doença de Chagas como doença cardíaca coincidiu com um episódio expressivo do definitivo reconhecimento de que a tripanossomíase e o bócio eram endemias totalmente distintas: o decreto n. 39.814, de 17 de agosto de 1956, delimitou a área bocígena do país e estabeleceu a obrigatoriedade de iodação do sal, criando as bases para a primeira campanha nacional de profilaxia do bócio endêmico, inaugurada no ano seguinte.

Também em 1956, o reconhecimento da importância médico-social da doença de Chagas expressou-se no âmbito da operação que sintetizava o projeto desenvolvimentista do governo JK: a construção de Brasília. A interiorização da capital federal foi uma ocasião especial para a afirmação da identidade social dos médicos do Brasil Central e de seu papel na solução dos problemas representados pelas 'doenças de massa' ${ }^{60}$ Reiterando a noção em voga de que "o padrão sanitário e o nível econômico encadeiam-se em recíproca e interativa correlação de causa e efeito", editorial da Revista Goiana de Medicina atribuiu a falta de medidas para romper o "círculo vicioso da pobreza e da doença" à permanência, até aquele momento, de "uma administração circunscrita, ensimesmada e distraída por um grande e agitado centro, como é o Rio" (Silveira, 1958: 2). Além disso, afirmou não ser coincidência o fato de que o primeiro médico eleito presidente da República era o primeiro chefe de governo a levar a sério a transferência da capital federal para o interior. José Peixoto da Silveira comemorou a inauguração das obras de Brasília, "que ensejará fecundas repercussões sobre o alevantamento do padrão sanitário do brasileiro" e sublinhou que "mais do que quaisquer outros profissionais estamos a par do precaríssimo nível de vida do brasileiro: não através de impiedosas informações estatísticas, mas pelo humano contato direto, pessoal e íntimo" (Silveira, 1958: 3) ${ }^{61}$ 
Tanto a classe médica do Brasil Central, especialmente de Goiás, quanto o MS se preocuparam em garantir que Brasília não estivesse sujeita à colonização pelos barbeiros. Em 1957, o médico Isaac Barreto Ribeiro - que estudava a doença de Chagas em Ceres, sede da Colônia Agrícola Nacional de Goiás, criada em 1941 e que teve os primeiros casos da doença confirmados em 1954 (Ribeiro, 1955) - informou Dias sobre as investigações que vinha fazendo quanto à possibilidade de haver chagásicos ou triatomíneos no local escolhido para o novo Distrito Federal, com resultados até então negativos.$^{62} \mathrm{O}$ DNERu realizava levantamentos sistemáticos em municípios no Planalto Central Goiano para verificar a distribuição destes insetos e sua infecção pelo Trypanosoma cruzi, especialmente na área do "retângulo de Cruls", “(...) de grande importância no momento, onde necessitamos conhecer bem a incidência das endemias a fim de preparar a região para receber as primeiras levas de pioneiros que devem iniciar a ingente tarefa da construção da nova capital" (Carvalho \& Verano, 1956a: 181) ${ }^{63}$ Além destes levantamentos, o DNERu realizava expurgos com BHC em vários municípios da região. ${ }^{64}$ No local onde se iniciaram, em 1957, as obras de construção de Brasília, apesar de não ter sido identificada a existência de barbeiros, medidas rígidas proibiam a construção de casas "do tipo primitivo", a fim de evitar que insetos trazidos nas bagagens dos trabalhadores provenientes de áreas endêmicas pudessem se domiciliar e se proliferar (Ribeiro, 1957: 197). ${ }^{65}$

A preocupação em garantir que Brasília continuasse "livre dos transmissores da doença de Chagas" (Ribeiro, 1957: 199) foi expressiva entre os 'pioneiros'. Manuel Mendes, funcionário do Instituto de Previdência e Assistência dos Servidores do Estado (Ipase), que se mudou para o local em fins de 1957, relatou, em seu livro Meu Testemunho de Brasília, o medo que havia em relação ao barbeiro em função da ocorrência da doença em localidades próximas, como Luziânia, Formosa e Planaltina. Segundo ele, este foi um motivo para que os trabalhadores deixassem a barba crescer, por saberem que o inseto picava preferencialmente o rosto. O berço de seu filho e a cama do casal eram protegidos por mosquiteiros, "temendo mais os barbeiros do que os mosquitos" (Mendes, 2006: 44). Mendes conta que o médico de seu acampamento tinha alguns exemplares do "perigoso inseto" dentro de um vidro, para ensinar aos recémchegados como identificá-lo. "Assim", narra ele, "todos nós passamos a temê-lo. Aliás, o servente Bodaia, que nos atendia no escritório, era um chagásico e morreria poucos anos depois de nossa chegada”. Entre 1958 
e 1959, Mendes editou um pequeno jornal mimeografado cujo título era justamente $O$ Barbeiro (Mendes, 2006: 30).

A projeção pública conferida ao Brasil Central pela 'operação Brasília' favorecia a mobilização dos meios de comunicação em torno do tema da doença de Chagas, reforçando sua disseminação junto ao grande público. Em 1957, uma equipe da revista O Cruzeiro viajou por $35 \mathrm{mu}$ nicípios de São Paulo e publicou reportagem especial sobre o assunto. Foram enfatizados a localização do "micróbio" no coração e os males provocados ao desenvolvimento econômico do interior do país: "Quando o mal chega a essa parte do organismo, o indivíduo já se acha praticamente inutilizado para o trabalho, em face das 'batedeiras' (taquicardia), falta de ar e incapacidade geral. A idade mais atingida é a que vai dos 20 aos 40 anos, anulando o período de maior produtividade do homem" (Ferreira, 1957: 37).

Estimando em cerca de $50 \%$ a incidência da doença na região, acentuou-se que o problema estava "ameaçando o sertão paulista, justamente uma das faixas de terra mais produtivas do País", podendo até mesmo gerar "colapso na produção de gêneros em São Paulo". A reportagem ressaltou a urgência de medidas de profilaxia: "que os doutores das assembléias as ponham em prática o mais rápido possível, é o apelo do caboclo paulista, espantado com o fato de tantos parentes que morrem 'de repente"" (Ferreira, 1957: 38). ${ }^{66}$

Em 1959, por ocasião das comemorações do cinqüentenário da descoberta, os próprios órgãos da imprensa atuaram como colaboradores dos programas de profilaxia da doença de Chagas. O jornal O Globo lançou uma grande campanha para apoiar as medidas do MS em Minas Gerais, fundando a Associação Brasileira de Combate à Doença de Chagas, cujos presidentes de honra eram Roberto Marinho, diretor e redator-chefe do jornal, e Pinotti, ministro da Saúde (O Globo, 1959a). ${ }^{67}$ Além de promover conferências, programas de rádio e distribuição de cartazes e folhetos educativos, o jornal enviou equipe - formada por um repórter, um técnico do DNERu e um cinegrafista da TV Itacolomi para uma viagem de vinte dias, num avião cedido pelo MS, a várias cidades do interior mineiro, destinada a documentar, numa série de reportagens especiais e num filme, a situação da endemia no estado. Embora não tivesse relação direta com a campanha, Dias apoiou-a publicamente $(O$ Globo, 1959c). A iniciativa contou com auxílio do Instituto Brasileiro do Café, sob a justificativa de que o problema afetava diversas regiões cafeeiras 
do país, e com recursos do governo de Minas, da Associação Comercial de Minas Gerais e da Federação das Associações Rurais do estado ( $O$ Globo, 1959b, 1959e).

Neste contexto de grande visibilidade, os próprios fazendeiros das regiões afetadas pela doença também passariam a demandar (ou realizar eles próprios) ações de profilaxia em suas terras, intensificando uma disposição que já se manifestara, esporadicamente, a partir da campanha de $1950 .^{68}$ Em entrevista a $O$ Globo, em 1959, um técnico do DNERu relatou que, quando os guardas sanitários começaram, no início da década, a realizar expurgos nas moradias, os fazendeiros geralmente recusavamse a abrir suas propriedades, mas que, com o decorrer do tempo, eles mesmos passaram a enviar barbeiros para os postos sanitários, pedindo a aplicação de inseticidas (O Globo, 1959d). Contudo, algumas vezes, esta colaboração tinha preço. Em 1957, O Cruzeiro registrou que, informados da necessidade de melhorias nas habitações de seus trabalhadores para evitar a infestação pelos barbeiros, os fazendeiros paulistas concordaram em realizá-las, desde que fosse dada garantia de preço na safra (Ferreira, 1957).

O empenho de Dias na conquista deste grupo social foi sintetizado em palestra na Rádio Inconfidência, em programa dirigido aos ruralistas e intitulado 'A Hora do Fazendeiro'. Depois de descrever a doença ("causada por um micróbio, que circula no sangue do paciente e se localiza no músculo cardíaco, donde a freqüência com que lesa o coração”), o diretor do CEPMC discorreu sobre a importância das medidas para sua erradicação, "para bem de Minas e do Brasil, livrando suas zonas rurais de seu mais perigoso flagelo, valorizando o homem do campo e seu trabalho árduo e heróico de que tanto depende o progresso da nação" ${ }^{69}$

\section{Divergências na Guerra aos Barbeiros}

A ampliação dos programas para combate à endemia chagásica provocou debates e gerou divergências quanto às técnicas a serem empregadas. Uma delas dizia respeito à metodologia dos expurgos domiciliares com inseticidas. Em 1956, Dias foi convidado, pelo Serviço de Profilaxia da Malária do Estado de São Paulo (SPM-SP), a apresentar seu método de erradicação, que vinha sendo testado em Bambuí, a técnicos daquele serviço e a pesquisadores da FMRP, num encontro que teve repercussão 
na imprensa paulista (Diário da Noite, 1956; Diário de São Paulo, 1956; Folha da Manhã, 1956). Ele foi recebido pessoalmente pelo governador Jânio Quadros, que declarou seu empenho em viabilizar um novo plano de profilaxia da doença em São Paulo, conforme a orientação estabelecida por Dias. Acertou-se então, com o diretor do SPM-SP, Oswaldo Urioste, que o 'método Bambuí' seria aplicado, em caráter experimental, em Ribeirão Preto e outros pontos do estado ${ }^{70}$ Em setembro de 1956, o diretor do CEPMC participou de cerimônia que reuniu dezenas de prefeitos da região da Alta Mogiana, em São Joaquim da Barra, onde, com a presença do governador e de várias autoridades sanitárias, foi oficialmente lançada a nova campanha contra a doença no estado (O Estado de $S$. Paulo, 1956). ${ }^{71}$ Animado com a parceria com os paulistas, Dias enviou ao secretário de Saúde, Coutinho Cavalcanti, um projeto para a erradicação do Triatoma infestans em São Paulo (Dias, 1957b).

Contudo, Pedreira de Freitas, da FMRP, discordava da metodologia defendida por Dias, declarando haver "um certo excesso de otimismo quando se considera que é possível uma erradicação dos triatomíneos através de um pequeno número de expurgos a curto intervalo". Afirmava ser necessária "uma ação continuada e intensa para que se consiga um combate eficaz" (Freitas, 1956: 317). Experiências conforme tal diretriz foram então iniciadas por ele em Cássia dos Coqueiros (SP), onde funcionava um posto de estudos sobre a doença sob sua liderança. ${ }^{72}$

As dúvidas quanto à viabilidade do 'método Bambuí' de erradicação foram corroboradas por Pinotti, diretor do DNERu. ${ }^{73}$ O SPM-SP também passaria a adotar a orientação de Pedreira de Freitas, de um expurgo anual, com acompanhamento sistemático para avaliar a necessidade de repetições. $\mathrm{O}$ assunto se tornou objeto de intenso debate, opondo Dias aos paulistas (Folha da Manhã, 1957a; A Cidade, 1957). ${ }^{74}$ Apesar das reservas de Pinotti, o DNERu decidiu, em junho de 1957 - depois de reunir, em Bambuí, prefeitos, autoridades sanitárias e parlamentares mineiros, bem como os diretores do IOC, da CVSF e o ministro da Saúde Maurício de Medeiros -, ampliar a campanha de erradicação iniciada naquela cidade no ano anterior a outros municípios do oeste de Minas e do Vale do São Francisco (Estado de Minas, 1957; Municípios Mineiros, 1957). ${ }^{75}$

Outro foco de divergências foi a própria natureza das medidas de profilaxia. A dúvida era se deveria ser privilegiada a aplicação de inseticidas ou a melhoria nas condições de habitação. Apesar de dar continuidade 
aos expurgos domiciliares com BHC, implementados pelo MS desde 1950, o DNERu começou a testar, em 1957, em algumas cidades mineiras, uma nova técnica de melhoria nas moradias, idealizada pelo próprio Pinotti, pela qual as paredes seriam construídas com argamassa à base de areia, barro e estrume de gado (Jornal do Commercio, 1958). Tal orientação passou a ser defendida por Pinotti e técnicos do DNERu como principal estratégia para combater a doença de Chagas. Embora não desprezassem a ação do BHC contra os barbeiros, eles afirmavam que somente as melhorias nas condições de habitação da população rural tornariam possível uma solução definitiva para a doença de Chagas do país (Carvalho, 1959).

Na década de 1960, quando se intensificaram as denúncias quanto ao impacto ambiental dos inseticidas (cujo marco foi a publicação, em 1962, do livro de Rachel Carson, Silent Spring), aqueles que defendiam a prioridade das melhorias habitacionais passaram a afirmar que a solução da doença de Chagas dependia não do BHC, mas do BNH (Banco Nacional de Habitação). ${ }^{76}$ Esta discussão, para além dos conteúdos técnicos, estava referida a distintas posições no debate mais amplo sobre como romper o 'círculo vicioso da doença e da pobreza'. Pode-se observar, neste caso, como tal debate expressava posicionamentos e interesses bem mais matizados do que uma franca oposição entre 'intervencionistas/ campanhistas' e 'desenvolvimentistas'. Mesmo os que defendiam que as intervenções sanitárias não deveriam ser isoladas, mas parte de um programa voltado para a melhoria nas condições socioeconômicas da população, faziam-no sob distintas perspectivas. Para Pinotti, o tema da habitação rural deveria ser enfrentado mediante intervenção estritamente técnica, enquanto que, para Samuel Pessoa, filiado ao Partido Comunista Brasileiro, a questão se encaminharia somente por meio de transformações profundas na própria ordem econômica. ${ }^{77}$

Diante do ceticismo dos paulistas em relação a seu projeto de erradicação e da tendência do DNERu em priorizar medidas voltadas para a habitação rural, Dias intensificou suas estratégias para conquistar outros aliados que já vinha buscando arregimentar: cientistas, sanitaristas e governos dos países latino-americanos. O principal objetivo era convencer a RSPA a coordenar ações sistemáticas para erradicar os triatomíneos das Américas, à semelhança do que era implementado no âmbito da campanha global da OMS para erradicação da malária. 


\section{Aliados nas Américas: a doença de Chagas como problema continental}

Desde o final da década de 1940, Dias buscava mobilizar a RSPA para o combate à doença de Chagas no continente americano. Seu principal interlocutor e aliado era o pesquisador argentino Cecilio Romaña que, em 1948, em Washington, por ocasião dos IV Congressos Internacionais de Medicina Tropical e Malária, foi designado coordenador da comissão formada pela RSPA para empreender estudos sobre a doença de Chagas nos diversos países americanos, destinados a estabelecer um plano global de controle. Foi nesta condição que Romaña visitou o Brasil em 1950, para observar os resultados da campanha iniciada em Uberaba (A Noite, 1950). Contudo, os sinais positivos por parte da RSPA não redundariam, nos anos seguintes, em atenção sistemática ao assunto e nem em medidas concretas referentes à profilaxia.

Em 1951, a despeito dos esforços de Romaña, a agência declarou não ter verbas para continuar o programa de estudos sobre a doença de Chagas, nem condições para patrocinar uma segunda Reunião Panamericana sobre o tema, como a que havia sido feita na Argentina, em $1949 .^{78} \mathrm{Em} 1955$, Romaña relatou a Dias que, em correspondência com Fred Soper, havia lembrado ao diretor da RSPA os compromissos assumidos pela agência, mas, em sua opinião, Soper estava mais preocupado com a erradicação da malária. ${ }^{79}$

A partir da formulação de seu plano de erradicação, em 1956, Dias passou a intensificar os esforços para conquistar a adesão da RSPA. Já no início daquele ano, buscou convencer seus dirigentes de que o momento era particularmente promissor para uma campanha, com aquele objetivo, nas Américas. Em correspondência com o argentino Carlos Alberto Alvarado, chefe do Coordination Office of the Malaria Eradication Program, unidade da RSPA em Washington, manifestou otimismo quanto ao interesse do governo JK pelo combate às endemias no Brasil e com os resultados do programa experimental de erradicação dos barbeiros em Bambuí: "É com satisfação que lhe dou estas notícias, pois sei que serão do agrado do grande sanitarista em cujos ouvidos tão bem soa a palavra erradicação" ${ }^{80}$

Em outubro de 1957, a visita à Argentina para participar de um simpósio sobre doença de Chagas foi a primeira das várias viagens que Dias faria, naquele ano, com o objetivo de estimular cientistas e autoridades sanitárias de distintos países a promoverem campanhas experimentais de 
erradicação dos triatomíneos, para que seus resultados pudessem ser apresentados nos VI Congressos Internacionais de Medicina Tropical e Malária, que ocorreriam no ano seguinte em Lisboa, e para o qual ele havia sido designado relator do tema 'tripanossomíase americana'. Ao pesquisador venezuelano José Francisco Torrealba, seu amigo, que chefiava um grupo de pesquisa sobre a doença em San Juan de los Morros, o diretor do CEPMC sintetizou sua 'missão': "Farei uma tentativa para organizar no continente uma liga ou comitê para estudar e promover a erradicação dos triatomas. Conto com o apoio do nosso Ministro da Saúde, Maurício de Medeiros." ${ }^{\prime 1}$

Na Argentina, Dias aproveitou para estreitar contatos com os colegas que, desde a época de Salvador Mazza, dedicavam-se à pesquisa sobre doença de Chagas. No contexto da redemocratização daquele país, eles estavam bastante entusiasmados em convencer as autoridades sanitárias e políticas a dedicar mais atenção àquela endemia e demonstravam vivamente o interesse em contar com o apoio brasileiro. ${ }^{82}$ Dias encontrou-se com o representante da RSPA, que manifestou apoio à sugestão do Ministério da Saúde argentino para que fosse realizada uma campanha-piloto de erradicação na província do Chaco. Em seguida, visitou o Uruguai, onde conversou com pesquisadores e sanitaristas e apresentou ao ministro da Saúde o mesmo plano, tendo recebido apoio deste e de representantes da RSPA (Acción, 1957). No retorno ao Brasil, o diretor do CEPMC relatou ao ministro da Saúde, Maurício de Medeiros, a boa acolhida que suas idéias tiveram na Argentina e no Uruguai e solicitou-lhe que intercedesse junto à RSPA para que esta assumisse efetivamente a responsabilidade por viabilizar "a organização da luta racional e progressiva para erradicação dos principais transmissores da doença de Chagas no continente". ${ }^{83}$

Ainda em 1957, tendo sido convidado para participar das Primeiras Jornadas Venezuelanas de Cardiologia, em Caracas, Dias voltou a viajar pela América Latina para propagar sua campanha. ${ }^{84}$ Ao mesmo tempo que fazia a mobilização política em torno da profilaxia, ele reforçava a divulgação dos conhecimentos clínicos produzidos pelo CEPMC, em especial sobre a cardiopatia chagásica. ${ }^{85} \mathrm{Em}$ carta a Dias, Torrealba comemorou o sucesso do evento: "como Usted muy bien lo dijo, el estudio de la Enfermedad de Chagas en Venezuela llegó a la etapa cardiológica, ya es inconcebible que no entre en la etapa final de controle." ${ }^{86}$ Do ministro da Saúde daquele país, Dias obteve o compromisso da realização de uma campanha-piloto de erradicação dos triatomas. 
No regresso da Venezuela, o diretor do posto de Bambuí fez, com o mesmo objetivo, rápidas visitas a Bogotá, Lima, Santiago do Chile e Buenos Aires. Em novo ofício ao ministro da Saúde brasileiro, no qual encaminhou relatório da viagem e das atividades do CEPMC, demandou, novamente, que ele sugerisse ao diretor da RSPA a realização de uma reunião "para cuidar especialmente da fixação de normas de combate aos triatomíneos e da coordenação da luta contra a doença de Chagas no continente" ${ }^{87} \mathrm{O}$ relatório foi enviado também a pesquisadores e a autoridades sanitárias de vários países sul-americanos, bem como aos representantes da RSPA, junto a uma carta em que Dias insistia na importância da realização de ensaios de erradicação, ainda que restritos, que pudessem ser apresentados no congresso a se realizar em Lisboa.$^{88}$ Como resultado desta intensa movimentação, Dias começou, em princípios de 1958, a receber várias cartas manifestando interesse e apoio à sua campanha. Elas vinham de cientistas e sanitaristas de países com tradição no estudo da doença, como Argentina, Uruguai e Venezuela, e também daqueles nos quais a importância da endemia chagásica ainda não havia sido identificada mediante pesquisas epidemiológicas ou não era reconhecida, como Bolívia, Equador, Panamá e Antilhas Holandesas. ${ }^{89}$

Apesar do apoio que angariava, Dias ia ficando cada vez mais impaciente com a falta de medidas concretas por parte da RSPA. Ele passaria a responsabilizar a prioridade concedida pelas agências internacionais à malária - segundo ele, um problema "já resolvido" e que não justificava uma campanha global de erradicação - pela falta de atenção ao problema da endemia chagásica..$^{90}$

Em carta a Marcolino Candau, diretor da OMS (enviada também a Fred Soper, diretor da RSPA), Dias queixou-se de que, na iminência do cinqüentenário da descoberta da doença de Chagas, apesar dos estudos que confirmavam sua importância como causa de cardiopatias em diversos países, não havia sido organizado um plano de caráter internacional destinado a equacionar sua profilaxia.

Aparentemente não mais será possível que os organismos sanitários internacionais continuem negligenciando este magno problema de saúde pública, persistindo em lamentável falta. Enquanto que milhões são gastos com problemas que, embora importantes, já foram superados do ponto de vista sanitário, a doença de Chagas continua praticamente ignorada por eles. ${ }^{91}$ 
Referindo-se à "feliz circunstância" de estar um brasileiro à frente da OMS, Dias reivindicava que esta promovesse uma reunião de especialistas para discutir a erradicação dos vetores do "terrível mal pan-americano, paradoxalmente tão grande quanto descurado", proporcionasse os recursos necessários à realização de ensaios com este objetivo em diversos países e estimulasse a criação de serviços nacionais de erradicação dos transmissores da doença de Chagas, "nos moldes criados para outras endemias". ${ }^{92}$ Em resposta, Soper comunicou que a RSPA, apesar de "ciente da importância social da doença de Chagas", já estava com seu orçamento para 1959 comprometido. ${ }^{93}$

Diante destas dificuldades, as críticas do diretor do CEPMC tornaram-se cada vez mais incisivas. Em agosto de 1958, enviou carta a Fernando Lobo, presidente do Conselho da Organização dos Estados Americanos, em Washington, a fim de "denunciar a negligência com que vem sendo tratado pelos organismos sanitários internacionais um dos mais graves problemas do continente". Solicitou que ele intercedesse no sentido de viabilizar sua participação na sétima reunião anual da American Society of Tropical Medicine and Hygiene, a se realizar em Miami, com o objetivo de "martelar o assunto nos Estados Unidos". ${ }^{94}$

Os VI Congressos de Medicina Tropical e Malária, realizados em Lisboa em setembro de 1958, marcaram o ápice das reivindicações de Dias junto à RSPA. Com uma apresentação da qual constava um balanço da evolução dos conhecimentos sobre a doença na década anterior e acentuando que já se podia contar com "farta literatura que demonstra sobejamente a significação da esquizotripanose como fator relevante ou principal de cardiopatia em grandes áreas sul-americanas" (Dias, 1958b: 79), ele discorreu sobre a viabilidade da erradicação e reiterou, mais um vez, seu descontentamento com a atuação das agências sanitárias internacionais em relação à doença de Chagas: "Poderá ser considerado como fato mais grave e lamentável da última década o alheamento praticamente total da Repartição Sanitária Panamericana ao problema, a despeito dos múltiplos apelos e recomendações que lhe têm sido endereçados, inclusive como conclusões formais de certames científicos importantes" (Dias, 1958b: 85).

Ao concluir seu pronunciamento, citou declarações de Soper, em seu discurso pela comemoração dos dez anos da OMS, em que este afirmou que "à medida que se vão coroando de êxito os programas de erradicação ora em curso, outras enfermidades, é de esperar-se, revelarse-ão como erradicáveis e erradicadas serão, em seguida" (apud Dias, 
1958b: 81), e cobrou do diretor da RSPA, que o ouvia como chairman da sessão: "Confiemos em que não continue tardando mais o dia em que comecem a concretizar-se em relação ao grave problema da esquizotripanose estas confortantes palavras do diretor da Repartição Sanitária Panamericana, certamente um dos maiores pioneiros da erradicação de vetores de doenças" (Dias, 1958b: 81). ${ }^{95}$

Em 1959, em comemoração ao cinqüentenário da descoberta, realizou-se, no Rio de Janeiro, o I Congresso Internacional de Doença de Chagas, organizado por Carlos Chagas Filho e que reuniu, no IOC, cerca de quatrocentos pesquisadores de diversos países. Ao proporcionar, pela primeira vez, o intercâmbio entre investigadores de todo os continentes, o encontro foi um marco fundamental a expressar a institucionalização do tema como objeto de uma cada vez mais ampla e definida comunidade científica. ${ }^{96}$

Do ponto de vista da campanha política empreendida por Dias, embora prosseguissem as divergências com Pinotti quanto aos métodos de profilaxia da doença, a ocasião serviu para amplificar a reivindicação dos cientistas pela inclusão do assunto na agenda das agências internacionais para o continente americano. Aprovou-se moção solicitando à RSPA que formulasse planos de combate à endemia e que se editasse um Tratado de Medicina Latino-Americana, cujo primeiro número seria dedicado à doença de Chagas (Jornal do Commercio, 1959). A caracterização da enfermidade como obstáculo ao progresso nas Américas foi enfatizada por Pinotti: "Do ponto de vista da epidemiologia, ficou reconhecido que a doença de Chagas está estreitamente relacionada ao subdesenvolvimento" (Correio da Manhã, 1959).

\section{Um Fato da Ciência e da Saúde Pública: novas perspectivas e desafios}

Em março de 1960, a OMS promoveu, em Washington, uma reunião de estudos sobre doença de Chagas, atendendo às reivindicações dos cientistas. Congregando especialistas de diversos países, o objetivo era traçar um panorama dos avanços no conhecimento, discutir os aspectos "relacionados à importância da doença para a saúde pública" e citar linhas de pesquisa que deveriam ser impulsionadas, a fim de se avançar na apreciação do problema e na busca de soluções. Emmanuel Dias e 
Pedreira de Freitas foram designados, respectivamente, chairman e relator da reunião (WHO, 1960: 3). Um primeiro ponto ressaltado foi a necessidade de dados mais precisos sobre a dimensão geográfica da doença nas Américas. O chileno Abraham Horwitz, diretor da Organização PanAmericana da Saúde (Opas, designação da RSPA a partir de 1958), afirmou que, embora sua existência tivesse sido identificada em praticamente todos os países do continente, "dista de estar resuelto el problema de la real incidencia de la enfermedad de Chagas en las Américas". ${ }^{97}$ Segundo Horwitz, devia-se a estas lacunas "[la] dificultad para organizar y justificar programas adecuados de control en los países donde evolucionan simultáneamente otros procesos que tienen un peso mayor aparente en la morbilidad y en la mortalidad". 98

No relatório final do grupo, este diagnóstico foi corroborado. Ainda que mencionando a necessidade de investigações mais aprofundadas, de modo a "indicar claramente a magnitude do problema de saúde pública representado pela doença de Chagas", os pesquisadores estimaram em 35 milhões o número de indivíduos expostos ao risco de contrair a infecção e em sete milhões o total de pessoas infectadas com o T. cruzi nas Américas (WHO, 1960: 3). A principal recomendação foi a de que se promovessem inquéritos clínicos e epidemiológicos sistemáticos, mediante metodologias e técnicas padronizadas, de forma a viabilizar a comparação entre dados de diferentes áreas endêmicas e a traçar um quadro estatístico mais completo da situação global da infecção no continente, bem como de suas peculiaridades em cada região. Outro aspecto enfatizado foi a necessidade de aperfeiçoar os critérios para registro dos casos da doença e das mortes a ela atribuídas, de forma a permitir melhores estatísticas sobre o problema (WHO, 1960). Tal orientação firmava-se na importância que as agências internacionais conferiam à produção de estatísticas vitais e à realização de estudos de campo nos países, de modo a gerar instrumentos de avaliação mais precisos do impacto econômico e social das doenças, do planejamento de medidas para seu enfrentamento e dos benefícios gerados por tais medidas (Winslow, 1955).

Também como expressão dos significados atribuídos às doenças transmissíveis com base na concepção do 'círculo vicioso entre doença e pobreza' e da importância do capital humano (Winslow, 1955), o relatório da reunião da OMS evidenciava que já se havia produzido um consenso em torno da idéia de que a tripanossomíase americana, pela incapacitação ao trabalho provocada, sobretudo, em sua fase crônica, era 
um problema real para o desenvolvimento dos países americanos. Os enunciados formulados por Carlos Chagas, sob o novo arranjo que lhe foi conferido por Dias, Laranja, Pellegrino e seus colaboradores do CEPMC, estabilizavam-se, assim, na posição oficial da OMS:

Although no special evaluation of the economic harm caused by Chagas' disease has been made, existing data show that it must be very considerable. In the first place, the incapaciting symptoms of the chronic forms of the disease generally develop in the second half of life when the individual is making his greatest contribution to society. Secondly the disease is found principally in rural areas where those affected are often rendered incapable of the heavy physical work demanded of them. (WHO, 1960: 11; grifos meus) $)^{99}$

Em relação aos métodos de prevenção, Horwitz afirmou que, apesar de parecer possível a eliminação dos vetores, um programa de profilaxia deveria centrar-se na melhoria das condições de habitação e de vida das populações afetadas e na perspectiva de "promover el desarrollo económico y el bienestar". ${ }^{100}$ O relatório final estabeleceu conclusões conciliatórias entre as diferentes posições que, no contexto brasileiro, dividiam os cientistas e sanitaristas. Se, por um lado, destacou a necessidade de melhorias habitacionais e do aumento nos níveis socioeconômicos das populações, por outro lado, reconhecendo que se tratava de medidas de longo prazo, assinalou que deveria ser estendida a luta contra os vetores por meio de inseticidas de ação residual, como o BHC (WHO, 1960: 15). Sobre a perspectiva da erradicação, o relatório afirmou que o ataque aos triatomíneos "should be directed towards as radical a control as possible of the vector species, in particular those most adapted to human dwellings", ${ }^{101}$ mas recomendou que prosseguissem os programas experimentais em distintas regiões, de modo a comprovar, de fato, a possibilidade de eliminação total das espécies de vetor mais relevantes, bem como os custos de programas desta natureza (WHO, 1960: 16).

O grupo concluiu suas recomentações reiterando a importância do apoio por parte dos governos nacionais e sugerindo que as organizações internacionais deveriam oferecer as mais completas condições para o treinamento técnico de profissionais capacitados a atuarem em inquéritos epidemiológicos e campanhas profiláticas, bem como encorajar a troca de experiências entre os países engajados nestas iniciativas.

The Group urged WHO and the Pan American Health Organization (PAHO) to arouse the interest of national and 
international institutions or foundations, whether official or private, in giving their support to projects for research on the biological, medical and public health aspects of Chagas' disease with the aim of extending knowledge of the disease and its control. It was also recommended that $\mathrm{WHO}$ and $\mathrm{PAHO}$ promote and co-ordinate projects for scientific investigation and facilitate interchange of bibliographical information. (WHO, 1960: 21) ${ }^{102}$

Além da necessidade de implementação de políticas sanitárias voltadas para a doença, o relatório final do encontro enfatizou a importância do estímulo a pesquisas de natureza básica, ainda como forma de viabilizar, a médio e longo prazos, melhores condições para atingir aqueles objetivos: "Any organized programme of action should include measures for the effective promotion of scientific investigations" (WHO, 1960: 18). ${ }^{103}$

Se o encontro em Washington expressou os elementos gerais do consenso em torno da doença de Chagas como fato científico e social, mesmo enfatizando a necessidade de maiores investigações destinadas ao mapeamento preciso de sua dimensão epidemiológica, um marco importante desta produção de consenso também ocorreu no Brasil, naquele mesmo ano, simbolicamente eloqüente da 'era JK' pela inauguração da nova capital. Em dezembro de 1960, o DNERu promoveu a reunião de Grupos de Trabalho para discutir e avaliar os resultados das diversas campanhas sanitárias sob sua responsabilidade, com a participação de técnicos do MS e convidados de outras instituições. No Grupo de Trabalho sobre doença de Chagas, as conclusões se assemelharam bastante àquelas da reunião de peritos promovida pela OMS. Para superar as deficiências dos trabalhos que vinham sendo realizados desde 1950, foram sugeridos a realização de estudos e levantamentos mais aprofundados - a fim de identificar o estado do problema em cada região do país -, a sistematização de normas técnicas para a profilaxia e a padronização de critérios para avaliar seus resultados (DNERu, 1962). ${ }^{104}$

Embora as agências internacionais e nacionais estivessem declarando, ao menos no plano das intenções, a disposição em prover meios para o combate à endemia chagásica neste momento, o entusiasmo ilimitado do início da década de 1950 quanto às campanhas de controle e/ou erradicação das doenças havia se esvanecido. Isso se dava tanto pelos problemas que tais campanhas vinham enfrentando (como a resistência dos vetores aos inseticidas e os danos ambientais provocados pela 'guerra química’) quanto pela tendência internacional de valorizar a posição segundo 
a qual, antes de tudo, as campanhas deveriam ser parte de programas horizontais e amplos de melhoria nas condições socioeconômicas das populações (Farley, 2004) ${ }^{105} \mathrm{O}$ 'pêndulo' da relação entre saúde e desenvolvimento estava se afastando da posição que norteara a militância de Dias, desde que este recebeu de Soper, em 1942, a primeira bomba para matar barbeiros e a concepção de que era possível erradicá-los. ${ }^{106}$

Em 1962, na Reunião de Debates sobre Doença de Chagas (promovida no Rio de Janeiro sob o patrocínio do Laboratório Eaton, dos Estados Unidos, e que visava a discutir a terapêutica da doença), o relatório do grupo de discussão que abordou o tema da profilaxia reiterou as recomendações do Grupo de Trabalho do DNERu de 1960. Dias, que tomou parte nos debates, votou em separado, mantendo sua concepção de que o programa de controle fosse transformado em programa de erradicação (Revista Goiana de Medicina, 1963: 279). Esta reunião constituiu mais uma evidência da estabilidade que a doença havia alcançado como objeto médicocientífico: a associação de interesses em torno da tripanossomíase contava, a partir de então, com mais um poderoso elemento: a indústria farmacêutica. Este foi o último evento do qual o diretor do CEPMC participou. Vítima de acidente rodoviário, ele faleceu aos 23 de outubro de 1962.

As perspectivas de uma campanha global coordenada pela Opas contra a doença de Chagas no continente americano não se concretizaram. O primeiro sucesso na interrupção da transmissão vetorial da doença seria alcançado em São Paulo, no início da década de $1970 .{ }^{107} \mathrm{Em}$ âmbito nacional, o controle seria implementado na década de 1980 por outra geração de cientistas, também herdeira de Carlos Chagas e Emmanuel Dias. Depois do Inquérito Sorológico Nacional realizado entre 1975 e 1980 para mapear a prevalência da infecção no território brasileiro, um programa nacional de controle da tripanossomíase americana foi conduzido, a partir do início da década de 1980, sob a coordenação da Superintendência de Campanhas de Saúde Pública (Sucam), do MS, em parceria com a USP (por meio do Departamento de Medicina Preventiva da Faculdade de Medicina de São Paulo e do Laboratório de Imunologia do Instituto de Medicina Tropical de São Paulo). O filho de Emmanuel Dias, João Carlos Pinto Dias, foi figura proeminente neste processo. ${ }^{108}$ Os dados do inquérito permitiram estimar que cerca de quatro milhões de brasileiros (3,5\% de uma população em torno de 120 milhões) estavam infectados pelo T. cruzi, numa área que se estendia do Piauí ao Rio Grande do Sul e que correspondia a 36\% do território (Vinhais \& Dias, 2000). ${ }^{109}$ 
No início da década de 1960, ao mesmo tempo que comemorou importantes conquistas na institucionalização da doença de Chagas como objeto de um campo específico de pesquisa científica e das políticas públicas de saúde, Dias testemunhou a configuração de novos caminhos nesta trajetória. Por um lado, o aprofundamento do processo de profissionalização da ciência, num contexto internacional de renovação metodológica das ciências biológicas propiciada com a biologia molecular e a engenharia genética, iria direcionar investimentos e interesses de pesquisa para o domínio das disciplinas biológicas básicas, reestruturando o próprio escopo cognitivo e institucional da parasitologia. Este processo, intensificado com a política de desenvolvimento científico e tecnológico promovida pelo regime militar na década de 1970, imporia novos contornos e demarcações à comunidade acadêmica organizada em torno da tripanossomíase americana. ${ }^{110}$

Além disso, a profissionalização ocorrida também no domínio das estruturas públicas da saúde geraria novos perfis profissionais e espaços institucionais para os que lidavam com o tema sob o ponto de vista do planejamento e da implementação das ações sanitárias. O início da década de 1960 marcava, assim, a conclusão de uma fase na atuação do CEPMC não apenas pelo falecimento de seu diretor, mas porque a ciência e a saúde pública às quais ele estava referido já assumiam novas características e perspectivas, assim como o próprio país, às vésperas do golpe civilmilitar de 1964.

Ainda que o itinerário da tripanossomíase americana prosseguisse em novas direções, com outros desafios e encaminhamentos, alguns dos quais diferentes daqueles vivenciados e idealizados por Dias, o discípulo e afilhado de Carlos Chagas encerrou sua trajetória num momento em que já se havia produzido o acordo básico de que este era um objeto médico-científico real, bem definido em seus contornos clínicos, e um assunto relevante para a saúde pública brasileira e para o continente latino-americano. A 'doença do Brasil' havia se transformado em 'fato'.

\section{Notas}

1 "Os homens de hoje percebem (...) que o mundo unido que eles pretendem construir não pode se estabelecer nem se manter com nações bloqueadas pelas cargas esmagadoras da pobreza e da doença (...). (...) as doenças que existem na Ásia, na 
África ou nos mares do Sul podem criar problemas econômicos para os comerciantes de Londres ou de Nova York" - Tradução livre.

2 "A pobreza é causa de doença e a doença cria maior pobreza, num círculo vicioso. Portanto, a saúde pública é um problema que está relacionado intimamente ao progresso econômico e social que se alcança numa dada coletividade" - Tradução livre.

3 O trabalho foi produzido sob os auspícios do Serviço Especial de Saúde Pública (Sesp). Manoel Ferreira e Ernani Braga eram importantes médicos sanitaristas vinculados ao Ministério da Educação e Saúde (MES). O primeiro havia dirigido o Serviço de Malária do Nordeste, por ocasião da campanha contra o Anopheles gambiae. Braga, que na ocasião era superintendente do Sesp, seria uma importante liderança das discussões sobre saúde e desenvolvimento no Brasil na década de 1950. Paulo de Assis Ribeiro era funcionário do Instituto Brasileiro de Geografia e Estatística (IBGE).

4 Os médicos sanitaristas Mário Magalhães da Silveira, Carlos Gentile de Melo - que integrou o Instituto Superior de Estudos Brasileiros (Iseb), criado em 1955 como um dos principais espaços de formulação do ideário nacional-desenvolvimentista e Samuel Pessoa foram algumas das lideranças deste grupo (Labra, 1988).

5 Outra dimensão desta polaridade seria a oposição entre a crença de que as campanhas deveriam ser dirigidas verticalmente contra doenças específicas e a noção de que elas deveriam se estabelecer horizontalmente em relação a um conjunto de enfermidades e envolver a promoção de condições básicas de infra-estrutura sanitária (Farley, 2004).

${ }^{6}$ É importante ressaltar que a análise de Farley (2004) não sugere um esquema simplificador, ou seja, uma contraposição 'dura' e dicotômica entre as duas posições. A partir da análise empírica de diversas campanhas da Fundação Rockefeller, o autor mostra que, ainda que seja possível identificar tendências hegemônicas em cada momento, as posições equivalentes aos dois extremos do 'pêndulo' constituem, antes de tudo, referenciais heurísticos para a análise dos processos históricos, muito mais complexos e multifacetados.

7 Para uma análise das concepções sobre saúde e desenvolvimento contidas no programa apresentado por JK em sua candidatura à presidência, ver Hochman (2009).

8 Esta foi a primeira e maior campanha promovida pela Organização Mundial da Saúde (OMS), em termos de países envolvidos e recursos mobilizados, para prevenir, controlar ou erradicar doenças (Packard, 1998; Farley, 2004; Cueto, 2007).

9 Segundo classificação vigente na época, as 'doenças de massa' eram aquelas que atingiam grandes contingentes da população, geralmente de natureza endêmica e profundamente associadas à pobreza nos chamados países subdesenvolvidos, como a malária, o bócio, as verminoses, a tuberculose, as doenças venéreas, as doenças de nutrição, entre outras enfermidades. A doença de Chagas era referida como parte deste grupo. As 'doenças degenerativas', como o câncer, as doenças cardíacas e endócrinas, eram problemas que predominavam nos países ricos e exigiam assistência muito mais individualizada e especializada. As 'doenças pestilenciais' eram enfermidades de natureza epidêmica, para cuja eliminação dependia-se pouco do desenvolvimento econômico ou da modificação nos hábitos dos indivíduos, como o cólera, a varíola, a febre amarela, a peste bubônica e o tifo (Athayde, 1957). 
10 É interessante como o texto estabelece a filiação de Pinotti à tradição sanitarista de Manguinhos: "No campo do sanitarismo, desde Oswaldo Cruz, através de Carlos Chagas, Belisário Pena e, nos últimos anos, Mário Pinotti, temos realizado conquistas notáveis" (Kubitschek, 1955: 53).

11 O programa menciona, entre as medidas para o desenvolvimento do interior, a extensão da legislação social às "numerosas comunidades dos obreiros rurais" (Kubitschek, 1955: 20).

12 Carta de Emmanuel Dias a Cecilio Romaña. Belo Horizonte, 27 de agosto de 1951. Fundo Centro de Pesquisas René Rachou, Seção Posto Avançado de Pesquisas Emmanuel Dias (doravante FCPqRR/SPAPED), caixa 31, maço 2. Em 1952, o Instituto Oswaldo Cruz (IOC) estabeleceu entendimentos com o Serviço Nacional de Malária (SNM) para que o Instituto Nacional do Cinema Educativo produzisse o filme sobre a doença idealizado por Dias, para o qual já haviam sido registradas algumas cenas em 1950. Ofício de Emmanuel Dias a Mário Pinotti, em 7 de maio de 1952. FCPqRR/SPAPED, caixa 15, maço 1. Roteiro de filme sobre a doença de Chagas, 1952. FCPqRR/SPAPED, caixa 16, maço 1.

13 Reportagem do jornal Tribuna de Minas (1951: 7) sobre o congresso reiterou esta noção: "Para que se possa ter uma idéia do desfalque que a doença de Chagas causa à economia mineira, é bastante assinalar que em 233 municípios do Estado [60\%] está constatada a existência do barbeiro".

14 Alguns trabalhos deste encontro foram publicados pela Revista Goiana de Medicina, 4(2), abr.-jun., 1957.

15 Do total de cem trabalhos apresentados, que abrangiam diversos temas, 39 foram sobre a tripanossomíase (SBH, 1952).

16 "A era dos inseticidas de efeito residual e a nova consciência que a medicina preventiva tem desenvolvido no mundo farão com que a cruzada que Chagas iniciou no Brasil tenha o nobre final que todos esperamos" - Tradução livre.

${ }_{17}$ O discurso de JK foi publicado também no Estado de Minas (1952f).

18 Carta de Fred Soper a Emmanuel Dias. Washington, 1o de abril de 1952. FCPqRR/ SPAPED, caixa 39, maço 1.

19 Sobre as investidas de Dias para garantir a participação desses cientistas no evento, ver correspondência enviada por ele em maio de 1952. FCPqRR/SPAPED, caixa 39, maço 1 .

20 O nome de Dias foi sugerido por Henrique da Rocha Lima, pesquisador brasileiro que trabalhara com Oswaldo Cruz em Manguinhos nos primeiros anos e que, a partir de 1909, seguiu carreira na Alemanha. Dias, por sua vez, indicou Pinotti para a parte relativa à malária. Ver Carta de Emmanuel Dias a E. Rodenwaldt, U. S. Naval Forces, Technical Section, Heidelberg. Belo Horizonte, 4 de outubro de 1949; Carta de A. R. Behnke, captain, Force Medical Officer, U. S. Naval Forces, Germany, para Emmanuel Dias. 8 de agosto de 1950; Carta de Mário Pinotti a Emmanuel Dias, 28 de novembro de 1950. FCPqRR/SPAPED, caixa 31, maço 1.

${ }_{21}$ À medida que ia produzindo os textos sobre a doença em cada país ou região, Dias os encaminhava para publicação na Revista Brasileira de Malariologia e Doenças Tropicais, como parte de uma série de artigos intitulada "a doença de Chagas nas Américas", publicada entre 1951 e 1955. Para a correspondência entre Dias e os 
pesquisadores dos vários países visando a tal objetivo, ver FCPqRR/SPAPED, caixa 31 , maços 1 e 3 .

22 O International Scientific Committee for Trypanosomiasis Research (ISCTR) foi criado, em 1949, em Londres, no âmbito da preocupação das novas agências internacionais com as perspectivas de desenvolvimento econômico nos países do Terceiro Mundo no pós-guerra e, em especial, com o processo de descolonização no continente africano. O relatório desta viagem de Dias encontra-se em "Conselho Nacional de Pesquisas”, Jornal do Commercio, 24 de outubro de 1954. FCPqRR/ SPAPED, caixa 36, maço 9. Entusiasmado com os avanços terapêuticos contra a tripanossomíase africana divulgados no encontro, Dias passou a enviar, a alguns pesquisadores que ali conheceu, soros de pacientes chagásicos para serem testados mediante técnicas adotadas para tratar aquela doença. Ver FCPqRR/SPAPED, caixa 31, maço 5.

23 Para o programa da exposição, ver Le Palais de la Découverte présente une exposition. Un aspect inconnu du Brésil: l'oeuvre de Carlos Chagas. 1879-1934. Paris, Université de Paris, Palais de la Découverte, 1955. Fundo Carlos Chagas Filho (organização preliminar). Para uma descrição das cenas do filme que Dias selecionou para serem exibidas na exposição, ver Carta de Emmanuel Dias a Carlos Chagas Filho. Bambuí, 16 de novembro de 1954. FCPqRR/SPAPED. Caixa 15, maço 2.

24 Maurício, João Valle. “A doença de Chagas", Jornal de Montes Claros, 22 de setembro de 1951. FCPqRR/SPAPED, caixa 36, maço 3.

25 "Itacambira", Jornal de Montes Claros, 19 de janeiro de 1952. FCPqRR/SPAPED, caixa 36 , maço 3 .

${ }^{26}$ É certo que o próprio fato de se tratar de linguagem escrita, ainda que precária, já indica que estes indivíduos possuíam condição social minimamente diferenciada entre os trabalhadores rurais da época ou então que solicitaram a outros que escrevessem tais cartas.

27 Carta de Francisco José da Silva a Emmanuel Dias. Cláudio, 16 de outubro de 1954. FCPqRR/SPAPED, caixa 31, maço 4.

28 Carta de Emmanuel Dias a Francisco José da Silva. Bambuí, 20 de novembro de 1954. FCPqRR/SPAPED, caixa 31, maço 4.

29 Carta de Antonio Martins de Souza a Emmanuel Dias. Cláudio, 28 de dezembro de 1954. FCPqRR/SPAPED, caixa 31, maço 4.

30 Carta de Emmanuel Dias a Antonio Martins de Souza. Bambuí, 7 de janeiro de 1955. FCPqRR/SPAPED, caixa 31, maço 4.

31 Carta de Maria Alves a Emmanuel Dias. Belo Horizonte, 23 de julho de 1958. FCPqRR/SPAPED, caixa 33, maço 14.

32 Carta de Maria Olinda Nepomuceno a Emmanuel Dias. Uberaba, s.d. FCPqRR/ SPAPED, caixa 33, maço 18.

33 Carta de Joaquim Simões de Oliveira Filho a Emmanuel Dias. Araxá, 7 de novembro de 1957. FCPqRR/SPAPED, caixa 33, maço 13.

34 Carta de Emmanuel Dias a Joaquim Simões de Oliveira Filho. Bambuí, 8 de dezembro de 1957. FCPqRR/SPAPED, caixa 33, maço 13. 
35 Cartas de Joaquim Graciano da Rocha a Emmanuel Dias. Uberaba, 16 de julho e 6 de agosto de 1956. FCPqRR/SPAPED, caixa 32, maço 8.

36 Carta de Emmanuel Dias a Joaquim Graciano da Rocha. Bambuí, 13 de outubro de 1956. FCPqRR/SPAPED, caixa 32, maço 8.

37 Carta de João Valle Maurício a Emmanuel Dias. Montes Claros, 20 de novembro de 1955. FCPqRR/SPAPED, caixa 32, maço 6.

38 Os próprios estudantes assumiram papel destacado nesta conscientização, criando, em 1956, a Liga Brasileira de Combate à Doença de Chagas, órgão do Centro Acadêmico da Faculdade de Medicina de Ribeirão Preto (FMRP), que promoveria iniciativas de educação sanitária e mobilização popular em torno do tema, engajandose diretamente nas campanhas de profilaxia empreendidas na região. $\mathrm{O}$ filho de Emmanuel Dias, João Carlos Pinto Dias, que estudou na FMRP entre 1957 e 1963, foi diretor da Liga. Ver Folha da Manhã (1957b) e "Realizam os estudantes de Ribeirão Preto importante trabalho contra o barbeiro. As atividades da Liga de Combate à Moléstia de Chagas", s.l., [maio], 1958. FCPqRR, SPAPED, Caixa 36, maço 10. Sobre a escola de Samuel Pessoa e as contribuições da FMRP, na década de 1950, para o conhecimento da doença de Chagas, ver os depoimentos orais de Joffre Rezende (2001), José da Rocha Carvalheiro (2002), Francisco Ferrioli Filho (2002), Erney Camargo (2002) e Ricardo Ribeiro dos Santos (1995).

39 Ver depoimentos orais de Aluizio Prata (2000) e Joffre Rezende (2001). Sobre as atividades de pesquisa sobre a doença, nas décadas de 1950/1960, em institutos de pesquisa e universidades no Rio de Janeiro, em São Paulo, em Belo Horizonte e em Salvador, ver, respectivamente, os depoimentos de José Rodrigues Coura (1999), Erney Camargo (2002), Zigman Brener (1995) e Zilton Andrade (2000).

40 Em 1963, a Revista Goiana de Medicina (RGM) tornou-se o periódico oficial da Faculdade de Medicina da Universidade Federal de Goiás. Ver Rezende (2001b).

41 Em 1958, novamente a RGM reuniu trabalhos sobre a doença, por parte de pesquisadores de diversos estados. Em 1959, um número comemorativo seria destinado aos estudos dos principais especialistas sobre o assunto em diversos países do continente americano. Emmanuel Dias era um dos cientistas que colaboravam regularmente com a revista. Ver Rezende (1958, 1959b).

42 Entre as resistências à tese da etiologia chagásica do megaesôfago, havia o temor de que a associação com o 'mal de engasgo' reeditasse o 'equívoco' da correlação com o bócio, cometido por Carlos Chagas. Além disso, elas expressavam as dificuldades e os preconceitos enfrentados, em seu processo de afirmação profissional, pelos clínicos do interior, vistos com desconfiança pelos 'papas do litoral', como relatou Joffre Rezende em seu depoimento (Rezende, 2001). Ver Rezende (2001a). Além do megaesôfago, a forma digestiva compreende também o megacólon.

43 Rassi (2001: fita 1, lado B) conta que, formado pela Faculdade de Medicina do Rio de Janeiro (FMRJ) em 1953, voltou a Goiânia para clinicar e logo se interessou pela cardiopatia chagásica, em função da grande quantidade de doentes com sintomas desta forma clínica que atendia em seu consultório e no hospital da cidade. Conhecedor da importância de Laranja como liderança no assunto, em alguns meses o médico goiano colecionou grande quantidade de "eletrocardiogramas interessantes" e os mostrou pessoalmente a Laranja, no Rio de Janeiro. 
44 As principais reivindicações da Sociedade Brasileira para o Progresso da Ciência (SBPC) eram o estabelecimento do tempo integral, criação da carreira de pesquisador nas universidades e nos institutos públicos, melhoria salarial, financiamento para a pesquisa, autonomia das universidades e dos institutos frente ao governo e concessão de bolsas de estudo para treinamento de cientistas no Brasil e no exterior (Fernandes, 1990).

45 O primeiro inquérito nacional para mapear a prevalência da infecção chagásica no Brasil seria feito somente na década de 1970. Sobre o controle da doença de Chagas no Brasil, ver Dias e Schofield (1999).

46 Ver Relatório dos trabalhos realizados pelo dr. Emmanuel Dias em 1952, $1^{\circ}$ de janeiro a $1^{\circ}$ de dezembro. FCPqRR/SPAPED, caixa 3, maço 4.

47 Em meados de 1953, por ocasião da reforma que separou o MES em duas pastas distintas e criou o Ministério da Saúde, Olympio da Fonseca Filho, que vinha enfrentando sérias críticas em sua gestão no IOC, renunciou ao cargo, para o qual foi nomeado Francisco Laranja, que passou, assim, a ser o primeiro diretor da instituição que não pertencia formalmente a seus quadros. Laranja, amigo pessoal de Vargas, deixou o cargo em 1954. A direção do IOC passou então a Antonio Augusto Xavier (1955-1958) e, posteriormente, a Amilcar Vianna Martins (19581960). Sobre a trajetória de Manguinhos durante a década de 1950, ver Fonseca Filho (1974) e Benchimol (2001).

48 Em agosto de 1953, pesquisadores enviaram ao ministro da Saúde um memorial solicitando que o IOC ficasse subordinado ao Ministério da Educação e Cultura (MEC), e não à pasta da Saúde, como havia sido estabelecido pela lei que desmembrou o MES (Hamilton \& Fonseca, 2003). Tomando como referência a antiga proposta da Reforma Capanema, defendiam que as atividades diretamente associadas à saúde pública (como produção de soros e vacinas e controle e fabricação de medicamentos) fossem transferidas para um instituto com tal finalidade precípua. Reivindicavam que Manguinhos deveria, assim, recuperar o que consideravam sua verdadeira vocação, constituindo-se como "um centro de pesquisas e de cultura biológicas, com feição ultra universitária”. O documento foi assinado pela maioria dos cientistas. Emmanuel Dias foi um dos poucos que se recusou a fazê-lo. As reivindicações dos cientistas não foram atendidas. Ver Memorial dos técnicos do Instituto Oswaldo Cruz ao Exmo. Sr. Ministro da Educação e Cultura. Rio de Janeiro, 21 de agosto de 1953. Fundo Instituto Oswaldo Cruz, Série Administração Geral (doravante FIOC/SAG), caixa 7, maço 2, pasta 1. Sobre a profissionalização da ciência na década de 1950, ver Fernandes (1990), Andrade (1999) e Azevedo, Kropf e Hamilton (2003).

49 Desde 1952, o Centro de Estudos e Profilaxia da Moléstia de Chagas (CEPMC) recebia verbas do SNM, que, tendo iniciado campanhas contra a esquistossomose, passou a financiar, sobretudo mediante pagamento de pessoal técnico, estudos experimentais realizados por Dias em Bambuí com vistas a desenvolver um método profilático de controle biológico dos caramujos. Em 1953, o CEPMC tornou-se um Posto Experimental de Esquistossomose vinculado ao SNM. Ver FCPqRR/SPAPED, caixas 5 e 6.

50 O Instituto Nacional de Endemias Rurais (Ineru) era composto de núcleos de pesquisa sobre endemias rurais em distintas regiões do país, para "ampliar o conhecimento das mesmas e aperfeiçoar os métodos profiláticos destinados a combatê-las, 
bem como estabelecer normas para inquéritos sobre as referidas doenças e promover sua realização". Ver Lei 2.743, de 6 de março de 1956, que cria o Departamento Nacional de Endemias Rurais, publicada no Diário Oficial de 7 de março de 1956. FCPqRR/SPAPED, caixa 3, maço 3. O Centro de Pesquisas de Belo Horizonte foi a origem do atual Centro de Pesquisas René Rachou, da Fundação Oswaldo Cruz (Fiocruz). Sobre Zigman Brener, pesquisador daquele centro e colaborador de Pellegrino, que constituiu grande liderança no campo da parasitologia mineira e nas pesquisas sobre a doença de Chagas (sobretudo nos aspectos relacionados à terapêutica), ver Klein et al. (2003).

51 Ofício de Mário Pinotti endereçado a Emmanuel Dias, 23 de novembro de 1956. FCPqRR/SPAPED, caixa 15, maço 4.

${ }^{52}$ Segundo o diretor do DNERu, a verba total destinada às campanhas contra endemias para o ano de 1957 foi de quase quatro milhões de dólares, "dez vezes mais do que a contribuição do Instituto Interamericano para o Serviço Especial de Saúde Pública" (Estado de Minas, 1956). O DNERu manteve os recursos que o CEPMC recebia do SNM para pagamento de seu pessoal. Ver FCPqRR/SPAPED, caixas 5 e 6 .

53 Palavras pronunciadas pelo presidente Juscelino Kubitschek por ocasião da inauguração da Fábrica de Produtos Profiláticos do DNERu, Circular n. 8/57 do Diretor Geral do DNERu ao senhor chefe do Posto Experimental de Bambuí, encaminhando discurso do Exmo. Sr. Presidente da República[1957]. FCPqRR/SPAPED, caixa 15 , maço 4 .

${ }^{54}$ O programa de JK menciona que "na região mineira de Bambuí existem 1.800 doentes" (Kubitschek, 1955: 17).

55 Carta de Emmanuel Dias a Cecilio Romaña, Rio de Janeiro, 4 de fevereiro de 1956. Por intermédio de Josué Montello, Dias enviou a JK o atlas publicado em 1954 sobre a doença de Chagas nas Américas. Carta de Emmanuel Dias a Josué Montello. Bambuí, 2 de março de 1956. FCPqRR/SPAPED, caixa 32, maço 7.

56 Ofício do diretor da Comissão do Vale do São Francisco, Assis Scaffa, ao diretor do IOC, Antonio Augusto Xavier, em 19 de junho de 1956. FCPqRR/SPAPED, caixa 15, maço 3. A Constituição Federal de 1946 determinou a execução de um plano de aproveitamento das possibilidades econômicas do rio São Francisco e de seus afluentes, num prazo de vinte anos, prevendo recursos anuais não inferiores a $1 \%$ da renda tributária da União. Em decorrência desta orientação, a Comissão do Vale do São Francisco (CVSF) foi criada pela lei n. 541, de 15 de dezembro de 1948 (Brasil, 1950: 220).

57 A conferência pronunciada por Dias na sessão de 29 de novembro de 1956 da Academia Nacional de Medicina (ANM), publicada no Jornal do Commercio em 2 de dezembro de 1956, foi publicada também na revista $O$ Hospital (Dias, 1957a).

58 Durante 1956, o Ministério da Saúde (MS) promoveu expurgos em 328 municípios nos estados da Bahia, de Minas Gerais, do Rio Grande do Sul, de Goiás e do Paraná e realizou inquéritos sobre a infestação dos domicílios em 74 municípios de Pernambuco, da Bahia, de Minas Gerais, de Goiás, do Paraná, de Santa Catarina e do Rio Grande do Sul (ver Jornal do Commercio, 1957).

59 Em 1957, em reunião em Bambuí, o ministro da Saúde Maurício de Medeiros, o diretor do DNERu Mário Pinotti, o diretor da CVSF Assis Scaffa, prefeitos e 
autoridades sanitárias do oeste de Minas, o secretário de Saúde de Minas Gerais Washignton Pires, o diretor do IOC Antonio Augusto Xavier e Emmanuel Dias discutiram a ampliação da campanha para toda a região do oeste de Minas e do Vale do São Francisco (Estado de Minas, 1957). Ver FCPqRR/SPAPED, caixa 39, maço 3.

60 Sobre os debates em torno da interiorização da capital, particularmente no que diz respeito à salubridade dos 'sertões' e ao papel dos médicos do Brasil Central nestes debates e na viabilização da construção de Brasília, ver Vieira (2007, 2009).

61 Sobre o desenvolvimento da economia rural e a valorização simbólica e política do interior como eixo da integração nacional durante o governo JK, em especial no âmbito da 'operação Brasília', ver Moreira (1998, 2003).

62 Carta de Isaac Barreto Ribeiro a Emmanuel Dias, em 7 de julho de 1957. FCPqRR/ SPAPED, caixa 15, maço 4. Segundo seu depoimento, motivado pelo ideal de construir 'algo novo' no interior do país, Ribeiro se dirigiu, na passagem do ano de 1956 a 1957, à área demarcada para a nova capital e instalou seu consultório no Núcleo Bandeirantes, para onde afluíam os 'candangos' que construiriam a nova cidade (ver Ribeiro, 2006). A trajetória de Isaac Barreto Ribeiro é exemplar de como a doença de Chagas propiciava oportunidades e espaços profissionais, até

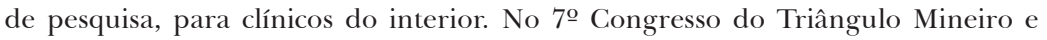
Brasil Central, em Uberlândia, em julho de 1955, Ribeiro apresentou seus estudos sobre a doença na Colônia Nacional Agrícola de Goiás, qualificando-os como "o esforço de um médico sertanejo que vive em pleno coração do Brasil, numa região afastada dos grandes centros de cultura e que, há cinco anos de sua formatura, tem, pela primeira vez, a oportunidade de assistir a um congresso médico. A vontade de expor a conduta seguida neste drama íntimo desenrolado em nossa alma, diante de tamanha calamidade, essa vontade venceu o complexo de inferioridade do profissional anônimo que labuta no interior da nossa Pátria, fazendo-o apresentar esta comunicação, apesar dos modestos recursos, próprios do meio em que vive" (Ribeiro, 1955: 83).

63 Neste trabalho, os técnicos do DNERu informaram que, em levantamento feito em 23 municípios, o principal transmissor na região, o Triatoma infestans, não havia atingido a área destinada ao novo Distrito Federal (Carvalho \& Verano, 1956a).

64 A profilaxia da doença de Chagas em Goiás teve início em 1951, com desinsetizações promovidas pelo então SNM. Ver Carvalho e Verano (1956b) e Carvalho e Castro (1957).

6๐ O médico Isaac Barreto Ribeiro (1957: 199-200) sugeriu a aplicação de inseticidas nas habitações que fossem surgindo em Brasília e também nas malas e nos utensílios dos 'pioneiros', além de outras medidas, como a destruição sistemática dos tatus (reservatórios silvestres do T. cruzi) e o controle de possíveis focos silvestres. A "propaganda sanitária intensiva" era enfatizada como fundamental para prevenir os moradores sobre o perigo da doença: "Constante vigilância, portanto, sobre os novos moradores (...) e atenção permanente para com as habitações".

${ }^{66}$ Sobre a freqüência da 'morte súbita', o autor da reportagem, Neil Ferreira, registrou: "Ouvimos 280 lavradores nos trinta e cinco municípios visitados. Perguntávamos se algum (ou alguns) dos seus parentes haviam morrido entre os 20 e 40 anos e qual o motivo de morte. Não houve sequer uma resposta negativa. (...) Cerca de $75 \%$ destas mortes (236 pessoas) tinham ocorrido 'de repente', isto é, por doenças 
cardíacas. E entre essas doenças era absoluta a preponderância do mal de Chagas" (Ferreira, 1957: 38)

67 A partir de então, $O$ Globo publicaria muitas reportagens sobre o assunto. Ver FCPqRR/SPAPED, caixa 36, maço 11 .

68 Reportagem do Correio Paulistano (1951) enfatizou que a colaboração dos pequenos fazendeiros e sitiantes no uso de inseticidas e na realização de melhorias habitacionais vinha se intensificando. Dias recebeu algumas solicitações nesse sentido. Em 1952, por exemplo, o chefe do Centro de Saúde de Divinópolis, Minas Gerais, escreveu-lhe encaminhando pedido de um fazendeiro do município de Abaeté para que se investigassem suspeitas quanto à presença de barbeiros em sua fazenda e, caso confirmadas, fossem feitas aplicações de inseticidas. Carta de João Machado Veloso a Emmanuel Dias. Divinópolis, 28 de julho de 1952. FCPqRR/ SPAPED, caixa 15 , maço 2.

${ }_{69}$ Dias, Emmanuel. Palestra na Rádio Inconfiência em 9 de outubro de 1960. FCPqRR/ SPAPED, caixa 38, maço 6 .

70 Carta de Emmanuel Dias ao diretor do IOC, Antonio Augusto Xavier, 24 de agosto de 1956. FCPqRR/SPAPED, caixa 32, maço 9; Circular n. 46, enviada por Oswaldo Urioste, diretor do Serviço de Profilaxia da Malária do Estado de São Paulo. São Paulo, 30 de agosto de 1956. FCPqRR/SPAPED, caixa 15, maço 3. Ver também Buralli (1985: 103).

${ }^{71}$ Dias, Emmanuel. Discurso em São Joaquim da Barra, S.P., 22-9-1956. FCPqRR/ SPAPED, caixa 29, maço 25.

72 Dias e Freitas discutiram suas divergências em: Carta de José Lima Pedreira de Freitas a Emmanuel Dias. Ribeirão, 3 de fevereiro de 1957. FCPqRR/SPAPED, caixa 32, maço 10; Carta de Emmanuel Dias a José Lima Pedreira de Freitas. Bambuí, 19 de abril de 1957. FCPqRR/SPAPED, caixa 32, maço 10.

73 Carta de José Lima Pedreira de Freitas a Mário Pinotti. Ribeirão Preto, 28 de fevereiro de 1957. FCPqRR/SPAPED, caixa 15, maço 4.

74 Ver também: Carta de Emmanuel Dias ao governador de São Paulo Jânio Quadros. Bambuí, 4 de abril de 1957; Carta de Emmanuel Dias a J. N. Coutinho Cavalcanti, Hospital dos Servidores do Estado. Bambuí, 3 de setembro de 1957; Urioste, Oswaldo. Informações do Serviço de Profilaxia da Malária do Estado de São Paulo, 29 de maio de 1957. FCPqRR/SPAPED, caixa 32, maço 10; caixa 33, maço 12; caixa 39, maço 3.

75 Ver Ofício de Emmanuel Dias ao chefe da Circunscrição Minas Gerais do DNERu Átila Gomes de Carvalho, em 25 de junho de 1957. FCPqRR/SPAPED, caixa 36, maço 10, caixa 15, maço 4 . Para correspondência relativa a esta reunião organizada em Bambuí, ver FCPqRR/SPAPED, caixa 39, maço 3.

76 Sobre a discussão BHC/BNH, ver Coura (1993).

$\pi$ No VII Congresso Brasileiro de Higiene, realizado em 1948, Pessoa havia proposto, em moção que foi rejeitada, que a principal medida para combater as endemias rurais no Brasil era o fim do latifúndio e a realização de uma reforma agrária $(\mathrm{SBH}$, 1949: 46).

78 Na ocasião, entusiasmado com o apoio do MES, Dias lamentou com Romaña: "Afinal a Oficina Sanitária Panamericana caiu em ponto morto em relação aos seus 
planos sobre a doença de Chagas? Caramba! Temos mesmo que tocar para diante sem esperar por ela, e ainda bem que o fizemos". Carta de Emmanuel Dias a Cecilio Romaña, Rio de Janeiro, 5 de maio de 1951. FCPqRR/SPAPED, caixa 31, maço 2.

79 Carta de Cecilio Romaña a Emmanuel Dias. Tucumán, 15 de agosto de 1955. FCPqRR/SPAPED, caixa 32, maço 6.

so Carta de Emmanuel Dias a Carlos Alberto Alvarado, Rio de Janeiro, 1o de fevereiro de 1956; Carta de Emmanuel Dias a Carlos Alberto Alvarado. Bambuí, 30 de março de 1957; grifo do autor. FCPqRR/SPAPED, caixa 32, maço 7, maço 10.

81 Carta de Emmanuel Dias a José Francisco Torrealba. Rio de Janeiro, 1o de outubro de 1957. FCPqRR/SPAPED, caixa 33, maço 12.

82 Dias, que mantinha contato sistemático e relação de amizade com Romaña, trocou, nesta época, cartas com outros antigos colaboradores de Mazza, como Miguel Yorg e Mauricio Rosembaum. O grupo da Misión de Estudios de Patología Regional Argentina (Mepra) havia se desfeito com a morte de Mazza, em 1946, e com as dificuldades políticas enfrentadas por conta da ditadura peronista. Com a redemocratização, estes cientistas tentavam recriar um núcleo de trabalho sobre a endemia chagásica no país e conquistar o interesse do governo. Em suas cartas a Dias, Yorg sempre reforçava que o exemplo a ser seguido era o brasileiro, particularmente a experiência do CEPMC, e que uma cooperação entre os diversos países do continente fazia-se cada vez mais indispensável. Da mesma forma, Rosembaum (que, como outros, havia perdido suas funções depois da 'revolução' e, em 1957, fora nomeado chefe de cardiologia da Dirección de Lucha contra la Enfermedad de Chagas), manifestou a Dias sua disposição em convencer as autoridades sanitárias de seu país, afirmando que seria de grande utilidade apresentar os avanços na 'luta antichagásica' no Brasil. Ao saber que Dias iria à Argentina, ele propôs que o diretor do CEPMC proferisse uma conferência naquele órgão do Ministério da Saúde. Os argentinos também eram parceiros importantes nos estudos sobre a cardiopatia chagásica, contribuindo para a sua difusão e reconhecimento. Comentando o inquérito que realizara em 1956, Rosembaum informou a Dias que "en total tenemos hechas unas 1.600 RFC [reações de fixação de complemento] y unos 900 electrocardiogramas (...) Lo que no cabe duda es que el problema chagásico es sumamente importante en el país y tal vez más extendido aún que en Brasil " ("ao todo, temos feitas umas 1.600 RFC e uns 900 eletrocardiogramas (...). Não há dúvida de que o problema chagásico é sumamente importante no país e, talvez, mais estendido ainda que no Brasil" - Tradução livre). Carta de Mauricio Rosembaum a Emmanuel Dias. Buenos Aires, 11 de agosto de 1957; Carta de Miguel Yorg a Emmanuel Dias. Buenos Aires, 27 de setembro de 1956; Carta de Miguel Yorg a Emmanuel Dias, Vicente López, 3 de agosto de 1957; Carta de Mauricio Rosembaum a Emmanuel Dias. Buenos Aires, 8 de setembro de 1957. FCPqRR/SPAPED, caixa 32, maços 9 e 11 .

83 Para um relato da viagem, ver Carta de Emmanuel Dias ao diretor do IOC. Rio de Janeiro, 29 de outubro de 1957; Ofício encaminhado por Emmanuel Dias a Maurício de Medeiros, em 31 de outubro de 1957. FCPqRR/SPAPED, caixa 39, maço 3. Na ocasião, Dias dirigiu-se diretamente ao representante da Repartição Sanitária Pan-Americana (RSPA) no Brasil (Carta de Emmanuel Dias a Kenneth Courtney, Bambuí, 2 de novembro de 1957). Em sua resposta, datada de 8 de novembro, 
Courtney manifestou apoio à idéia e disse que poderiam discuti-la melhor na reunião de dirigentes da RSPA no ano seguinte. FCPqRR/SPAPED, caixa 33, maço 13.

84 Dias, Emmanuel. Discurso del dr. Emmanuel Dias en la sessión de clausura de las Primeras Jornadas Venezoelanas de Cardiologia, Caracas, 22, novembre, 1957. FCPqRR/SPAPED, caixa 29, maço 32.

85 A conferência de Dias neste encontro foi publicada em Dias (1958a). Em 1954, uma revisão da literatura sobre o tema desde a época de Carlos Chagas, produzida por Laranja em 1949, foi publicada em livro, em espanhol, na Venezuela (Laranja, 1954).

86 "como o senhor muito bem disse, o estudo da Doença de Chagas na Venezuela chegou à etapa cardiológica, já é impensável que não entre na etapa final de controle" - Tradução livre. Carta de José Francisco Torrealba a Emmanuel Dias. San Juan de los Morros, 5 de dezembro de 1957. Em carta a Laranja, relatando suas impressões sobre as Jornadas, Dias afirmava: "A coisa aqui está muito adiantada, a doença em plena fase cardiológica, confirmando-se os achados de Bambuí mais uma vez”. Carta de Emmanuel Dias a Francisco Laranja, Caracas, 5 de dezembro de 1957. FCPqRR/SPAPED, caixa 33, maço 11.

87 Ofício de Emmanuel Dias ao ministro da Saúde, encaminhando relatório de viagem, em 2 de fevereiro de 1958. Anexo: Resumo das atividades do Centro de Estudos e Profilaxia de Moléstia de Chagas do IOC e do Posto Experimental de Bambuí, do Departamento Nacional de Endemias Rurais, durante o ano de 1957. FCPqRR/SPAPED, caixa 3, maço 1.

s Ver FCPqRR/SPAPED, caixa 39, maço 4.

89 Os argentinos também criticavam, na época, a falta de providências por parte da RSPA. Em 1958, Rosembaum publicou, no jornal La Nación, o artigo "grave problema sanitario: la enfermedad de Chagas", denunciando a inoperância dos serviços sanitários argentinos e o descaso das organizações internacionais. Ele e Dias trocaram cartas sobre a grande repercussão da matéria. Dias parabenizou e estimulou o colega: "Faça você, por seu lado, outro tanto. Impossível as coisas não melhorarem depois". Carta de Mauricio Rosembaum a Emmanuel Dias. Buenos Aires, 2 de março de 1958; Carta de Emmanuel Dias a Mauricio Rosembaum. Rio de Janeiro, 17 de abril de 1958. FCPqRR/SPAPED, caixa 33, maço 14. Dias também mantinha correspondência com o chefe do Servicio Nacional de Profilaxis y Lucha contra la Enfermedad de Chagas, Manuel Vidaurreta, que se dispôs a convencer os dirigentes argentinos quanto às suas reivindicações. Ver FCPqRR/SPAPED, caixa 15, maço 6. Para correspondência de Dias com os uruguaios e os venezuelanos, ver FCPqRR/SPAPED, caixa 15, maço 6; caixa 33, maço 13. Para correspondência com pesquisadores/médicos dos outros países, ver FCPqRR/SPAPED, caixa 33, maço 13; caixa 15, maço 4; caixa 13, maços 14 e 15 .

90 Em 1958, o MS iniciou no Brasil uma campanha de erradicação da malária, que, além dos recursos do ministério, contaria também com apoio da OMS e da International Cooperation Administration (agência do governo norte-americano). Em carta ao diretor do Serviço de Profilaxia da Malária do Estado de São Paulo (SPM-SP), Dias questionou: "Poderá comparar-se o dano que produz a doença de Chagas, infecção cardiotrópica grave e incurável, com o produzido pelo paludismo 
residual? Ou mesmo como dano potencial, por um problemático recrudescimento da malária, doença facilmente despistável, contra a qual dispomos de eficazes recursos, não só da terapêutica, como da prevenção e do combate?" Carta de Emmanuel Dias a Victor Homem de Mello. Bambuí, 20 de janeiro de 1959. FCPqRR/SPAPED, caixa 15 , maço 7 .

91 Carta de Emmanuel Dias a Marcolino Candau. Bambuí, 23 de fevereiro de 1958. FCPqRR/SPAPED, caixa 33, maço 14.

92 Carta de Emmanuel Dias a Marcolino Candau. Bambuí, 23 de fevereiro de 1958. FCPqRR/SPAPED, caixa 33, maço 14.

93 Carta de Fred Soper a Emmanuel Dias. [Washington], 25 de junho de 1958. FCPqRR/SPAPED, caixa 15, maço 6.

94 Carta de Emmanuel Dias a Fernando Lobo. Bambuí, 4 de agosto de 1958. FCPqRR/ SPAPED, caixa 39, maço 6.

95 Em outubro de 1958, a XV Conferência Sanitária Pan-Americana, realizada em Porto Rico, declarou que o Brasil e vários outros países sul-americanos estavam livres do Aedes aegypti, vetor da febre amarela (Benchimol, 2001).

96 Ver Anais do Congresso Internacional sobre a Doença de Chagas. Rio de Janeiro, Oficina Gráfica da Universidade do Brasil, volumes I a V, 1959/1964.

97 "está longe de ser resolvido o problema da real incidência da doença de Chagas nas Américas" - Tradução livre. "Discurso pronunciado por el dr. Abraham Horwitz, director de la Oficina Sanitaria Panamericana, en la sessión inaugural', Grupo de Estudios sobre Enfermedad de Chagas, 7-11 marzo 1960, Washington D.C., Organización Mundial de la Salud/Organización Panamericana de la Salud, mimeo., p. 2. FCPqRR/SPAPED, caixa 38, maço 6 .

98 "a dificuldade para organizar e justificar programas adequados de controle nos países onde evoluem simultaneamente outros processos que têm maior incidência aparente na morbilidade e na mortalidade" - Tradução livre. "Discurso pronunciado por el dr. Abraham Horwitz...”, Grupo de Estudios sobre Enfermedad de Chagas, 7-11 marzo 1960, Washington D.C., Organización Mundial de la Salud/ Organización Panamericana de la Salud, mimeo., p. 2. FCPqRR/SPAPED, caixa 38, maço 6 .

99 "Embora não exista uma avaliação específica sobre o prejuízo econômico causado pela doença de Chagas, os dados existentes mostram que este deve ser bastante considerável. Em primeiro lugar, os sintomas incapacitantes decorrentes das formas crônicas da doença se desenvolvem, de modo geral, na segunda metade da vida, quando o indivíduo está dando sua maior contribuição para a sociedade. Em segundo lugar, a doença ocorre principalmente em áreas rurais, onde as pessoas afetadas tornam-se, freqüentemente, incapazes de realizar o trabalho físico pesado que lhes é demandado" - Tradução livre.

100 "de promover o desenvolvimento econômico e o bem-estar" - Tradução livre. "Discurso pronunciado por el Dr. Abraham Horwitz...", Grupo de Estudios sobre Enfermedad de Chagas, 7-11 marzo 1960, Washington D.C., Organización Mundial de la Salud/Organización Panamericana de la Salud, mimeo., p. 3. FCPqRR/ SPAPED, caixa 38, maço 6. 

vetores, em especial daquelas mais adaptadas às moradias humanas" - Tradução livre. meados da década de 1970, passou a vincular-se ao Centro de Pesquisas René Rachou, após a integração deste à recém-criada Fiocruz. Em 1980, recebeu a denominação de Posto Avançado de Pesquisas Emmanuel Dias. Sobre a trajetória de João Carlos Pinto Dias, ver seu depoimento oral (Dias, 1998). Paraguai e Uruguai) estabeleceram acordo para o combate à doença mediante a aplicação de inseticidas (Dias \& Schofield, 1999; Dias, 2002). Vinhais e Dias (2000: 10) afirmaram: “(...) indicadores entomológicos de uso rotineiro apontam para a virtual eliminação da principal espécie vetora no país, Triatoma infestans, dos domicílios". Em junho de 2006, a Opas concedeu ao Brasil o certificado de interrupção da transmissão por esta espécie de triatomíneo. Apesar disso, os cientistas 
continuam alertando para a importância da vigilância epidemiológica, de modo a evitar a domiciliação de outras espécies de triatomíneos, sobretudo em certas regiões, como o Nordeste. A situação da transmissão vetorial é considerada equacionada também no Chile e no Uruguai (Vinhais \& Dias, 2000). Ver também Brasil (2005), Programa Integrado de Doença de Chagas da Fiocruz (2007), Dias (2007), Dias, Prata e Correia (2008).

110 Na década de 1970, os principais marcos na institucionalização de uma comunidade de pesquisa de âmbito nacional em torno da doença de Chagas foram o Programa Integrado de Doenças Endêmicas (Pide) - organizado pelo CNPq e gerido, com grande autonomia, pelos cientistas, de 1973 até meados da década de 1980 (Azevedo, Kropf \& Coura, 2007) -, que impulsionou fortemente as investigações sobre o tema, e as chamadas Reuniões Anuais de Pesquisa Básica em Doença de Chagas, iniciadas em 1974 e que até hoje se realizam em Caxambu, Minas Gerais. As pesquisas se beneficiaram também do apoio concedido pelo então criado Tropical Diseases Research (TDR), programa da OMS iniciado em 1975 e do qual a doença de Chagas foi e continua sendo um dos temas constitutivos. Ver Azevedo, Kropf e Hamilton (2003) e depoimentos de Prata (2000), Morel (1992), Coura (1999) e Brener (1995). 



\section{Conclusão}

Seguiu-se até aqui um longo itinerário. Foram percorridos distintos espaços, em distintas temporalidades: laboratórios europeus, anfiteatros e enfermarias da Faculdade de Medicina na capital federal da Belle Époque, laboratórios de Manguinhos, os sertões mineiros de Lassance, salões das academias médicas, institutos de pesquisa na Argentina, repartições do Ministério da Educação e Saúde, campos de batalha da Segunda Guerra Mundial, os sertões de Bambuí, Uberaba e outras paragens do Brasil Central, instituições de ciência, de medicina e de saúde pública, no país e no exterior.

Foram muitas as viagens e os deslocamentos, idas e vindas entre o litoral e o sertão, para conformar a imagem de uma nova doença tropical que, descoberta por um cientista dos 'trópicos', foi construída e reconhecida, sob as condições específicas da ciência e da sociedade brasileiras, como a 'doença do Brasil'. Associando as teorias européias sobre germes, vetores e doenças às questões e aos desafios particulares de uma nação que se pretendia moderna (e da ciência que pretendia conduzi-la), o caminho pelo qual se partiu de um novo parasito encontrado no sangue de uma menina sertaneja para se chegar a uma endemia do continente americano permite refletir sobre as intricadas e estreitas relações entre ciência e sociedade. 
Cabe lembrar as perguntas de David Bloor, e que foram as perguntas de Ludwig Fleck, Thomas Kuhn e de todos os que seguiram nesta trilha. Qual a dimensão social dos processos pelos quais o conhecimento científico é produzido, transmitido, se estabiliza e muda ao longo do tempo? Como enxergar nos enunciados 'objetivos', pelos quais os cientistas apreendem a natureza, as múltiplas dimensões de uma intensa movimentação humana e coletiva, que envolve acordos e desacordos, negociações e disputas, interesses e crenças? Vejamos os principais aspectos destacados pelo presente estudo, que buscou respostas a estas perguntas a partir do caso da doença de Chagas e do diálogo conceitual entre os estudos sociais e históricos da ciência e a história social da medicina.

A fim de compreender as condições teóricas, sociais e institucionais que levaram Carlos Chagas à descoberta que o consagraria no 'panteão' da ciência nacional, procurei situar sua formação no panorama das teorias médicas emergentes ao final do século XIX, que acenavam com novas e poderosas ferramentas para compreender e combater as doenças causadas por germes e transmitidas por vetores, especialmente insetos. Foi sob o boom dos estudos e interesses em torno das doenças tropicais, que assumiam significados particulares no contexto sanitário e político da capital federal brasileira, que Chagas concluiu seu curso médico e ingressou em Manguinhos, para estudar e combater a malária. O contexto particular de construção do próprio instituto, que Oswaldo Cruz buscava transformar num centro de excelência em medicina experimental, foi determinante para o caminho que levou o jovem cientista a descrever a nova doença em Lassance.

A articulação entre microbiologia e medicina tropical - não só como arranjo teórico, mas sob a perspectiva de reforçar e ampliar os vínculos entre as atividades de Manguinhos e as demandas da saúde pública que lhe conferiam sustentabilidade e legitimidade social - foi decisiva para que o Instituto Oswaldo Cruz (IOC) sobrepujasse os contornos restritos sob os quais havia sido criado e se consolidasse como instituição científica estável, referência para uma nova fase na institucionalização da ciência no Brasil. A descoberta da doença de Chagas, ao mesmo tempo que se viabilizou graças a este processo, veio reforçá-lo, servindo de emblema para uma instituição que afirmava sua legitimidade pública não apenas pela capacidade de responder a demandas sociais, mas pela excelência acadêmica, que a permitia descortinar novos problemas para a ciência e a sociedade. 
Em termos cognitivos, os marcos teóricos da medicina tropical serviram de balizamento fundamental tanto para o processo da descoberta como para os rumos que, a partir de 1909, Chagas seguiria para definir, como entidade nosológica específica, a doença que recebeu seu nome. O parasito foi a instância decisiva de enquadramento deste objeto, do ponto de vista dos elementos que viriam a compor seu quadro clínico e também dos critérios utilizados para a comprovação de sua existência e especificidade, caminho este reforçado ainda mais pela peculiaridade de não se dispor de qualquer experiência clínica prévia sobre os fenômenos patológicos atribuídos ao novo tripanossoma.

Ao seguir os enunciados pelos quais Chagas, junto a seus colaboradores em Manguinhos, foi estabelecendo o desenho clínico da nova doença e seus significados sociais, destaquei os caminhos pelos quais a nova tripanossomíase assumiu a identidade de uma patologia fundamentalmente endócrina, mais precisamente tireoidiana. A 'tireoidite parasitária' foi vista como enfermidade que comprometia seriamente o desenvolvimento orgânico dos indivíduos (especialmente crianças) e que tinha como um de seus sinais mais visíveis e característicos o 'papo', que passou a servir como principal critério clínico para a busca de casos da doença. Além de ser uma afecção muito comum na região de Minas Gerais onde Chagas realizava suas pesquisas, o bócio endêmico era investido de particular importância social como expressão do 'atraso' e da 'degeneração' das populações do interior. Sob o impacto da microbiologia, muitos médicos aventavam a possibilidade de doenças endócrinas terem causas infecciosas. A correlação com distúrbios neurológicos fazia destas patologias objeto de especial interesse para a ciência médica, num contexto em que o tema da 'degeneração' mobilizava os debates sobre as perspectivas do 'progresso'. Diante destes fatores, procurei mostrar que, para tal enquadramento científico e social da tripanossomíase, foi fundamental o apoio dos médicos da Academia Nacional de Medicina (ANM), conquistados mediante mobilização do próprio Oswaldo Cruz e que serviram não apenas como fonte de credibilidade para os enunciados de Chagas, mas o impulsionaram a seguir na trilha pela qual se desenhava a 'tireoidite parasitária'.

O encontro da ANM com os sertões - com o que estes representavam como espaço geográfico, social e simbólico da miséria, da doença e do abandono, na chave interpretativa de Euclides da Cunha - foi promovido nas várias apresentações pelas quais Chagas divulgou suas pesquisas, entre 
1910 e 1913, nas principais associações médicas. Nesse processo, a doença foi definida como objeto científico e social que, materializado na habitação miserável que servia de abrigo ao barbeiro e nas deformações físicas e mentais de suas vítimas, traduzia a realidade de um país cujo progresso se emperrava diante das graves endemias que assolavam suas populações rurais. A nova tripanossomíase emoldurava a nação também na medida em que representava o protagonismo da ciência em revelar esta realidade e em reivindicar intervenções do poder público para transformá-la.

Na chave de uma intelligentsia reformadora, que aproximava a identidade social dos cientistas de Manguinhos do perfil dos intelectuais da chamada geração de 1870, Chagas formulou, no processo mesmo de construção médica da nova doença, os valores e as categorias que, anos mais tarde, seriam amplificados no debate político em torno do saneamento rural do Brasil. A doença de Chagas emergia, assim, do laboratório e também da mobilização política em torno dos significados que lhe eram imputados como imagem da própria nação.

No decorrer de tal processo, o convencimento em torno deste objeto médico-científico passou a enfrentar desafios, do ponto de vista das próprias pesquisas, na medida em que o diagnóstico com base na verificação parasitária - fundamental para os preceitos da chamada 'medicina de laboratório' - revelou-se procedimento difícil, sobretudo para os casos crônicos, que eram a maioria dos portadores da infecção. A partir de então, surgiram questionamentos sobre os enunciados a respeito do quadro clínico da doença (em especial sobre a correlação com o bócio) e sobre a tese de que se tratava de vasta endemia no Brasil e no continente americano. Formuladas na Argentina, entre 1914 e 1916, estas dúvidas levaram Chagas a uma importante revisão de seus estudos. Embora reiterando suas teses principais, ele começou a proceder a uma expressiva reorientação na maneira de apresentar os elementos constitutivos da doença, minimizando os elementos endócrinos e reforçando os aspectos cardíacos, tanto discursivamente na composição dos textos quanto no que dizia respeito aos investimentos de pesquisa.

Ao mesmo tempo que foi alvo de tais questionamentos, a doença de Chagas, no contexto fortemente nacionalista da Primeira Guerra Mundial, assumiu proeminência no debate público sobre os destinos da nação, tornando-se uma das principais bandeiras daqueles que denunciavam os males de um 'Brasil doente' e reivindicavam a intervenção do Estado mediante ampla reforma dos serviços sanitários federais. No âmbito deste 
movimento - que, entre 1916 e 1920, projetou na cena nacional não apenas a doença, mas seu descobridor -, os traços que vinham se fragilizando no domínio da discussão científica (os elementos tireoidianos e neurológicos, a partir dos quais se aquilatava o impacto médico-social da doença) ganharam nova força, no plano simbólico, como signos por excelência das enfermidades que flagelavam o Brasil e da ciência que o redimiria. A noção da existência de 'milhões de idiotas e papudos' vitimados pelo mal de Chagas, como dizia Monteiro Lobato e outros partidários da campanha pelo saneamento rural do Brasil, ganhou as páginas dos jornais e as tribunas do Congresso Nacional.

Como desdobramento do movimento sanitarista, a tripanossomíase americana tornou-se objeto de intensa polêmica que, travada na ANM, mobilizou profundamente a classe médica durante 1922 e 1923 e teve grande impacto na trajetória da doença e de seu descobridor. Ao analisar de perto o desenrolar desta querela, que fez parte do próprio processo de construção da doença de Chagas, pude observar em que medida, também na sua negação, tratava-se de enfermidade que envolvia, de maneira inextricável, ciência e política. Os que a qualificaram como 'mal de Lassance' acionando as dúvidas de fato existentes quanto a suas características clínicas e a sua dimensão epidemiológica, expressavam, além de rivalidades políticas e pessoais com Chagas, sua posição contrária aos que concebiam esta e outras doenças tropicais/endemias rurais como traços distintivos da identidade nacional. Ao mesmo tempo, manifestavam sua resistência aos significados assumidos pela medicina tropical como chave para uma dada compreensão médica e política dos dilemas e caminhos do país.

Acompanhando os impactos deste episódio, observei os caminhos seguidos pelas pesquisas sobre a doença até o falecimento de Chagas em 1934. Além de abandonar a antiga primazia dos sinais endócrinos e de intensificar o estudo dos aspectos cardíacos e neurológicos, ele passou, num processo que qualifiquei como o início de um 'novo enquadramento' para a doença, a reforçar a necessidade de imprimir maior força e credibilidade ao diagnóstico clínico. O descobridor da nova doença tropical estava ciente de que, diante dos impasses que o laboratório não conseguia equacionar, este era o caminho para recuperar a força dos enunciados a respeito daquela entidade nosológica que, justamente, representava o primado do laboratório no saber e na prática médicas, e também nos destinos da nação. 
Foi no âmbito deste deslocamento direcionado ao domínio cognitivo e social da clínica que ocorreu o primeiro passo importante para reverter o ambiente de dúvidas que cercava a tripanossomíase americana. A descrição na Argentina, em 1935, do sinal de Romaña, ao prover um meio fácil para o diagnóstico clínico de casos agudos da doença, esteve inscrita num projeto mais amplo de divulgar o assunto entre os médicos do interior, fazendo-os aliados dos cientistas no estudo e no mapeamento da doença, bem como na sua afirmação como assunto de saúde pública.

No Brasil, este projeto foi implementado pelo filho de Carlos Chagas, Evandro Chagas, que, em 1937, criou o Serviço de Estudo das Grandes Endemias (Sege) e estabeleceu, em parceria com pesquisadores mineiros, nova frente de pesquisas sobre a tripanossomíase americana no interior de Minas. O tema das endemias rurais como expressão do projeto de ciência de Oswaldo Cruz e Carlos Chagas deslocou-se, no IOC, para o âmbito específico do programa de Evandro Chagas, não constituindo diretriz prioritária da instituição, que vivia um período de indefinições sob a gestão de Antonio Cardoso Fontes, sucessor de Chagas.

A transferência das atribuições que Manguinhos detivera na formulação das políticas de saúde pública do país para as novas estruturas sanitárias do Ministério da Educação e Saúde (MES), no bojo das transformações por que passou o Estado e a sociedade brasileira a partir de 1930, impôs ao IOC a necessidade de redefinição de seus vínculos com a saúde pública. Tal movimento foi implementado, sobretudo, nos primeiros anos da década de 1940, valendo-se de condições específicas do contexto da Segunda Guerra Mundial. O novo interesse conferido aos 'obstáculos' representados pelas doenças infecciosas (não apenas nas frentes de batalha, mas nos países fornecedores de materiais estratégicos), configurando o início de uma era de grande otimismo quanto aos novos recursos técnicos e políticos para combatê-las, consolidou uma determinada abordagem da relação entre saúde e desenvolvimento, pela qual as intervenções sanitárias eram vistas como pré-requisito para qualquer perspectiva de modernização econômica.

No início da gestão de Henrique Aragão (1942-1949), ao tornar-se uma instituição comprometida em fornecer produtos e serviços ao esforço de guerra, Manguinhos vislumbrou as condições materiais, políticas e simbólicas para reconfigurar seus laços e sua identidade com a saúde pública, sob uma perspectiva mais ampla, que foi a de recolocar, em sua agenda, a centralidade do tema das endemias rurais, desta vez com a 
ênfase em sua profilaxia. Num contexto nacional em que o tema do trabalho era valorizado como eixo do projeto de modernização, e em que o mundo rural ganhava novos significados econômicos e simbólicos como espaço de povoamento e abastecimento para o próprio processo de industrialização e urbanização, recompunham-se, ainda que sob outros formatos, os valores e as bandeiras dos projetos associados ao saneamento rural do país.

Tal movimento ganhava contornos particulares em Minas Gerais, onde se intensificava a preocupação das elites em superar o atraso econômico, estancar o êxodo rural e recuperar a tradicional vocação agrícola do estado, desta vez como 'grande celeiro' do mercado interno nacional. No cenário político-administrativo da saúde pública federal, as novas estruturas burocráticas e administrativas criadas no MES acenavam com a perspectiva de se concretizar e fazer avançar os projetos voltados para o interior. Foi sob tais circunstâncias que, apoiado pela direção de Aragão, os cientistas do IOC interessados em dar continuidade às pesquisas de Carlos Chagas voltariam a Minas, criando, em 1943, o posto de estudo e de profilaxia da doença em Bambuí.

Os trabalhos desenvolvidos no Centro de Estudos e Profilaxia da Moléstia de Chagas (CEPMC) representaram um marco decisivo no processo de construção e certificação da tripanossomíase americana. O estudo clínico da doença em sua fase crônica foi o caminho privilegiado para enfrentar os aspectos mais controversos daquela entidade. Numa época em que as concepções sobre a correlação com o bócio e a forma neurológica já não eram mais aceitas, a ênfase nos estudos cardíacos constituiu não apenas o desdobramento de um caminho já esboçado por Carlos Chagas, mas uma nova maneira de segui-lo, representada por um deslocamento substantivo em direção ao campo da clínica e dos profissionais e técnicas a ele específicos.

Entre 1943 e 1948, lançando mão dos novos procedimentos da eletrocardiografia e das condições materiais e institucionais para a pesquisa garantidas pela direção do IOC, os cientistas vinculados ao CEPMC produziram uma série de estudos que, segundo eles, permitiam individualizar a doença de Chagas como cardiopatia específica, materializada em alterações eletrocardiográficas peculiares. $\mathrm{O}$ aperfeiçoamento dos métodos de diagnóstico sorológico, por sua vez, reforçou a idéia de que se podia prescindir da verificação parasitária para firmar, com base em critérios clínicos, o diagnóstico da doença. Sob este novo enquadramento, 
a cardiopatia chagásica crônica tornava-se uma entidade clínica a representar, em si mesma, o principal traço de especificidade e materialidade da tripanossomíase americana.

Além disso, a ampla mobilização implementada pelo diretor do CEPMC destinada a divulgar, sobretudo entre os médicos das áreas rurais, os novos conhecimentos sobre a doença e também a idéia de que, por ser um mal cardíaco, comprometia a produtividade dos trabalhadores agrícolas, foi uma dimensão fundamental do próprio processo de produção daqueles novos conhecimentos. A noção de que já se dispunha de um método concreto para combater os barbeiros por meio de um inseticida - estabelecido, mediante as pesquisas do posto de Bambuí, em 1948 - foi mais um elemento a atrair interesses sociais diversos em torno do tema. Graças a tal mobilização, conduzida num contexto em que o MES enaltecia publicamente as campanhas que o inseriam na chamada 'era DDT', a doença tornou-se, pela primeira vez, objeto das políticas sanitárias federais, iniciando-se em Uberaba uma campanha de profilaxia em 1950.

A estabilidade conquistada pelos enunciados sobre a cardiopatia chagásica crônica, a partir do trabalho do CEPMC, constituiu não o resultado 'inexorável' de um progressivo avanço na capacidade dos cientistas em produzir provas de uma realidade já descrita (ou pelo menos esboçada) por Carlos Chagas, mas implicou diferenças e deslocamentos expressivos em relação à maneira pela qual esta realidade foi por ele estabelecida. Do esquema proposto em 1910, foi recortado um novo desenho clínico para a tripanossomíase americana e foram estabelecidos novos espaços sociais para a produção e a validação dos conhecimentos sobre a doença. Este processo, a um só tempo social e cognitivo, foi possível tanto pela decisão de adotar novas estratégias de pesquisa quanto pelo empenho dos cientistas em persuadir diversos grupos sociais, sobretudo os médicos, a aceitarem os produtos destas investigações como evidências de um dado objeto que se pretendia construir.

O novo enquadramento deve ser compreendido em referência a um projeto político-científico que mobilizou pesquisadores do IOC empenhados em reconstruir a identidade pública de Manguinhos como instituição comprometida com os problemas sanitários e os interesses sociais mais amplos do país. Também pressupôs continuidades não apenas como estratégia de autolegitimação e de busca de credibilidade, mas pelo sentido social maior que o próprio processo de deslocamento 
assumiu. Sob as novas condições históricas da ciência, da saúde e da sociedade brasileira da década de 1940, os pesquisadores do CEPMC produziram os meios para que, imprimindo novos traços àquele objeto, estivesse garantida sua reprodução como símbolo de uma tradição, pela qual se expressava uma determinada visão da ciência, dos cientistas e da própria nação.

Durante a década de 1950, beneficiando-se dos significados conferidos, no pós-guerra, aos debates sobre o desenvolvimento e sobre os modos de se romper o 'círculo vicioso da doença e da pobreza' tanto no cenário internacional quanto no contexto brasileiro, os cientistas associados ao CEPMC continuaram divulgando o tema da doença de Chagas. Este alcançou novos espaços de institucionalização, em especial as faculdades de medicina criadas em áreas endêmicas, e as organizações sanitárias envolvidas com os programas de profilaxia. Aproveitando o apoio conferido ao problema das endemias rurais no âmbito do projeto desenvolvimentista de JK e da dimensão simbólica que o interior alcançou com a construção de Brasília, Emmanuel Dias intensificou sua mobilização política, tendo em vista conquistar os interesses da Repartição Sanitária Pan-Americana (RSPA) para a implementação de uma campanha global de erradicação dos transmissores. Apesar de este objetivo não ter sido alcançado, ocorreram, ao longo desta década, vários marcos importantes a evidenciar que os cientistas haviam sido bem sucedidos em tornar a doença reconhecida e aceita, consensualmente, como fato médicocientífico e problema sanitário relevante. Estava estabelecido, definitivamente, o caminho que fazia deste tema uma tradição para a ciência e para a saúde brasileiras, que seguiria em outras e distintas direções, a partir das décadas seguintes.

O percurso pelo qual a tripanossomíase americana assumiu contornos diferenciados, em diversos momentos, no processo de sua estabilização como fato científico e social conduz à seguinte questão: a doença descrita por Carlos Chagas em Lassance era a 'mesma' doença definida em Bambuí, sobre cujos traços essenciais se produziu um consenso que perdura até hoje? Num sentido mais amplo: como lidar com diferenças e continuidades na 'comparação' entre estes distintos 'objetos' ou distintas 'fases/faces' do mesmo objeto? Este ponto foi abordado quando se questionou o argumento de François Delaporte (2003) de que o conceito de tripanossomíase americana teria 'emergido' apenas na década de 1930, com o trabalho do argentino Cecilio Romaña. Cabe aqui retomar o assun- 
to, não em diálogo com a perspectiva deste autor, mas pela reflexão que desperta no campo da história social, no qual o caso assume outros desafios e complexidades.

Por um lado, a preocupação em evitar o anacronismo implica avaliar cada 'arranjo' assumido pela doença valendo-se de sua dimensão sincrônica, das condições históricas específicas que o produziram. Por outro, a própria noção de diacronia, estruturante do tempo histórico, conduz a pensar as especificidades próprias de cada momento sob a perspectiva de um 'processo' que lhes confere inteligibilidade, em complexa composição entre diferenças e continuidades.

Neste livro buscou-se mostrar que a doença definida por Carlos Chagas apresentou-se de modo bastante diferente, em sua fisionomia clínico-epidemiológica, daquela sob a qual seria configurada a partir de Romaña e, sobretudo, dos trabalhos desenvolvidos pelo CEPMC. Mas, ao mesmo tempo, salientou-se que tais diferenças foram possíveis e ganharam sentido justamente em função do projeto de se constituírem em continuidade com os enunciados de Chagas sobre a entidade nosológica descoberta em Lassance e com os significados que lhe foram imputados. Foi este projeto, que se encaminhou tanto no sentido cognitivo quanto no que diz respeito a seus significados sociais, que criou as condições e as motivações para a atuação dos que se colocavam como discípulos daquele que, por sua vez, apresentava-se como herdeiro de Oswaldo Cruz. Sob tal perspectiva, as diferenças não excluem continuidades e permanências, mas, ao contrário, constituem dimensões interligadas de um mesmo movimento, desde que tais afinidades ou filiações sejam concebidas não como traços de uma unidade biológica ou epistemológica, mas como elementos de um processo social.

Isso é o que garante a perspectiva histórica, em que conceitos só ganham sentido sob a perspectiva diacrônica que, situando-os em temporalidades e em espacialidades diversas, estabelece, ao mesmo tempo, vínculos e diferenças. As especificidades são, portanto, partes de um processo e não elementos de compartimentos estanques. Se, por um lado, somos capazes de identificar diferenças na maneira pela qual a doença se apresentou, como objeto médico, durante a vida de Carlos Chagas e depois de 1935, por outro lado, ela constituiu, como fato social, a expressão de um projeto mais amplo, que se realizou no decorrer destas duas fases e que, em suas várias dimensões, teve conseqüências efetivas no plano institucional de Manguinhos e na própria sociedade brasileira. Este 
foi um projeto para a ciência nacional e para a saúde pública, sob o qual se produziu uma determinada visão do Brasil, de seus problemas e dos meios para enfrentá-los, e que contribuiu para a criação de valores e estruturas materiais concretas que, sob a orientação dos próprios cientistas, seriam acionadas para sua implementação.

Foi justamente tal projeto que orientou os esforços dos cientistas e os distintos caminhos que seguiram na trilha de enquadramento da doença de Chagas como fato coletivo produzido ao longo do tempo. É a perspectiva desta diacronia, que insere os objetos da ciência no terreno da história social, que permite aquilatar as diferenças, sem tratá-las como evidências da incomensurabilidade entre objetos puramente conceituais. Supor continuidades nos marcos de um processo não significa produzir relatos lineares, mas, justamente, situar o sentido das especificidades e das transformações.

Entre Carlos Chagas e Emmanuel Dias, dois cenários de grande entusiasmo com o poder transformador das 'balas mágicas' da ciência. Em 1909, as vacinas e os soros da microbiologia e as primeiras campanhas da medicina tropical. Em 1950, a era dos antibióticos e do DDT. Ambos expressaram tal confiança nas suas próprias trajetórias e nos significados que impuseram à doença à qual se dedicaram. De Carlos Chagas a Emmanuel Dias, uma sociedade que se complexificou, um Estado que adquiriu novas feições e alcance e reservou novos espaços e atribuições aos cientistas num crescente processo de profissionalização, tanto da ciência quanto da saúde pública. Neste gradiente de afinidades e contrapontos, desenhou-se o caminho de uma doença que, de tireoidite parasitária a cardiopatia chagásica crônica, alinhavou não apenas Carlos Chagas e Emmanuel Dias, e os tantos outros cientistas e não cientistas que a eles se associaram, mas a própria sociedade brasileira, nas múltiplas relações entre ciência, saúde e nação.

Em 23 de outubro de 1962, Carlos Drummond de Andrade lamentou, em crônica no Correio da Manhã intitulada "O cientista", a trágica e repentina morte de Emmanuel Dias, ocorrida três dias antes. $O$ poeta e amigo registrava que o diretor do posto de Bambuí tinha um "inimigo na vida": o barbeiro. Uma vez, Dias lhe mencionara que o transmissor da 
doença de Chagas despertava-lhe "ganas de sair pelo Brasil afora", tocando fogo em todas as "palhoças" que encontrasse, para impedir a proliferação daquela doença tão ligada à miséria rural. Contudo, "como destruir a cafua ignóbil do roceiro, sem lhe dar em troca uma habitação decente?” Este era o problema que Dias "não podia resolver por conta própria”, e, imaginava o poeta, o cientista provavelmente morrera com a melancolia de reconhecer que ainda não se havia feito o esforço nacional para resolver aquela situação. Mas, reiterou, "ele, por si, fez o máximo". Disse Drummond:

Culto, sensível, afeiçoado às letras e às artes, poderia viver num centro civilizado e adquirir uma dessas reputações de cientista de litoral, que tanto rendem em glória e conforto. Preferiu passar a vida entre gente abandonada do interior, estudando a tripanossomíase americana. Não sei de vocação mais fiel a um pensamento humanitário do que a desse homem que procurou seguir o caminho do pai, o cientista Ezequiel Dias, e o de Carlos Chagas. (Andrade, 1962: 6) ${ }^{1}$

Transcreveu então trecho de carta que Dias lhe escrevera na época em que se iniciavam as atividades do CEPMC, manifestando seu entusiasmo com as pesquisas, sobretudo as cardiológicas, que iam constituindo "um formidável material de estudo". Contudo, o cientista também expressara ao amigo poeta sua tristeza diante do quadro mórbido que se descortinava na pequena cidade do oeste mineiro: "Você não calcula a pena que dá ver gente nova, meninos de 10 e 15 anos, homens e mulheres na flor da idade, com o coração gravemente atingido pela doença (...)". E, diante da grande quantidade de casos que iam se acumulando nos fichários do posto, o pesquisador de Manguinhos lançava a pergunta: "Isto é uma terrível advertência para todos nós. Como não será no Estado todo? No Brasil inteiro?"

Drummond terminou sua crônica lembrando que, muitas vezes, ouviu o amigo mineiro afirmar que invejava os poetas, que "fazem o que querem, ao sabor dos impulsos do momento" e que, desfrutando da liberdade de criar verdades, recriam o mundo. Com os cientistas, dizia Dias, é diferente: "Temos a sensibilidade recalcada pela constante obrigação de sermos exatos, terra a terra, em tudo o que observamos e dizemos. Espiões e prisioneiros da realidade". Vinte anos depois da criação do CEPMC, num mundo em que as associações entre ciência e política se expressavam em conquistas para o progresso, mas também em situações 
de medo - como a chamada "crise dos mísseis", à qual Drummond se referiu implicitamente ao mencionar a "hora de pânico" vivida em outubro de 1962 - o poeta afirmou, sobre aquele que também fez política fazendo ciência: "Foi em tudo um cientista a serviço do homem".

Para concluir este livro, que se iniciou com um poema e percorreu longos caminhos por entre as muitas dimensões entrelaçadas do itinerário seguido pela 'doença do Brasil', lanço mão novamente das palavras de um poeta. Nelas, encontramos, de forma diferente, mas com a síntese própria aos artesãos da palavra, uma idéia que gostaria de reforçar. Não são apenas os poetas que criam o mundo e o transformam. Os cientistas também o fazem. E o caso que serviu de objeto à presente análise é um exemplo disso.

No processo pelo qual a 'nova entidade mórbida' descoberta nos sertões mineiros ganhou contornos como 'doença do Brasil', a ciência de Carlos Chagas e Emmanuel Dias, que era a ciência de Oswaldo Cruz, ao mesmo tempo que expressou o mundo em que se inseria também o criou, sob contornos bastante particulares: um mundo em que a ciência, ao expor aos olhos da nação as faces dramáticas de seus habitantes doentes, assumia a missão e o compromisso de redimi-la. Estratégia de autolegitimação acionada por tais cientistas? Sem dúvida, mas com impactos efetivos e decisivos sobre a sociedade brasileira. A doença descoberta por Carlos Chagas emoldurou não apenas a ciência de Manguinhos, mas a nação que esta, em si mesma, pretendeu emoldurar.

A intricada tessitura que faz dos indivíduos a expressão de grupos, interesses, projetos e contextos que se colocam para além deles próprios contém, como dimensão constitutiva, a maneira pela qual estes indivíduos vêem e compreendem a si próprios e conferem sentido ao lugar que ocupam, e que desejam ocupar, no mundo. É justamente a partir do esforço para situar os cientistas de Manguinhos na sociedade e no seu tempo que se pode humanizá-los e, ao mesmo tempo, compreender a dimensão mítica que tiveram. É por meio deste caminho que me vejo diante do sentimento tão vibrante nas palavras do poeta. A admiração que este lhes devotou também é passível de mobilizar os historiadores que buscam compreender estes cientistas, em suas ambições, ideais, conquistas, contradições e conflitos, a partir do sentido coletivo e social que se imprimiu às suas trajetórias. 


\section{Notas}

1 O escritor assinou C. D. A. O poema "O cientista" foi publicado posteriormente, em 1966, em Cadeira de Balanço, pela José Olympio Editora. 


\section{Imagens}

1 - Carlos Chagas em seu laboratório no Instituto de Manguinhos. Rio de Janeiro

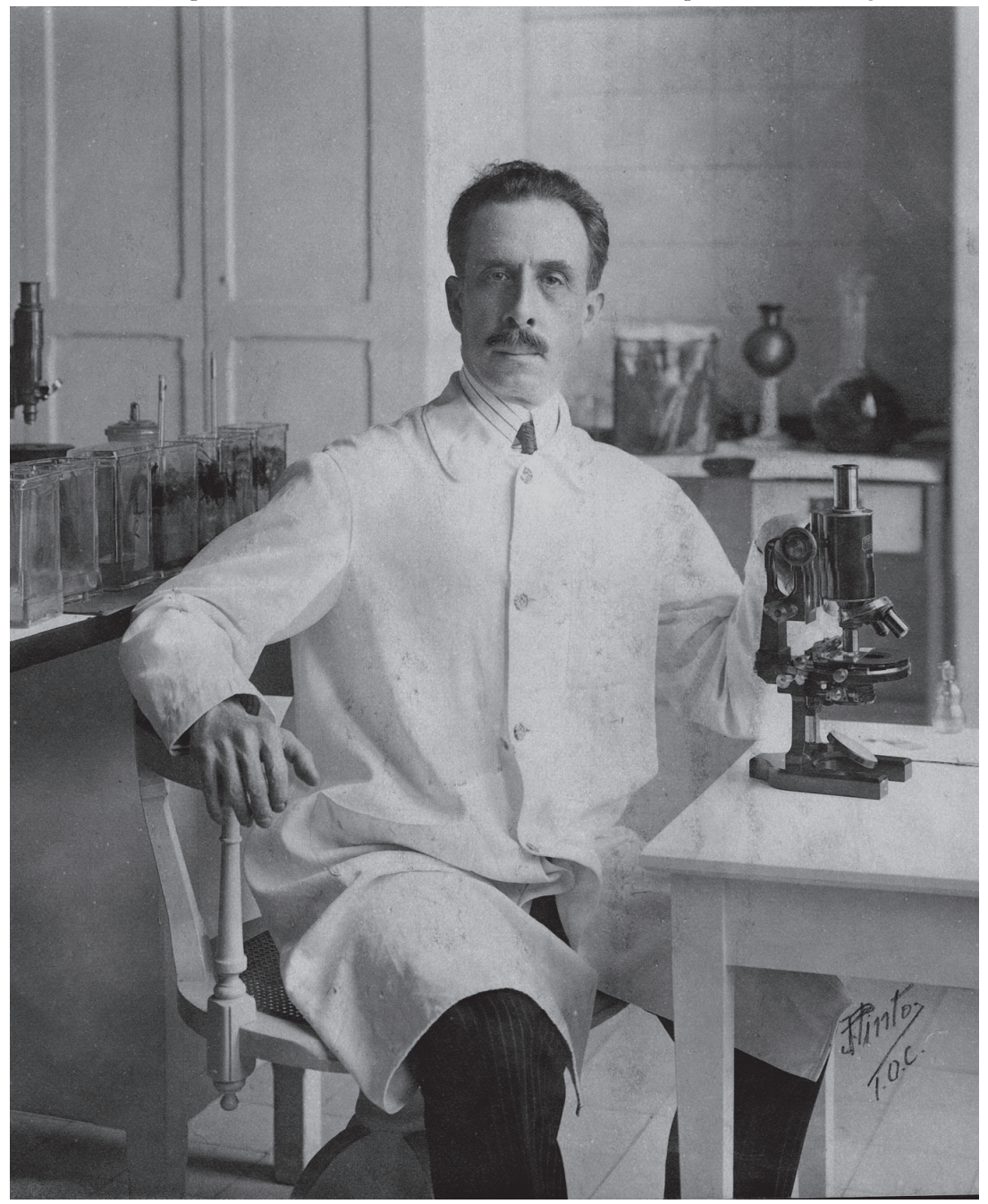

Fonte: Acervo Arquivo Casa de Oswaldo Cruz / Foto: J. Pinto. 
2 - Instituto Oswaldo Cruz. Cartão com dedicatória manuscrita de Carlos Chagas, [1934]

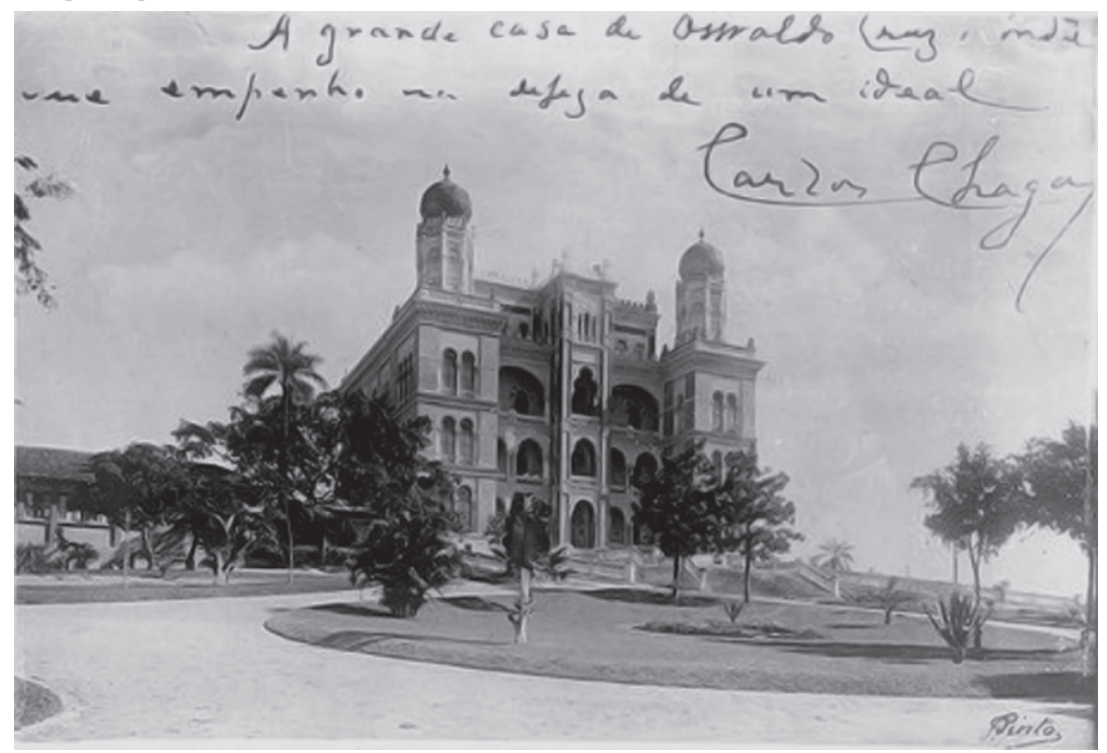

Fonte: Acervo Arquivo Casa de Oswaldo Cruz / Foto: J. Pinto.

3 - Carlos Chagas e Belisário Penna com a equipe que trabalhava nas obras da Estrada de Ferro Central do Brasil no norte de Minas Gerais, entre Corinto e Pirapora, [1908]. Chagas é o primeiro à direita

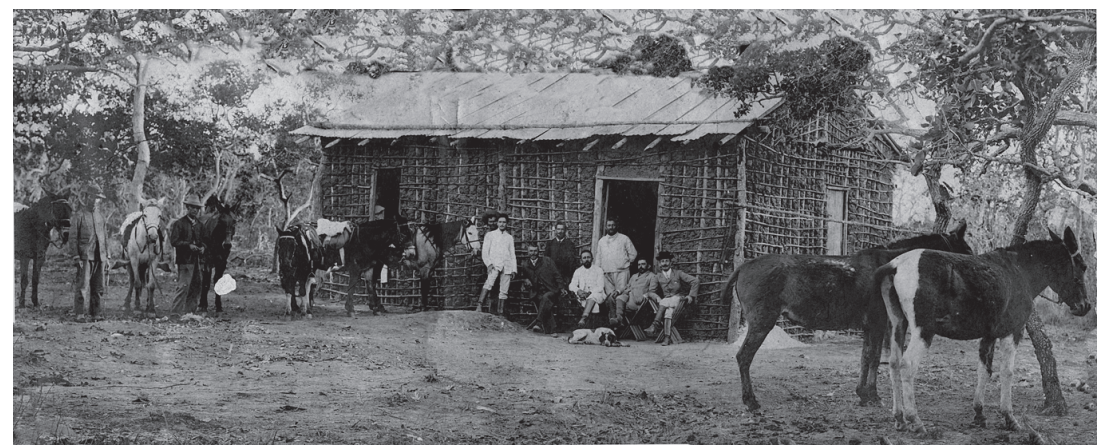

Fonte: Acervo Arquivo Casa de Oswaldo Cruz. 
4 - Estação da Estrada de Ferro Central do Brasil em Lassance, inaugurada em fevereiro de 1908

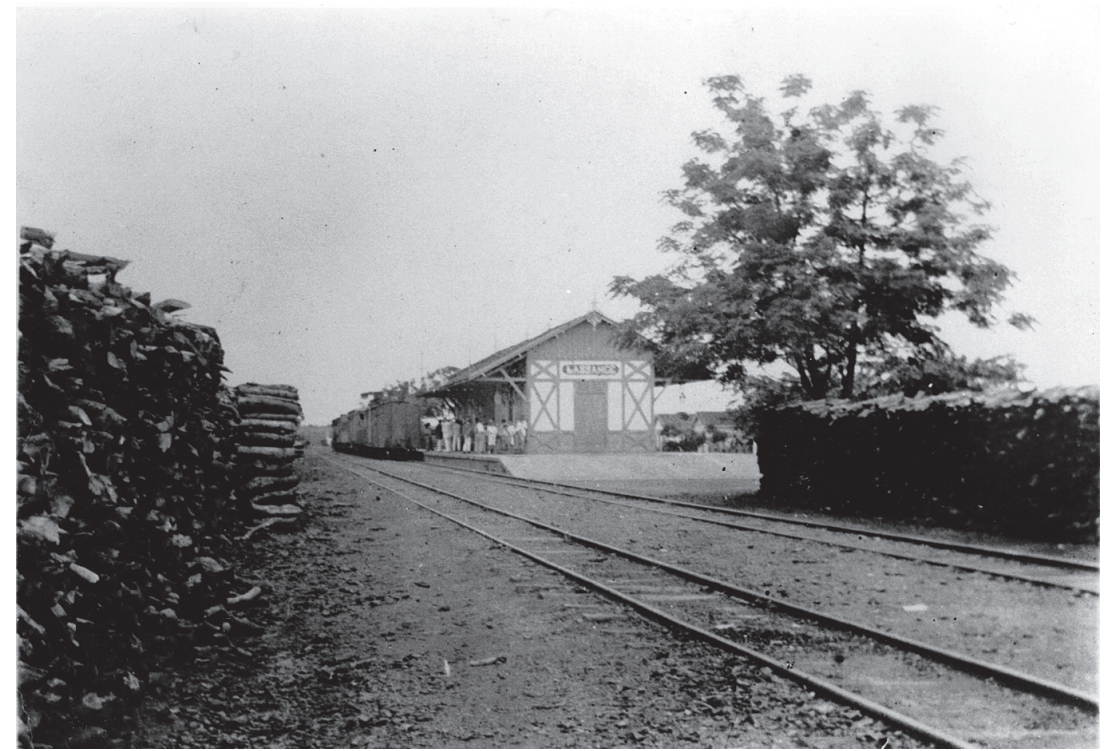

Fonte: Acervo Arquivo Casa de Oswaldo Cruz.

5 - Legenda original: "Estampa 1. Conorrhinus megistus Burm., transmissor de Schizotrypanum cruzi". Prancha de Castro Silva publicada em artigo de Carlos Chagas nas Memórias do Instituto Oswaldo Cruz, em 1909

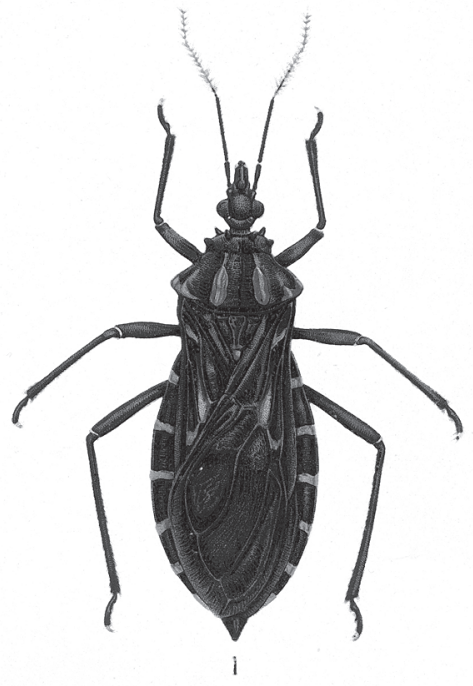

Fonte: Chagas, 1909d. 
6 - Legenda original: "Estampa 13. Preparados do Schizotrypanum cruzi". Prancha de Castro Silva publicada em artigo de Carlos Chagas nas Memórias do Instituto Oswaldo Cruz, em 1909

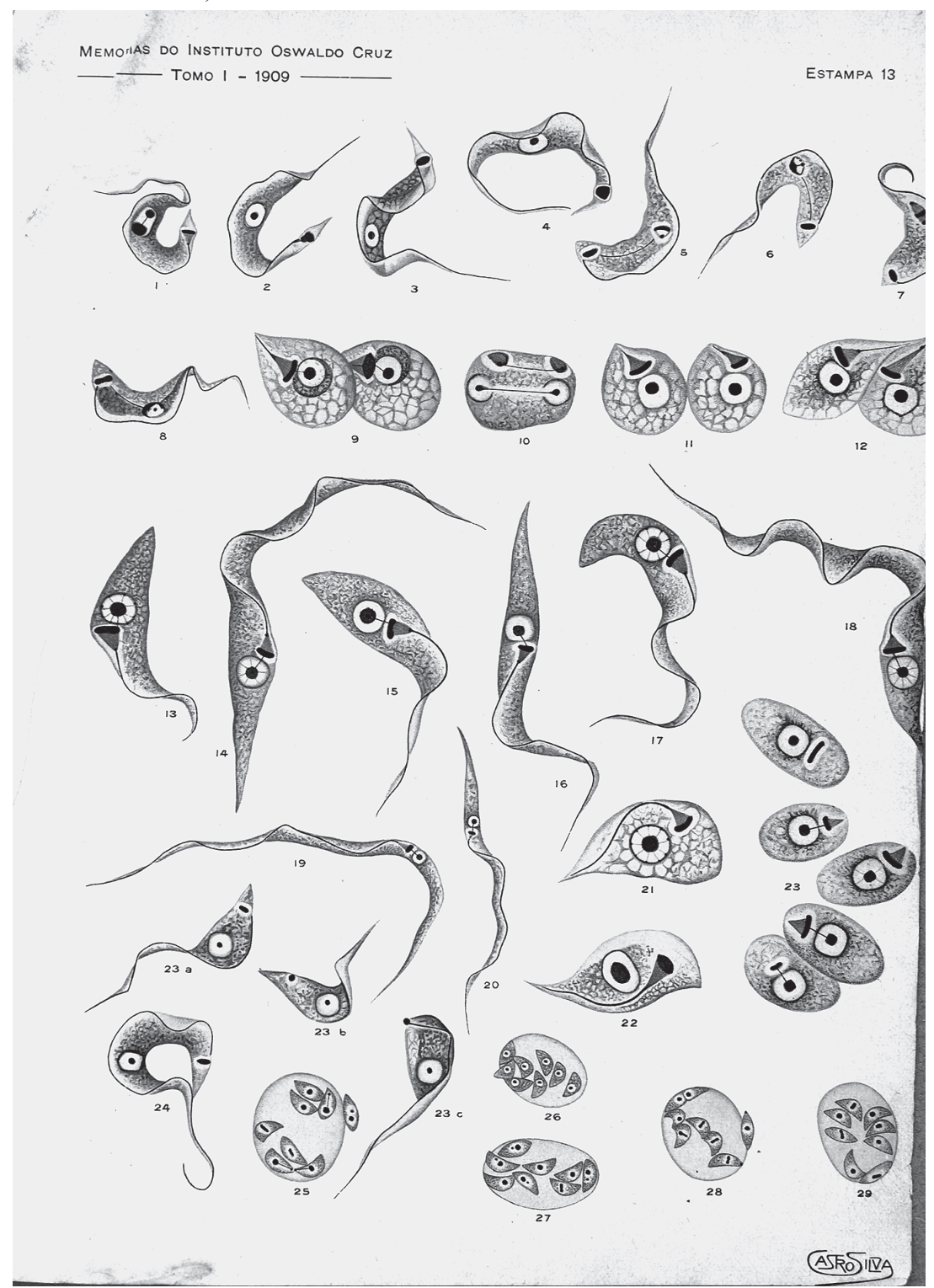

Fonte: Chagas, 1909d. 
7 - Cafua em Lassance

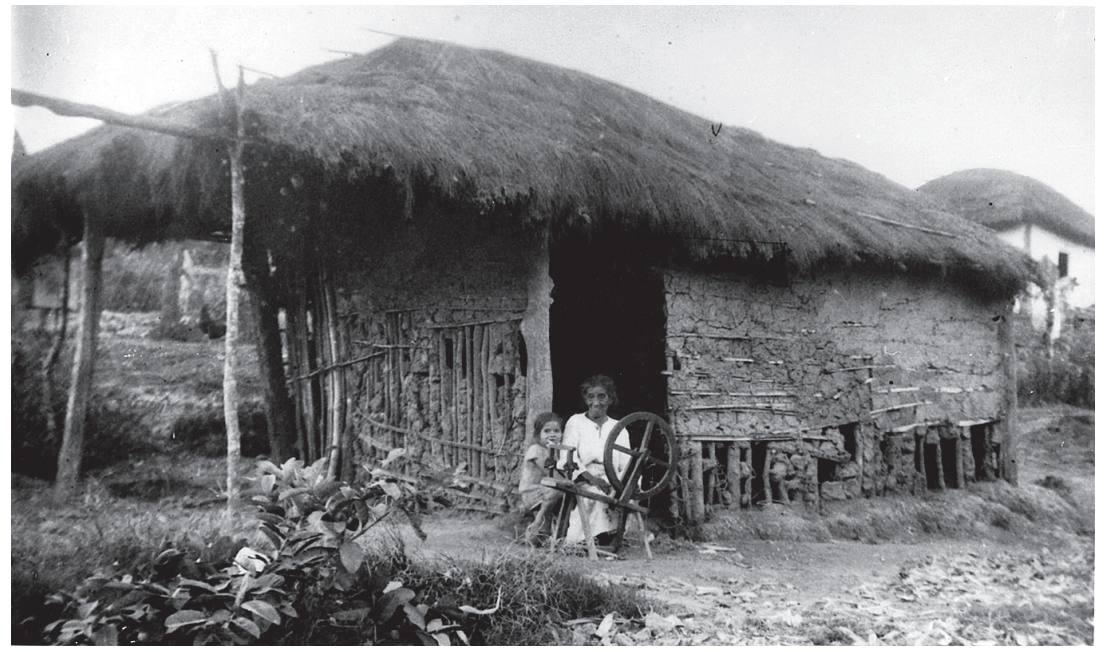

Fonte: Acervo Arquivo Casa de Oswaldo Cruz.

8 - Carlos Chagas examinando Rita, um dos primeiros casos agudos identificados da tripanossomíase americana em Lassance, início de 1910. Durante muito tempo, pensou-se que esta menina era Berenice, o primeiro caso identificado da doença de Chagas

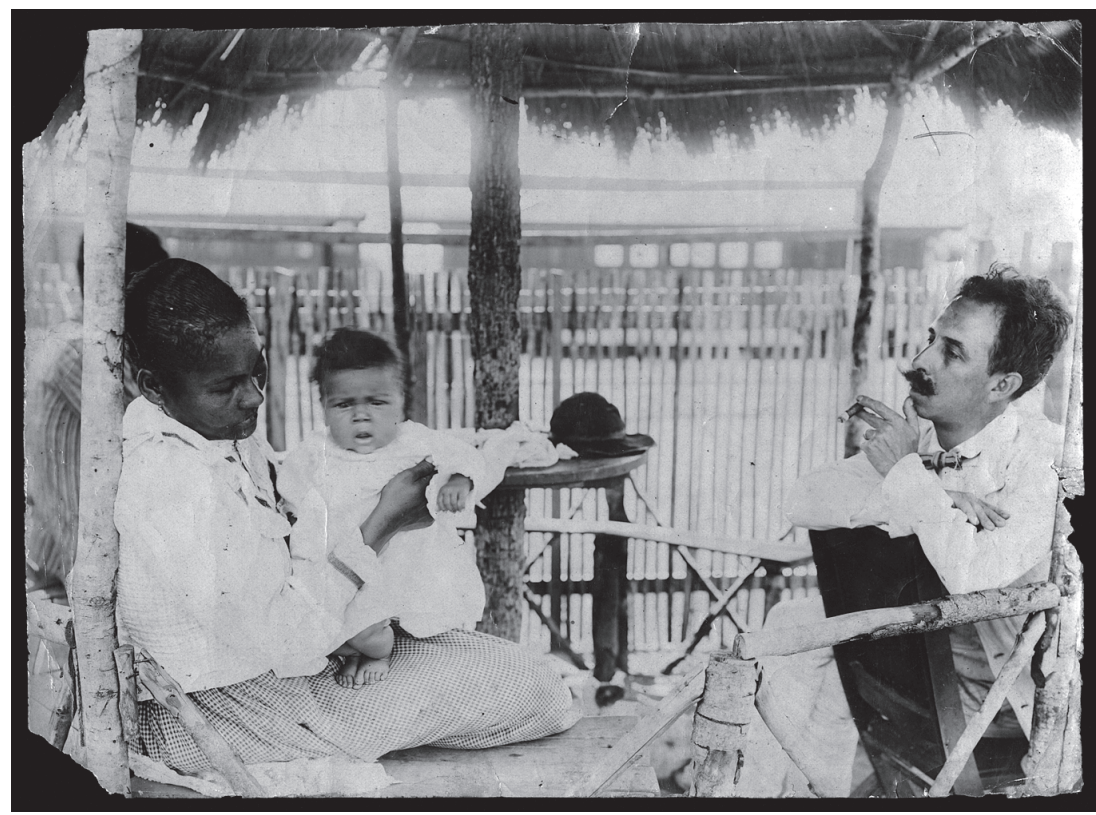

Fonte: Acervo Arquivo Casa de Oswaldo Cruz. 
9 - Hospital Regional de Lassance

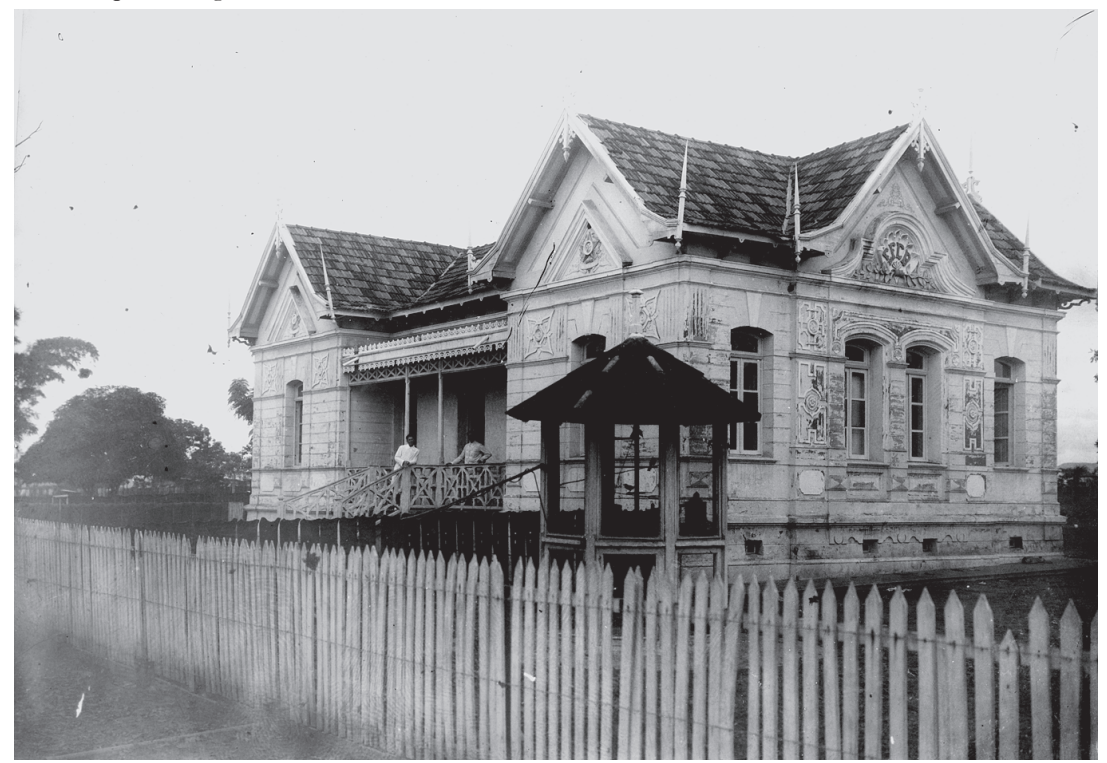

Fonte: Acervo Arquivo Casa de Oswaldo Cruz.

10 - Hospital Oswaldo Cruz, em Manguinhos. Inaugurado em 1918, foi denominado Hospital Evandro Chagas em 1941. Atualmente, é o Instituto de Pesquisa Clínica Evandro Chagas/Fiocruz

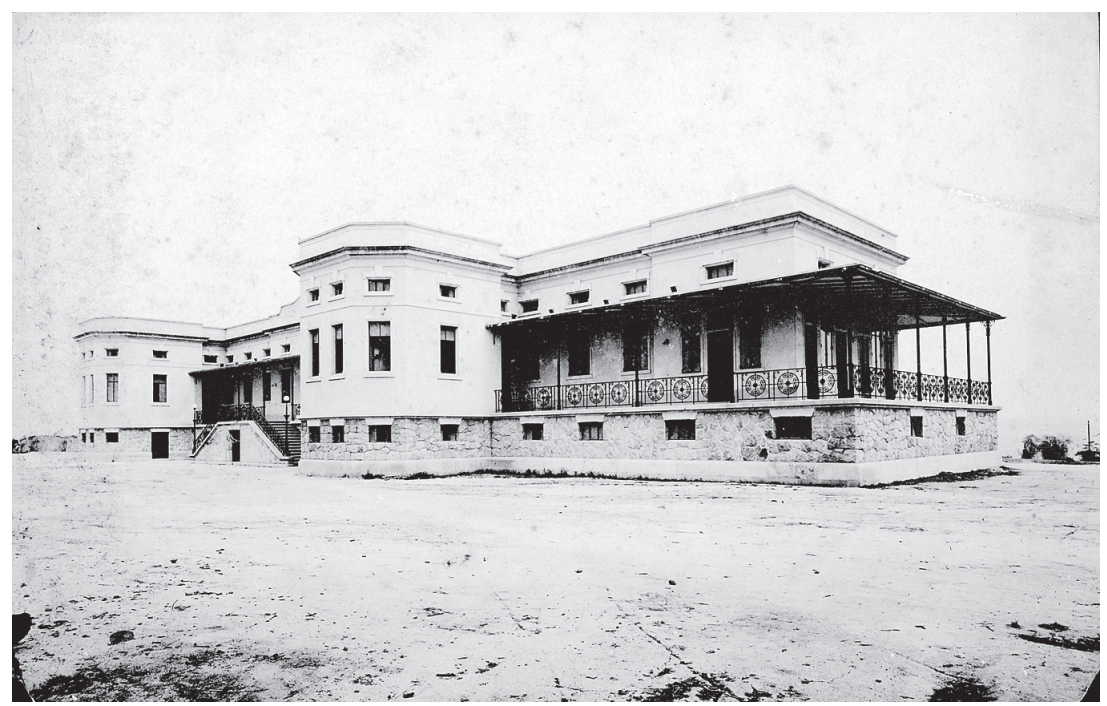

Fonte: Acervo Arquivo Casa de Oswaldo Cruz. 
11 - Carlos Chagas com pacientes no Hospital Oswaldo Cruz, em Manguinhos. Entre as crianças, vêem-se portadores de bócio e de distúrbios neurológicos atribuídos à tripanossomíase

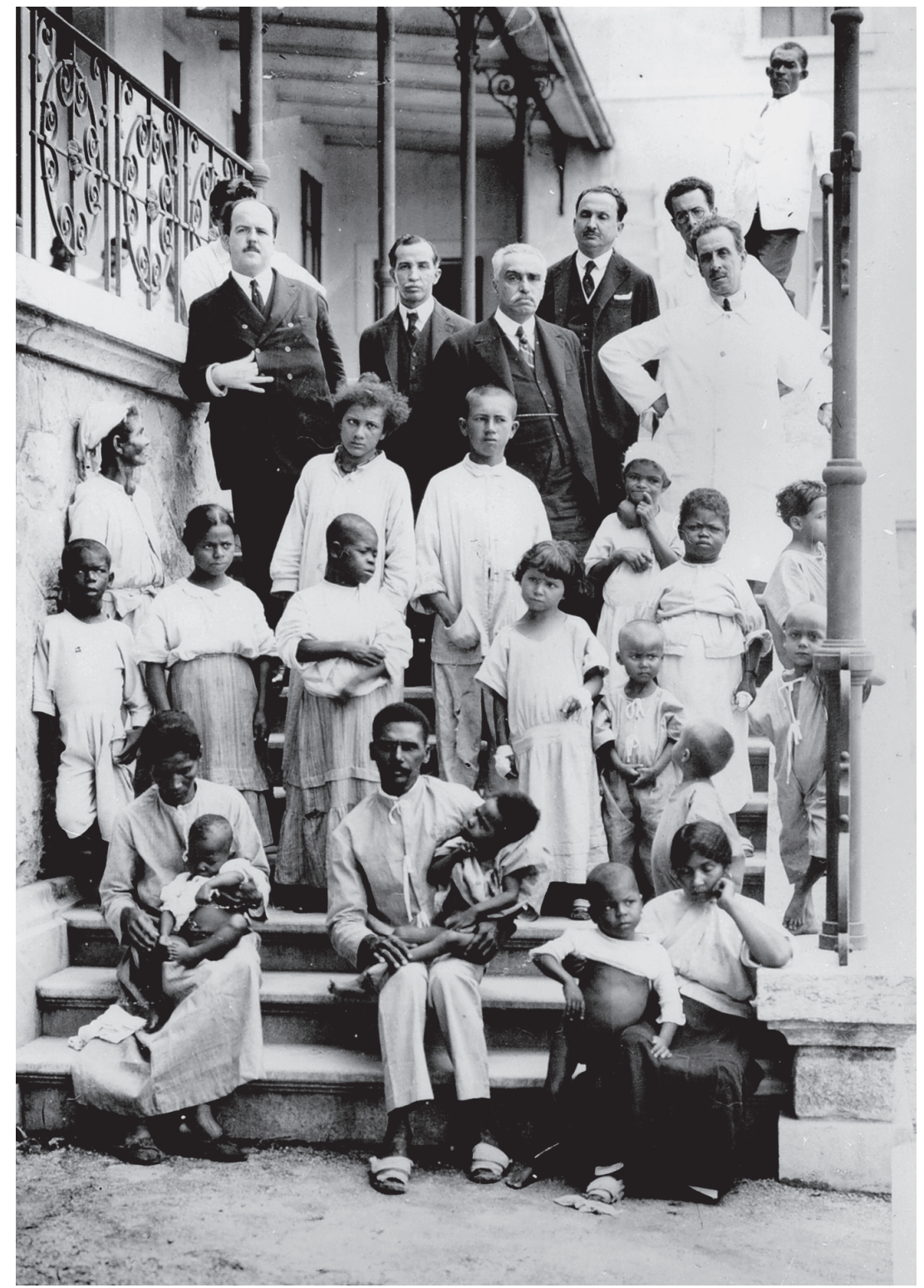

Fonte: Acervo Arquivo Casa de Oswaldo Cruz. 
12 - Materiais relativos à doença de Chagas, em sala do pavilhão brasileiro na Exposição Internacional de Higiene e Demografia, em Dresden, Alemanha, junho de 1911

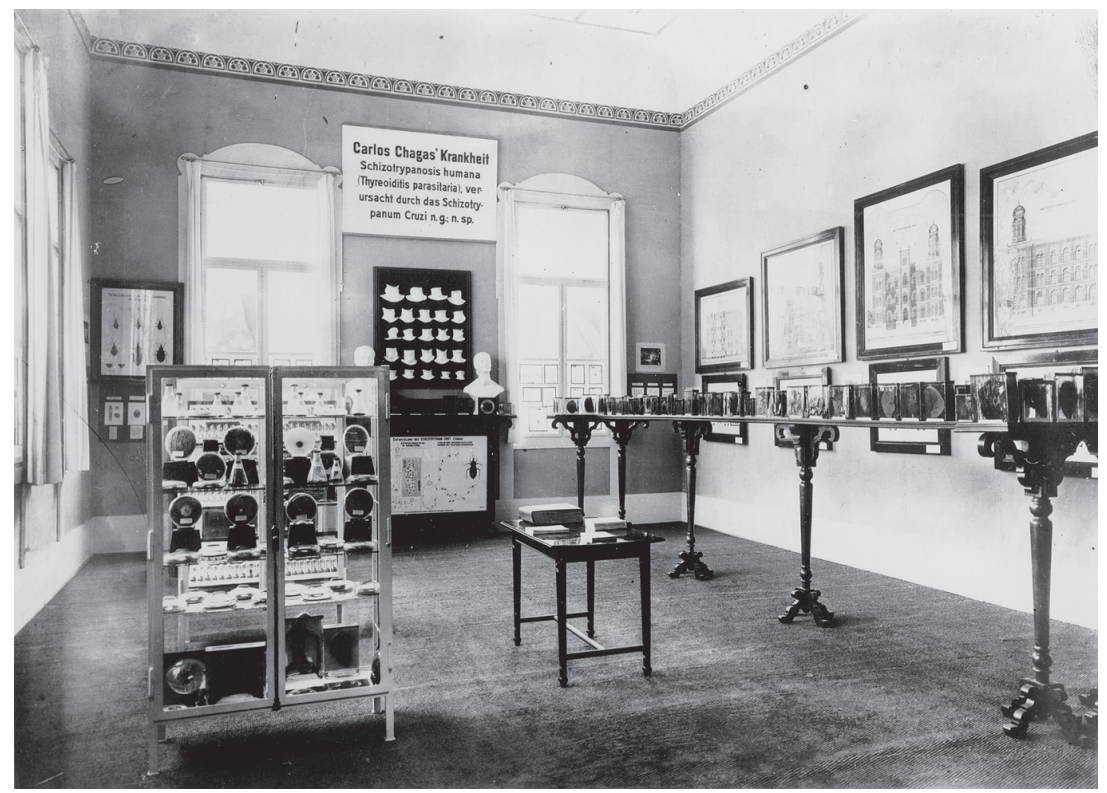

Fonte: Acervo Arquivo Casa de Oswaldo Cruz.

13 - Grupo de mulheres portadoras de bócio fotografadas durante expedição de Arthur Neiva e Belisário Penna. Goiás, 1912

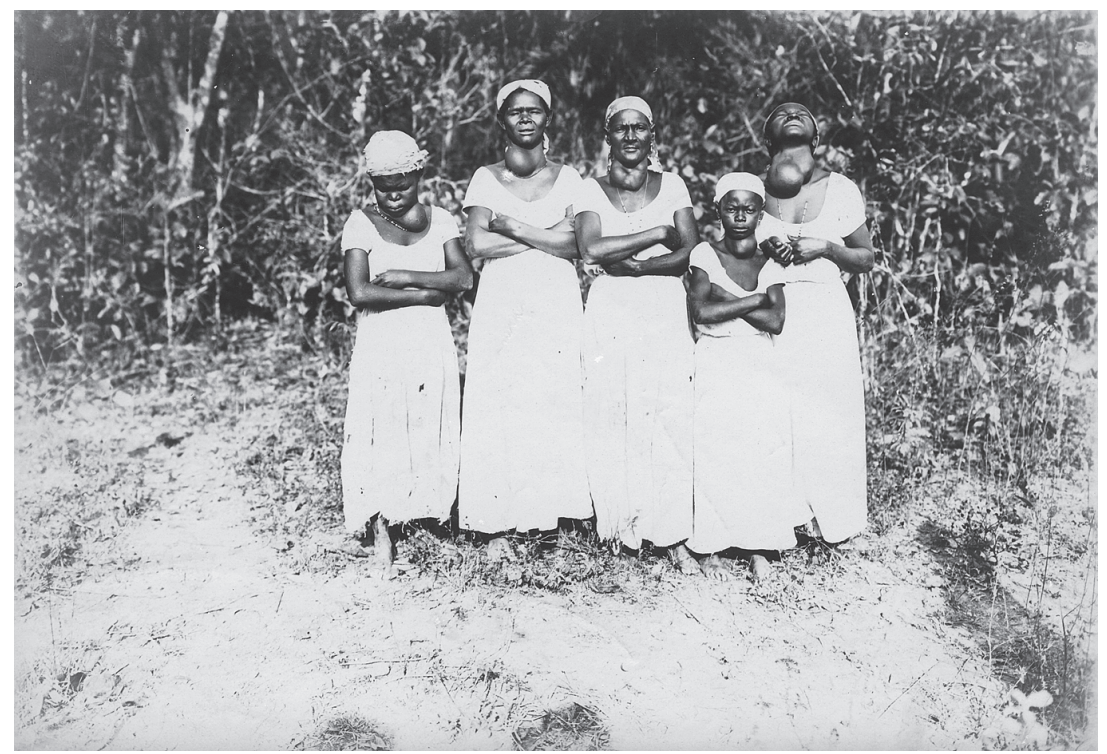

Fonte: Acervo Arquivo Casa de Oswaldo Cruz. 
14 - "Casos fotografados no sertão de Amaro Leite - Goiás. Portadores de bócio, inteligência rudimentar e má articulação da palavra" (Legenda original em Neiva e Penna, 1916 - Imagem 101). Goiás, 1912

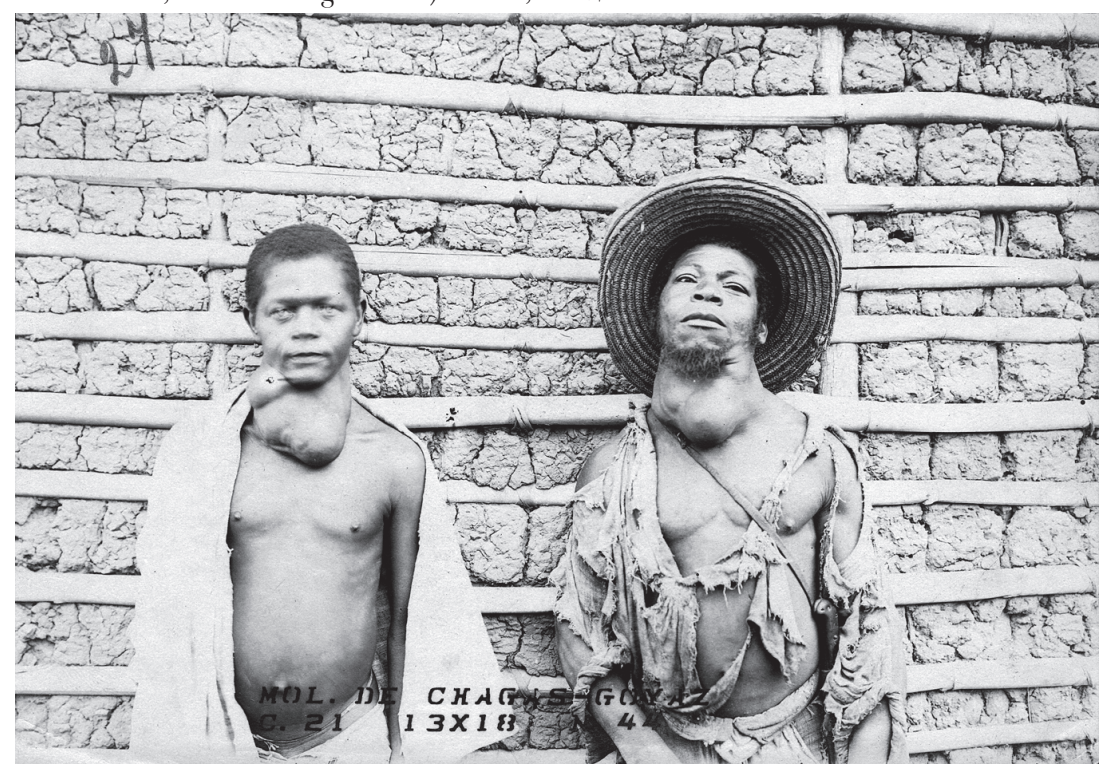

Fonte: Acervo Arquivo Casa de Oswaldo Cruz.

15 - "Grupo de cretinos. Asilo S. Francisco de Paula" (Legenda original em Neiva e Penna, 1916 - Imagem 97). Goiás, 1912

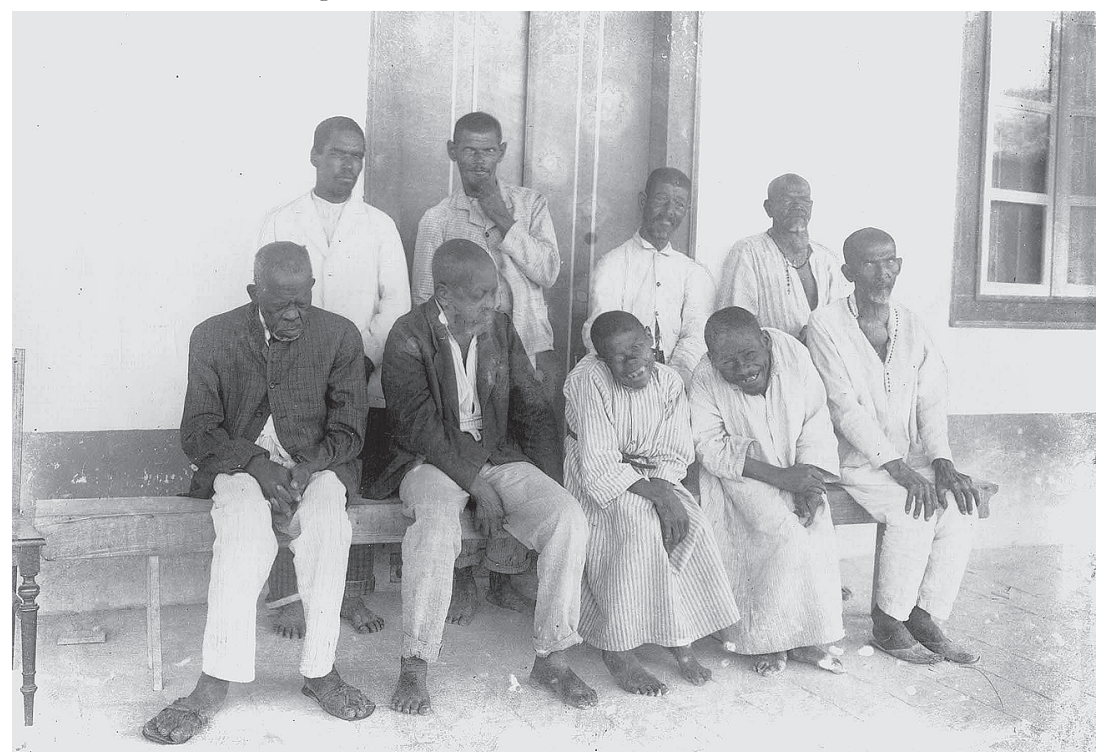

Fonte: Acervo Arquivo Casa de Oswaldo Cruz. 
16 - "(...) Fotografia tirada no Asilo S. Francisco de Paula, Capital de Goiás, onde os doentes foram identificados como representantes das várias modalidades clínicas descritas por Chagas e encontradas em Minas Gerais" (Legenda original em Neiva e Penna, 1916 - Imagem 96). Goiás, 1912. Publicada também em Penna, 1918b:

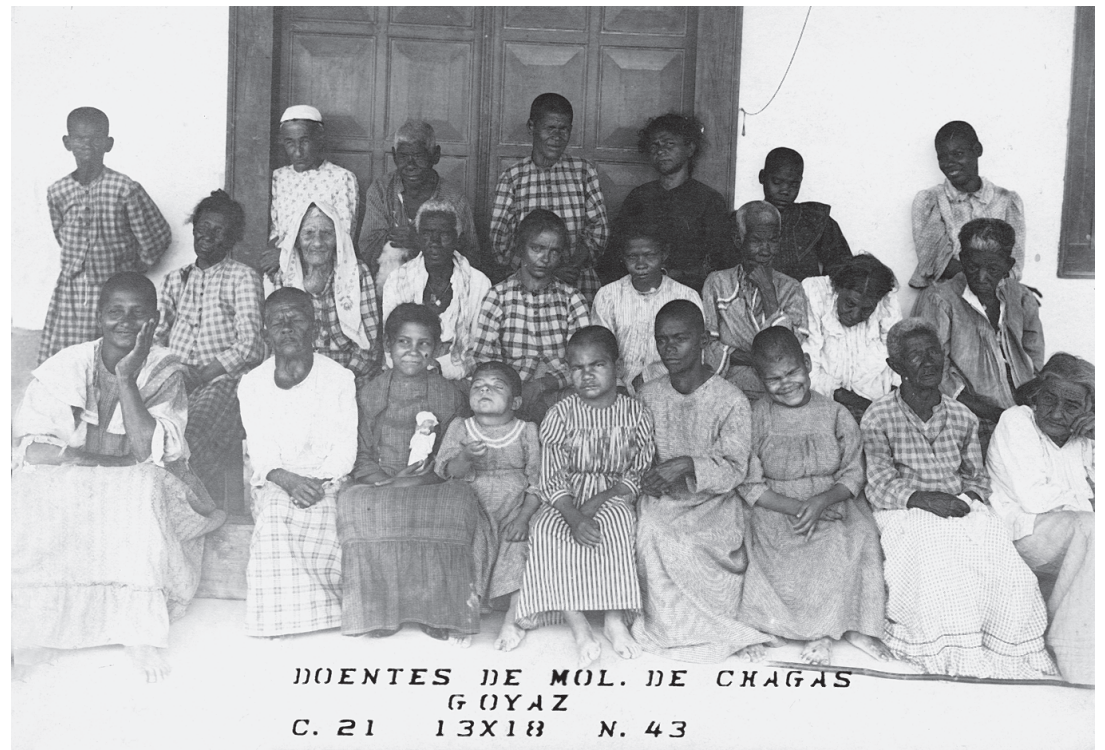

96

Fonte: Acervo Arquivo Casa de Oswaldo Cruz.

17 - Emmanuel Dias e Evandro Chagas, por ocasião da IX Reunião da Misión de Estudios de Patología Regional Argentina (Mepra) em Mendoza. Argentina, 1935

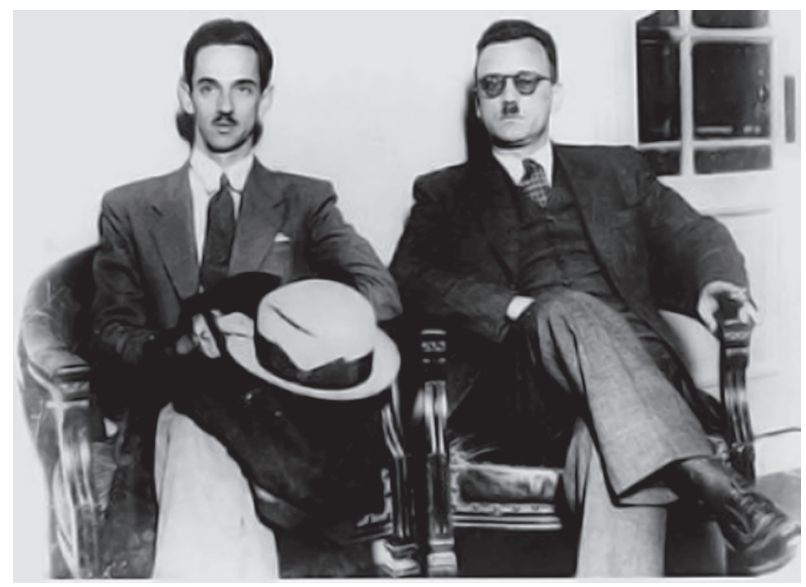

Fonte: Acervo Arquivo Casa de Oswaldo Cruz. 
18 - Maria Albina da Silva, primeiro caso agudo da doença de Chagas identificado em Bambuí, em 1940. Vê-se o 'sinal do olho' ou 'sinal de Romaña'

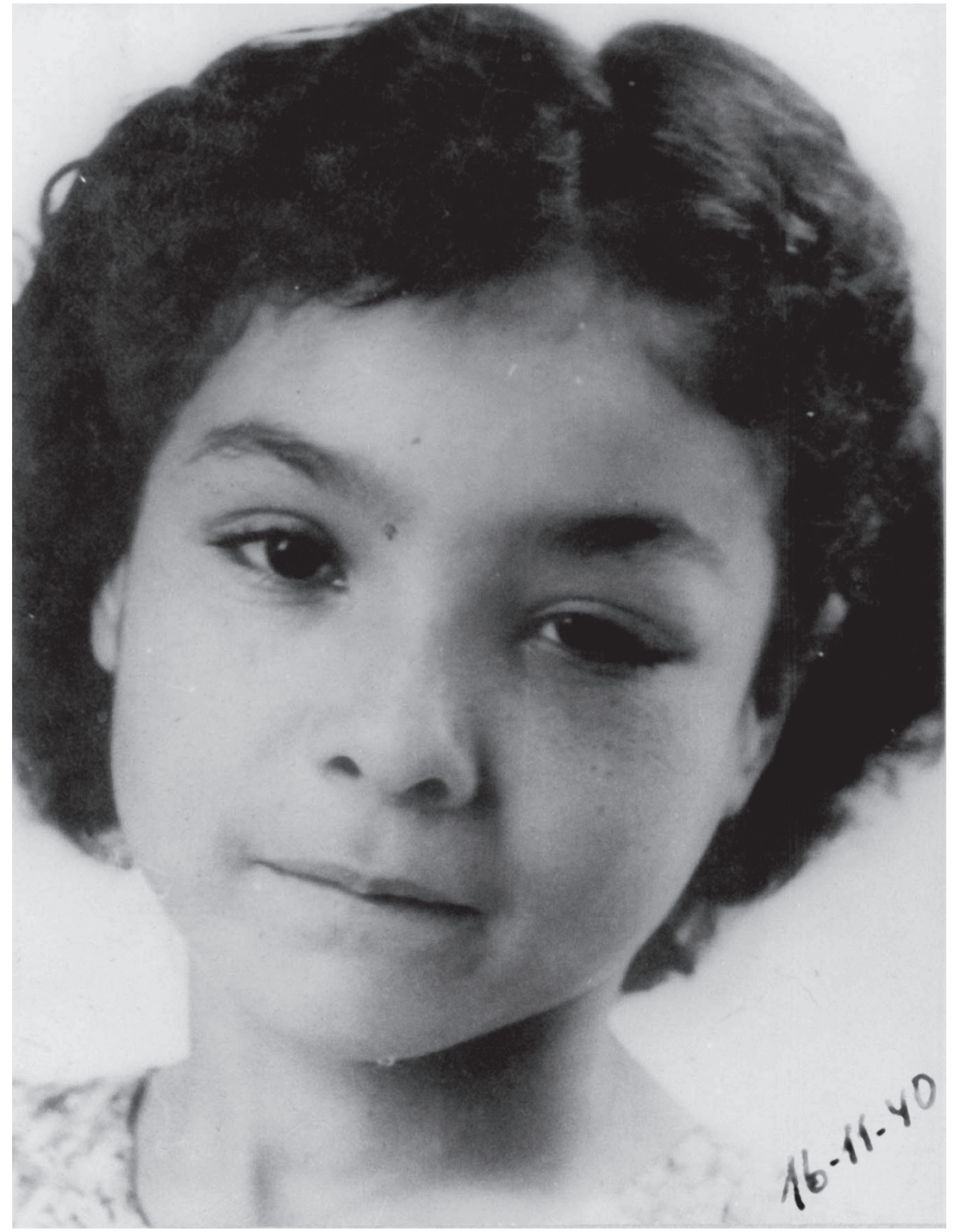

Fonte: Acervo Arquivo Casa de Oswaldo Cruz. 
19 - Folheto de propaganda de eletrocardiógrafo Sanborn, década de 1940

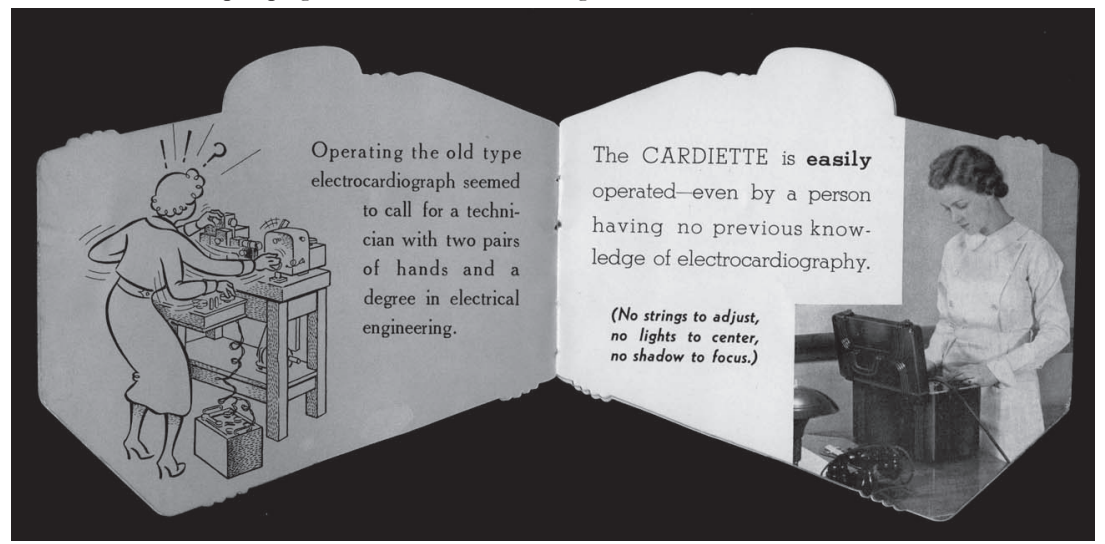

Fonte: Acervo Arquivo Casa de Oswaldo Cruz.

20 - Emmanuel Dias e moradores de Bambuí no Centro de Estudos e Profilaxia da Moléstia de Chagas, década de 1940

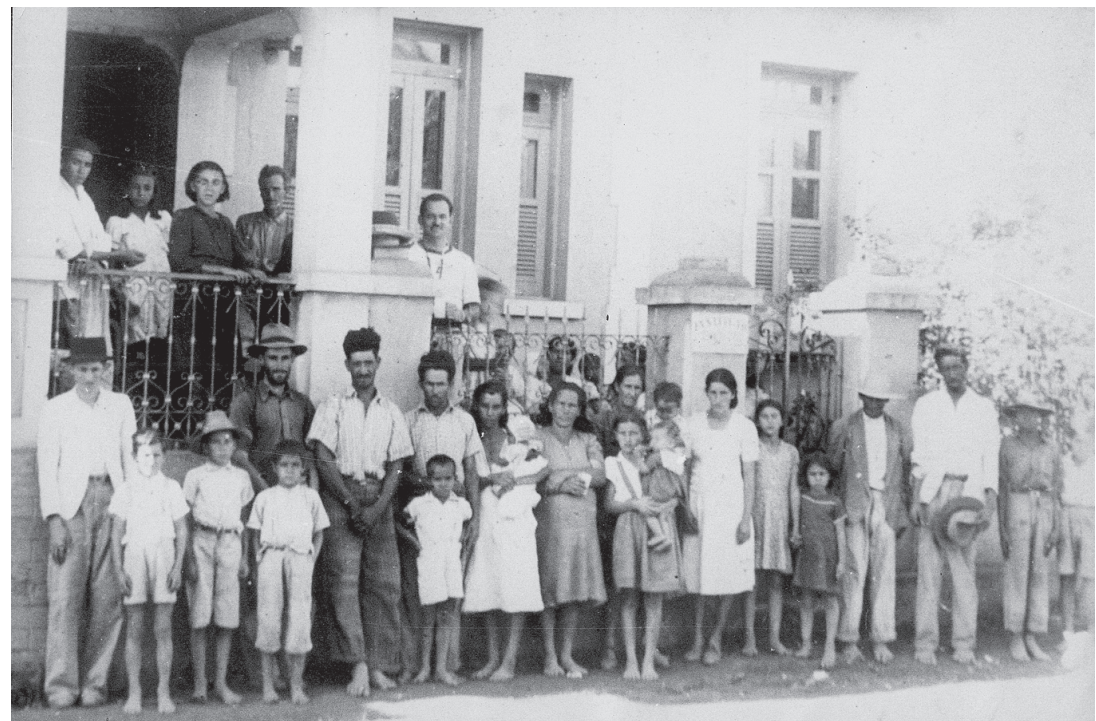

Fonte: Acervo Arquivo Casa de Oswaldo Cruz. 
21 - Emmanuel Dias examinando moradora de Bambuí, junto a eletrocardiógrafo. Bambuí, década de 1940. A imagem desta senhora, em cujos braços se vêem caixas com barbeiros para a realização do xenodiagnóstico, foi publicada em Dias (1946c)

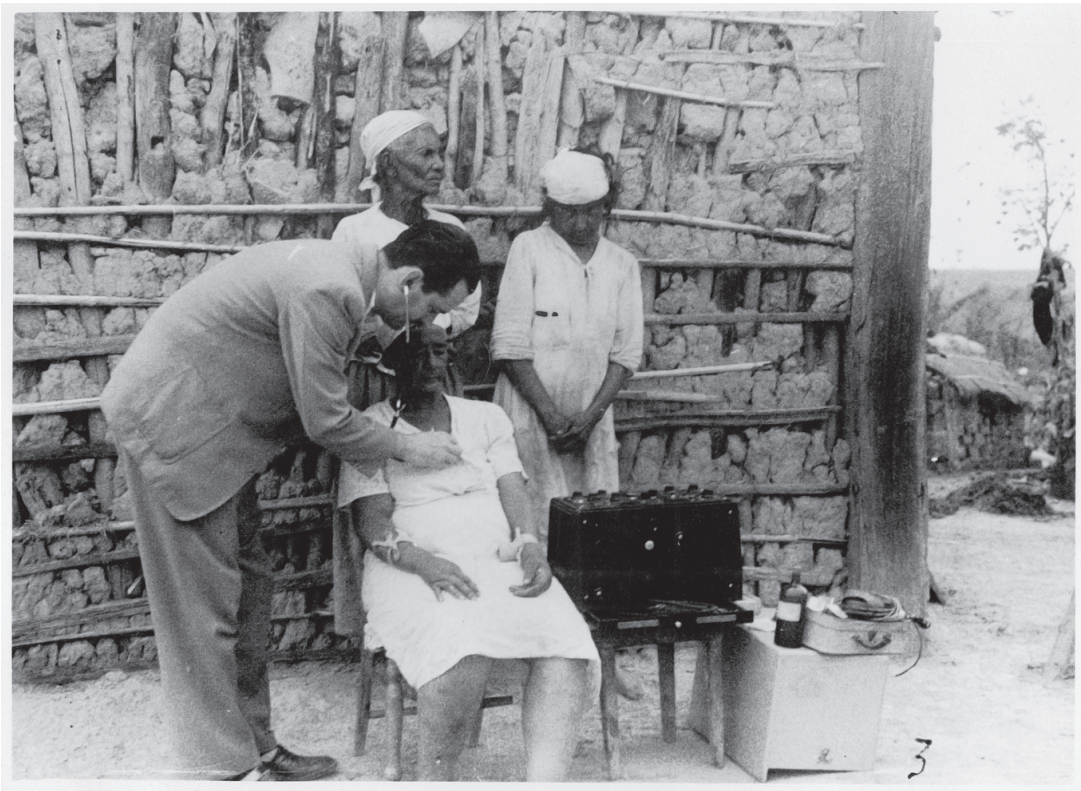

Fonte: Acervo Arquivo Casa de Oswaldo Cruz.

22 - Emmanuel Dias e Antonio, funcionário do Centro de Estudos e Profilaxia da Moléstia de Chagas, fumigando inseticida em moradia. Bambuí, 1944-1945

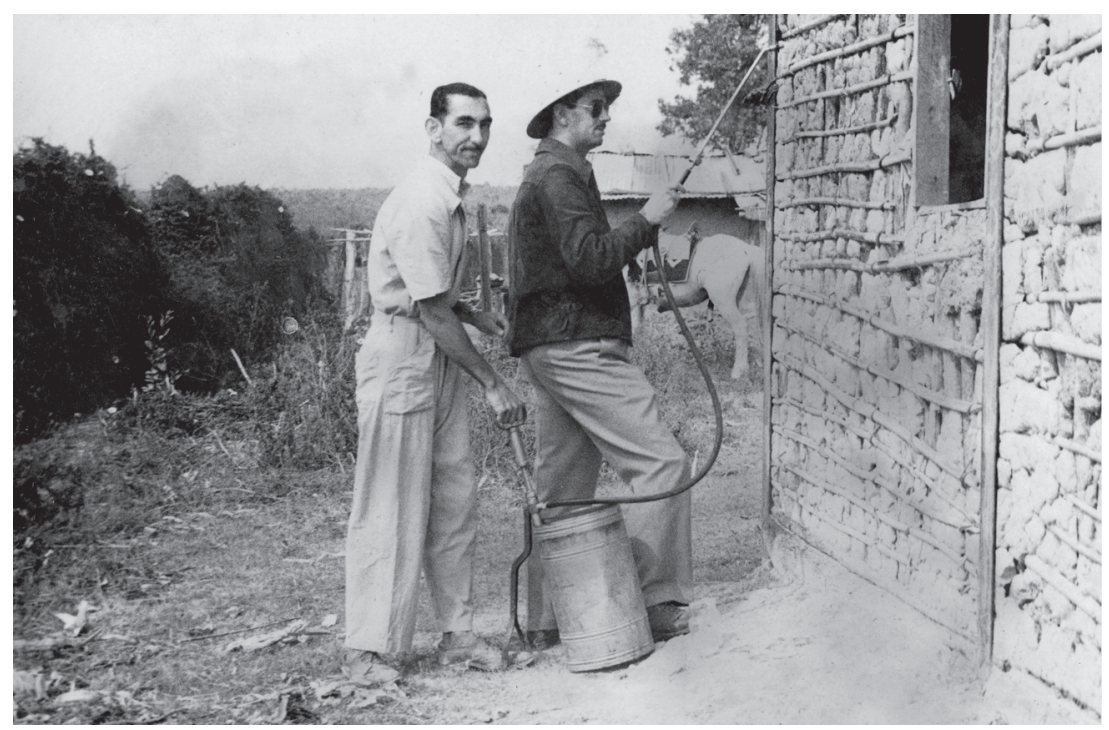

Fonte: Acervo Arquivo Casa de Oswaldo Cruz. 
23 - Expurgo com lança-chamas. Bambuí, 1944

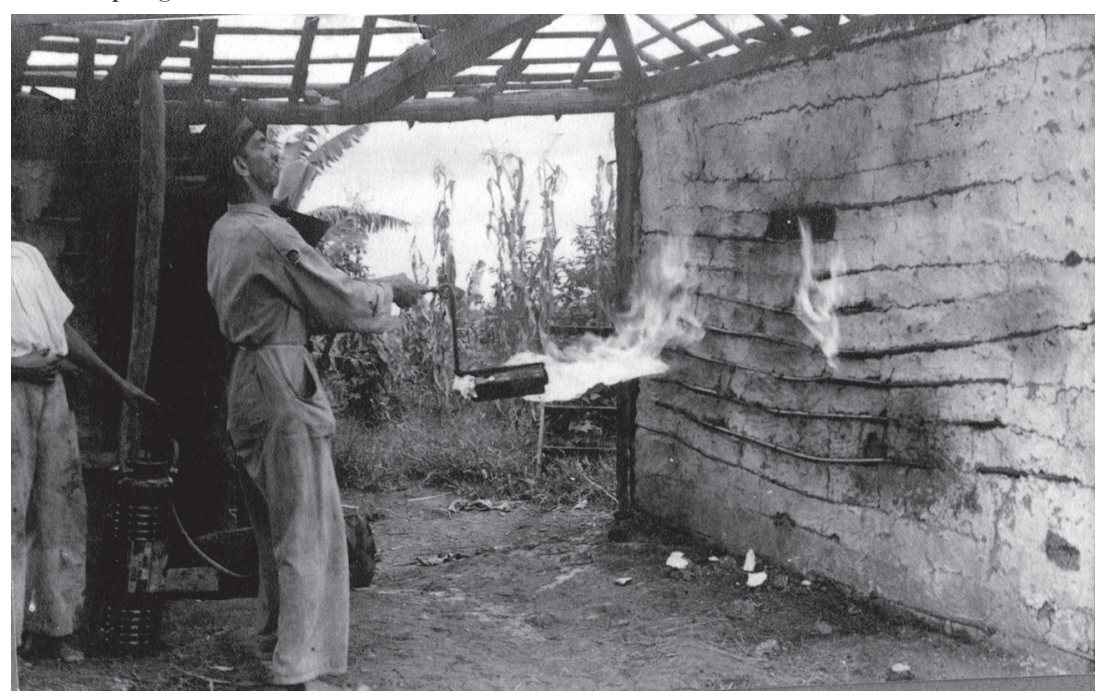

Fonte: Acervo Arquivo Casa de Oswaldo Cruz.

24 - Casa reformada pelo Centro de Estudos e Profilaxia da Moléstia de Chagas. Bambuí, década de 1940

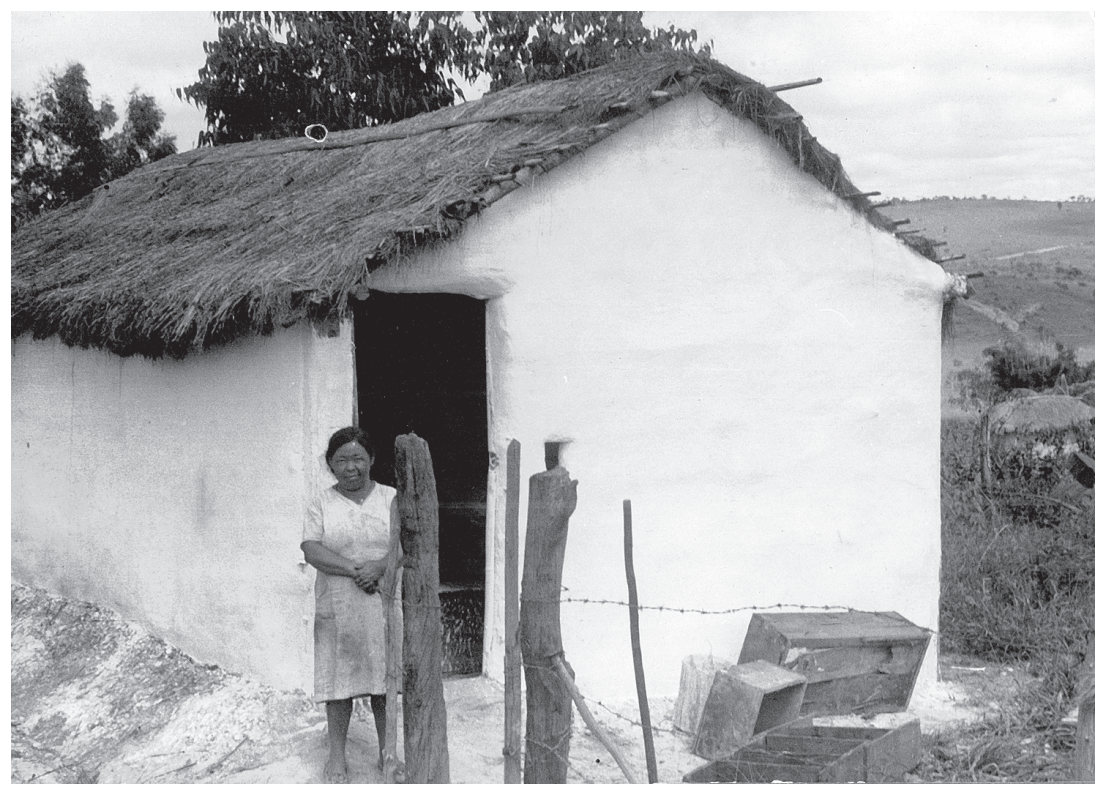

Fonte: Acervo Arquivo Casa de Oswaldo Cruz/Fiocruz. 
25 - Cartaz chamando a atenção para a necessidade de profilaxia da doença de Chagas.

Ministério da Educação e Saúde, Instituto Oswaldo Cruz. Bambuí, 1944

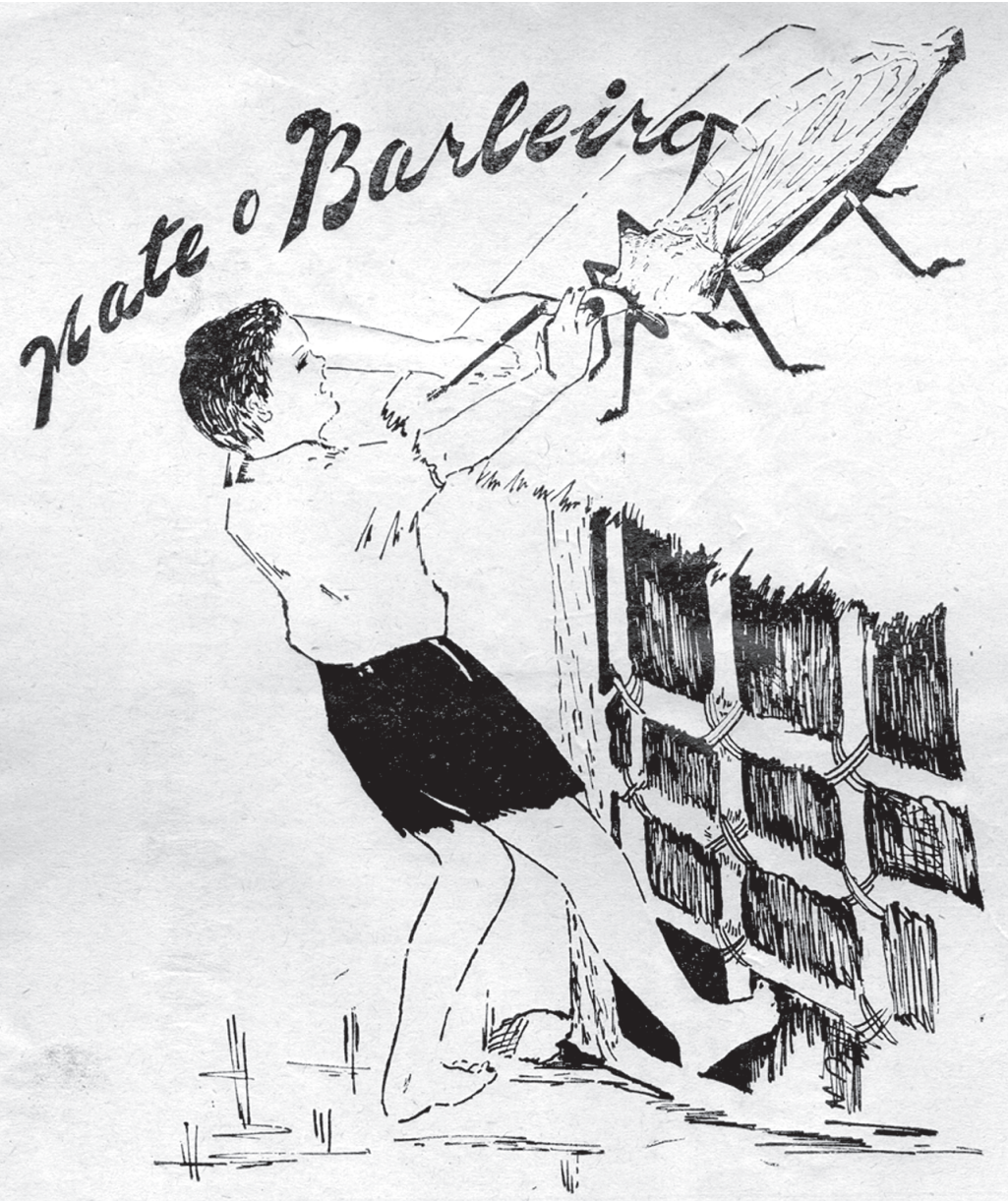

M. E. S. - D. N. S.

Instituto Oswaldo Cruz - D. E. E.

Centro de estudos e profilaxia de molestia de chagas - Bambuí, M. G.

D. ALVES

Fonte: Acervo Arquivo Casa de Oswaldo Cruz/Fiocruz. 
26 - Francisco Laranja, Olympio da Fonseca Filho e Emmanuel Dias. Bambuí, 1949

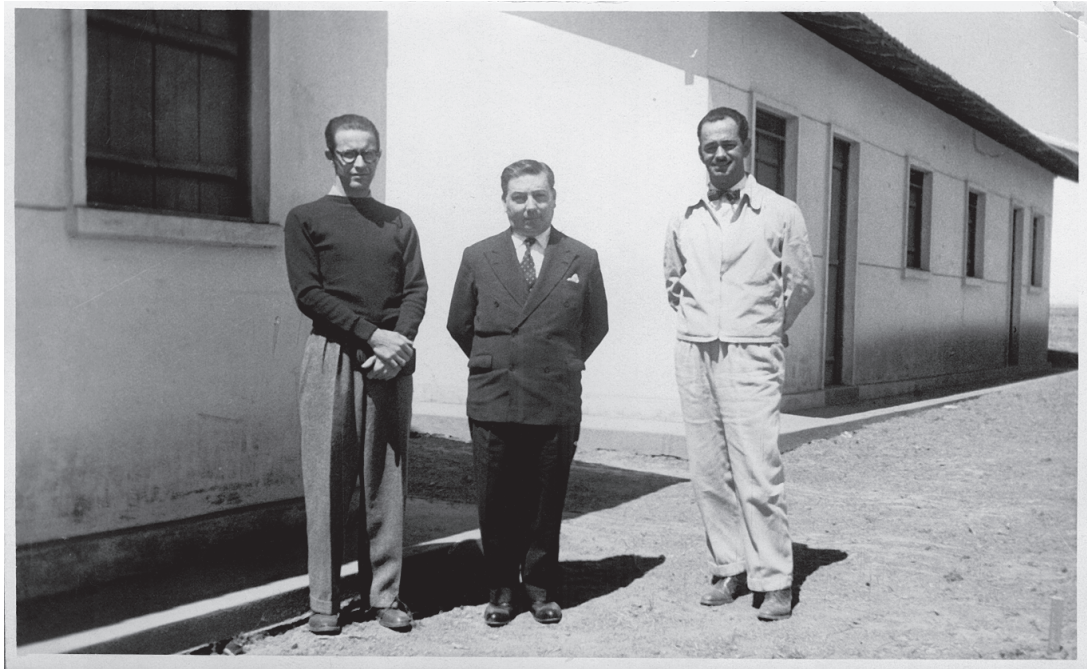

Fonte: Acervo Arquivo Casa de Oswaldo Cruz/Fiocruz.

27 - Exposição sobre a obra de Carlos Chagas, no Palais de la Découverte. Paris, 1955. Foto-montagem do laboratório de Chagas em Manguinhos

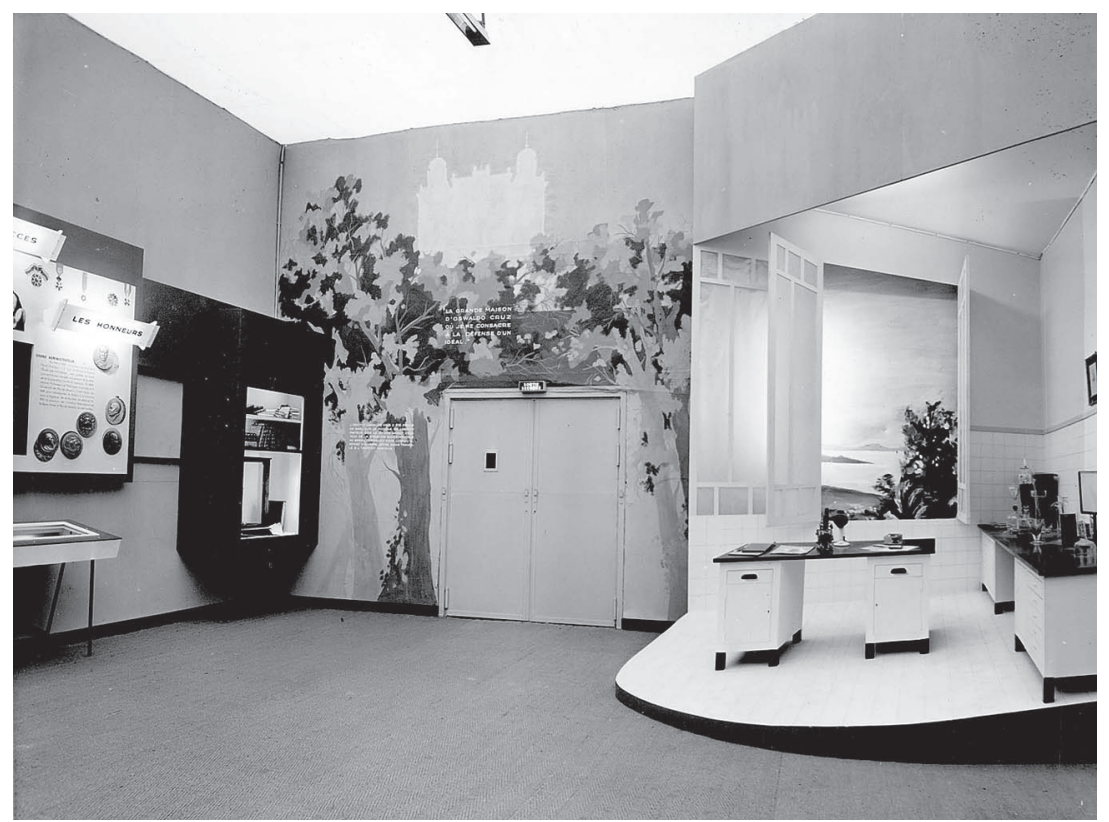

Fonte: Acervo Arquivo Casa de Oswaldo Cruz/Fiocruz. 
28 - Exposição sobre a obra de Carlos Chagas, no Palais de la Découverte. Paris, 1955. Cafua cenográfica

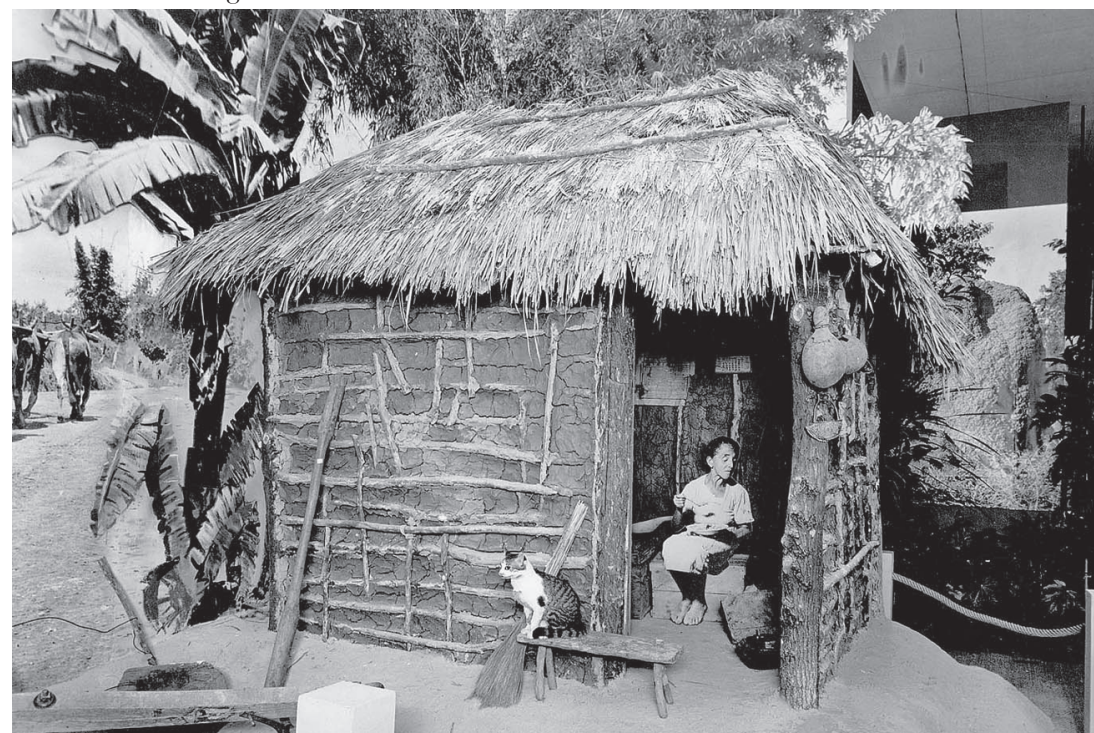

Fonte: Acervo Arquivo Casa de Oswaldo Cruz/Fiocruz

29 - Exposição sobre a obra de Carlos Chagas, no Palais de la Découverte. Reservatórios silvestres do T. cruzi (sagüi e gambá), mapa da América do Sul mostrando a distribuição da doença e, no painel de cima, realização de exames eletrocardiográficos e radiológicos. Paris, 1955.

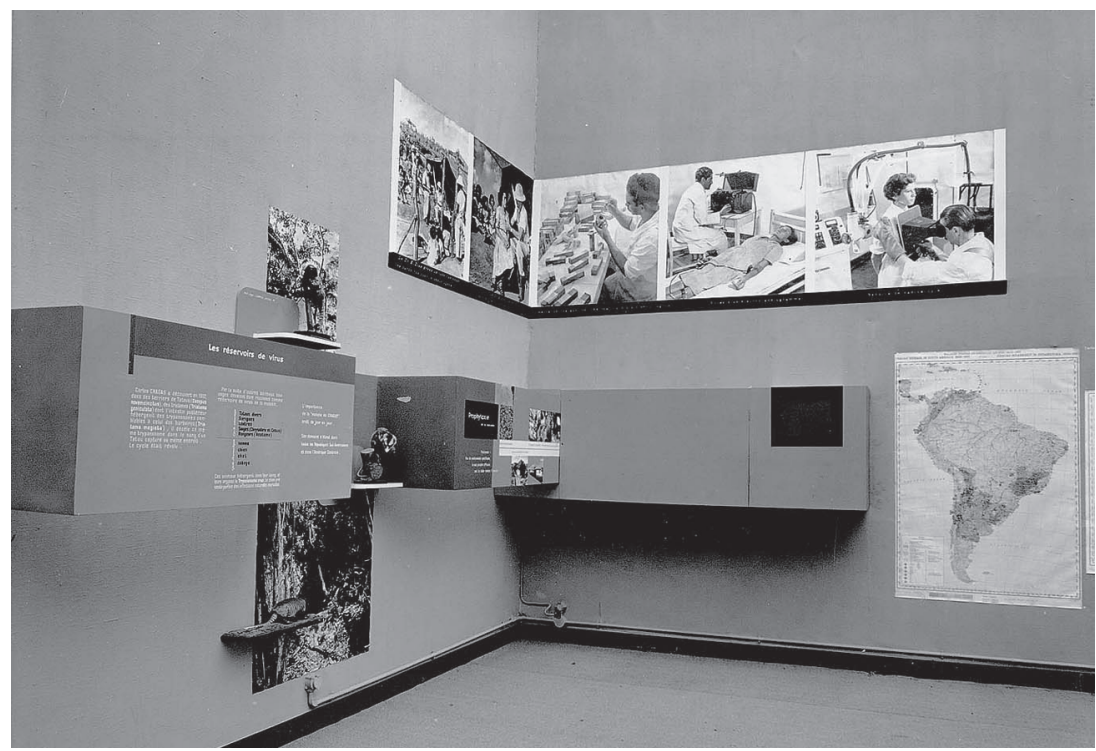

Fonte: Acervo Arquivo Casa de Oswaldo Cruz. 
29 - Exposição sobre a obra de Carlos Chagas, no Palais de la Découverte. Detalhe da foto anterior

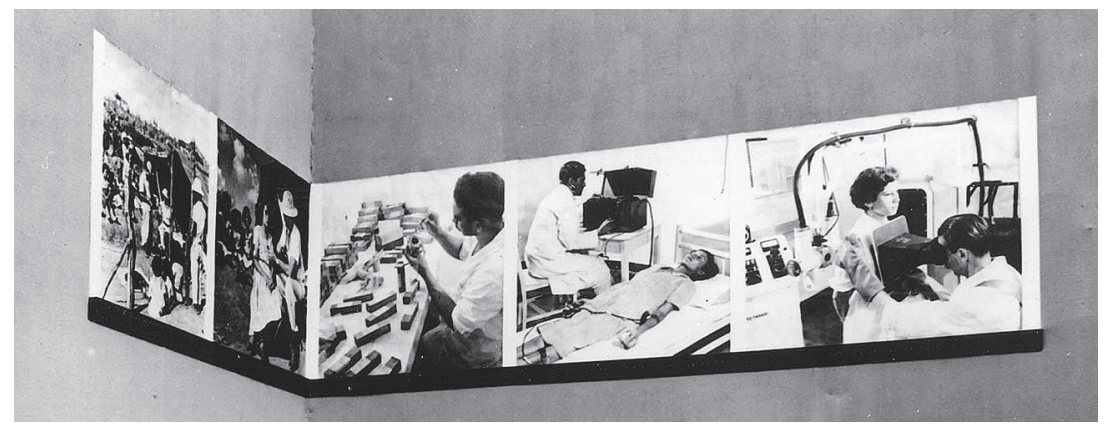

Fonte: Acervo Arquivo Casa de Oswaldo Cruz.

30 - Exposição sobre a obra de Carlos Chagas, no Palais de la Découverte. Paris, 1955. São apresentadas algumas das 'grandes obras do Brasil moderno', como a usina siderúrgica de Volta Redonda e hidrelétricas

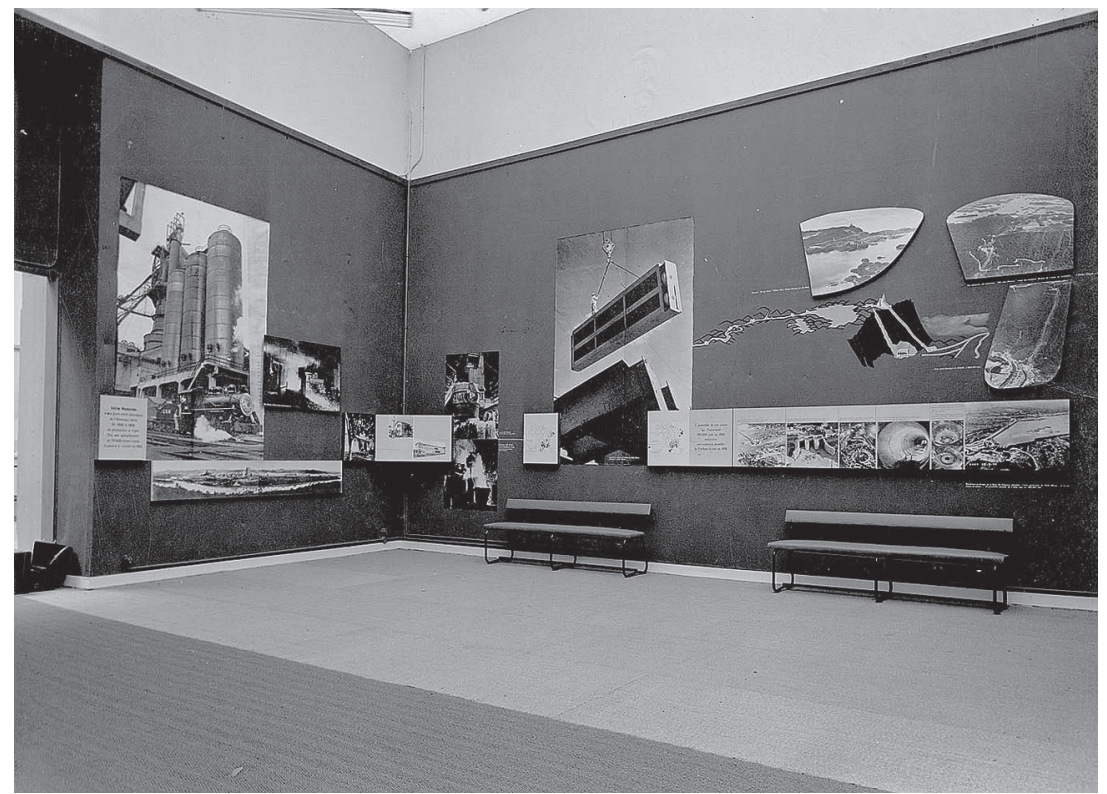

Fonte: Acervo Arquivo Casa de Oswaldo Cruz. 


\section{Fontes e Referências}

\section{I - Fontes Primárias}

\section{Arquivos Institucionais}

Arquivos da Casa de Oswaldo Cruz/Fundação Oswaldo Cruz (COC/Fiocruz)

Arquivo do Dicionário Histórico-Biográfico das Ciências da Saúde no Brasil (18321930)

Fundo Arthur Neiva

Fundo Belisário Penna

Fundo Carlos Chagas

Fundo Carlos Chagas Filho

Fundo Evandro Chagas

Fundo Cornélio Homem Cantarino Mota

Fundo Centro de Pesquisas René Rachou/Seção Posto Avançado de Pesquisas Emmanuel Dias

Fundo Instituto Oswaldo Cruz

Setor de Imagem em Movimento 
Arquivo do Centro de Pesquisa e Documentação de História Contemporânea do Brasil/Fundação Getúlio Vargas (CPDOC/FGV)

Arquivo Gustavo Capanema

\section{II - Fontes Impressas}

A CIDADE. Doença de Chagas. Combate intensivo ao terrível mal caboclo. A Cidade, Ribeirão Preto, 23 jun. 1950.

A CIDADE. Combatendo a moléstia de Chagas. Realizou-se na Faculdade de Medicina importante reunião. A Cidade, Ribeirão Preto, 7 abr. 1957.

A EPHOCA. Instituto de Manguinhos. Carlos Chagas substitui Oswaldo Cruz. A Ephoca, Rio de Janeiro, 15 fev. 1917.

A GAZETA. Plano quadrienal para combater as endemias. A Gazeta, São Paulo, 14 abr. 1951.

A IMPRENSA. Um terrivel flagello que assola os sertões centraes do Brasil. Minas, Bahia, Goyaz, Mato-Grosso e parte de São Paulo presas do horrivel morbus. Entrevista com o dr. Carlos Chagas, o sabio descobridor do temivel microbio. A Imprensa, Rio de Janeiro, 6 ago. 1911, p. 1.

A NOITE. O Brasil no exterior. O prêmio Schaudinn conferido ao Dr. Carlos Chagas. A Noite, Rio de Janeiro, 26 jun.1912, p.1.

A NOITE. Os nossos representantes ao Congresso Medico Argentino. A obra scientifica de Oswaldo Cruz no Prata. O Dr. Carlos Chagas dá-nos suas impressões. A Noite, Rio de Janeiro, 10 out. 1916a, p. 3.

A NOITE. Como se formam as novas gerações em localidades do interior. O Dr. Carlos Chagas concede-nos importante entrevista. A Noite, Rio de Janeiro, 24 out. 1916b, p. 1.

A NOITE. Como Chagas descobriu a molestia que lhe immortalisou o nome. Uma originalidade nas pesquisas scientificas posta em pratica pela primeira vez no Brasil. A Noite, Rio de Janeiro, 15 fev. 1917, p. 2.

A NOITE. Um exaggero: o Brasil é um vasto hospital! A molestia de Chagas na Argentina. Estudos e observações do professor Kraus. A Noite, Rio de Janeiro, 17 ago. 1920 a, p. 1.

A NOITE. O Brasil, um vasto hospital. Em torno da molestia de Chagas. O que nos diz uma autoridade scientifica. A Noite, Rio de Janeiro, 20 ago. 1920b, p. 2.

A NOITE. Específico contra doença de Chagas. A campanha contra os 'barbeiros', na palavra do ilustre cientista argentino dr. Cecilio Romana. A Noite, Rio de Janeiro, 10 jun. 1950, p. 11.

A NOTÍ́CIA. A nossa opinião. A Noticia, Rio de Janeiro, 7 dez. 1923, p. 2 
A NOTÍCIA. A 'Moléstia de Chagas' na XI Conferência Sanitária Pan-Americana. Os trabalhos em torno dessa grave doença no continente americano. Palavras do Dr. Carlos Chagas Filho, em torno das próximas atividades do importante certame científico. A Notícia, Rio de Janeiro, 21 ago. 1942.

A RUA. Um grande benemérito da cidade. A Rua, Rio de Janeiro, 9 jul. 1919a.

A RUA. O novo director da Saude Publica. O dr. Carlos Chagas concede-nos importante entrevista. A Rua, Rio de Janeiro, 2 out. 1919b, p. 1.

A RUA. A moléstia de Chagas. A sua difusão no Brasil e em quase toda a América. $A$ Rua, Rio de Janeiro, 18 ago. 1920, p. 1.

ACADEMIA NACIONAL DE MEDICINA (ANM). Sessão em 22 de abril de 1909. Annaes da Academia Nacional de Medicina, (75): 185-190, 1909.

ACADEMIA NACIONAL DE MEDICINA (ANM). Sessão ordinária em 13 de outubro de 1910. Annaes da Academia de Medicina, (76): 191-197, 1910a.

ACADEMIA NACIONAL DE MEDICINA (ANM). Sessão ordinária em 26 de outubro de 1910. Annaes da Academia de Medicina, (76): 197-198, $1910 \mathrm{~b}$.

ACADEMIA NACIONAL DE MEDICINA (ANM). 'Sessão de 30 de novembro de 1922'. Boletim da Academia de Medicina, Rio de Janeiro, 719-763, 1922a.

ACADEMIA NACIONAL DE MEDICINA (ANM). 'Sessão extraordinária de 14 de dezembro de 1922'. Boletim da Academia de Medicina, Rio de Janeiro, 765$779,1922 b$.

ACADEMIA NACIONAL DE MEDICINA (ANM). 'Sessão de 8 de novembro de 1923'. Boletim da Academia Nacional de Medicina, Rio de Janeiro, 629-656, $1923 \mathrm{a}$.

ACADEMIA NACIONAL DE MEDICINA (ANM). 'Sessão de 16 de novembro de 1923’. Boletim da Academia de Medicina, Rio de Janeiro, 657-691, 1923b.

ACADEMIA NACIONAL DE MEDICINA (ANM). 'Sessão de 22 de novembro de 1923’. Boletim da Academia de Medicina, Rio de Janeiro, 693-726, 1923c.

ACADEMIA NACIONAL DE MEDICINA (ANM). 'Sessão de 23 de novembro de 1923'. Boletim da Academia de Medicina, Rio de Janeiro, 727-784, 1923d.

ACADEMIA NACIONAL DE MEDICINA (ANM). 'Sessão de 6 de dezembro de 1923'. Boletim da Academia Nacional de Medicina, Rio de Janeiro, 785-814, 1923e.

ACADEMIA NACIONAL DE MEDICINA (ANM). 'Sessão de 24 de novembro de 1927’. Boletim da Academia de Medicina, Rio de Janeiro, 597-606, 1927.

ACCIÓN. Visita Montevidéo el inimigo n. 1 de la vinchuca. América debe combatir unida para erradicar el mal de Chagas. Acción, Montevideo, 22 out. 1957.

ALmeidA, M. O. de. Carlos Chagas. In: ALmeIDA, M. O. de. Ensaios, Críticas e Perfis. Rio de Janeiro: F. Brigueit \& Cia., 1938.

ANAIS DO CONGRESSO INTERNACIONAL SOBRE A DOENÇA DE CHAGAS. Rio de Janeiro: Oficina Gráfica da Universidade do Brasil, 1959/1964. v. I ao V. 
AQUINO, L. El profesor Dr. Rodolfo Kraus. Revista del Círculo Médico Argentino y Centro de Estudiantes de Medicina, Buenos Aires, 21: 235-236, 1921. Disponível em: <www.houssay.org.ar/hh/bio/kraus.htm>. Acesso em: 26 jan. 2006.

ANDRADE, C. D. de. Um cientista. Correio da Manhã, 26 out. 1962, p. 6.

ARAGÃO, H. de B. Sociedade de Medicina e Cirurgia do Rio de Janeiro. Discurso pronunciado pelo Dr. Henrique Aragão, chefe de serviço do Instituto Oswaldo Cruz, por ocasião de tomar posse como sócio efetivo da mesma sociedade científica. Jornal do Commercio, 24 jul. 1919, p.8-9.

ARAGÃO, H. de B. Carlos Chagas, diretor de Manguinhos. Memórias do Instituto Oswaldo Cruz, 51: 1-10, 1953.

ARAGÃO, H. de B. Nota sobre as squizogonias e gametogonias dos trypanosomos. Brazil-Medico, 27(27): 271-272, 1913.

ATHAYDE, A. Conferências Pronunciadas em 1955 pelo Ministro Dr. Aramis Athayde. Rio de Janeiro: Serviço de Documentação do Ministério da Saúde, 1957.

AZEVEDO, A. P. de. Histologia pathologica da glândula thyreoide na fórma aguda da moléstia de Chagas (Trypanosomose americana). Memórias do Instituto Oswaldo Cruz, 27(2): 93-123, 1933.

BACELlAR, R. C. Carlos Chagas. Separata do periódico. Medicina Universitária, 1(2): 3-13, 1938.

BARRETO, J. de B. A organização da saúde pública no Brasil. Arquivos de Higiene, 12(2): 169-215, 1942.

BAYMA, T. Moléstia de Carlos Chagas (nota sobre sua verificação parasitologica no homem, em São Paulo). Revista Médica de São Paulo, 17(1): 3, 1914a.

BAYMA, T. Molestia de Carlos Chagas (segunda verificação parasitologica no homem, em S. Paulo). Annaes Paulistas de Medicina e Cirurgia, 3(3): 57-58, 1914b.

BILAC, O. A Defesa Nacional (discursos). Rio de Janeiro: Liga da Defesa Nacional, 1917.

BRASIL. Câmara dos Deputados. Comissão de Saúde Pública, 22ạ. Reunião, 29/10/ 1936. Diários do Poder Legislativo dos Estados Unidos do Brasil, 460: 20.160, 1936.

BRASIL. Coleção das Leis da República. Decreto n. 13.000, de 1 de maio de 1918. Cria o serviço de quinina oficial, profilático da malária, inicial ao dos medicamentos do Estado, necessários ao saneamento do Brasil. Atos do Poder Executivo. Rio de Janeiro: Imprensa Nacional, 1919a. v. 2.

BRASIL. Coleção das Leis da República. Decreto n. 13.001, de 1ode maio de 1918. Dispõe sobre organização das comissões de médicos e auxiliares para o serviço de profilaxia rural. Atos do Poder Executivo. Rio de Janeiro: Imprensa Nacional, 1919b. v. 2.

BRASIL. Coleção das Leis da República. Decreto n. 13.055, de 6 de junho de 1918. Adita providências aos decretos n. 13.000 e n. 13.001, de 1o de maio de 1918. Atos do Poder Executivo. Rio de Janeiro: Imprensa Nacional, 1919c. v. 2. 
BRASIL. Ministério da Justiça e Negócios Interiores. Regulamento do Instituto Oswaldo Cruz a que se refere o Decreto n. 13.527, de 26 de março de 1919. Imprensa Nacional, 1919d.

BRASIL. Coleção das Leis da República. Decreto n. 13.538, de 9 abr. 1919. Reorganiza o serviço de profilaxia rural. Atos do Poder Executivo. Rio de Janeiro: Imprensa Nacional, 1920. v. 2.

BRASIL. Coleção de Leis da República. Decreto n. 3987, de 2 jan. 1920. Reorganiza os serviços da saúde pública. Atos do Poder Legislativo. Rio de Janeiro: Imprensa Nacional, 1921. v. 1.

BRASIL. Coleção das Leis da República dos Estados Unidos do Brasil. Decreto n. 14.354, de 15 de setembro de 1920. Aprova o regulamento para o departamento nacional de saúde pública, em substituição do que acompanhou o decreto n. 14189, de 26 de maio de 1920. Atos do Poder Executivo (julho a dezembro). Rio de Janeiro: Imprensa Nacional, 1921. v. 3, Tomo I.

BRASIL. Coleção de Leis da República. Decreto Lei n. 82, de 18 dez. 1937. Incorpora o Instituto Nacional de Saúde Pública ao Instituto Oswaldo Cruz e define as atribuições deste. Atos do Poder Legislativo. Rio de Janeiro: Imprensa Nacional, 1938. v. 3 .

BRASIL. Coleção de Leis da Republica. Decreto n. 10.252, de 14 de agosto de 1942. Aprova o regimento do Instituto Oswaldo Cruz. Atos do Poder Executivo. Rio de Janeiro: Imprensa Nacional, 1942. v. 4.

BRASIL. Presidência da República. Plano de reorganização do Ministério da Educação e Saúde Pública, apresentado ao Poder Legislativo pelo Presidente da República. Rio de Janeiro: Imprensa Nacional, 1935.

BRASIL. Presidência da República. Mensagem apresentada ao Congresso Nacional por ocasião da abertura da sessão legislativa de 1949 pelo General Eurico Gaspar Dutra, Presidente da República. Rio de Janeiro, 1949.

BRASIL. Presidência da República. Mensagem apresentada ao Congresso Nacional por ocasião da abertura da sessão legislativa de 1950 pelo General Eurico Gaspar Dutra, Presidente da República. Rio de Janeiro, 1950.

BRASIL. Presidência da República. Mensagem ao Congresso Nacional apresentada pelo Presidente da República por ocasião da abertura da sessão legislativa de 1951. Rio de Janeiro, 1951.

BRAZIL-MEDICO. Sociedade Sul-Americana de Hygiene, Microbiologia e Pathologia. Brazil-Medico, 30(40): 320, 1916.

BRUMPT, E. Penétration du Schizotrypanum cruzi à travers de la muqueuse oculaire saine. Bulletin de la Société de Pathologie Exotique, 5: 723-724, 1912.

BRUMPT, E. O xenodiagnostico: applicação ao diagnostico de algumas infecções parasitarias e em particular à trypanosomose de Chagas. Annaes Paulistas de Medicina e Cirurgia, 3(5): 97-102, 1914. 
CAMPOS, M. Mensagem apresentada à Assembléia Legislativa em sua sessão ordinária de 1947 pelo governador Milton Campos. In: ASSEMBLÉIA LEGISLATIVA DO ESTADO DE MINAS GERAIS, 1947, Belo Horizonte. Anais... Belo Horizonte: Imprensa Oficial, 1947. v. 1.

CAPriglione, L. A. \& Benchimol, A. B. Temas Atuais de Cardiologia. Rio de Janeiro: s.n., 1941.

CAPRIGLIONE, L. A. \& STRUMPELL, E. A. G. Esquizotripanosomíase cruzi (Tripanosomíase americana. Doença de Carlos Chagas). In: CAPRIGLIONE, L. A. \& STRUMPell, E. A. G. (Orgs.) Patologia e Terapêutica das Doenças Internas. Rio de Janeiro: Editora Científica, Editora Brasil, 1946.

CARINI, A. \& MACIEL, J. Existencia da molestia de Chagas no Estado de São Paulo. Annaes Paulistas de Medicina e Cirurgia, 2(3): 75-77, 1914a.

CARINI, A. \& MACIEL, J. Distribuição dos triatomas no Estado de S. Paulo. Annaes Paulistas de Medicina e Cirurgia, 2(3): 78-79, 1914b.

CARNEIRO, O. Ode aos chagásicos. Revista Goiana de Medicina, 4(2): 196, 1958.

CARVAlho, A. G. de. Realizações do Departamento Nacional de Endemias Rurais no combate à doença de Chagas. Revista Goiana de Medicina, 5(4): 311-314, 1959.

CARvalho, A. G. de. \& CASTRO, A. A. Realizações da circunscrição Goiás do Departamento Nacional de Endemias Rurais durante o ano de 1956. Revista Goiana de Medicina, 3(2): 99-118, 1957.

CARVAlho, A. G. de. \& VERANO, O. T. Contribuição ao conhecimento da distribuição geográfica dos triatomídeos domiciliários e de seus índices de infecção natural pelo Schizotrypanum cruzi na região do Planalto Central (retângulo de Cruls), estado de Goiás, Brasil. Revista Goiana de Medicina, 2(3): 181-200, 1956a.

CARVAlHO, A. G. de. \& VERANO, O. T. Epidemiologia e profilaxia da doença de Chagas em Goiás. Revista Goiana de Medicina, 2(4): 241-266, 1956 b.

CHAGAS, C. Estudos Hematologicos no Impaludismo. Rio de Janeiro: Typographia da Papelaria União, 1903.

CHAGAS, C. Prophylaxia do Impaludismo. Rio de Janeiro: Typographia Besnard Frères, 1906.

CHAGAS, C. Uma nova especie do genero Taeniorhynchus. Brazil-Medico, 21(32): 313-314, 1907a.

CHAGAS, C. O novo genero Myzorhynchella de Theobald: duas novas anophelinas brazileiras pertencentes a este genero - Myzorhynchella parva (nov. sp.). BrazilMedico, 21(30): 291-293, 1907b.

CHAGAS, C. O novo genero Myzorhynchella de Theobald: duas novas anophelinas pertencentes a este genero - Myzorhynchella nigritarsis (nova sp.). BrazilMedico, 21(31): 303-305, 1907c. 
CHAGAS, C. Prophylaxia do impaludismo. Nota previa sobre uma causa de erro nos exames de sangue para a pesquiza do hematozoario de Laveran. Revista Medica de São Paulo, 11(19): 391-399, 1908a.

CHAGAS, C. Trypanosoma minasense: nota preliminar. Brazil-Medico, 22(48): 471, 1908b.

CHAGAS, C. Neue Trypanosomen: vorläufige mitteilung. Archiv für Schiffs- und Tropen-Hygiene, 13: 120-122, 1909a.

CHAGAS, C. Nouvelle espèce de trypanosomiase humaine. Bulletin de la Société de Pathologie Exotique, 2 (6): 304-307, 1909b.

CHAGAS, C. Nova especie morbida do homem, produzida por um trypanozoma (trypanozoma Cruzi): nota previa”. Brazil-Medico, 23(16): 161, 1909c.

CHAGAS, C. Nova tripanozomiase humana: Estudos sobre a morfolojia e o ciclo evolutivo do Schizotrypanum cruzi n. gen., n. sp., ajente etiolojico de nova entidade morbida do homem. Memórias do Instituto Oswaldo Cruz, 1(2): 159-218, 1909d.

CHAGAS, C. Relatório aprezentado pelo chefe da comissão medica ao sub-diretor da 6 ${ }^{\mathbf{a}}$ divizão da E. F. Central do Brazil. In: REIS, A. Relatorio da Estrada de Ferro Central do Brazil referente ao ano de 1907 apresentado ao Exmo. Sr. Dr. Miguel Calmon du Pin e Almeida, Ministro e Secretario d'Estado dos Negocios da Industria, Viação e Obras Publicas. Rio de Janeiro: Imprensa Nacional, $1909 \mathrm{e}$.

CHAGAS, C. Trabalho do Instituto de Manguinhos sobre uma nova trypanosomiase humana, pelo dr. Carlos Chagas, assistente do Instituto. Annaes da Academia de Medicina do Rio de Janeiro, 75: 188-190, $1909 \mathrm{f}$.

CHAGAS, C. Uber eine neue trypanosomiasis des menschen. Archiv für Schiffs- und Tropen-Hygiene, 13: 351-353, 1909g.

CHAGAS, C. Aspecto clinico geral da nova entidade morbida produzida pelo Schizotrypanum cruzi: nota previa. Brazil-Medico, 24(27): 263-265, 1910a.

CHAGAS, C. Nova entidade morbida do homem. Brazil-Medico, 24(43, 44, 45): 423428, 433-437, 443-447, 1910b.

CHAGAS, C. Sobre a etiologia do bocio endemico no estado de Minas Gerais: nota preliminar. Brazil-Medico, 24(17): 163, 1910c.

CHAGAS, C. Molestia de Carlos Chagas ou thyreoidite parasitaria: nova doença humana transmitida pelo barbeiro (Conorhinus megistus). Revista Medica de São Paulo, 14(18): 337-356, 1911a.

CHAGAS, C. Molestia de Carlos Chagas: Conferencia realizada em 7 de agosto na Academia Nacional de Medicina. Brazil-Medico, 25(34, 35, 36, 37): 340-343, 353-355, 361-364, 373-375, 1911b.

CHAGAS, C. Nova entidade morbida do homem: rezumo geral de estudos etiolojicos e clinicos. Memorias do Instituto Oswaldo Cruz, 3(2): 219-275, 1911c. 
CHAGAS, C. Discurso pronunciado pelo Dr. Carlos Chagas, orador official, na sessão solene do VII Congresso Brasileiro de Medicina e Cirurgia realizado em Bello Horizonte em 21 de abril de 1912. Bello Horizonte: Imprensa Oficial, 1912a.

CHAGAS, C. O mal de Chagas: Conferencia realizada em São Paulo pelo dr. Carlos Chagas, a convite da Sociedade de Medicina e Cirurgia, sobre a tripanozomíase brazileira e de sua descoberta. Archivo da Sociedade de Medicina e Cirurgia de São Paulo, 3(9, 10): 34-366, 1912b.

CHAGAS, C. Sobre um trypanosoma do tatú, Tatusia novemcincta, transmitido pela Triatoma geniculata Latr. (1811): possibilidade de ser o tatú um depositario do Trypanosoma cruzi no mundo exterior (Nota prévia). Brazil-Medico, 26(30): 305-306, 1912c.

CHAGAS, C. Les formes nerveuses d'une nouvelle trypanosomiase (Trypanosoma cruzi inoculé par Triatoma magista) (Maladie de Chagas). Nouvelle Iconographie de la Salpêtrière, 26: 1-9, 1913a.

CHAGAS, C. Revisão do cyclo evolutivo do 'Trypanozoma cruzi'. Brazil-Medico, 27(23): 225, 1913b.

CHAGAS, C. Aspectos clínicos y anatomo patológicos de la tripanosomiasis americana. La Prensa Médica Argentina, 3(13, 14, 15): 125-127, 137-138, 153-158, 1916a.

CHAGAS, C. Processos patojenicos da tripanozomiase americana. Memórias do Instituto Oswaldo Cruz, 8(2): 5-35, 1916b.

CHAGAS, C. Tripanosomiase americana: forma aguda da molestia. Memórias do Instituto Oswaldo Cruz, 8(2): 37-60, 1916c.

CHAGAS, C. Epidemiologia da trypanozomiase americana. Brazil-Medico, 32(27): 213-214, 1918a.

CHAGAS, C. Trypanosomiase americana. Synonimia: doença do barbeiro. Revista do Brasil, 3(8): 362-386, 1918b.

CHAGAS, C. Discurso do Dr. Chagas no banquete offerecido pela classe medica do Rio de Janeiro no Edifício do Derby-Club em homenagem aos médicos bahianos, em 9 de dezembro de 1918. Rio de Janeiro: Typ. Jornal do Commercio, 1919.

CHAGAS, C. Descoberta do Trypanozoma Cruzi e verificação da Tripanozomiase Americana: retrospecto historico. Memórias do Instituto Oswaldo Cruz, 15(1): 67-76, 1922a.

CHAGAS, C. Inauguração do Instituto de Radium em Bello Horizonte: discurso pronunciado pelo Dr. Carlos Chagas, director do Departamento Nacional de Saúde Pública em 7 de setembro de 1922. Rio de Janeiro: s.n., 1922b.

CHAGAS, C. Discurso Pronunciado pelo Dr. Carlos Chagas (presidente da Sociedade) na sessão inaugural da Sociedade Brasileira de Hygiene. Rio de Janeiro: s.n., 1923. 
CHAGAS, C. Quelques aspects de la trypanosomiase américaine. Revue D’Hygiene, 48: 694-702, 1926.

CHAGAS, C. A forma cardiaca da trypanosomiase americana. Brazil-Medico, 41(52): $1.386-1.387,1927$.

CHAGAS, C. Sur les altérations du coeur dans la trypanosomiase américaine (Maladie de Chagas). Archives des Maladies du Coeur des Vaisseaux et du Sang, 21(10): 641-655, 1928.

CHAGAS, C. Forma nervosa da tripanosomiase americana. Revista das Clinicas, 4(4): $2-5,1930$.

CHAGAS, C. Estado actual da trypanosomiase americana. Revista de Biologia e Hygiene, 5(2): 58-64, 1934.

CHAGAS, C. Agradecimento ao banquete offerecido por um grupo de collegas, amigos e admiradores, por occasião seu regresso da Argentina, onde representou o Brasil no congresso medico, realizado em setembro de 1916, em Buenos Aires. In: CHAGAS, C. Discursos e Conferencias. Rio de Janeiro: A Noite, 1935a.

CHAGAS, C. Saudação ao Prof. Bowman C. Crowell ao ser recebido como membro honorario da Academia Nacional de Medicina. Sessão em 8 de junho de 1922. In: CHAGAS, C. Discursos e Conferencias. Rio de Janeiro: A Noite, 1935b.

CHAGAS, C. Agradecimento ao banquete oferecido por collegas, amigos e admiradores, por occasião de seu regresso da Europa, onde presidiu a representação brasileira nas commemorações do centenario de Pasteur - setembro de 1923. In: CHAGAS, C. Discursos e Conferencias. Rio de Janeiro: A Noite, 1935c.

CHAGAS, C. Oração proferida na sessão da Academia Nacional de Medicina dedicada à memória de Miguel Couto - sessão de 14 de junho de 1934. In: CHAGAS, C. Discursos e Conferencias. Rio de Janeiro: A Noite, 1935d.

CHAGAS, C. Conferência realizada em 17 de outubro de 1913, sobre as condições medico-sanitarias do rio Amazonas. In: CHAGAS, C. Discursos e Conferencias. Rio de Janeiro: A Noite, 1935e.

CHAGAS, C. Aula inaugural da Cadeira de Medicina Tropical - 14 de setembro de 1926. In: CHAGAS, C. Discursos e Conferencias. Rio de Janeiro: A Noite, $1935 f$.

CHAGAS, C. Lição de abertura dos cursos da Faculdade de Medicina do Rio de Janeiro - 1928. In: CHAGAS, C. Discursos e Conferencias. Rio de Janeiro: A Noite, 1935g.

CHAGAS, C. Luta contra a malária. Conferencia proferida no Nucleo Colonial S. Bento - Abril de 1933. In: Chagas, C. Discursos e Conferências. Rio de Janeiro: A Noite, 1935h.

CHAGAS, C. \& CHAGAS, E. Trypanosomiase americana. In: CHAGAS, C. \& CHAGAS, E. Manual de Doenças Tropicaes e Infectuosas. Rio de Janeiro: Officinas Graphicas da Empreza Almanak Laemmert, 1935. v. 1.

CHAGAS, C. \& VILlELA, E. Forma cardiaca da Trypanosomiase Americana. Memórias do Instituto Oswaldo Cruz, 14(1): 5-61, 1922. 
CHAGAS, E. Forma cardíaca da Trypanosomiase americana. Memórias do Instituto Oswaldo Cruz, 24(3): 9-126, 1930.

CHAGAS, E. Novos estudos sobre a forma cardiaca da trypanosomiase americana. Memórias do Instituto Oswaldo Cruz, 26(3): 329-338, 1932.

CHAGAS, E. A vida e a obra de Carlos Chagas. A Folha Medica, 7: 507-511, 1935.

CHAGAS, E. Endemias ruraes na América. O Hospital, 8(2): 127-134, 1936.

CHAGAS, E. Estudos sobre as grandes endemias no Brasil. O Hospital, 14(6): 1.323$1.353,1938$.

CHAGAS, E. \& DIAS, E. A propósito do sinal de Romaña. O Hospital, 19(2): 185-189, 1941.

CHAVES, L. Carlos Chagas e o Instituto Oswaldo Cruz. A Folha Médica, 27(21): 308310, 1936. (Edição especial: Doenças Tropicaes e Infectuosas)

CONGRESSO BRASILEIRO DE MEDICINA E CIRURGIA. Quarto Congresso Brasileiro de Medicina e Cirurgia, junho de 1900. Rio de Janeiro: [s.n.], 1901.

CONGRESSO BRASILEIRO DE MEDICINA E CIRURGIA. Annaes do VII Congresso Brasileiro de Medicina e Cirurgia, reunido em Bello Horizonte, 21 a 27 de abril de 1912. Bello Horizonte: Imprensa Oficial, 1912. v. 1.

CORREIO DA MANHÃ. Um palpitante problema nacional. O dr. Carlos Chagas fez hontem, na Academia de Medicina, a sua conferencia, mostrando a necessidade premente de um serviço de prophylaxia contra a grave doença que devasta o interior do Brazil e degenera a população. Correio da Manhã, Rio de Janeiro, 8 ago. 1911 a, p. 3.

CORREIO DA MANHÃ. A 'doença Carlos Chagas'. A sessão de hontem no hospital da Misericordia. Correio da Manhã, Rio de Janeiro, 11 ago. 1911b, p. 3.

CORREIO DA MANHÃ. A conferencia de ontem do Professor Carlos Chagas. A forma cardiaca da tripanosomiase foi o assunto. Correio da Manhã, Rio de Janeiro, 1 ago. 1919, p. 3

CORREIO DA MANHÃ. Uma notavel sessão na Academia de Medicina. O dr. Carlos Chagas, como estava annunciado, fez a sua defesa de modo brilhante. Correio da Manhã, Rio de Janeiro, 7 dez. 1923, p. 3.

CORREIO DA MANHÃ. Malária, infecção essencialmente domiciliar. Uma exposição feita pelo Sr. Evandro Chagas nos Estados Unidos. Correio da Manhã, Rio de Janeiro, jun. 1940a, p. 3.

CORREIO DA MANHÃ. Os serviços de saneamento da Amazônia. Vai ser fundada uma Escola de Malariologia para especialistas de diversos padrões. Correio da Manhã, 16 out. 1940b, p. 3.

CORREIO DA MANHÃ. Congresso encerrado. Progressos no combate aos transmissores da doença de Chagas no Brasil. Correio da Manhã, Rio de Janeiro, 12 jul. 1959, p. 2, 12 . 
CORREIO PAUlistano. Prossegue a luta contra a doença de Chagas. Correio Paulistano, 18 set. 1951 , p. 8.

COUTO FILHO, M. Lesões do sistema específico do miocárdio num caso de tripanossomiase americana. O Hospital, 8(11): 1.223-1.227, 1936.

CRUZ, O. G. Relatorio sobre as Condições Medico-Sociais do Vale do Amazonas, Apresentado a S. Ex. o Snr. Dr. Pedro de Toledo, Ministro da Agricultura, Indústria e Comércio. Rio de Janeiro: Typ. Jornal do Commercio, 1913.

CRUZ, O. G. Algumas molestias produzidas por protozoarios. Conferencia feita na Bibliotheca Nacional pelo Dr. Oswaldo Cruz. Brazil-Medico, 29(44-45): 345346, 353-356, 1915.

CRUZ, O. G. The prophylaxis of malaria in Central and Southern Brazil. In: ROSS, R. The Prevention of Malaria. London: John Murray, 1910. (reproduzido em Oswaldo Gonçalves Cruz: Opera Omnia. Rio de Janeiro: Imprensa Brasileira, 1972.)

CUNHA, A. M. da. O Schizotrypanum cruzi e sua transmissão. A Folha Médica, 4(3): 17-19, 1923.

DE LAMARE, R. \& AGUIAR, A. Ubicação pediátrica da doença de Chagas. Anais Nestlé, 29: 3-23, 1952.

DEPARTAMENTO NACIONAL DE ENDEMIAS RURAIS (DNERu). Campanha contra a doença de Chagas. Combate a Endemias no Brasil. Rio de Janeiro: Ministério da Saúde, 1962. (Relatórios dos Grupos de Trabalho reunidos em 1960 na cidade do Rio de Janeiro)

DIÁRIO CARIOCA. Descoberto o inseticida para o combate da 'doença de Chagas'. Ação do perigoso 'barbeiro' entre as populações rurais. Produtor de $65 \%$ das cardiopatias. Iniciada a campanha contra o triatomídeo. Diário Carioca, Rio de Janeiro, 10 maio. 1950, p. 3.

DIÁRIO DA NOITE. Plano para erradicação da moléstia de Chagas. Diário da Noite, São Paulo, 21 ago. 1956.

DIÁRIO DA TARDE. Em maio próximo será desfechada grande campanha contra a Doença de Chagas. Diário da Tarde, Belo Horizonte, 28 abr. 1950, p. 3.

DIÁRIO DE MINAS. Carlos Chagas. Diário de Minas, Belo Horizonte, 2 ago. 1911, p. 2.

DIÁRIO DE NOTÍCIAS. O prêmio ‘Schaudinn'. Dr. Carlos Chagas. Diário de Notícias, Rio de Janeiro, 29 jun. 1912.

DIÁRIO DE NOTÍCIAS. I Congresso Interamericano de Higiene. Participação de cientistas brasileiros e debates sobre a doença de Chagas. Diário de Notícias, Rio de Janeiro, 4 jul. 1952, p. 1.

DIÁRIO DE SÃO PAULO. Mesa-redonda sobre moléstia de Chagas. Diário de São Paulo, 21 ago. 1956.

DIAS, E. Molestia de Carlos Chagas: estudos hematolojicos. Memórias do Instituto Oswaldo Cruz, 4(1): 34-62, 1912 
DIAS, E. Estudos sobre o Schizotrypanum cruzi. Memórias do Instituto Oswaldo Cruz, 28(1): 1-110, 1934.

DIAS, E. O sinal de Romaña e sua influência na evolução dos conhecimentos sôbre a moléstia de Chagas. Brasil-Medico, 53(42): 965-970, 1939.

DIAS, E. Técnica do xenodiagnostico na molestia de Chagas. Memórias do Instituto Oswaldo Cruz, 35(2): 335-342, 1940.

DIAS, E. Apêlo aos clínicos do interior para a colaboração no estudo da doença de Chagas. O Hospital, 21(6): 921-926, 1942.

DIAS, E. Instruções para captura e remessa de triatomideos ou 'barbeiros'. BrasilMedico, 57 (16/17): 197-198, 1943.

DIAS, E. Doença de Chagas: noções. Rio de Janeiro: Ministério da Educação e Saúde, Serviço Nacional de Educação Sanitária, 1944.

DIAS, E. Um Ensaio de Profilaxia de Moléstia de Chagas. Rio de Janeiro: Imprensa Nacional, 1945.

DIAS, E. Acerca de 254 casos de doença de Chagas comprovados em Minas Gerais. Brasil-Medico, 60(5/6): 41-43, 1946a.

DIAS, E. Profilaxia da doença de Chagas. Resumo das principais atividades do Centro de Estudos do Instituto Oswaldo Cruz em Bambuí, Minas Gerais, durante dois anos. Brasil-Medico, 60(18/19): 161-163, $1946 \mathrm{~b}$.

DIAS, E. O ‘barbeiro' e a doença de Chagas: Carlos Chagas e a sua grande descoberta de uma nova doença humana. Eu Sei Tudo, set. 1946c. [separata]

DIAS, E. Doença de Chagas: um grande problema de Saúde Pública. Brasil-Medico, 61(14/15): 162-164, 1947.

DIAS, E. Importância continental da doença de Chagas. Brasil-Medico, 62(23/24): 217-219, 1948a.

DIAS, E. Contrôle das doenças transmitidas pelos triatomas. Boletín de la Oficina Sanitaria Panamericana, 27(12): 1.160-1.164, 1948b.

DIAS, E. Considerações sôbre a Doença de Chagas. Memórias do Instituto Oswaldo Cruz, 47(3/4): 679-685, 1949a.

DIAS, E. Considerações sôbre a importância da moléstia de Chagas em Minas Gerais e estados vizinhos. Necessidade urgente de ser desenvolvido o estudo dessa endemia e de serem tomadas medidas para combatê-la. Brasil-Medico, 63(34/ 35): 217-220, 1949b.

DIAS, E. Chagas Krankheit. In: RODENWALDT, E. Welt-Seuchen-Atlas. Weltatlas der Seuchenverbreitung und Seuchenbewegen. Hamburg: Falk-Verlag, 1954.

DIAS, E. O Centro de Estudos e Profilaxia de Moléstia de Chagas em Bambuí, Minas Gerais. Notícia histórica em homenagem ao Professor Henrique Aragão. Memórias do Instituto Oswaldo Cruz, 54(1): 309-357, 1956.

DIAS, E. Profilaxia da Doença de Chagas. O Hospital, 51(3): 286-298, 1957a. 
DIAS, E. Sugestões preliminares para um plano de erradicação dos transmissores domicilários da doença de Chagas no Estado de São Paulo. Revista Médica do Sul de Minas, 3(2): 104-113, 1957b.

DIAS, E. Aspectos sanitários da luta antichagásica no Brasil. O Hospital, 54(4): 471482, 1958a.

DIAS, E. Doença de Chagas: um problema americano. In: INTERNATIONAL CONGRESSES ON TROPICAL MEDICINE AND MALARIA, 6, 5-13 set. 1958, Lisboa. Anais... Lisboa: Instituto de Medicina Tropical, 1958b. v. III.

DIAS, E. \& CHANDLER, A. Moléstias humanas transmitidas por hemípteros sugadores. Memórias do Instituto Oswaldo Cruz, 47(3-4): 403-441, 1949.

DIAS, E. \& LARANJA, F. Chagas' disease and its control. In: INTERNATIONAL CONGRESSES OF TROPICAL MEDICINE AND MALARIA, 4, 10-18 maio 1948, Washington. Anais... Washington: Department of State, 1948. v. II.

DIAS, E. \& PELLEGRINO, J. Alguns ensaios com o gammexane no combate aos transmissores da doença de Chagas. Brasil-Medico, 62(18-20): 185-191, 1948.

DIAS, E. \& PINTO, O. da S. Combate aos triatomíneos com BHC na cidade de Bambuí, Minas Gerais. Revista Brasileira de Malariologia e Doenças Tropicais, 4(1): 62-64, 1952.

DIAS, E. \& ROMAÑA, C. Reação de fixação de complemento na Doença de Chagas, com antígeno alcoólico de cultura do 'Schizotrypanum cruzi'. Memórias do Instituto Oswaldo Cruz, 37(1): 1-10, 1942.

DiAS, E.; LARANJA, F. \& NÓBREGA, G. Doença de Chagas. Memórias do Instituto Oswaldo Cruz, 43(3): 495-581, 1945.

DIAS, E.; LARANJA, F. \& PELLEGRINO, J. Estudo sôbre a importância social da doença de Chagas. I - Inquérito clínico-epidemiológico feito nas vizinhanças de Bambuí, oeste de Minas. Brasil-Medico, 62(49/52): 412-413, 1948.

DIAS, E.; LARANJA, F. \& PELLEGRINO, J. Inquérito clínico-epidemiológico sobre doença de Chagas feito entre as estações de Iguatama e Campos Altos, Oeste de Minas. In: REUNIÓN PANAMERICANA SOBRE ENFERMEDAD DE CHAGAS, 1, 1950, Tucumán. Anais... Tucumán, 1950.

DIAS, E.; LIBÂNIO, S. \& LISBOA, H. M. Luta contra os escorpiões. Memórias do Instituto Oswaldo Cruz, 17(1): 5-25, 1924.

DIAS, E. et al. Ensaio experimental de luta contra os triatomíneos por meio de inseticidas de ação residual (nota prévia). Revista Brasileira de Malariologia e Doenças Tropicais, 4(1): 22-46, 1952.

DIAS, E. et al. Estudo preliminar de inquéritos sorológico-eletrocardiográficos em populações não selecionadas de zonas não endêmicas e de zonas endêmicas de doença de Chagas. Revista Brasileira de Malariologia e Doenças Tropicais, 5(3): 205-210, 1953. 
ESTADO DE MINAS. Combate à moléstia de Chagas em Minas. Um novo convênio com o Serviço Nacional de Malária. Estado de Minas, Belo Horizonte, 14 jan. 1950a, p. 3.

ESTADO DE MINAS. Combate à moléstia de Chagas. Estado de Minas, Belo Horizonte, 15 jan. 1950b, p. 4.

ESTADO DE MINAS. Prestes a se iniciar o combate aos transmissores da moléstia de Chagas. 200 mil residências serão borrifadas com inseticidas no Triângulo Mineiro e sudoeste de Minas. Estado de Minas, Belo Horizonte, 14 abr. 1950c, p. 3.

ESTADO DE MINAS. Uma campanha profilática. Estado de Minas, Belo Horizonte, 14 abr. 1950 d, p. 4.

ESTADO DE MINAS. O 'Barbeiro' conduz a morte em suas asas ligeiras. A moléstia de Chagas, mal mais grave do que a tuberculose e a lepra. Estado de Minas, Belo Horizonte, 5 maio. 1950e, p. 7.

ESTADO DE MINAS. Assinado um convênio para combate à malária e à doença de Chagas em Minas. O Estado contribuirá como 4 milhões de cruzeiros este ano, cabendo à União a aplicação de inseticidas de ação residual. Estado de Minas, Belo Horizonte, 26 abr. 1951a.

ESTADO DE MINAS. No Instituto de Tecnologia, o governador. Estado de Minas, Belo Horizonte, 7 nov. 1951b, p. 4.

ESTADO DE MINAS. Campanha contra a doença de Chagas. Estado de Minas, Belo Horizonte, 31 jul. 1952a, p. 4.

ESTADO DE MINAS. A luta contra a moléstia de Chagas no interior de Minas. Vai ser concedida subvenção federal para o reaparelhamento do posto de pesquisas de Bambuí. Estado de Minas, Belo Horizonte, 11 set. 1952b, p. 7.

ESTADO DE MINAS. Havana vai transformar-se por alguns dias em capital da saúde pública das Américas. Estado de Minas, Belo Horizonte, 27 set. 1952c, p. 3.

ESTADO DE MINAS. Será apreciada em Havana a experiência de Minas na campanha contra o 'barbeiro'. Estado de Minas, Belo Horizonte, 30 set. 1952d, p. 3.

ESTADO DE MINAS. Coube à delegação brasileira a palavra final em Havana sobre a doença de Chagas. Estado de Minas, Belo Horizonte, 15 out. 1952e, p. 3.

ESTADO DE MINAS. O Governo de Minas resgata uma dívida de gratidão. Lançada a pedra fundamental do monumento a Carlos Chagas. Estado de Minas, Belo Horizonte, 23 out. 1952f, p. 5.

ESTADO DE MINAS. 70.000 prédios protegidos contra escorpiões em Belo Horizonte. Apenas seis vítimas nos três últimos meses de 52. Combatem-se também a doença de Chagas e a esquistossomose. Declarações do sanitarista Mário Pinotti, diretor do SNM. Estado de Minas, Belo Horizonte, 22 fev. 1953, p. 6.

ESTADO DE MINAS. Amplo programa de combate a endemias em Minas. A Doença de Chagas, malária, bouba e esquistossomose na mira do D.N.E.R.U. Estado de Minas, Belo Horizonte, 14 dez. 1956, p. 7. 
ESTADO DE MINAS. Estudos sobre a possibilidade de ser ampliado o combate ao 'barbeiro'. Estado de Minas, Belo Horizonte, 4 jun. 1957, p. 6.

FALCÃO, J. de B. Caso agudo de tripanosomose americana observado em Santo Angelo das Missões, Rio Grande do Sul. Brasil-Medico, 57(14/15): 179-182, 1943.

FERREIRA, N. A doença de Chagas aniquila o caboclo paulista. O Cruzeiro, 27 jul. 1957 , p. $36-41$.

FOLHA DA MANHÃ. Será lançada a campanha contra os transmissores do mal de Chagas. Emprego de inseticidas de grande potência tóxica no extermínio do 'barbeiro': declarações do sr. Mário Pinotti, diretor do S.N.M. Folha da Manhã, São Paulo, 13 abr. 1950, p. 3.

FOLHA DA MANHÃ. Mesa-redonda no S.P.M. sobre a profilaxia da moléstia de Chagas. Expõe o prof. Emmanuel Dias o resultado de seus trabalhos no Centro Experimental de Estudos da moléstia, em Bambuí. Folha da Manhã, São Paulo, 23 ago. 1956, p. 13.

FOLHA DA MANHÃ. O problema da luta contra os barbeiros deve ser colocado em termos de erradicação'. Declarações do Dr. Emmanuel Dias que realiza em Bambuí pesquisas sobre a moléstia de Chagas. Folha da Manhã, São Paulo, 12 mar. 1957 a, p. 19.

FOLHA DA MANHÃ. Estudantes de medicina promovem campanha de esclarecimento sobre o mal de Chagas. Fundada a Liga Brasileira de Combate à Doença de Chagas, sob a orientação de professores da Faculdade de Medicina de Ribeirão Preto. Folha da Manhã, São Paulo, 13 set. 1957b, p. 8.

FOLHA DE MINAS. Os aspectos essenciais do problema da malária. Folha de Minas, Belo Horizonte, 13 abr. 1940.

FOLHA DE MINAS. Fixação das normas para o futuro. Iniciada oficialmente a Campanha contra a moléstia de Chagas. Folha de Minas, Belo Horizonte, 8 de maio de 1950a.

FOLHA DE MINAS. Minas participa na luta contra a 'moléstia de Chagas'. O discurso proferido pelo professor Baeta Viana ao ter início a campanha contra a terrível endemia em Araxá. Folha de Minas, Belo Horizonte, 10 maio 1950b, p. 3.

FOLHA DE MINAS. A maior campanha sanitária jamais encetada em Minas. Firmado importante acordo entre Governo do Estado e o Ministério da Educação. Folha de Minas, Belo Horizonte, 20 ago. 1952, p. 1, 11.

FONSECA, J. M. da. Carlos Chagas e sua glorificação pelo descobrimento da tripanossomíase americana. In: CONGRESSO INTERNACIONAL SOBRE A DOENÇA DE CHAGAS, 5-11 jul. 1959, Rio de Janeiro. Anais... Rio de Janeiro, 1964. v. 5.

FONSECA, J. M. da. Miguel Couto e o seu centenário. Revista da Academia Nacional de Medicina, 2: 76-81, 1965. 
FOURTH INTERNATIONAL CONGRESSES OF TROPICAL MEDICINE AND MALARIA. Resolution VIII - Chagas' disease and leishmaniosis. In: INTERNATIONAL CONGRESSES OF TROPICAL MEDICINE AND MALARIA, 4, 10-18 maio 1948, Washington. Anais... Washington: Department of State, 1948. v. I.

FRAGA, C. Nova entidade morbida do homem descoberta e estudada pelo Dr. Carlos Chagas. Brazil-Medico, 25(47): 473-478, 1911.

FRAGA, C. et al. Academia Nacional de Medicina, 13 de dezembro de 1934. Sessão conjunta das Sociedades sábias em homenagem ao Prof. Carlos Chagas. $O$ Hospital, 7(1): 77-82, 1935.

FREITAS, J. L. P. de. Dados atuais sobre a distribuição de triatomíneos e moléstia de Chagas no Estado de São Paulo. Revista Paulista de Medicina, 37(3): 227-236, 1951.

FREITAS, J. L. P. de. Comentário aos trabalhos apresentados ao $8^{\circ}$ Congresso Médico do Triângulo Mineiro e do Brasil Central sobre o tema 'estado atual da doença de Chagas em Goiás'. Revista Goiana de Medicina, 2(4): 315-320, 1956.

GAINZA, E. Discurso del presidente de la Sociedad Medica de Mendoza. Revista del Circulo Medico de Mendoza, 2(19): 25-27, 1935. (numero dedicado a la Novena Reunión de Patología Regional Argentina)

GAZETA DE NOTICIAS. Em Xerém. Na captação das águas a febre palustre dizima. A 'Gazeta de Noticias' no local. Gazeta de Noticias, Rio de Janeiro, 2 maio. 1907, p. 3.

GAZETA DE NOTICIAS. Uma nova molestia. Na Academia Nacional de Medicina. Importante communicação. A 'trypanozoma Cruzi'. Gazeta de Noticias, Rio de Janeiro, 23 abr. 1909, p. 1.

GAZETA DE NOTICIAS. Academia Nacional de Medicina. O Dr. Carlos Chagas e os seus estudos sobre a trypanozomiase americana. Gazeta de Noticias, Rio de Janeiro, 13 nov. 1923, p. 3.

GUERREIRO, C. \& MACHADO, A. Da reação de Bordet e Gengou na moléstia de Carlos Chagas como elemento diagnostico (nota preliminar). Brazil-Medico, 27(23): 225, 1913.

GUimarãeS, F. N. Notas bio-bibliográficas do Prof. Dr. Henrique de Beuarepaire Aragão, Diretor Emérito do Instituto Oswaldo Cruz. Memórias do Instituto Oswaldo Cruz, 53(2, 3, 4): 144-156, 1955.

HAYNES, W. The Chemical Front. New York: Alfred Knopf, 1943.

IHERING, R. von. Percevejos brazileiros hematophagos ou sugadores de sangue. Chacaras e Quintaeis, (2): 23-25, $1911 \mathrm{a}$.

IHERING, R. von. Como se desenvolve o barbeiro (chupança) e como extirpal-o. Chacaras e Quinateis, 3(4): 9-19, 1911 b.

INSTITUTO BRASILEIRO DE GEOGRAFIA E ESTATÍSTICA (IBGE). Campanha Municipalista. Congresso de Prefeitos do Triângulo Mineiro. Rio de Janeiro: 
Serviço Gráfico do Instituto Brasileiro de Geografia e Estatística do Rio de Janeiro, 1949.

INSTITUTO OSWALDO CRUZ (IOC). Instituto Oswaldo Cruz em Manguinhos. Rio de Janeiro: Oficina de Kósmos, 1909.

INSTITUTO OSWALDO CRUZ (IOC). Decreto 17.512, de 5 de novembro de 1926. Dá novo regulamento ao Instituto Oswaldo Cruz. Rio de Janeiro: Imprensa Nacional, 1926.

INSTITUTO OSWALDO CRUZ (IOC). Relatório dos trabalhos realizados durante o ano de 1944 apresentado ao diretor geral do Departamento Nacional de Saúde, Dr. João de Barros Barreto, pelo Dr. Henrique de Beaurepaire Rohan Aragão, diretor. Rio de Janeiro: Imprensa Nacional, 1945.

INSTITUTO OSWALDO CRUZ (IOC). Relatório dos trabalhos realizados durante o ano de 1945 apresentado ao diretor geral do Departamento Nacional de Saúde, Dr. Roberval Cordeiro de Farias, pelo Dr. Henrique de Beaurepaire Rohan Aragão, diretor. Rio de Janeiro: Imprensa Nacional, 1946.

INSTITUTO OSWALDO CRUZ (IOC). Carlos Chagas (1879-1934): bio-bibliografia. Rio de Janeiro: Instituto Oswaldo Cruz, 1959.

JÁCOMO, R. Doença de Chagas em Uberaba. Revista da Sociedade de Medicina e Cirurgia de Uberaba, 1(1): 38-50, 1950.

JORNAL DO BRASIL. Em torno da reorganisação dos Serviços da Saude Publica. O plano geral da reforma. Jornal do Brasil, Rio de Janeiro, 3 fev. 1920, p. 5.

JORNAL DO COMMERCIO. Entrevista com o professor Austregesilo. Jornal do Commercio, Rio de Janeiro, 6 out. 1910a, p. 4.

JORNAL DO COMMERCIO. Academia Nacional de Medicina. Jornal do Commercio, Rio de Janeiro, 27 out. 1910b, p. 3.

JORNAL DO COMMERCIO. A manifestação dos acadêmicos ao professor Aloysio de Castro. Jornal do Commercio, Rio de Janeiro, 11 out. 1916a, p. 4.

JORNAL DO COMMERCIO. Banquete ao dr. Carlos Chagas. Jornal do Commercio, 22 out. 1916 b, p. 3.

JORNAL DO COMMERCIO. Trypanosomiase americana. Uma rectificação do Sr. Dr. Carlos Chagas á conferência do Dr. Figueiredo de Vasconcellos. Jornal do Commercio, Rio de Janeiro, 23 de agosto de 1919, p. 6-7.

JORNAL DO COMMERCIO. A nova orientação do serviço sanitário no Brasil: conferencia do Dr. Carlos Chagas. Jornal do Commercio, Rio de Janeiro, 11 fev. 1921 a, p. 4.

JORNAL DO COMMERCIO. Dr. Carlos Chagas: o banquete no Club dos Diarios. Jornal do Commercio, Rio de Janeiro, 21 ago. 1921b, p. 3

JORnAL DO COMMERCIO. Academia Nacional de Medicina. Uma carta do Dr. Carlos Chagas. Jornal do Commercio, Rio de Janeiro, 13 dez. 1922, p. 5. 
JORnal Do COMmercio. Faculdade de Medicina. Discurso do Professor Dr. Carlos Chagas. Jornal do Commercio, Rio de Janeiro, 28 maio. 1925, p. 3.

JORNAL DO COMMERCIO. Elogio de Carlos Chagas e o professor argentino Salvador Mazza. Jornal do Commercio, Rio de Janeiro, 20 out. 1935, p. 14.

JORNAL DO COMMERCIO. Considerações sobre a doença de Chagas. Conferência realizada pelo dr. Emmanuel Dias, do Instituto Oswaldo Cruz, no 1ํ Congresso Médico do Brasil Central e 3 o do Triângulo Mineiro, reunido em Araxá. Jornal do Commercio, Rio de Janeiro, 12 fev. 1950, p. 5.

JORNAL DO COMMERCIO. Sociedade de Biologia do Rio de Janeiro. Trabalhos de sua última sessão: profilaxia da doença de Chagas. Jornal do Commercio, 10 ago. 1956, p. 7.

JORNAL DO COMMERCIO. Mais de 300 municípios combateram a doença de Chagas. Jornal do Commercio, 19 jan. 1957, p. 3.

JORNAL DO COMMERCIO. Plano de combate à doença de Chagas. Vai ser intensificada a construção de paredes à prova da ação de barbeiros. Jornal do Commercio, Rio de Janeiro, 22 fev. 1958, p. 4.

JORNAL DO COMMERCIO. Moções aprovadas no Congresso de Chagas. Jornal do Commercio, Rio de Janeiro, 12 jul. 1959, p. 12.

KRAUS, R. \& ROSENBUSCH, F. Bocio, cretinismo y enfermedad de Chagas. 2a Comunicación. La Prensa Medica Argentina, 3(17): 177-180, 1916.

KRAUS, R.; MAGGIO, C. \& ROSENBUSCH, F. Bocio, cretinismo y enfermedad de Chagas. 1a. Comunicación. La Prensa Medica Argentina, 2(1): 2-5, 1915.

KUBitscheK, J. Programa de Saúde Pública do Candidato. São Paulo: L. Nicollini, 1955.

LA PRENSA MÉDICA ARGENTINA. El primer Congreso Nacional de Medicina. Un éxito brillante de la Medicina Argentina. La Prensa Médica Argentina, 3(11/ 12): 101-107, 1916.

LARANJA, F. Evolução dos conhecimentos sôbre a cardiopatia da doença de Chagas. Revisão crítica da literatura. Memórias do Instituto Oswaldo Cruz, 47(3-4): 605-669, 1949.

LARANJA, F. Aspectos clínicos da moléstia de Chagas. Revista Brasileira de Medicina, 10(7): 482-491, 1953.

LARANJA, F. Evolución de los Conocimientos sobre la Cardiopatia de la Enfermedad de Chagas. Revisión Crítica de la Literatura. Caracas: Imprensa Nacional, 1954 .

LARANJA, F.; DIAS, E. \& NÓBREGA, G. O eletrocardiograma na cardiopatia crônica da doença de Chagas. Brasil-Medico, 62(8/9): 51-53, 1948a.

LARANJA, F.; DIAS, E. \& NÓBREGA, G. Clínica e terapêutica da doença de Chagas. Memórias do Instituto Oswaldo Cruz, 46(2): 473-529, 1948b. 
LARANJA, F.; DIAS, E. \& PELLEGRINO, J. Chagas' heart disease: a clinical entity. In: CONGRÈS MONDIAL DE CARDIOLOGIE, RESUMÉS, 1, 1950, Paris, Anais... Paris, 1950.

LARANJA, F.; PELLEGRINO, J. \& DIAS, E. Experimental Chagas' heart disease. In: INTERNATIONAL CARDIOLOGICAL CONGRESS, 3, 1948, Chicago. Abstracts... Chicago, 1948.

LARANJA, F. et al. Chagas' Disease: a clinical, epidemiologic and pathologic study. circulation, 14: 1.035-1.060, 1956.

LASMAR, J. E. Casos agudos de doença de Chagas em Bambuí, oeste de Minas Gerais. Brasil-Médico, 58 (23/24): 232-233, 1944.

LAVOURA E COMÉRCIO. Gigantesca campanha contra a ‘doença de Chagas' será iniciada domingo próximo, nesta cidade. Lavoura e Comércio, Uberaba, 3 maio. 1950 a, p. 2.

LAVOURA E COMÉRCIO. Sociedade de Medicina e Cirurgia de Uberaba. Conferência de Francisco Laranja sobre 'Cardiopatia chegásoca' [sic]. Lavoura e Comércio, Uberaba, 15 maio. 1950b, p. 2.

LEÃO, P. et al. Afranio versus Afranio. Niterói: Typ. Jerônimo Silva, 1922.

LENT, H. In memoriam - Arthur Neiva (1880-1843). Revista Brasileira de Biologia, 3(3): 273-291, 1943.

LOBATO, M. Mr. Slang e o Brasil e Problema Vital. 7. ed. São Paulo: Brasiliense, 1956.

LOBO LEITE, A. Doença de Chagas e bocio endemico. Brasil-Medico, 53(46): 1.031$1.033,1939$.

LOBO LEITE, A. O bócio endêmico em Minas Gerais. Um ensaio de prevenção pelo iodo. Memórias do Instituto Oswaldo Cruz, 38(1): 1-19, 1943.

LUTZ, A. \& MACHADO, A. Viagem pelo rio S. Francisco e por alguns de seus afluentes entre Pirapora e Joazeiro. Memórias do Instituto Oswaldo Cruz, 7: 5-50, 1915 .

Magalhães, F. Centenário da Faculdade de Medicina do Rio de Janeiro. Rio de Janeiro: Tip. A. P. Barthel, 1932.

MAGalhães, O. de. Un Poco da la Vida de Carlos Chagas. Mendoza: Best Hermanos, 1944.

MAGALHÃES, O. de. Importância social da doença de Chagas. O Hospital, 31 (1): 9$19,1947$.

MANSON, P. The necessity for special education in tropical medicine. The Lancet, 2: 842-845, 1897.

MANSON, P. Tropical diseases: a manual of the diseases of warm climates. 3. ed. London: s.n., 1903.

MARCHOUX, E. Notice Nécrologique sur Carlos Chagas (de Rio de Janeiro) (18791934). Paris: Masson et Cie., 1934. 
MARCHOUX, E. Carlos Chagas. A Folha Médica, 27(21): 313-314, 1936.

MARSHALL, G. C. 'Address of wellcome by the honorable George Marshall, Secretary of State'. In: INTERNATIONAL CONGRESSES ON TROPICAL MEDICINE AND MALARIA, 4, 10-18 maio 1948, Washington. Anais... Washington: Government Printing Office, 1948. v. II. (Department of State, 3.246).

MARTINS, A. V. \& TUPINAMBÁ, A. Sobre dois casos agudos de molestia de Chagas observados em Minas Gerais, Brasil. Brasil-Medico, 54(51): 839-841, 1940.

MARTINS, A. V.; VERSIANI, V. \& TUPINAMBÁ, A. Sobre 25 casos agudos de molestia de Chagas observados em Minas Gerais. Memórias do Instituto Ezequiel Dias, 3-4: 5-51, 1939/1940.

MARTINS, A. V.; VERSIANI, V. \& TUPINAMBÁ, A. Estudos sobre a Tripanosomiase americana em Minas Gerais, Brasil. Memórias do Instituto Oswaldo Cruz, 35(2): 285-301, 1940.

MAURÍCIO, J. V. Doença de Chagas como fator de despovoamento. Arquivos Brasileiros de Cardiologia, 3 (225): 225, 1954.

MAZZA, S. la palabra del dr. Salvador Mazza. Revista del Círculo Médico de Mendoza, 2(19): 30-32, 1935. (numero dedicado a la Novena Reunión de Patología Regional Argentina).

MAZZA, S. La enfermedad de Chagas en la Republica Argentina. Memórias do Instituto Oswaldo Cruz, 47 (1, 2): 273-287, 1949.

MENDES, M. Meu Testemunho de Brasília. 3. ed. Brasília: Thesaurus, 2006.

MENDONÇA, W. Editorial. Revista Goiana de Medicina, 1(1): 1, 1955.

MENEZES, M. de. Miocardite chagásica crônica: sua incidência no Brasil Central. O Hospital, 36(4): 577-587, 1949.

MINAS GERAIS. Intensa e enérgica campanha contra a doença de Chagas. O Ministro da Educação determinou a mobilização do Instituto Oswaldo Cruz, da Divisão de Organização Sanitária e do Serviço Nacional de Malária para largas atividades profiláticas nas zonas de maior incidência endêmica. Minas Gerais, 3 jan. 1950, p. 16.

MOREIRA, J. A sífilis como fator de degeneração. Gazeta Médica da Bahia, 31(3): 112-125, 1899.

MOREIRA, J. \& PEIXOTO, A. Les maladies mentales dans les climats tropicaux. Arquivos Brasileiros de Psiquiatria, Neurologia e Ciências Afins, 2(1): 222238, 1906.

MÜLHENS, P. Sobre algunos progresos de la medicina e higiene tropical y de la guerra. Revista Médica de Hamburgo, 5: 301-309, 1924.

MUNCíPIOS MINEIROS. Em Bambuí o Ministro da Saúde. Intensificada a luta contra o 'barbeiro'. Municípios Mineiros, Bambuí, jul. 1957.

MUNIZ, J. \& FREITAS, G. de. Contribuição para o diagnóstico da doença de Chagas pelas reações de imunidade. I - Estudo comparativo das reações de aglutinação 
e fixação do complemento. Memórias do Instituto Oswaldo Cruz, 41: 303333, 1944a.

MUNIZ, J. \& FREITAS, G. de. Contribuição para o diagnóstico da doença de Chagas pelas reações de imunidade. II - Isolamento de polissacarídeos de $S$. cruzi e de outros tripanosomídeos, seu comportamento nas reações de precipitação, de fixação do complemento e de hipersensibilidade. Os testes de floculação (sublimado e formogel). Revista Brasileira de Biologia, 4: 421-438, $1944 \mathrm{~b}$.

MYRDALL, G. Les aspects économiques de la santé. Chronique de l'Organisation Mondiale de la Santé, 6(7-8): 224-242, 1952.

NEIVA, A. Informações sobre a biolojia do Conorhinus megistus Burm. Memórias do Instituto Oswaldo Cruz, 2(2): 206-212, 1910.

NEIVA, A. Revisão do Genero Triatoma. Tese da Faculdade de Medicina. Rio de Janeiro, 1914.

NEIVA, A. 'Profilaxia da malária e trabalhos de engenharia. Notas, comentários e recordações'. Malária e Mosquitos. Rio de Janeiro: Imprensa Nacional, 1941.

NEIVA, A. \& PENNA, B. Viajem cientifica pelo norte da Bahia, sudoeste de Pernambuco, sul do Piauhí e de norte a sul de Goiaz. Memórias do Instituto Oswaldo Cruz, 8(3): 74-224, 1916.

NUNES, C. Uma reedição importante e necessária. In: NEIVA, A. \& PENNA, B. Viagem Científica pelo Norte da Bahia, Sudoeste de Pernambuco, Sul do Piauí e de Norte a Sul de Goiás. Brasília: Senado Federal, 1999.

O DIÁRIO. Empreendimento inédito no mundo. Oficialmente inaugurada em Uberaba a campanha contra a doença de Chagas - Falam o Ministro da Educação, o Secretário da Saúde e o diretor do Serviço Nacional de Malária. O Diário, Belo Horizonte, 9 maio. 1950, p. 12.

O DIÁRIO. Mesa redonda sobre a doença de Chagas. O Diário, Belo Horizonte, 26 jul. 1952, p. 5 .

O ESTADO DE S. PAULO. Dr. Carlos Chagas. O Estado de S. Paulo, 7 set. 1912, p. 5.

O ESTADO DE S. PAULO. Moléstia de Chagas. O Estado de S. Paulo, 11 ago. 1951, p. 5.

O ESTADO DE S. PAULO. Reuniram-se ontem em S. Joaquim da Barra prefeitos da Alta Mogiana. Lançadas as bases para debelar a moléstia de Chagas. O Estado de S. Paulo, 23 set. 1956.

O GLOBO. De nada valem os planos sem as necessárias condições de exequibilidade. Como o cientista Emanuel Dias, do Instituto Oswaldo Cruz, se refere aos planos e às equipes de trabalho do Serviço Nacional de Malária, na campanha contra a Doença de Chagas inaugurada no Triângulo Mineiro. O Globo, Rio de Janeiro, 25 maio. 1950, p. 6.

O GLOBO. Cientista brasileiro convidado para orientar os debates do Primeiro Congresso Interamericano de Higiene. A distinção concedida ao Dr. Emmanuel Dias, do Instituto Oswaldo Cruz. O Globo, Rio de Janeiro, 29 abr. 1952, p. 9. 
O GLOBO. Guerra sem quartel à doença de Chagas. O Globo, Rio de Janeiro, 22 jan. 1959 a, p. 1-2.

O GLOBO. Frota de helicópteros para combate à doença de Chagas. O Globo, Rio de Janeiro, 26 jan. 1959b, p. 1, 13.

O GLOBO. Solidário com 'O Globo' na campanha contra a doença de Chagas. O Globo, Rio de Janeiro, 30 jan. 1959c, p.2.

O GLOBO. Falta de transporte dificulta a luta contra o mal de Chagas. O Globo, Rio de Janeiro, 12 fev. 1959d, p. 1-2.

O GLOBO. Voto de louvor a 'O Globo' pela campanha contra a doença de Chagas em Minas. O Globo, Rio de Janeiro, 12 fev. 1959e, p. 4.

O IMPARCIAL. O novo director do Instituto Oswaldo Cruz. Foi nomeado hontem o dr. Carlos Chagas. Uma entrevista com o eminente scientista. O Imparcial, Rio de Janeiro, 15 fev. 1917, p. 5.

O IMPARCIAL. Memoravel sessão da Academia Nacional de Medicina. O dr. Carlos Chagas expoe serenamente, á luz da verdade scientifica, os seus estudos sobre a trypanosomiase americana. O Imparcial, Rio de Janeiro, 7 dez. 1923a, p.1.

O IMPARCIAL. A molestia de Chagas. O Imparcial, Rio de Janeiro, 8 dez. 1923b, p. 2.

O JORNAL. A doença de Cruz e Chagas. O Jornal, Rio de Janeiro, 17 dez. 1922, p. 6.

O JORNAL. O caso da Doença de Chagas. Como o discutiu a Academia de Medicina. O Jornal, Rio de Janeiro, 23 nov. 1923a.

O JORNAL. Câmara dos Deputados. A luta contra a 'doença de Chagas' em Minas. O Jornal, Rio de Janeiro, 17 maio. 1950, p. 3.

O JORNAL. Debate sobre o 'mal de Chagas'. Mesa redonda em Cuba com a participação de cientistas brasileiros. O Jornal, Rio de Janeiro, 17 set. 1952, p. 8

O PAIZ. O Estado sanitario. O Paiz. Rio de Janeiro, 12 fev. 1920a, p. 3.

O PAIZ. A reforma da Saude Publica. O Paiz, Rio de Janeiro, 9 mar. 1920b, p. 3.

O PAIZ. O regulamento sanitario. O Paiz, Rio de Janeiro, 4 jun. 1920c, p. 3.

PEIXOTO, J. A. Coreotripanose (doença de Chagas). In: PEIXOTO, J. A. Elementos de Hygiene. Rio de Janeiro, São Paulo, Bello Horizonte: Francisco Alves, 1913.

PELLEGRINO, J. O eletrocardiograma na fase crônica da doença de Chagas experimental no cão. Memórias do Instituto Oswaldo Cruz, 44(4): 615-647, 1946.

PELLEGRINO, J. O eletrocardiograma na doença de Chagas experimental no cão. Brasil-Medico, 61 (33, 34, 35): 299-301, 1947.

PELLEGRINO, J. Comentários aos trabalhos apresentados a VI Jornada de Pediatria e Puericultura sobre o tema 'doença de Chagas na infância'. Jornal de Pediatria, 17(5): 210-223, 1952.

PELlEGRINO, J. A doença de Chagas em Minas Gerais. Esbôço crítico dos trabalhos publicados até 1951. Memórias do Instituto Oswaldo Cruz, 51: 611-668, 1953. 
PELLEGRINO, J. \& BORROTCHIN, M. Inquérito sôbre a doença de Chagas no Hospital da Santa Casa de Misericórdia de Belo Horizonte (Minas Gerais, Brasil). Memórias do Instituto Oswaldo Cruz, 46(2): 419-457, 1948.

PELlegrino, J. \& BRENER, Z. Profilaxia de um foco da doença de Chagas nas proximidades de Belo Horizonte (Cidade Industrial). Revista da Associação Médica de Minas Gerais, 2(2): 233-250, 1951.

PELleGRINO, J. \& REZENDE, C. L. A doença de Chagas na infância. Memórias do Instituto Oswaldo Cruz, 51: 545-610, 1953.

PELLEGRINO, J.; REZENDE, C. L. \& BRENER, Z. Métodos e critérios para a realização de inquéritos sobre doença de Chagas em crianças. Jornal de Pediatria, 17(5): 224-248, 1952.

PELLEGRINO, J. et al. Inquérito sôbre a Doença de Chagas em candidatos a doadores de sangue. Memórias do Instituto Oswaldo Cruz, 49: 555-564, 1951.

PENNA, B. Instituto Oswaldo Cruz. A Noite, Rio de Janeiro, 16 fev. 1917.

PENNA, B. Minas e Rio Grande do Sul. Estado da Doença e Estado da Saúde. Rio de Janeiro: Revista dos Tribunaes, 1918a.

PENNA, B. Saneamento do Brasil. Rio de Janeiro: Typ. Revista dos Tribunaes, 1918b.

PENNA, B. Exército e Saneamento. Rio de Janeiro: Typ. Revista dos Tribunaes, 1920.

PENNA, B. Saneamento do Brasil. 2. ed. Rio de Janeiro: Editor Jacintho Ribeiro dos Santos, 1923.

PESSOA, S. B. Parasitologia Médica. São Paulo: Renascença, 1946.

PESSOA, S. B. Ensaios Médico-Sociais. 2. ed. São Paulo: Cebes, Hucitec, 1978.

PINOTTI, M. A campanha de profilaxia da doença de Chagas. I - Os resultados da campanha antimalarígena. Folha de Minas, Belo Horizonte, 12 maio. 1950a, p. 4,10 .

PINOTTI, M. A campanha de profilaxia da doença de Chagas. II - Resultados e ensinamentos dos trabalhos experimentais. Folha de Minas, Belo Horizonte, 13 maio. 1950 b, p. $4-5$.

PINOTTI, M. Malária e doença de Chagas: dois problemas em via de solução. Revista Brasileira de Medicina, 8(1): 34-40, $1951 \mathrm{a}$.

PINOTTI, M. Malária e doença de Chagas: dois grandes problemas nacionais de saúde em via de solução. Parte II. Revista Brasileira de Medicina, 8(2): 97-105, 1951b.

PINOTTI, M. A situação actual no Brasil da luta contra a malária e a doença de Chagas. Revista Brasileira de Medicina, 9(3/4): 191-198, 262-267, 1952.

PINOTTI, M. 'Profilaxia da doença de Chagas'. In: CONFERENCIA SANITÁRIA PANAMERICANA PARA COMEMORAR EL CINQUENTENÁRIO DE LA OFICINA SANITÁRIA PANAMERICANA Y EN HOMENAJE A CARLOS J. FINLAY, 13, 26 set. - 01 out. 1952, Havana. Memoria del Primer Congreso Interamericano de Higiene... Havana, 1953. 
PINOTTI, M. Contrôle da doença de Chagas no Brasil. Revista Brasileira de Malariologia e Doenças Tropicais, 6b(3): 301-310, 1954.

PINOTTI, M. Saúde e Riqueza. Discurso Pronunciado em Nome da Sociedade Brasileira de Higiene, a 24 de abril de 1958 - Sala do Automóvel Clube do Brasil. Rio de Janeiro: s.n., 1958.

PINOTTI, M. Vida e Morte do Brasileiro. Rio de Janeiro: Civilização Brasileira, 1959.

PINTO, C. Tripanosomiasis Cruzi (Doença de Carlos Chagas) no Rio Grande do Sul, Brasil. Memórias do Instituto Oswaldo Cruz, 37(4): 443-537, 1942.

REPARTIÇÃO SANITÁRIA PAN-AMERICANA (RSPA). A doença de Chagas em Belo Horizonte. Boletín de la Oficina Sanitária Panamericana, 9(1): 1.397$1.398,1930$.

REPARTIÇÃO SANITÁRIA PAN-AMERICANA (RSPA). Atas da XI Conferência Sanitária Panamericana. Rio de Janeiro, 7-18 set. 1942.

REPARTIÇÃO SANITÁRIA PAN-AMERICANA (RSPA). Memoria del Primer Congreso Interamericano de Higiene. Convocado por resolución de la XIII Conferencia Sanitaria Panamericana para comemorar el cinquentenário de la Oficina Sanitária Panamericana y en homenaje a Carlos J. Finlay. 26 de septiembre a 1 octubre de 1952. La Habana, 1953.

PINTO, G. de S. Contribuições originais de Carlos Chagas à epidemiologia e à profilaxia da malária. A Folha Médica, 27(21): 307, 1936.

PONDÉ, A. A cardiopatia chagásica da doença de Carlos Chagas. Arquivos Brasileiros de Cardiologia, 1(1): 27-70, 1948.

PORTO, C. \& PORTO, C. C. História do megaesôfago nos Congressos Médicos do Brasil Central. Revista Goiana de Medicina, 16(1/2): 117-136, 1970.

REVISTA GOIANA DE MEDICINA. Reunião de debates sobre doença de Chagas. Revista Goiana de Medicina, 9, supl., 1963.

REZENDE, J. M. de. Megaesôfago por doença de Chagas. Revista Goiana de Medicina, 2(4): 297-314, 1956a.

REZENDE, J. M. de. Editorial. Doença de Chagas em Goiás. Revista Goiana de Medicina, 2(4): 239-240, 1956b.

REZENDE, J. M. de. Editorial. Doença de Chagas no Brasil. Revista Goiana de Medicina, 4(2): 81-82, 1958.

REZENDE, J. M. de. Carlos Chagas. Revista Goiana de Medicina, 5(4): 285-302, 1959a.

REZENDE, J. M. de. Editorial. Doença de Chagas nas Américas. Revista Goiana de Medicina, 5(4): 281, 1959b.

REZENDE, J. M. de. Obstáculos ao reconhecimento da etiologia chagásica do megaesôfago e megacólon endêmico (uma visão histórica). In: REZENDE, J. M. de. Vertentes da Medicina. São Paulo: Giordano, 2001a. 
REZENDE, J. M. de. Revista Goiana de Medicina - 30 anos. In: REZENDE, J. M. de. Vertentes da Medicina. São Paulo: Giordano, 2001b.

RIBEIRO, I. B. Doença de Chagas na Colônia Agrícola Nacional de Goiás. Revista Goiana de Medicina, 1(2): 83-88, 1955.

RIBEIRO, I. B. Profilaxia da doença de Chagas em Brasília. Revista Goiana de Medicina, 3(3): 197-202, 1957.

RIBEIRO, P. de A.; FERREIRA, M. J. \& BRAGA, E. Economic value of health. Revista Brasileira de Epidemiologia, 1(3): 303-344, 1998.

ROCHA, I. da. A doença de Carlos Chagas. Uma sessão memoravel na Academia Nacional de Medicina. O Paiz, Rio de Janeiro, 31 out. 1910, p. 6.

ROMAÑA, C. Acerca de um sintoma inicial de valor para el diagnostico de forma aguda de la enfermedad de Chagas. La conjuntivitis esquizotripanózica unilateral (Hipotesis sobre la puerta de entrada conjuntival de la enfermedad). Publicaciones Mepra, 22: 16-28, 1935.

ROMAÑA, C. 'Panorama continental de la enfermedad chagásica'. In: CONGRESSO BRASILEIRO DE Higiene, 9, 4 - 11 nov. 1951, Porto Alegre. Anais... Porto Alegre: Ofina Gráfica da Livraria do Globo, 1952.

ROMAÑA, C. \& ABALOS, J. Acción del Gammexane sobre los triatomideos. Control domiciliario. Anales del Instituto de Medicina Regional, 2: 95-106, 1948.

ROMEIRO, O. dos S. Encontro de caso agudo e de casos crônicos da doença no Estado de Goiaz. O Hospital, 20(4): 587-590, 1941.

ROSS, R. Inaugural lecture on the possibility of extirpation of malaria from certain localities by a new method. British Medical Journal, jul. 1897.

ROSS, R. The Prevention of Malaria. London: E. P. Dutton, 1910.

SCAFFA, A. As realizações do governo no Vale do São Francisco. Alterosa, 15 mar. 1958, p. 54-55.

SEIDL, C. O ensino da patologia tropical no Brasil. Brazil-Medico, 14(20): 173-174, 1900.

SILVEIRA, J. P. da. Editorial. Revista Goiana de Medicina, 4(1): 1-3, 1958.

SOCIEDADE BRASILEIRA DE HIGIENE (SBH). Sétimo Congresso Brasileiro de Higiene: publicação preliminar. São Paulo: Tip. Departamento de Investigações, 1949.

SOCIEDADE BRASILEIRA DE HIGIENE (SBH). Anais do IX Congresso Brasileiro de Higiene. Porto Alegre, 4 a 11 de novembro de 1951. Porto Alegre: Of. Gráfica da Livraria do Globo, 1952.

SOCIEDADE BRASILEIRA DE HIGIENE (SBH). Anais do X Congresso Brasileiro de Higiene. Belo Horizonte, 19 a 25 de outubro de 1952. Belo Horizonte: Imprensa Oficial do Estado de Minas Gerais, 1953. 
SOCIEDADE BRASILEIRA PARA O PROGRESSO DA CIÊNCIA (SBPC). III Reunião anual da SBPC. Belo Horizonte, 5 a 10 de novembro de 1951. Resumos das comunicações. Ciência e Cultura, 3(4): 257-258, 1951.

SODRÉ, L. Necrologia. Dr. Evandro Seraphim Lobo Chagas. Brasil-Medico, 49: 820$822,1940$.

SOUZA-ARAúJO, H. C. de. História da Lepra no Brasil. Rio de Janeiro: Departamento de Imprensa Nacional, 1956. v. III. (Período Republicano).

TORRES, A. Liga de Defesa nacional. Em torno de um discurso. Gazeta de Noticias, Rio de Janeiro, 14 out. 1916, p. 2.

TORRES, C. B. de M. Estudo do miocárdio da moléstia de Chagas (forma aguda). I. Alterações na fibra muscular cardíaca. Memórias do Instituto Oswaldo Cruz, 9(1): 114-139, 1917.

TORRES, C. B. de M. A tripanosomíase americana e sua anatomia pathologica. A Folha Médica, 4(4): 25-29, 1923.

TRIBUNA DE MINAS. Imperativa a luta contra o 'barbeiro'. Problema sanitário da maior relevância, ligado aos interesses econômicos e ao aprimoramento progressivo de nossa raça. Tribuna de Minas, Belo Horizonte, 16 out. 1951, p. 7, 14.

USIngER, R. L. The Triatominea of North and Central America and the West Indies and Their Public Health Significance. Washington: Government Printing Office, 1944. (Public Health Bulletin, n. 288)

VARGAS, G. A Nova Política do Brasil. Rio de Janeiro: José Olympio, 1938. v. 3.

VASCONCEllos, H. F. de. Moléstia de Cruz e Chagas. A conferencia do Dr. Figueiredo de Vasconcellos. Jornal do Commercio, Rio de Janeiro, 21 ago. 1919 a, p. 6.

VASCONCELLOS, H. F. de. Moléstia de Cruz e Chagas. Conferencia do Dr. Figueiredo de Vasconcellos na Sociedade de Medicina e Cirurgia. Jornal do Commercio, Rio de Janeiro, 23 ago. 1919b, p. 6.

VASCONCELlos, I. de. Carlos Chagas e a Medicina Brasileira. Rio de Janeiro: Instituto Brasileiro de História da Medicina, 1959.

VIANNA, G. Contribuição para o estudo da anatomia patolojica da 'Molestia de Carlos Chagas' (esquizotripanoze ou tireoidite parazitaria). Memórias do Instituto Oswaldo Cruz, 3(2): 276-294, 1911.

VIANNA, J. B. Bocio endemico em Minas Gerais. Annaes da Faculdade de Medicina da Universidade de Minas Gerais, 3(1): 53-75, 1931.

VIDAL, G. Uma calamidade. Correio da Manhã, Rio de Janeiro, 18 nov. 1910, p. 1.

VILLELA, E. Carlos Chagas. Memórias do Instituto Oswaldo Cruz, 29(1): I-XV, 1934.

VILLELA, E. "Carlos Chagas e sua projeção no estrangeiro. A Folha Médica, 27(21): 297-303, 1936. (Edição especial: Doenças Tropicaes e Infectuosas) 
VILLELA, E. \& BICALHO, C. As pesquisas de laboratorio no diagnostico da molestia de Chagas. Memórias do Instituto Oswaldo Cruz, 16(1): 13-29, 1923.

WINSLOW, C.-E. A. Lo que Cuesta la Enfermidad y lo que Vale la Salud. Washington: Organización Mundial de la Salud, Oficina Sanitaria Panamericana, 1955 (Publicaciones Científicas, n.16)

WORLD HEALTH ORGANIZATION (WHO). Chagas' Disease: report of a Study Group. Geneva: World Health Organization, 1960. (WHO Technical Report Series, 202).

YORKE, W. Chagas' disease. A critical review. Tropical Diseases Bulletin, 34(4): 275$300,1937$.

\section{III - Fontes Orais}

ANDRADE, Zilton. Depoimento. Projeto História da Pesquisa sobre a Doença de Chagas no Brasil. Rio de Janeiro: Programa de História Oral da Casa de Oswaldo Cruz, 2000.

BREner, Zigman. Depoimento. Projeto História da Pesquisa sobre a Doença de Chagas no Brasil. Rio de Janeiro: Programa de História Oral da Casa de Oswaldo Cruz, 1995.

CAmargo, Erney. Depoimento. Projeto História da Pesquisa sobre a Doença de Chagas no Brasil. Rio de Janeiro: Programa de História Oral da Casa de Oswaldo Cruz, 2002.

CARVAlHeiro, José da Rocha. Depoimento. Projeto História da Pesquisa sobre a Doença de Chagas no Brasil. Rio de Janeiro: Programa de História Oral da Casa de Oswaldo Cruz, 2002.

CHAGaS FILHo, Carlos. Depoimento. Projeto Memória de Manguinhos. Rio de Janeiro: Programa de História Oral da Casa de Oswaldo Cruz, 1987.

COURA, José Rodrigues. Depoimento. Projeto História da Pesquisa sobre a Doença de Chagas no Brasil. Rio de Janeiro: Programa de História Oral da Casa de Oswaldo Cruz, 1999.

DIAS, João Carlos Pinto. Depoimento. Projeto História da Pesquisa sobre a Doença de Chagas no Brasil. Rio de Janeiro: Programa de História Oral da Casa de Oswaldo Cruz, 1998.

FERRIOLI FILHO, Francisco. Depoimento. Projeto História da Pesquisa sobre a Doença de Chagas no Brasil. Rio de Janeiro: Programa de História Oral da Casa de Oswaldo Cruz, 2002.

LARANJA, Francisco. Depoimento. Projeto Memória de Manguinhos. Rio de Janeiro: Programa de História Oral da Casa de Oswaldo Cruz, 1986.

LARAnja, Francisco. Depoimento. Projeto Memória da Saúde Pública da Escola Nacional de Saúde Pública. Rio de Janeiro: Escola Nacional de Saúde Pública, 1978. 
LOBATO PARAense, Wladimir. Depoimento. Projeto Memória de Manguinhos. Rio de Janeiro: Casa de Oswaldo Cruz,1987/1989.

MARTINS, Amilcar Vianna. Depoimento. Projeto Memória de Manguinhos. Rio de Janeiro: Programa de História Oral da Casa de Oswaldo Cruz, 1987.

MOREL, Carlos Médicis. Depoimento. Projeto História da Pesquisa sobre a Doença de Chagas no Brasil. Rio de Janeiro: Programa de História Oral da Casa de Oswaldo Cruz, 1992.

PRATA, Aluizio. Depoimento. Projeto História da Pesquisa sobre a Doença de Chagas no Brasil. Rio de Janeiro: Programa de História Oral da Casa de Oswaldo Cruz, 2000.

RASSI, Anis. Depoimento. Projeto História da Pesquisa sobre a Doença de Chagas no Brasil. Rio de Janeiro: Programa de História Oral da Casa de Oswaldo Cruz, 2001.

REZENDE, Joffre Marcondes de. Depoimento. Projeto História da Pesquisa sobre a Doença de Chagas no Brasil. Rio de Janeiro: Programa de História Oral da Casa de Oswaldo Cruz, 2001.

RIBEIRO, Isaac Barreto. Depoimento. Projeto História da Pesquisa sobre a Doença de Chagas no Brasil. Rio de Janeiro: Programa de História Oral da Casa de Oswaldo Cruz, 2006.

SANTOS, Ricardo Ribeiro dos. Depoimento. Projeto História da Pesquisa sobre a Doença de Chagas no Brasil. Rio de Janeiro: Programa de História Oral da Casa de Oswaldo Cruz, 1995.

\section{IV - Referências}

ABREU, A. A. de. O nacionalismo de Vargas ontem e hoje. In: D'ARAÚJO, M. C. (Org.) As Instituições Brasileiras da Era Vargas. Rio de Janeiro: Eduerj, Editora FGV, 1999.

ACADEMIA BRASILEIRA DE LETRAS (ABL). Presidentes. Disponível em: $<$ www.academia.org.br>. Acesso em: 10 mar. 2006.

ACADEMIA NACIONAL DE MEDiCinA (ANM). Presidentes. Disponível em: <www.anm.org.br>. Acesso em: 8 mar. 2006.

ACKERKNECHT, E. H. Anticontagionism between 1821 and 1867. The Bulletin of the History of Medicine, 22: 562-593, 1948.

ALMEIDA, M. de. República dos Invisíveis: Emílio Ribas, microbiologia e saúde pública em São Paulo - 1898-1917. Bragança Paulista: Editora da Universidade São Francisco, 2003.

ALONSO, A. Idéias em Movimento: a geração 1870 na crise do Brasil-Império. São Paulo: Paz e Terra, 2002. 
ANDERSON, W. Natural histories of infectious disease: ecological vision in twentiethcentury biomedical science. Osiris, 19: 39-61, 2004.

ANDRADE, A. M. R. Físicos, Mésons e Política: a dinâmica da ciência na sociedade. São Paulo, Rio de Janeiro: Hucitec, Museu de Astronomia e Ciências Afins, 1999.

ARAÚJO, A. J. G. de.; SABROZA, P. C. \& SILVA, L. F. F. Paleoepidemiologia da doença de Chagas. In: PROGRAMA INTEGRADO DE DOENÇA DE CHAGAS DA FIOCRUZ. Portal Doença de Chagas. Rio de Janeiro: Fundação Oswaldo Cruz, 2007. Disponível em: <www.fiocruz.br/chagas/cgi/cgilua.exe/sys/ start.htm?sid=130>. Acesso em: 24 nov. 2008.

ARNOLD, D. (Ed.) Imperial Medicine and Indigenous Societies. Manchester: Manchester University Press, 1988.

ARNOLD, D. Introduction: tropical medicine before Manson. In: ARNOLD, D. (Ed.) Warm Climates and Western Medicine: the emergence of Tropical Medicine, 1500-1900. Amsterdam, Atlanta: Rodopi, 1996a.

ARNOLD, D. The Problem of Nature: environment, culture and European expansion. Oxford, Cambridge: Blackwell Publishers, 1996b.

ARNOLD, D. Medicine and colonialism. In: BYNUM, W. F. \& PORTER, R. (Eds.) Companion Encyclopedia of the History of Medicine. London, New York: Routledge, 1997. v.2.

ASSOCIAÇÃO NACIONAL DE PRESERVAÇÃO FERROVIÁRIA (ANPF). Histórico da Estrada de Ferro Central do Brasil. Disponível em: <www.anpf.com.br/ historico_efcb.htm>. Acesso em: 16 nov. 2005.

AZEVEDO, N. \& KROPF, S. P. Ciência, saúde e vida pública. In: KLEIN, L. (Org.) Professor Amilcar Vianna Martins: ciência para a saúde. Rio de Janeiro: Casa de Oswaldo Cruz, Centro de Pesquisas René Rachou, 2007.

AZEVEDO, N.; KROPF, S. P. \& COURA, J. R. O Programa Integrado de Pesquisa em Doenças Endêmicas (PIDE/CNPq) e a pesquisa sobre doença de Chagas nas décadas de 1970 e 1980. In: PROGRAMA INTEGRADO DE DOENÇA DE CHAGAS DA FIOCRUZ. Portal Doença Chagas. Rio de Janeiro: Fundação Oswaldo Cruz, 2007. Disponível em: <www.fiocruz.br/chagas/cgi/cgilua.exe/sys/start.htm?sid=59>. Acesso em: 28 set. 2008.

AZEVEDO, N.; KROPF, S. P. \& HAMILTON, W. A profissionalização da ciência no Brasil: a trajetória de Zigman Brener. In: KLEIN, L. et al. (Orgs.) Inovando a Tradição: Zigman Brener e a parasitologia no Brasil. Rio de Janeiro: Casa de Oswaldo Cruz, Centro de Pesquisas René Rachou, 2003.

BARNES, B. Scientific Knowledge and Sociological Theory. London: Routledge \& Keagan Paul, 1974.

BARNES, B. T. S. Kuhn y las Ciencias Sociales. México: Fondo de Cultura Econômica, 1986.

BEATTIE, P. M. The Tribute of Blood: army, honor, race and nation in Brazil - 18641945. Durham, London: Duke University Press, 2001. 
BElOCH, I. \& ABREU, A. A. de (Orgs.) Dicionário Histórico-Biográfico Brasileiro: 1930-1983. Rio de Janeiro: Editora Forense Universitária, FGV, CPDOC, Finep, 1984. v. 2.

BENCHIMOL, J. L. (Coord.) Manguinhos do Sonho à Vida: a ciência na Belle Époque. Rio de Janeiro: Casa de Oswaldo Cruz, 1990a.

BenChimol, J. L. Pereira Passos, um Haussmann Tropical. Rio de Janeiro: Prefeitura da Cidade do Rio de Janeiro, Secretaria Municipal de Cultura, Turismo e Esportes, Departamento Geral de Documentação e Informação Cultural, 1990b.

BENCHIMOL, J. L. Dos Micróbios aos Mosquitos: febre amarela e a revolução pasteuriana no Brasil. Rio de Janeiro: Editora Fiocruz, Editora UFRJ, 1999.

BENCHIMOL, J. L. (Coord.) Febre Amarela: a doença e a vacina, uma história inacabada. Rio de Janeiro: Editora Fiocruz, Bio-Manguinhos, 2001.

BENCHIMOL, J. L. Reforma urbana e Revolta da Vacina na cidade do Rio de Janeiro. In: FERREIRA, J. \& DELGADO, L. de A. N. (Orgs.) O Tempo do Liberalismo Excludente: da Proclamação da República à Revolução de 1930. Rio de Janeiro: Civilização Brasileira, 2003. (O Brasil Republicano, v. 1)

BENCHIMOL, J. L. \& SILVA, A. F. C. da. Ferrovias, doenças e medicina tropical no Brasil da Primeira República. História, Ciências, Saúde - Manguinhos, 15: 719762, 2008.

BENCHIMOL, J. L. \& TEIXEIRA, L. A. Cobras, Lagartos \& Outros Bichos: uma história comparada dos institutos Oswaldo Cruz e Butantan. Rio de Janeiro: Editora UFRJ, 1993.

BENCHIMOL, J. L. \& SÁ, M. R. Insetos, humanos e doenças: Adolpho Lutz e a medicina tropical. In: BENCHIMOL, J. L. \& SÁ, M. R. (Orgs.) Febre Amarela, Malária e Protozoologia. Rio de Janeiro: Editora Fiocruz, 2005. (Adolpho Lutz Obra completa, v. 2, livro 1)

BENCHIMOL, J. L. \& SÁ, M. R. Adolpho Lutz e a Entomologia Médica no Brasil (Apresentação histórica). Rio de Janeiro: Editora Fiocruz, 2006. (Adolpho Lutz Obra completa, v. 2, livro 3)

Biblioteca virtual Em SAÚde CARlos CHagas. Site. Disponível em: $<$ www.bvschagas.coc.fiocruz.br $>$.

BIbLIOTECA VIRTUAL EM SAÚde ADOLPHO LUTZ. Site. Disponível em: $<$ www.bvsalutz.coc.fiocruz.br $>$.

BILHARINHO, J. S. História da Medicina em Uberaba. Uberaba: Academia de Letras do Triângulo Mineiro, Bolsa de Publicações do Município de Uberaba, 1983. v. III.

BLOOR, D. Knowledge and Social Imagery. 2. ed. Chicago, London: The University of Chicago Press, 1991.

BLOOR, D. Anti-Latour. Studies in History and Philosophy, 30(1): 81-112, 1999a.

BLOOR, D. Reply to Bruno Latour. Studies in History and Philosophy of Science, 30(1): 131-136, 1999b. 
BOMENY, H. Infidelidades eletivas: intelectuais e política. In: BOMENY, H. (Org.) Constelação Capanema: intelectuais e políticas. Rio de Janeiro: Editora FGV, Editora da Universidade São Francisco, 2001.

BORGES, M. E. L. Elite Agrária em Tempo de Mudança Social: Minas Gerais 1928-1946, 1997. Tese de Doutorado, Rio de Janeiro: Instituto Universitário de Pesquisas do Rio de Janeiro, Universidade do Estado do Rio de Janeiro.

BRANDT, A. Aids and metaphor: toward the social meaning of epidemic disease. In: MACK, A. (Ed.) In Time of Plague: the history and social consequences of lethal epidemic disease. New York, London: New York University Press, 1991.

BRANnigan, A. A Base Social das Descobertas Científicas. Rio de Janeiro: Zahar, 1984.

BRASIL. Ministério da Saúde. Consenso Brasileiro em Doença de Chagas. Revista da Sociedade Brasileira de Medicina Tropical, 38, supl. III: 7-29, 2005.

BRENER, Z. A descoberta (homenagem aos 80 anos da descoberta da Doença de Chagas). Memórias do Instituto Oswaldo Cruz, 84, supl. II: 1-6, 1989.

BRITTO, N. Oswaldo Cruz: a construção de um mito na ciência brasileira. Rio de Janeiro: Editora Fiocruz, 1995.

BROWN, P. Malaria, Miseria and underpopulation in Sardinia: the 'malaria blocks development' cultural model. Medical Antrhropology, 17(3): 239-254, 1997.

BURAlli, G. M. Estudo do Controle dos Triatomíneos Domiciliados no Estado de São Paulo, 1985. Dissertação de Mestrado. São Paulo: Faculdade de Saúde Pública, Universidade de São Paulo.

BURNETT, J. The origins of the eletrocardiography as a clinical instrument. In: BYNUM, W. F.; LAWRENCE, C. \& NUTTON, V. (Eds.) The Emergence of Modern Cardiology. London: Wellcome Institute for the History of Medicine, 1985.

BYNUM, W. F. Nosology. In: BYNUM, W. F. \& PORTER, R. (Eds.) Companion Encyclopedia of the History of Medicine. London, New York: Routledge, 1997. v. 1.

BYNUM, W. F.; LAWRENCE, C. \& NUTTON, V. (Eds.) The Emergence of Modern Cardiology. London: Wellcome Institute for the History of Medicine, 1985.

CALLON, M. \& LATOUR, B. (Eds.) La Science Telle Qu’elle se Fait. Paris: La Découverte, 1991.

CAMPOS, A. L. V. de. Combatendo nazistas e mosquitos: militares norte-americanos no Nordeste brasileiro (1941-45). História, Ciências, Saúde - Manguinhos, 5(3): 603-620, 1998/1999.

CAMPOS, A. L. V. de. Políticas internacionais de saúde na era Vargas: o Serviço Especial de Saúde Pública. In: GOMES, A. de C. (Org.) Capanema: o ministro e seus ministérios. Rio de Janeiro, Bragança Paulista: Editora FGV, Editora da Universidade São Francisco, 2000.

CAMPOS, A. L. V. de. Políticas Internacionais de Saúde na Era Vargas: o Serviço Especial de Saúde Pública, 1942-1960. Rio de Janeiro: Editora Fiocruz, 2006.

CAPONI, S. Trópicos, micróbios y vectores. História, Ciências, Saúde - Manguinhos, 9, supl.: 111-138, 2002. 
CARnEIRO, M. História da Doença de Chagas. Curitiba: s.n., 1963.

CARRARA, S. Tributo a Vênus: a luta contra a sífilis no Brasil, da passagem do século aos anos 40. Rio de Janeiro: Editora Fiocruz, 1996.

CARRARA, S. Estratégias anticoloniais: sífilis, raça e identidade nacional no Brasil do entre-guerras. In: HOCHMAN, G. \& ARMUS, D. (Orgs.) Cuidar, Controlar, Curar: ensaios históricos sobre saúde e doença na América Latina e Caribe. Rio de Janeiro: Editora Fiocruz, 2004.

CARVALHO, M. A. R. de. Entre a cultura heróica e a cultura democrática. Presença, 17, nov. 1991.

CARVALHO, M. A. R. de. Quatro Vezes Cidade. Rio de Janeiro: Sette Letras, 1994.

CASA DE OSWALDO CRUZ (COC). A Ciência a Caminho da Roça: imagens das expedições científicas do Instituto Oswaldo Cruz ao interior do Brasil entre 1911 e 1913. Rio de Janeiro: Casa de Oswaldo Cruz, Fiocruz, 1991.

CASTRO-SANTOS, L. A. de. O pensamento sanitarista na Primeira República: uma ideologia de construção da nacionalidade. Dados, 28 (2): 193-210, 1985.

CASTRO-SANTOS, L. A. de. Power, Ideology and Public Health in Brazil (1889-1930), 1987. PhD Thesis, Cambridge: Harvard University.

CASTRO-SANTOS, L. A. de. \& FARIA, L. A Reforma Sanitária no Brasil: ecos da Primeira República. Bragança Paulista: Editora da Universidade São Francisco, 2003.

CASTRO-SANTOS, L. A. de \& FARIA, L. O ensino de saúde pública no Brasil: os primeiros tempos no Rio de Janeiro. Trabalho, Educação e Saúde, 4(2): 291-324, 2006.

CHAGAS FILHO, C. Histórico sobre a doença de Chagas. In: CANÇADO, J. R. (Org.) Doença de Chagas por um grupo de colaboradores especializados. Belo Horizonte: Imprensa Oficial de Minas Gerais, 1968.

CHAGAS FILHO, C. Meu Pai. Rio de Janeiro: COC/Fiocruz, 1993.

CHAGAS FILHO, C. Um Aprendiz de Ciência. Rio de Janeiro: Nova Fronteira, 2000.

CHAlhoub, S. Cidade Febril: cortiços e epidemias na Corte Imperial. São Paulo: Companhia das Letras, 1996.

CHARTIER, R. A História Cultural: entre práticas e representações. Lisboa, Rio de Janeiro: Difel, Bertrand Brasil, 1990.

CHARTIER, R. Poderes y limites de la representación: Marin, el discurso y la imagen. In: CHARTIER, R. Escribir las Prácticas. Buenos Aires: Manantial, 1996.

COLLINS, H. The seven sexes: a study in the sociology of a phenomenon or the replication of the experiment in physics. Sociology, 9(2): 205-224, 1975.

COLLINS, H. \& YEARLEY, S. Epistemological chicken. In: PICKERING, A. (Ed.) Science as Practice and Culture. Chicago, London: The University of Chicago Press, 1992.

CORSI, F. L. Estado Novo: política externa e projeto nacional. São Paulo: Unesp, Fapesp, 2000. 
COURA, J. R. Síntese histórica e evolução dos conhecimentos sobre doença de Chagas. In: DIAS, J. C. P. \& COURA, J. R. (Orgs.) Clínica e Terapêutica da Doença de Chagas: uma abordagem prática para o clínico geral. Rio de Janeiro: Editora Fiocruz, 1997.

COURA, J. R. O falso dilema sobre a luta antivetorial e as perspectivas de controle da doença de Chagas no Brasil, BHC ou BNH? Cadernos de Saúde Pública, 9(4): 514-518, 1993.

COURA, J. R. \& CANÇADO, J. R. A história da terapêutica da doença de Chagas. In: PROGRAMA INTEGRADO DE DOENÇA DE CHAGAS DA FIOCRUZ. Portal Doença de Chagas. Rio de Janeiro: Fundação Oswaldo Cruz, 2007. Disponível em: <www.fiocruz.br/chagas/cgi/cgilua.exe/sys/start.htm?sid=124>. Acesso em: 25 nov. 2008.

COUTINHO, M. Ninety years of Chagas disease: a sucess story at the periphery. Social Studies of Science, 29(4): 519-549, 1999.

COUTINHO, M. Tropical Medicine in Brazil: the case of Chagas disease. In: ARMUS, D. (Ed.) Disease in the History of Modern Latin America: from malaria to Aids. Durham, London: Duke University Press, 2003.

COUTINHO, M. \& DIAS, J. C. P. A reason to celebrate: the saga of Brazilian chagologists. Ciência e Cultura, 51(5/6): 394-410, 1999.

COUTINHO, M; FREIRE JR., O. \& DIAS, J. C. P. The Nobel Enigma: Chagas' nominations for the Nobel Prize. Memórias do Instituto Oswaldo Cruz, 94, supl. I: 123-129, 1999.

CUETO, M. Nacionalismo y ciências médicas: los inícios de la investigación biomédica en el Perú: 1900-1950. Quipu, 4(3): 327-355, 1987.

CUETO, M. Visions of science and development: the Rockefeller Foundation's Latin American Surveys of the 1920s. In: CUETO, M. (Ed.) Missionaries of Science. The Rockefeller Foundation and Latin America. Bloomington, Indianapolis: Indiana University Press, 1994.

CUETO, M. Tropical medicine and bacteriology in Boston and Peru: studies of Carrión's disease in the early Twentieth century. Medical History, 40: 344-364, 1996.

CUETO, M. Cold War, Deadly Fevers: malaria eradication in Mexico - 1955-1975. Washington, Baltimore: Woodrow Wilson Center Press, The Johns Hopkins University Press, 2007.

CUNNINGHAM, A. Transforming plague: the laboratory and the identity of infectious diseases. In: CUNNINGHAM, A. \& WiLliams, P. (Eds.) The Laboratory Revolution in Medicine. Cambridge: Cambridge University Press, 1992.

CUNHA, E. Os Sertões. Rio de Janeiro: Laemmert, 1902.

D’ARAÚJO, M. C. (Org.) As Instituições Brasileiras da Era Vargas. Rio de Janeiro: Eduerj, Editora FGV, 1999a.

D’ARAÚJO, M. C. Nos braços do povo: a segunda presidência de Getúlio Vargas. In: D’ARAÚJO, M. C. (Org.) As Instituições Brasileiras da Era Vargas. Rio de Janeiro: Eduerj, Editora FGV, 1999b. 
DANTES, M. A. M. Introdução: uma história institucional das ciências no Brasil. In: DANTES, M. A. M. (Org.) Espaços da Ciência no Brasil (1800-1930). Rio de Janeiro: Editora Fiocruz, 2001.

DELAPORTE, F. Chagas, a lógica e a descoberta. História, Ciências, Saúde-Manguinhos, 1(2): 39-53, 1994/1995.

DELAPORTE, F. Romaña's sign. Journal of the History of Biology, 30: 357-366, 1997.

DELAPORTE, F. A Doença de Chagas: história de uma calamidade continental. Ribeirão Preto: Holos, 2003.

DELAPORTE, F. Chagas today. Parassitologia, 47(3-4): 319-327, 2005.

DI LISCIA, M. S. Relaciones peligrosas: sobre bocio, cretinismo y inferioridad (Argentina, 1870-1920). In: AGOSTONI, C. \& GUERRA, E. S. (Eds.) De Normas y Transgresiones: enfermedad y crimen en América Latina (1850-1950). México: Universidad Nacional Autónoma de México, 2005.

DIAS, J. C. P. Reseña histórica de los conocimientos sobre la enfermedad de Chagas y reflexiones sobre algunos aspectos políticos e sócio-economicos de la endemia en el contexto latino-americano. Revista de la Federación Argentina de Cardiología, 17(2): 121-135, 1988.

DIAS, J. C. P. Cecílio Romaña, o sinal de Romaña e a doença de Chagas. Revista da Sociedade Brasileira de Medicina Tropical, 30(5): 407-413, 1997.

DIAS, J. C. P. O controle da doença de Chagas no Brasil. In: SILVEIRA, A. C. (Org.) EI Control de la Enfermedad de Chagas en los Países del Cono Sur de América: historia de uma iniciativa internacional. Uberaba: OPS, Faculdade de Medicina do Triângulo Mineiro, 2002.

DIAS, J. C. P. Globalização, iniqüidade e doença de Chagas. Cadernos de Saúde Pública, 23, supl. 1: S13-S22, 2007.

DIAS, J. C. P. Atualidade de Carlos Chagas. Os 90 anos do descobrimento e a importância social da doença de Chagas. In: BIBLIOTECA VIRTUAL EM SAÚDE CARLOS CHAGAS. Site. Disponível em: <www.bvschagas.coc.fiocruz.br>. Acesso em: 10 mar. 2008.

DIAS, J. C. P. (Org.) Dr. Emmanuel Dias (1908-1962). Rio de Janeiro: Fundação Oswaldo Cruz, 2009.

DIAS, J. C. P. \& COURA, J. R. (Orgs.) Clínica e Terapêutica da Doença de Chagas: uma abordagem prática para o clínico geral. Rio de Janeiro: Editora Fiocruz, 1997.

DIAS, J. C. P. \& SCHOFIELD, C. J. The evolution of Chagas Disease (American Tryoanosomiasis) control after 90 years since Carlos Chagas discovery. Memórias do Instituto Oswaldo Cruz, 94, supl. 1: 103-121, 1999.

DIAS, J. C. P. \& SCHOFIELD, C. J. A Iniciativa do Cone Sul (Incosul). In: PROGRAMA INTEGRADO DE DOENÇA DE CHAGAS DA FIOCRUZ. Portal Doença de Chagas. Rio de Janeiro: Fundação Oswaldo Cruz, 2007. Disponível em: $<$ www.fiocruz.br/chagas/cgi/cgilua.exe/sys/start.htm?sid=37>. Acesso em: 24 nov. 2008. 
DIAS, J. C. P; PRATA, A; CORREIA, D. Problems and perspectives for Chagas disease control: in search of a realistic analysis. Revista da Sociedade Brasileira de Medicina Tropical, 41(2): 193-196, 2008.

DIAS, M. O. da S. Aspectos da Ilustração no Brasil. Revista do IHGB, 278: 105-170, 1968.

DIOTAIUTI, L. Ecologia do vetor da doença de Chagas. In: PROGRAMA INTEGRADO DE DOENÇA DE CHAGAS DA FIOCRUZ. Portal Doença de Chagas. Rio de Janeiro: Fundação Oswaldo Cruz, 2007. Disponível em: <www.fiocruz.br/chagas/cgi/cgilua.exe/sys/start.htm?sid=83>. Acesso em: 24 nov. 2008.

DINIZ, C. C. A industrialização mineira após 1930. In: SZMRECSÁNYI, T. \& SUZIGAN, W. (Orgs.) História Econômica do Brasil Contemporâneo. 2. ed. São Paulo: Hucitec, Edusp, Associação Brasileira de Pesquisadores em História Econômica, Imprensa Oficial de São Paulo, 2002.

DULCI, O. S. Elites e políticas de desenvolvimento em Minas Gerais. Ciências Sociais Hoje, 139-159, 1992.

DULCI, O. S. Política e Recuperação Econômica em Minas Gerais. Belo Horizonte: Editora UFMG, 1999.

EDLER, F. As Reformas do Ensino Médico e a Profissionalização da Medicina na Corte do Rio de Janeiro (1854-1884), 1992. Dissertação de Mestrado, São Paulo: Faculdade de Filosofia, Ciências e Letras, Universidade de São Paulo.

EDLER, F. O debate em torno da medicina experimental no Segundo Reinado. História, Ciências, Saúde - Manguinhos, 3(2): 284-299, 1996.

EDLER, F. A Constituição da Medicina Tropical no Brasil Oitocentista: da climatologia à parasitologia médica, 1999. Tese de Doutorado, Rio de Janeiro: Instituto de Medicina Social, Universidade do Estado do Rio de Janeiro.

EDLER, F. A institucionalização da medicina no Brasil Imperial. In: ANDRADE, A. M. R. (Org.) Ciência em Perspectiva: estudos, ensaios e debates. Rio de Janeiro: Museu de Astronomia e Ciências Afins, Sociedade Brasileira de História da Ciência, 2003.

EDLER, F. Opilação, hipoemia ou ancilostomíase? A sociologia de uma descoberta científica. Varia Historia, 32: 48-74, 2004.

ENGLISH, P. C. Emergence of rheumatic fever in the nineteenth century. In: ROSEnBerG, C. E. \& GOLDEN, J. (Eds.) Framing Disease: studies in cultural history. New Brunswick, New Jersey: Rutgers University Press, 1992.

ESCOBAR, A. Encountering Development: the making and unmaking of the Third World. Princeton, New Jersey: Princeton University Press, 1995.

ESCOLA ANATÔMICA, CIRÚRGICA E MÉDICA DO RIO DE JANEIRO. Dicionário Histórico-Biográfico das Ciências da Saúde no Brasil (1832-1930). Disponível em: $<$ www.dichistoriasaude.coc.fiocruz.br>. Acesso em: 10 mar. 2006.

FARIA, L. Os primeiros anos da reforma sanitária no Brasil e a atuação da Fundação Rockefeller (1915-1920). Physis - Revista de Saúde Coletiva, 5(1): 109-127, 1995.

FARIA, L. Saúde e Política: a Fundação Rockefeller e seus parceiros em São Paulo. Rio de Janeiro: Editora Fiocruz, 2007. 
FARLEY, J. Bilharzia. A history of tropical medicine. Cambridge: Cambridge University Press, 1991.

FARLEY, J. Parasites and the germ theory of disease. In: ROSENBERG, C. \& GOLDEN, J. (Eds.) Framing Diseases: studies in cultural history. New Brunswick, New Jersey: Rutgers University Press, 1992.

FARLEY, J. To Cast out Disease: a history of the International Health Division of the Rockefeller Foundation (1913-1951). New York: Oxford University Press, 2004.

FAUSTO, B. A Revolução de 30. 13. ed. São Paulo: Brasiliense, 1995.

FEE, E. Public health, past and present: a shares vision. In: ROSEN, G. (Ed.) A History of Public Health. Baltimore, London: The Johns Hopkins University Press, 1993.

FERNANDES, A. M. A Construção da Ciência no Brasil e a SBPC. Brasília: Editora UnB, Anpocs, CNPq, 1990.

FERREIRA, J. \& DELGADO, L. de A. N. (Orgs.) O Tempo do Liberalismo Excludente: da proclamação da República à Revolução de 1930. Rio de Janeiro: Civilização Brasileira, 2003a. (Coleção O Brasil Republicano, livro 1)

FERREIRA, J. \& DELGADO, L. de A. N. (Orgs.) O Tempo do Nacional-Estatismo: do início da década de 1930 ao apogeu do Estado Novo. Rio de Janeiro: Civilização Brasileira, 2003b. (Coleção $O$ Brasil Republicano, livro 2)

FERREIRA, J. \& DELGADO, L. de A. N. (Orgs.) O Tempo da Experiência Democrática: da democratização de 1945 ao golpe civil-militar de 1964. Rio de Janeiro: Civilização Brasileira, 2003c. (Coleção $O$ Brasil Republicano, livro 3)

FERREIRA, L. O. O Nascimento de uma Instituição Científica: os periódicos médicos brasileiros da primeira metade do século XIX, 1996. Tese de Doutorado, São Paulo: Faculdade de Filosofia, Ciências e Letras, Universidade de São Paulo.

FERREIRA, L. O. Os periódicos médicos e a invenção de uma agenda sanitária para o Brasil (1827-1843). História, Ciências, Saúde - Manguinhos, 6(2): 331-351, 1999.

FERREIRA, L. O.; FONSECA, M. R. F. da \& EDLER, F. A Faculdade de Medicina do Rio de Janeiro no século XIX: a organização institucional e os modelos de ensino. In: DANTES, M. A. M. (Org.) Espaços da Ciência no Brasil (1800-1930). Rio de Janeiro: Editora Fiocruz, 2001.

FERREIRA, L. O. et al. Entre o básico e o aplicado: práticas e tradições de pesquisa no Instituto Oswaldo Cruz (1935-1970). Relatório das atividades realizadas entre outubro de 2000 e agosto de 2002. Rio de Janeiro: Casa de Oswaldo Cruz, 2002. (Projeto realizado no âmbito do Programa de Apoio à Pesquisa Estratégica em Saúde/COC/Fiocruz)

FIGUEIRÔA, S. F. de M. As Ciências Geológicas no Brasil: uma história social e institucional, 1875-1934. São Paulo: Hucitec, 1997.

FIGUEIRÔA, S. F. de M. Mundialização da ciência e respostas locais: sobre a institucionalização das ciências naturais no Brasil. Asclépio, L(2): 107-123, 1998.

FLECK, L. La Génesis y el Desarrollo de um Hecho Científico. [1935] Madrid: Alianza Editorial, 1986. 
FONSECA, C. M. O. Local e Nacional: dualidades da institucionalização da saúde pública no Brasil (1930-1945). Rio de Janeiro: Editora Fiocruz, 2007.

FONSECA, M. R. F. da. As 'Conferências Populares da Glória': a divulgação do saber científico. História, Ciências, Saúde - Manguinhos, 2(3): 135-166, 1995/1996.

FONSECA FILHO, O. da. A Escola de Manguinhos: contribuição para o estudo do desenvolvimento da medicina experimental no Brasil. São Paulo: Revista dos Tribunais, 1974. (Separata do Tomo II de "Oswaldo Cruz monumenta histórica")

GARRET, L. Transição da saúde. A era do otimismo: vamos erradicar a doença. In: GARRET, L. (Org.) A Próxima Peste: novas doenças num mundo em desequilíbrio. Rio de Janeiro: Nova Fronteira, 1995.

GEISON, G. A Ciência Particular de Louis Pasteur. Rio de Janeiro: Contraponto, Editora Fiocruz, 2002.

GIERYN, T. Relativism/constructivism programmes in the sociology of science: redundances and retreat. Social Studies of Science, 12(2): 279-298, 1982.

GOMES, A. M. de C. A construção do homem novo: o trabalhador brasileiro. In: OLIVEIRA, L. L; Velloso, M. P. \& GOMES, A. M. de C. (Org.) Estado Novo: ideologia e poder. Rio de Janeiro: Zahar, 1982.

GOMES, A. M. de C. A Invenção do Trabalhismo. Rio de Janeiro, São Paulo: Iuperj, Vertice, 1988.

GOMES, A. M. de C. Ideologia e trabalho no Estado Novo. In: PANDOLFI, D. (Org.) Repensando o Estado Novo. Rio de Janeiro: Editora FGV, 1999.

GOMES, A. M. de C. (Org.) Capanema: o ministro e seu ministério. Rio de Janeiro: Editora FGV, 2000.

GOMES, A. M. de C. (Org.) O Brasil de JK. 2. ed. Rio de Janeiro: Editora FGV, 2002.

GOMES, A. M. de C. (Org.) Escrita de Si, Escrita da História. Rio de Janeiro: Editora FGV, 2004.

GOMES, A. M. de C. (Org.) Minas e os Fundamentos do Brasil Moderno. Belo Horizonte: Editora UFMG, 2005.

GOULART, A. da C. Revisitando a espanhola: a gripe pandêmica de 1918 no Rio de Janeiro. História, Ciências, Saúde - Manguinhos, 12(1): 101-142, 2005.

GUIMARÃES, A. P. A Cidade Industrial. Boletim Mineiro de Geografia, 1: 38-54, 1957.

HAMILTON, W. \& FONSECA, C. M. O. Políticas, atores e interesses no processo de mudança institucional: a criação do Ministério da Saúde em 1953. História, Ciências, Saúde - Manguinhos, 10(3): 791-826, 2003.

HANNAWAY, C. Environment and miasmata. In: BYNUM, W. F. \& PORTER, R. (Eds.) Companion Encyclopedia of the History of Medicine. London, New York: Routledge, 1997. v.1.

HARRISON, G. Mosquitoes, Malaria and Man: a history of hostilities since 1880. New York: E. P. Dutton, 1978. 
HERShMANN, M.; KROPF, S. P. \& NUNES, C. Missionários do Progresso: médicos, engenheiros e educadores no Rio de Janeiro - 1870-1937. Rio de Janeiro: Diadorim, 1996.

HERZLICH, C. Modern medicine and the quest for meaning. Illness as a social signifier. In: AUGÉ, M. \& HERZLICH, C. (Eds.) The Meaning of Illness: anthropology, history and sociology of illness. Routledge, London: Harwood Academic Publishers, 1995.

HOCHMan, G. A Era do Saneamento: as bases da política de Saúde Pública no Brasil. São Paulo: Hucitec, Anpocs, 1998.

HOCHMAN, G. A saúde pública em tempos de Capanema: continuidades e inovações. In: BOMENY, H. (Org.) Constelação Capanema: intelectuais e políticas. Rio de Janeiro: Editora FGV, 2001.

HOCHMAN, G. João de Barros Barreto. In: BYNUM, W. F. \& BYNUM, H. (Eds.) Dictionary of Medical Biography. Wesport: Greenwood Press, 2007a.

HOChMan, G. Mário Pinotti. In: BYNUM, W. F. \& BYNUM, H. (Eds.) Dictionary of Medical Biography. Wesport: Greenwood Press, 2007b.

HOCHMAN, G. From autonomy to partial alignement: national malaria programs in the time of global eradication, Brazil, 1941-1961. Canadian Bulletin of Medical History, 25(1): 161-192, 2008.

HOCHMAN, G. O Brasil não é só doença: o Programa de Saúde de Juscelino Kubitschek. História, Ciências, Saúde - Manguinhos, 16, supl. 1, no prelo.

HOCHMAN, G. \& ARMUS, D. Cuidar, controlar, curar em perspectiva histórica: uma introdução. In: HOCHMAN, G. \& ARMUS, D. (Orgs.) Cuidar, Controlar, Curar: ensaios históricos sobre saúde e doença na América Latina e Caribe. Rio de Janeiro: Editora Fiocruz, 2004.

HOChMAN, G. \& FOnSECA, C. M. O. O que há de novo? Políticas de saúde pública e previdência, 1937-1945. In: PANDOLFI, D. (Org.) Repensando o Estado Novo. Rio de Janeiro: Editora FGV, 1999.

HOCHMAN, G. \& FONSECA, C. M. O. A I Conferência Nacional de Saúde: reformas, políticas e saúde pública em debate no Estado Novo. In: GOMES, A. M. de C. (Org.) Capanema: o ministro e seu ministério. Rio de Janeiro: Editora FGV, 2000.

HOCHMAN, G.; MELO, M. T. B. de \& SANTOS, P. R. E. dos. Malária em foto: imagens de campanhas e ações no Brasil da primeira metade do século XX. História, Ciências, Saúde - Manguinhos, 9, supl.: 233-273, 2002.

HUMPHREYS, M. Poverty, Race and Public Health in the United States. Baltimore: The Johns Hopkins University Press, 2001.

JASANOFF, S. Reconstructing the past, constructing the present: can science studies and the history of science live hapilly after ever? Social Studies of Science, 30(4): 621-631, 2000.

JORDANOVA, L. The social construction of medical knowledge. Social History of Medicine, 8(3): 361-381, 1995. 
KEAN, B.H. Carlos Chagas and Chagas' disease. The American Journal of Tropical Medicine and Hygiene, 26(5): 1.084-1.087, 1997.

KLEIN, L. et al. (Orgs.) Inovando a Tradição: Zigman Brener e a parasitologia no Brasil. Rio de Janeiro: Casa de Oswaldo Cruz, Centro de Pesquisas René Rachou, 2003.

KLEIN, L. \& THIELEN, E. A ciência das doenças nas Gerais. Da filial de Manguinhos ao Centro de Pesquisas René Rachou. In: CENTRO DE PESQUISAS RENÉ RACHOU/FUNDAÇÃO OSWALDO CRUZ. (CPqRR/FIOCRUZ) Centro de Pesquisas René Rachou. Produção científica (1980-1999). Belo Horizonte: Centro de Pesquisas René Rachou, Fundação Oswaldo Cruz, 2003.

KNORR-CETINA, K. Scientific communities or transepistemic arenas of research? A critique of quasi-economic models of science. Social Studies of Science, 12: 101-30, 1982.

KREIMER, P. De Probetas, Computadoras y Ratones: la construcción de una mirada sociológica sobre la ciência. Quilmas: Universidad Nacional de Quilmes, 1999.

KREIMER, P. \& ZABALA, J. P. Que conocimiento y para quién? Problemas sociales, producción y uso social de conocimientos científicos sobre la enfermedad de Chagas en Argentina. Redes, 12(23): 49-78, 2006.

KREMENTSOV, N. The Cure: a story of cancer and politics from the annals of the cold war. Chicago, London: University of Chicago Press, 2002.

KROPF, S. P. Conhecimento médico e construção social das doenças: algumas questões conceituais. In: KREIMER, P. et al. (Eds.) Producción y Uso Social de Conocimientos: estudios de sociología de la ciencia y la tecnología en América Latina. Bernal: Universidad Nacional de Quilmes, 2004.

KROPF, S. P. Ciência, saúde e desenvolvimento: a doença de Chagas no Brasil (19431962). Tempo, 10(19): 107-124, 2005.

KROPF, S. P. El mal de Chagas en los ojos de la Nación: ciencia y salud en Brasil a comienzos del siglo XX. Salud Colectiva, 4(3): 363-372, 2008a.

KROPF, S. P. En busca de la enfermedad del Brasil: los médicos del interior y los estudios sobre el mal de Chagas (1935-1956). In: CARBONETTI, A. \& GONZÁLEZLEANDRI, R. (Eds.) Historias de Salud y Enfermedad en América Latina, Siglos XIX y XX. Córdoba: Universidad Nacional de Córdoba, Conicet, 2008b.

KROPF, S. P. \& FERREIRA, L. O. A prática da ciência: uma etnografia no laboratório. História, Ciências, Saúde - Manguinhos, 4(3): 589-597, 1998.

KROPF, S. P. \& HOCHMAN, G. Chagas, Carlos Ribeiro Justiniano. In: BYNUM, W. F. \& BYNUM, H. (Eds.) Dictionary of Medical Biography. Connecticut, London: Greenwood Press, 2007. v. 1.

KROPF, S. P.; AZEVEDO, N. \& FERREIRA, L. O. Doença de Chagas: a construção de um fato científico e de um problema de saúde pública no Brasil. Ciência e Saúde Coletiva, 5(2): 347-365, 2000.

KROPF, S. P.; AZEVEDO, N. \& FERREIRA, L. O. Biomedical research and public health in Brazil: the case of Chagas' disease (1909-1950). Social History of Medicine, 16(1): 111-129, 2003. 
KUHN, T. A Estrutura das Revoluções Científicas. 3. ed. São Paulo: Perspectiva, 1989.

KUHN, T. La Révolution Copernicienne. Paris: Fayard, 1973.

LABRA, M. E. O Movimento Sanitarista nos Anos 20: da conexão sanitária internacional à especialização em saúde pública no Brasil, 1985. Dissertação de Mestrado, Rio de Janeiro: Escola Brasileira de Administração Pública, Fundação Getúlio Vargas.

LABRA, M. E. 1955-1964: O sanitarismo desenvolvimentista. In: TEIXEIRA, S. F. (Coord.) Antecedentes da Reforma Sanitária. Rio de Janeiro: Escola Nacional de Saúde Pública, 1988 (Textos de Apoio - Saúde)

LACAZ, C. da S. Vultos da Medicina Brasileira. Rio de Janeiro, 1963. v. 1.

LACAZ, C. da S. Vultos da Medicina Brasileira. Rio de Janeiro, 1966. v. 2.

LACAZ, C. da S. Vultos da Medicina Brasileira. Rio de Janeiro, 1977. v. 4.

LACERDA, A. L. \& MELLO, M. T. V. B. de. Produzindo um imunizante: imagens da produção da vacina contra a febre amarela. História, Ciências, Saúde Manguinhos, 10, supl. 2: 537-571, 2003.

LAKATOS, I. \& MUSGRAVE, A. (Orgs.) A Crítica e o Desenvolvimento do Conhecimento Científico. São Paulo: Editora Cultrix, Editora da Universidade de São Paulo, 1979.

LATOUR, B. Les Microbes: guerre et paix, suivi de Irréductions. Paris: Métailié, 1984.

LATOUR, B. For David Bloor... and beyond: a reply do David Bloor's 'Anti-Latour. Studies in History and Philosophy of Science, 30(1): 113-129, 1999.

LATOUR, B. Ciência em Ação: como seguir cientistas e engenheiros sociedade afora. São Paulo: Editora Unesp, 2000.

LATOUR, B. \& WOOLGAR, S. A Vida de Laboratório: a construção dos fatos científicos. Rio de Janeiro: Relume-Dumará, 1997.

LAWRENCE, C. Moderns and ancients: the 'new cardiology' in Britain, 1880-1930. In: BYNUM, W. F.; LAWRENCE, C. \& NUTTON, V. (Eds.) The Emergence of Modern Cardiology. London: Wellcome Institute for the History of Medicine, 1985.

LAWRENCE, C. Definite and material: coronary thrombosis and cardiologists in the 1920s. In: ROSENBERG, C. \& GOLDEN, J. (Ed.) Framing Disease: studies in cultural history. New Brunswick, New Jersey: Rutgers University Press, 1992.

LE GOFF, J. Uma história dramática. In: LE GOFF, J. (Org.) As Doenças Têm História. Lisboa: Terramar, 1991.

LEME, C. de A. História da eletrocardiografia no Brasil. Revista do Hospital das Clínicas da Faculdade de Medicina de São Paulo, 36(4): 179-183, 1981.

LEOPOLDI, M. A. P. A economia política do primeiro governo Vargas (1930-1945): a política econômica em tempos de turbulência. In: FERREIRA, J. \& DELGADO, L. de A. N. (Orgs.) O Tempo do Nacional-Estatismo: do início da década de 1930 ao apogeu do Estado Novo. Rio de Janeiro: Civilização Brasileira, 2003. (Coleção O Brasil Republicano, livro 2) 
LESSA, R. A Invenção Republicana. Campos Sales, as bases e a decadência da Primeira República brasileira. Rio de Janeiro, São Paulo: Iuperj, Vértice, 1988.

LEWINSOHN, R. Prophet in his own country. Perspectives in Biology and Medicine, 46(4): 532-549, 2003.

LIMA, N. T. Missões civilizatórias da República e interpretação do Brasil. História, Ciências, Saúde - Manguinhos, 5, supl.: 163-193, 1998.

LIMA, N. T. Um Sertão Chamado Brasil: intelectuais e representação geográfica da identidade nacional. Rio de Janeiro: Revan, Iuperj, 1999.

LIMA, N. T. Viagem científica ao coração do Brasil: nota sobre o relatório da expedição de Arthur Neiva e Belisário Penna à Bahia, Pernambuco, Piauí e Goiás. Revista da Fundação Museu do Homem Americano, 1(3): 185-215, 2003.

LIMA, N. T. \& BRITTO, N. Salud y nación: propuesta para el saneamiento rural - un estudio de la revista Saúde (1918-1919). In: CUETO, M. (Ed.) Salud, Cultura y Sociedad en América Latina: nuevas perspectivas históricas. Lima: IEP, Organización Panamericana de la Salud, 1996.

LIMA, N. T. \& FONSECA, C. M. O. História da especialização em saúde pública no Brasil. In: LIMA. N. T.; FONSECA, C. M. O. \& SANTOS, P. E. dos (Orgs.) Uma Escola para a Saúde. Rio de Janeiro: Editora Fiocruz, 2004.

LIMA, N. T. \& HOCHMAN, G. Condenado pela raça, absolvido pela medicina: o Brasil descoberto pelo movimento sanitarista da Primeira República. In: MAIO, M. \& SANTOS, R. V. (Orgs.) Raça, Ciência e Sociedade. Rio de Janeiro: Editora Fiocruz, Centro Cultural Centro do Brasil, 1996.

LIMA, N. T. \& HOCHMAN, G. Pouca saúde e muita saúva: sanitarismo, interpretações do país e ciências sociais. In: HOCHMAN, G. \& ARMUS, D. (Orgs.) Cuidar, Controlar, Curar: ensaios históricos sobre saúde e doença na América Latina. Rio de Janeiro: Editora Fiocruz, 2004.

LIMA, N. T.; FONSECA, C. M. O. \& HOCHMAN, G. A saúde na construção do Estado Nacional no Brasil: a reforma sanitária em perspectiva histórica. In: LIMA, N. T. et al. (Orgs.) Saúde e Democracia: história e perspectivas do SUS. Rio de Janeiro: Editora Fiocruz, 2005.

LÖWY, I. Yellow fever in Rio de Janeiro and the Pasteur Institute Mission (1901-1905). Medical History, 34: 144-163, 1990.

LÖWY, I. The controversy on the early history of Chagas disease. Parassitologia, 47(3-4): 329-333, 2005.

LÖWY, I. Vírus, Mosquitos e Modernidade: a febre amarela no Brasil entre ciência e política. Rio de Janeiro: Editora Fiocruz, 2006.

LUZ, M. T. Medicina e Ordem Política Brasileira: políticas e instituições de saúde (18501930). Rio de Janeiro: Graal, 1982.

LYONS, M. The Colonial Disease: a social history if sleeping sickness in northern Zaire, 1900-1940. Cambridge: Cambridge University Press, 1992. 
MANNHEIM, K. O problema da 'intelligentsia': um estudo de seu papel no passado e no presente. In: MANNHEIM, K. Sociologia da Cultura. São Paulo: Perspectiva, 1974.

MARCUS, A. The South's native foreigners: hookworm as a factor in Southern distinctiveness. In: SAVITT, T. \& YOUNG, J. H. (Eds.) Disease and Distinctiveness in the American South. Knoxville: The University of Tennessee Press, 1988.

MARQUES, R. de C. \& MITRE, S. Mr. Bócio endêmico em Minas Gerais: a pesquisa biomédica na terra dos 'papudos'. In: NASCIMENTO, D. R. \& CARVALHO, D. M. (Orgs.) Uma História Brasileira das Doenças. Brasília: Paralelo 15, 2004.

MCLEOD, R. \& LEWIS, M. (Eds.) Disease and Empire: perspectiveson Western medicine and the experience of European expansion. London: Routledge, 1988.

MENDONÇA, S. R. de. Estado e Economia no Brasil: opções de desenvolvimento. Rio de Janeiro: Graal, 1986.

MERTON, R. K. Ciencia, Tecnología y Sociedad en la Inglaterra del Siglo XVII. Madrid: Alianza Editorial, 1984.

MERTON, R. K. La Sociologia de la Ciencia. Madrid: Alianza Editorial, 1985. 2v.

MICELI, S. Intelectuais e Classe Dirigente no Brasil (1920-1945). São Paulo: Difel, 1979.

MOREIRA, V. M. L. Brasília: a construção da nacionalidade. Vitória: Edufes, 1998.

MOREIRA, V. M. L. Os anos JK: industrialização e modelo oligárquico de desenvolvimento rural. In: FERREIRA, J. \& DELGADO, L. de A. N. (Orgs.) O Tempo da Experiência Democrática: da democratização de 1945 ao golpe civil-militar de 1964. Rio de Janeiro: Civilização Brasileira, 2003. (Coleção O Brasil Republicano, v. 3)

MOREL, C. M. Chagas disease: from discovery to control - and beyond: history, myths and lessons to take home. Memórias do Instituto Oswaldo Cruz, 94, supl.: 3-16, 1999.

MOULIN, A-M. Tropical without the Tropics: the turning-point of Pastorian Medicine in North Africa. In: ARNOLD, D. (Ed.) Warm Climates and Western Medicine: the emergence of Tropical Medicine, 1500-1900. Amsterdam, Atlanta: Rodopi, 1996.

NÁJERA, J. A. The control of tropical diseases and socioeconomic development (with special reference to malaria and its control. Parassitologia, 36: 17-33, 1994.

NEVES, M. de S. Os cenários da República. O Brasil na virada do século XIX para o século XX. In: FERREIRA, J. \& DELGADO, L. de A. N. (Eds.) O Tempo do Liberalismo Excludente: da proclamação da República à Revolução de 1930. Rio de Janeiro: Civilização Brasileira, 2003. (Coleção O Brasil Republicano, livro 1)

OBREGÓN, D. Building national medicine: leprosy and power in Colômbia, 1870-1910. Social History of Medicine, 15(1): 89-108, 2002.

OliveIRA, L. L. A Questão Nacional na Primeira República. São Paulo: Brasiliense, 1990. 
OLIVEIRA, L. L; VELlOSO, M. P. \& GOMES, A. M. de C. Estado Novo: ideologia e poder. Rio de Janeiro: Zahar, 1982.

OPINEL, A. \& GACHELIN, G. Emille Brumpt's contribuition to the characterization of parasitic diseases in Brazil, 1909-1914. Parassitologia, 47(3-4): 299-295, 2005.

ORGANIZACIÓN MUNDIAL DE LA SALUD/PROGRAMA ESPECIAL DE INVESTIGACIONES Y ENSEÑANZAS SOBRE ENFERMEDADES TROPICALES. (OMS/TDR). Reporte sobre la Enfermedad de Chagas: 17-20 de abril de 2005; actualizado en julio de 2007. Buenos Aires, 2007. (TDR/Grupo de Trabajo científico 09). Disponível em: <www.who.int/tdr/svc/publications/tdr-research-publications/ reporte-enfermedad-chagas $>$. Acesso em 03 de maio de 2009.

PACKARD, R. Malaria dreams: postwar visions of health and development in the Third World. Medical Anthropology, 17(3): 279-296, 1997.

PACKARD, R. No other logical choice: global malaria eradication and the politics of international health in the post-war era. Parassitologia, 40(1-2): 217-229, 1998.

PACKARD, R. \& BROWN, P. Rethinking health, development and malaria: historicizing a cultural model in International Health. Medical Anthropology, 17(3): 181194, 1997.

PACKARD, R. \& GADELHA, P. A land filled with mosquitos: Fred L. Soper, the Rockefeller Foundation and the Anopheles gambiae invasion of Brazil. Parassitologia, 36: 197-213, 1994.

PAIVA, C. H. A. Samuel Pessoa: uma trajetória científica no contexto do sanitarismo campanhista e desenvolvimentista no Brasil. História, Ciências, Saúde Manguinhos, 13(4): 795-831, 2006.

PAN AMERICAN HEALTH ASSOCIATION (PAHO). Chagas disease (American trypanosomiasis). Disponível em: < www.paho.org/english/ad/dpc/cd/chagas.htm>. Acesso em: 30 nov. 2007.

PANDOLFI, D. Os anos 1930: as incertezas do regime. In: FERREIRA, J. \& DELGADO, L. de A. N. (Orgs.) O Tempo do Nacional-Estatismo: do início da década de 1930 ao apogeu do Estado Novo. Rio de Janeiro: Civilização Brasileira, 2003 (Coleção $O$ Brasil Republicano, livro 2)

PARAENSE, W. L. Chagas como protozoologista. In: CONGRESSO INTERNACIONAL SOBRE A DOENÇA DE CHAGAS, 5, 5 a 11 jul. 1959, Rio de Janeiro. Anais... Rio de Janeiro, 1964.

PATARRA, N. L. Dinâmica populacional e urbanização no Brasil: o período pós-30. In: PIERUCCI, A. F. de O. et al. O Brasil Republicano: economia e cultura (19301964). 3. ed. Rio de Janeiro: Bertrand Brasil, 1995. (História Geral da Civilização Brasileira, Tomo III, Volume 4)

PEARD, J. Medicina tropical en el Brasil del siglo XIX: la 'Escuela Tropicalista Bahiana', 1860-1890. In: CUETO, M. (Ed.) Salud, Cultura y Sociedad en América Latina: nuevas perspectivas históricas. Lima: IEP, Organización Panamericana de la Salud, 1996. 
PEARD, J. Race, Place and Medicine: the idea of the tropics in nineteenth-century Brazilian Medicine. Durham, London: Duke University Press, 1999.

PÉCAUT, D. Os Intelectuais e a Política no Brasil: entre o povo e a nação. São Paulo: Ática, 1990.

PELLING, M. Contagion/germ theory/specificity. In: BYNUM, W. F. \& PORTER, R. (Eds.) Companion Encyclopedia of the History of Medicine. London, New York: Routledge, 1997. v. 1.

PENA, M. V. J. Saúde nos planos governamentais. Dados, 16: 69-96, 1977.

PERLETH, M. Historical Aspects of American Tripanosomiasis (Chagas' Disease). Frankfurt am Main: Peter Lang, 1997.

PESTRE, D. Por uma nova história social e cultural das ciências: novas definições, novos objetos, novas abordagens. Cadernos IG/Unicamp, 6(1): 3-56, 1996.

PICKERING, A. (Ed.) Science as Practice and Culture. Chicago, London: The University of Chicago Press, 1992.

PORTER, D. The history of public health: current themes and approaches. Hygea Internationalis, 1(1): 9-21, 1999.

PORTER, R. The Greatest Benefit to Mankind: a medical history of humanity. New York, London: W. W. Norton \& Company, 1999.

PORTOCARRERO, V. (Org.) Filosofia, História e Sociologia das Ciências: abordagens contemporâneas. Rio de Janeiro: Editora Fiocruz, 1994.

POSER, C. M. \& BRUYN, G. W. An Illustrated History of Malaria. New York, London: The Partenon Publishing Group, 1999.

PRATA, A. Evolution of the clinical and epidemiological knowledge about Chagas Disease 90 years after its Discovery. Memórias do Instituto Oswaldo Cruz, 94, supl. 1: 8188, 1999.

PRATA, A. \& SANT'ANNA, E. P. de. Bibliografia Brasileira sobre Doença de Chagas (1909-1979). Brasília: Editora UnB, 1983. (Coleção Temas Brasileiros, v. 55)

PROGRAMA INTEGRADO DE DOENÇA DE CHAGAS DA FIOCRUZ. Portal Doença de Chagas. Rio de Janeiro: Fundação Oswaldo Cruz, 2007. Disponível em: $<$ www.fiocruz.br/chagas>. Acesso em: 28 set. 2008.

QUADROS DA SILVA, S. A era Vargas e a economia. In: D’ARAUJO, M. C. (Org.) As Instituições Brasileiras da Era Vargas. Rio de Janeiro: Eduerj, Editora FGV, 1999.

RAMACCIOTTI, K. Mazza, Salvador. In: BYNUM, W. F. \& BYNUM, H. (Eds.) Dictionary of Medical Biography. Westport, London: Greenwood Press, Connecticut, 2007. v. 4.

RANGER, T. \& SLACK, P. (Eds.) Epidemics and Ideas. Cambridge: Cambridge University Press, 1992.

REIS, N. B. Evolução da cardiologia no Brasil. In: QUEIROZ, J. S. (Ed.) Memória da Sociedade de Medicina e Cirurgia do Rio de Janeiro num Século de Vida. Rio de Janeiro: Rioarte, MEC, 1986. v. 1. 
REY, L. Dicionário de Termos Técnicos de Medicina e Saúde. São Paulo: Guanabara Koogan, 1999.

REZENDE, J. M. de. Linguagem Médica. Goiânia: Editoria AB, 2004.

REZENDE, J. M. de. \& RASSI, A. Por que os triatomíneos são chamados de 'barbeiros'. Linguagem Médica, 37(1): 75-83, 2008.

ROSEN, G. Uma História da Saúde Pública. São Paulo, Rio de Janeiro: Editora Unesp, Hucitec, Abrasco, 1994.

ROSENBERG, C. Disease and social order in America: perceptions and expectations. In: ROSENBERG, C. Explaning Epidemics and Other Studies in the History of Medicine. Cambridge: Cambridge University Press, 1992a.

ROSENBERG, C. Explaning Epidemics and Other Studies in the History of Medicine. Cambridge: Cambridge University Press, 1992b.

ROSENBERG, C. Framing disese: Illness, society and history. In: ROSENBERG, C. (Ed.) Explaning Epidemics and Other Studies in the History of Medicine. Cambridge: Cambridge University Press, 1992c.

ROSENBERG, C. The tyranny of diagnosis: specific entities and individual experience. The Milbank Quaterly, 80(2): 237-260, 2002.

ROSEnBERG, C. \& GOLDEN, J. (Eds.) Framing Disease: studies in cultural history. New Brunswick, New Jersey: Rutgers University Press, 1992.

SÁ, D. M. de. A viagem Penna-Neiva e o tema do saneamento rural no Brasil da década de 1920. In: CONGRESSO INTERNACIONAL DA BRAZILIAN STUDIES ASSOCIATION (BRASA), VII, 2004, Rio de Janeiro. Anais... Rio de Janeiro: PUC, 2004.

SÁ, D. M. de. A Ciência como Profissão: médicos, bacharéis e cientistas no Brasil (18951935). Rio de Janeiro: Editora Fiocruz, 2006.

SÁ, D. M. de. Uma interpretação do Brasil como doença e rotina: a repercussão do relatório médico de Arthur Neiva e Belisário Penna (1917-1935). História, Ciências, Saúde - Manguinhos, 6, supl. 1, no prelo.

SÁ, D. M. de.; SÁ, M. R. \& LIMA, N. T. Telégrafos e inventário do território no Brasil: as atividades científicas da Comissão Rondon (1907-1915). História, Ciências, Saúde - Manguinhos, 15, supl.: 779-710, 2008.

SÁ, M. R. The history of Tropical Medicine in Brazil: the discovery of Trypanosoma cruzi by Carlos Chagas and the German school of protozoology. Parassitologia, 47(3-4): 309-317, 2005.

SALDAÑA, J. J. Ciência e identidade cultural: história da ciência na América Latina. In: FIGUEIRÔA, S. F. de M. (Org.) Um Olhar sobre o Passado. Campinas, São Paulo: Editora da Unicamp, Imprensa Oficial, 2000.

SALGADO, J. A. O centenário de Carlos Chagas e a menina Berenice. Memórias do Instituto Oswaldo Cruz, 75 (1-2): 193-195, 1980. 
SANGLARD, G. Entre os Salóes e o Laboratório: Guilherme Guinle, a saúde e a ciência no Rio de Janeiro, 1920-1940. Rio de Janeiro: Editora Fiocruz, 2008.

SAWIN, C. T. Goiter. In: KIPLE, K. F. (Ed.) The Cambridge World History of Human Disease. Cambridge: Cambridge University Press, 1999.

SCHWARTZMAN, S. Formação da Comunidade Científica no Brasil. São Paulo, Rio de Janeiro: Editora Nacional, Finep, 1979.

SCHWARTZMAN, S.; BOMENY, H. \& COSTA, V. M. Tempos de Capanema. São Paulo: Paz e Terra, 1984.

SCHWEICKARDT, J. C. \& LIMA, N. T. Os cientistas brasileiros visitam a Amazônia: as viagens científicas de Oswaldo Cruz e Carlos Chagas (1910-1913). História, Ciências, Saúde - Manguinhos, 14, supl.: 15-50, 2007.

SCOTT, H. A History of Tropical Medicine. London: Edward Arnold, 1939.

SEGURA, E. El control de la enfermedad de Chagas em la República Argentina. In: SILVEIRA, A. C. (Org.) El Control de la Enfermedad de Chagas em los Países del Cono Sur de América: história de una iniciativa internacional, 1991-2001. s.l.: Organización Pan-Americana de Salud, 2002. Disponível em: <www.paho.org/ Spanish/AD/DPC/CD/dch-historia-incosur.htm >.

SHAPIN, S. History of science and its sociological reconstructions. History of Science, 20(49): 157-211, 1982a.

SHAPIN, S. Discipline and bounding: the history and sociology of science as seen through the externalism-internalism debate. History of Science, 30: 333-369, 1982b.

SHAPIN, S. Following scientists around. Social Studies of Science, 18: 533-550, 1988.

SHAPIN, S. La Revolución Científica: una interpretación alternativa. Barcelona, Buenos Aires, México: Paidós, 2000.

SIERRA-IGLESIAS, J. P. Salvador Mazza, su vida e su obra, redescubridor de la enfermedad de Chagas. San Salvador de Jujuy: Universidad Nacional de Jujuy, 1990.

SILVA, E. História de Brasilia: um sonho, uma realidade, uma esperanza. Brasilia: Charbel, 2006.

SILVA, L. J. da. A Evolução da Doença de Chagas no Estado de São Paulo. São Paulo: Hucitec, 1999.

SILVEIRA, A. J. T. \& NASCIMENTO, D. R. A doença revelando a história: uma historiografia das doenças. In: NASCIMENTO, D. R. \& CARVALHO, D. M. de (Orgs.) Uma História Brasileira das Doenças. Brasília: Paralelo 15, 2004.

SIR RONALD ROSS (1857-1932). The University of Liverpool: investing in knowledge. special collections and archives. Disponível em: <www.sca.lib.liv.ac.uk/collections/ colldescs/lstm/ross.htm>. Acesso em: 7 nov. 2005.

SKIDMORE, T. Brasil: de Getúlio a Castelo. Rio de Janeiro: Paz e Terra, 1975.

SNOWDEN, F. M. The Conquest of Malaria: Italy, 1900-1962. New Haven, London: Yale University Press, 2006. 
SONTAG, S. A Aids e suas Metáforas. São Paulo: Companhia das Letras, 1989.

STAPLETON, D. H. The dawn of DDT and its experimental use by the Rockefeller Foundation in Mexico, 1943-1952. Parassitologia, 40: 149-158, 1998.

STARLING, H. M. M.; GERMANO, L. B. de P. \& MARQUES, R. de C. (Orgs.) Fundação Ezequiel Dias: um século de promoção e proteção à saúde. Belo Horizonte: Editora UFMG, 2007.

STEPAn, N. L. Gênese e Evolução da Ciência Brasileira: Oswaldo Cruz e a política de investigação científica e médica. Rio de Janeiro: Artenova, Fundação Oswaldo Cruz, 1976.

STEPAN, N. L. Picturing Tropical Nature. London: Reaktion Books, 2001.

STEPAN, N. L. The only serious terror in these regions: malaria control in the Brazilian Amazon. In: ARMUS, D. (Ed.) Disease in the History of Modern Latin America: from malaria to Aids. Durham, London: Duke University Press, 2003.

STEPAN, N. L. 'A Hora da Eugenia': raça, gênero e nação na América Latina. Rio de Janeiro: Editora Fiocruz, 2005.

SCHWARTZMAN, S. Formação da Comunidade Científica no Brasil. São Paulo, Rio de Janeiro: Editora Nacional, Finep, 1979.

SZMRECSÁNYI, T. O desenvolvimento da produção agropecuária (1930-1970). In: PIERUCCI, A. F. de O. et al. (Orgs.) O Brasil Republicano: economia e cultura (1930-1964). 3. ed. Rio de Janeiro: Bertrand Brasil, 1995. (História Geral da Civilização Brasileira, tomo III, v. 4).

THOMAS, H. \& KREIMER, P. La apropiabilidad social del conocimiento científico y tecnológico: una propuesta de abordaje teórico-metodológico. In: DAGNINO, R. \& THOMAS, H. (Org.) Panorama dos Estudos sobre Ciência, Tecnologia e Sociedade na América Latina. Taubaté: Cabral Editora e Livraria Universitária, 2002.

TILLEY, H. Ecologies and complexity: tropical environments, African trypanosomiasis and the science of disease control in British Colonial Africa, 1900-1940. Osiris, 19: 21-38, 2004.

TREICHLER, P. How to Have Theory in an Epidemic: cultural chronicles of Aids. Durham, London: Duke University Press, 1999.

VIEIRA, T. R. Uma Clareira no Sertão? Saúde, nação e região na construção de Brasília (1956-1960), 2007. Dissertação de Mestrado, Rio de Janeiro: Casa de Oswaldo Cruz, Fundação Oswaldo Cruz.

VIEIRA, T. R. No coração do Brasil, uma capital saudável: a participação dos médicos e sanitaristas na construção de Brasília (1956-1960). História, Ciências, Saúde Manguinhos, 16, supl. 1, no prelo.

VINHAIS, M. \& DIAS, J. C. P. Doença de Chagas no Brasil. Cadernos de Saúde Pública, 16, supl. 2: 7-12, 2000.

WILliAMS, D. Gustavo Capanema, ministro da Cultura. In: GOMES, A. M. de C. (Org.) Capanema: o ministro e seu ministério. Rio de Janeiro: Editora FGV, 2000. 
WOOLGAR, S. Ciencia: abriendo la caja negra. Barcelona: Anthropos, 1991.

WOOLGAR, S. \& LYNCH, M. (Eds.) Representation in Scientific Practice. London: The Mit Press Cambridge, 1990.

WORBOYS, M. Manson, Ross and colonial medical policy: tropical medicine in London and Liverpool, 1899-1914. In: MCLEOD, R. \& LEWIS, M. (Eds.) Disease and Empire: perspectiveson Western medicine and the experience of European expansion. London: Routledge, 1988.

WORBOYS, M. Germs, malaria and the invention of mansonian tropical medicine: from 'diseases in the tropics' to 'tropical diseases. In: ARNOLD, D. (Ed.) Warm Climates and Western Medicine: the emergence of tropical medicine, 1500-1900. 2. ed. Amsterdan, Atlanta: Rodopi, 1996.

WORBOYS, M. Tropical diseases. In: BYNUM, W. F. \& PORTER, R. (Eds.) Companion Encyclopedia of the History of Medicine. London, New York: Routledge, 1997. v. 1.

WORBOYS, M. Spreading Germs: disease theories and medical practice in Britain, 1865-1900. Cambridge: Cambridge University Press, 2000.

WORLD HEALTH ORGANIZATION (WHO). Chagas disease. Disponível em: <www.who.int/topics/chagas_disease/en/>. Acesso em: 30 nov. 2007.

ZABALA, J. P. Producción y Uso de Conocimientos Científicos Vinculados a la Enfermedad de Chagas: Argentina, 1915-2000, 2007. Tese de Doutorado, Buenos Aires, Paris: Facultad Latinoamericana de Ciencias Sociales-Argentina, Université Paris 1 Panthéon-Sorbonne. 


\section{Outros títulos da Coleção História e Saúde}

Os Índios no Império do Brasil:

a etnografia do IHGB entre as décadas de 1840 e 1860

Kaori Kodama, 2009.

Proteção à Natureza e Identidade Nacional no Brasil:

anos $1920-1940$.

José Luiz de Andrade Franco e José Augusto Drummond, 2009.

A Gripe Espanhola na Bahia:

saúde, política e medicina em tempos de epidemia

Christiane Maria Cruz de Souza. Co-edição Edufba, 2009.

Enfermidades Endêmicas da Capitania de Mato Grosso:

a memória de Alexandre Rodrigues Ferreira (Clássicos \& Fontes)

Ângela Pôrto (Org.). Co-edição Faperj, 2008.

Entre os Salões e o Laboratório:

Guilherme Guinle, a saúde e a ciência no Rio de Janeiro, 1920-1940

Gisele Sanglard, 2008.

Iluminismo e Império no Brasil:

O Patriota (1813-1814) (Clássicos \& Fontes)

Lorelai Kury (Org.). Co-edição Fundação Biblioteca Nacional, 2007.

Saúde e Política:

a Fundação Rockefeller e seus parceiros em São Paulo

Lina Faria, 2007.

Saúde no Governo Vargas (1930-1945):

dualidade institucional de um bem público

Cristina M. Oliveira Fonseca, 2007.

Vírus, Mosquitos e Modernidade:

a febre amarela no Brasil entre ciência e política

Ilana Löwy, 2006.

Políticas Internacionais de Saúde na Era Vargas:

o Serviço Especial de Saúde Pública, 1942-1960

André Luiz Vieira de Campos, 2006.

A Ciência como Profissão:

médicos, bacharéis e cientistas no Brasil (1895-1935)

Dominichi Miranda de Sá, 2006. 
Textos Hipocráticos:

o doente, o médico e a doença (Clássicos \& Fontes)

Henrique F. Cairus e Wilson A. Ribeiro Jr., 2005.

'A Hora da Eugenia':

raça, gênero e nação na América Latina

Nancy Leys Stepan, 2005.

As Pestes do Século XX:

tuberculose e Aids no Brasil, uma história comparada

Dilene Raimundo do Nascimento, 2005.

Cuidar, Controlar, Curar:

ensaios históricos sobre saúde e doença na América Latina e Caribe Gilberto Hochman e Diego Armus (Orgs.), 2004.

A Recepção do Darwinismo no Brasil

Heloísa Maria Bertol Domingues, Magali Romero Sá

e Thomas Glick (Orgs.), 2003.

Um Lugar para a Ciência:

a formação do campus de Manguinhos

Benedito Tadeu de Oliveira (Coord.), Renato da Gama-Rosa Costa

e Alexandre José de Souza Pessoa, 2003.

A Arte de Enganar a Natureza:

contracepção, aborto e infanticídio no início do século XX

Fabíola Rohden, 2003.

Visões do Feminino:

a medicina da mulher nos séculos XIX e XX

Ana Paula Vosne Martins, 2001.

Espaços da Ciência no Brasil:

1800-1930

Maria Amélia M. Dantes (Org.), 2001.

Ser Médico no Brasil:

o presente no passado

André de Faria Pereira Neto, 2001. 



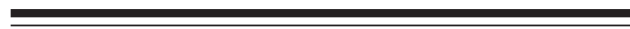

Formato: $16 \times 23 \mathrm{~cm}$ Tipologia: Century Gothic e Baskerville Win95BT Papel: Pólen Bold $70 \mathrm{~g} / \mathrm{m}^{2}$ (miolo) Cartão Supremo $250 \mathrm{~g} / \mathrm{m}^{2}$ (capa)

CTP, Impressão e acabamento: Imprinta Express Gráfica e Editora Ltda. Rio de Janeiro, junho de 2009

Não encontrando nossos títulos em livrarias, contactar a EDITORA FIOCRUZ:

Av. Brasil, 4036 - Térreo, s. 112, Manguinhos - 21041-361 - Rio de Janeiro - RJ

Tel: (21) 3882-9039 e 3882-9007 - Telefax: (21) 3882-9006 editora@fiocruz.br www.fiocruz.br/editora 